
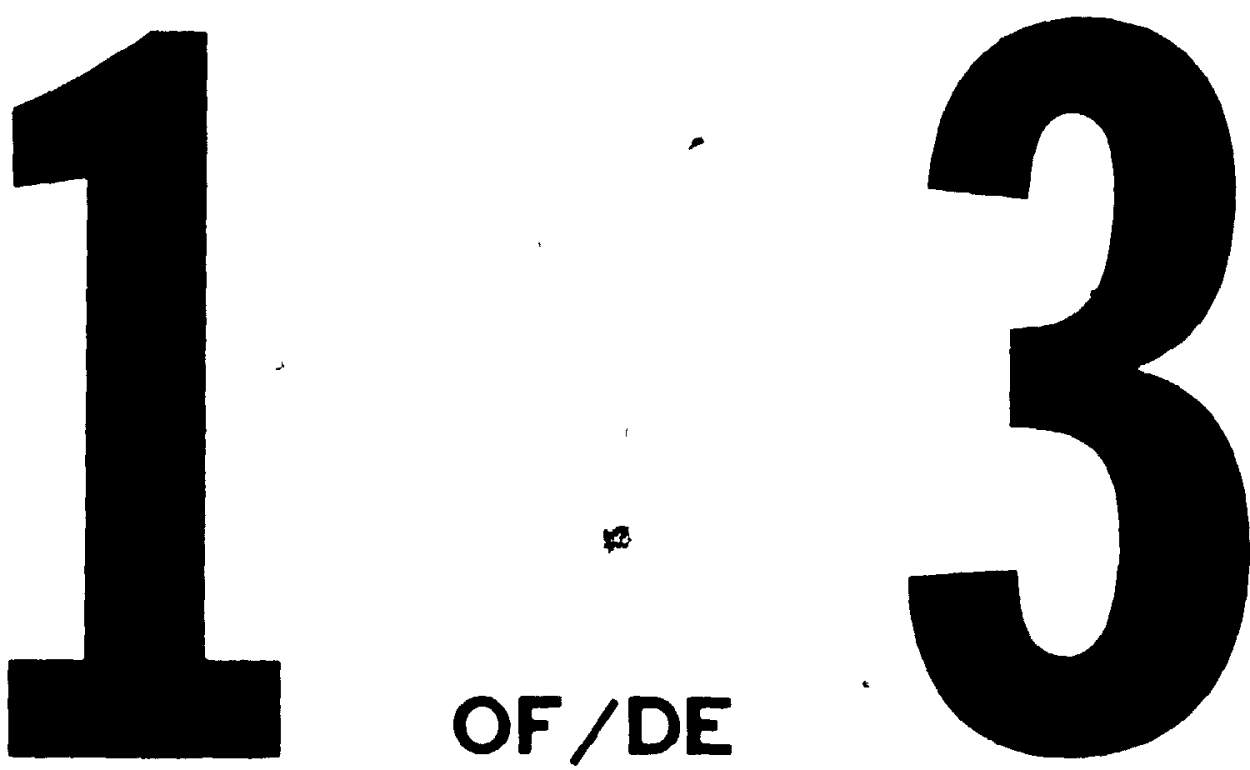

*

4

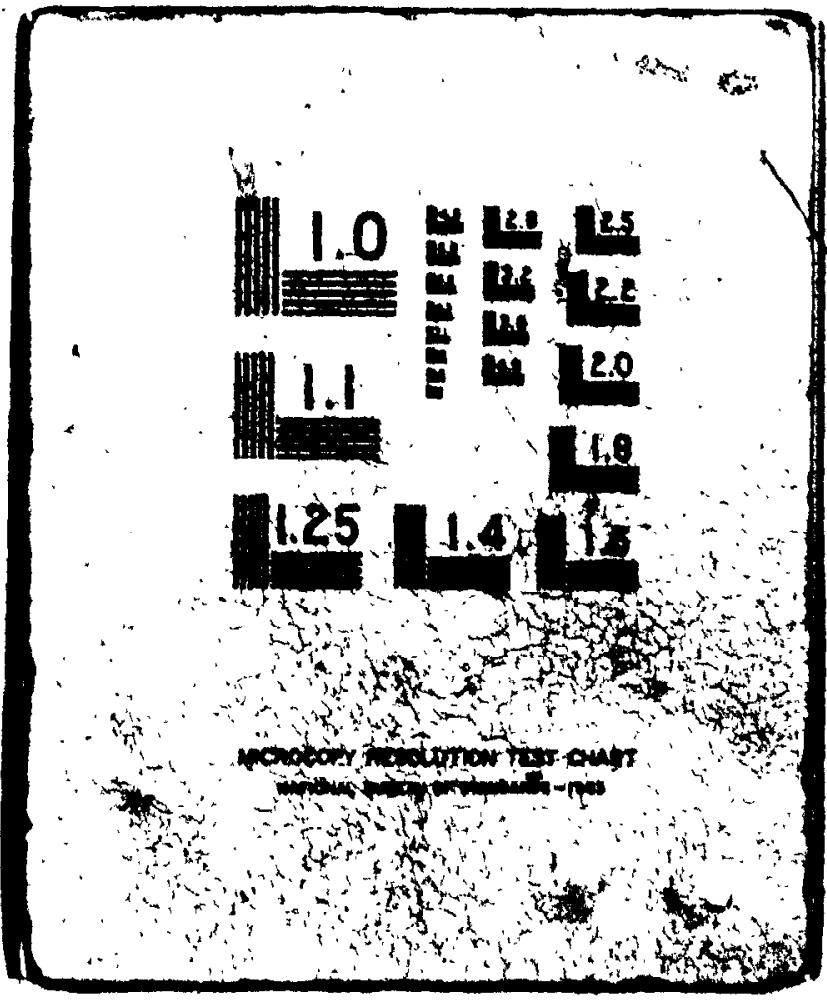




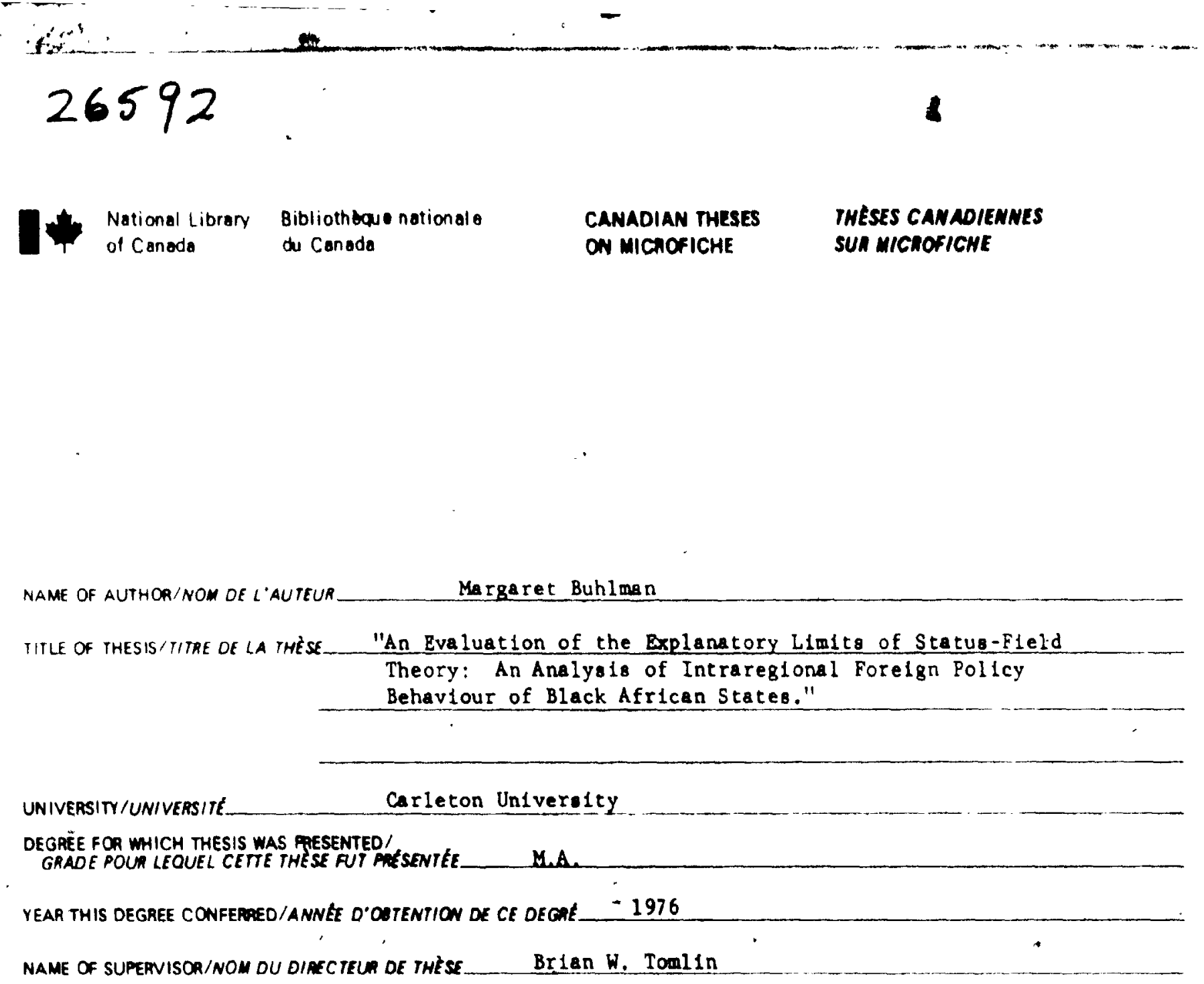

CANADIAN THESES ON MICAOFICHE
THESES CANADIENNES SUN MICROFICHE
Bibliotheque national a

"An Evaluation of the Explanatory Limits of Status-Field Theory: An Analysis of Intrareglonal Forelgn Pollcy Behaviour of Black African States."

Permission is hereby grented to the NATIONAL LIERARY Of CANADA to microfilm this thesis and to lend or sell copies of the film.

The author reserves other publication rights, and noither the thesis nor extensive extracts from it may be printed or other. wise reproduced without the suthor's witten permission.
L'autarisotion est, per lo presente, eccordle la 810L10THE. QUE NATIONALE DU CANADA do microfilmer cotte thise of do preter ou de vendre dos exomplaine du film.

L'eutour se riserve hes outres drofts de publicotion; ni lo theseni de longe extralts do cello-ci ne doivent ctre imprinds

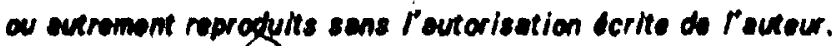

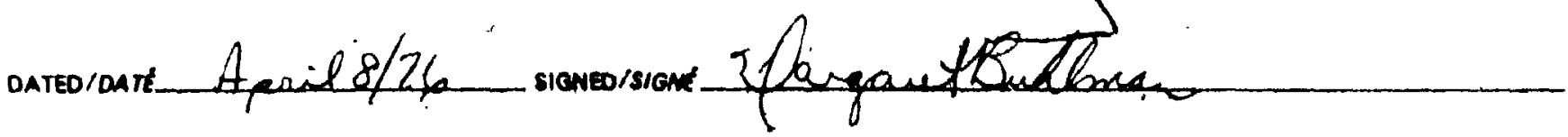

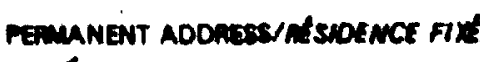
561. G11mour Street, Apt. 1. Ottara, Ontar10. R1R 5L5 
INFORMATION TO USERS

THIS UISSERTATION HAS BEEN MICROF ILMED EXACTLY AS RECEIYED

This copy was produced from a microfiche copy of the original document. The quality of the copy is heavily dependent upon the quality of the original thes is submitted for microfilming. Every effort has been made to ensure the highest quality of reproduction possible.

PLEASE NOTE: Some pages may have indistinct print. Filmed as received.
AVIS AUX USAGERS

\section{LA THESE A ETE MICROFILMEE TELLE QUE NOUS L.'AVONS RECUE}

Cette copie a ete faite a partir d'une microfiche du document original. La qualite de la copie depend grandement de la qualite de la these soumise pour le microfimage. Nous avons tout fait pour assurer une qualite superteure de reproduction.

NOTA BENE: La qualite d'impression de certaines pages peut laisser a desirer. Microfilmee telle que nous l'avons reçue.

Division des theses canadiennes Direction du catalogage Biblyotheque nationale du Canada Ottawa, Canada
Canadian Theses Division Cataloguing Branch National Library of Canada Ottawa, Canada KIA ON4 


\author{
AN EVALUATION OF THE EXPLAMATORY LIMITS OF \\ STATUS-FIELO THEORY: AN ANALYSIS OF \\ INTRAREGIONAL FOREIGN PQICY BEHAVIOUR OF \\ BLAK AFRIĆNAN STATES.
}

BY

Maneancet A. BUHLMAN B.A.

\begin{abstract}
A THEOIs suemittco to THE FAOULTY OF GRaduate STUOIEs Im PARTIAL FULFILMENT or THE REquincmente fon the ocente of

Materne of Arta
\end{abstract}

DePantment of Politioal Solenot

Cancton UNIVEneitr

OTTAMA, Ontanio

Mnkon 23, 1976. 


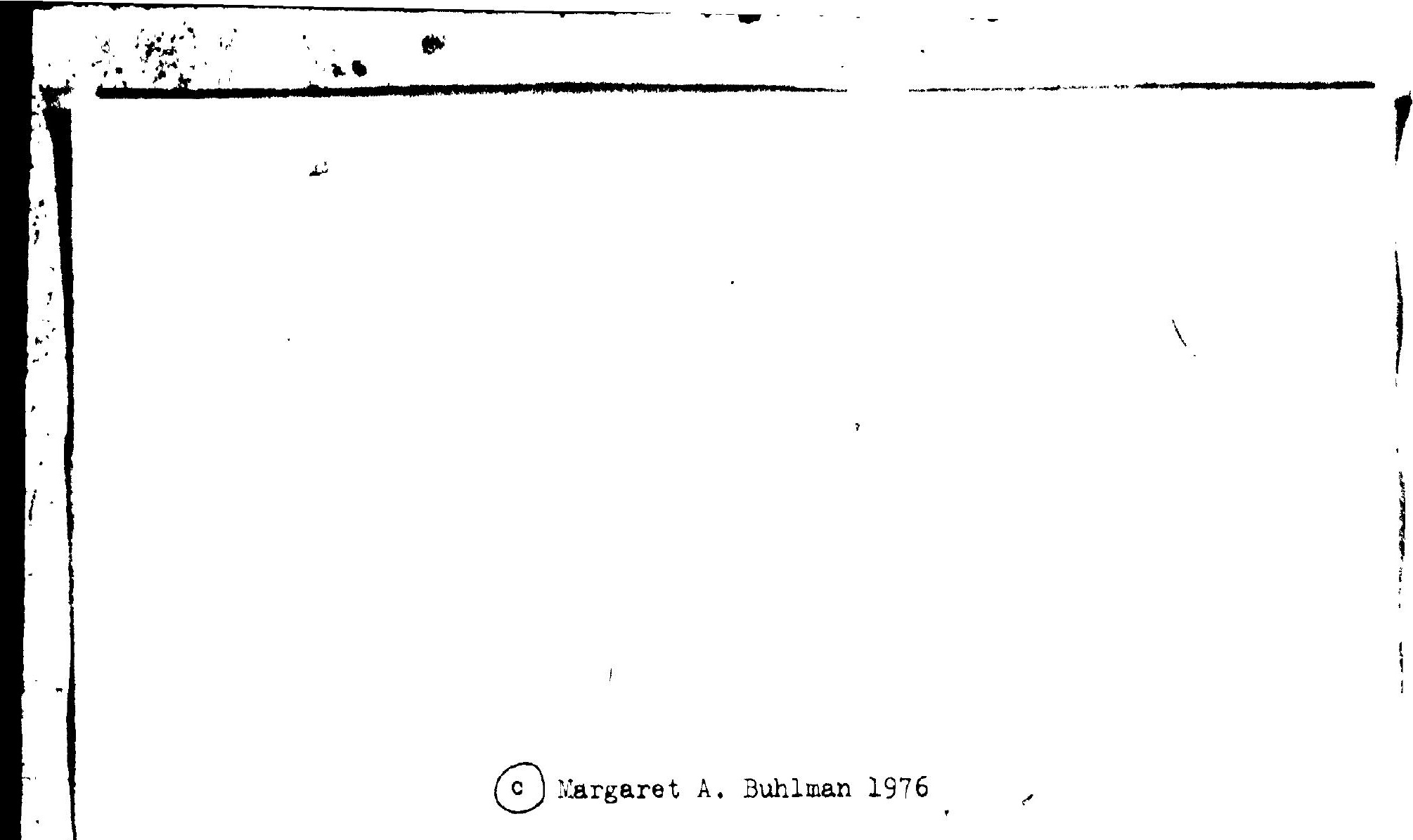




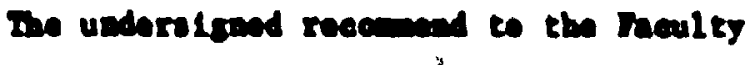
of Oraduate studies eacoptance of the thasls

"An sveluation of the Bplanatory Lindte of

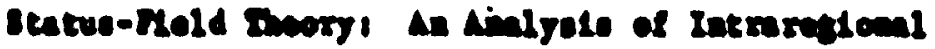

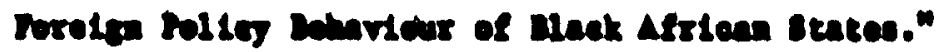

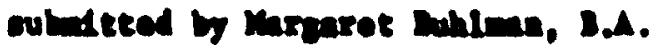

In partial fulflimat of the repulremante lor the dogrev of unoter of Arte

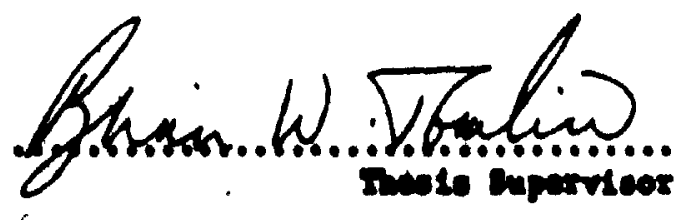
Ineste Enparvices

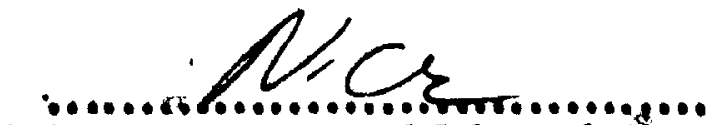

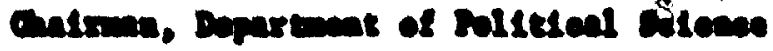

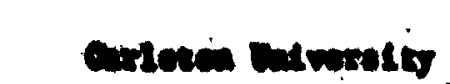




\section{ABSTRACT}

INTEAMATIONAL RELATIONS HAS PROORCESTO mOM AN TMPHABIE

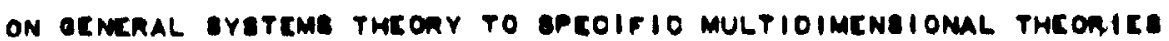

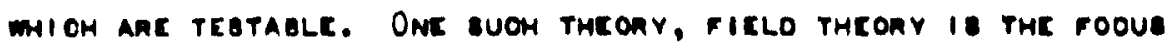

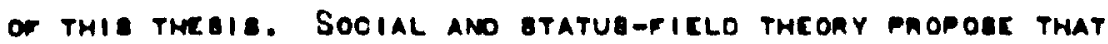

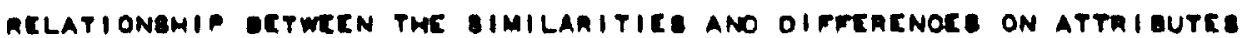

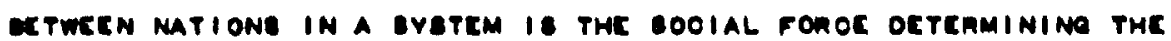
Foncion POLIOY OCHAVIOUN IN THAT OYAO. IN AODITION, WMILE

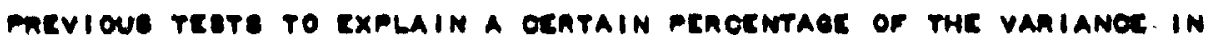

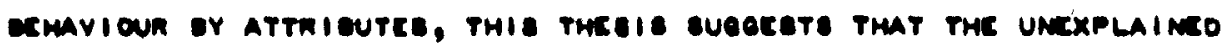

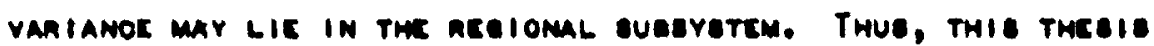

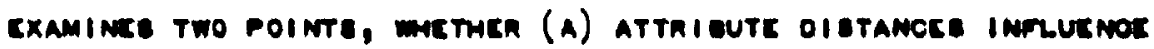

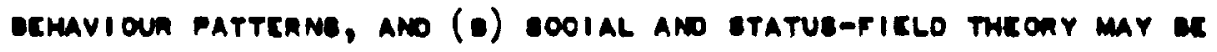
EMPLOYTO TO EXPLAIN DYAOIO ERHAVIOUR WHER THERE IS A RELATIVELY

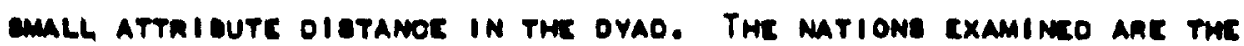
32 BlaOK AmionN etatrs.

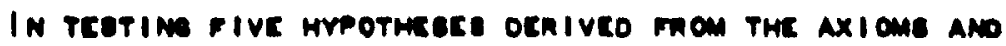

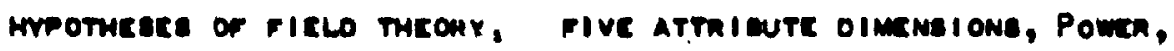
EoOmonio Development, Uneanization, Politioal ORIEntation ano RCLigion, ano thace cemavioun dimineions Intchaotive, Comitreo Conilot, ano Coopenative Decos cemavioun ane abetraoteo mow

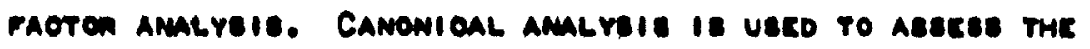

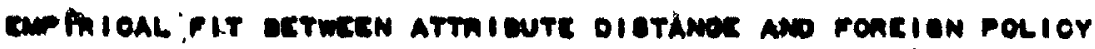

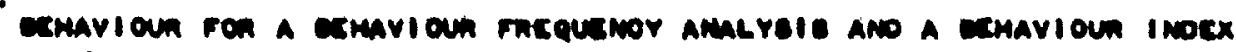
analrese. 


\section{ACKNOMLDENENTS}

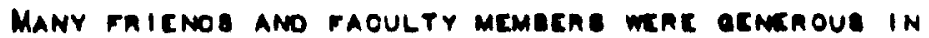

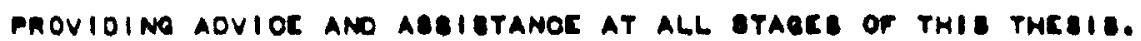

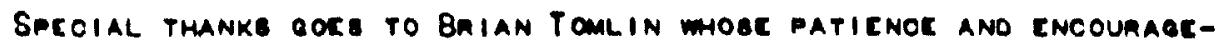

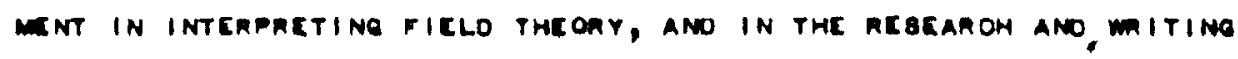
OF THIO THESIE HAS OEEN OESTOWEO INOULOENTLY. I WOULO ALSO LIKE TO EXTENo Mr anatituder to JOHN BUHLMAN FOR HID GUIOANCE IN THE mathematioal INTEAPRETATION OF FIELD THEONY AHO KEN HANT FON HIS

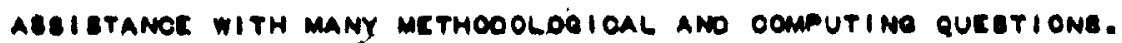




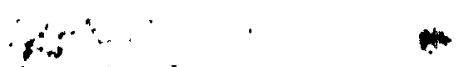

4.

TABLE OF CONTENTS

ACKNOMLOGMENTS

111

Chaptea

1. THE OEVELOPMENT OF THEORY IN INTERMATIONAL

RELATIONS

2. THE DEVELOPMENT OF STATUS-FIELO THEORY

STATUE

Ficlo Theony

STATUAFIKLO THEOAY

3. STATUS-FIELD THEORY ANO IMPLICATIONS FOR THE

REGIONAL SUBSYSTEM

AXIOME ANO THEOAEMS

Rreiomal AMALYeIa

4. APPLIED FIELD THEORY IN A REGIONAL SYSTEM ....... 75 Foneion Polloy Bemavioun

ATtR I OUTE DIMEME I ONe

Ficlo Theony Explanatione of afrioan bemavioun Openational Prockoune

5. BLACK AFRICAN ATTRIBUTE DISTANCE ANO BEHAVIOUA RELATIONGHIP

MOOCL I AMLYYEIE

Moocl II Amalyole

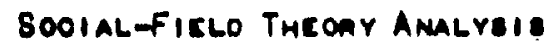

STATUE-FIELO THEOAY ANALreTE

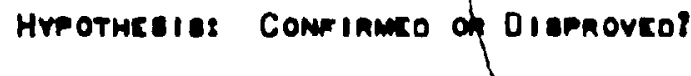

6. SUMURY ANO CONCLUSION: FIED THEORY

ANO AFRICAN FOREIGN PQLICY BEHAVIOUR

APPENDIX

BIQLIOGRAPHY 
Fiounc

1. Reacanoh Ocelon ............................... II

2. A HYPOTHETIOAL REPACEENTATION OF ATTRIGUTE

SPace ................................. 53

3. GEOMETRIO REPREeENTATION OF THE GAOIO FIELLO

THEOAETIOAL RELATIONEHIP BETWETN ATTMI GUTE

SPaOr ano Brmavioun SPAor ..................... 53

4. Hienanchioal Clustemina Regult .................. 91

5. HYPOTHEBIzED SIQNa FOM SOCIAL ANO

Statug-ficlo theony fon Black Amioa .......... 12 ?

LIST OF TABLES

Tancer

1. The Sugonoinate Stretem - Amica ................ 72

2. 16 Collaparo Catcoonize of Blaok amican

Benaviour ................................. 86

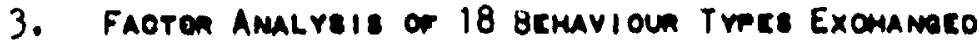

Amond 32 Black AFRIOAN NaTIONE ................ 88

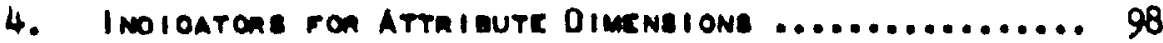

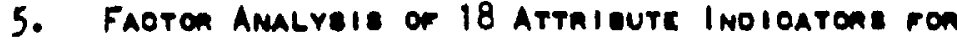

32 BLAOK ATRIOAN NATIONA: ORTMOgONAL

FAoton RotaTION ............................. 100

6. Relative Plactimemt of Nations acconoing to

FAOTOO SOOnEs ............................. 113

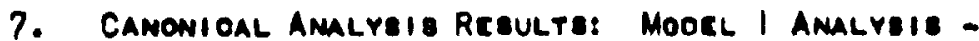

Sooial Ficlo Theony ........................... 130

8. Camomioal amalveie Regultse Moorl II Amalreis -

StATUE-FIELO THEOUY ......................... 133

9. CANONIOAL AMaLYeIs Results ron Soolal-firLo

Theonr - Facquenor Analyeis ................... 138

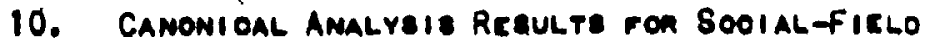

Treonr - Bcmavfoun I nocx Amalreis .............. 143

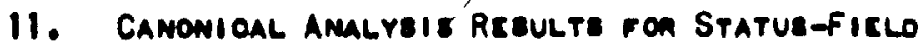

Tukony - Facquenor Amalrale .................... 149

12. Camomioal Amalyeis Resulte ron Status-Ficlo

Theonr - demavioun Inosx Amalvals .............. 155

13. AOTUal 8I ame ron SOOIAL ano Statuefílo

Tmienr Hrootncece epo............................. 161 


\section{Chaptin 1}

THE OEVELOPMENT OF THEORY IN INTERNATIONML RELATIONS

ReOKNT disouselons have ponthayeo a parvalling view that

INTERMATIONAL ACLATIONE THEORY IE IN A BTATC OF DIBARRAY, WITH A

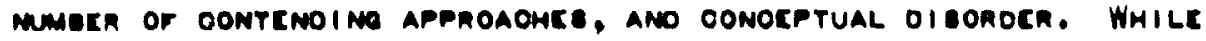

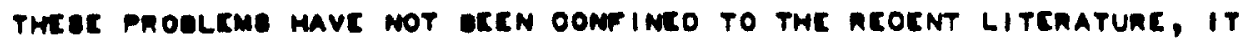

HAE ONLY OEEN IN THE LABT FEW YCANG THAT THESC PMOELEMB MAVE OEEN

taken ecriously. Autmono suoh as Chanles Moclellamo, ancmo lijemant, 2

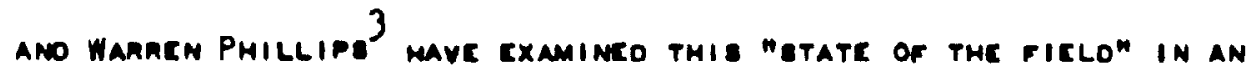

ATTEMPT TO OETEMMINE mERE PHE DNBOIPLIM HAS OONE, ANO WHERE IT IS

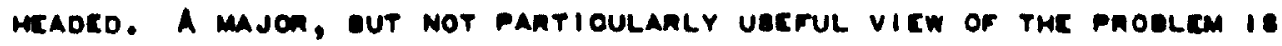

REPRE EENTED IN THE OIOMOTOWY SETWEEN THE TRAOITIONAL ANO DEHAVIOUAAL

appnoaches to intenmatiomal nelatione. Charles MoClellano, howeven,

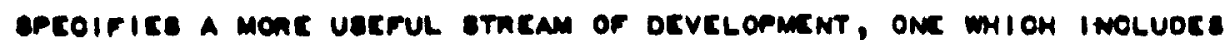

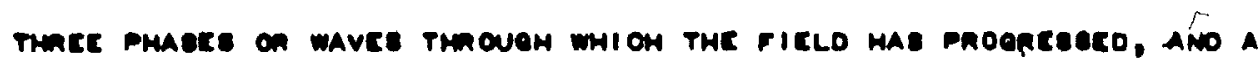

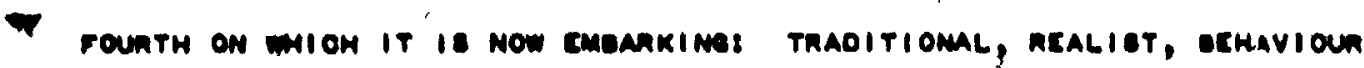

ANo The rounth mave on postecmaviounal phasc.

1. C.A. Moclellano, mon the founth wave: Paet ano furume in

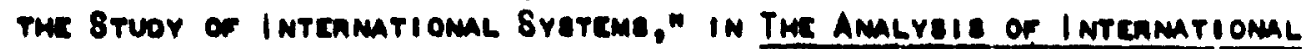

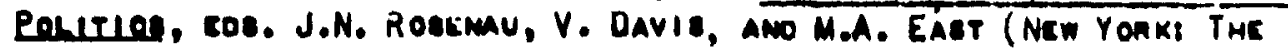
Farec Paras, 1972).

2. A. Li smmat, "The Stauotunc of nHe Tmeonetionl Revolution

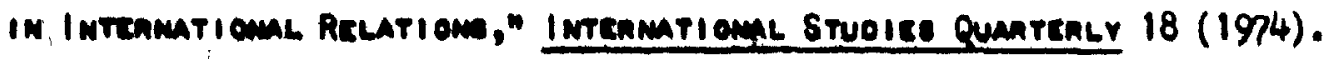

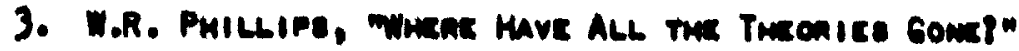
Venco Pobitios (Jamany 1974 ). 


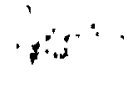

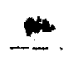

2.

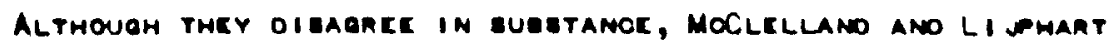
OCFIMC THE FIAGT waVk, on TAADITIONAL PARADIOM IN TERME OF a FOOUE ON INTERMATIOMAL LAW ANO OREANIZATION WITM AN CMPMABI ON OTATES AE DOVEREION ENTITIES. IN THIE APPNOACH A NOAMATIVE ANO OIPLOMATIC

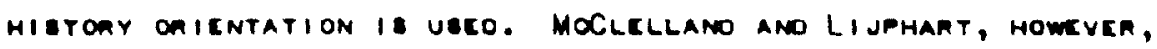

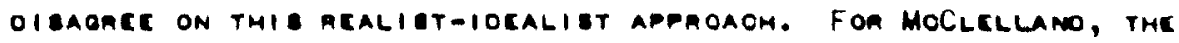

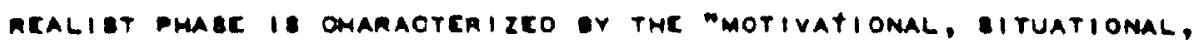

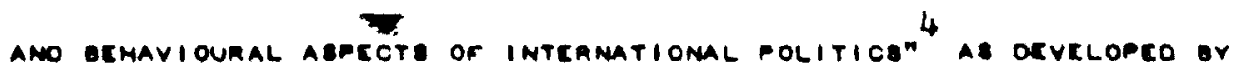

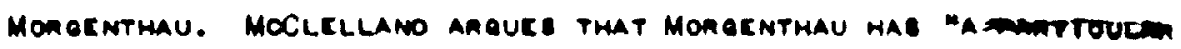
Philosomical echt" ano his attitude of inguing oore hot delome to

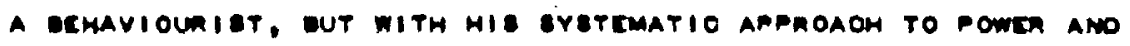

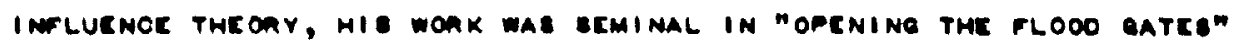
of ocmaviounal Imtenmatiomal nelatione theony. Li JPhaAt, on the

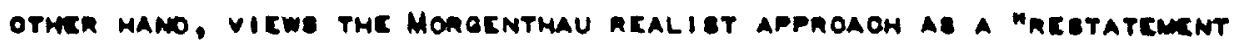
ANO REFIMEMENT OF THE TRAOITIONAL POWER POLITIOE APPMOAOH ANO

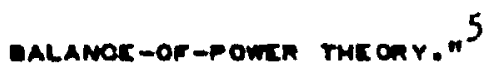

Both Li JPmant amo MoClellamo aenex tmat megcanoh cefonte in

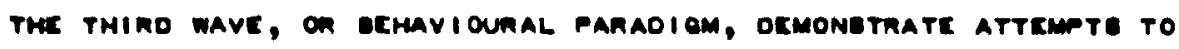

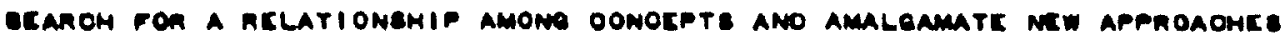

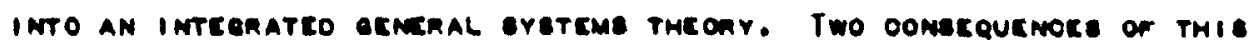

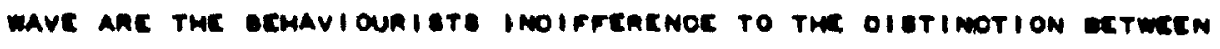
Dentetio ano intenmatidmal politios, ano a ectren unotnetanoime or

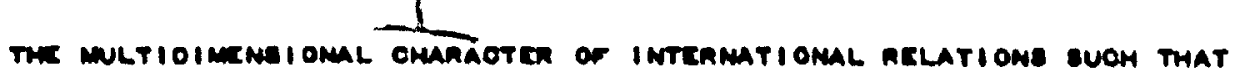

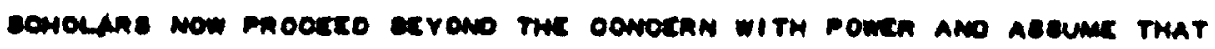

4. Meclellatio, "founth Wave," 2.25.

5. Li somukt, "The 8muorune," p. 54. 


\section{3.}

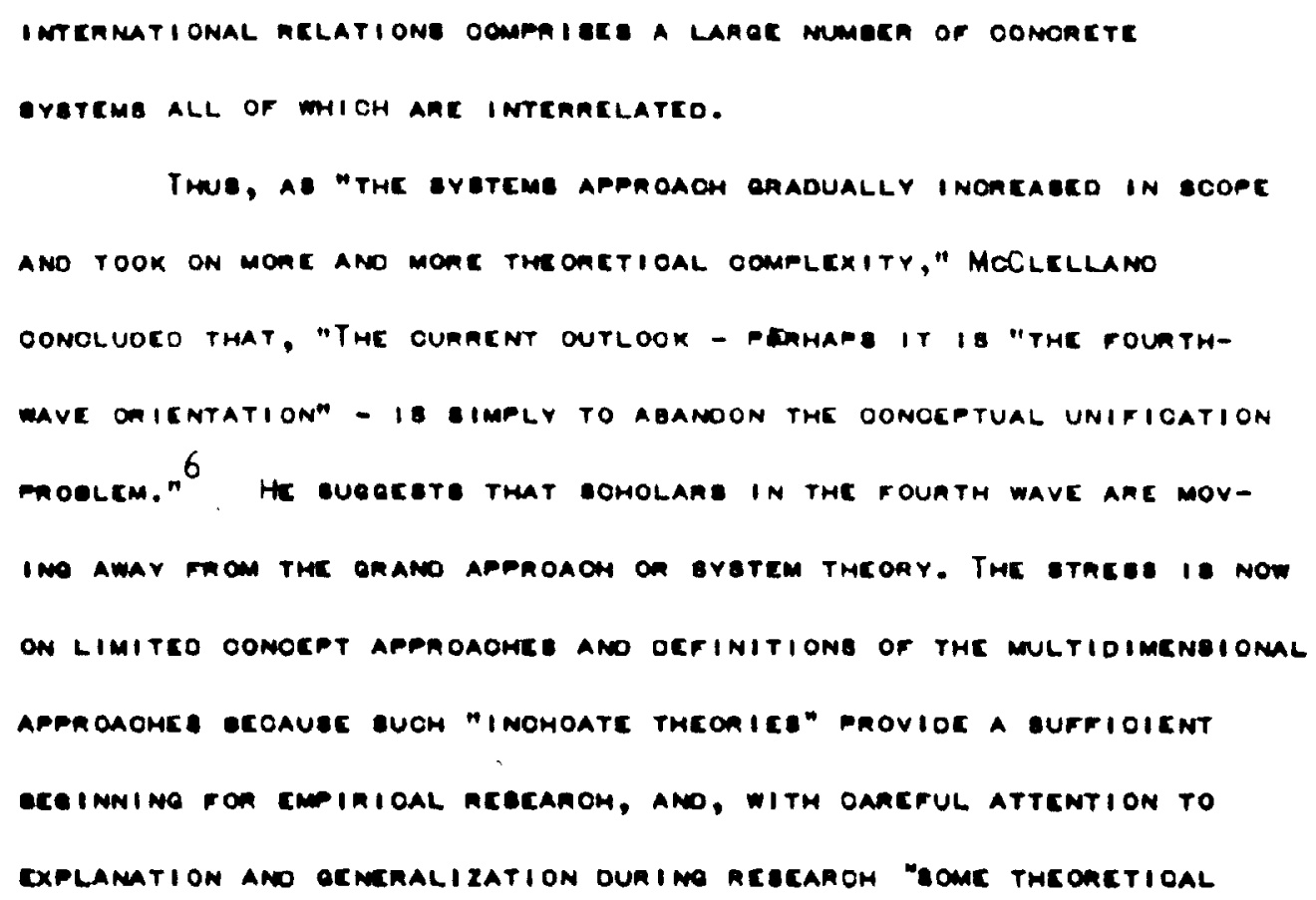

6. Moclellano, "Founth wave," 29.

7. 1010.

8. Lidmant, "The 8muotunt," -. 69. 


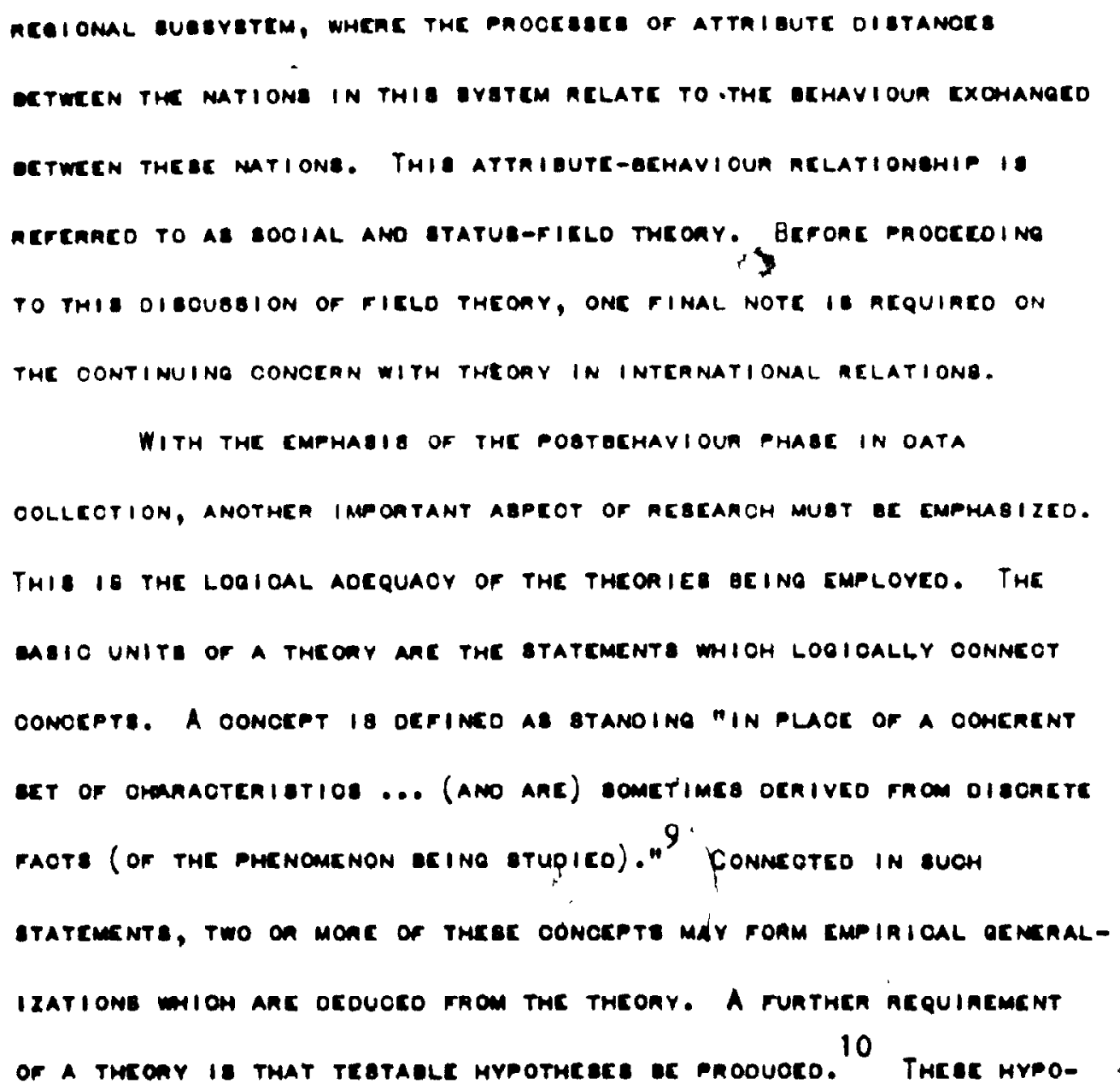

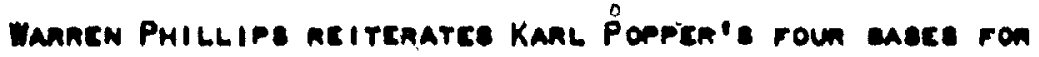

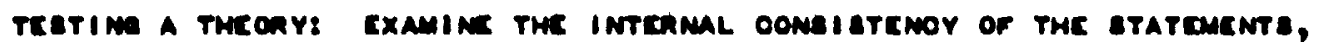

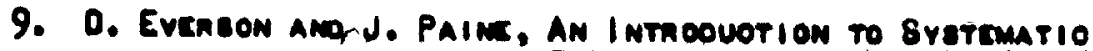

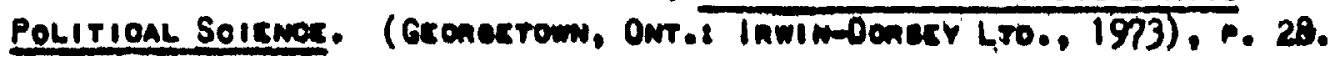
10. Pyillips, "Thiconice Ganci" p. 166. 


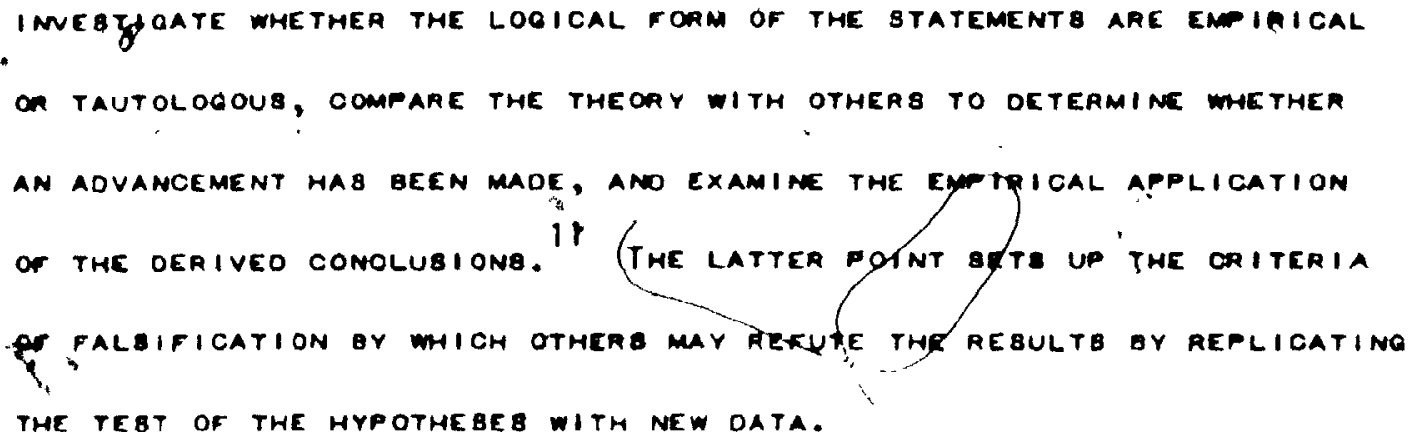

11. 1010., P. 163.

12. J. Galtung, Theonr and Methoo of Social Rcacarch (Oslo: Umiveneiteteronlaeet, 1967), P. 465. Galtume oefince a temale

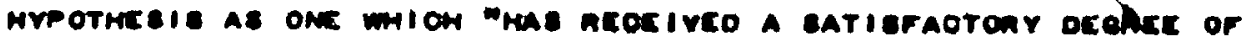
conrinmation.". (p. 337). 


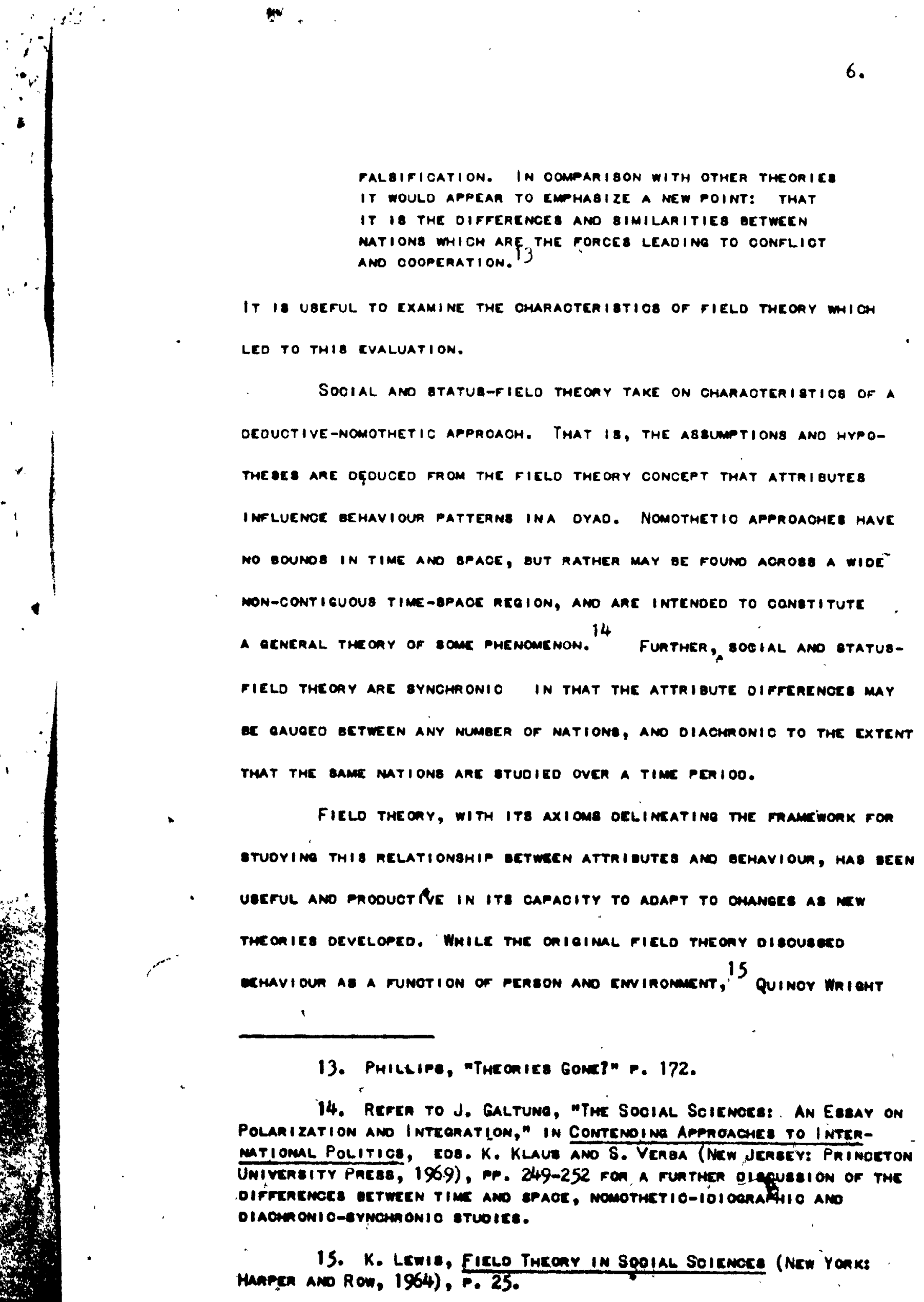


maE FIAST TO CONCEIVE IT AB BOCIALGFICLO THEOAY IN INTERMATIOMAL RELATIONA. HERE, THE OONOCPT OF ATTRIOUTE DIBTANOC BCTMECN MATIONB, RETEARING TO A COMBINATION OF THE TUNGTION OF DOOIAL AND CMMAMONMENT FACTOAB INFLUENOING THE FOAEION POLICY DEHAVIOUR OF MATIONB WAS INTROOUCEO. RUDOLFH RUMMEL, THAOUEH WORK ON THE DIMENBIONALITY OF NATIONB (DON) PROJECT, OEVELORED MOAE PRECIBE AXIOMB, A METHOOOLOQIOAL FRAMEWORK FOR BOOIALAFIELD THEORY ANO TEBTEO IT IN INTERNATIONAL RELATIONB. MATHEMATICAL ABBUMPTIONB GONCERNING THE LIMEARITY OF ATTRIBUTE DIBTANCES ANO THEIR AELATIONGHAP TO BEHAVIOUA WERE UEEO. DYADIO EEMAVIOUA WAB CONBIDEREO TO BE A FUNCTION OF THE DIBTANCE VEOTOAB IN ATTRIBUTE BPAOC DEFIMED, THROUQH THE TECHNIQUE OF FAOTOR ANALY8I8, OY ATTRIBUTE OIMENBIONB OONMECTINO THE BOOIAL UNIT VEOTORB. THE FIELO ENOOMPABSINA THESE MATIONB WAB OEFINED AB A EUOLIDEAN SACE WITH MATIONB AB POINTB ANO VARIAELES AB VECTORB, FOR DOTH

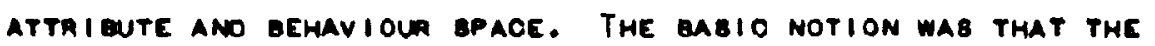
DIBTANOE GETWEEN THEBE TWO POINTB, THE VECTOR, IN ATTAIDUTC EPACE WAE A FORCE OETERMINING THEIR GEHAVIOUR TOWARDB EACH OTHEA IN ERMAVIOUA BPACE. THE LIMEARITY ABEUMPTION OF THIB RELATIONBHIP ALLOWEO JHE INTERRELATIONEHIP AMONO POINTE ANO VARIABLES TO OE

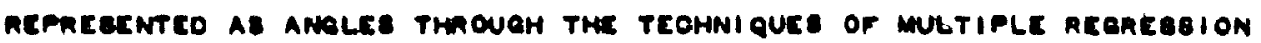

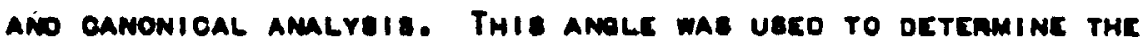

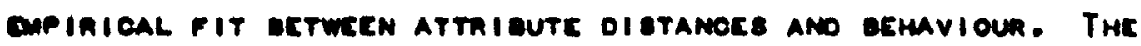
LINCARITY ABSUMPTION WIOENCO THE BOOPC OF BOOIAL-FIELD THEOAY,

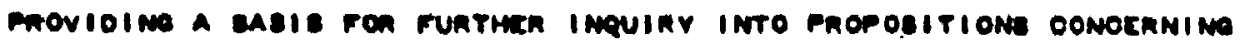
mis RELATIOWEHIP.

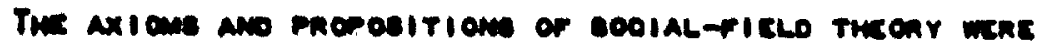




\begin{abstract}
usco to oevelon a susarquent theOAY, statua-ficlo theonY. THE

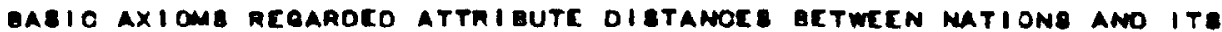

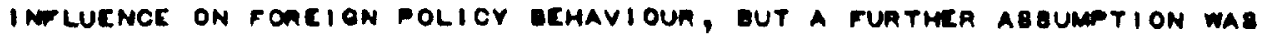
AOOEO; THAT 18, MATIONB IN A BTAATIFICO BYOTEM DEBIRE UPWARO MOALITY. THE heURISTIO BIONIFICANCE OF THIB AXION PEAMITTED THE OEVELOPMENT OF MORE AXIOMB ANO THEOREMS FOR THE BTUOY OF BTATUB

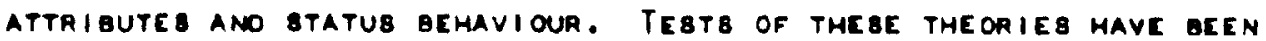
EXECUTEO, AND ARE OIBCUBSEO IN THE FOLLOWINE CHAPTER.
\end{abstract}

THE PRESENT REBEARCH PREBENTB AN ADOITIOMLL EXAMINATION OF THE CMPIRIOAL VALIOITY OF BOCIAL ANO BTATU8-FICLO THEORY. HOWTER, ITSA FIELD OF APPLICAPILITY IS ALTEAED BLIOHTLY FAOM OTHEA TEETS OF THE THEONIEA. HHILE THEBE TESTE CLAIM THAT A CEATAIN PEROENTAOE OF THE VARIANCE OF MATIONE' INTERNATIONAL BEHAVIOUR 18 EXPLAIMED OY ATTRIBUTE8, THIE THESIB SEEKE TO OIBTINOUISH THE ORIGINS OF EXPLAINEO VERQU8 THE UMEXPLAINED VARIANOE BV FOCUBINE ON MATIOMAL GEMAVIOUA IN A REOIONAL CONTEXT. THAT 18, MATIONB' OEOIBION-WMKERs PEACEIVE

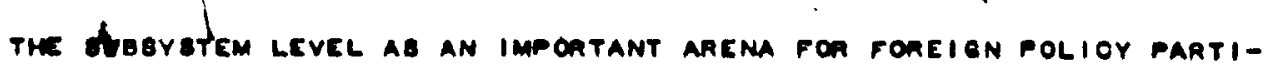

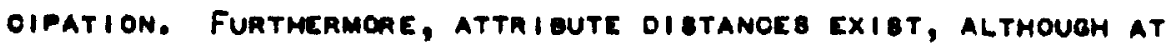
EMALLER MAONITUDES ANO OIRECTIONG RELATIVE TO MATIONO IN THE INTEAMATIONAL SYATEM AB A WhOLC. THEREFONE, THIS THEBIS EXPLONE THE ABILITY OF BOCIAL ANO BTATUB FILLO THEOAY TO EXPLAIN BEMAVIOUR AT A

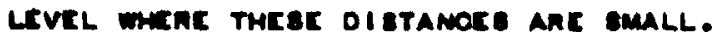

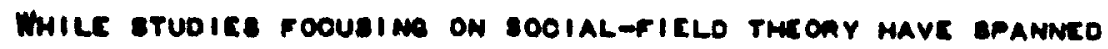
a Lanec ecoton or mirion, 16 antioles on etatub-ficlo theomy have

16. Eete ron example R. VAN ATta, mfiklo Theoner ano Matiomal-

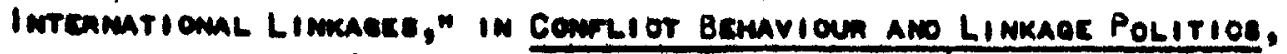
co. J. Wilkermerlo (New Yenke Davio Mokay Co., 1973), M. 208. 


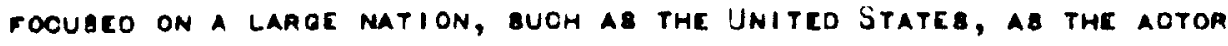
MUTION. CONBCQUENTLY ANY ATTRIBUTE DIBTANCE BCTWEEN THE ACTORmations ano the taroets have beEn laroe. TheacFore, thesc studies

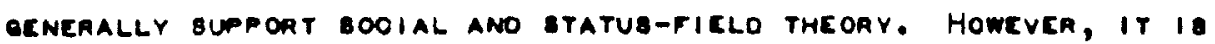
NOT KNOWN IF THE THEORIES EXPLAIN ONLY THE BEMAVIOUR IN OYADB WITH MAXIMUM DIETANCE, OR IF THEY OAN AOCOUNT FOR BEHAVIOUR IN OYAOB WITH BMal oIBTANOE8, THAT IB, MORE BYMMETRIC OYAOS. THIB THEBIB THEN PMOFOBE TO FOCUS ON THE8E MORE BYMMETRIO OYAO8, ANO IN PARTIOULAR OYAOB WICH ARE IN A REBION. THE LITEAATURE ON BUBBYateM LEVELB GUEQESTE THAT INTERACTION BETWEEN NATIONB IN A REQION IB IMPORTANT,

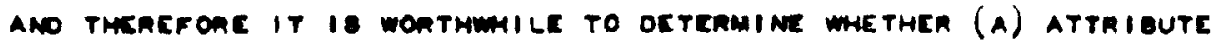

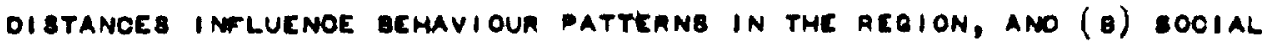

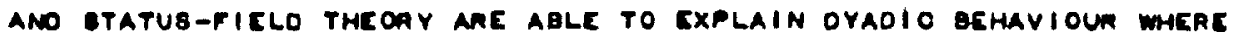

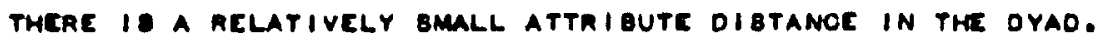
In APPLYINO BOCIAL ANO OTATUB-FIELO THEOAY TO A REBIOMAL

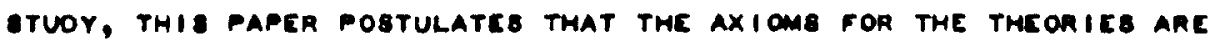
APPLIOABLE gaBioally to THE BEMAVIOUA PATTERNB OF THE 32 BLAOK AmIOAN NATIONB. THESE MATIONB ARE OHOSEN AS AN EXMMPLE OF A ONOUP OF EMLL MATIONE WHIOH DO INTEAAOT IN THE INTEANATIONAL OYTETEM OUT

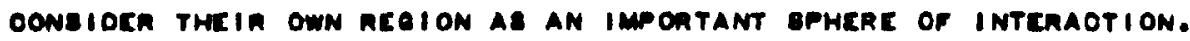

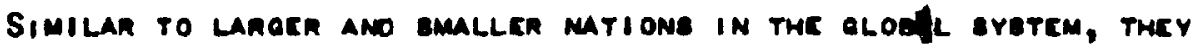

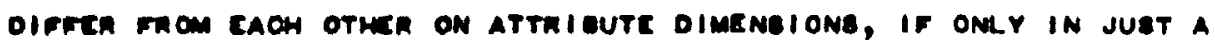

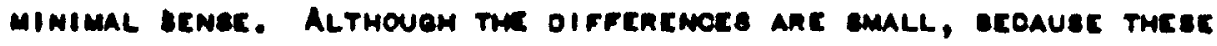

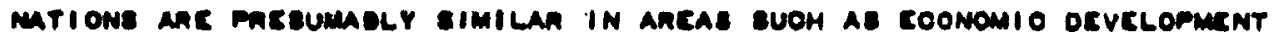

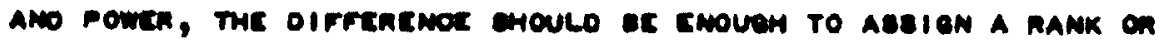
etatue to mucer mations in a BThatifico erotch. If sooial ano 


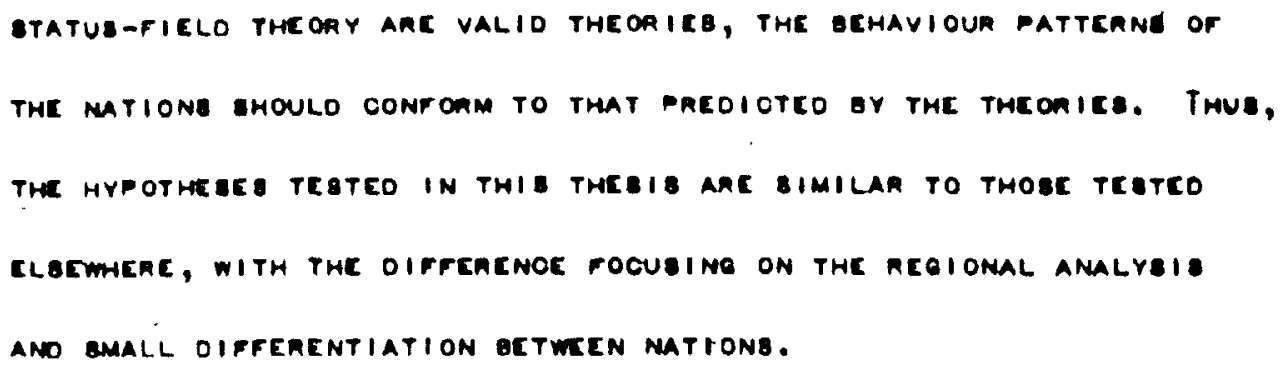

17. R. RUMmel, "U.S. Foncion Relatione," in Peacr, Wak ano

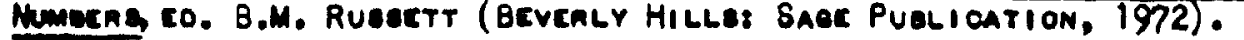

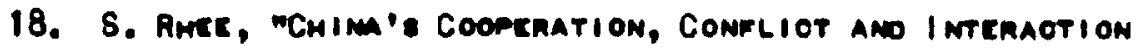
Bemavioun," in Aovanoing ano Contenolmo Ampronomes to the Studey or Chimear foncion Polloy, ro. R.L. Dial (Halifax: Centar ron foncien

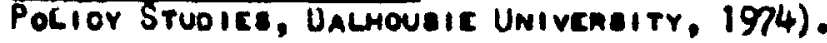

19. R. VAn ATta, "ficlo Theony ano Natiomul-I nTtenmatiomal Li meaces," in Conrllot Bermavi oun ano Limkaer Poultios, co. J. WILKennelo (New Yonxs Oavio nokay Co., T973). 


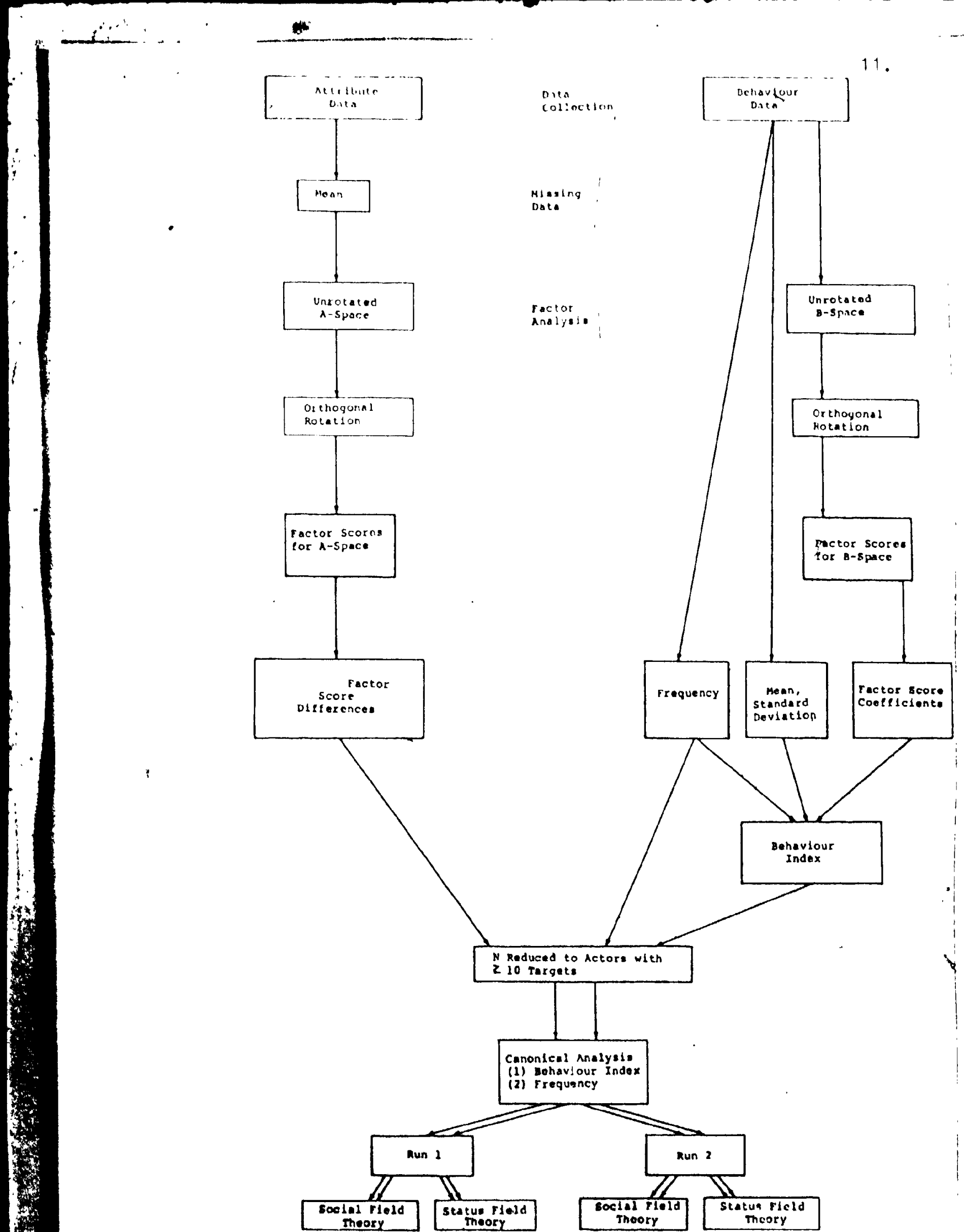

FICURE I. NESEATCH D. SIGN 


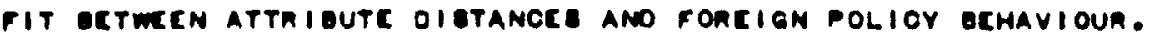

FamLly, two majon moorle aAe cxaminco. THE rinet, calleo

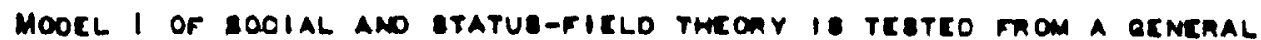

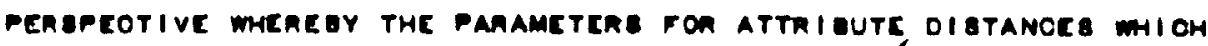

INFLUENOE DEHAVIOUR AAE ABQUMCO TO BE CONATANT ACAOBS ALL OYAOB.

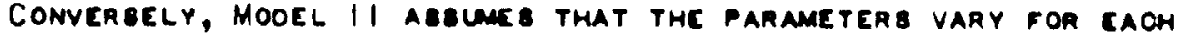

ACTOR ON EACH ATTRIDUTE DIMENEION. THUS, MHILC THERE IS ONLY ONE

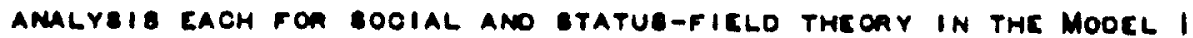

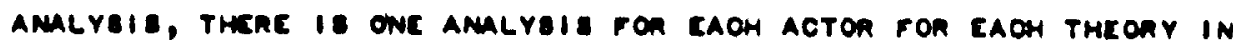

THE scoONO MOOLL. THE OOMPLKXITIES OF THIB ARE DIBCUESEO IN OAEATER

detail in Chapten 4.

IN THE AMALYSIS IT 18 EXPEOTED THAT ACOULTE COMPARABLE TO

OTHER TESTS WILL EL POUNO. IT IE mUTHER EXPEOTEO THAT, ALTHOUEH

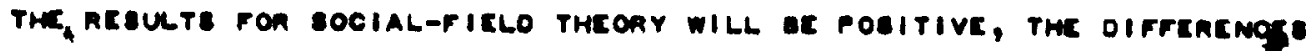

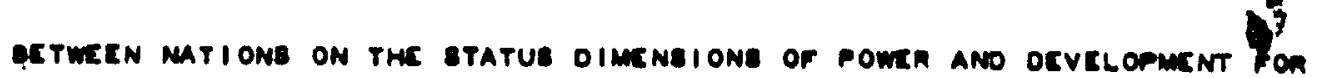

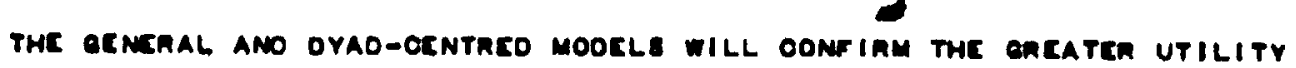

OF ETATUSAIELO THEONY IN THE EXPLAMATION OF OCMAVIOUN PATtCRNE.

IT 1 E EXPEOTEO ALOO THAT THE ACBULT WILL INOIOATE THE VALIOITY OF

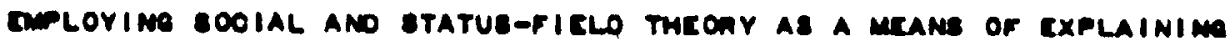

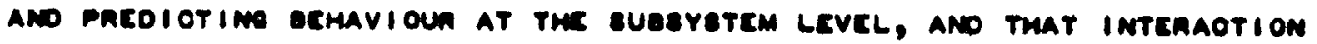

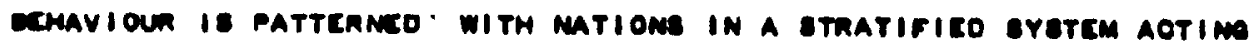

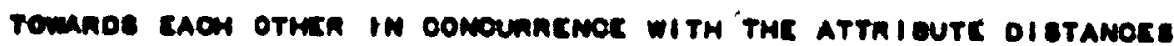
extrucen THeM. 


\section{ChaptKa 2}

THE DEVELOHMENT OF STATUS-FIELO THEORY

THEOAY-BUILOINE MUBT OTART FROM BIMPLE ANO BABIO ABBUMPTIONB ANO THROUEH LOOIOAL OEOUCTION ELAgOMATE GRAOUALLY a THEOAY, THE hYPOTHEBES OF WHIOH MAY OE TEBTED EMPIRICALLY. THIS THEQIS OOMMEMOEB THEN, WITM ATTRIQUTE THEOAY, THE CATALYET FOR THE BASIO ABBUMPTIONE OF FILLO THEURY.

ATTAIBUTE THEORY IB THE SOUNCE OF A OHAIN OF THEORIE DABEO ON THE AESUMPTION THAT THE ATTRIQUTES OF A NATION IN EITHER A OIREET ON INDIREOT FAEMION IMFLUEMOE THE EXTERMAL GEMAVIOUR OF THAT MATION.

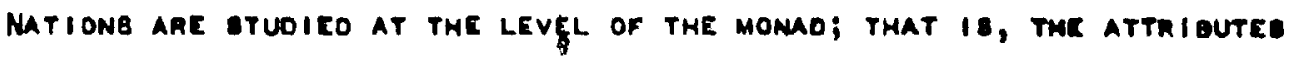
OF A MATION SHOULO AOOOUNT FOR ITB EEHAVIOUR TO ALL TAROET ON OEJEOT

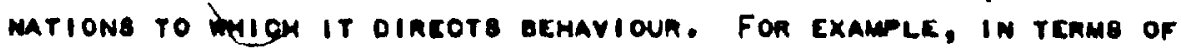
TRAOITIOMAL REOEAMOH IN INTEAMATIOMAL RELATIONE, ATTRIOUTE TMEOAY TAKES THE FOAM THAT 10 MATIONE TENO TO PUASUE OCATAIN OOUNECE OF AOTION.

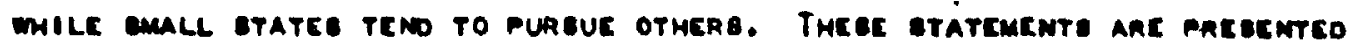

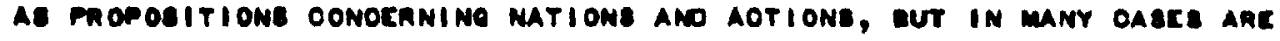

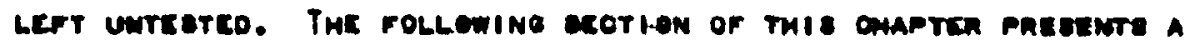
FAIRLY OETAILEg DELONIPTION OF THIS TAAOITIOMAL UEAER OF ATTRIDUTC

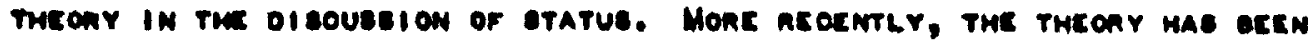

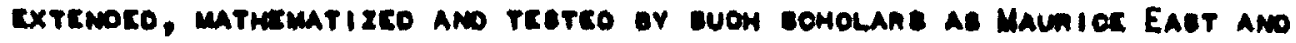

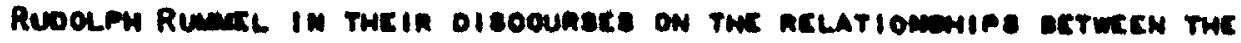

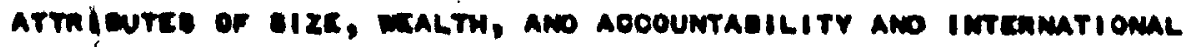




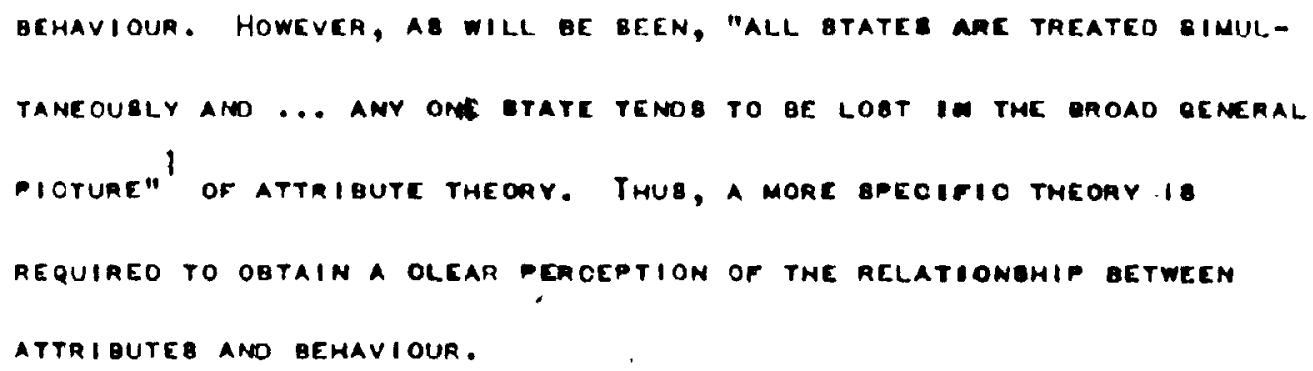

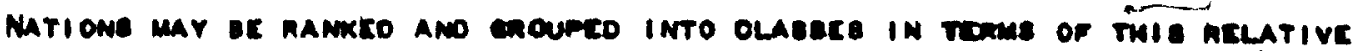

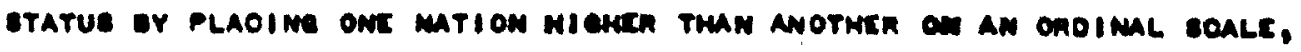

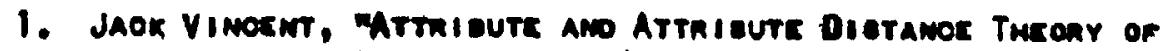

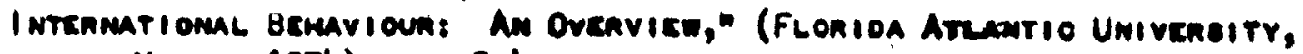
misco, manow, 1974), Po. 3-4.

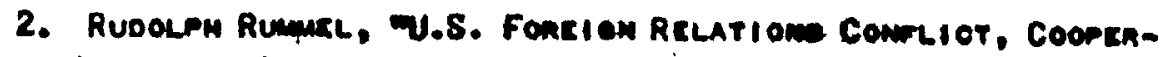

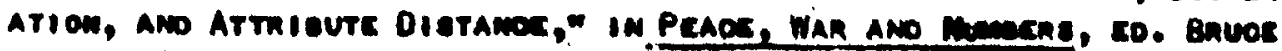

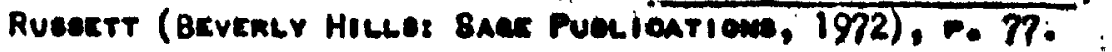




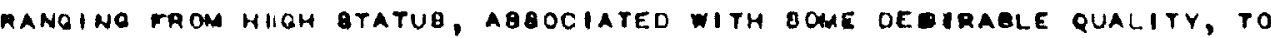
Low etatuB.

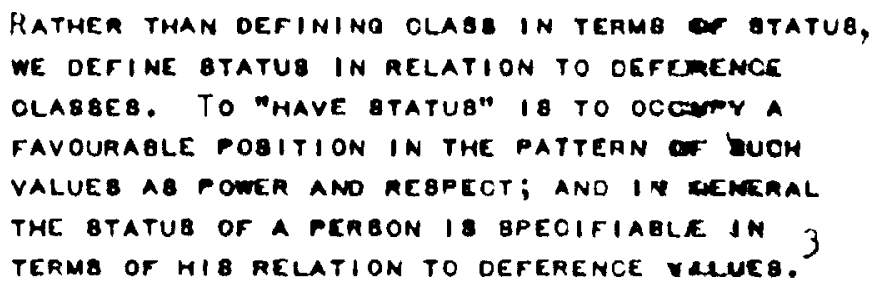

IT 18 AB8UMED, THAOUQH THE BABIO A8BUMPTIOM DF ATTRIHUTE THEORY,

THAT THE DIBTANCE BETWEN MTIONB ON BTATUB WILL GESAT IN DIFFERENT

FORMS OF INTERNATIONAL GEMAVIOUA. THREE OIFFERENT APPROAOHEB HAVE GEEN

EMPLOYED IN DETERMININO WHTHER IN FACT THIB IS THE OABE. THEBE ARE:

(A) THE TAADITIOMAL MOOE OF CLABEIFYING mTIONE INTO GRCAT, MIDOLE and Small Powens:

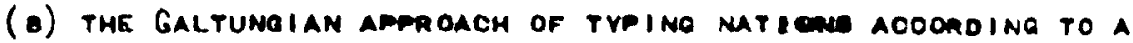
-cheme bimilar to the above, ut more preciac in casasifrine the

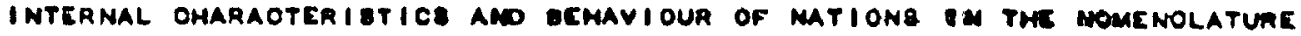
TOPDOQ, MIDOLEOOQ ANO UnOEnODa;

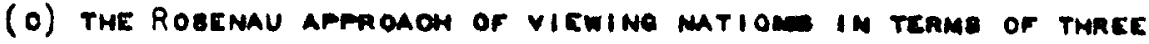

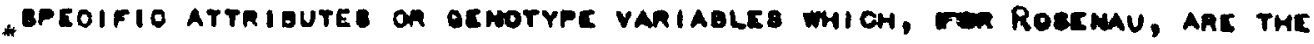

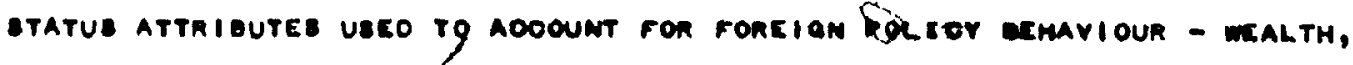
4 HzE Ano pomen.

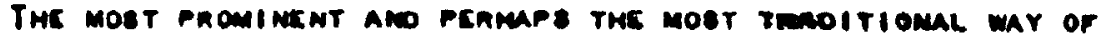

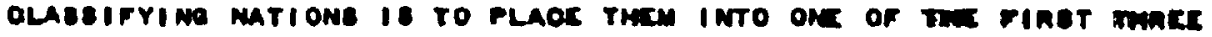

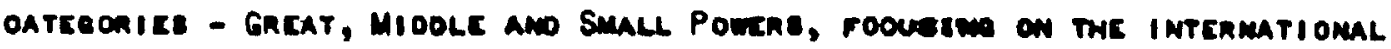

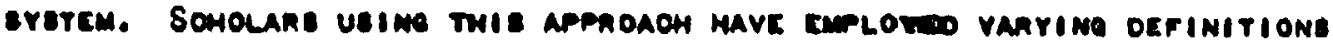

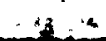

3. Harolo Lasswell ano A. Karlam, Powen alo Sooictry (New Havern: , Yale Univgneity Pares, 1961), me. 66-67. 


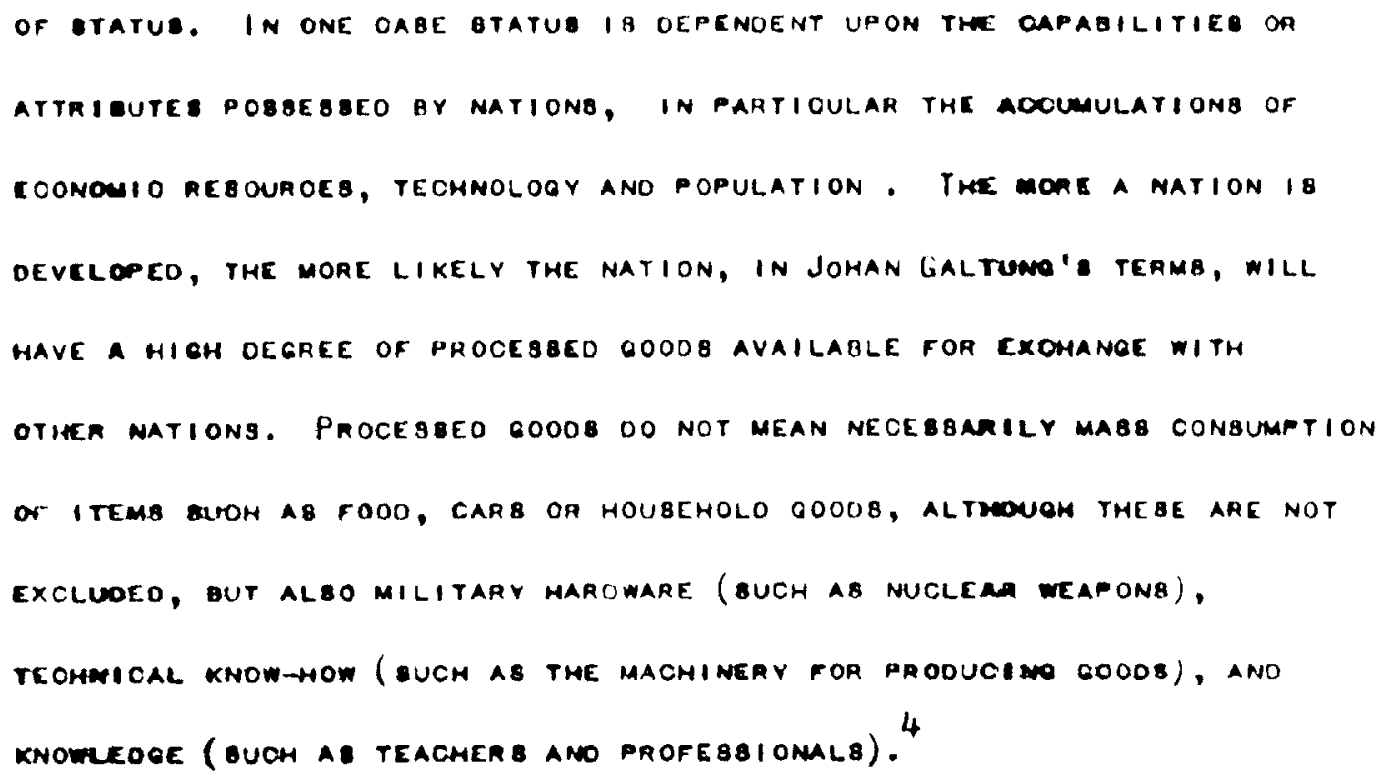

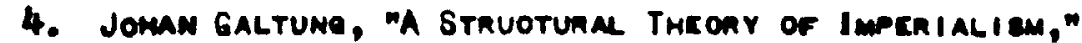
Jounmal of PEAOC REecaron, 8 (1971): 104.

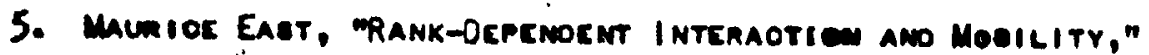
Peace Recanow Sooletr, PAreng 14 (1970): 114.

6. 1010., . 116. 

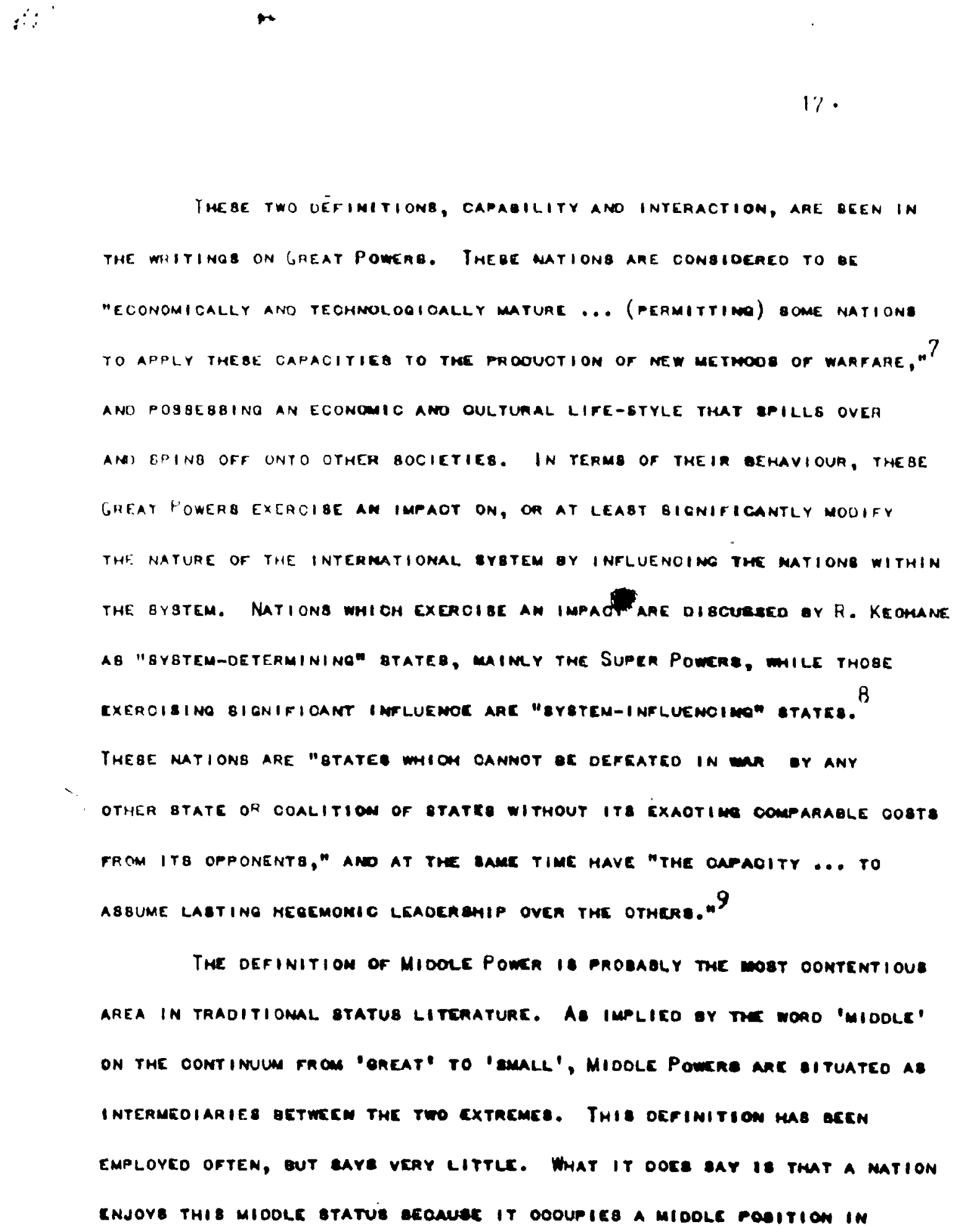

7. G. Lacos, Imtenmatiomal Sthatifioation ano Unoknocryelooco Countrice (Chapel HILl: Univensity of Nonth Canolim Pacel, 1963), P. 12.

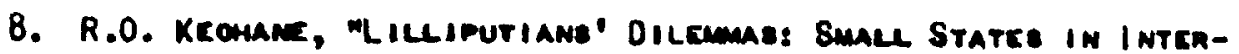
NATIONAL POLITIOE," InTEMmatiomal ORQANIZATION 23 (Serim 1969): 295.

9. Davio Vital, Twe Sunviyal of Small States (Wagmineton, D.C.: Publio Afralas Phises, 1971$),$ m. 4-5. 
between Centre ano Periphert mere tme decaee OF PROCESBINE OF ITS EXPORT PRODUCTE IS CONCERNED.

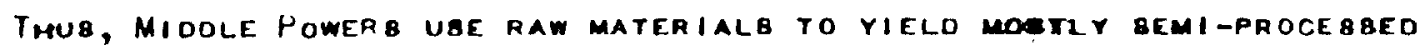
COOOB, BELL THEQE TO OTHER MATIONB, THEN QUUY BAOK THE MANUFACTUREO

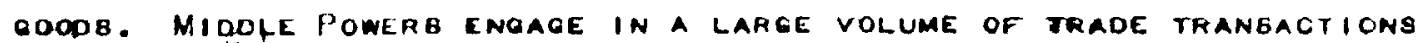

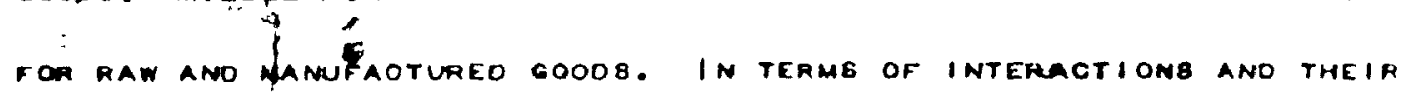
aBility to fE a leader of other mations, they are mot capable of

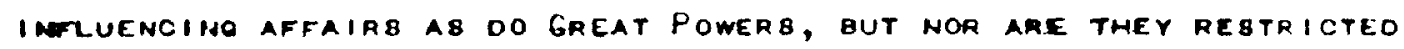
FROA ANY TYPE OF INFLUENOE AT ALL. THEY ARE "BYaTEM-ÁFFEOTIIH" MATION8. 13 RATHER THAN ATTEMPT! WO TO ABgERT BOME WFLUENOE INDIVIDUALLY, THEY ARE ABLE TO EY,ERT BOME IMPAOT OY WORKINO ON A EPECIFIC PROBLEM, OR THEOVEH BOME CAOUP OR ORGANIZATION.

UNLIKE THE GREAT POWER, MIODLE POWEAS ARE NOT UBUALLY CAPABLE OR DEgIROUB OF ATTEMPTINO TO ALTER THE INTERMATIOMAL RELATIONB OF WEAKER etaTEB. THEIR INVOLVEMENT IB UEUALLY LIMITEO TO BPECIFIO KINOS OF EOONOMIO, MILITARY ANO POLITIOAL PARTICIPATION IN IBOLATED COUNTRIES.

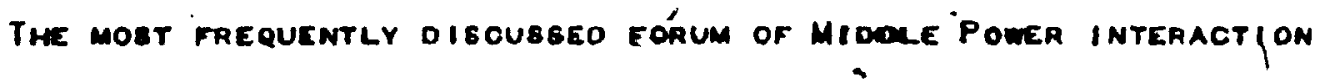

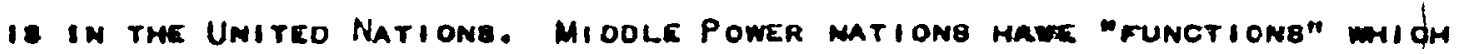

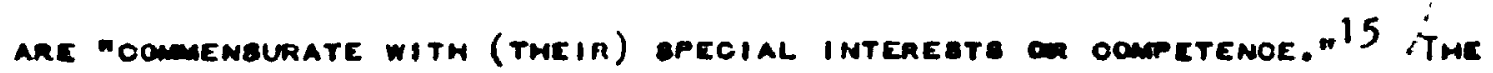
AREAS OF OOMPETENCE INCLUDE STRATEQIO LOCATION, ECOMOMIO REBOUROCE, $\gamma$

TEOMMLOOJOAL SKILLS ANO MILITARY AOEQUACY, ATTRIEUTER POBgEABEO IN

12. Galtune, mimpeaialiom," p. 104.

13. Keomanc, "Lilliputiane" Dilemas," P. 296.

14. L. CAMTOAI ANO S. SPICEEL, "THE INTtPanATIOMAL SYeTEM OF Rcesone, in Reolonal Politios amo Wonlo ORoer. . cos, R. FalK amo 5. Mnolonitz (SAN FaAnolecoz Faceman ANO Co., 1973), 0.14.

15. Jonn Houme, Betren PART or VALOUn (Tomontos Canleton Licaner, 1970), P. 17. 


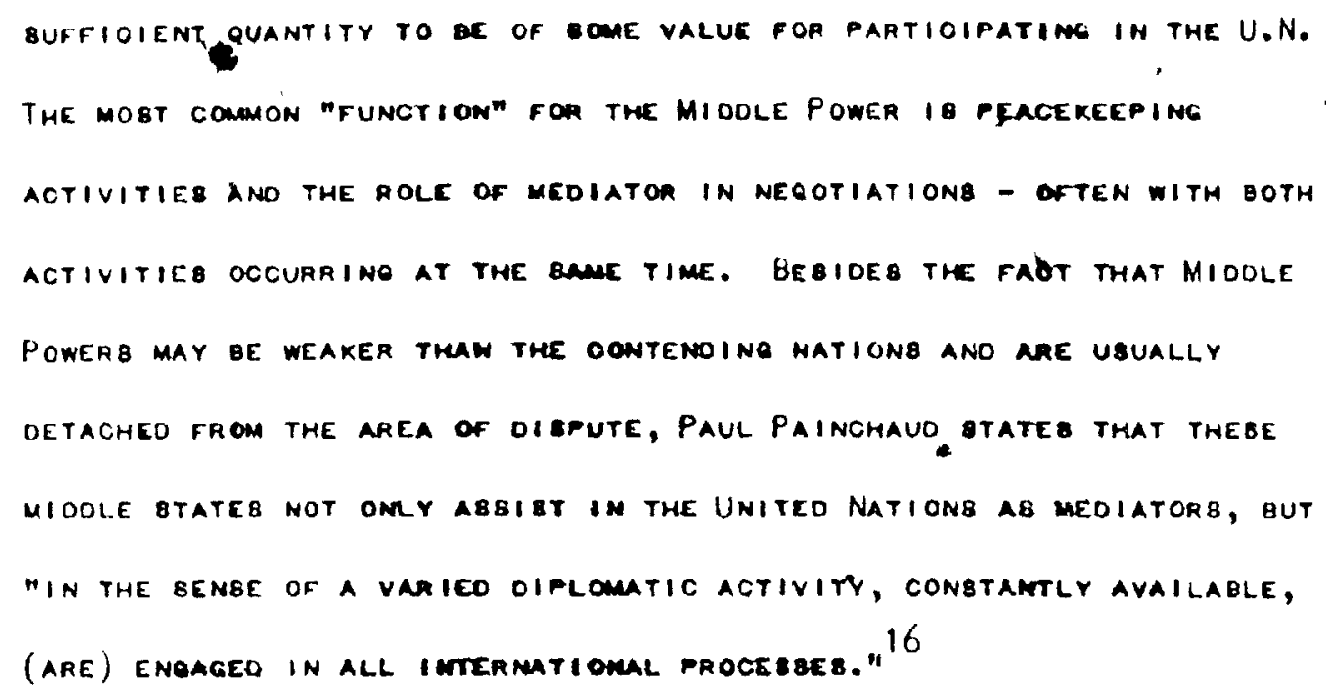

THESE FUNCTIONB AS PEACEKEEPERS ARE CONGRUOUS TO THE PERCEIVEO 'status' of a Miode Power mation. They aAe perceiveo as fainly AFFLUENT, BUT NOT RICH, ANO AE A LIAIBON BETWEEN CONTEMOINO FACTIONB, WHETHER RIOH OR POOR, CAPITALIBT OA COMAUNIBT, BABED ON THEBE ATTRI\}:

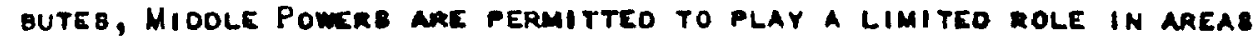
OUTBIOE THEIR OWN OOUMTRY.

AT THE Opposite ENo of the contimum to the Cheat Power is the

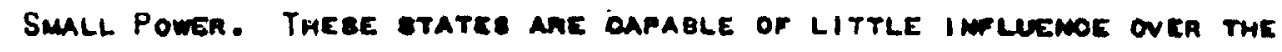
SYBTEM-WIDE FOACES WHION AFFEOT THEM, NOR ARE THEY ACLE TO WHKE AN

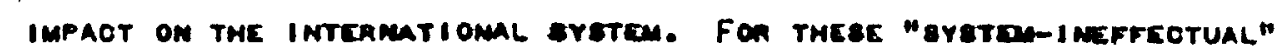

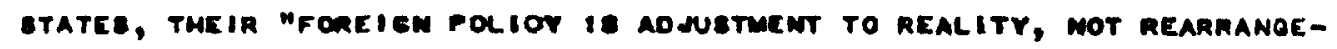

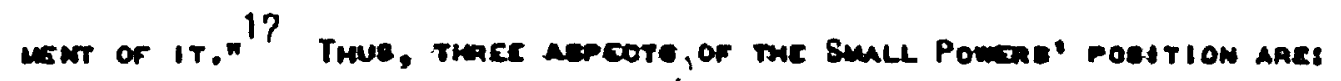

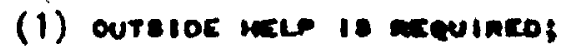

(2) THE state wa a manom magin or safery at

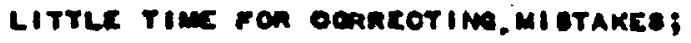

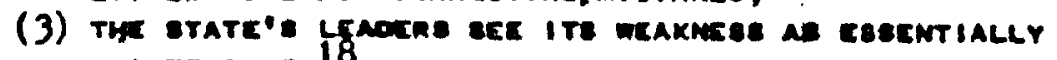
umatrenaece. 18

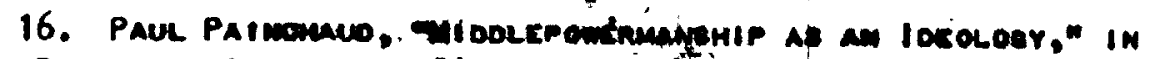
GAMAN' ROLE, Eo. Gamom, F. 31.

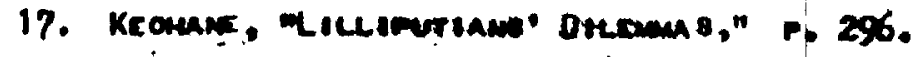

18. $1010 . . .20 \ddot{3}$. 



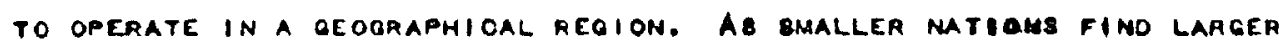
MTIONB ATTEMPTING TO IMPINGE UPON THEIR POLIOIEB (DOAESTIO AB WELL AB FOREIGN), IT MAY BE TO THEIR AOVANTAEE TO COMBINE INFORMATION OATHERIMG ANO FOREIGN POLIOY CONOUCT. BY BUCH A FORM OF COLLECTIVE action, Small POWER 8 may be able to withotano the efFonts to influence THEIR BEHAVIOUR OY OTHER NATIONB. THU8,

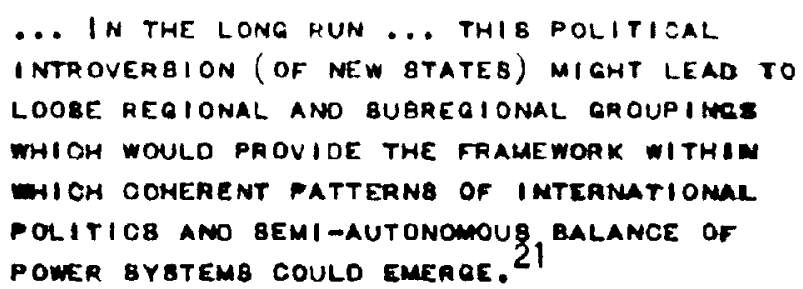

The ambiguity in deFining Gaeat, Midole ano sancl Pomer 18 EVIDEET. EVEN IF A PLAUBIBLE DIBTINOTION OOULO BE DRAWN ERTWEEN THEM, THE PROBLEM OF THE DFFFERENTIAL GETWEEN BELFOABSIONED ANO IMTERMATIONALLY ASCRIBED BTATUB BTILL REMAIMS. ON THE OTHER MAN, RHTRE AAE MATIONS WICH WERE ONOE ACCOAOCO A OERTAIN BTATUS ANO HAVE METAINEO TMAT BTATUS ALTHONOH THEY NO LONOCR MEET THE ORITERIA POR TMAT POOITION. GREAT BAITAIN, FOR EXAMPLE, RELIES ON ITS PABT PERFORMANCQ TO RETAIN ITA

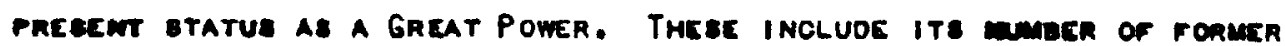
-

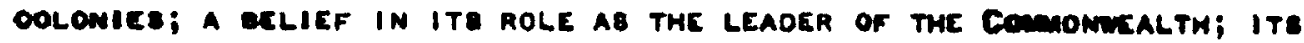

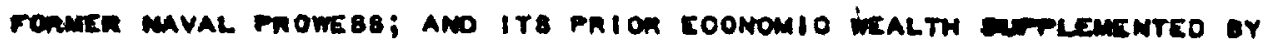

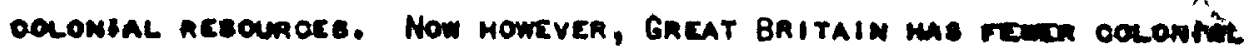

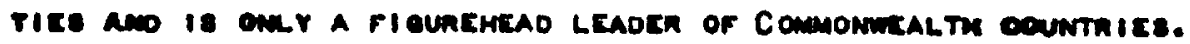
FUnTmBRMOAE, ITE MILITARY CAPAOITY MAS DECLIMED OUUETANTIALLY TO OME

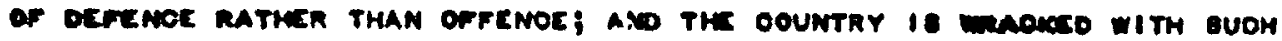
-

21. 18í., . 303. 


\begin{abstract}
ECDNOMIC ANO INTERNAL PROBLEMB AB A LOW LEVEL OF EELF-BUFFIOIENCY, LABOUR TROUBLEB ANO A LAOK OF INTERNAL COHEBION VIB-A-VIS BEOTARIAN

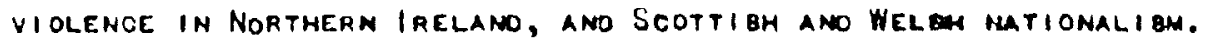
GREAT BRITAIN. THEN, I8 a GREA POWER ONLY IN TERMB OF PABT PREBTIGE, NOT IN ABBOLUTE TERMB OF THE POWER IT NOW POBBEBSEG. SOME-
\end{abstract} THING MORE BUBSTANTIAL THEN I8 REQUIRED IN A DEFINITION OF BTATUB. THE 8ECONO APPROACH FOR CLABSIFYING NATIOME ACCOROING TO THEIR

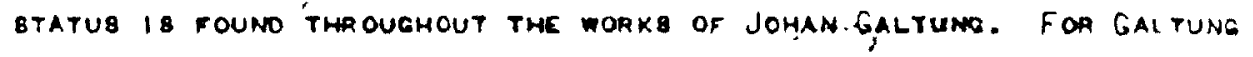
DHE BTATUB OF A NATION 18 DEBCRIBED BY THE CHARAOTLAIBTICS OF TME BTATE, WHICH ARE A VIBIBLE MEANE OF IOENTIFYINO MATIONB. OMGE TMEBE GHARAOTERI8TIC8 ape OIVEN VALUES BPEOIFIO TO A NATION, THE DOCIAL POSITION OF TMT NATION VIB-A-VIE OTHEA MAY AE IOENTIFIED. THIB GOOIAL POBITION BEOOMES THE BASI8 FOR IMTERACTION IN A BYBTEM OF WATIONE. GALTUNO OOMMENCE CLAESIFYINO BOOIAL POSITIONS OY OIVIOIM BOOIETY INTO THREE

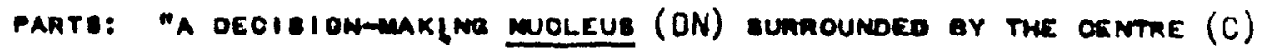
OF THE BOOIAL ETRUOTURE, MHION AGAIN 18 SURAOUNOES GY THE PERIPHERY(P)," WITH THE ABBUMTION TMAT MTE BOCIAL CENTRE OCOUPIES POBITIONS THAT ARE $800 I A L L Y$ NEWANDEO, ANO THE BOOIAL PEAIPHEAY POSITIONS THAT ARE LEB8

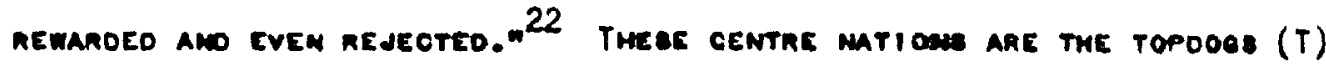

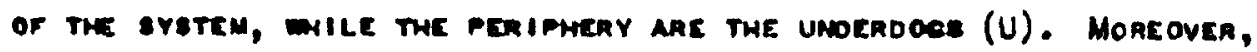

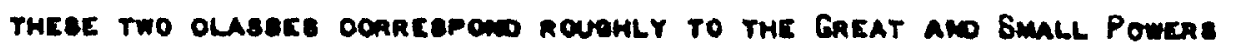

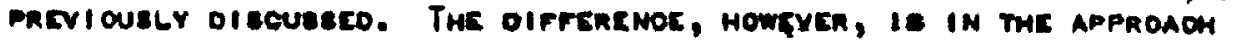

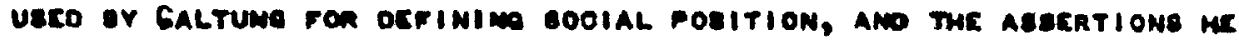

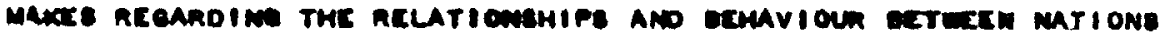

22. J. Galtuma, "Foncian Pollor Opinion al a Funotion of Soolal

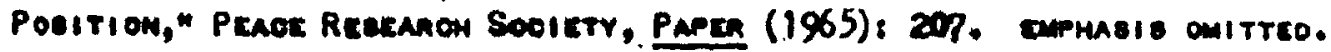


POBBEBSING THE BAME OR. DIFFERENT POBITIONB.

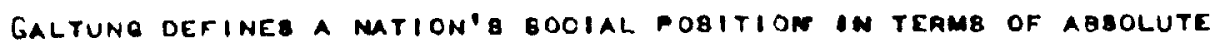
PROPERTIEB BUCH AS BOCIETAL IMOICATOAB OF EOUCATIOM AMO MEALTH. 23 THE BYBTEM IN WHICH THEQE MATIONB INTERACT 18 BTRATIFIED ACOOROING TO THE 'RANK OF a NATION ON THEBE ATTRIBUTE DIMENBIONB. TMUR, GaLTUNG OCFIMEB RAMK OIMENBION AB

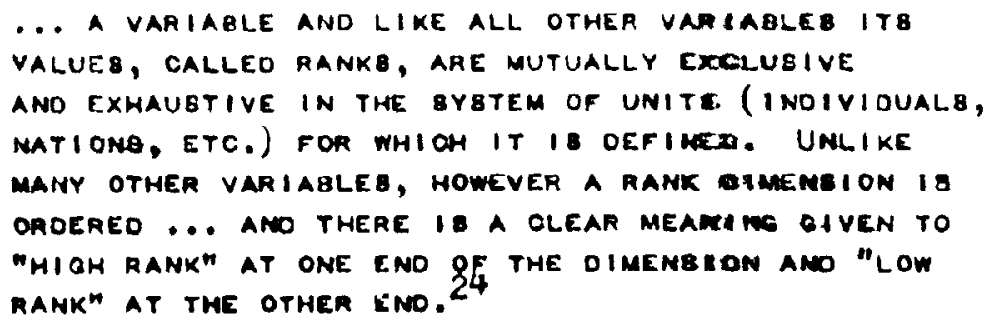

ONOE THE RANK DIMENBIONB ARE dETERMINEO EMPIRICALLY, THE DIMENBIONB MAY

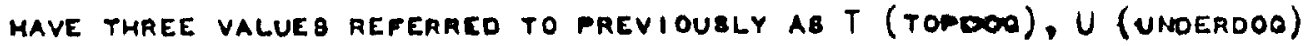
ANO A FINAL M (MIOOLEOOQ). AB IN MOBT BOCIAL BITUATIONB, IT IB ABSUMED THAT THE T OOOIAL POSITION IS BOUGHT ANO IE BOOIALLY REMAROEO, WHILE THE U 800 IAL POSITION IS AVOIDSO AMD REJEÓtED. MOREOVER, "THE BOOIETY BELONOE TO THE OENTAE." 25

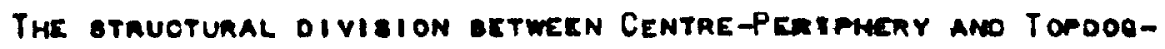
UNOEROOQ IS THE BABIB FON DIFFERENT MINTERAOTION MOLATIONBN BETWEEN MTIONS. GALTUNO BUEOESTE THAT THE FIVE MAJON FOBME OF THIO RELATIONEHIP ARE THE ECONOMIO, POLITIOAL, MILITARY, COMMUMLOATION ANO OULTURAL

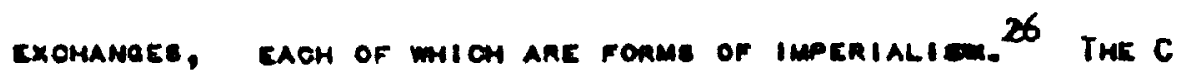

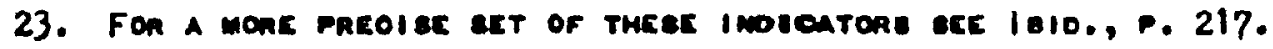

24. J. Galtume, "I mT Eamational Relatione mo Inteamational

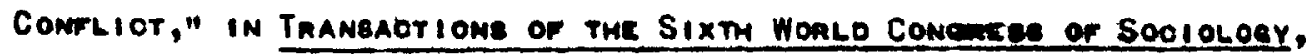

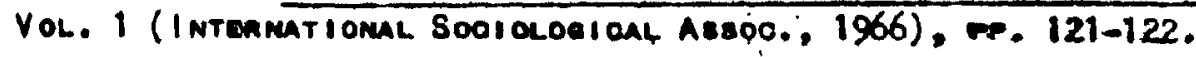

25. Galtune, "Foneleh POLior," 206.

26. Fon a monc ortaluco oiscuselon or ras reve peame of imponialien, sec biqtuneo, "Impenialism," npe. 91-93. 


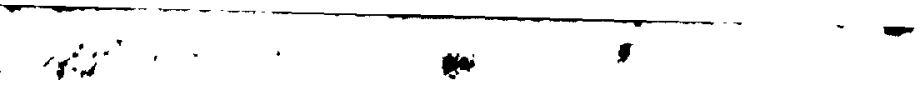

25.

DIBBEMIMATES ATTITUDEB AND KNOWLEDEE, FOR EXAMPLE, ONE OIVIBION 18 getweEn teacherg (The C) who taAnbmit the cultural moreb from the T to the U ano the learnerb (The P). ThuB, in any trPe of interaction THE CENTRE HAB THE DONIMANT POBITION, WHEREAB THE PCRIPHERY IB IN A BUGORDINATE ROLE.

GALTUNG PROPOBEB A BTRUCTURE FOR BPECIFIC TYPES OF INTERACTIONB BETWEEN NATIONB WITH DIFFEAENT OTATUGE,. THE GTRUCTUAE MOBT COMMONLY USED 1 G THE FEUDAL INTERACTION BTRUCTURE CHARACTERIZEO BY A COMPLFTE DIVIBION BETWEEN THE TOPDOQ AND UNDERDOQ. HERE, COMPLETE RANKCONCORDANCE EXI8TB amome the nationg IN THE C ANO LIKEWIBE IN THE P WITH ALL MATIONB RAMEED THE gMME WAY ON TME RANK OIMENBIONB. FUPTHER, NO INTERACTION EXIBTB BETWEEN UNDERDOOS, AND LITTLE BETWEEN UNDEROOGB ANO TOPOOES, BUT THEAE 18 A GAEAT DEAL OF INTERAOTION OETWEEN TOPOOGS. THUS, THE BVSTEM OF INTERACTION 18 INTERAOTION-DEPENOENT. 27 THIB BTRUOTUAE IS REINFORCEO BY POBITIVE RELDBAOK. SIMOE TWE AMOUNT OF INTERAOTION 18 IMOICATIVE OF THE SOCIAL POSITION A MATION HOLOB, IT WILL BEEK TO MAINTAIN ITB FOBITION ANO TME BTATUE QUO OF MHE BYSTEM BY

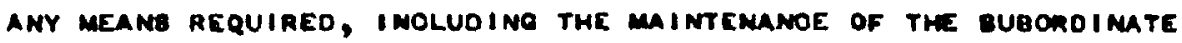
position of the peaiphear. FuRtheamone, the mone the C has, tME MORE IT WILL CET, THEREGY IMCAEABING ITE INTERAOTION TO MAINTAIN ANO I MOREABE ITE POBITION. A T WILL PREFER-TO INTDACT WITH OTHER T'S aEOAUEE It IS ABLE TO ATTAIN HONE REMAROS, IN TORM OF ADOEO REBOURCES, THAN THROUQH IMTEAACTION WITH A U. THE OMLY TIME A T WILL INTERAOT

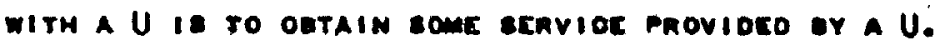

27. J. Galtume, "Rank ano 800ial Imtenation," in Sooial Imeony

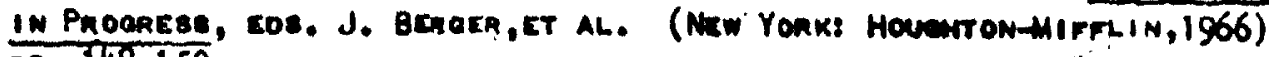
Pe. 148-150. 
IN THIB CONTEXT THE SIGNIFICANCE IB THAT THE BECONO CONOITION (INTERAOTION-OEPENOENCE) OF A FEUDAL BYOTEM WILL REINFORCE THE FIRAT CONOITION (RANK CONCORDANCE) PERHAPB JUAT AB MUCH AB THE FIRST CONO TION WILL REINFOROE THE BECOND CONOITION. 28

THUB THE BYBTEM IN ITG OIRCULAR COMCEPTION 18 A VERY STABLE STRUOTURE.

The hemaviour exchanged betweEn mations in the fevoal bTRUCTURE

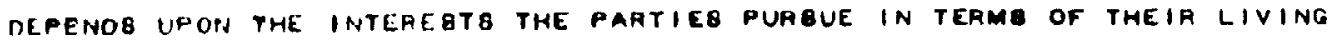
OONDITIONB - LC, MEABUREO OY INOIOATORB BIMILAR TO THE BOCIAL POBITION OF NATIONB. WHERE THERE 18 a QAP IN THE LC BETWEen mations, that 18 ONE

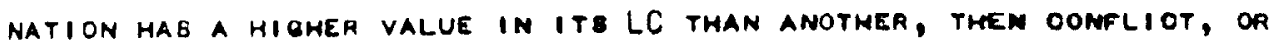
OIBMARMONY OF INTEREBT TAKE PLACE. WMERE THERE IB MaRMONY OF INTEREBT, NO CONFLIOT OOCURB. 29

COOPERATION OCCUAB WHEN MATIONB ARE PURBUINO DOAL OUCH AB EOONOMIO GROWTH AND BOCIAL DEVELOPMENT WHIOH MAY LEAO MATIONE INTO A MIQMER RANK COMPARIBON WITH OTMER NATIONA. COOPEAATION IS BAEEO ON EXCHANGE OF 8 OMETHINO WHIOH HAS AN INOAEABED VALUE FON THE OTHER MEOCBBARY TO ATTAIN THIB HIOH RANK. 30 HOWEVER, IN EITUATIONB MMERE THE MATION GAINB TO THE EXTEMT THAT IT WILL BE TO THE OETAIMENT OF ANOTHER, OONFLIOT ARIBES ANO IN EXYREME FORM MAY LEAO TO AOQRESBION BY THE OPPREBBED NATION.

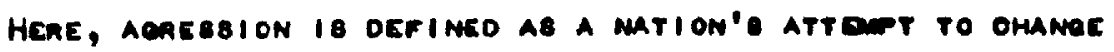
THE EXIBTINR BTRUCTURE OF THE BVBTEM IN OROER TO ATTAIN OCEIREO DOALE.

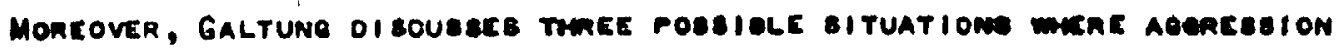

28. 1010., .. 151.

29. GALTUNe, "Imigenialiem," pr. 81-82.

30. J. Galtune, "a Tmcony or Prackful Coopemation," Coorenation in Europe $3(1970)$ : 9-18: 


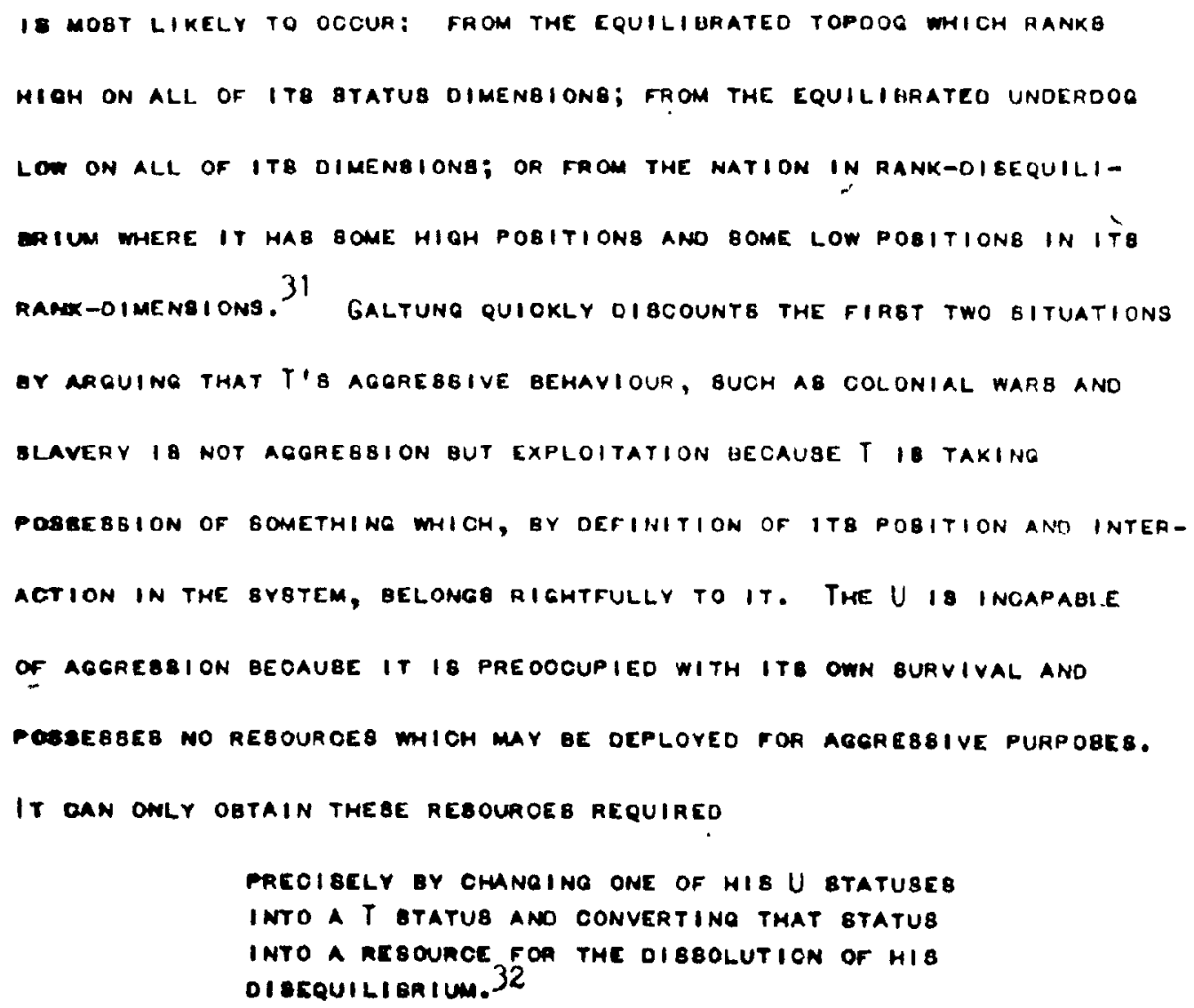

TINU TME RANK-OIBCQUILIBRATEO NATION 18 MOAE LIKELY TO BE AGQREBBIVE GCOAUEE, ON THE ABEUMPTION THAT NATIONB GEEK THE MIQHER BTATUB ANO THE RLIMARDS COMARNBURATE WITH THE POBITION, A MATION WITH ONE HIOH ANO ONC Lem POEITION, TU, WILL ATTEMPt TO OMANoE ITE U ATATUB TO A T FOATION. THue, maEseune is DUILT UP FOA MOBILITY TO EQUALIzE THE OIBEQUILIBRATEO MATI ONE' MANK DIMENSIONE.

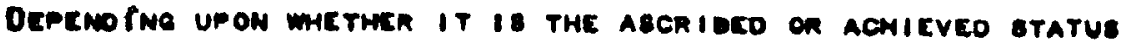

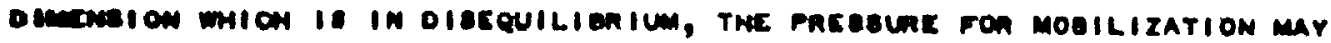

31. J. Galtuma, "A Stauotural Theony of Acareselow," JouramL or Peace Reeranon 1 (1964): 97. .

32. 1010., P. 98. 
BECOME MANIFE HAS OVEMAOHIEVED, THET IA, IT HAS ACHIEVED A BOCIAL POBITION WHIOH IT WA8 NOT EIVEN AT UIRTM, AND WHIOH SOCIETY DOE NOT RCOOQNIZE, THE eyotem is Olameo ró the overachiever'o lack of mogility ano ite

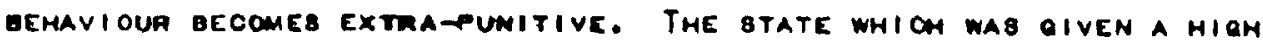
ABCRIEED BTATUS, BUT MAS AONIEVEO LE8B THAN WHAT WAB LXPECTED, CONYERTB IT8 AQQREBBIVE EEEL MASB INTO INTAA-PUNITIVE MEABUAEB. THUS, THE UNOERACHIEVER IB PITTED ARAINET THE OVENACHIEVER A8 THE LATTER ATtEMPTE TO TAKE OVER THE BOCIAL POAITION OF THE FORMER IN A BYatEM whERC "ONE" QANN 18 THE OTHERS LOSE. 33

THE MIOOLEDOS MA A POAITION IN THIS ETRUOTURE OF INTERACTION.

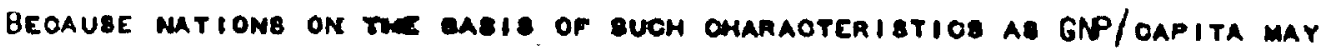
DE PLACEO ON a CONTIBNM, THS M ALBO hAB A POBITION RLLATIVE TO OTHEA

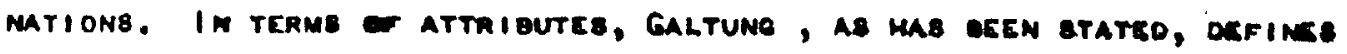

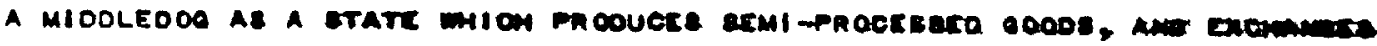

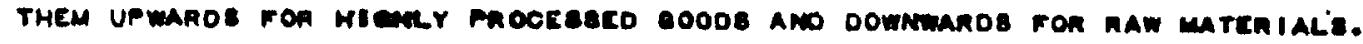

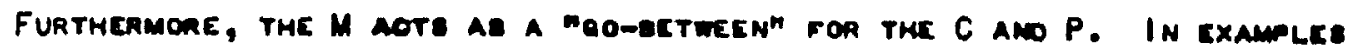

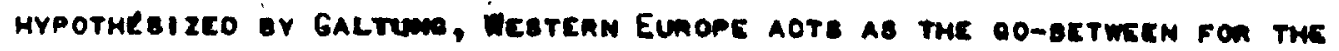

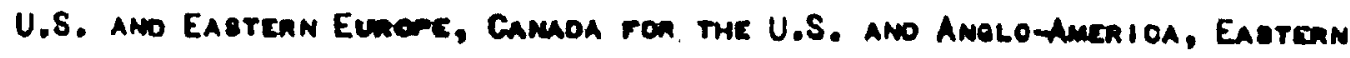
Eunope ron Wretenn Eunope awo twe Soviet UNION. 34

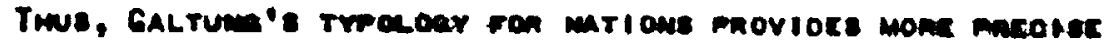

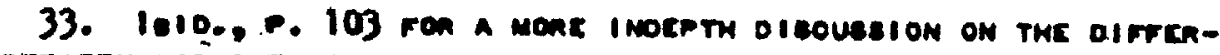

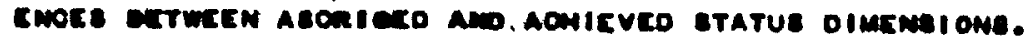

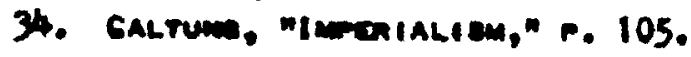




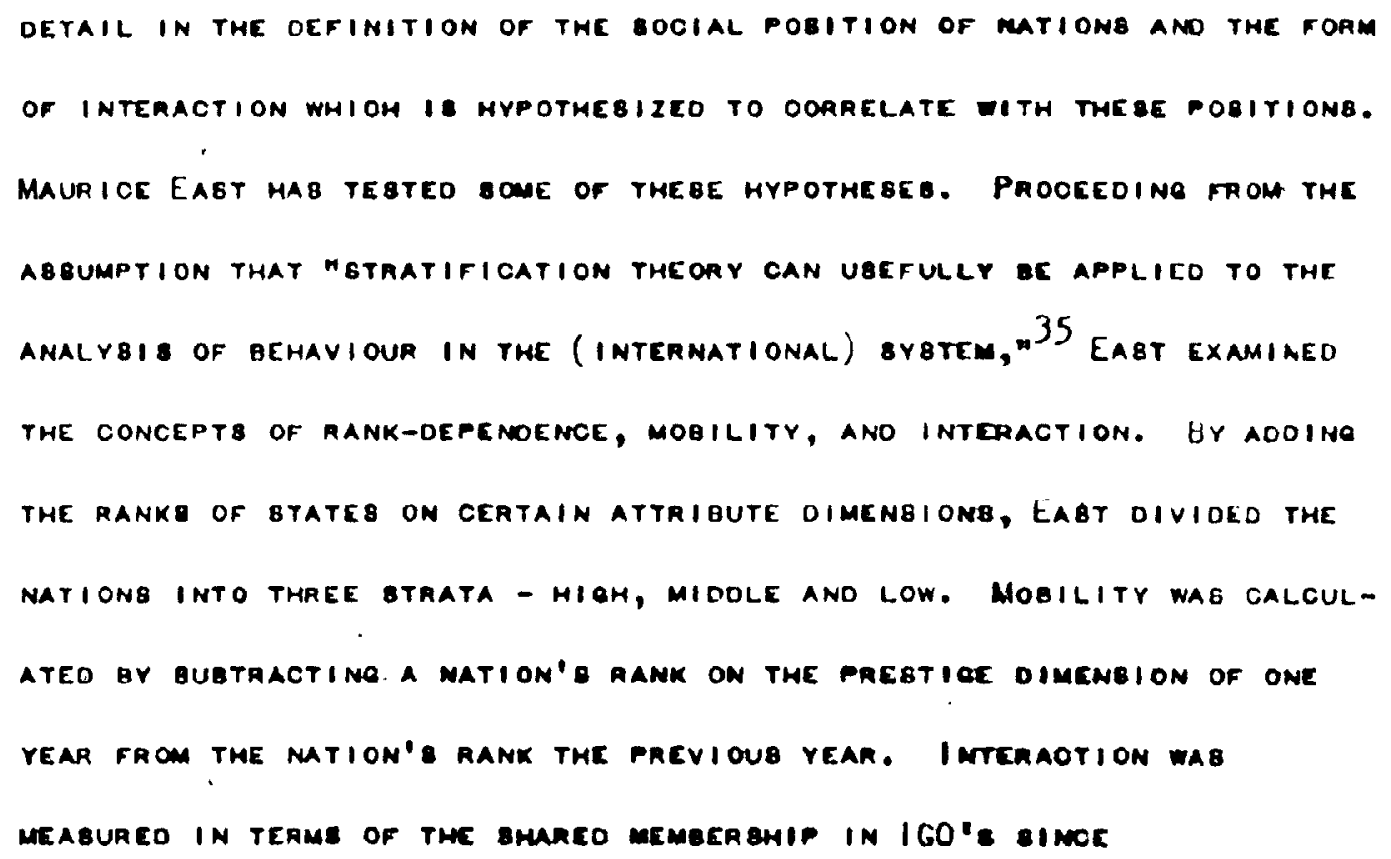

35. Ealet, mank Oepenocm," p. 113.

36. $1810 ., 120$. 
in.

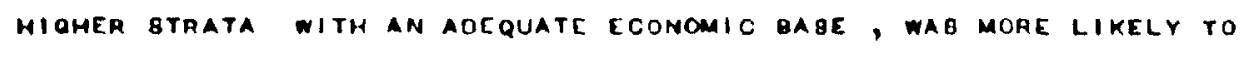

EECOME INVOLVEO IN INTERNATIONAL POLITICB.

The olabical and Galtungian approaches to clasgityino nationg

OEMONBTRATE THE ATTRIBUTE ANO FOREION POLICY BEHAVIOUR VARIATIONB

DETWEEN THE GROUPB, WITH THE FORMEA REING VERY GLLUBIVE IN ITB DEFIN-

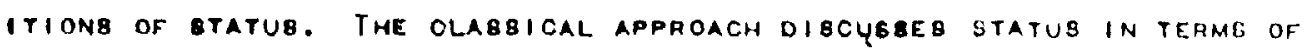

BOME CAPABILITIES WHICH ALLOW A BTATE TO EXEROIBE COHTAOL OVER OTHLAB, BUT DOEG NOT BTATE WHAT TYPEB OF BEHAVIOUR ARE INVOLVED. GALTUNG

DI scueseg atatuB oENEAALLY AG THE OOMPONENTB OF A MATION MHICH CONTRIDUTE TO ITB AOCIAL POBITION IN THE INTERNATIONAL BYBTEM. THE

RoEemU APPAOACH DIBCUB8Eg BTATU8, ANO THE OONBEQUENT FOREION POLICY EEMAVIOUA As OEPENOENT UPON TMAEC OENOTYPE ATTRIDUTEB: WEALTH, BIZE ANO POLITIOAL ORIENTATION, ANO FIVE PRDCEEB VARIABLEC.

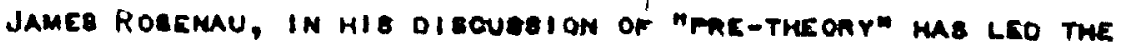

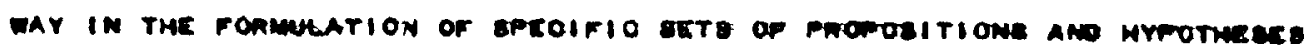

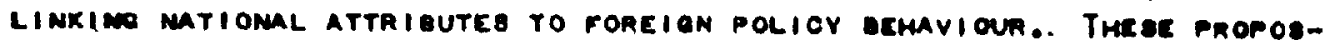
ITIONB REVOLVE AROUNO FIVE PROCEBS VARIABLES:

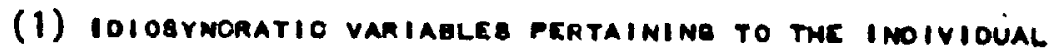
DCOI 81 ON-MAKERS' CONST I TUTION:

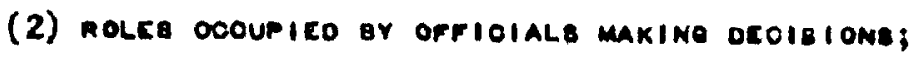

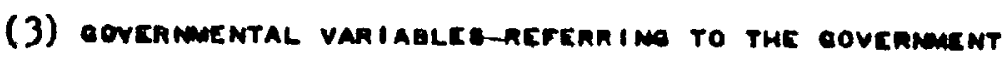

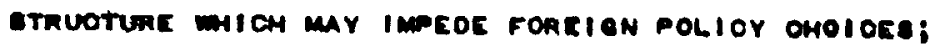

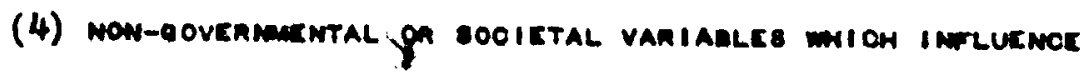
extraml acmavioup;

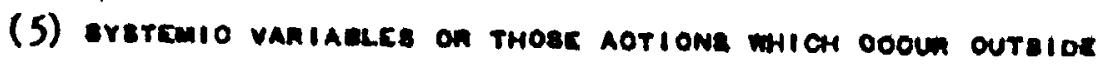

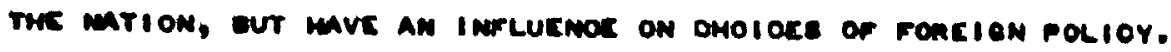


ALthOUQH ROBCMAU BELIEVE ALL PRE-THEOAIES OF FOAEION POLIOY AAE TRANB-

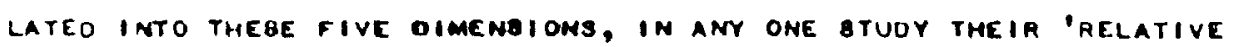

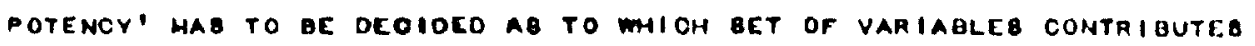

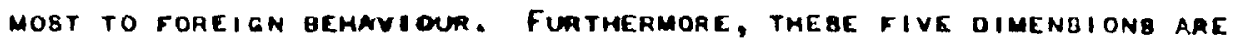
ABBEBBED IN TEAMB OF TREE OENOTYEE ATTAIBUTEB: BIZE, WEALTH ANO POLITICAL ORIENTATION. BY EXAMIMING THE DICHOTOMY BETWEEN OPEN ANO CLOBEO POLITICAL BYBTEMB FOA DEVELOPEO AND UNOEROEVELOPEO COUNTAIEB

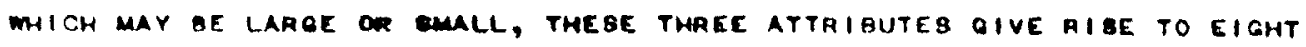

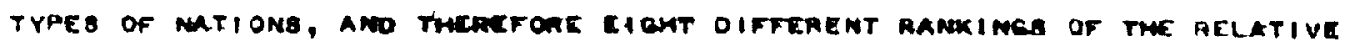
POTENCY FOR THE FIVE PROOESE VARIABLE. 37

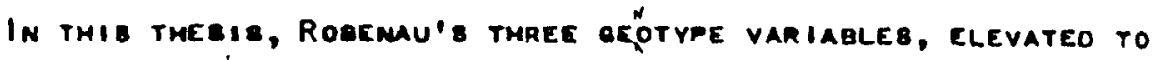

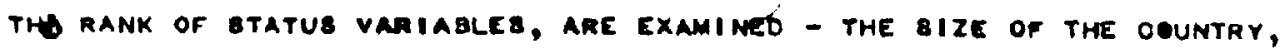
IOONOMIO OEVELOPMENT OR WEALTH, ANO POLITIOAL ORIENTATION (OPEN OR

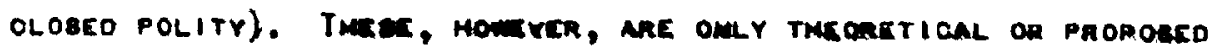

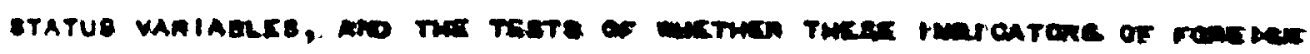

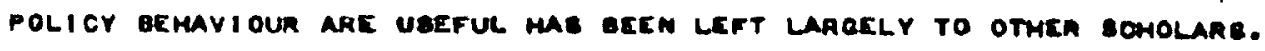

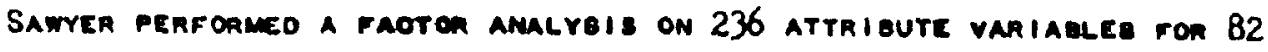

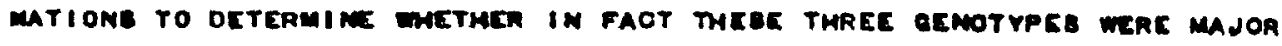

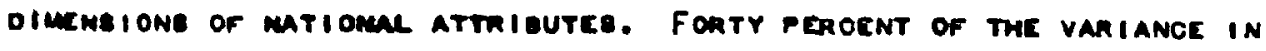
THE ATTRIgUTE DATA wAS ACOOUNTED FOR EY THAEE MAJOA DIMENBIONB: SIzE.

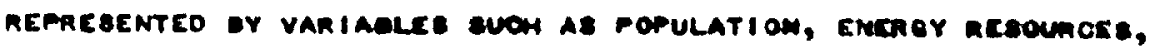

37. J. Roacmu, mare-Theonies and Theony in Foneian Pollov," In Approaches to Comparative ano Intenmational Politios, co, R.8.

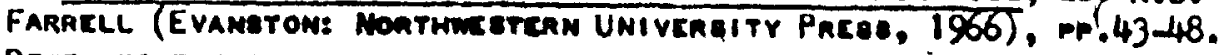

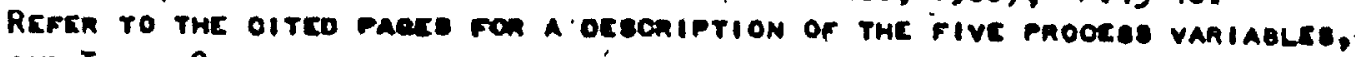

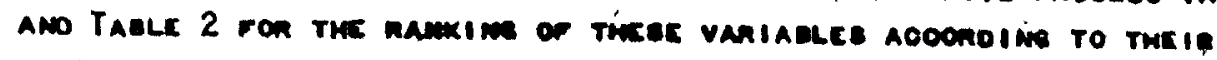

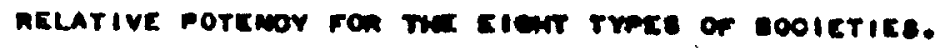




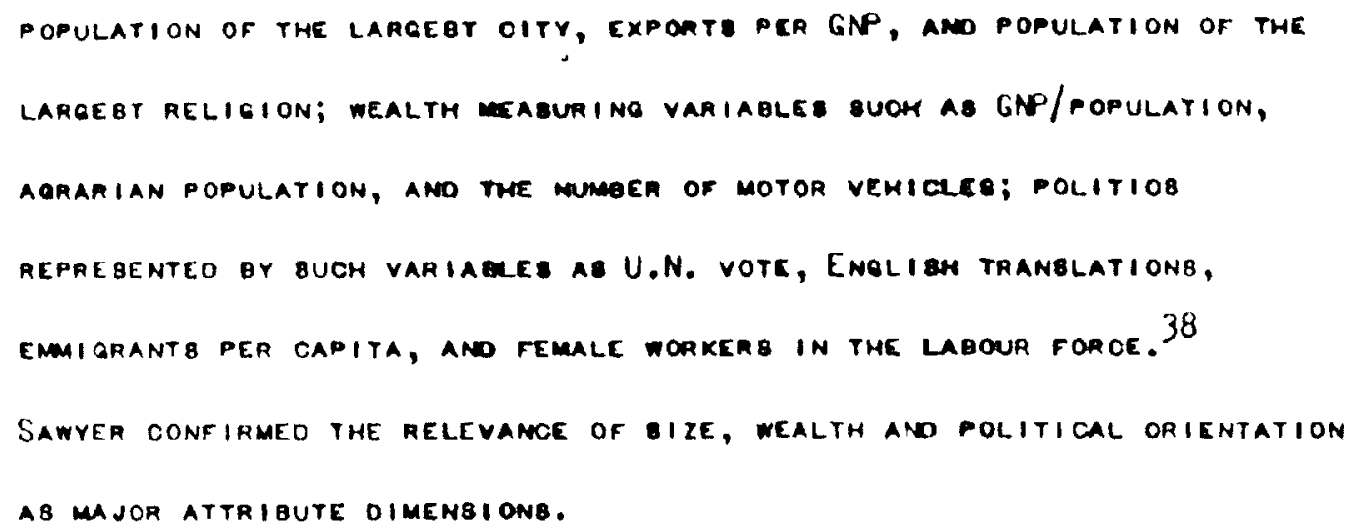

38. J. SAWrer, "Dinemsione of Mationes Size, Wealtw ano Polltoe," - American Jounmal of Socioloór. 17(Scetemeza 1967): 147.

39! S.A. Balmone ano C. Henmane, "The Erretor or Size, Oeveloement ano hooquitadility in Fonkien Arraine," Penoc Reseanoh 800ietr, Parcene (1970): $15-30$. 


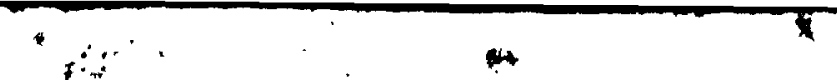

33.

s

M. EABT LOOKED B'PECIFICALLY AT BIZE IN AN ATTEMPT TO EXPLORE THE FEABIBILITY OF TWO MOOEL8: THE OONVENTIONAL MOOEL PROPOBEO THAT

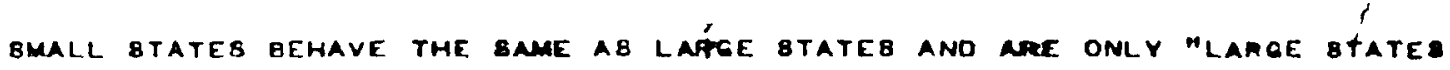
"WRIT BMALL"; ANO AN ALTERNATE MODEL IN WHICH SMALL amo LARQE gTATEB DIFFER IN STYLE ANO TECHNIQUE MMEN PROCEBBING ANO REAOTIME TO FOREIGN POLIOY IBgUE8. IN LINE WITH ROBENAU'B PROPOBITIONG, EABT HYPOTHEGIZEO THAT BINGE BMALL BTATEB POBBE8B BMALLER QUANTITIES OF MOBT REBOURCEB, THE IR BEMAVIOUA DIFFERB FROM TMAT OF LAREE BTATES. EABT FUATHER DIBYINGUIBHEO BETWEEN BMALL OEVELOPEO ANO BMALL OEVELOP INO NATI ONB ANO FOREION POLICY BEMAVIOUR. WITH THE VOE OE EVENT OATA, EABT BUPPORTEO THE ALTERNATE MOOEL. HE FOUNG THAT $812 E$ WAS MORE IEPOATANT THAN DEVELOPMENT BINCE THERE WAB WO DIFFEAEMCE IN BEMATIOUR PATTERMB GETWEEN 8MALL DEVELOPEO ANO DEVELOPIMG MATIONB. ALTHOVOH OMAL BTATEB INITIATED MORE JOINT EEMAVIOUR EVEMTB WITH MORE MULTIPLE AOTON TARGETB THAN LARGE BTATES, THEY DEMEAATED LE88 VERBAL AMP wONE MONYERBAL BEMAVI OUR. 40

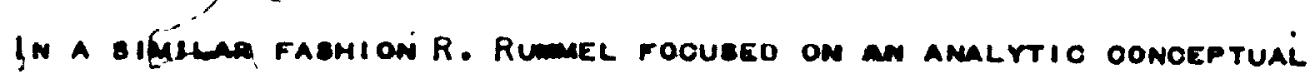
BOHEME OF INTERMTIOMLL RELATIONE BY CEFINING ATTIIOUTE EPACE ANO DEMAVIOUR BPACE OY EICHT ARO TEN DIMEMSIONE REEPECTIVELY, OBTAIMED

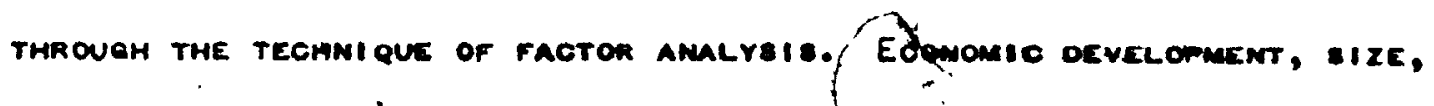

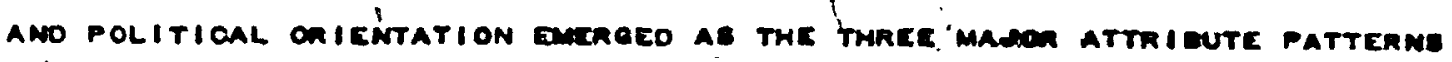

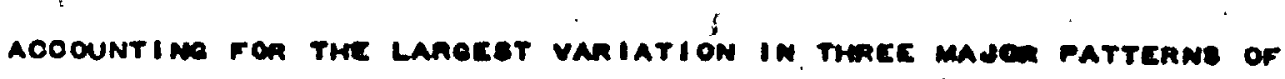
$\therefore \quad \therefore \quad \therefore$

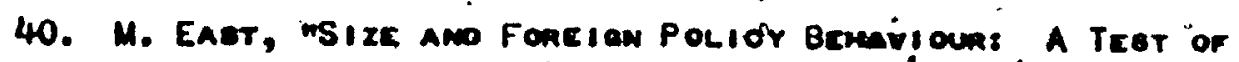
Two Mgarle," Moalo Politios 25 (Juiry 1973): 564-573." 
BEHAVIOUN, U.N. VOT RNG, EMIGRATION AND COMBUNICATION, ANO OFFICIAL CONFLICT HEHAVIOUR. 41

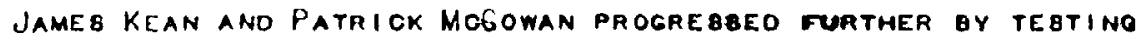
TWO ATTRIBUTEB TAKEN FROM THE LITERATURE ON ATTRIOATE8, TH́OBE OF BIZE AND MODERNIZATION, ANO FOUR RELATEO ANO BPECIFIC AEPECTB OF PARTICIPATION: INTERNATIONAL INVOLVEMENT, AEGIONAL INVOLVEMENT, ORGANIZATIONAL INVOLVEMENT ANO FOREIGN POLICY FOCUA. 42 THEY HYPOTHEBIZEO THAT BIZE AND MOOERNIZATION INFLUENCED FOREIGN POLICY THROUGH THE INTERVENING VARIABLEB OF RE LARGE ANO BMALL STATEB, ANO MOOERN AND LEB8 MODERN STATEB. IN THREE OF \) THE FOUR TYPEB OF PARTICIPATION THE RELATIONBHIP DETWEEN GIZE ANO MOOERNIZATION WAB BPURIOU8. WHEN THE TWO INTERYENING VARIABLE WEAE INTRODUOED, THE LINK DETWEEN THE INOEPENOENT AND DEPENOENT VARIABLEB DI BAPPEAREO. InSTEAD, NEEDS ANO REBOUROEB WERE LIMEO DIRECTLY TO FOREIGN POLIOY BEMAVIOUR. THE PATHB BETWEEN THE IMTERVENINO VARIABLES SNO THREE OF THE FOUR INTERACTION PATTERNS WERE CONFIRMEO. HOWEVER, FOR REGIONAL INVOLVEMENT, THE DIRECT PATH FROM BIZE ANO ESPECIALLY . MOOERMIZATION WAB BIGNIFICANT. REBOURCEB WERE NOT RELATED TO REOIONAL I NOLVEMENT, AND NEEDB WERE RELATEO NEGATIVELY. THA AUTHOAB OOMCLUDEO: OUR FIMOINOS BUSGEST THAT THE MATI ONMLYATTAIBUTE APPROACH TO THE COMPARATIVE BTUOY OF FOREION POLIOY MAY DE VALIO FOA FOAEION POLICY

41. R. RUMmELL, "INDIOATOAS OF CROSB-NATICOML ANO I NTERMATIOMAL PATTERME, APSR 63 (1969): 127 r147.

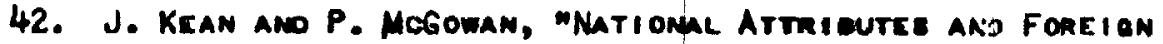
POLIOU PARTIOIPATION;" IN SACE I NTERNATIOMAL YEARBOOK OF FOREION POLIOY STUDIEB, ED. P. MOGomaM (BeVEeqLY HILLE: SAOE PUBLIOarion, 1973), Pr. 223-229. 
$\therefore=$

I 8BUE 8 OF WORLOWIOE BCOPE WHERE COUNTRIES DO

DIFFER ON THEBE ATTRIBUTE8. HOWEVER, WHEN

THE $183 U E$ IS REQIONAL IN BCOPE, $A B$ IB MUCH

OF CONFLICT BEHAVIOUR FOR EXAMPLE, BTATEB IN

THE BAME REGION TENO NOT TO OIFFER CAEATLY

EXCEPT FOR BIZE, ANO THEREFORE THE MATIONAL

ATTRIBUTE APPROACH IS LEBS UBEFUL. 43

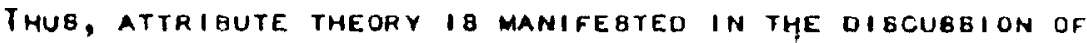

BTATUB THROUGH ITS LINKAGE TO MATIONAL ATTRIBUTES AMO FOREION POLICY

gemariour. The I UEA that mations may be RANKED accordine to gome gtatus

DIMENBION ANO THAT THIB RANK INFLUENCEB FOREIGN POLIOY GEMAVIOUR has

evolved from gPeculation about GReat, mLodle amo Small Powere, ano

THEIR OIFFERING GEHAVIOUR PATTERNB TO THE DAPIRICALAY TEBTABLE HYPOTHEEEB

RELATINO BPEOIFIU TYPEg OF NATIONAL ATTRIBUTES MHIOH INFLUENOE GPECIFIO

TYPEB OF bemaviour. HOWEVER, the wORK OF KEAN ANO HOGOWAN has demon-

BTRATED THAT THE8E DIBQUBBIONB OF MATIONAL ATTRIBUTEB ANO FOREIGN

POLICY EEMAVIOUR PERTAIN TO ONI.Y CERTAIN INTERNATIOMAL AOTORB AND THEIR

FOREION POLICY BEHAVIOUR. THEY FOCUE ON FOREIGN POLIOY GEMAVIOUR IN AN

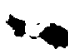

I MTERMATIONAL BYBTEM WHERE IT 18 EXPEOTED THAT LAREE STATEB DOMINATE

THE BYBTEM, ANO INTERACt MORE THAN BMALL BTATEB. THIG 18 EVIOENT

PARTIOULARLY IN THE wORK EY GALTUNG. WMAT THEgE THEDRIBTS IONORE IS

THAT EMLL MATIONB DO INTERAOT, BUT THESE MATIONB MAY PEROEIVE THE

AEOJOMAL OR BUE-BYSTEMIO LEVEL AB THE IMPORTANT AREA OF INTEREBT. SINCE

THE MATIONS ARE INTERATTING WITH OTHERS OF BIMILAR EAOKEROUNDS, THEY

ARE AGLS TO PARTIOIPATE ON A MORE EQUITABLE BABIB IN BEMAVIOU

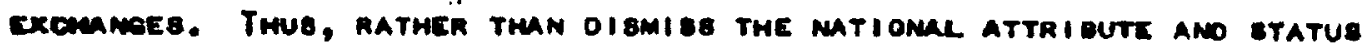

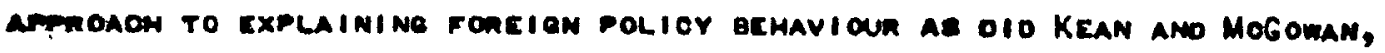

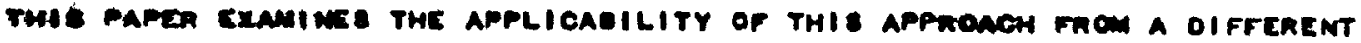

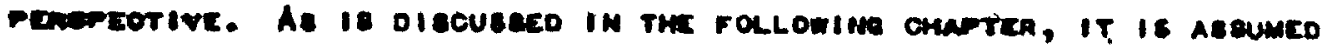




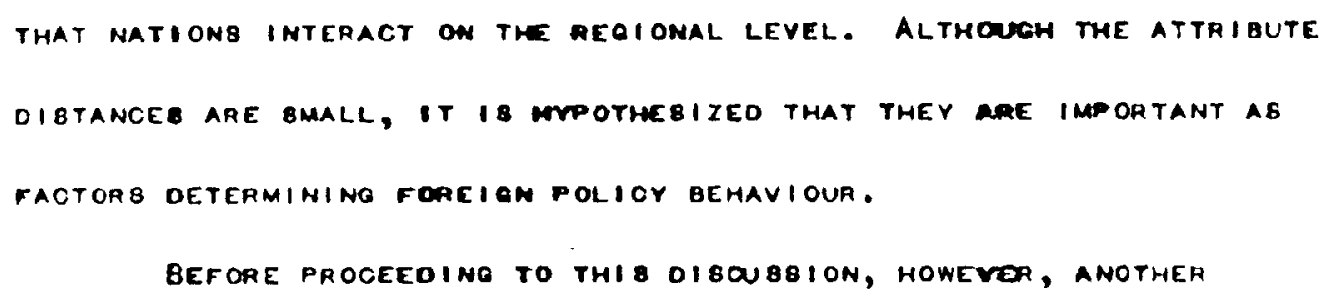

(A) EEMAVIOUn Has TO DE OERIVED From a TOTALITY

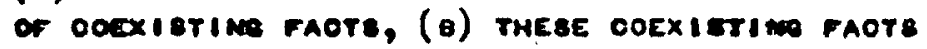
Have the omaknoten of A "OYMaMlo FIELO" IN 80 FAN AE THE STATE of ANY PANT OF THE FIELO OEPCNOS ow Evear orime PART or THE FICLD.

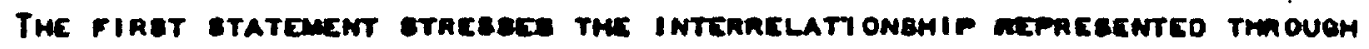

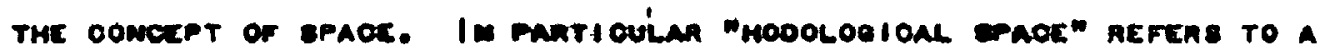

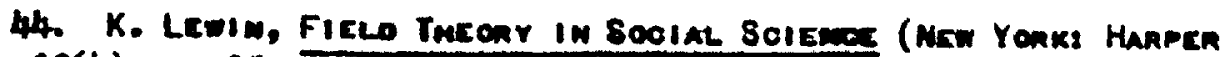
Ano Row, 1964), P. 25. 


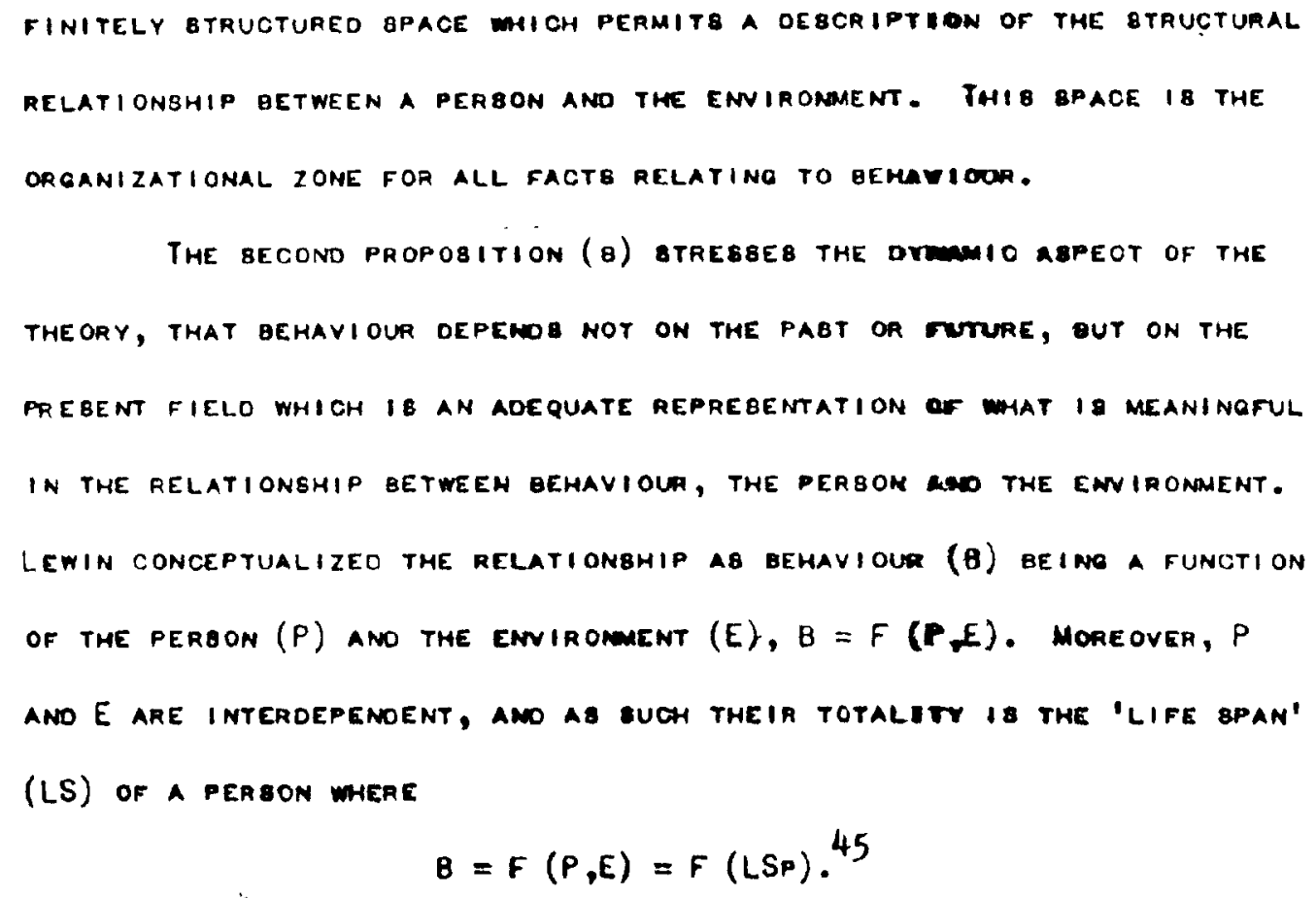

45. Hoid., P. 240.

46. 1010., P. 256. 
AND THE ENVIPONENT WAB EXTENOEO TO THE BOCIETAL ANO BVBTEMIO CNYIRONMEMT RATHER THAN THE FAMILY ANO PEABONAL BOOIETAL YALUEB ANO GOALB. FOR NAIGHT, FIELD THEOAY WAB AN ANALYTIGAL APPROACA, IMPLYINO THAT

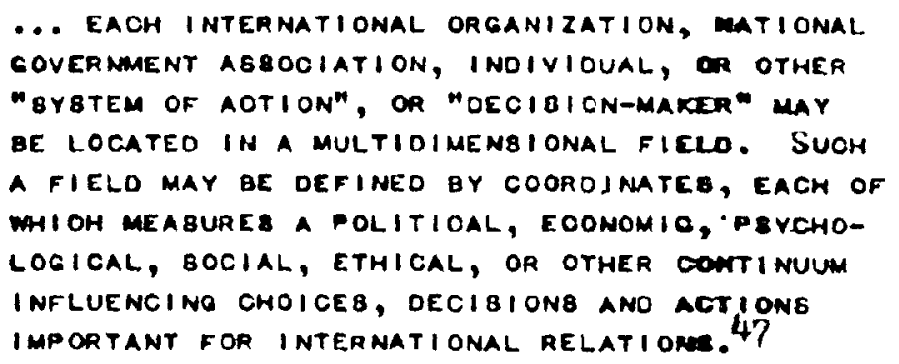

A FIELO 18 THE CENTRAL CONCEPT AROUNO MHOH EVERTTHHW IN THE THEORY REVOLVE8. NATIONB AMO EVENTB ARE LOCATEO IN TIME AND BPAOE, AND THE

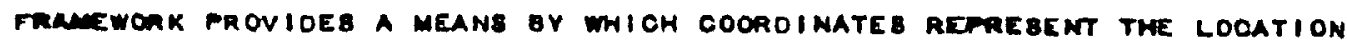
OF mTIONB ANo VARIABLes IN RELATION TO EACH OTHER. ThEME OOOROINATEg

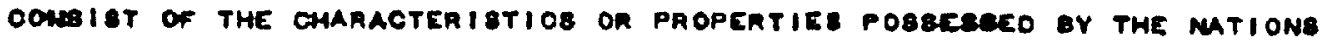

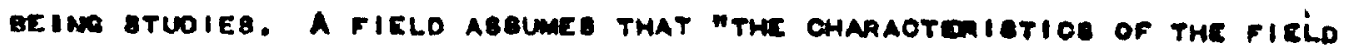
AND OF THE EMTITIEA WITHIN IT AEOIPAOCALLY IMFLUELCE ONE ANOTMER ...

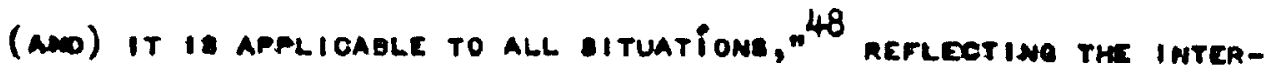

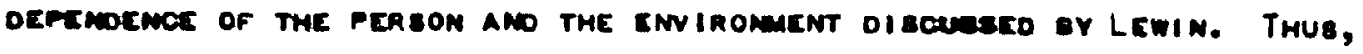

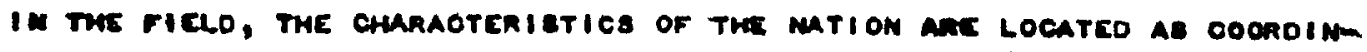

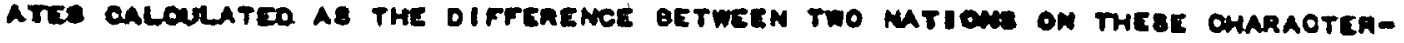
12104.

In comunotion mith the Dimeneiomality or Matiome (DOM) PRojeot

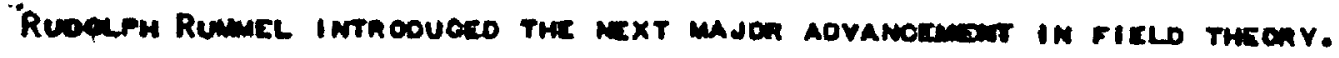
$-$

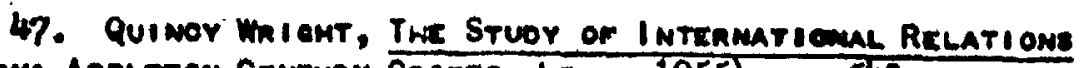
(new Yonks Applctow-CentunY-Crofte, LTO., 1955), P. 543.

48. 1010., P. 524: 


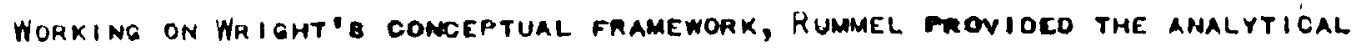
REQUIAEMENTS TO TEET THE THEOAY. THE CONBTRUCT "TIELON PROVIOED THE OVERARCHING BTRUCTUAE WITHIN WHICM ALL THE THEORETIOAL STATEMENTS OF THE THEORY ARE OPANMED. WTKE FIELO CONCEPT ITBELF DOEB NOT BPECIFY THE KINDE OF VARIABLCE TO OE INGLUOEO; IT ONLY PRONIDES THE RELATIONBHIP AMONO VARIABES ONCE THEY ARE INCLUDKD." 49 TWO BABIC CONCEPTB WHICH DELINEATE THE OIVIBION OF LEMIN'B mODOLOGICAL BPACE aRE atTRIBUTE (A) ANO BEHAVIOUR (B) SPACE. AN ATTRIBUTE IB ANY CHAAACTERIBTIC OR DIMENBION MICH DIFFEREMTIATE MATIONE, SUGH AB WERTH, POPULATION $8 I 2 E$ ANO RELIOION. THE CONCEPT OF OIBTANCE MEABUAEB THIQ OIFFERENTIATION BUOH THAT THE MATIONE ARE PLAOED AT A POINT IN A-EPAOE OCFIMED BY ATTRIBUTE DIMENSIONS, ANO ARE DIFTERENTIATEO FROM OTHER MAIONE OY THE RELATIVE DISTANCE EETIEEN THE POINTB. IHIS OABTALCE PLAVB AN IMLORTANT ROLE IN EXPLAINIM THK EEHAVIOUR OF MATIONS IN B-EPAOE. IT IB THIB ATtRIQUTE DIBTAMOE ON RELATIVE POBITION OF DYAB,, A PAIR OF MATIONB, WHICH" PROVIOES THE SOCIAL FONOE IMFUENOINO DRHAVIDUA. :

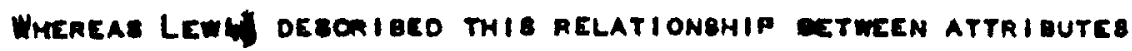
AMD BEHAVIOUR AE

$$
B=F(P, E)=F(L S P)
$$

THE MORE BOPHIBTICATEO VEABION or RUMELL is

$$
u_{1 \rightarrow j, k}=\sum_{1=1}^{p} \alpha_{1} d_{1-j, 1}
$$

(Moocl 1)

49. SAma-woo RHEE, "Chima' COOFERATION, Comrlot and I nTERAOTION Bemavioun," in AOvameine ano COntenoine Ammenonce to the Study Of Chinese foreion Polior, co. R.L. Dial (Halifaxe Ccatre fon Fonelon PolioY Stuoles, DAlhovale Uwi yenaity, 1974), P. 117. 
WHERE $W_{1 \rightarrow j, k}$, ANALOGOUB TO $B, 18$ THE $K$-TH OIMENBION OF GEHAVIOUR bpace of nation I acting towaro mation $J$, and $d, j, 1$ ig the distance VECTOR FROM I TOJ ON THE ATtRIOUTE oIMENBION, 1. THE parameter DEBCRIGES THE PRECIBE RELATIONBHIP GETWEEN THE AQOVE TWO TGRMS. THEBE

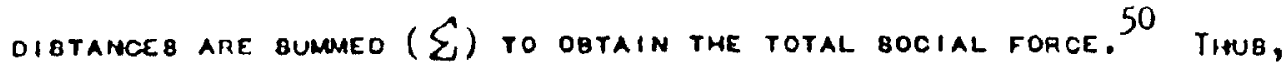
THE LOCATION OF A OYAD ON THE DIMENBION OF GEMAVIJUR BPACE IB DETERMINED BY THE DIBTANCE VECTOR THAT CONNECTB THE OYAD IN ATTRIGUTE BPACE. THIB

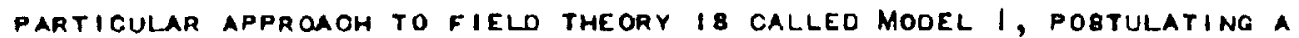
OEMERAL FIELO FORCE WIICH EVOKEB 8 IMILAR BEHAVIOURAL RESPONBES FROM ALL

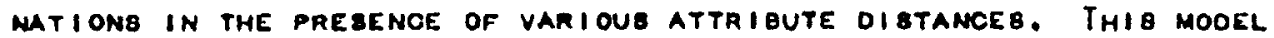
CORREBPONDS TO LETIN'B IOEA THAT

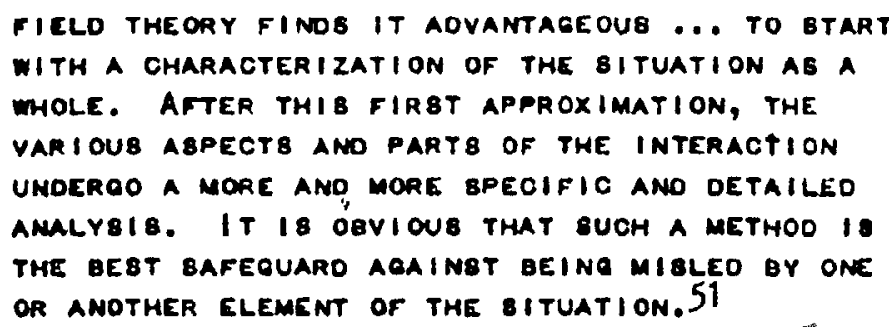

IN RESPONSE TO AN INNITATION FOR A MORE DETALLE AMLLYEIB OF

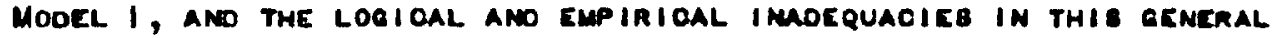
MODEL, A MOOEL II MAB BEEN PROPOBED. I METEAO OF POEITIMG A EEMERAL. EqUATION ONER ALL PAIRS, IN THE MODEL THE LINKAEE IS OPEOIFIO TO THE particular actor mation 1 . Althoveh thene is oonsiograble lose of

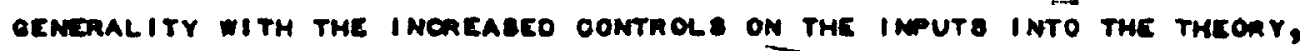
UMLIXE THE OUTPUT of MOOEL I, BeHAVIOUN IN MOOEL II IE UNLIKELY TO OE

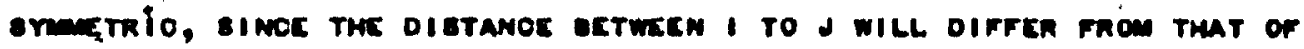

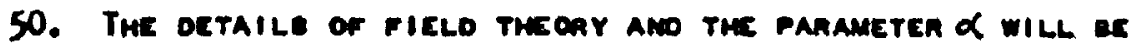
Discusero in CHAPTER 5.

51. LEwIN, FiELO ThaonY, P. 63. 


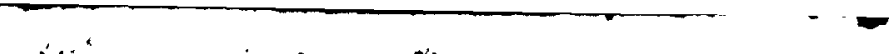

41.

J TO 1. Therefore, the secono model 18 more REPREgentative of the

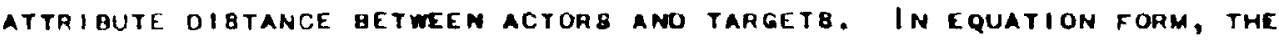
RELATIONBHIP BETWEEN ATtRIBUTE DIBTANCE AND BEHAVIOUH BECOMEB:

$$
w_{1+j, k}=\sum_{1=1}^{p} \alpha i, j_{i-j, 1}^{d}
$$

(MOOEL 11)

WHERE THE PAPAMETER $\alpha 1$ I8 NOW ACTOR-GPEOIFIC FOR THE ACTING NATION 1.

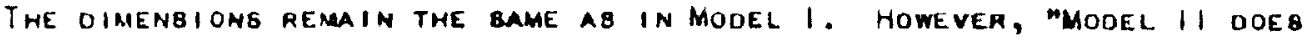
IMPLY ... THAT THE FORCES OPERATING FOR A PARTICULAR ACTOR ARE CONSIBTENT ACROS8 ALL OF ITB OYADIC LINKAGES." 52 THAT 18, IN ANY PARTICULAR DYADIC set, such as Camada to the United States, Camada to great bri-ain, Canada to Chima ano 80 on, the parameter will remain the game. For a OIFFERENT OYADIO BEY, THE PARAMETER WILL BE OIFFEREMT FROM THAT OF CAMUOA. THEBE PARAMETERS REPREAENT EAOH ACTOR's IDIOBYNCRABIEs IN THAT EACH MATION MAY EMPHASIZE a PAATICULAR ATtRIBUTE OIMENBION. FoR

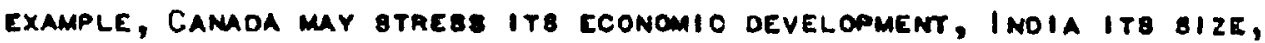
THE SOVIET UNION ITS POLITICAL OAIENTATION. IT WILL BDWEEN LATEA WUW THEBE MOOELB ARE TRANBFORMED INTO WORKING, TEBTABLE WOOELS BY OPERATIONALIZING TMERE ATTRIQUTES.

1

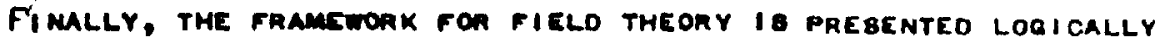
ANO OOMEAENTLY AB SOOIAL-FIELD THEORY BY RUMMEL. AMONE TME MTVEN AXIONB THERE ANE PROPOEITIONE RELATINO BPECIFIO ATTMIDUTE DIMENEIONB, IDEATIFIEO AE EXPLAMATOAY VARIAGLES, TO FOREIEN POLIOY ERMAVIOUN

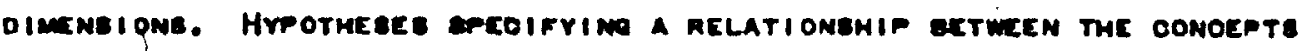
may ez ozovoco mom the axiome, ano teeted. 53 Moneover, Mookle I ano II

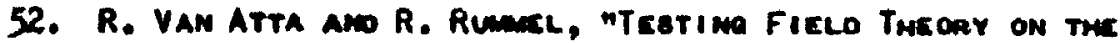

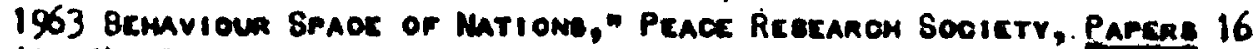
(1971): 39.

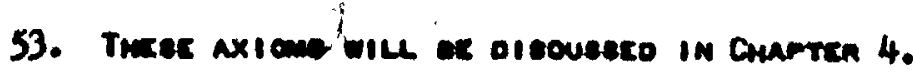
1 
IMPLY THAT THERE ARE TWO FORCEB AT WORK IN THE IMTDRMATIONAL BYBTEM.

THE FIRBT 18 A GENEAAL FORCE WHICH AFFECTB ALL NATIONB, AND A BECOND WHIOH CONBIBTS OF FORCEB UNIQUE TO THE INTEAMAL STMUCTURE OF EACH ACTOR. THEBE BPEOIFIO INFLUENCEB, IN CONORUENCE WTH THE OENERAL FORCEB, CAUSE EACH MATION TO AEACT OIFFERENTLY IN AEEPONBE TO THE BAME ATTRIBUTE DIFFERENCE 8.54

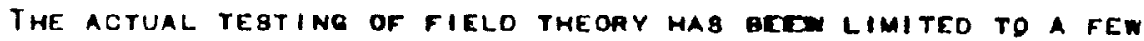
PUBLI BHEO PAPEA BY RUMMEL AND HIS FOLLOWERS. IW EA TEST OF 8OCIALFIELO THEORY, RUMWEL USEO TMREE DIFFERENT TYPE OF ATTRIBUTEB: TWO RANK DIMENBIONB - ECONOMIO DEVELOPMENT AND POWER FIVE VALUE DIMENSIONS FEMININE RIOHTS, INTERNATIOMALI BM, CATHOLIOIBM, PELF-OOVERNAENT ANO $\checkmark$ COMMUMI8M; AND GEOGRAPHIC DIETANCE. THE OEPENOELT VARIÄ́LE WAB A CONFLICT DIMENSION COMPOBEO OF VIOLENOE, OOMNNICATION, HOBTILITY ANO DIPLOMATIO REPRE8ENTATION. FoURTEEN MATIONS mERE BAMPLO, 8ELEOTED FOR THEIR HIQH, MIODLE AM LOW POBITIONS ON THE FMOTOK SOONES OF EACH ATTRIBUTE BFACE DIMENBION. THE NEBULTS IMIOATES TMAT WHLE EOONOMIC DEVELOPMENT WAS A POEITIVE IMOIOATOA FOR OYADS EMAAOING IN OONFLIOT, POWER WAS NOT BIONIFICAMT. NEITHEA TME CATHOLIGEM NOA THE IMTER-

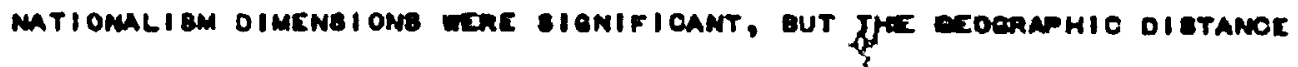

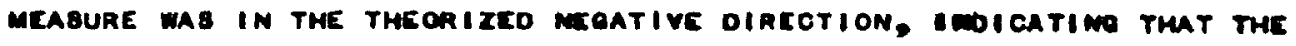

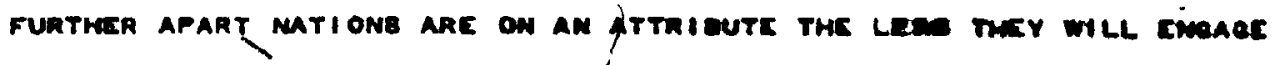

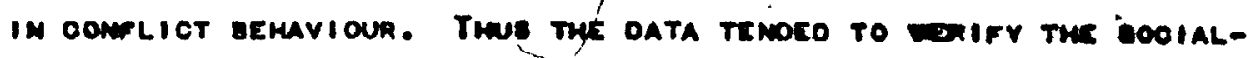

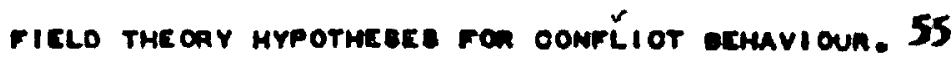

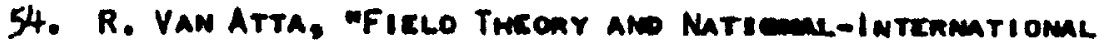

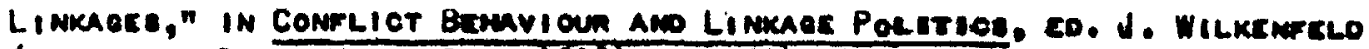
(NEw YoRk: Davio Mokar Co., TST3)., Pr. 214-215.

55. R. Rumel, A Social Fielo Theony er Foneigm Confliot Bemuriour," Peaor Rcecancon Soolctr, Paeche 4 (1966), 142-145. 
;

Tegts of Bocial-fielo theory haVe VERIfied PARTIALLY MOOEL 11 , but have unoomfiameo model I. UBine a data oet foh 1955 ano 1963 , RICOARD VAN ATTA EMPLOYEO THE ATTAIBUTE OIMENBIONB OF EOONOMIC DEVELOPMEMT, BIzE OR POWER CAPABILITY, POLITICAL ORIENTATION, PLUB CATHOLIC QULTUAC IN 1963 AG THE 800 IAL FORCE INFLUENGING PRIVATE INTERNATIONAL AELATIONE, ADMINIBTRATIVE BEHAVIOUR ANO OOMFLICT BEHAVIOUR DIMENBIONB. MOOEL I BHOWEO A LACK OF EMPIRIOAL FIT BETWEEN ATTRIBUTE ANO BEHAVIOUR 8PACE. MODEL II WAB mORE PROMIBING, INOICATING a FIT BetweEn the tho GPAOE FOR DOTH DATA SETB. THE MOBT IMPORTANT ATTRIBUTE OIBTANCE IN RELATION TO CONFLIOT WAB POWER, ANO PRIVATE INTERNATIONAL RELATIONE Was PREDICTEO FROM THE NEGATIVE DIFFERENGE ON THE POWER DIMENSION. 56

\section{STATUB-FIELD JHEORY}

FiELo' THE ORY CONTINUES TO EYOLVE, TREATIMO MOAE CONCRETELY TEE BPECIFIO PATTERNB OF RELATIONBMIPB BETWEEN ATTRIBUTEB AND BEHAYIOUR, IU A PAREIMONIOUB AND HEURIBTIO FASHION, RUMMEL COMBINED FIELO THEORY -ITH TME OONOEPT OF BTATUE TO FOAM YET ANOTHER THEORY - BTATUB-FIELD TrEenr.

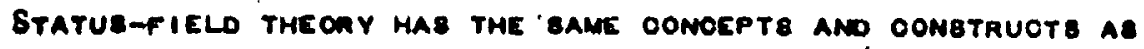

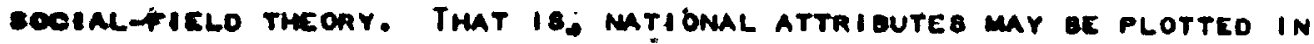

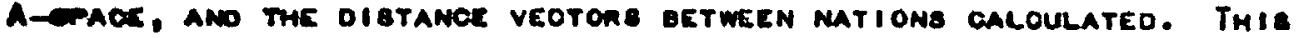

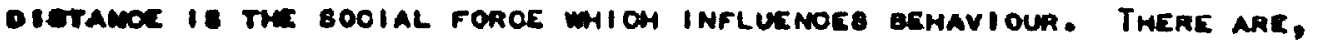
Herven, TWO MAJOA DIFFEAENOE EETWEEN THE SOOIAL ANO ETATUB-FIELO

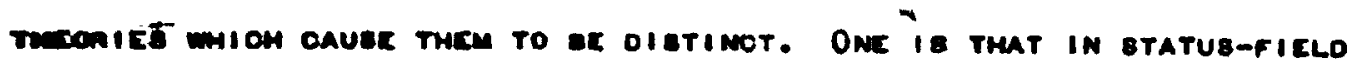

56. Van ATrA, "Fiklo Theony," pe. $241-244$. 
THEOPY THE INTEAMATIONAL BYSTEM 18 DEFINED AB A BTATUB BYBTEM IN WHICH NATIONB ARE LOCATEO ON BTATU8 ATTAIBUTE DIMENBIONB. THE BECOND DIFFEAENCE I8 IN THE CONCEPTB OF BOCIAL BTAATIFICATION AND BOOIAL MOBILITY Ot8CU8BCo PREVI QUBLY. THE MAJOR ASBLMPTION IS THAT MMTIONB ARE RANXED

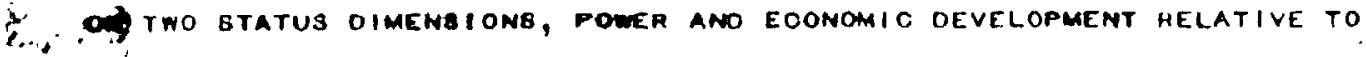
f: HER NATIONS IN THE GTRATIFIED INTEANATIONAL BYSTEM. STATUS DIBTANCE 1.

SFF SELF IS gABED ON THE DIFFERENCE GETWEEN TWO NATIONB ON THE STATUB MENSIONB. IT 8 THIB OISTAME, PLUS THE DEBIRE FOA a HIGHER STATUB ANK ON BOTH DIMENBIONB MMICM I8 THE FORCE INFLUENCIMG THE BEMAVIOUR OF NATION 1 TO J. THE AXIOMB AND THEOAEMB FUATHER BPECIFY THE DIFFERENT TYPES OF OOOPERATION, OONGLIOT OR BTATUB-OEPENDENT BEHAYIOUA ABgOCIATEO WITH DIFRERENT ATTRIQUTE DIBTANCE8.

FINALLY, 8TATU8-FIELo THEORY MAY BE TEBTED ALEO UNOER THE

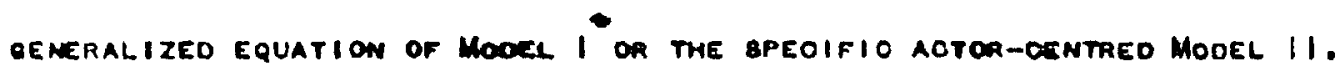

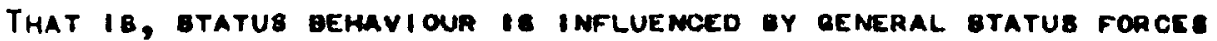
AFFEOTINS ALL MATIONS AND UNIQUE BTATUB FORCEB AFFECTINO INOIVIDUAL NATIONB. HOWEVEA, THCRE MATE DEEN FEW EMPIRICAL TEBTB OF 8TATUB-FIELD TMEOAY. MOREOVEA, THOET TMAT HAVE BEEN UNDERTAKEN OIVE A VEAY LIMITEO PERBPEOTIVE OF BTATUE-FIELD tHEORY, ONE CENTRED ON THE UNITEO STATEB ANO THE OTMER ON CHIMA.

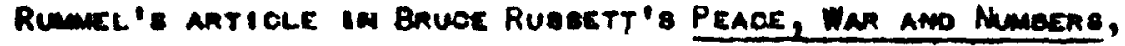

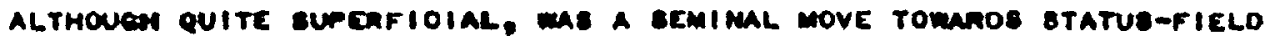

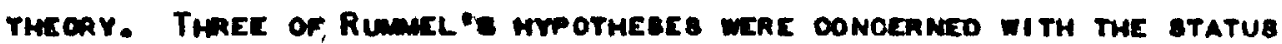

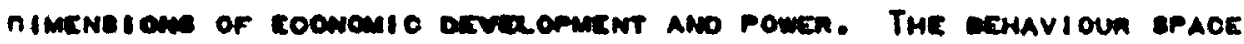

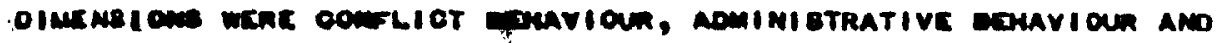

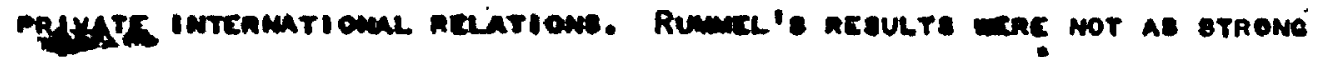


AB HE HYPOTHEBIZED. THE ECONOMIO DEVELOPMENT DIMENBION WAB NOT IN THE

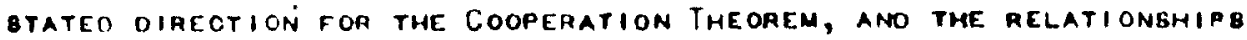
FOUNO TO EXIBT DETWEEN ATTRIBUTES ano oEMAVIOUR IN THE CONFLIOT Gemaviour Theorem meae not those paeoloteo. The Status Behayioup THE OREM WAS CONFIAMED. $5 ?$

Sang-woo Rhe tegteo Btatus ano gooial-fielo thecay uBing nite gemaViour oIMENBIONS; BIX COOPERATIVE - PENETRATION, Formal DiplomaOY,

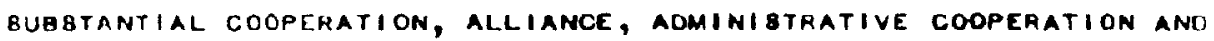
gONGUNICATIONB NETWORK, TWO CONFLICT - PEOPLE'B LIBERATION MAa ANO FORMAL CONFLICT, AND THE LABT a TIME VARIABLE; ANO TWELVE ATTMIBUTE OIMENBIONB - COMMUNIBM, ECONOMIO DEVELOPMENT, PCWEA, CATHOLIC CULTURE, DIVEABITY, DENBITY, CHINE8E BPHERE, POLITICAL GYAGILITY, POPULATION,

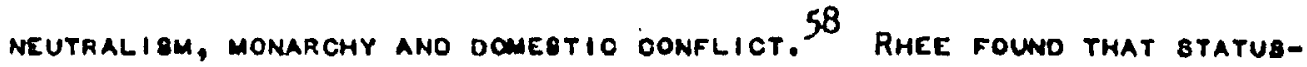
DEPENOENT OONFLICT BEMAVIOUR ANO COOPERATIVE GEMAVIOUA WAE MOT DEPENOENT UPON ECONOMIC DEVELOPMENT. FORMAL COMFLiCT WAB AELATEO TO power distance. Sugatantial cooperation was dePEMoEnt uPON POWER D IOTANCE ANO ECOMOMIO DEVELOPMENT, BUT OTHEA DIBTAMOES OVERMELMED THE STATUS DIMENBIONS. 59

STATUS-FIELD THEORY THEM DOCB NOT APPEAR PROMISIM ON THE DASIO OF THE EMPIRICAL APPLIOATIONS WHIOH MAVE EEEN OONONOTEO, WITH THE AXIONS AND THEOREMB OEVELOPED AT PREEENT, THEAE Is WNOH MORE HEURIOTIO VALUE THEN ODMONBTRATEO In THEEE ARTICLEA. IT IE VERY OIFFIOULT TO

57. Rumarl; M.S. ," . 108.

58. Rheе, "Снiмn's, " "P. 144-147, 159-160.

59. 1810., Pr. 173-4. 
CAPTURE ALL THE IMPLICATIONB OF THE THEORY WHEN IT IB VIEMEO IN TEHMB

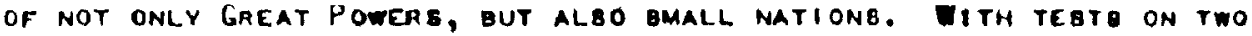
GREAT POWEA ONLY, THERE REMAINS GAEAT BCOPE FOA AFPLICATION OF THE THE ORY TO OTHER NATIONB. THE IMPLIOATIONB FOA NATIONS HIOMER AMO LOWEA IN THE BTATUS THAN THE ACTOA MATION HAVE VET TO BE TESTEO. FUATHERMORE, IN VIEW OF KEAN ANO MCGOWAN'S FINDINGS ON THE REGIONAL LEVEL, IT WOULD BE IMTEREBTING TO DETERMINE WHETHER THEGE THEOAIES MAY BE BUCCEBGFULLY APPLIED TO MATIOMB mIOH HAVE BMALL DYAOIC ATTEIBUTE DIBTANCE IN COMPARIBON WITH OTHER NATIONS IN THE CLOQML EYSTEM, AND WHETHER THEIR BEHAVIOUR PATTERNS DABEO ON THEQE DIETAFCEB ACCUAATELY REFLECT THE THEOREMS OF THE THEOAIES. THE MEXT CAMPTIR EXAMIMES ETATUS-

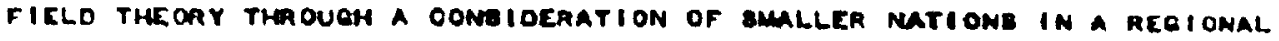
CONTEXT. 
STATUS FIELO THE ORY ANO IMPL ICATIONS FOF THE REGIONAL SUBSYSTEM

FIELD THEORY REgTB ON A EUCLIDEAN BPACIAL FORMAT with aTtRIGUTE AND BEHAVIOUR BPACE AS THE AMALYTICAL FRAMEWORK FOR BPECIFIC ABBUMPTIONS

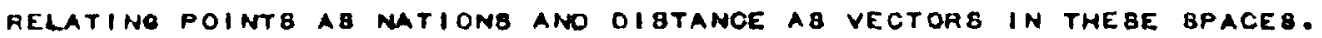
THMOUEH THF AB8UMPTION OF LINEARITY SURROUNOING THIB FRAMEWORK, ATTRIBUTE DIBTANOKS ARE LINKEO TO BEMAVIOUN VIA THE FOACE CREATED BY THE ATTRIBUTE DIBTANOES BETWEEN MATIONE MHICM INFLUENOE THEIR FORM OF INTERACTION. MOREOVER, THE FIELO THEORY OUTLINE I GEMERAL ENOUGH THAT MIODLE-RANGE THEORIEB BUCH AB POWER ANO OEOQRAPHICAL LOOATIOM THEORIEB mAY BE INCORPOAATED.

IN THIE FAQHIQN, WHILE FICLg THCORY IE AEsTHPOT IN RELATION TO THOEC HYPOTHEBEs areatine BPECIFIC VARIABLE AELATIONEHIPE, ITE ABILITY TO BUBSUME SUCH HYPOTHEOE PROYIDEQ A GENERAL FRAMEWORK WITHIN WMIOH BUOH RELATIPNGAIPB CAN BE OEVELOPEO ANO BTRUCTUREB."

THE BEMIMLL ABPEOTB OF STATUB-FIELO THEOAY ARE AN EXTENBION OF BOOIAL-FIELD THEONY. THEY MAVE IN OOMMON BABIO AXIOMB, THE EVOLIDEAN

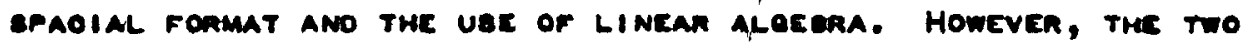
THEOAIE OTFFER FUNOAMENTALLY ON THE CONOCPT OF ATTRIBUTE SPACE AMO On mes position of mations in the intenmational ersten. In status

1. R. VAN ATtA, "FIELo ThEONY AMO "MATIOMAL-I NTEANATI OMAL LINKaec," in Complot Bemayioun ano Limkage Politiog, co. J. Milkenrelo, (New Yonk: Davio Mokay Co., 1973). P. 211. 
FIELO THEORY THE ATTRIBUTE8, PONER ANO ECONOMIC DEVELOPMENT ARE THE BTATUB DIMENSIONB WHICH ACT AB THE FOACED ADOUCINO BEHAVIDUR GETWEEN MATIONB, ANO ARE THE COANERBTONE IN EBTABLIBHINE THEONEMB TO TEBT THIB RELATIONBHIP. THE GTATUS ATTRIB̈UTE OIMENBIONB OLOBELY OORRE BPONO TO THE MOAE TRADITIOMAL VIEWB OF MATIONAL BTATUS. THAT I8, IN A BTRATIFIEO AFRAMEEMENT OF NATIONB, A MATION'S STATU8 IB DETERMINED OY ITS POBITI W IN THE HIERAACHY BABED ON ITE RELATIVE AMOUNT OF WEALTH, OR ECONOMIO

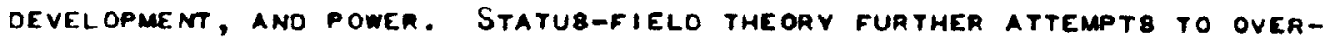
COME THE CRITIOIGM DIRECTED AQAINBT BOOIALFIELD THEOAY THAT "YHE REBEARCH THAUET REVOLVED AROUND AN ATHEOAETICAL APPROACH TO THE ANALYBI: OF INTERMATIOMAL RELATIONB." ${ }^{2}$ FUNTHERMOAE, BOOIAL-FIELO THEORY DOEB NOT PROVIOE AN EXPLAMATION OF THE PATTERN THAT THE LIMKAOE BETWEEN ATTRIBUTE AMO BEMAVIOUR MIOHT TAKE, OMLY A FRAMEWORK FOR

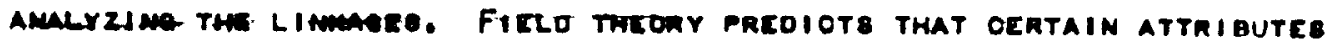

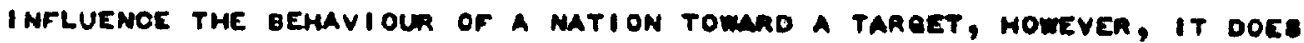

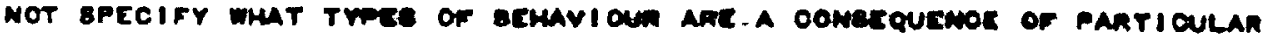

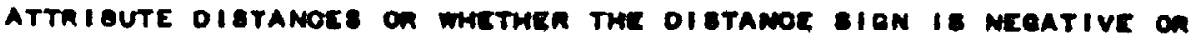

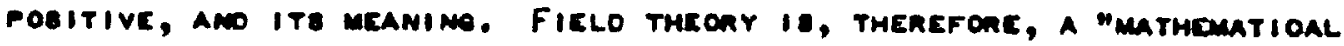
akeLton. 3

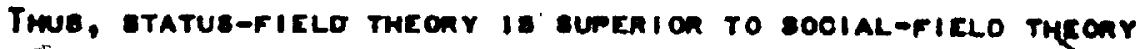

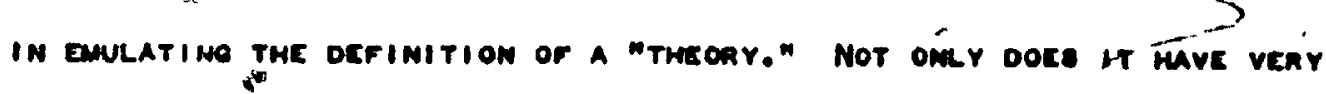

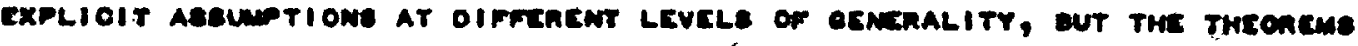

2. 6. Hicton, A Revizm of TME Dimenelomality of Matione Proucot

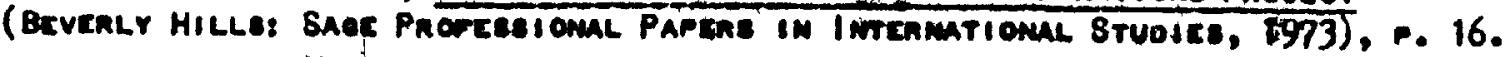

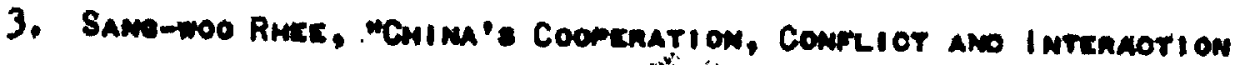

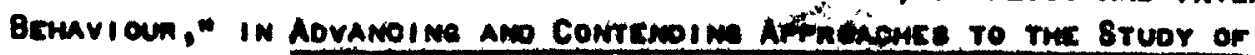

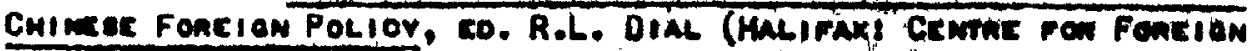
Polior Stuoice, Oalmousic Univeneitr, 1974), i. 127. 
EMOEAYOUA TO PROVIOE SOME OAUBAL LIMK BETWEEN THE DIRECTION OF ATTAIBUTE DISTANCE VECTORB ANO BEHAVIOUA IN AN ATTEMPT TO EXPLAIN BEHAVIOUR. SCMOLARB ARE AQLE THEN TO PAEDIOT FUTURE BEMAVIOUR WITHIN THE LIMITE OF THE THEORY, THE DATA AVAlLABLE amo THE 8ChOLAR's OWN APTITUDE FOR THE BUBJECT MATTER./

THE AXIOMS OOMNON TO BOTH THEORIEB, PLUS THOBE AODITIONAL AXIOMB ABSOCIATEO WITH STATUE-FIELO THEORY ARE THE CENTRAL POINT FROM WHICH TO COMMENCE A OIBOUBBION ON THE CONNEOTION OETWEEN ATTAIBUTEB, THE ATTRIBUTC DISTANCES ETTWEN NATIONB ANO THEIR PROJEOTION ON THE OIMENBI ONB OF BEHAVIOUR BPACE.

\section{AXIOMS ANO THEOREMS}

THE FIRET AXIOM PRESENTS THE CONCEPT OF FIELO, OEFINEO IN TERME of attributes aho inteanotione of mations:

1. I mtenmatiomal aclatione ia a Fielo consistine OF ALL MATIONB ATTRIBUTES ANO IMTERAOTIONE ano THEIR COMPLEX RELATIOHGHIPE THMOUEH TIMA."

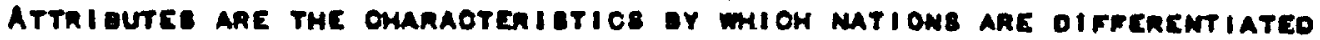
.PROM EAOH OTMER. NATIONB MAY DE OISTIMQUIBHEO IN TERMO OF BIZ,

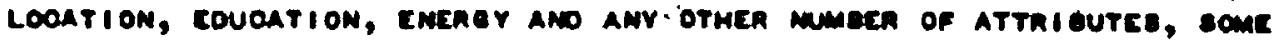

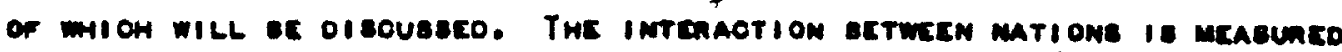
4. ermavioun

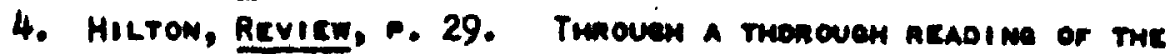

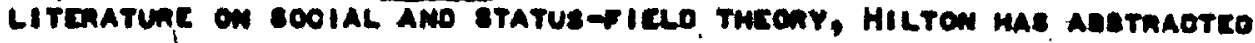

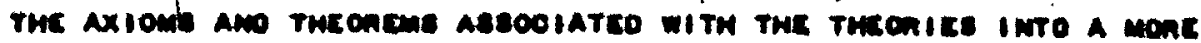
ogmetrol ous rona. 


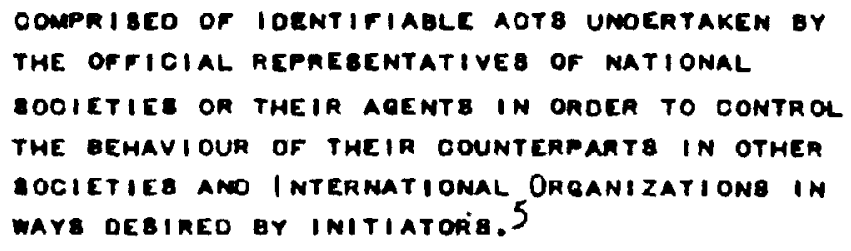

2. THE INTERMATIOMAL FILLO COMnRISES A EUOLIOEAN ATtRIEUTE BPAOE DEFININE ALL MATIONE ATTRIEUTCS ano a Euoliocan apagr offinine all matione oraolo intrenaot iomé

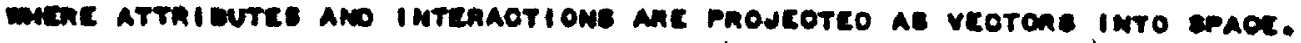

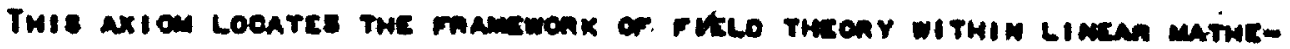

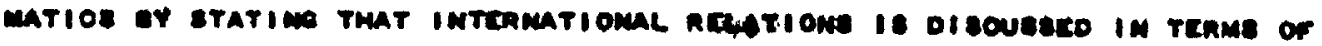

5. P. Mocoman and o'Leany, Gominarative Foncien Pousor

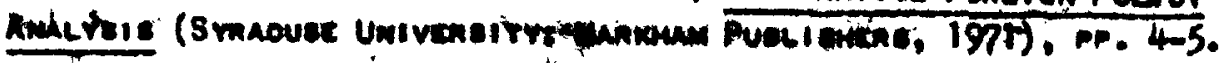
6. Histow, Reviex, : 29. 
THE THIRO AXION:

3. INTERMATIONAL RELATIONB I8 A BTRATIFIED BOCIAL ВYвTEM. 9

LEAOB INTO ONE OF THE GABIC OIFFERENOES BETWEEN BOOIAL AND BTATU8FIELO THEOAY DIBCUSEED EARLIER. THEAE AAE FOUR THEOREMS ANo FIVE DEFINITIONB IN BTATUB-FIELD THEORY DERIVED FROM THIB AXIOM WHIOH MELP IN THE FORMULATION OF HYPOTHE BE. IHEOREM 2 ITATES THAT BTATUB oIMENBIONB ARE a BUBBET OF THE LARGER, mORE GENERAL ATTRIBUTE DIMENBIONB. ON THEBE DIMENBIONB MATIONB MAY DE RANKED FROM A HIOH

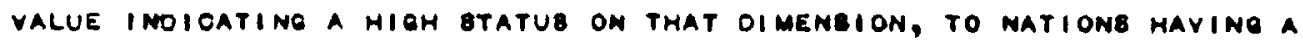
LOW VALUE ON THE BAME DIMENBION, THEREFORE POBBEBSINO A LOW 8 TATUE. IN EUCLIDEAN BPAOE THE THIRD THEONEM PLACES MATIONB AO VEOTORB

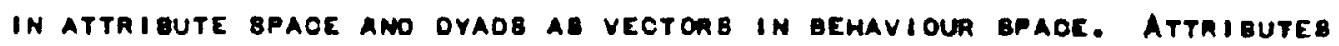
ANO BEHAVIOUF ARE THE TWO MAJOR OONOEPTB IN MATION'B ENVIROMAENTB WITHIN THE OONBTRUOT OF BOOIAL EPAOE. ATtMIBUTE BPACE CONBIETE OF AN INFINITE MUMBER OF INTEROEPCNDENT ATTRIEUTES OEFIMEO BV VEOTORE ANO BQUNo OY THE TOTAL MUMER OF NATIONB O WITH MATIONO DEFINED AE POINTE IN ATTRIBUTE BPAOE, THE DIBTAMCE VECTOR BETMECN ANV TWO MATION-POINTS MAY OE DEFINED WITH ITS OIRECTION BEING THE OORRELATION OCTWEEN THE ATTRIEUTES FOR THE IMATIONB. THUS, THE ATTRIBUTES FOAM THE AXES FOA

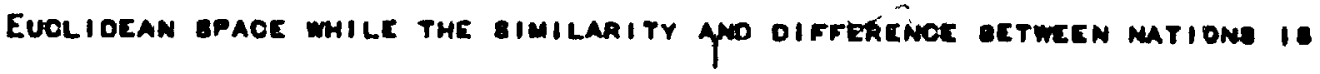
Locateo ae veotons in the epace. (Figune 2) Bemavioun apaor, on the INTERDCPCMOENOS DETWEEN INTERAOTIONB HS IMILAR IN OQMEOSITION TO

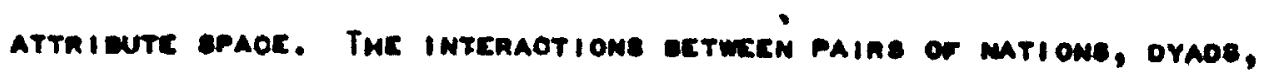

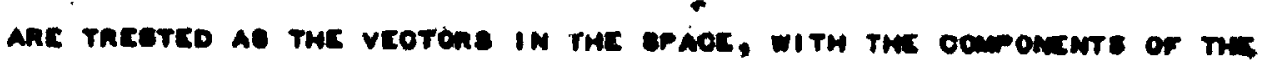

9. Iolo. 


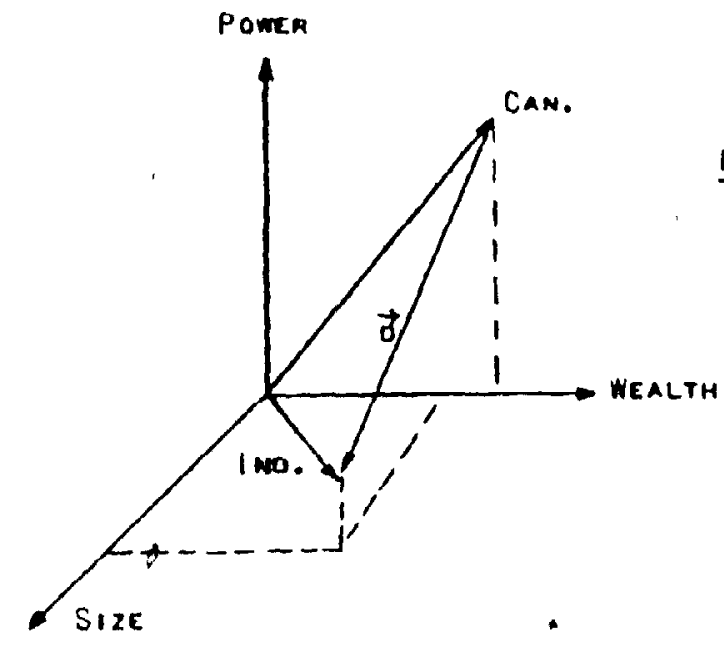

FloURE 2 A HYPOTHETICAL REPREBENTATION of ATtal Bute SPace

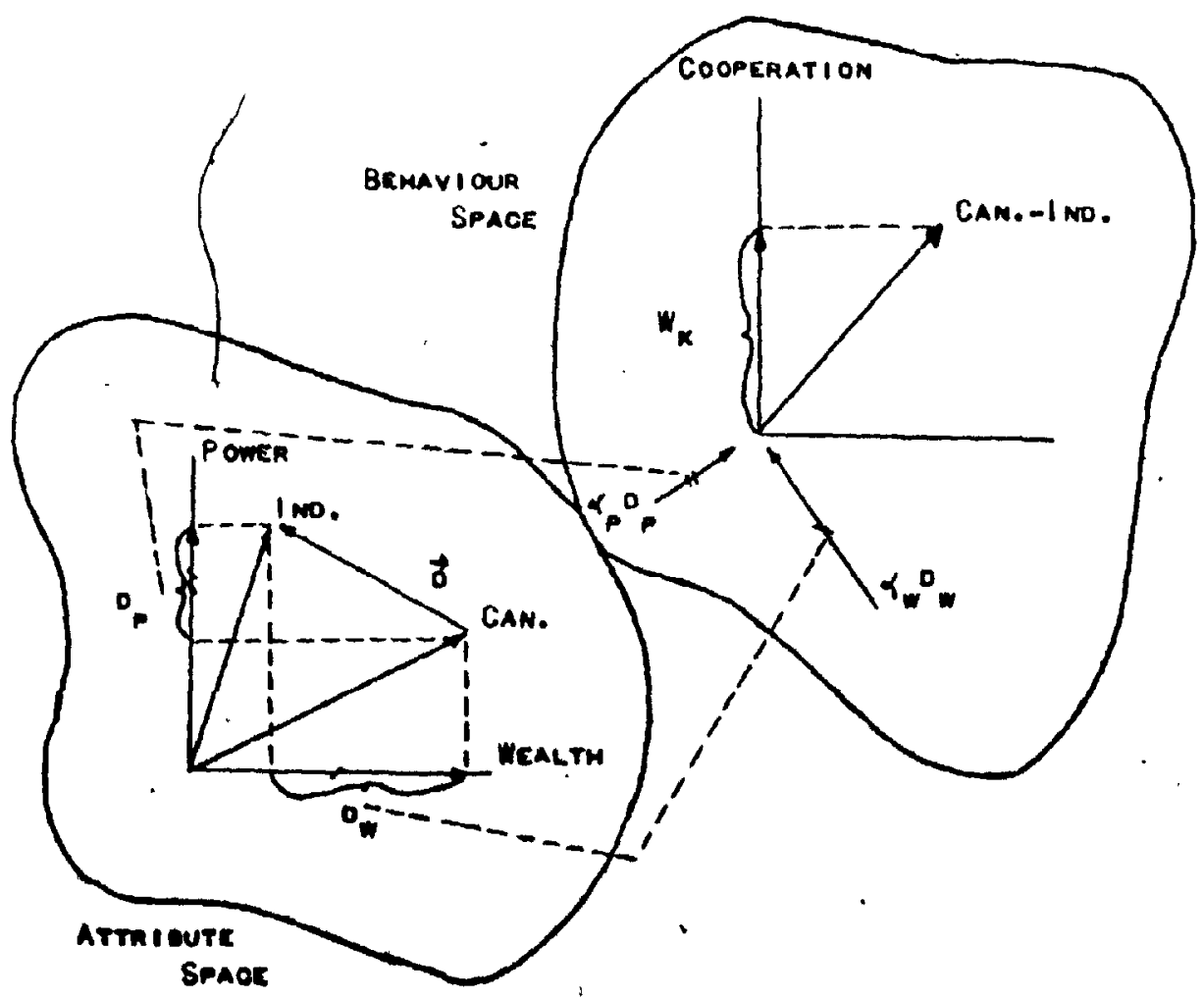

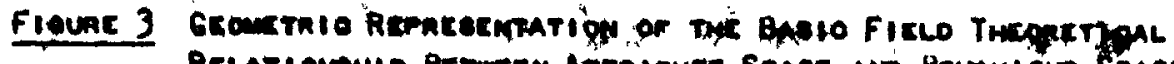
Relationanio Betwecm Attrigute Space and Beravioun Brace 
VEOTORB BEING THE VALUE OF EACH OYAD ON THE INTERACTION DIMENBIONB. THE BemaVIOUR DIMENBIONB FORM the aXe8. THE LOCATION OF NATIONB AB

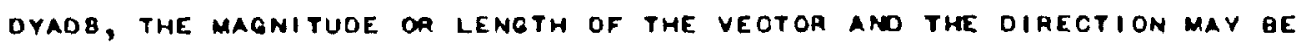
FOUNO BINCE THE ORIOIN OF THE EUCLIDEAN BPACE, WHERE THE OIMENBIONB INTERBECT, 18 ALWAYB ZERO.

THE F QURTH THEOREM, THE MOQILITY THEOREM BTATEB that " NATI ONB DEBIRE UPWARD MOBILITY" 10 BINCE a hIGH BTATUB 18 more debirable than

a low 8tatus. Furthermore, theorem 5, the Equilibrium Theorem,

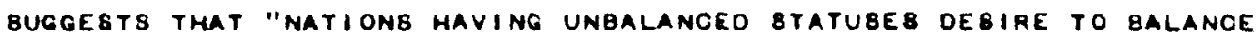
THEM," " A gTATE OF IMBALANCE OCOURB WHEN A MATION IB MIGM ON ONE OIMENBION, BUCH AB ECONOMIO DEVELOPMENT, BUT LOW ON THE OTHER, BUCM AB POWER. THE THEOREM PREDIOT THAT THE NATION OEBIREB TO haVe the BAME BTATUS ON BOTH DIMENGIONB, NOT GY DECREABINO THE HIEH BTATUB QUT OY OHANOING THE LOW BTATUB TO A hIBH ONE.

AXIOM 4 PROVIDEE THE LINKAEE BETWEEN ATTRIBUTE DIGTANCE VECTOAB AMO BEMAVIOUR:

4. BETWEen MATIONB, atTRIBUTE oIBTAMEE at a particular TIME ARE BOCIAL FORCES DETERMINING DVAOIC GEHAVIOUR AT THAT TIME. 12

THE FOBITION OF DYADB IN BEHAVIOUR BPAOE IB A FUMCTION OF THE BOOIAL VEOTORB OR THE DISTAMOE BETWEEN MATIONB IN THE ATTAIBUTE BPACE. THIS

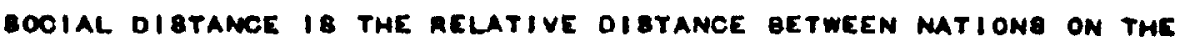
ATTRIQUTE DIMEMBIONB. (FIOUAE 2) THE DI OTAMCE veOTOA, REPREACNTCO oY D measupes the gPaOIAL nelation betweEn Camada ano I moia in teame

10. 1010., P. 30.

11. I010.

12. 1010., .. 33. 
$\therefore$

,

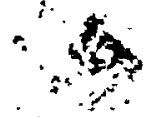
.
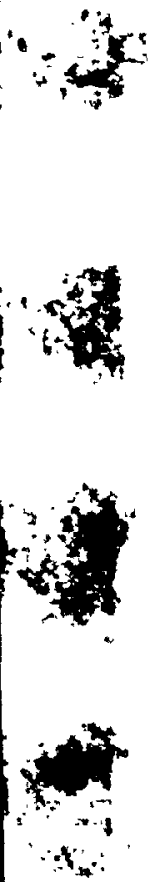

OF THEIR chaRAOTERIBTICB ON THREE ATTRIEUTE OIMENBIONB. THEORETIOALL BEHAVIOUA 8PACE. THE BOCIAL FORCEs aCt at THE ORIQIN OF THE BEHAVIOUR BPACE AND THE POBITION OF THE OYAD IB A FUNCTION OF THE RESOLUTION OF THEBE FOACEB. WHEN THEBE FORCE8 AND THEIR REBULTB ON BEHAYIOUR AAE

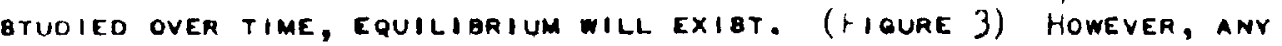

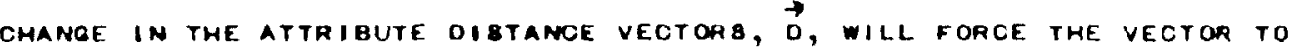
CHANGE ANO CONBEQUENTLY BEHAVIOUR WILL BE ALTERED, CREATING A NEW EQUILIERIUM. THEBE SOOIAL FORCEB ARE ALBO LIMITEO TO THE ENVIRONMENTAL OONOITIONB UNOER MHICH DEOIBIONMAKERB DEOIOE THE NATION'B POLICY. THE FORCES DO NOT IMRUEMCE DIRECTLY A NATION'B BEMAVIDUR, BUT RATHER THE PROCESB IB MEDIATED BY A LINK OF HUMAN DELIBERATIONB. STATIBTIOALLY, THE SOCIAL FOROE8 EXPLAIN 8 OME PORTION OF THE BEHAVIOUR, BUT THE UNEXPLAIMEO PORTION LIEB IN THE HUMAN ABPEOTE OF FOREIGN POLIOY. "IN OTHER wOROB, FIELO FOACE8 DETERMINE THE DIAPOSITIONAL DIRECTION ANO MAONITUOE OF THE' BEHAVIOUR; THE AOTOR, MOWEVER MAY OHOOSE OTHER BEMAYIOUR." 13

THIS RELATIONAHIP EETIEEN ATTRIBUTEB ANO BEHAVIOUA IB GTAE8OED IN WHAT RUMEL MA OALLEO MORE REOENTLY THE "CONCEPT OF RELATIVITY." FIELO THECKY DOEB nOT LOOK AT A NATION'B ABBOLUTE ATTRIBUTE8 ANO

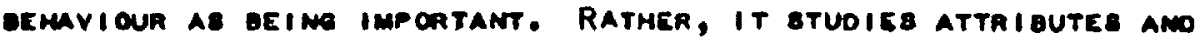

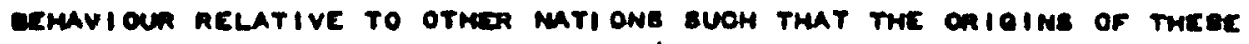

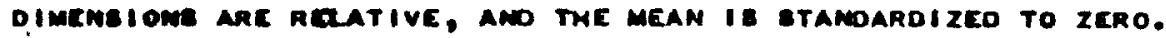

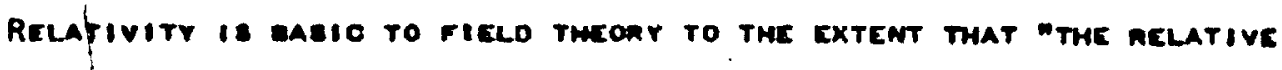

13. Rmer, "ChIm's Coopenatigy," p. 119. 
$\therefore^{\prime}$

56.

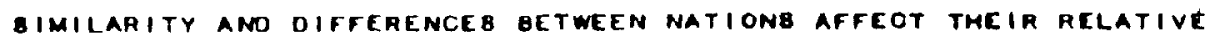

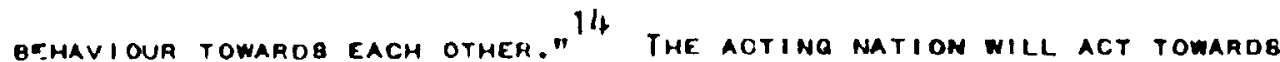
ITS TARGETB IN TEAMB OF THE BIMILARITIEB BETWEEN THE TWO NATIONB ON THE ATTAIOUTE OIMENBIONB.

A8 THE NEXT AXIOM INOICATEB, THEBE ATTRIBUTE DIMENBIONB LINKED TO BEHAVIOUR IN BTATUB-FIELD THEORY ARE BTATUB ATTAIBUTEB:

5. SOME BEHAV IOUR DIMENBIONS ARE LINEARLY DEPENOENT ON BTATUS. 15

THI 8 AXIOM DELINEATEB BTATUB-DEPENDENT BEHAVIOUR TO THE DEGREE THAT THE FORM OF INTERACTION BETWEEN NATIONB IB DEPENOENT UPON THEIR RELATIVE OIFFERENCE8 IN LEVELS OF ECOHOMIO DEVELOPMENT ANO POWER, THE BTATUB ATTRIBUTE DIMENEIONB.

CORAE BPONOINO TO GALTUNG's DICTUM ON WHO AND HOW MUCH INTERaction takes PLAOE, AXIOM 6 stateg that:

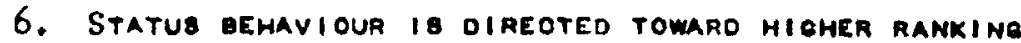
MATION8 ANO THE GREATFP A MATION'B RANK THE MOAE ITS BIATUS BEHAVIOUR.

Statug behaviour, IE DIRECTED TOMARD NATIONB WHIOH ARE HIOHER IM AAMK MOT ONLY BEOAUBE, THJB HIGHER RAMKINO MATION IO A MOOEL FOR MATIONB ABPIRINO TO INOREABE THEIR BTATUE, DUT AL8O AB A MEANB OF ATTAINIME DOODE AMO KMOWLEDGE TO HELP ACHBEVE THI AOCELEAATION. FURTHERMORE, MATIONB WITH HIOH RANKE INTERAOT MORE, EBPECIALLY WITH OTHER HIOH

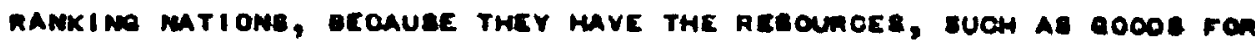

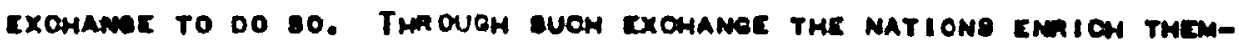
H

14. R. Rumatl, "Soolal Time ano I mTennatiomal Relations," in

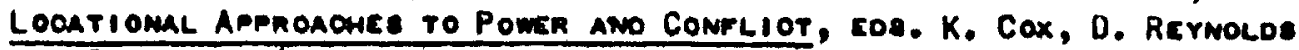
AMD S. ROKKan (TORONTO: JONM WILEY SONa, 1974), P. 77 .

15. HILTON, REVIEX, P. 33.

16. 1810., r. 34. 


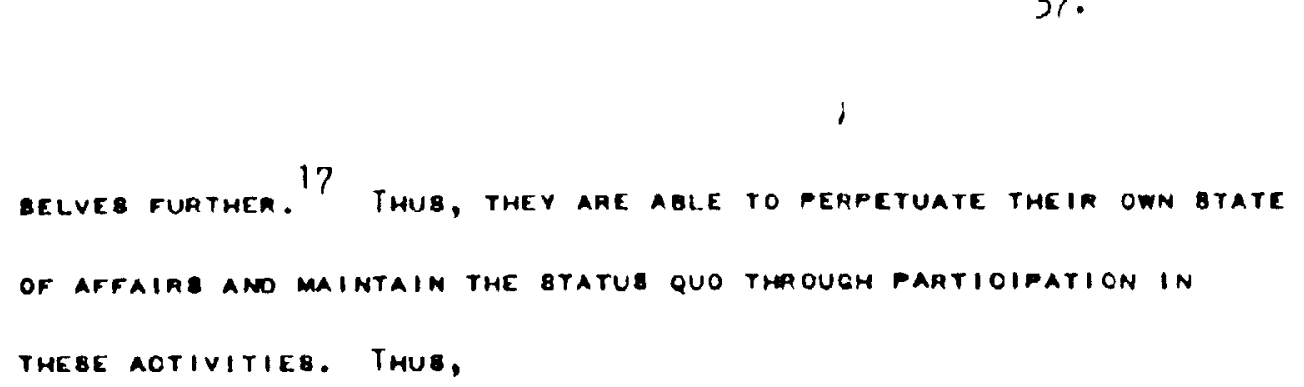

7. HIOH RANKINE MATIONB SUPPORT THE CURRENT IMTERNATI ONAL OROER.

THEY BUPPORT THE CURRENT INTERNATIONAL ORDER IN ORDER TO BUBTAIN THEIR OWN POBITION IN THAT EYOTEM.

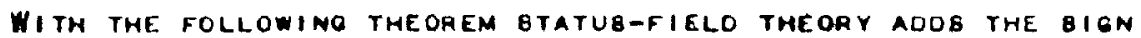

ANO BEHAYIOUR PREOICTION DIMENBION MHICH BOOIAL-FIELD THEORY LACKB.

THE COOPERATION THEOAEM POBTULATEB THE FOLLOWIME RELATIONBHIP:

WTHE HICHER THE JOINT RANK OF MATIONB I AMO J THE MORE COOPERATIVE

THEIR BEHAVIOUR." 19 THE JOIMT aANK REFERo TO THE INFLUENOE OF poth

EOONOMIC OEVELOPMENT ANO POWER ON TWO HIGH RANKINO MATIONB MOTIVATINE

THEM TO ENOAOE IN MORE OOOPERATIVE OEMAVIOUA WITH EAOM OTHER THAN

mOULO OTHERWIBE OCCUA. BY EAGAQINO IN THIB COOPERATIVE GEHAVIOUA, THE

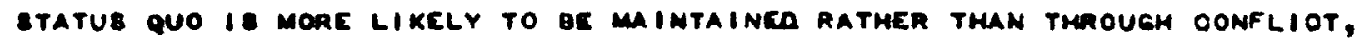

A RELATIONBHIP INCLIMED TO OEBTROY AN EXIBTIM OTATE OF AFFAIRB ANO

REPLACE IT OY ANOTHER LEB OOMOUOIVE TO THE OESIRES OF HIOH BTATUS

Mr I ONe.

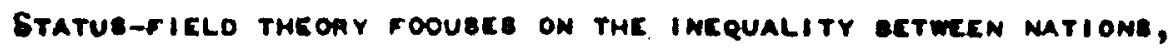

WHIOH, ACOONOINO TO GALTUNG, IS LIKELY TO REBULT IN COMFUIOT.

Axion 8 mRoposes THE FRAMEWOAK FO THIS OY STATIM THAT:

8. Matione cmomasize thein ocminant etátus ano the othere' guscondimate statue IN INTEAACTION.20

17. J. Galtume, "A Struotuaal Theony of Aeanession," Jounmal or Peace Reseanch 2 (1974): 99-100.

18. Hilton, Review, P. 34.

19. 1010.

20. 1010... 35 . 
THIS DIBEQUILIGRIUM BETWEEN HON THE NATION EXPECTB TO BE TREATED ON THE BABIB OF ITE MIOH BTATUB, AND hOW IN FACT IT IB TREATEO CAUBEB THE NATION TO GE IN A BTATE OF COONITIVE DIBBOMANCE. THIB DIBQONANCE OFTEN REBULT FRON THE DIFFEREMCE BETWEEN ABCRIBEO (POWER) ANO

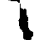
ACHIEVED (EOONOMIC DEVElopment) BTATUB. AB DiBCU8Beo IN THE PREVIOUB OHAPTER, THE GTATUB IN DIBEqUILIBRIUM DETERMINEB THE GEHAVIOUR OF THE MATION. IF THE MATION I8 hIOH ON ACHIEVEMENT atATUB, OUT haB MOT RECEIVEO THE RECOCNITION CONGRUENT TO THE POBITION, Ig Ig LIKELY TO EMCACE IN CONFLICT GEHAVIOUR, WHILE a NATION WITH THE REVERBE BTATUB, LOW ON ACHIEVEMENT ANO HIOH ON ABCRIPTION, IB LIKELY TO TAKE INTRA-

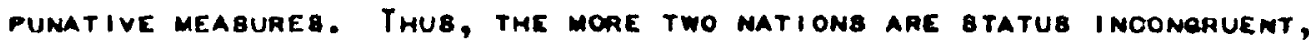
THE MORE LIKELY THEIR AELATIONBHIP WILL BE UNCEATAIN BINCE MEITHER IB CERTAIN OF WHAT THPE OF BEHAVIOUR IS EXPECTEO FROM THE OTHER. 21

THE TYPE OF EEHAVIOUR EXCHANOEO DETWEEN NATIONB WNICH ARE

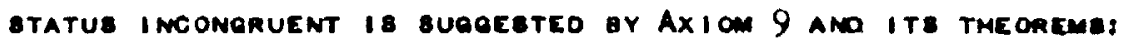

9. THE MOAE BIMILAR IN ECONOMIO OEVELOPMENT STATUE, THE MORE NATIONB AAE MUTUALLY COOPERATIVE. 22

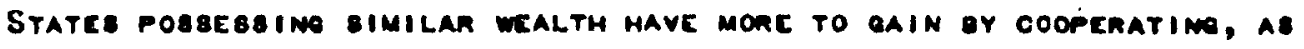

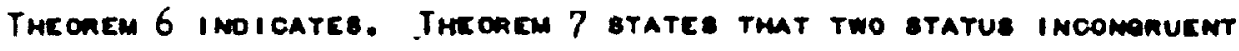
NATIONS WILL MAVE ETATUE-DEPEMOENT OOMFLICT BEMAVIOUR. ThUB LESE OONFLIOT I EXPEOTEO DETHEin CENTAE-CEMTAE (EOONOMICALLY OEVELOPEO) MATI ONE TMAN DETWEEN PERIPMERY PERI PHERY (EOONOMIOALLY UNOEROEVELOPGO) NATIONB, ANO MONE CONFLIOT BETWEN CEMTRE-PERIPMEAY MATI ONE. TMEBE

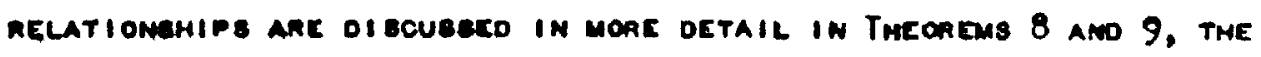

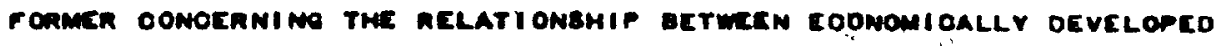

21. Galtum, "Aeanzesion,n P. 92.

22. Hilton, Revien, •. 36. 
MATI ONB, THE LATTER REPAEBENTING ECONOMICALLY UNOEROEVELOPED NATIONB. HOTH THEOREMB GTATE THAT THE CONFLIOT BEHAV PUR OETWEEN NATIONB IQ DEPENOENT UPON THEIR DISTANCEg ON BOTH OIMENBIONE. THE DIFFERENCEg OCCUR IN THE BIGN PREDICTION. IN THEOREM 8, IF MATIONB ARE NOT BIMILAR ON THE ECONOMIC DEVELOPMENT DIMENGION, BUT ARE ON THE POWER DIMENSION, CONFLICT 18 LIKELY TO OCCUA. THE OPPOBITE OCCURB FOR ECONOMICALLY UNOEROEVELONCO NATIONS WHERE BEHAVIOUA IS A FUNOTION OF THE LEVEL OF ECONOMIC DEVELOPMENT. BEHAVIOUR, hOMEVER, IB NOT AN EITHER/OA PROPOSITION. A NATION MAY ENGAGE IN EITHEA COOPERATION OR CONFLICT, OR IT MAY EMGAGE IN BOTH OOOPERATIVE ANO CONFLICTFUL AOTB WITH ITB TAREETS. TMIG TYPE OF INTEAACTION IS ALBO RELATEO TO THE atTAIBUTE oIBTANCE BETWEen MATION8. TWO ADOITIONAL THEOREMB, 10 AND 11 PROPOAE TO TAP TMIO MIX OF INTERAOTIONS. ONCE AGAIN IT 18 ABgUMED THAT THIB BTATUS ORIENTED BEHAVIOUR OIFFER FOR ECONOMICALLY DEVELOME" ANO UMOEROEVELOEED MATIONS.

- The eoonomicalle developeo btatub behaviour theonem (10) states that "YHE BTATUB DEPEMOENT COOPERATION AND CONFLIOT BEMAVIOUA DF ECONOMIOALLY DEVELOPEO MMTIONB TO OTHERB 18 A FUNCTION OF TMEIR POWER IMOON-

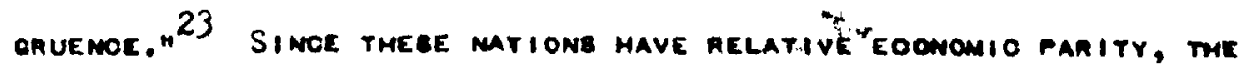
EXTENT TO WHICH THEY UBE THEIA POWER BEOOMES A CRUCIAL MATTER IN THEIR

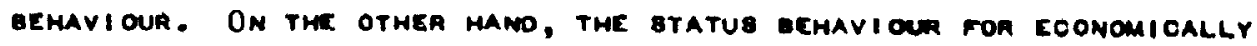
UNOEROCVELOPEO MATIONE, THEOAEM 11, etates TMAT COMAVIOUR IS A FUMOTION OF COONOMIO DEVELOPMENT INOONORUENCE. SINCE EOONOMIO DEVELOPMENT IS AOHIEVED AE COMPARED TO POWER, IT Is KMOWH FaOM THEONEM 4 TMAT UNOER23. 1810.,... 37 . 
DEVELOPED NATIONB ARE CONCEHNED WITH INCREABING THEIH 9 TATUB ON OEVELOPMENT BV WMATEVER MEANB ARE NECEBBARY. IF TME MEANB TO ATTAIN THIS DQAL ARE BLOCKED, CONFLIOT MAY BE THEIR LABT REBORT.

Finally, Theohem 12 atates that the gtatub-oepenoent behavioua AT TIME T IS LINEARLY DEPENDENT UPON THE OTATUB DIBTANCE VEFTOR BETWEEN THE ACTOR AMD TARGET AT THAT BAME TIME.

STATUB-FIELO THEORY IB AN EXPLICIT FAAMEWORK WITH AXIOMB ANO THE OAEMS DETERMININO THE EXTENT TO MHIOH OYAOIC BEHAVIOUR IB DEPENOENT UPON THE BOCIAL ATTAIBUTE DIBTANCE BETWEEN THE GAME NATIONB. STATUBFIELD THEOAY 18 POTENTIALLY FAUITFUL BECAUBE OF THE RICH BET OF

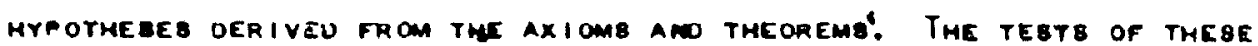
HYPOTHEBEB HAVE BEEN OIBCUBBEo PREVIOUBLY. ALL OF THE TEBTB OONCENTRATE OA MATIONB IN THE EMTIRE INTERNATIOMAL BYBTEM WHEAE ATTRI BYTE DIETAMOE BETWEEN ACTOR AMO TAREET MAY BE OREAT... JME BASIO AEBUMPTION

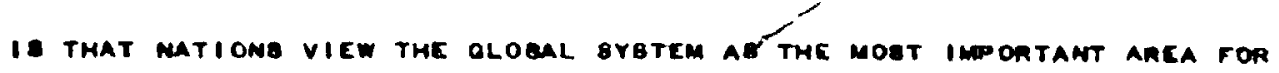

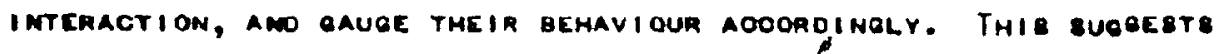
THAT REOIONALLY DABEo BeHAVIOUR 19 OF NO LEBg OR OREATEA IMPOATANOE. THAN IMTEANATIONAL EEMAVIOUA, gUT 18 BTUDILO OOINOIOENT TO THIE ELOBAL I MTERAOT ION.

\section{Regi OMAL Analyeis}

KeAN ANo MOGOWAN mave queBtionco THIB ABBUMPTION OF THE DONIN-

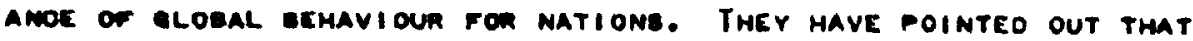
ALTHOUEA THE IMTERMATIOMAL AREMA IS IMPORTANT FOR INTERAOTION, TWERE

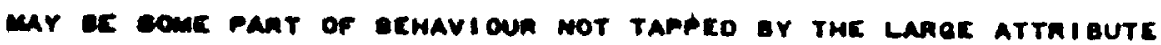

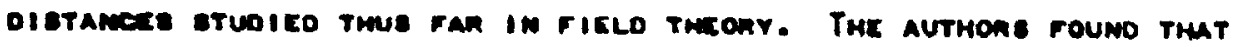




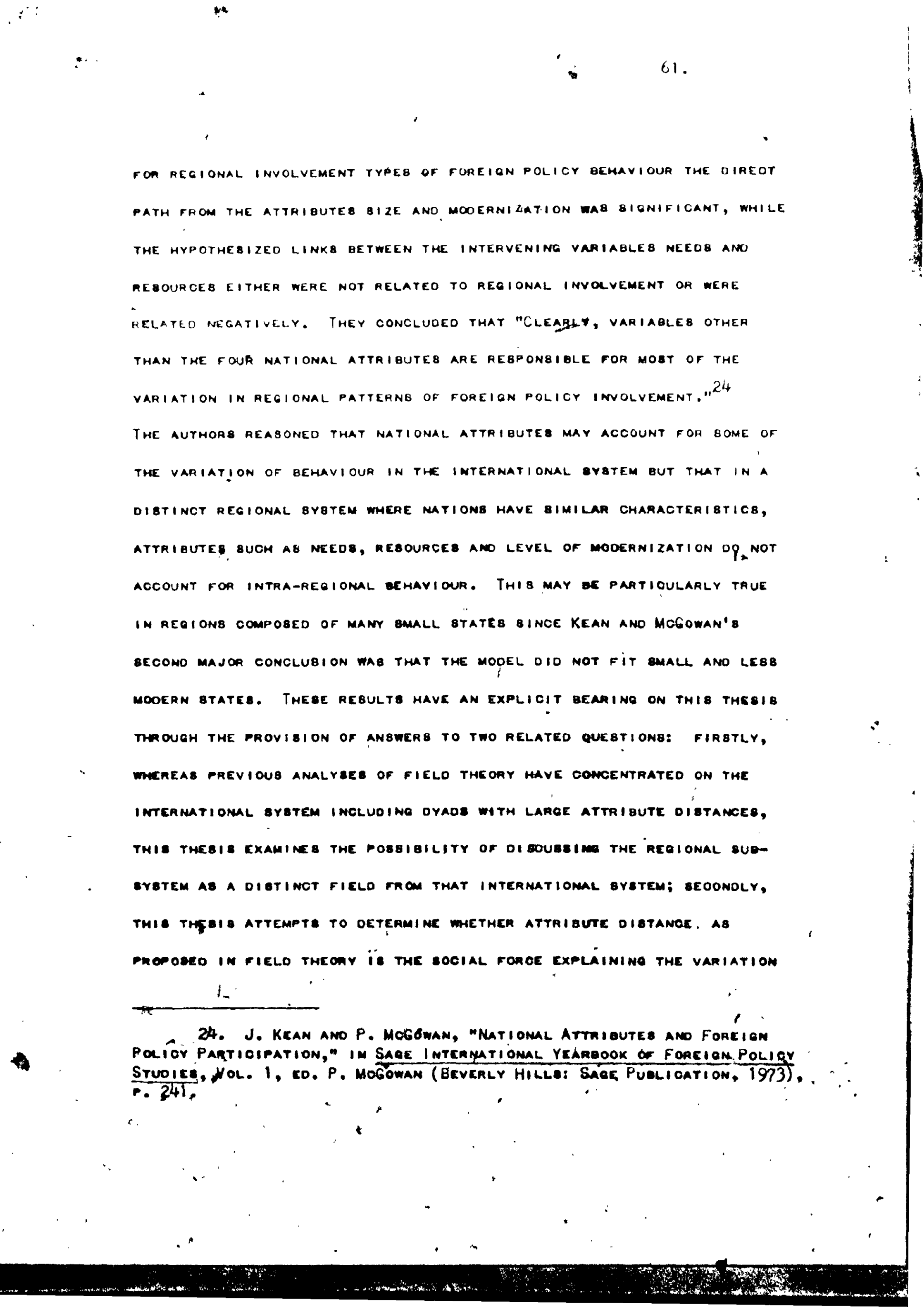


IN BYBOYBTEM BTATEB' FOHEIGN POLICY BEHAVIOUR.

THUB, THIB THEBIS POINTB OUT THAT UNTIL NOW ANALYBEB OF BOCIAL

ANO BTATUB-FIELO THEORY HAVE FOOUBED ON THE FOREION POLICY BEHAVIOUR

OF OYAOB WHICH INGLUDE THOBE WITH VEAY LAROE DIBTANCE BCOREB, FOR

Example the U.S. ro Egrpt, or Chima ro Aloania. It 1 B imposgible to

RECOQNIZE FROM THEBE RESULTB WHETHER OR NOT THE THEORY ACCOUNTB ONLY

FOR BEHAVIOUR IN THEBE OYAOB WITH THE TARGETB DIBTANCT FROM THE ACTORB,

OA IF TME THEORY AL8O AOCOUNTB FOR GEMAVIOUR IN MORE BYMMETRIC DYAOB

WHERE FHE DIBTANCE DETHEEN ACTOR ANO TAROET 18 maLL. THAT 16, IT

maY BE TMAT MORE OF THE UMEXPLAINEO VARIANCE IN BEMAVIOUR AMALYBE OF

THEBE LAREE DIBTAMCE MAY BE AOCOUNTEO FOR BY THOEE DYAOB WITH BMALLER ATTRIBUTE DIBTANCE8.

4

IM ADOREBBINO THE FIABT QUEBTION, THE AXIONB OF FIELO THEORY
EMPHABIZE THE EXHAUSTIVENEBS OF ATTRIBUTEB AND GEHAVIOUR WITHIN THE BTRUOTURE OF THEIR REBPEOTIVE SPAOES. AXIOMB 1 ANO 2 DEFINE INTERMATIOMIL RELATIONB A8' a FIELo COMPRIBEO OF A EUCLIOEAN ATTRIBUTE

space fop all mations' atraibutes amo a Euolidean behaviour grace DEFININO ALL MATIONB' IATERACTIONB, THU: NOT BTIPULATINO AMY AREMA FOA MATION IMOLUSION IN THE FIELO. THIB THEBIE, THEN ABSUMCE TMAT A FIELO MAY COMBIIT OF ANY IYBTEM OEFINEO OY NATIONS ANO THEIN INTERACTIONB, ANO WHICH maY GE OEMONBTAATEO AE A RELEVANT BYBTEM TO THE PARTICIPANTS.

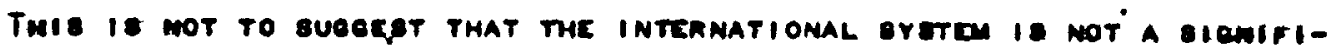
OAMT AREMA FON InTERACTION TO THEBE MOTONB, DUT THAT,

-.. APANT mon aeine pant of the glogal Syetrm,

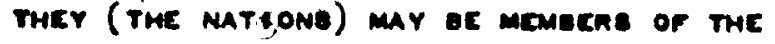
Domimant SYeter ano one on mone ousondimate evercme. DIFFERENT AOTIONE AMO DEOIBIONS OCRIVE 


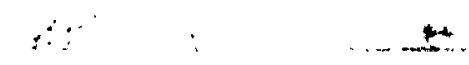

63.

FHCM OIFFERENT ABBOCIATIONB. IT IO UBEFUL TO GEPARATE AMO CORRELATE POLICY ACTB WITH BPECIFIC MEMEER holeB.25

THE PCGION PROVIDEB AM ALTERNATE BPHERE FOR NATIONAL INTERACTION WITH NATIONB OFTEN MORE BIMILAR IN ATTRIBUTE DIBTANCEB THAN MATIONB OUTBIDE THE REQION.

VIEWED IN THEBE TERMB, THE LITERATURE ON REQIONB BTRONGLY BUGGESTB THAT NATIONB PEACEIVE THE REGIONAL SYBTEN AB AN IMPORTANT BPHERE OF INTERACTION. THE BABIC REABON FOR THIB PEHCEPTION IB THAT CERTAIN IBSUES ARE RELEYANT ONLY TO MATIONB IN REGIONB, WHILE 8 ONE glogal ibgueg mave little relevamoe to their foreign policy relationg. THERE ARE BPEOIAL INTEREBTB WMICH AAE OERMANE TO MMTIONB WITHIN A OERTAIN LOCATIOM, BUCH A A BORDER DIBPUTE OR A COOPERATIVE AGREEMENT FOR HYORO-ELECTRIC POWEA, WHILE OTHEA I8BUES OUTBIDE THEIR REGION, buch ab the palebtine Ligeration Organization amo i brael. are not oONEIDERED TO BE AB IMPORTANT. That IB, -.. WhILE THE SPECIFIC IB8UE ano mixture betweEn REQIONAL ANO OLOBAL DONGERMB WILL VARY FROM ONE subsrateM TO THE NEXT (YOUMG, 1\%69:339), THE CONTEMPOAARY INTEAMATIOMAL BYSTEM IS REBIONAL BOBSYETEM DOMIMANT BCCAUBE, TO MO8T AOTOAB, REOIONAL ROLES ANO PROELEM AAE OF DONBIDERgELY

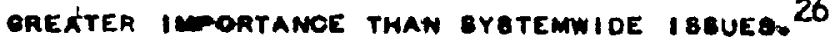

RECIONAL MUTIONB MAVE A CERTAIN AFFINITY ANO GEOQRAPHIOAL MOXIMITY MICH INFLURESE GOTH THEIA COOPERATIVE ANO OONFLICTFUL

25. M. BaEchen, The New SYstem of SMall States: a Polltioal AmaLreis (LonoON: OXFone UNI VEREITY PREBe, 1963), P. 17.

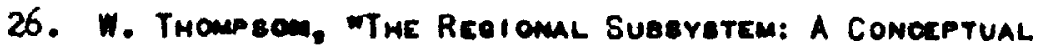

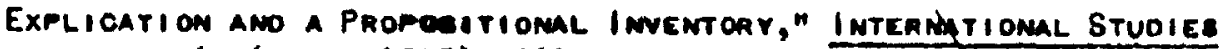
QUARTERLY 17 (MAMCH 1973): 111. 


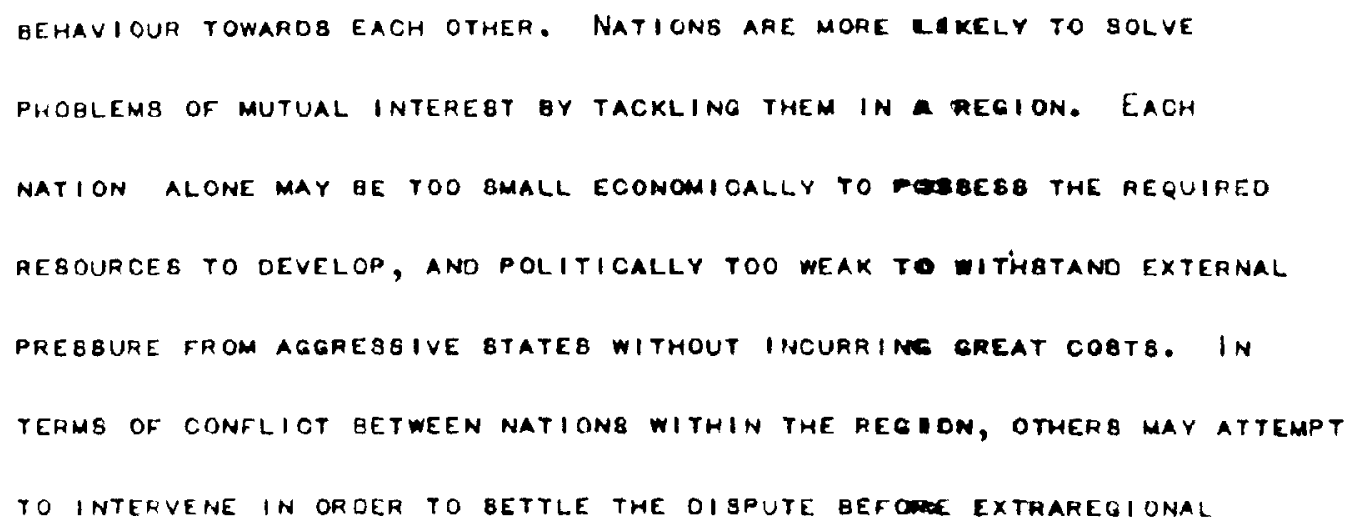

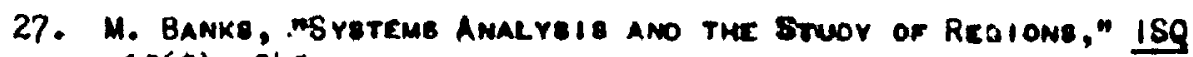
13 (Droemanes 1969): 345.

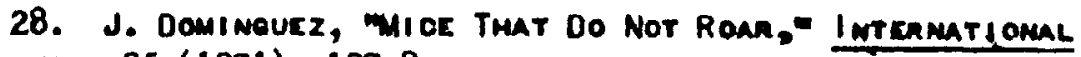
OREAMIZATION $25(1971)$ ) $197-8$. 
THEIR PROBLEMB.

A OEMONBTFATION OF THE IMPORTANCE OF THE REQIONAL BYBTEM AS A aEleVANT BPHERE TO THE PARTICIPANTB IB MANIFEBTED IN OYAOB EVIDENCINE TARGET 8ALIENCE. THAT IB, THE ACtORB REGARO THEIR TARGETB AB IMPORTANT NATIONB WITH WHICH TO INTERAOT. THIB TARGET BALIENCE OCCURB PRIMARILY IN THE GEOGRAPHICAL REGIONB IN WHICH ACTORS ANO TARGETB

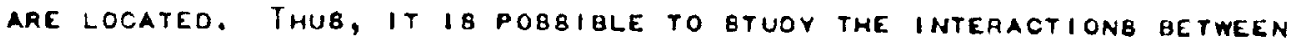
THEBE MATIONB. ALTHOUGH THEBE INTERACTIONB MAY NOT BE ON A GRANO BOALE BUCH AS MAR OA BUPPLYINO MILITARY AIO, TO TWE MATIONB INVOLVEO THEIR ACTIONB CONBTITUTE IMPORTANT EVENTE WITH TAREETB BUBBTANTIAL ENOUEH TO WARAANT THEIR INITIAL ATTENTION.

4

SINOE INTERAOTIONS BETWEEN NATIONG AT THE BUBOROIMATE LEVEL ARE IMPORTANT, IT I8 WORTHMHILE TO EXAMINE MHETHER THE BAME FAOTORB WHIOH EXIBT IN THE INTERNATIONAL BVBTEM ALBO INFLUENOE REOIONAL FOREIGN POLIOY BEHAYIOUR. THAT 18, DO THE AB8UMPTIOME AMO THEOREMS OF BOOIAL ANO BTATUB-FIELO THEORY EMOURE FOR THE RELATIVELY BMALL OIBTANCES

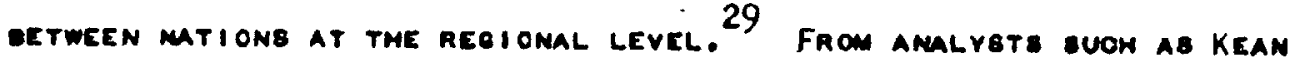

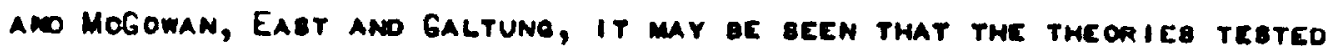
DO NOT DIBCRIMINATE BETWEEN MATIONE WMIOH HAVE BMALL DIFFERENTIALE ON ATTRIBUTE DIMENBIOMS ANO THOSE WITH LAREE OIFFEREMTIALB. TME

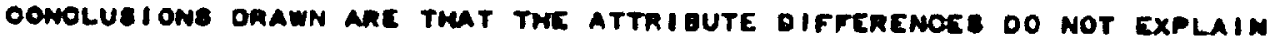
AMY VARIATION IN EEMAVIOUR, ON FUATHER, AS IN TME OABC OF EAOT aNO

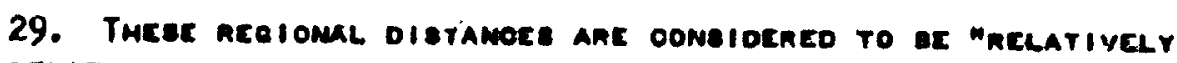

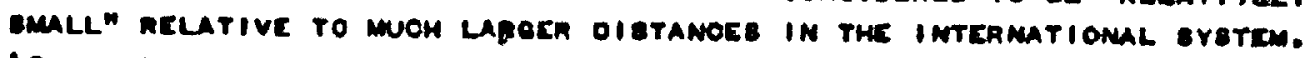

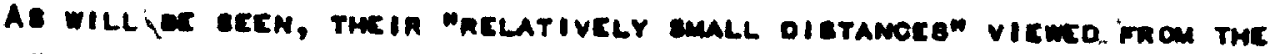

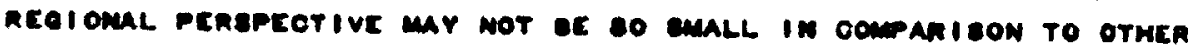
Distanoes within the negion. 


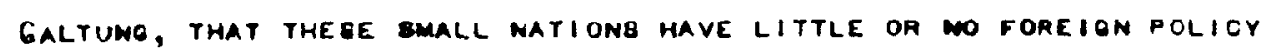
INTERACTIONS. HOWEVER, ACCOROING TO FIELD THEORY, WHERE atTRIBUTE DISTANCEB DO EXIBT, THEIR DIBTANOE INFLUENCE FOREIGN POLICY BEHAVIOUR.

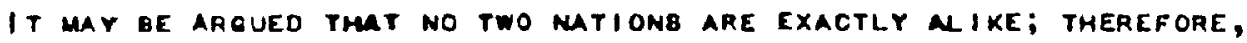
8OME AMOUNT OF DIBTANCE DOEQ EXIBT BETWEEN NATIONS. THE AIM OF THIB THE 818 IS TO OETEAMIME WMETHER 8OOIAL AND BTATUG-FIELD THEOAY, FORMALIZEO FOR THE CLOBAL OYBTEM WHERE DIEPARITIEB EETWEEN NATIONB ARE LARGE, MAY ALBO DE APPLIEO ANO FOUNO UBEFUL IN THE REOIONAL BYBTEM WHERE THE MAGNITUDE OF THE OIBTANCEB BETWEEN MATIONB ARE RELATIVELY EMLLER, THAT 18, WEENE THE MATIONE AAE MORE SYMEETRIO THAN IN THE INTERMATIOMAL EYSTIM. A EEOONO ALTERATION UNDERLYINE THIB ANALYBIB 1. THAT MHEN MATIONB DO ENGAOE IM TOREION POLICY EEHAVIOUR, THEN THIS DEMAYIOUR maY BE EXPLAINED IN A FABHION BIMILAR TO TKAT OF LARGE MATIONB IN THE QLOQRL EYBTEM.

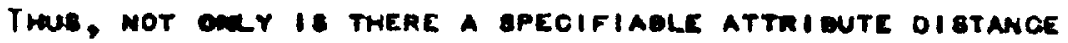
EETWEEN REQIOMAL MATIONE, OUT THEY EMGAOC IM FOAEION POLIOY BEHAVIOUR WITH OTHEA MATIONB IN THE AEGION. THIB THESIE TEETS MHETHEA PATTEANS IN EEMAYIOU VARIATION ARE A FUNOTION OF THEBE ATTRIBUTE DIBTANOEB.

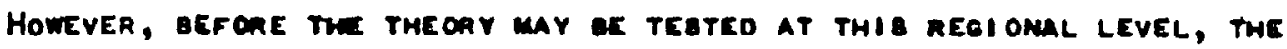

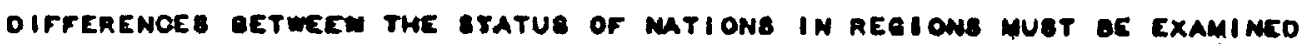
IN MORE DETAIL.

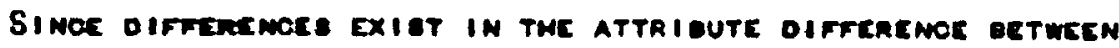

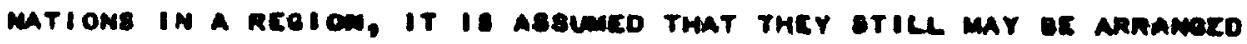
MIERAROMICALLY. THE DIFFEnEWOC IN THE RAMKIME TRON THAT OF TME INTER-

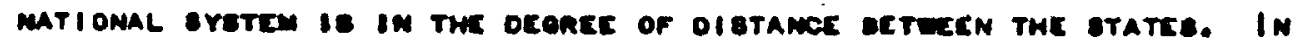

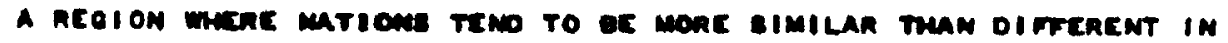


COMPARIBON WITH NATIONS ON THE INTEAMATIONAL LEVE, THEIR OIFFERENT ATTRIBUTE OIBTANCE WILL' Be RELATIVELY GMALL. NATIONE BTILL RAHEE FROM THOBE WIGH ON THE ATTRIBUTES TO THOBE LOW. SOME NATIONB WILL

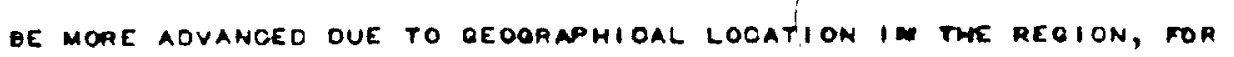
EXAMPLE, NATIONB IN TEMPERATE ZONEB, AND TME DIETMIBUTION OF MINERAL REBOURCE8. POLITICAL BOUNOARIEB ARE NOT DRAWN TO "BHAME THE WEALTH" BUT AAE OUE TO POLITICAL CHARACTERIBTICS, BUCH AS COMQUEBT ANO NEGOTIATION, ANO CORREBPOND WITH GEOGRAPHICAL COABIDERATIONB, BUCH AB RIVERG ANO MOUNTAIN BARRIER8. THEBE ATTRIBUTE DAFFERENCEB WILL INFLUENCE FOREION POLICY BEMAVIOUR TO THE EXTENT THAT THE -.. Sugrv8tem replisateg the hierareghical pattern OF THE INTERNATIONAL BYBTEM BO THAT WOET COUNTRIEB -.. ARE ENGAGED IN BUPERORDINATE AMO SUBOROINATE RELATIONBHIPB WHICH BTROMELY SHAPE TWE SOOPE AND DOMAIN OF THEIR FOREIGN POLIOY. 30

THAT 18, DEPENOINE ON A MATIONB' POBITION IN THE GEOIOMAL HIERARCHY ANO THE DISTANCE BETWEEN MATIONB IN THIS ARRANGBUENT, MATIONS'

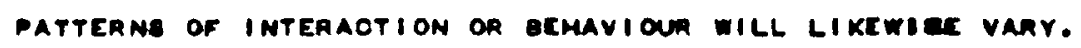

WITH MATIONE RANKED IN A ETRATIFICo EVETE mon TOPDOO to

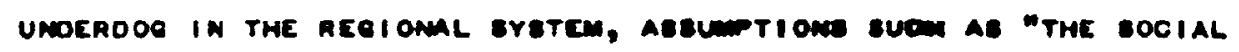
OENTRE DCOUPIES POSITIONE TMAT ARE SCOIALLY REWAOECO, ANO THE BOCIAL

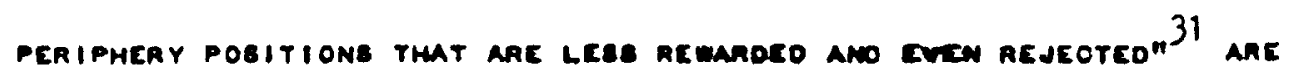
APPLIOABLE TO THE REBIONAL SUEBVETEM. BEMAVIOUR ABBUMPTIONB ARE AL8O

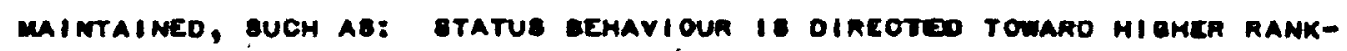

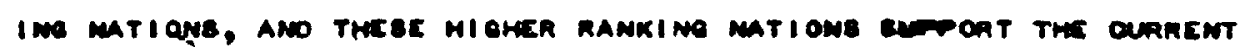

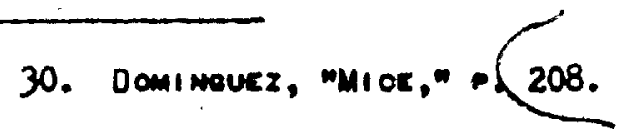

31. J. Galtune, "Fontien Polior opinion an a funotion of Sooial Poeition," Peaog Researoin Sooirty, Papere (1964): 207. 


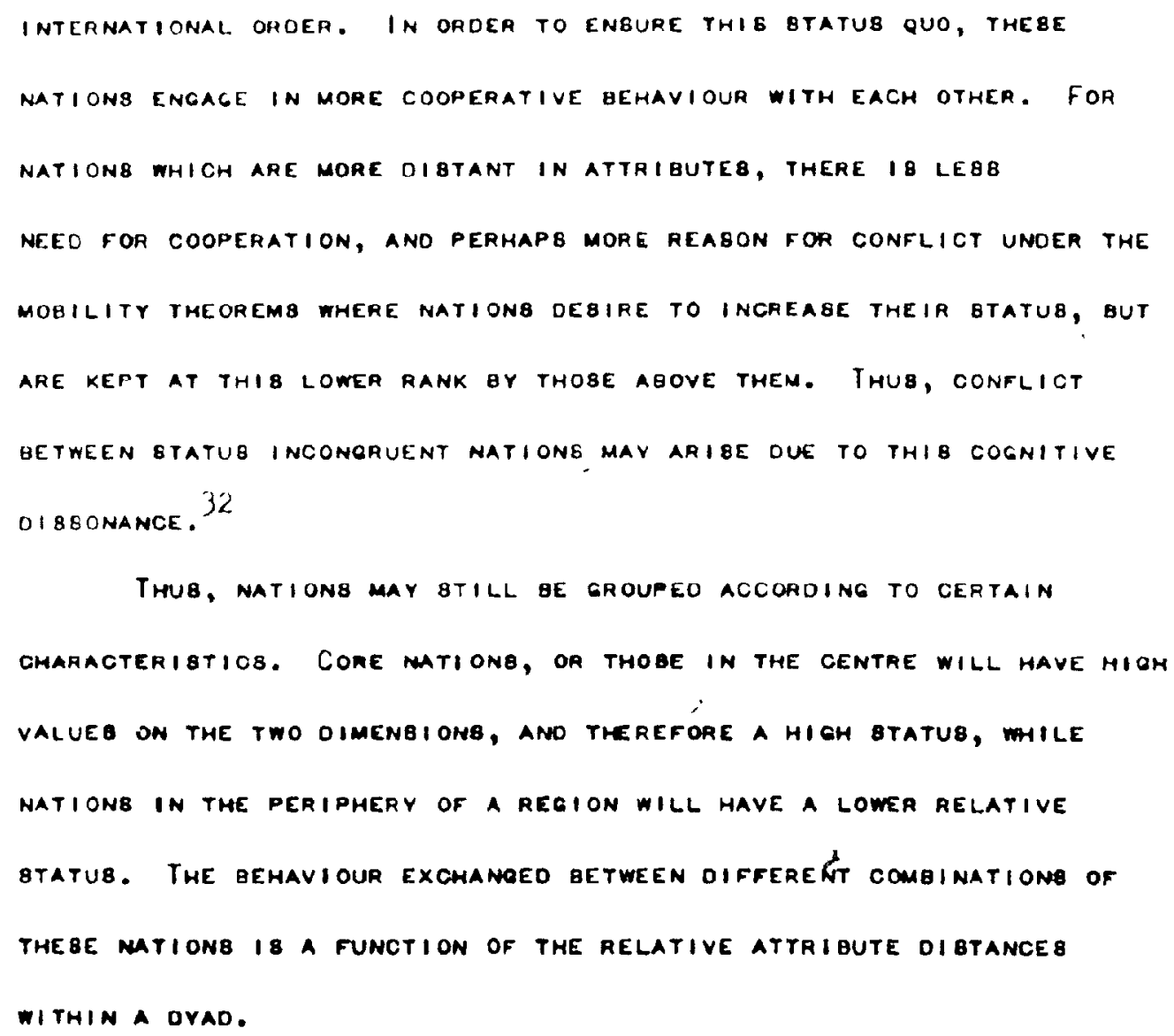

32. REFER TO THE AXIOMS ANO THEONEMB OI EOUSBCO EARLIER IM THIE CHAPTER FOA A FULLER OIBCU88ION OF THEBE POIMTB.

33. L. Canton I ano S. Spiecel, The Internatiomal Politice of Regione (New Jeager: Pnewtioe-HaLl INC., 1970), P. 4.

$$
\text { ; }
$$


(1) CEERY MATION-8TATE ... IB a MEMBEh OF ONLY ome subordimate BYgTEM ...

(2) ALL BUBORUINATE BYSTEMB ARE GEOGRAFHICALLY DELINEATEO ... BV REFERENCE TO geOgRAPHICAL CONBIDERATIONS, BUT BOCIAL, ECONOMIC, rolitical, ano organizational factopB are RLEO RELEVANT ...

(4) DITHIN THE gounoARIES OF THE BUBOROINATE ETETEM, THEAE 19 A COMPLEX INTERACTION BETWEEM POLITICAL, BOCIAL ANO GEOOAAPHICAL FACTOA8 .... (ANO)

(8) -.. A BUBOROINATE BYBTEM CONBIBTS OF ONE BTATE, OA TWO OR MOAE PROXIMATE ANO INTERACTING ETATEB WHICH, Mave bome Common ETHMIC, LINGUIBTIO, CULTURAL ANO HIBTORICAL BONDS, ANO MHOEE BENBE OF IOEMTITY 18 SOMETIMEB INCREABED OY THE ACTIONB ANO ATTITÚDEQ OF BTATEB EXTERMAL TO THE eratem. 34

WNY OF THE DEFIMITIONE OF REOIONB BABED ON DEFENCE ANO ECONOMIC

ORGANIZATION DO MOT CORREBPONO TO THE CRITERIA PROPOBEO BY CANTORI AMO

SPIEgel. Nationg, in particular olobal Great Powers, are often members OF MORE THAN ONE ORANIZATION, ANO THE REgIONG ARE uBUALLY EXTAAMious TO MANY GMAREO OMAMAOTERIGTICB. RATHER THAN BEING MOMOQENEOUB QROUPB, THEY TENO TO BE A EIXTURE OF BOOIAL AND POLITICAL DIVERBITIEB WITH ONLY A Common INTEREST DINOINO THEM.

FURTHERMOAE; OIFFERENT REOIONB REBULT FROA DIFFERENT OEFINITIONB.

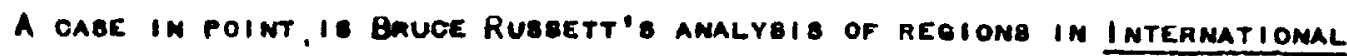

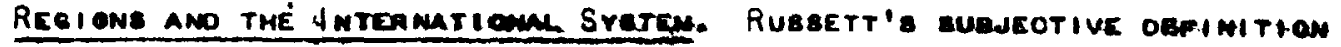

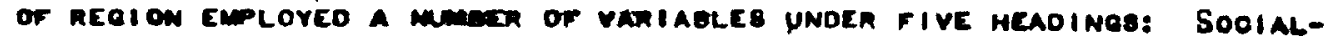
OULTURAL MOMOEENITY, MENAD POLITIOAL ATTAIBUTEE, POLITIOAL INTEA34. 1010., m. 5-6. 


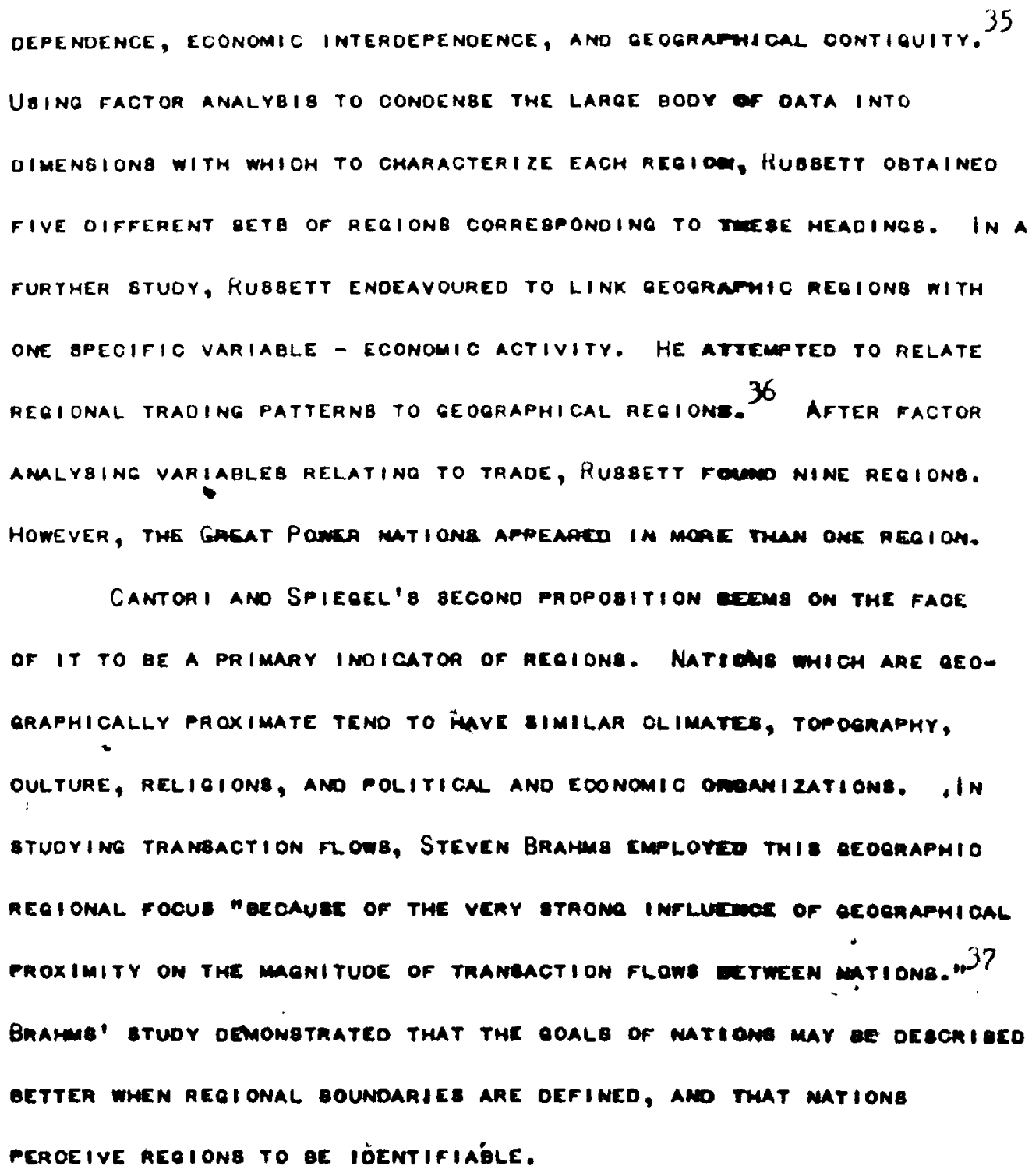

35. B. RUBEETt, InTERMATI OMAL REeIONE ANO I MTERMATIOMAL SVETEMas a Stuor in Political Ecoloey (Chloado: Rano Monalle, 1967), Chaps, 2-10.

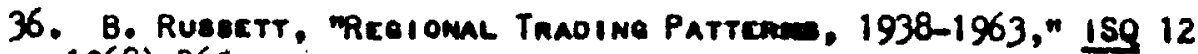
(Orocmarn 1968):365.

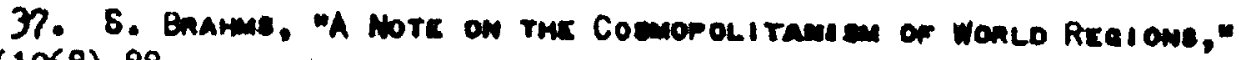
JPR $5(1968)$ \& 88. 
CENERALLY EXIBTS AS TO WHICH NATIONB CONBTITUTE A REBION. A COMBINATION OF REGIONB FROM THE WOAK OF THAEE AUTHORB, BRAMMB, 38 . KOHN ANO

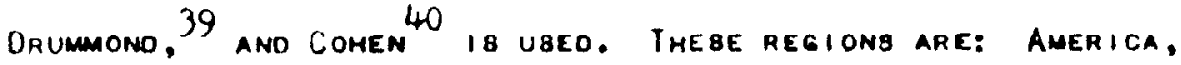
hebtern Eufore, eabtean kurope and the Soviet Union, the Middle Eabt and the maghreg, Africa (South of the Samara), Abia, and OffBhore abia ANO DCEANIA.

DIFFEAENCEg OF OPINION MAV EXIGT ON THE VALIDITY OF THEBE REQIONB ANO THE IR MEMBERS BINCE, GENERALLY, NATI QNB IN a geOBAAPHICAL REQION ALBO HAVE RELATIVELY BIMILAA ATTRIQUTES, SUCA A 8 THE LEYEL OF ECONOMIO DEVELOPMENT OR THE CULTURAL OOMPOBITION OF THE MATIONB. HOWEVER, KEEPINO IN MINO THE LATteR PART OF CANTORI ano SPIEOEL's 8ECONO PAOPOBITION, REgIONB haVE TO QE CONBIDEREO ON THE DABIB OF

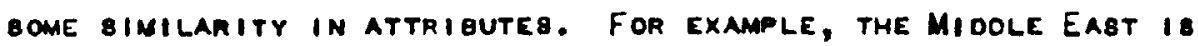
8EPARATEO TKOM THE REST OF AFRICA BECAUBE OF THE BABIC OIFFEREMOEB IN POLITICAL, CULTUNAL, CCOMOMIO AMD BOCIAL MOREB.

BLAOK AFKIOA 18 THE REOIOMAL BYSTEM OMOBEN FOR THIS BTUDY. THE NATIONB IN THIQ AEGION HAVE A PREDOMINANTLY BLAOK POPULATION MANORITY ano black nule. (Table 1) for this reason South Amioa ano Rhooseia, ceogaphically located in the Region, mave Ben OMITTED. The matione IN THE REOION ARE CONBIOERED TO BE BMALL IN QLOBAL COMPARIBONB IN

38. 1010.

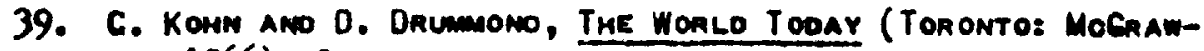
Hill Puoliemen, 1966), Cmapten meno imes.

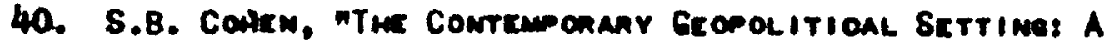
Proposal ron Glomal Geopolitioal Equiliemiun," in Esesare in PoLitioal

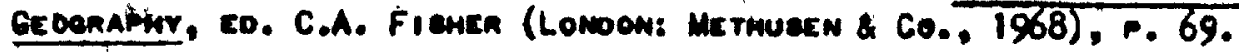


72.

TABLE 1

The Suboadmate System - Africa (South of the Sahara)

BLACK AFRICA

BOT BWANA

BURUNDI

CAMEROON

CENTRAL AFRican REPUBLiC

Credo

Congo

DAHOMEY

ETHIOPIA

GABON

Gambia

GHANA

Guinea

IVORY COAST

KENYA

LESOTHO
LiBERia
LiBra

MALI

MaURitANIA

NIGER

NIGERIA

RWANDA

SENEGal

Si Emma Leone

Somalia

SUDAN

Tanzania

Togo

UGANDA

UPPER VOLTA

- zaire

LAMB IA 


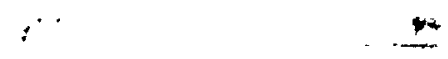

TERMB OF MEAN ANNUAL INCOME, MILITARY WEAKNEBB, aAD POPULATION, GUT THEY DO DIFFER FROM ONE ANOTHER IN THE VALUEB THET POBSEBB ON THEBE ATTRIBUTE 8 .

SCHOLAKB haVE INOICATED THAT REgIONAL FORE Ben POLICY BEHAVIOUH DOES OCCUR BETWEEN THE AFFICAN NATIONS. In PARTICULAa, MaMMOND COPSON EXAMINEO THE CONFLICT PATTERNS OF AFHICAN MATIONB WITHIN THE pegions of hest Africa, nofth AFrica, The horn, tast and lenthal Africa ano South Africa. The conflict patterng in each region were QAUEEO IN TERMS OF THE MUMEER OF EVENTS SXCHANGEO GETWEEN MATIONG TO DETERMINE WHETHER THE AMOUNT OF CONFLICT IN THE REGION MAB INCFEABED OR DECREABEO. COPBON BMOWED THAT THEBE BTATEB DO WOT LIMIT THEIR BEMAVIOUR TO NATIONB WITHIN THEIR IMMEOIATE NEIGKGOUAHOOD, BUT ALBO EXCHANGE INTERACTIONB at THE LAREER BLACK ÁFRICAM REQIONAL LEVEL.

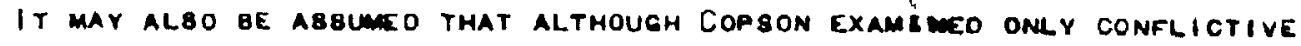
bemaviour, the mationg albo engage in cooperative aotB. Thebe resulta TENO TO REFUTE GALTUNG'B ABgUMPTION THAT BMALL ULOEROEVELOPEO NATIONB,

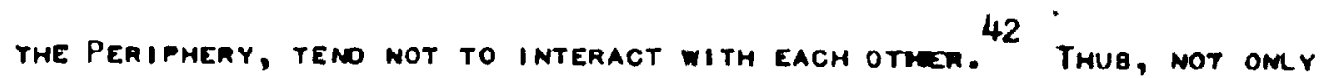

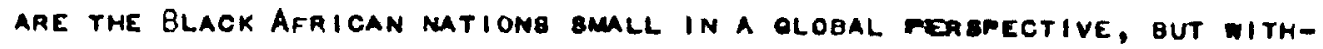

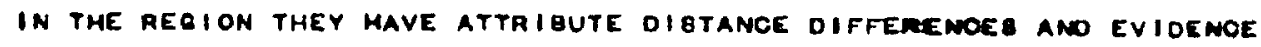
TARGET BALIENCE.

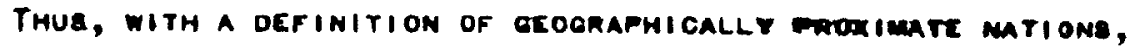

41. R. COPBON, "FOREION POLIOY CONFLiot Mmane AFrioan STATE8, 1964-1969," IN SAEE INTERNATIONAL YEAaboOK OF FOAKION POLICY STUOIEB, Vol. 1, Eo. P. Hégoman (Beverly Hille: Saoe Puelication, 15,3), . 201.

42. Galtume, "Impicaialism," .. 89. 
THIS THEBIS 18 PREPARE TO EXAMINE THE OURABILITY OT BOTH SOCIAL AMD BTATUB-FIELO THEORY. THE UURABILITY 18 TEgTED ON TWO AEPCCTB: THE UTILITY OF THE THEORIEB IN EXPLAINING FOAEIGN POLICY BEHAVIOUA, ANO

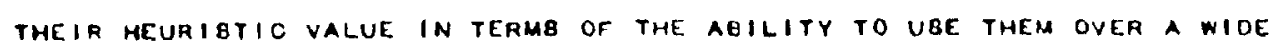

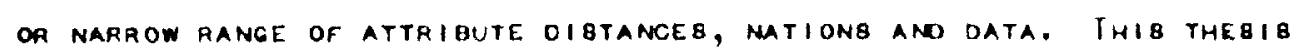
TEBTB THE THEORIES UBING CONYENTIONB AS GIMILAR AB POSBIBLE TO PREVIOUB TESTS EMPLOYINO THE SAME AXIOMB AND METHOOB. IT FURTHER EXAMINES THE HEURIBTIC VALUE OF THE THEORIES BY FOCUSIHG ON A RANGE OF MUTIONG NOT TEBTEO PREVIQUQLY. MHOAEAS HATIONS WITH WIOE MAONITUDES IN ATTRIQUTE DIBTANOEB HAVE BEEN BTUDIEO, THIB THEBIS TAKES A MARROWER PERBPECTIVE oY GaveING THE FEABIBILITY OF BOCIAL and BTATUB-FIELO THEORY AT A RANOE WHERE THE MAGNITUDE OF ATTRIQUTE OIFFERENOEB GETWEEN MATIONB 18 VERY SMLLL, IN THE REOIONAL SYBTEM. THE PAPER NOW MOVEB TO A AEBTATEMENT OF THE AXIOMB IN A MORE EXPLIOIT FOAM BUCH THAT THE

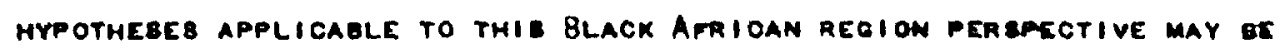
DERIVE.O ANO TEBTEO. 


\title{
CHAPIER 4
}

\author{
APPLIED FIELO THEORY IN A REGIONAL SYSTEM
}

THIS THEBIB HAB OIBOUBSCO THE IMPLIOATIONB OF OONOEPTS BUOH AS ATTRIBUTEB ANO FOAEION POLIOY EEHAVIOUR IN BOCIAL AMO BTATUE-FIELO THEORY. THIS CHAPTER MOVE TO AN CXAMIMATION OF OPEAATIOMAL FONMB FOA TEBTINE hYPOTHEBEg RLLATING THE COMCEPTB OF FIELO THEOAY TO AOTUAL EVENTS IN THE REQIOMAL SYETEM OF BLACK AFRIOA.

\section{Foneion Policy Bemavioun}

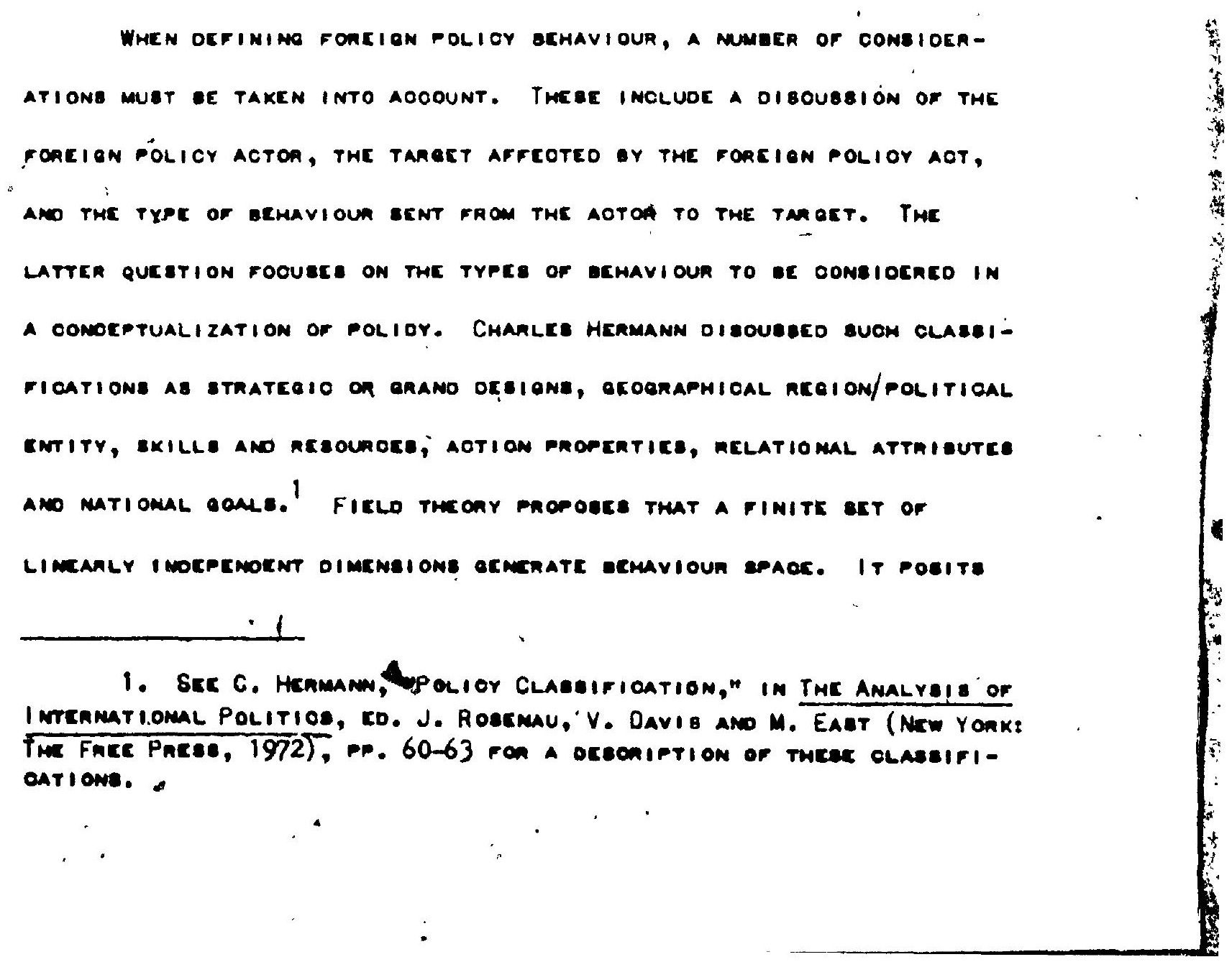



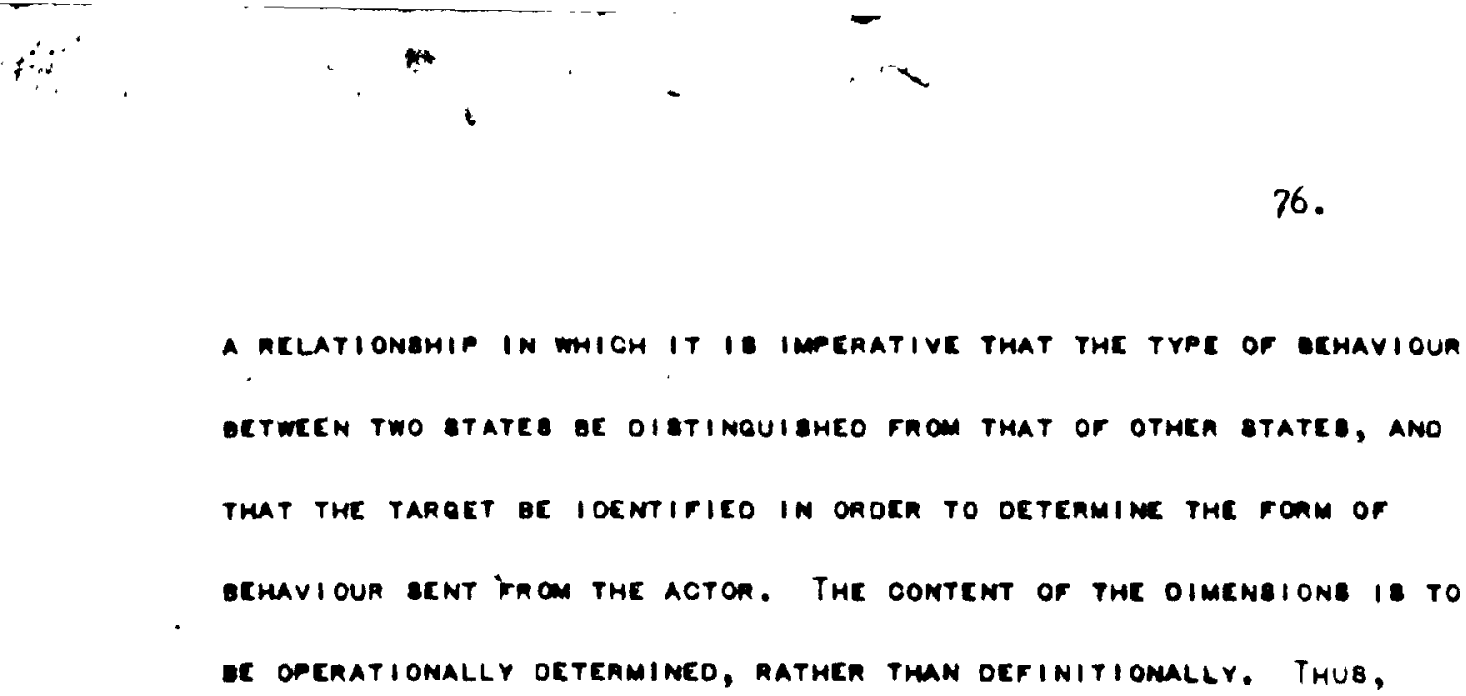

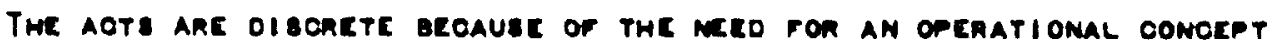
WHIOH MAY OL JEgTEO EMPIRICALLY, REQUIRINO EVENTE WHIOH MAY OC IOENTIFIEO ANO OOOCO WITH SUFFIOIEN FREQUENOY TO PEAMIT GTATIBTIOAL

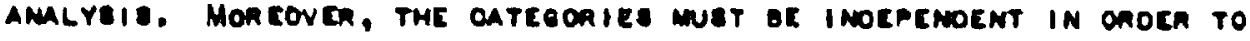
OAPITALIZE ON THL OIFFERET TYPES OF FOALION POLICY AOTE. TME TEM OEPLOYLD TO DENOTE THEBE AOTS 18 AN EVENT, OCFINEO AS

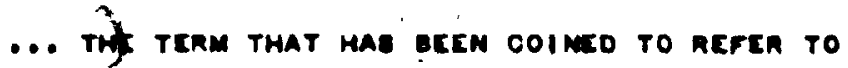
monos AMO DCEDS - I.E. VIRBAL AMO PHYBIOAL AOTIOM ANO RLAOTIONE - TMAT INTERNATIONAL AOTOA (Joonm INTEROOVER MAENTAL OROANIZATIONE (160'8). ANO MOMS OV DAMENTAL INTERNATI ONAL ONQANIZATIONE

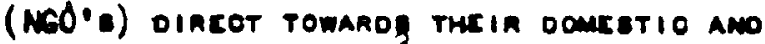
extenMAL CNVIRONMENT. 3

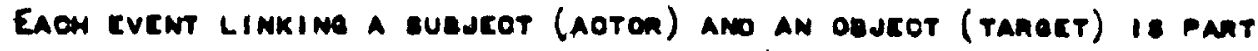

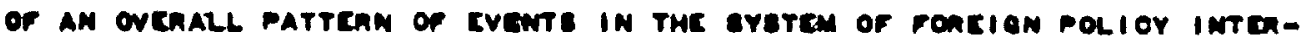

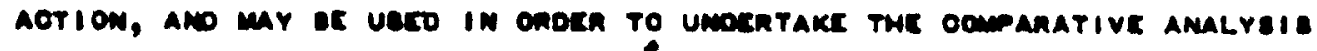

2. $1010 ., 72$

3. P.M. Bundese Ano W. Lawtom, InoIgatone of InTchmatiomaL Bemavioum (Brventr Hillei Sage Pivolioation, 1972), P. 6. 
OF FOAEION POLIOY. ONE OF THE AIME OF FOAEION POLIOY AMALYTS 18 TO OREATE TYFOLOQIES OF THE IVENTS 80 THAT THE BEMAVIOUR OF MATIONB MAY

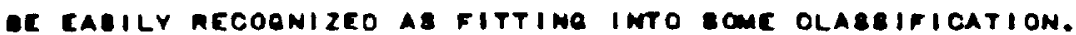

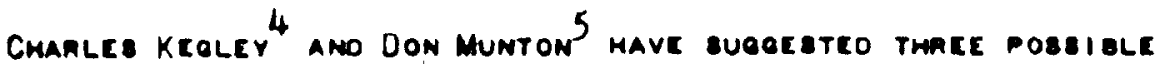

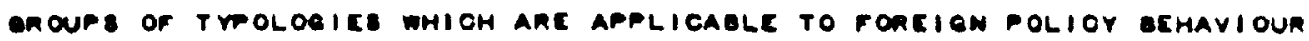
otUdis. KEQLEY aUQQEBTED THAT MOST REBEARCHERB DEFINE FOREION

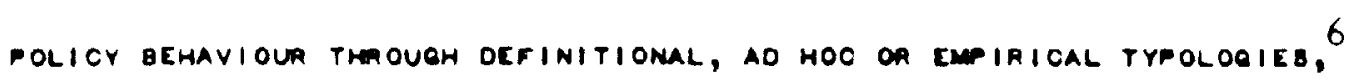
WHILE MUNTON EUGEETEO LEAVINE THE EVEMTS DATA IN NON-AOGREGATEO FORM,

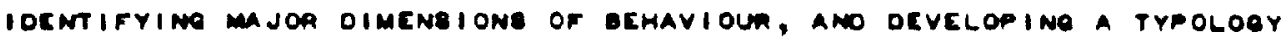

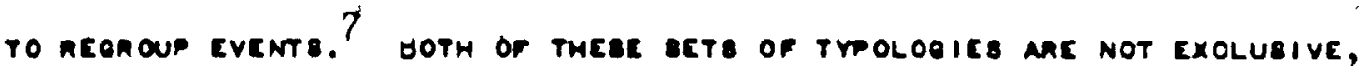

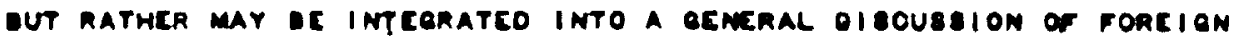
Polior gravioun.

THE DEFINITIOMAL TYOLOQY MREETS ON THE ABSUMPTION THAT OLABSES

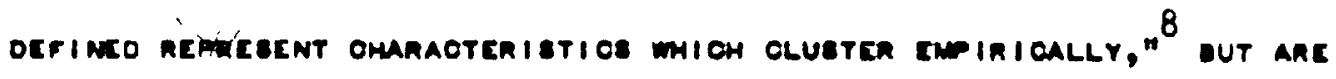

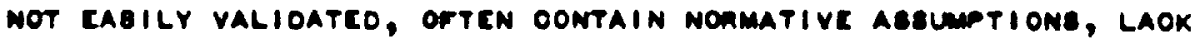
OPEAATIOMAL REFERENT, ANO FIMALLY, accaUeE OF THEIR UEC OF OOLLOQUIAL-

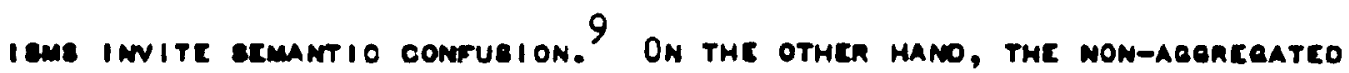
EYENTS OATA MCTHOO DOES NOT MANIPULATE THE EVENT TYPCS ON THC ABSUMPTION

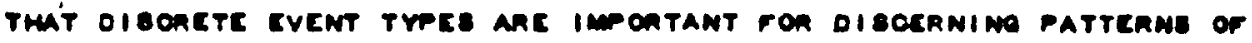

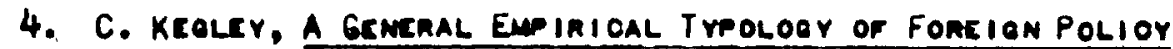
Bcmavioun (Bevealy Hilla: Saer Pualioation, 1973).

5. D. MUnton, "in Scanom of the "Fonejeme Conocet mpoliov";

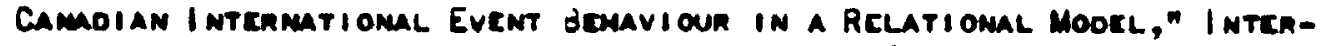

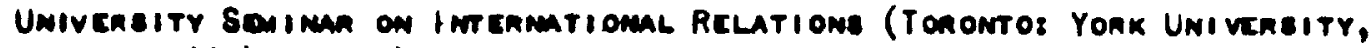
Feonuarr 1974, mimco).

6. Kealer, Trpolosy, pp. 8-15.

7. Munton, "In Scanow," P. 5

8. Keeur, Trouos, P. 8.

9. $1010 ., 0.9$ 


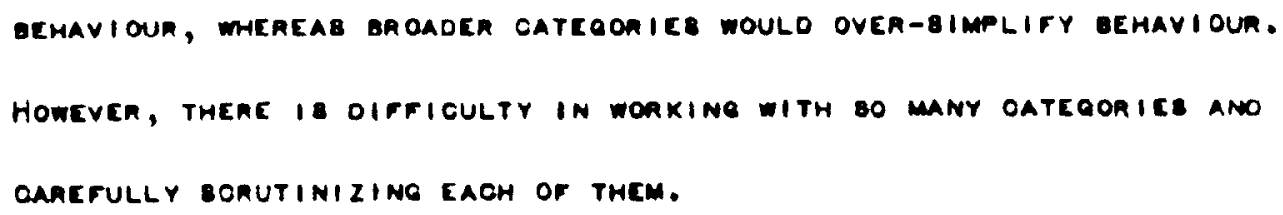

12. S. Salmont and C. Henmanu, "The Erfect or Size, Oevelor-

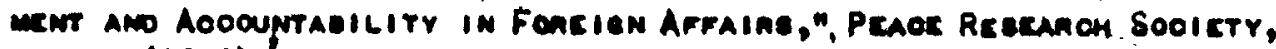
Papcas (1970). 


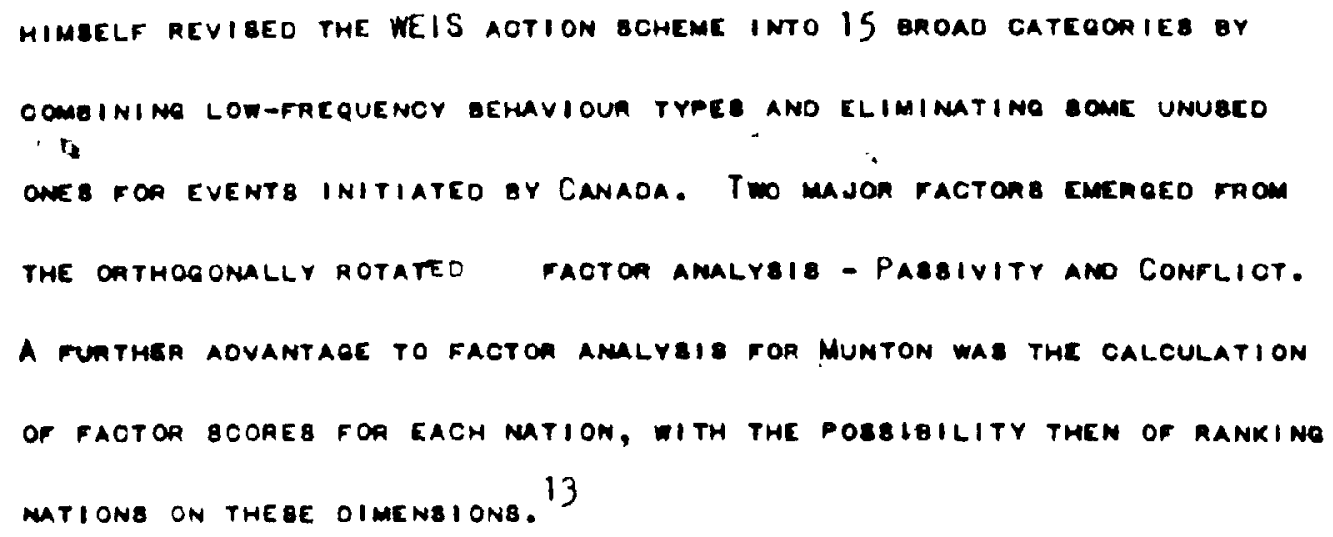

13. MUnton, "In Seanow," P. 6.

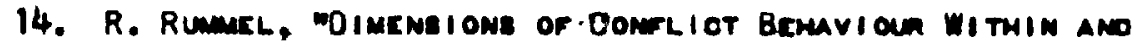
BCTmEen Nations," in Confliot Bemavioun ano LIMKACE Politice, co. J. Wilkemelo (New Yonk: Davio Mokar Co. 1mo., 1973), P. 6?.

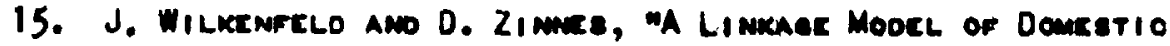

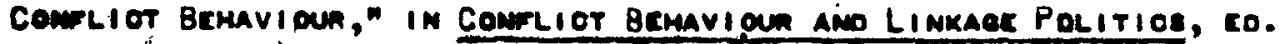
J. Wilkenrelo (NEw Yonki Uavio Mokar Comany InO., 1973).

16. R. TANTER, MOInEmerom of OOMrLiot Bemavioun WITMIN Matione, 1955-60, Pcaor Rcesanou Sbolctr, Papens No. 3 (1965).

17. "L.A. Hazelwooo, "Extrenmalizima Sratemio Staces," in

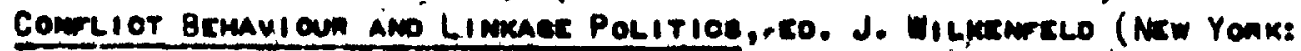
Davio Mokar copmany (mo., 1973).

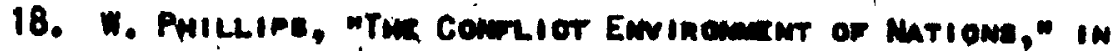

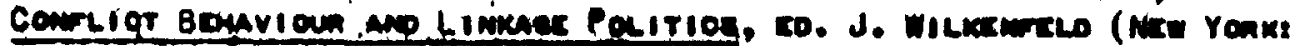
Davio Mokar Comand (nio., 1973). 
$\therefore 0^{\circ}$

80.

THE FIMAL TOREION POLIOY TYOOLOOY TAKE DIBCAETE EEHAVIOUN

TYPEg, COMBINES THEM INTO BAOAOER DEMAVIOURAL OATEOORIES ANO

OEMONGTAATED EMPIRICALLY THAT THEY EXIST. THIS APPROACM INYOLVES

OATEQORIZINO BEHAVIOUR AND CREATINO AN EMIRICAL TYPOLOOY. AN

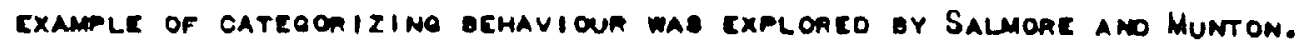

THEY OONTENOEO THAT A EETTER DISTIMCTION DETWEEN THE TWO FACTORE

OOOPERATION ANO CONFLICT BHOULO DE DRAWN RATHER TMAN MERELY OVER-

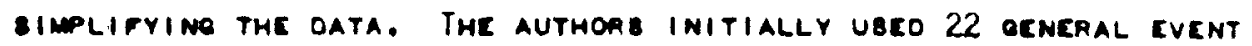

OATEOORIES ANO DIBAGOREGATEO CEATAIN BEMAVIOUA TYPEB WHIOH HAD A OIVEN

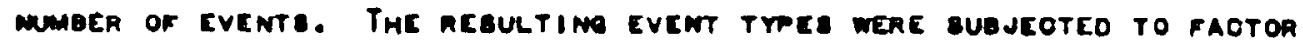

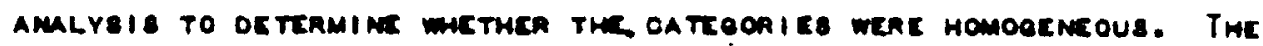

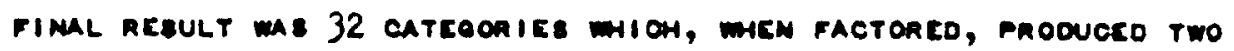
unotateo factons - I merer Comituent ano CoOpenation Comfliot. A THIND FAOTOR WITH MO MIOH LOAOING VARIABLE ANO BIMILAR TO THE SEOONO FAOTOR WAS CLIMINATED. ONCE THESE TWO FAOTOR SOLUTIONB WERE PLOTTEO

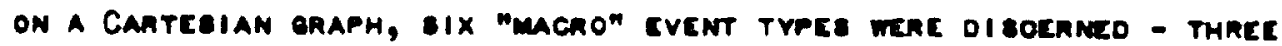
OOMFliot - MILITANY COMFLIOT AOTION, NOH-NILITANY COMHLIOT AOTION, Vergal Conflict, ano thaEc coOpenative - PARTICIOATION, DIPLOMATIO

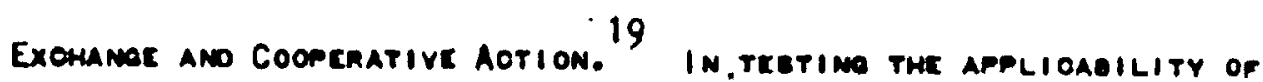

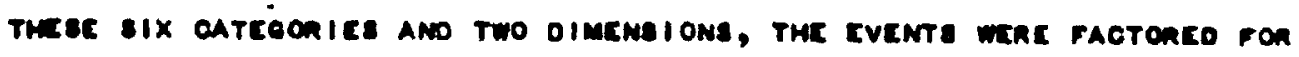

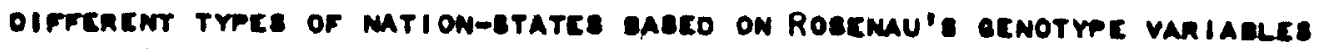
or ize, orveloment anó apoocuntability. THE nesulte ró the un

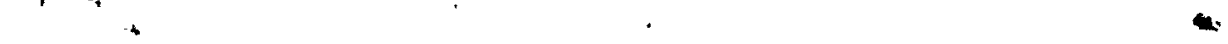

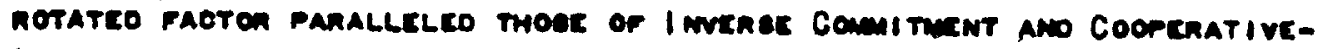

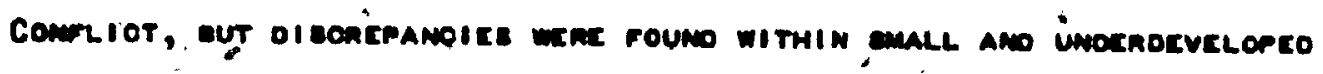
$\therefore$

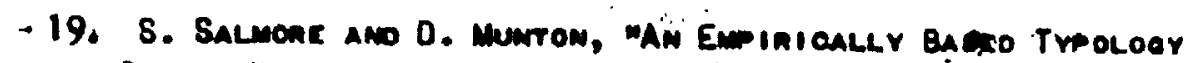

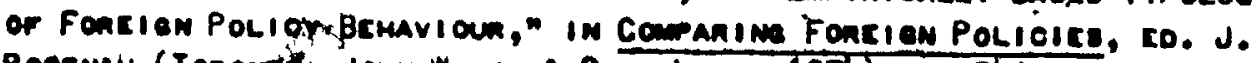
Roermu (Tonowto Jown WILEV a Som LTO., 1974), P. 343. 
$\therefore \therefore$

81.

COUNTRIEB. COOPERATIVE ACTIÓN WAE MUCH LESa hIOHLY CORACLATEO ON

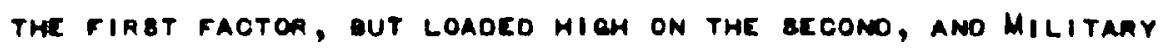
CONFLIOT AOTION haO A EEMERALLY LOWER INTERCOARELATION. 20

C. KEQLEY HAB CAITIOIZED THIB FACTOR AMULYBIS METHOO OF CREATINO

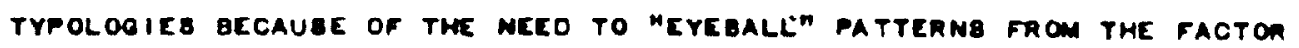

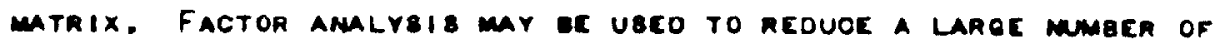
VARIABLE\&, BUT KEGLEY GELIEVEO REAEARGHERB MEEO TO DEMONBTRATE, THESE

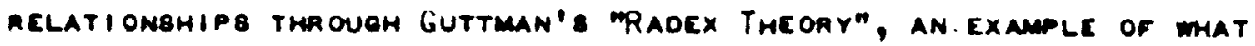
Keoley believed to be an cmpirical typolooy. The madex 18 a "oemeral OMOER PATTERN FOR THE INTEROORRELATION MMONG A EET OF VARIABLEB" 21

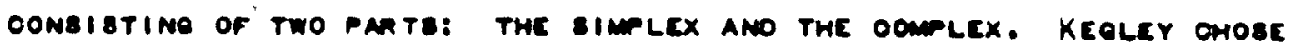

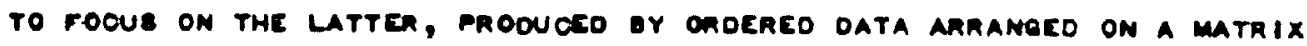
OF the interconarlateo vaMiagleE. THE mathIX mar then oE I matecteo TO DETERMINE WIOH VARIAGLES HADE THE MOST IN OOMMON OY REARRANGINA THE VARIABLES SUOH THAT THE LAROEST OONRELATEO VARIABLEO OLUETEA

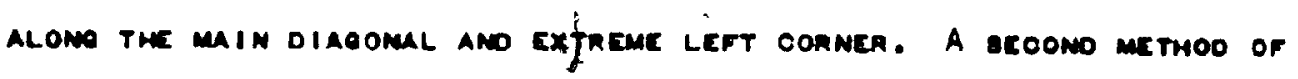
ORTERMININE THESE OLUSTERB OR TYPOLDOIES IB THROUEH FAOTOR AMALYSIS.

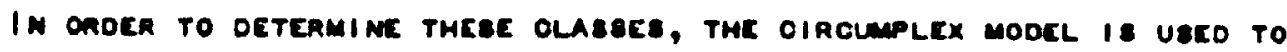

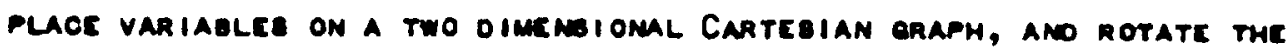

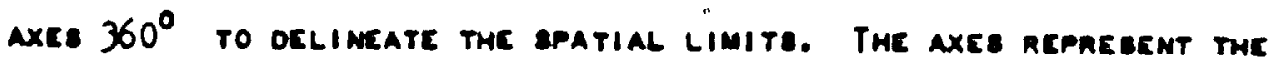
TWO OIMENSIONS WITH OPPOSITE ENOS INOICATIMO THE OPPOBITE SIDES OF TIE DIMENSION, FOR EXAMPLE PASBIVITY-AOTIVITY OA MIENOEMIP-HOSTILITY.

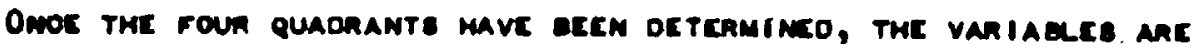

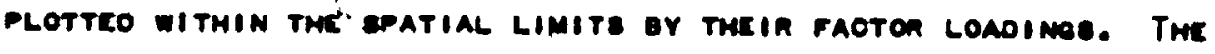

20. $1010 ., \ldots .346$.

21. Keeler, Irpaloer,,$y \cdot 21$. 


\begin{abstract}
ERAPH MAY BE INBPECTEO TO EXAMINE THE EMPIRIOAL TYPOLOQIEB WHICH

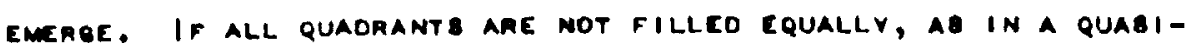
GIRCUMPLEX MOOEL, THIS INOIOATEB GAPB IN THE TYPOLOQY DUE TO THE

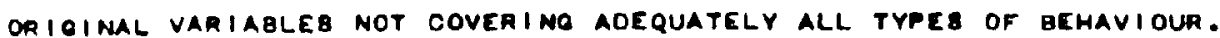
DON MUNTON alBo CREATEO a BIMILAR tyPOLOQY OY ARRAMGINO EVENT TYAEB ON THE $X$ AND Y COORDINATES OF A TWO-OIMENBIONAL GRAPH. HE

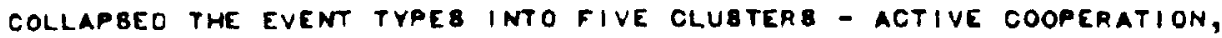
EXCHANGE, PARTIOIPATION, VERBAL CONFLICT ANO ACTIVE CONFLICT 22 OY a

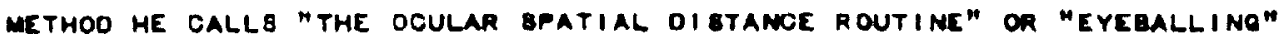
THE GRAPH. THEPE ARE, HOWEVEA, MORE BOPHIBTICATED ITATIBTICAL PROCEOURES FOR CLUOTERIMG VARIABLES MMICH FORM THE OPTIMUM GROUPINGS FOR A OIVEN BET OF OBJECT8. SUCH OROUFINOS SHOULO MAXIMIZE THE AVERAEE INTER-QROUP OIBTANOE WILE MINIMIZING THE AVERAOE INTMASROUP OIBTANCE. THE PROOEDUAE BECONEB VERY COMPLEX, HOWEVER, AB THE MUMEER OF OBJECTE IMCREABEs INCE EVEAY POBEIBLE ONOUPINO OF OAJECTS MEEO TO EE UEEO WAE A BABIB FOR CALCULATINE AN INDEX OF OLUBTER IEPARATION. 23

THUS, THERE ARE THEE POSBIBLE APPROAOHES WHIOH MAY ar USEO tO OETERMIINE A TYPJLC; FOR AmIOAN FORSION POLIOY BEHAVIOUA. IN THIE THESIE FAOTOR AMALYBIB 18 EMPLOYEO ON A OATA ECT OEYCLOPCO OY PATRIOK

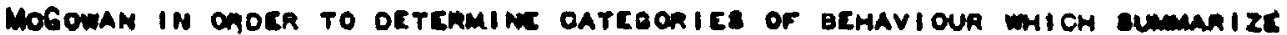

22. MUATON, "In Seanow," Floune 4, P.. ?.

23. D.1. Veloman, Fontran Proganuming fon the Bemavional Solemere (New Yonk: HOLT, Rimenano \& Winetón, I wo., 1967), PP. 308-9. 


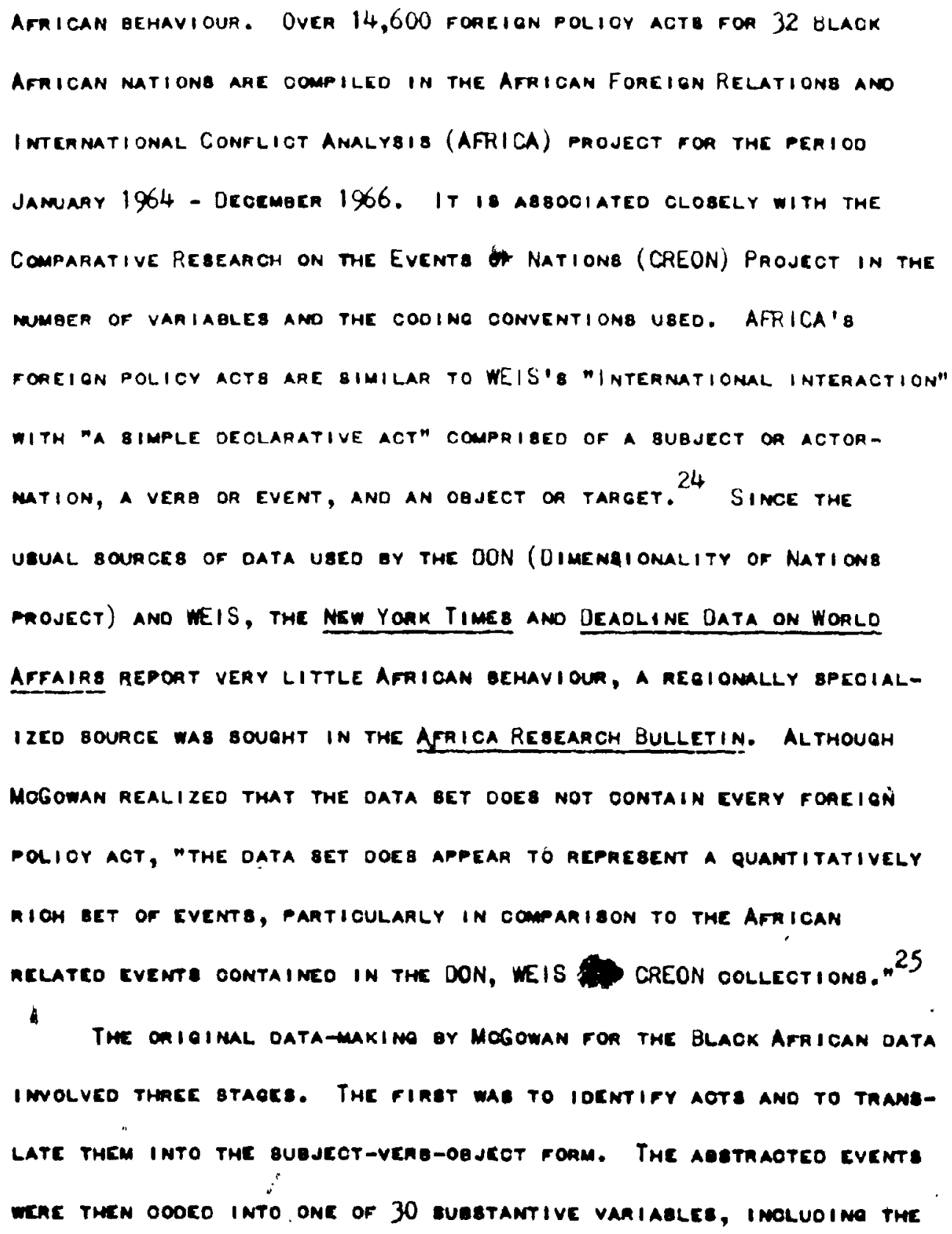

24. P.J. MOGOMAN, "DImensions or AFRICAN Foreion Pollor Bemavioun: In SEanch of Depenoemar," Camudian Aseociation of Amsican" Studie: (Comfenmae: Ottama, Ontanio, Frenuarer 16-18, 1973, mimeo), P. 6 .

25. 1010., P. ? 
$\therefore \quad 4$

84.

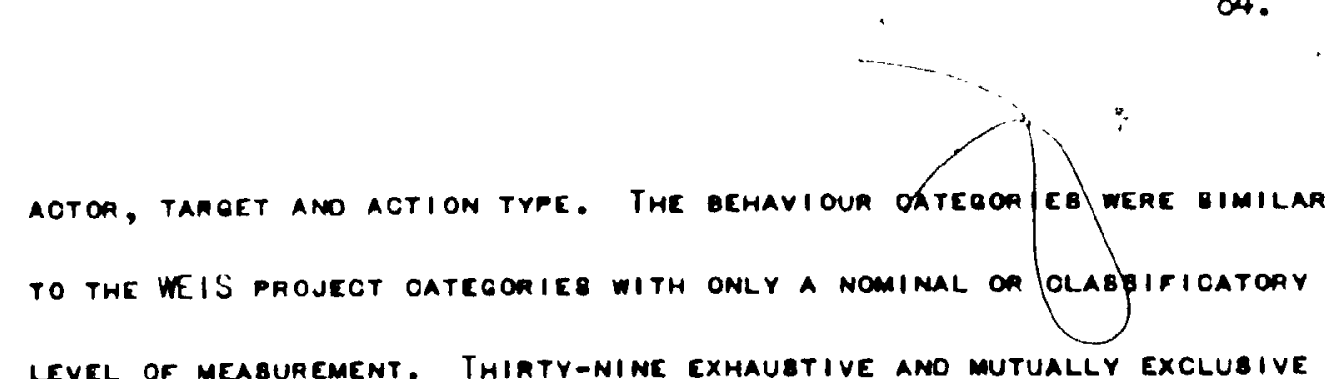

leVEl of MEABUREMENT. ThIRTY-NINE EXHAUstive ano mutually EXCLUBIVE

ACTION CATEOORIEB GAOUPCD ON A OOOPERATIVE-CONFLICT ANO VEABAL-

PHYSICAL DIBTINCFION WEAE DEVELOPEO FROM THE ORIOINAL 22 WEIS OENERAL

OLA88E8 OF BEMAVIOUR. BAQEO ON W. CORBON'B MOOIFIEO WEIS BCHEME

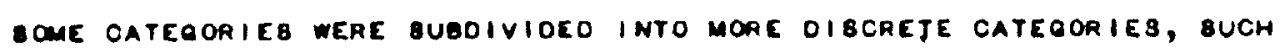

AB PROPOBE ANO COMENT, TO AVOID A HIGH FREQUENCY OF BEHAVIOUR IN

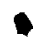

THEBE CATEGOAIEB, WHILE OTHERB WEAE AOOEO, SUCH AB INCAEABE MILITARY

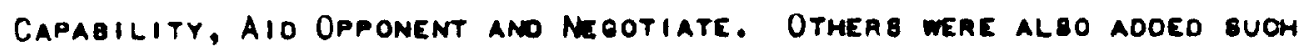

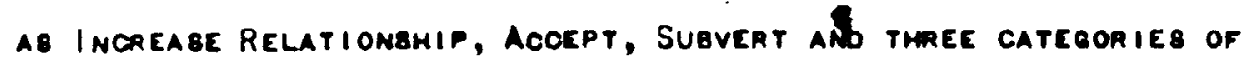

ACTS AB MEITHER COOPEAATION MON CONFLIOT, TO COANEBPONO WITH THE

CREON PROJECT ANO TO ENBURE EXCLUBIVITY. 26

I MTER-CODER RELIABILITY WAB OETERMINED WITH EAOH BTEP IN THE

OCOINO PROCEOUAE. FURTHERMONE, FAVOURABle COMPARI BONB WERE MADE WITH

,THE WEIS DATA SET'FON THE PERCENTAEE OF ACTS UNDER BROADER OATECOAIES.

Fon example, the pencentage of CoOpenative acts was 35.2 fON the

AFRICA stUOY, ANO 33.0 fOn THE 1966 WEIS stUDY, AND THE PEROENTAOE OF aOts ron PaAtioipation mas 47.1 ano 35.5 aesectively. 27 MhILC

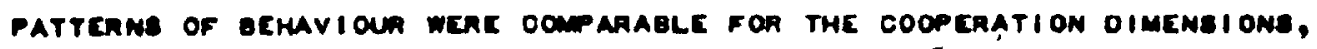

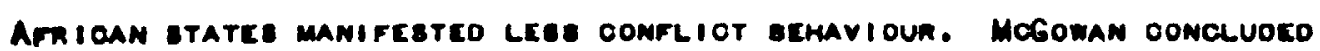

26. 1e10., re. 11-12.

27. 1010., TABls 3. 
$\therefore: n^{\circ}$

THAT "THESE DIFFEACNCE AAE TO OE EXPEOTED OIVEN THE DIFFERENCE IN THE CAPABILITY LEVELE OF THE etATCB BTUDIED IN THE TWO PAOJECTE (WEIS ANO AFRICA)." 28 THE HIOH FMEQUENCY OF CONFLICT ACT8 IN MEIS maY AL8O BE DUE TO THE TENOENOY OF MEWBPAPEAS LIKE THE NEW YOAK TIMEB TO OVER AEPONT THEBE ACTIONB.

IN THF THESIB, A MUMBER OF BEPS WERE FULFILLEO IN PUAQUINO THE REQUIAEMENT OF FIELO THEORY THAT THE BEMAVIOUR DIMENBIONB BE

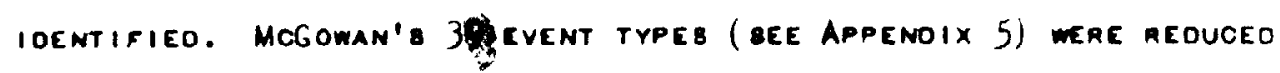
TO 17 OY EMPLÓYING a PROCEDUAE BIMILAR TO MUNTON's. FROM THE TOTAL of 14, 699 EVENTB ANY VARIABLES WITH LEB8 THAN 300 EVENT: meRE

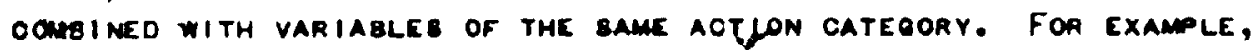
WARN ANO REJECT ARE BOTH EXPREBBED CONFLICT VARIABLEB AMO EXPREBB INTENTION ANO THUB WERE COMOINËD. ELEVEN EVENTS TYPES WERE ABOVE THE MINIMUM LEVEL REQUIREO, CONTAINING $85.7 \%$ OF ALL INTEAACTIONB. AFTER THIS POINT, THE FREQUENCY OF EVENTS RAPIOLY DEOREABEO. FURTHERMORE, THE REMAINING VARIABLEB ACCOUNTEO FOR FEW EVENT ACTS overall. The revigeo 18 oatecories, presenteo in table 2 , inoicate THE TYPEB OF ACTIONB UBED ANO THE TOTAL MUMBER OF EVENTS FOR EAOM. 29

FAOTOR AMALYBI8 WAS APFLICO TO THE OATA mathIX OF THE VARIACLES TO OETERMINE THE UNOERLYINO MHYPOTHETICAL VARIAELE" TO DEVELOP A OLABSIFICATION BOMTME FOR DELINEATINO THE MAJOR EMPIRICAL CONOEPTE

28. 1e10.,. 16.

29. MOGOWAM INOLUOCO THE MEUTRAL OATECORIES FON THOSE ACTIONE

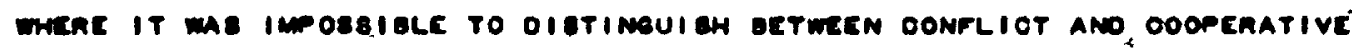

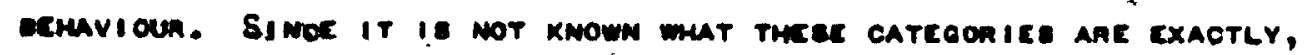

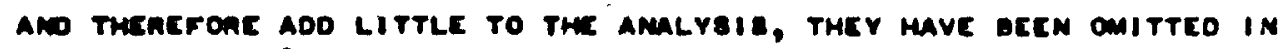

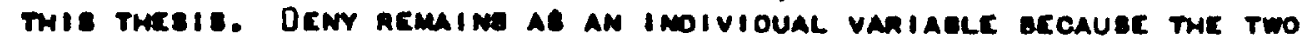

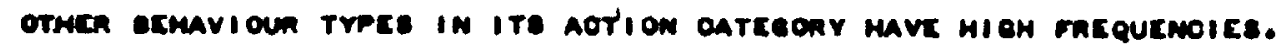


TABLE 2

18 Collapseo Catecomirs or Black Afaican bemavioun - Fagquenct ano

Penoent of Each Event Typea

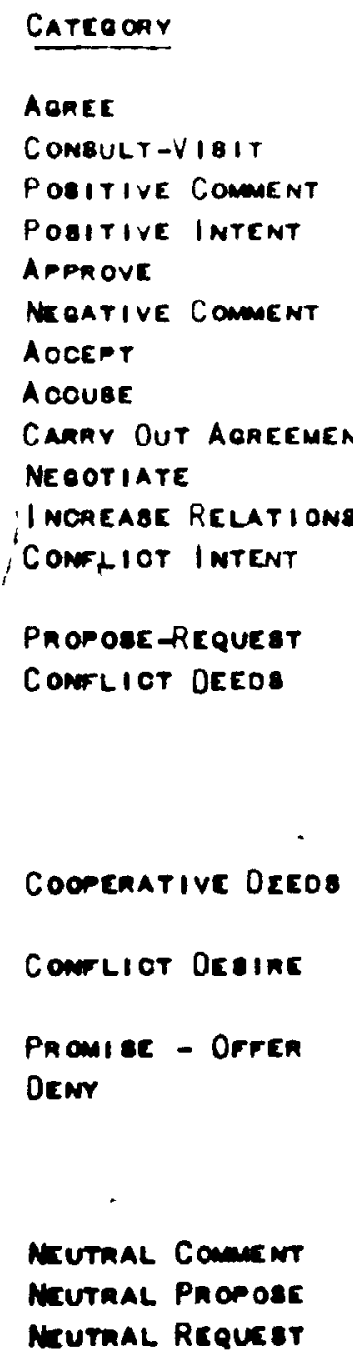

VARIABLEB

HARM, REJEOT, THAEATEN

- I MTEMT

+ Propoer, + REquest

REDUOE RELATIONBHIP,

ogmonstrate, Expel,

Seize, Suevent, Fonce, I moncase Militaky CAPA-

DILITV, AID OPPONEMT

GRAnt, REwARO, REDUCE

MILITARY CAPABILLYY

- Pnorose, Photest,

- Reques, Demano

Promiser, Orfen

\begin{tabular}{cc} 
Fnrquencr & Pencent \\
\hline 1730 & 14.5 \\
1651 & 13.8 \\
1381 & 11.6 \\
1171 & 9.8 \\
1051 & 8.8 \\
852 & 7.1 \\
686 & 5.7 \\
648 & 5.4 \\
375 & 3.1 \\
344 & 2.9 \\
303 & 2.5
\end{tabular}

$436 \quad 4$

3.6

334

2.8

335

2.8

206

1.7

261

135

$\pi, 954$

2.2

1.1

$\frac{.6}{100.0}$ 


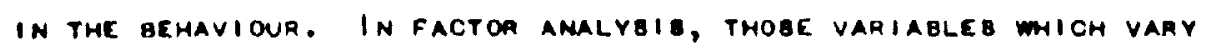

UNIFORMLY ARE LINKED INTO A PATTERN OF EEHAVIOUR DY THEIA CORRELATION

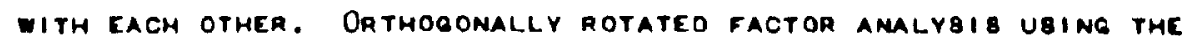
VARIMAX TECHNIQUE WAS UBCo TO OBTAIN INOEPENOENT DIMEMBIONB. 30 THE

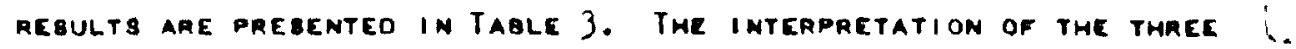
REBULTING FACTORB IN TEAMB OF PREVIOUBLY IOENTIFIED OIMENBIONB IB NOT APPARENT. HOWEVER, THROUGM AN INBPECTION OF THE FACTOR 8CORES, AOTUAL FREQUENCIES AND FACTOR LOAOINGB, THE FACTOAB MAY GE INTERPRETED TÓ REPREBENT INTERACTIVE, CONFLICT, AND COOEERATIVE BEHAVIOUR OIMENSI ONS. 31

THE HIEH VARIAQLES LOAOIMES ON THE FIRET FAOTOR ARE VERBAL

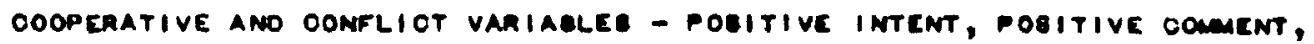
APPROVE, MEOOTIATE, MEQATIVE COMMENT, CONFLICT INTEMT ANO PROPOBE-

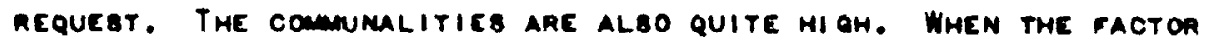
SOORE OF MATIONB ARE TAKEM INTO CONBIOEAATION, ALONG WITH THE

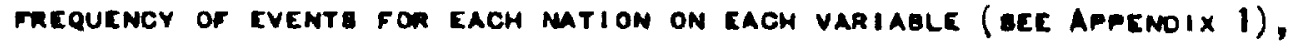

30. THE METHOD OF FAOTORINE EMLLOVED WAB THE PAINGIPLE OOMOONEMTE WETHOD WHEREOY FACTORE ARE ARAANEED IN THE OROEA OF THEIR IMPOAT-

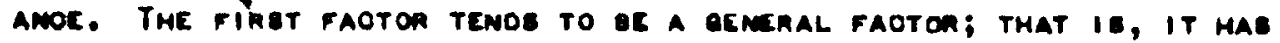

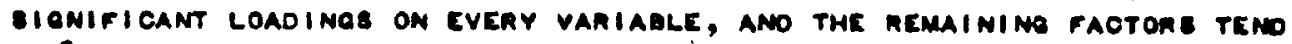

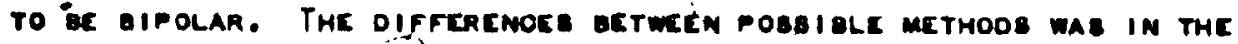
DCOIBION OF WHETHER TO AEPLAOE THE MAIN OIAGOMALS WITH THE ESTIMATEE or dommumalitY OR UNITIES, ANO THE OALOULATION OF THE PROPORTION OF THE TOTAL VARIAMCE AOOOUNTEO FO BY THE FACTON. IN THIB CABE, UNITICE WERE IMBEATEO IN THE DIAQOMAL, AMO THE EIEEMVALUE COMOUTED FON THE

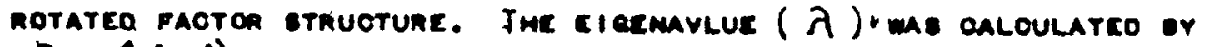

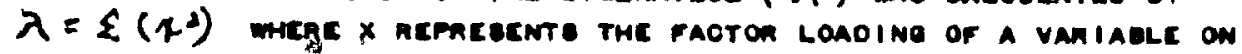
THE OIMENAIONE, AMD THE MAOPORTION OF THE TOTAL VARIANCE EXPLAIMED OY cach oImension ma caloulatco or $i$ a $\lambda i / n$. From twe unmotateo fauton

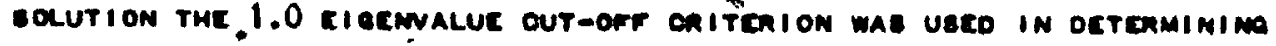
The muser or Faotone. Reren ro NoH. NIE, ET AL, SPSS (Tononto:

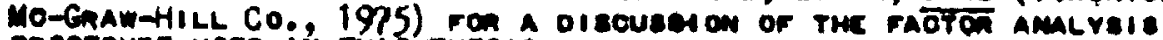
encorounc vaco in tivis rmears.

31. Rerten to R. Rumme, Aprliso Faoton Amalvese (Evanetow:

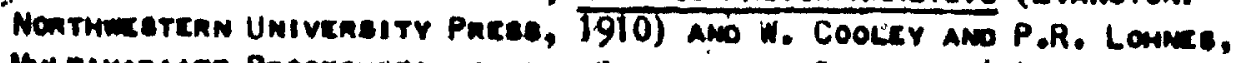

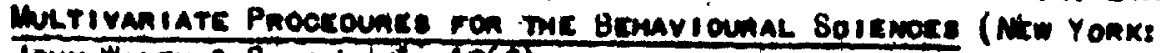
Jown Wier \& Sow (to. (962). 
a

88.

TABLE 3

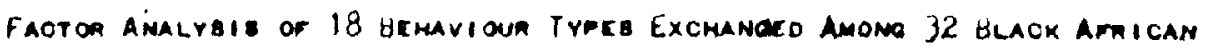

$$
\text { MATIONE" }
$$

i

1

IntrRactive COMmitteo COoperative Bemavious

CONFLIOT INTENT

PMOP OAE REQUEST

Positive Comenert

Neantive Conment

Positive InTENT

Ampoove

Neootiate

Promide Orfer

CourleICT Decoe

Aocuse

Denr

Coopenative Deecos

Confliot OEEIRE

Carar OUt AoREement

I moacaer RELATIONBHIP

Aooret

Aenec

CONBULT-VIEIT

Ejornualue

\& Total vaaianor

.93
$\frac{.88}{.86}$
.82
$\frac{.82}{.78}$
.72
$\frac{.62}{.01}$
.34
.36
.36
.08
.51
.38
.17
.14
.47
.56
5.96
32.2

.20

.12

.24

.48

.37

.24

.18

$\frac{88}{87}$

80

$\frac{.72}{71}$

$\frac{21}{62}$

$-.01$

.36

.47

28.3

Deros

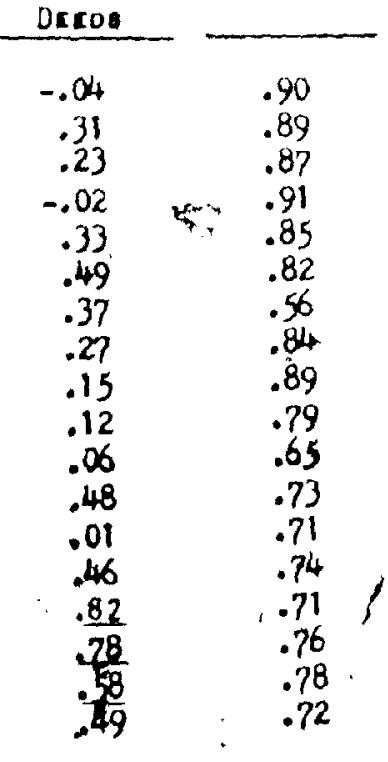

3.06

16.9

$H^{2} \cdot \because:$

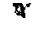

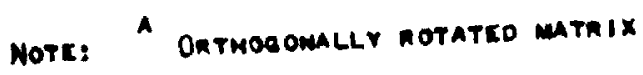

E;

i 

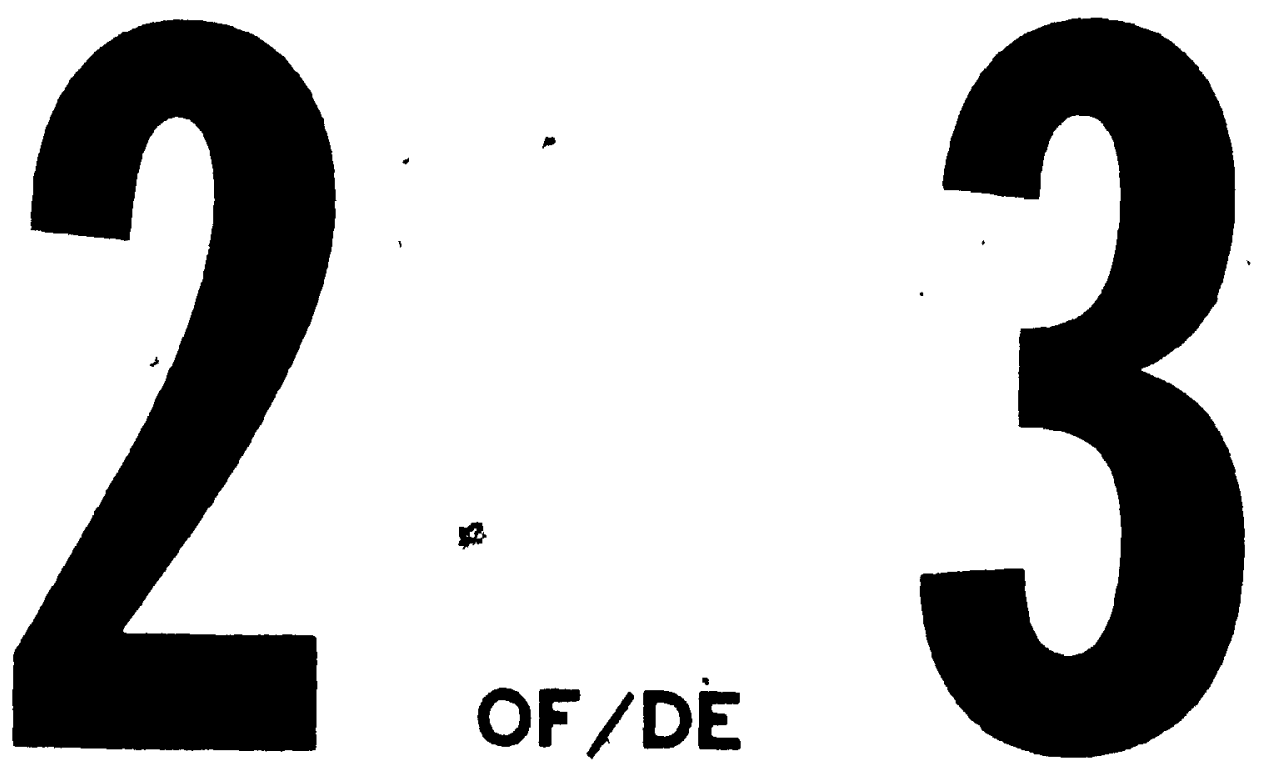

6

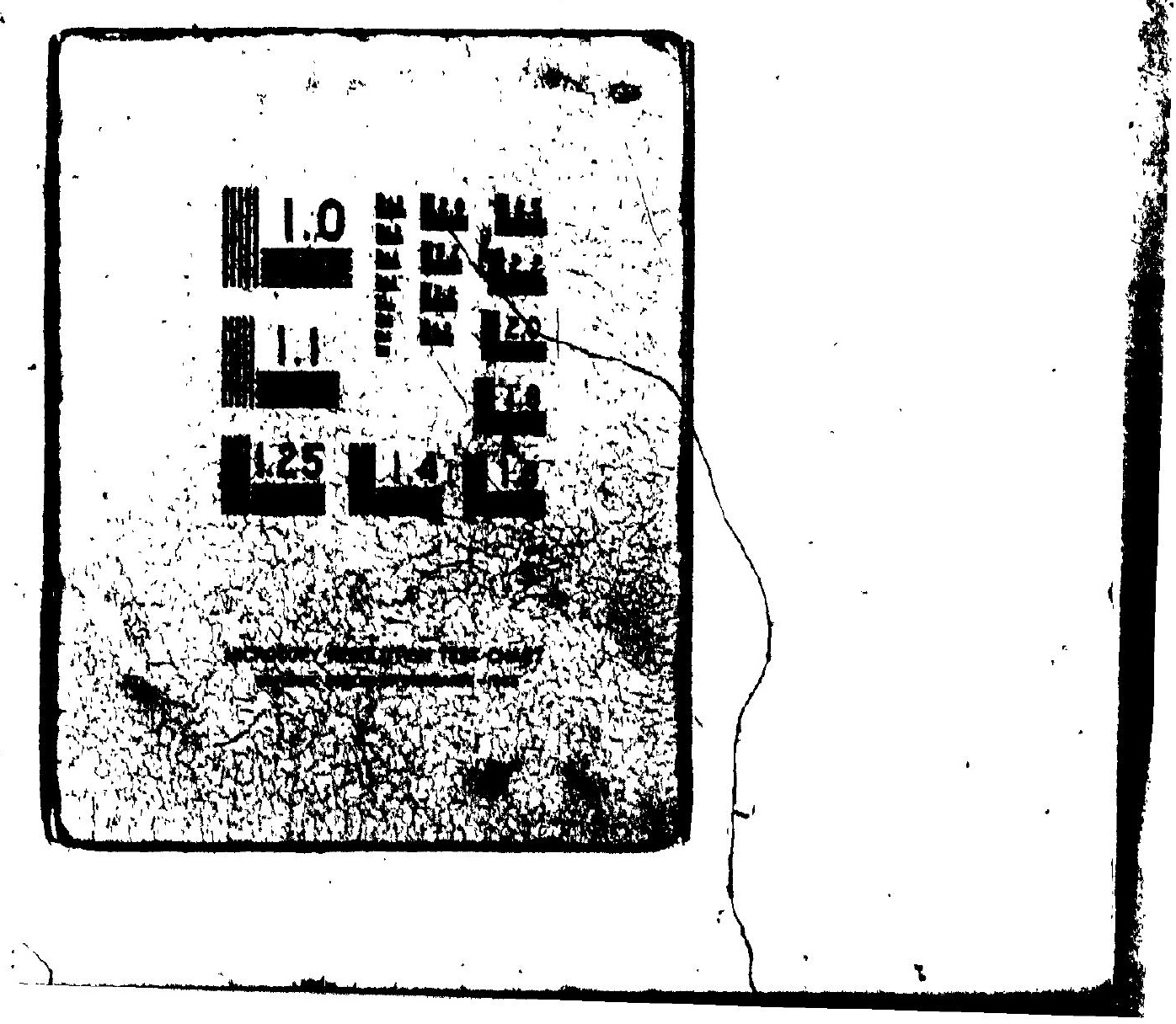




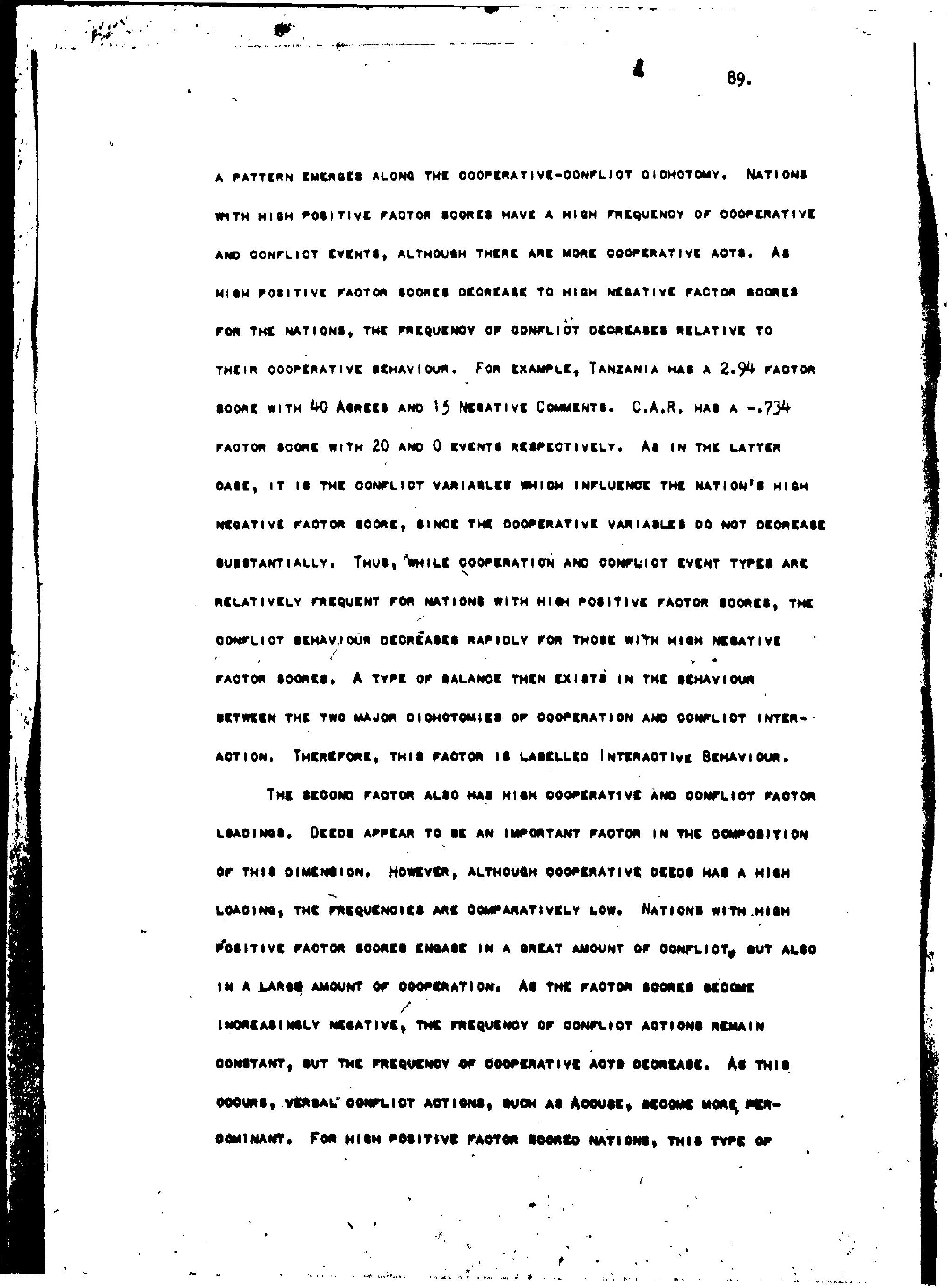


OONRLIOT IS ODSOUACO OY THC OOOPLAATION. HEAE, ALTHOUOH GMAMA,

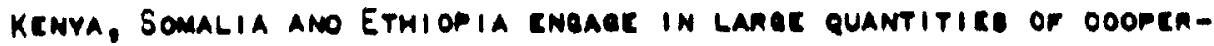

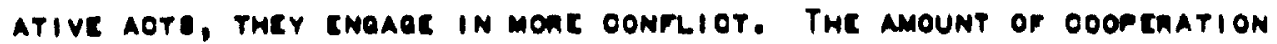

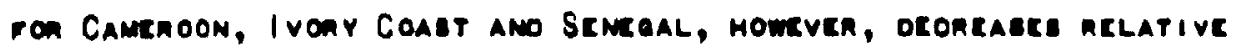
TO OOMFLIOT. THUS, OONFLIOT IS THC OOMIMANT FONM OF ECHAVIOUA, ANO

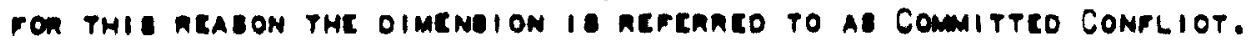

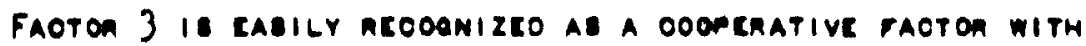
AOOLPT AMO I MOACAEC RELATIONEHIP OY TAM THE HIOHEST LOAOINO VAMIADLES. AE THE PAOTON SOOALE OF MATIONB APPAOAOH A MIOH MEOATIVE, THE

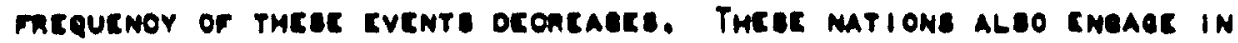
Lees ecmavioun oven ALL the trpce or crents. Thue, fon example

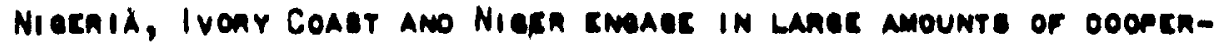

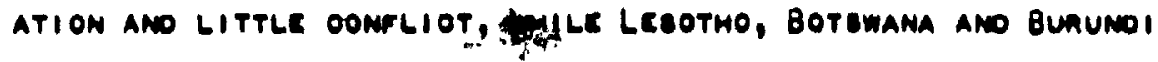

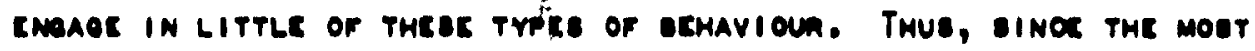

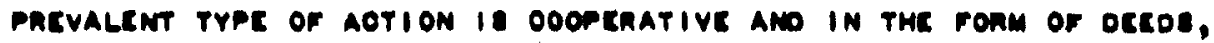

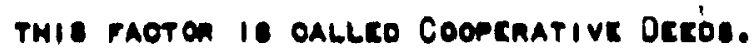

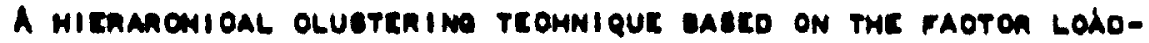

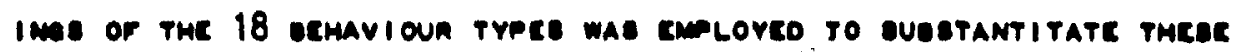
runce dimenelone. A enoupdim solution was atralnco with thace: oluetene ano an tanon or .46. Arten twis poInt twe canon incacases

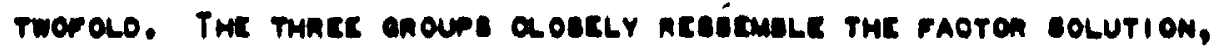
WITH OMLY BLIONT VARIATION. (FIOUnE 4) 

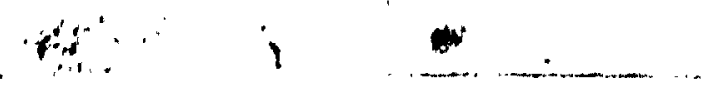

\section{Eloune 4}

HIERARCHICAL CLUSTERING RESULTS

Gnoup 1

Aence Coneult-VIEIT

+ COMment + I MTENT

APrnOVE NEEOTIATE

CARAYY OUT AQREEMENT

Pnopose - REquEat

- COMnENT

CONFLIOT INTEAEST

\section{Gnour 2}

Acover

Commlat Decos

Cocesative uceoa

CONFLIOT UESIRE

Promiar - Orfen
Gnoup 3

Aooret

I monsays Relationemip

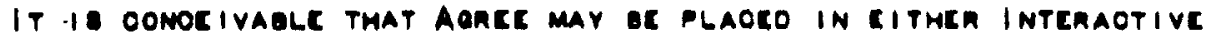

Bchavioun on Cooprative Decos oincr its maton loadimo le apacao

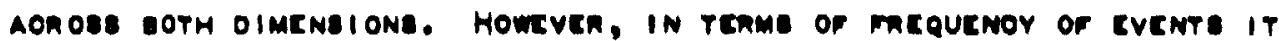

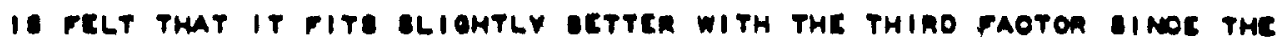

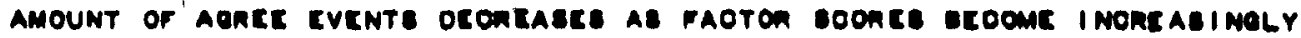
meative. ON the othos hamo, Canny OUt Aencement le inoludeo in the FIRST OLUOTER, WHILE IN THE FAOTON AMALYAIS IT COADS HIOHLY ON PHE

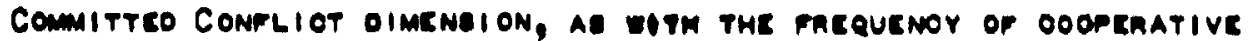

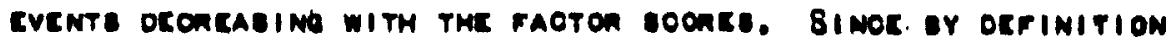
ooopenapive events anc minimal in Comaltreo Confliót, the vahiable

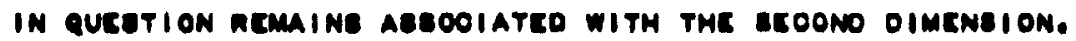

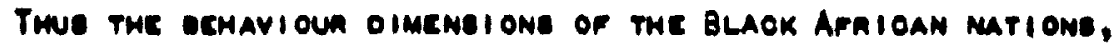

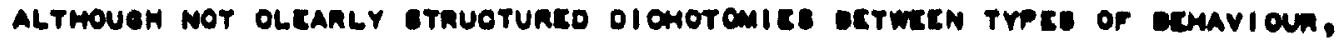

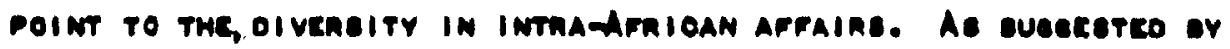

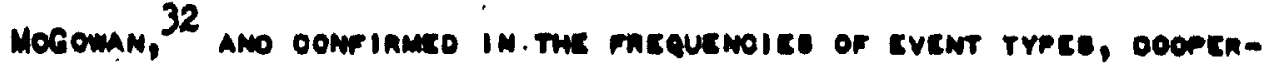

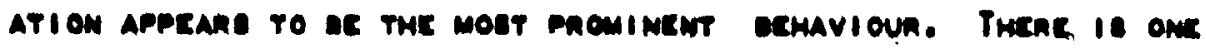

32. 8ace Mocoman, nolmensi ons, we. 6. 


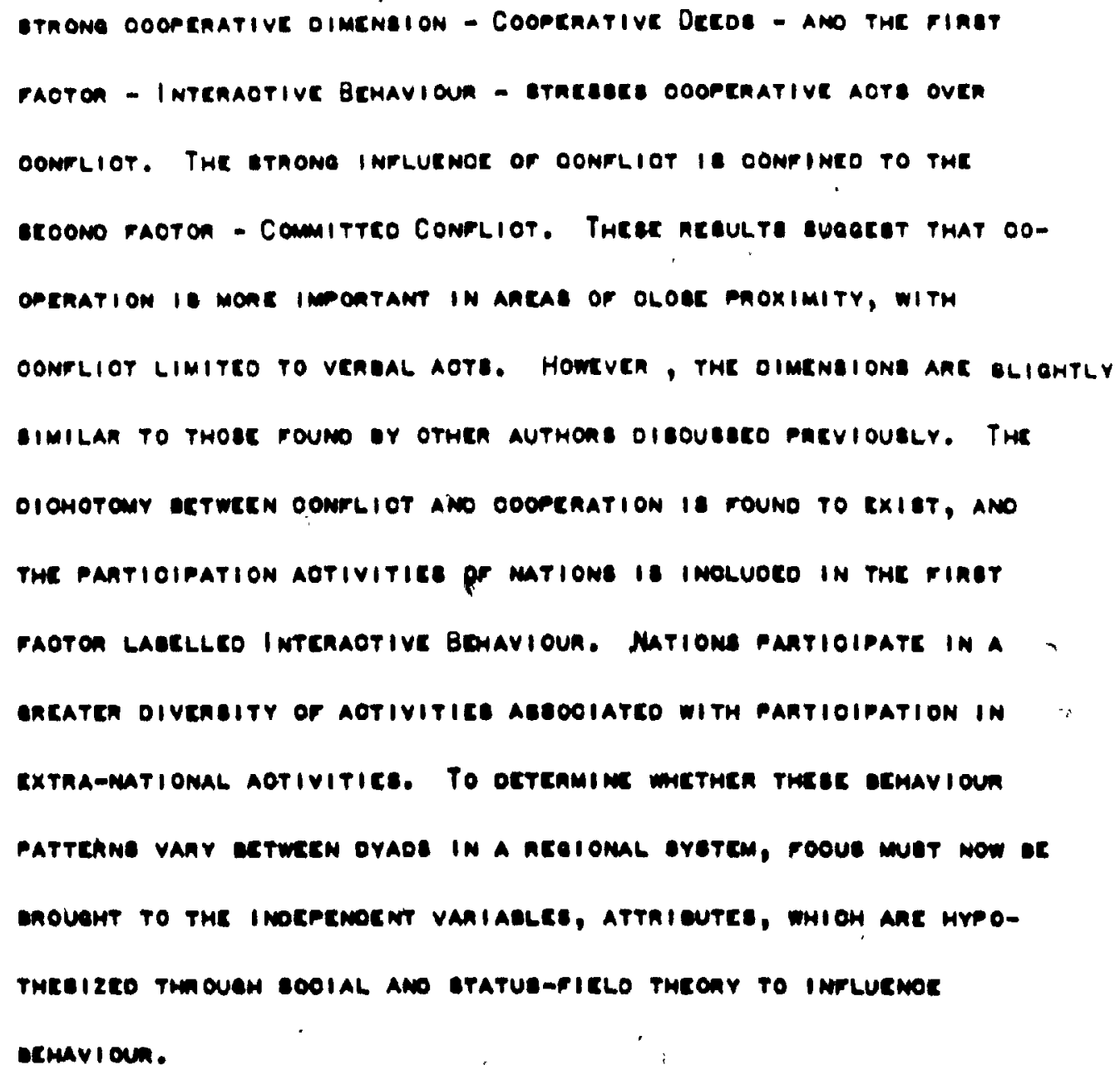

\section{ATtR I DUTE DIMENeI ONe}

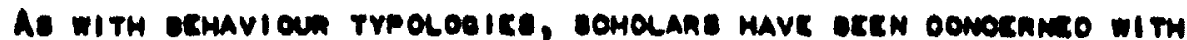
$\checkmark$

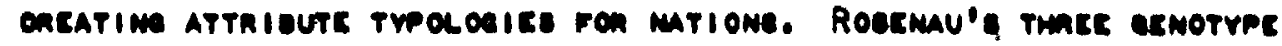

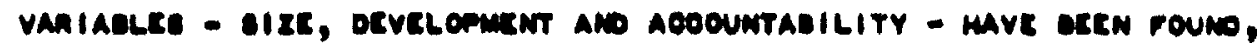

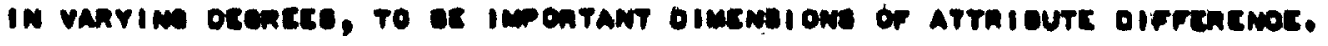

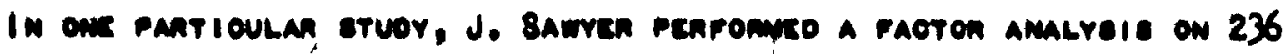

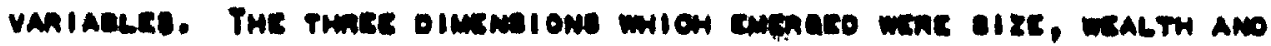

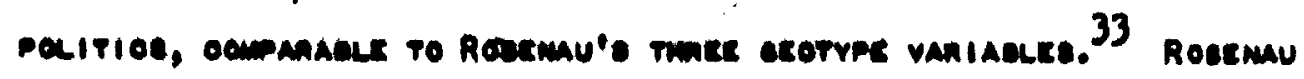



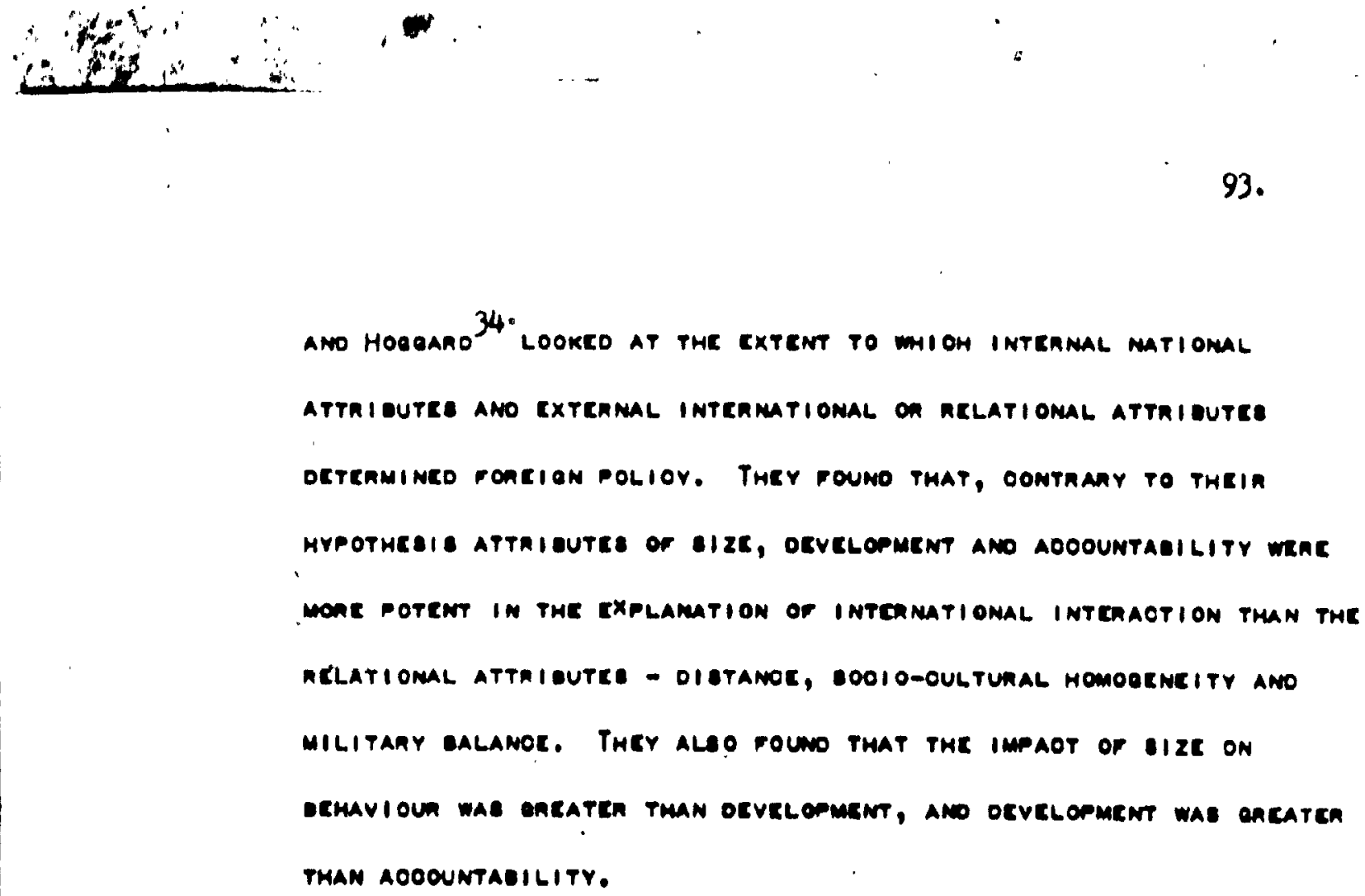

34. J. Rourmu ane 6. Hocenno, mFontsion Potioy Bewavioun in

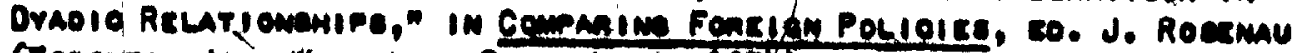
(Tomowros Joun WILEN ans 80NA, LTO., 1979).

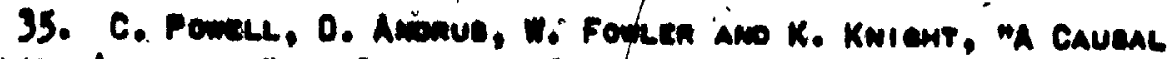

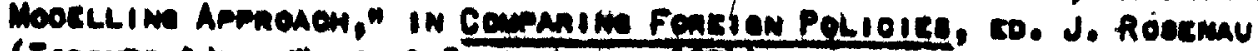

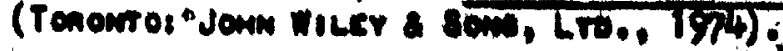

36. 1610., ค. 168. 


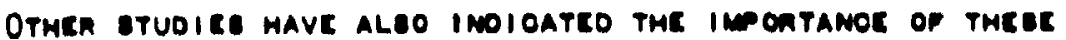

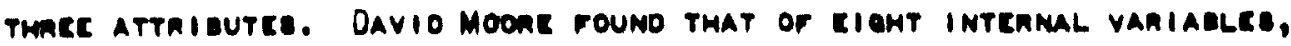
Theac thace cxplainco most of the vanianot in echavioun. Homeren, WE OONOLUDEO THAT, BIMOE AOOOUNTADILITY OHAMEC AS OOVEAMALNTE

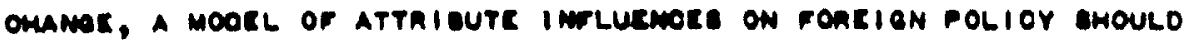

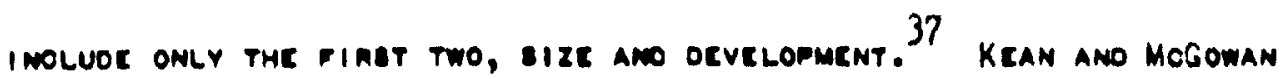
ALEO ABsunco TMAT IIZR ANO mOOEANIZATION, ANO THE INTEAVENINO

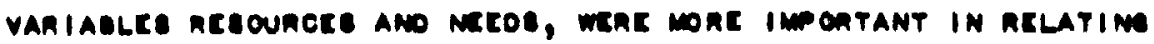

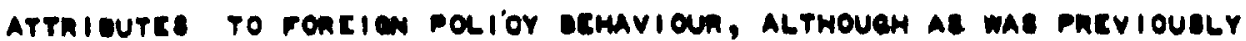

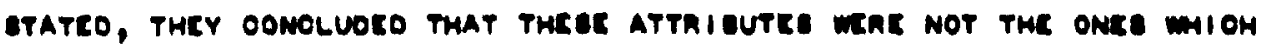
influemoco cemavioun at a Reeiomal level of amalyeis. 38 Moncover,

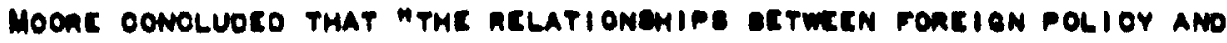

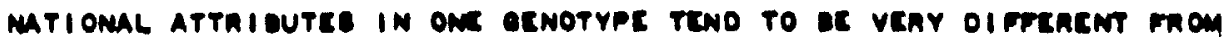

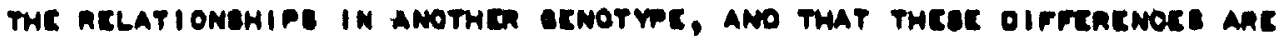
oseounco in AN AMALYele aOnose aLL mariont. 39

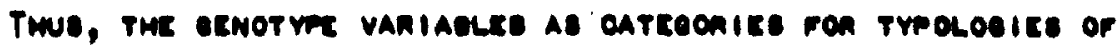

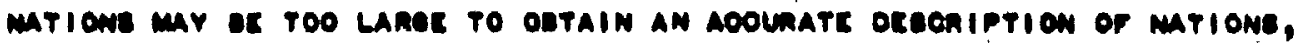

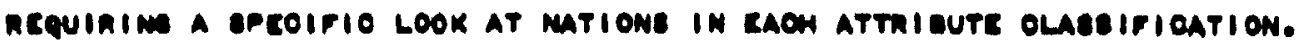

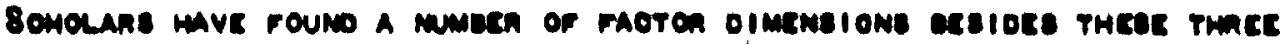

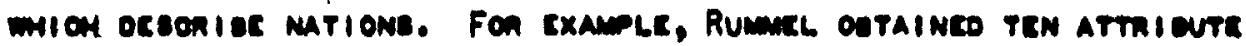

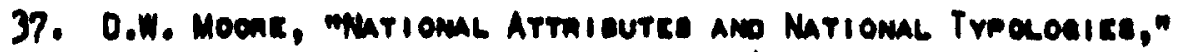
in Comanim Foncion Poljolce, co. J. Roscmu (Tonourtos Jown WILer 80w, Lro., TY74). . 251.

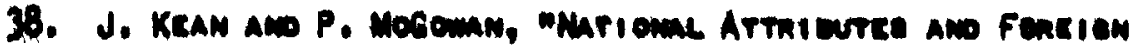

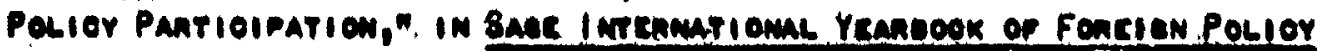

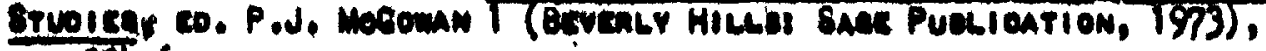
m. 24-6.

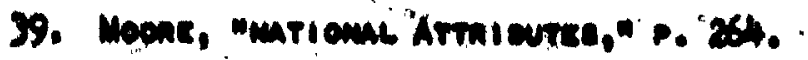


$\therefore f(x)$

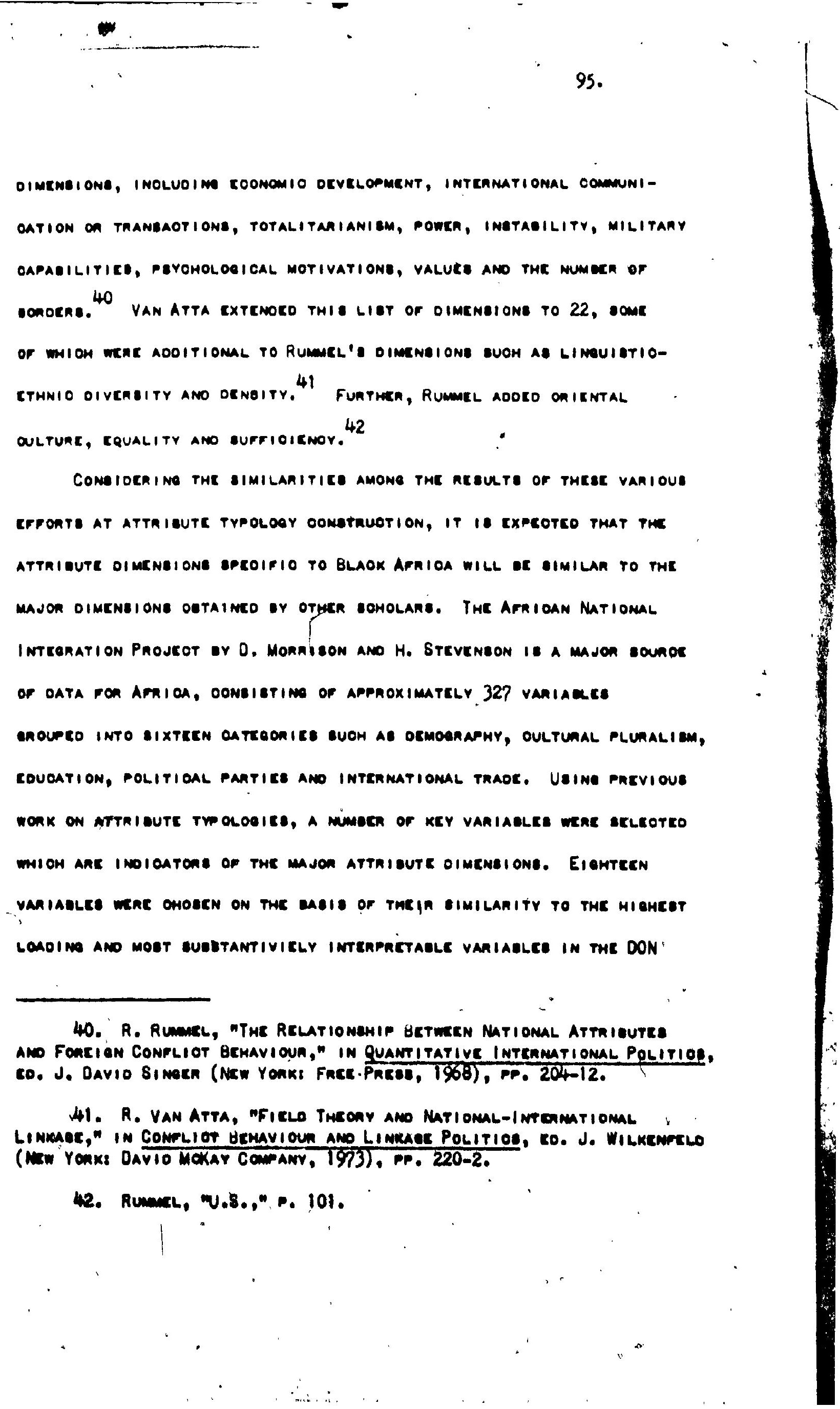




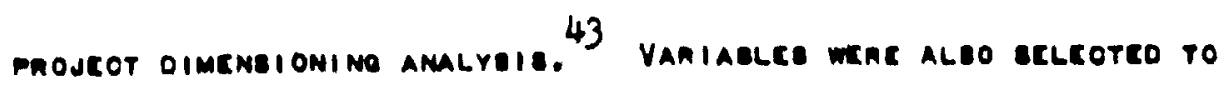

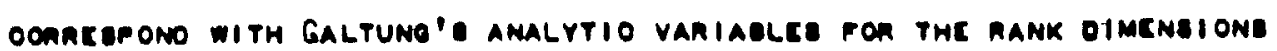
OF MATIONE, MAECO ON THE NATIOMAL DIOTAIDUTION OF AN INOIVIOUAL

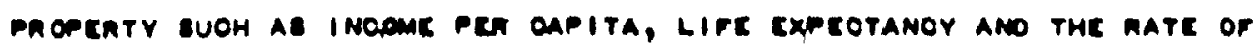

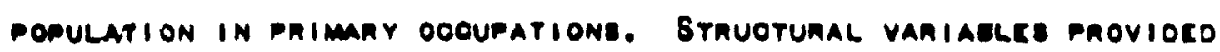
IMFONMATION ABOUT THE STAUCTUAE OF THE MATION, BUOH AS POPULATION ANO 81ze. Galtune's imoivioual oimensiong, 20 in all, mene oivioco into

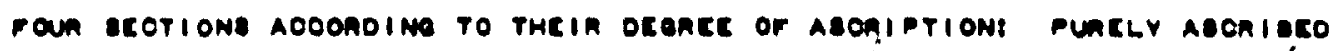

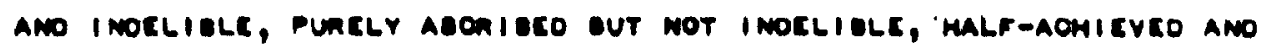

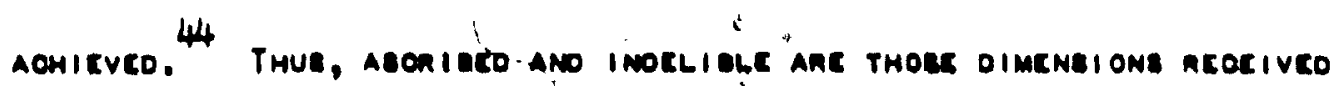

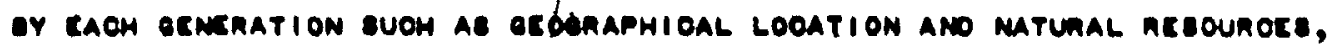

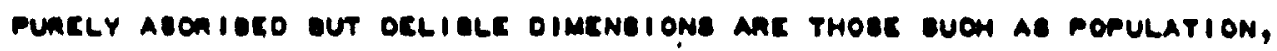

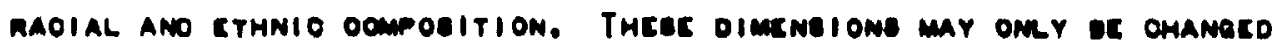

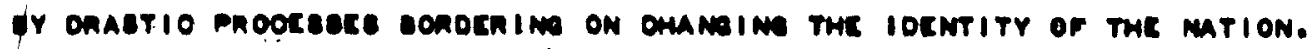

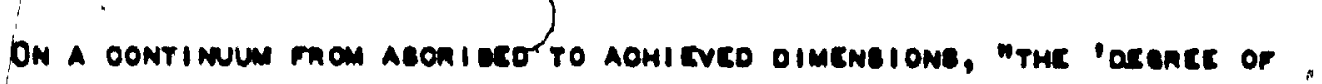

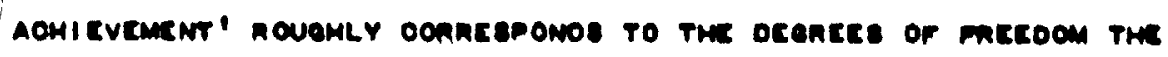

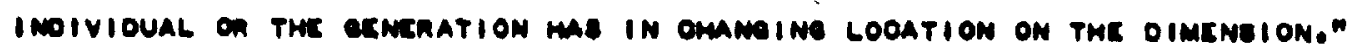

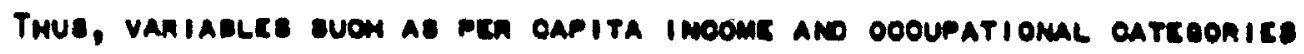

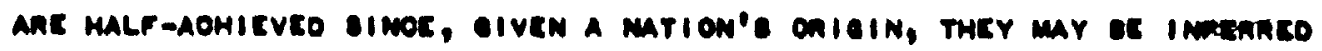

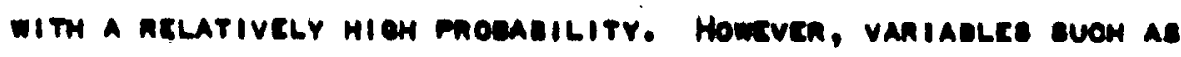

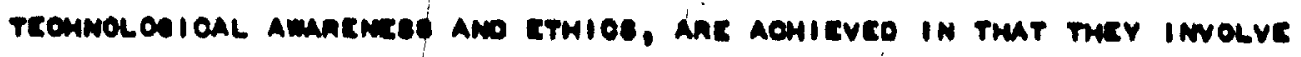
pensomal erronts to agovias sion valuce. Fon cxample, a mation mar

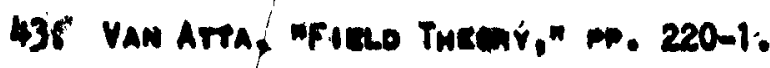

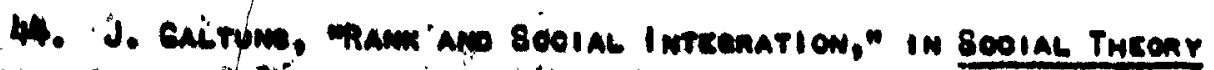

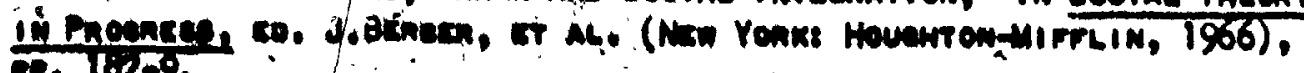
\%. 1878\% 


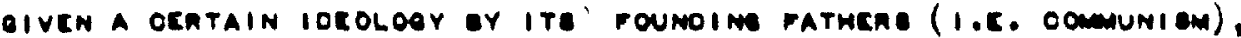

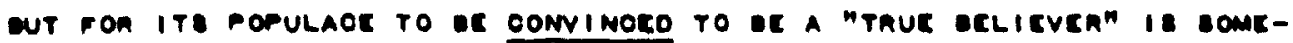

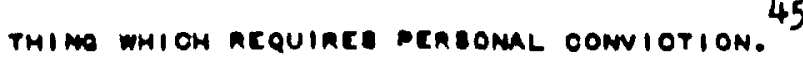

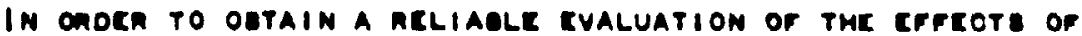

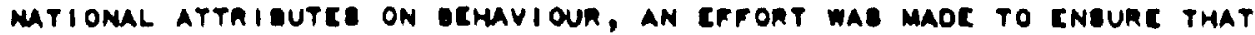
THE YEARs FON THE GEMAVIOUN AND ATTRIDUTE OATA OETS WERI BIMILAA.

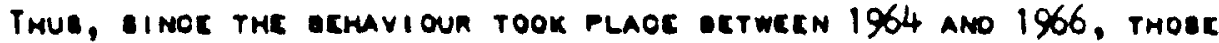

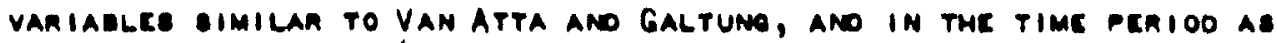

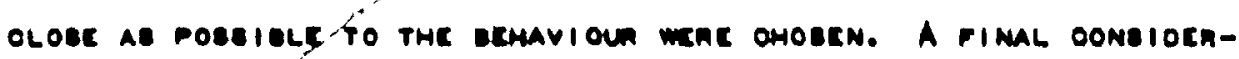

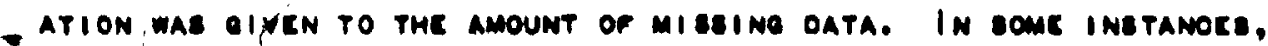

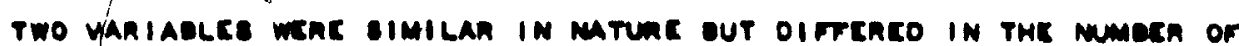

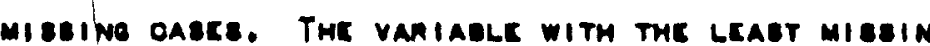

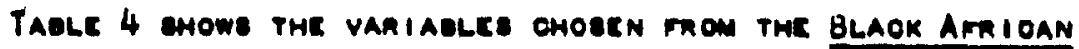
HANOEOOK, "47 ALONO WITH VAN ATTA' MIEMEST LOAOIME VARIAGLES ON THE

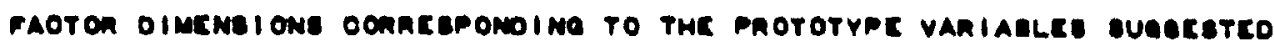

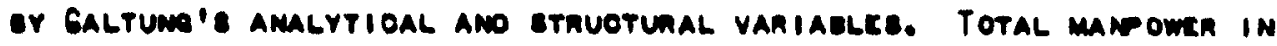

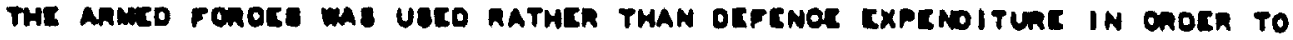

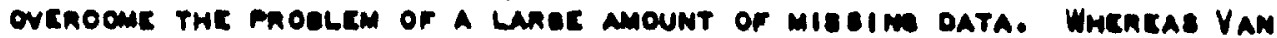

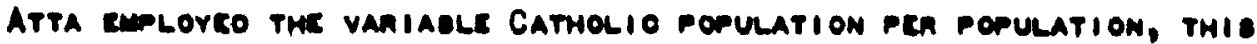

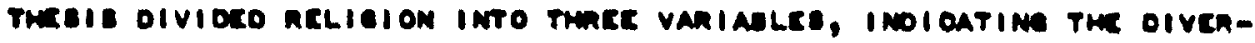

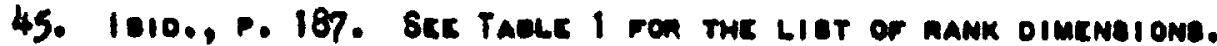

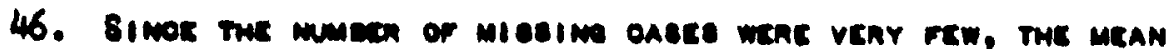

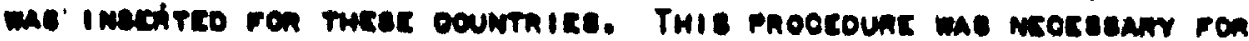

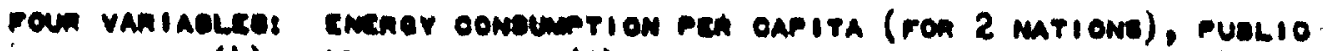
investment (4), EDP rommation (2) ano oumulative thaOr ealanoe (2).

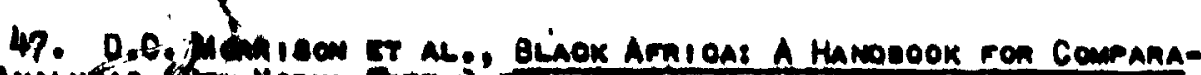

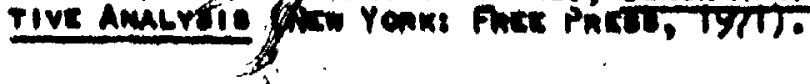


Dimineion

Eoonomito

DEVELOPMENT

Powne

Political

Oniemation

Relieioue

Compostion

\author{
R. VAM ATta \\ GN/POP
}

TCLEPHONTE/POP

ocernor execmoirunce

MTIOMLL I MOOME

oloo menocherif

\section{$\lambda$}

CATMOLIO por/POP

por or Laneret

Lametuer enoup/ pop

Demirr

\section{Diveneity}

ormitr
Matunal areounors

J. Galtume
Pea Capita I moome

D. Monn I son

GNP pER OAPITA

Enose Donsetio

CAPITAL Fonmation

TELEPHONEA/10,000 nop Emener OONSUnEPTION/OAPI TA TaAdo salanar

Puelio investmemt (\$ COP)

Population

Population

opP

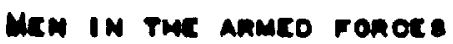

Eaetcrn Cloo REPRTEGMtation

Eastren bloo alo

EAOTEAN LLOO TRAOC True octievene
oomimat locology

Erma10

Compoeition

Uneanization o18c
$\$$ Cmistian iocatificas

\$ Traoítional aelieion iocmi ipicase

\& Muelim iorntificas

\$ or pop epeakim dominame venmouran

- or olrice Z20,000 rool whelom f or per in oitricez 20,000 


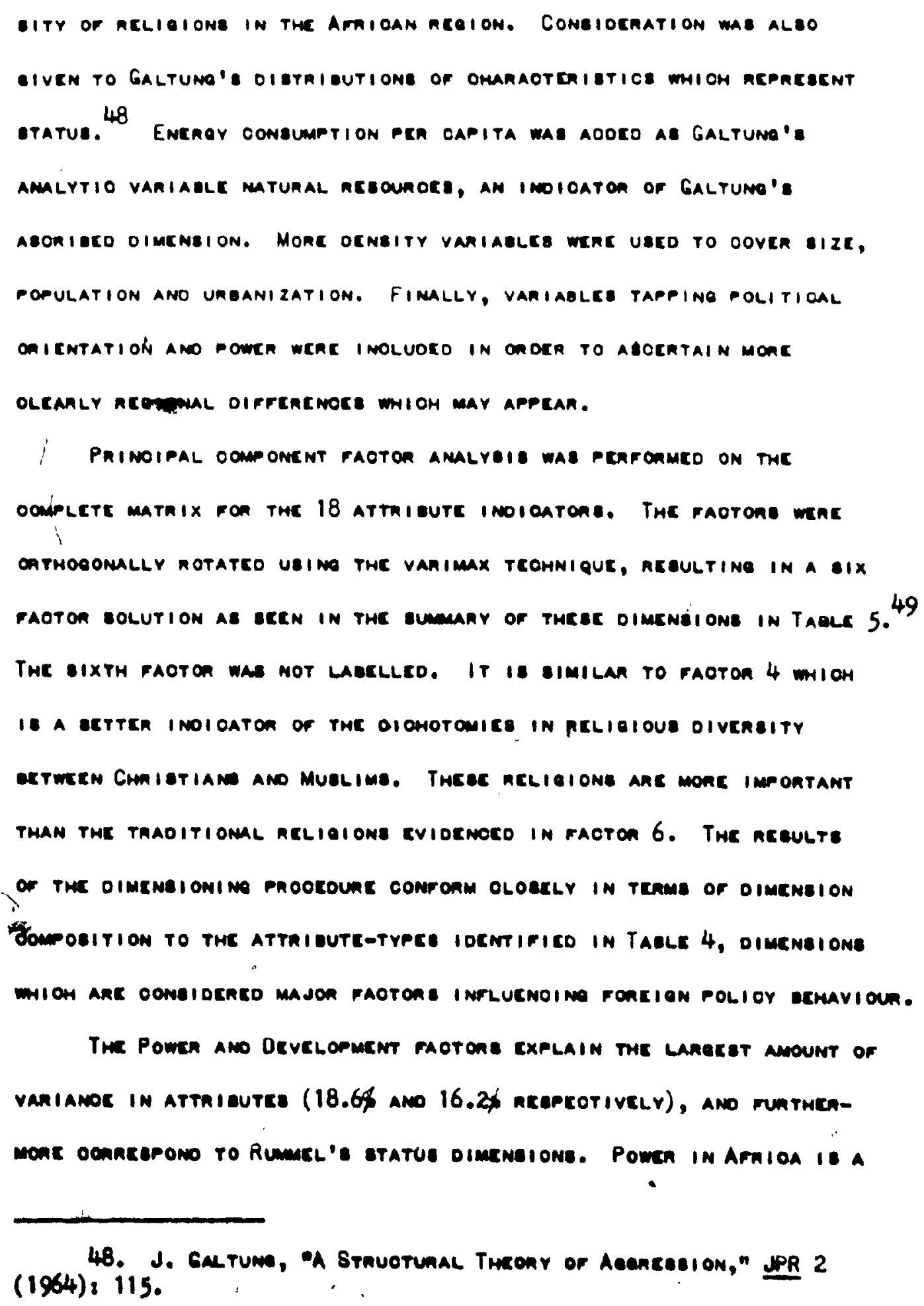

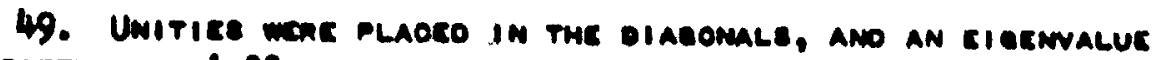
or encaten tman 1.00 mas veco as tum out-orr coniteniom. 


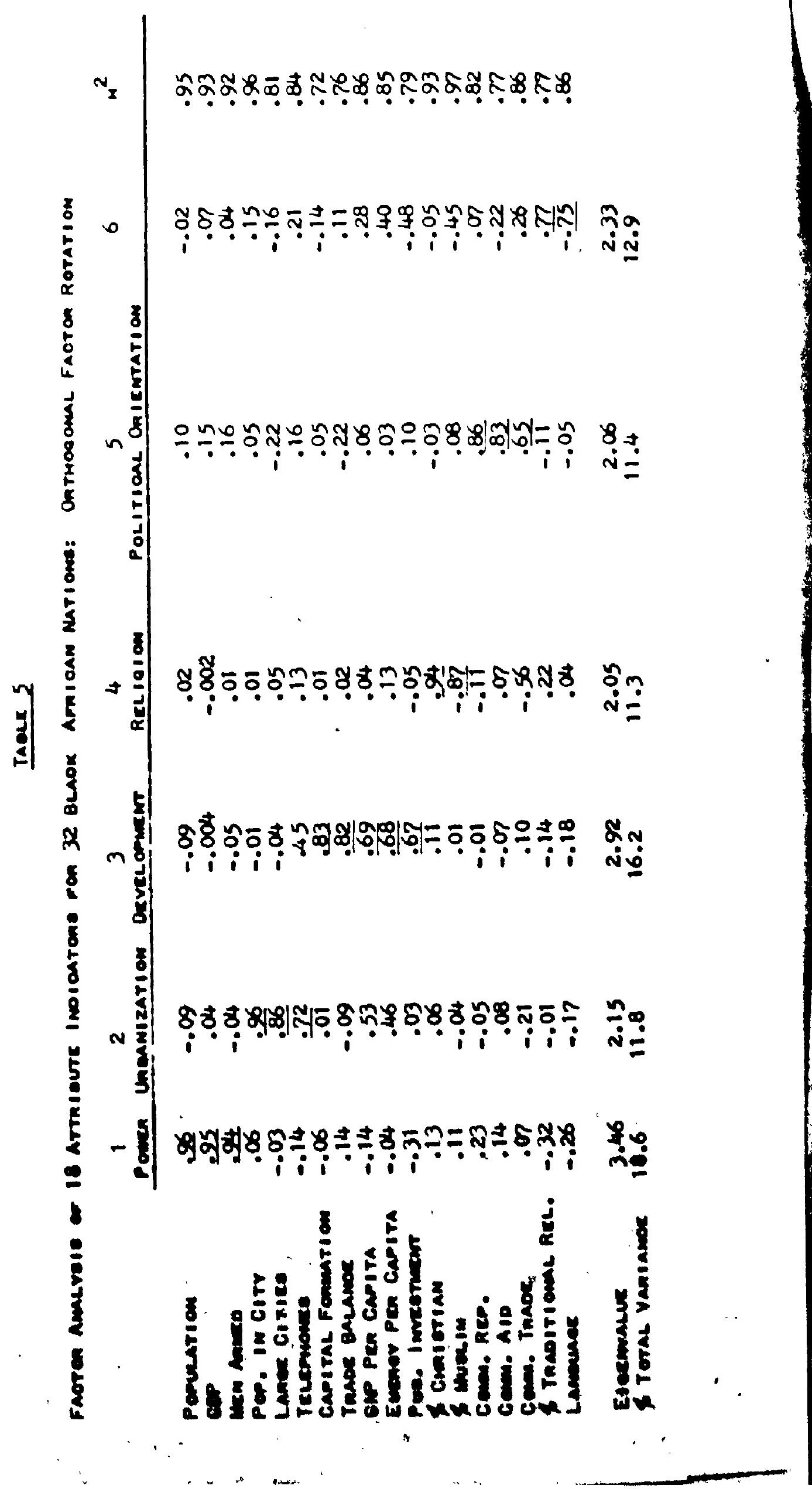


Har.

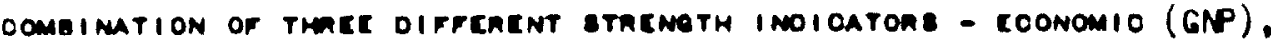

MILITARY (MEN ARMEO) ANO BIzE-(ROPULATION). In OOMPARIMO THESE LOAOINOE WITH THE FAOTOR SOORES OF NATIONE ANO THEIR RANK ON THC

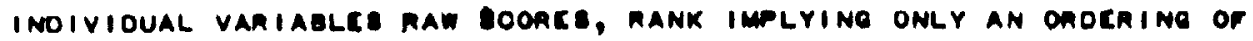

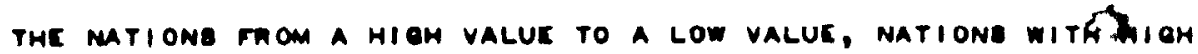
pogitive factó goonce also have a lange GN, aAmY ano population.

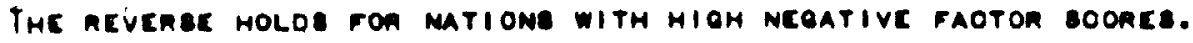

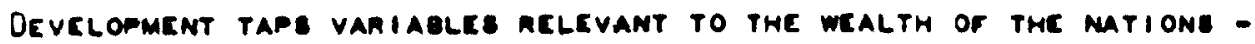

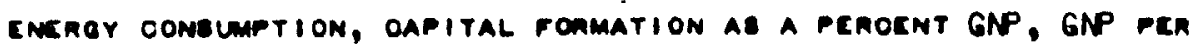

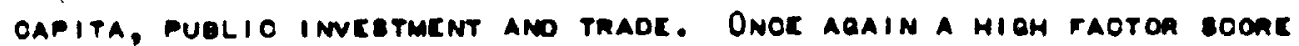

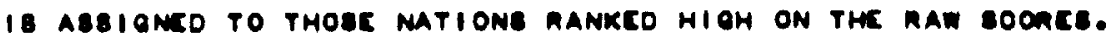

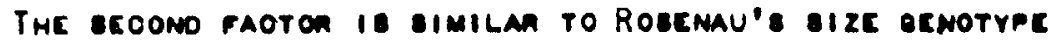

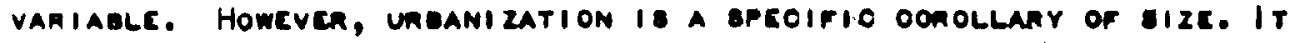

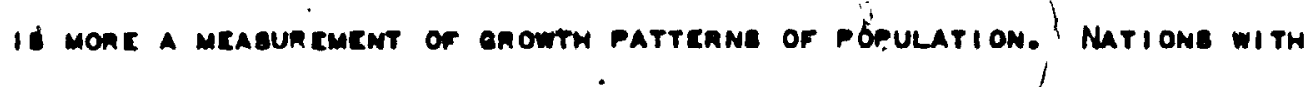
A HIOM FAOTON DOONE TENO TO MAVE MONE PEOPLE LIVINO IN LAROE OITIEO. WITH UREANIzATION THE TELEPMONT IS A PREVALENT MEANO OF OOMUMIOATION

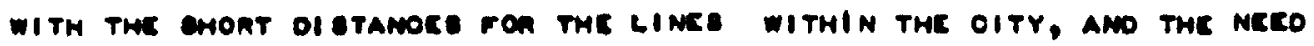

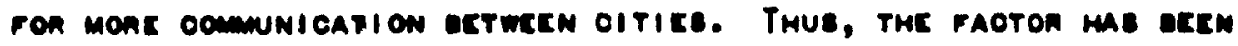
LACELED UnAAMIzATIOM.

THE FIFTM FAOTON, POLITIOAL ONIENTATION, IS AN INOIOATION OF

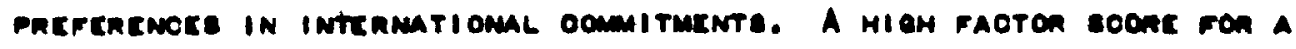

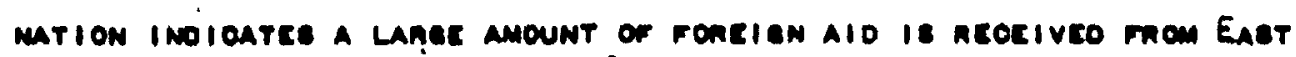

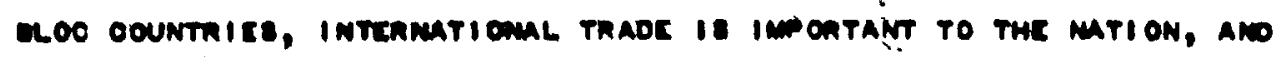

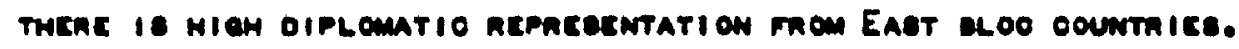

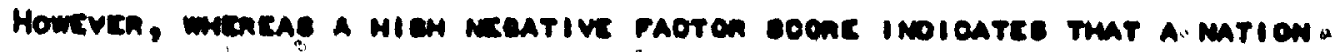

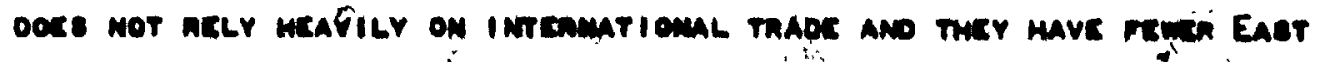


-loo diplomatic repacbentativea, a negative soone doce not mean that

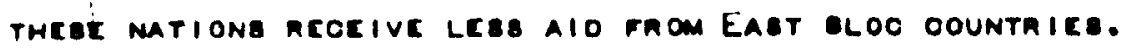

THE FINAL mató 10 OLEARLY A RELIOIOUE DIMENEION. IT OEMON-

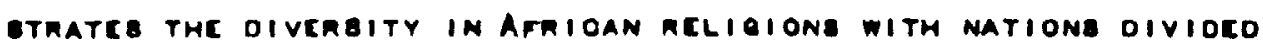
ertween those pacdominantly Chrietian ano those who ame muglim. MATIONB WITH a HIOH PEROENTAQE OF CHRIBTIAN IOENTITIEA HAVE A HIOH 2 PREOOMINGTL LY MUELIM. $P$

WITHOUT IOENTIFYINO THE OONTENT OF ATTRIOUTE ANO BehaVIOUR

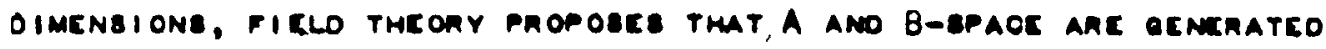

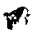
OY A FINITE BET OF LINEAMLY INOCPENOENT DIMENBIONS. WITH THESE

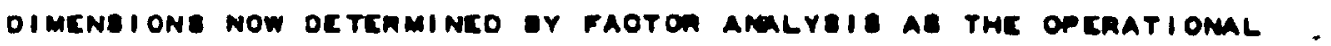

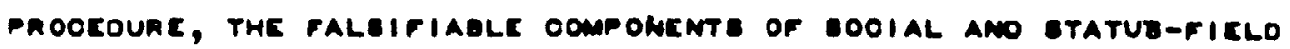

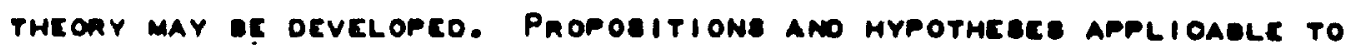

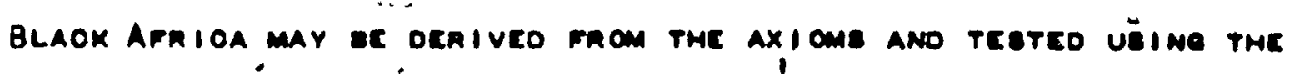

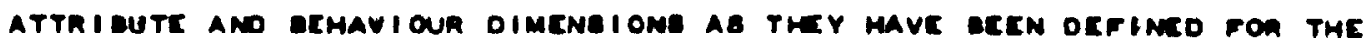
BLAOK AFRIOAN ACO!OMAL SYOTEM.

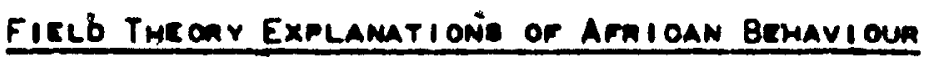
a.

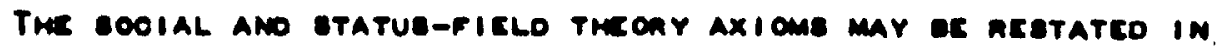

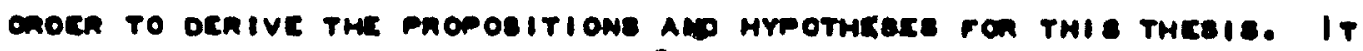

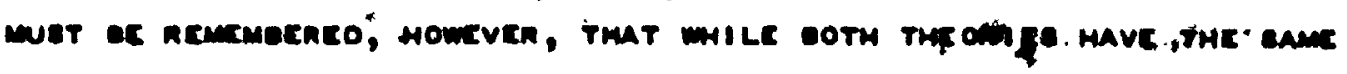

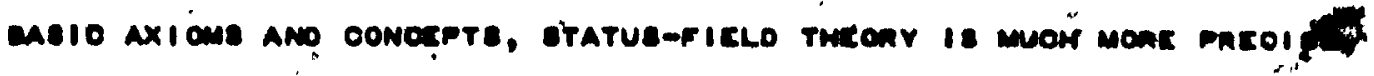

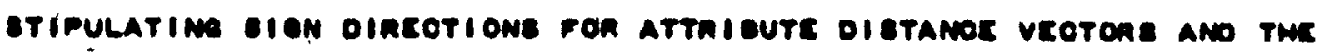

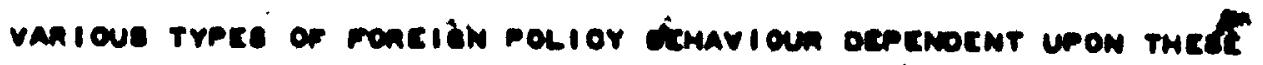

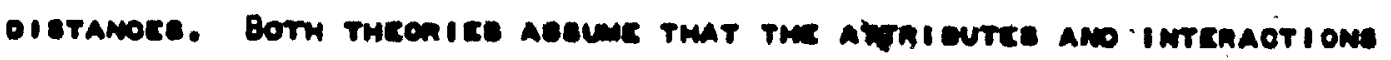


OF MATIONE FOAM A COMPLEX INTEARLLATIONAHIP WHIOH OONETITUTES INTEAMATIOML RELATIONS, ANO IN THIE ,IMETANOE REOIONAL RCLATIONA.

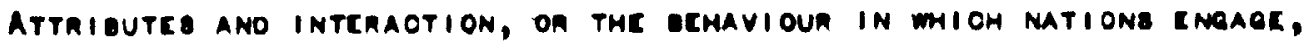

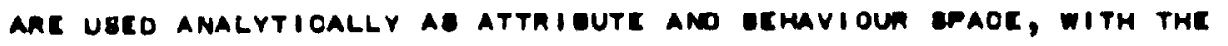
LOOATION OF ALL MATIONE ATTRIBUTE OIOTANOES IN ATTRIBUTE BPACE AND

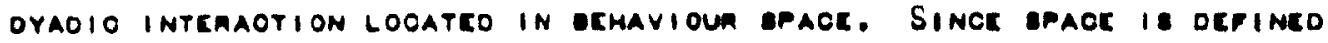

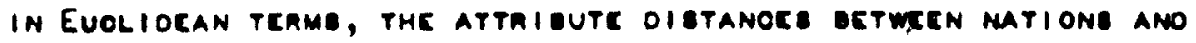
ovadio eemavioun ane plottro as veotons in theIR meapcotive spaoce.

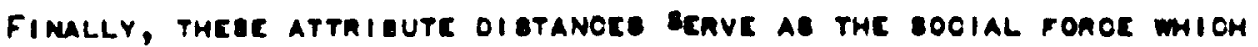

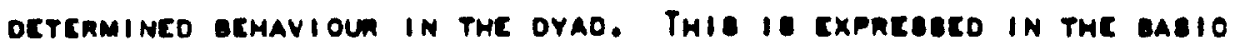
CQUATION:

$$
\vec{W}_{1 \rightarrow j, k}=\sum_{i=1}^{p} d_{1-j, 1}
$$

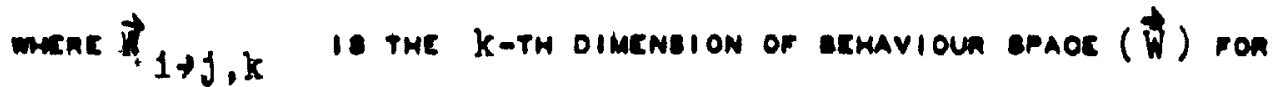

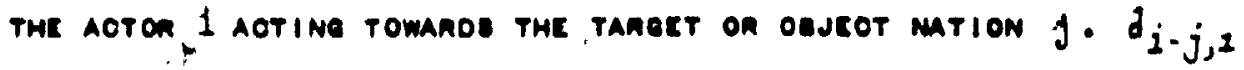

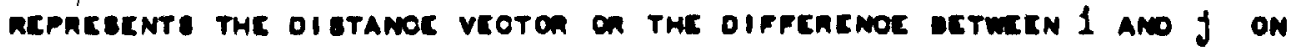

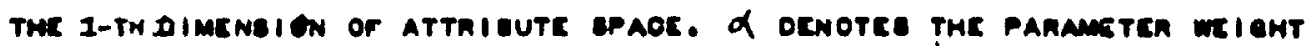

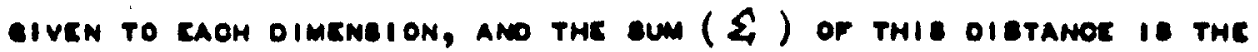
-ooial ronor detenminine oxmavioun. A ellomtly clacomateo rquation

$$
\nabla_{1 \rightarrow j, k}=\sum_{1=1}^{p} 1, d_{1-j, 1}
$$

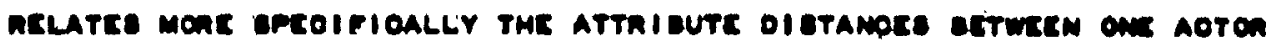
ano its tanecte (ocnoteo or the subenipt 1 in $\propto$ ) ro the camavioun

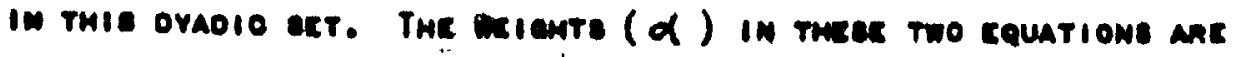

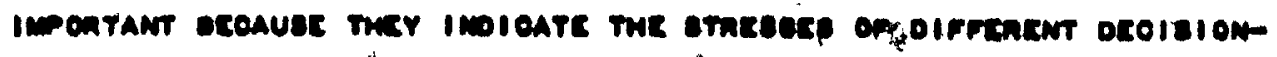


MAKERE ON ATTRIEUTE OIMENEIONE IN REROCIVINE MHAT TOAM OF INTCAAOTION 10 ncouinto.

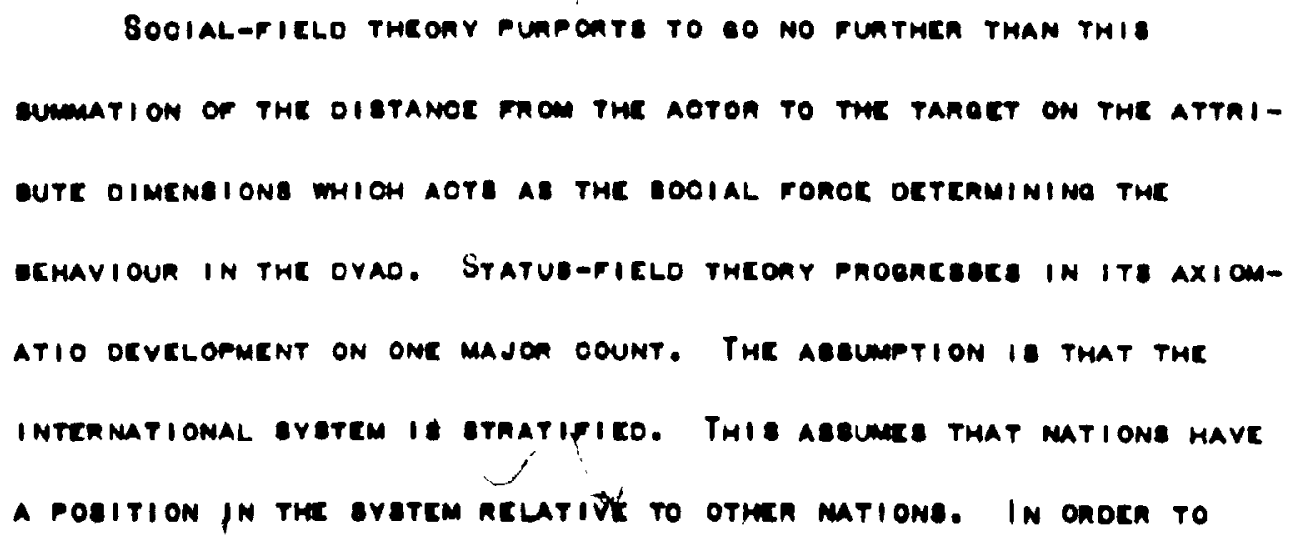

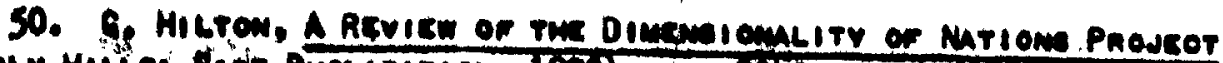

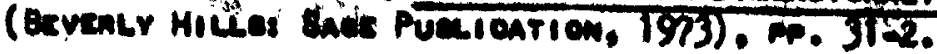




$$
\pm \alpha\left(s_{11}-s_{11}\right) \pm \alpha\left(s_{12}-s_{\jmath 2}\right)
$$

whenc of 10 the positive panameten ano $S_{11}$ ano' $S_{12}$ anc mation 1 's

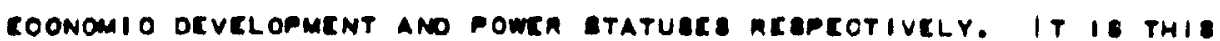

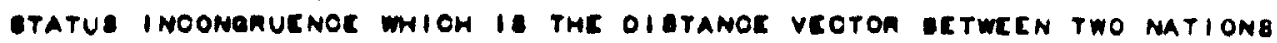
etatue veOTOR ON ETATUE DIMENEIONE.

THE cemaVIOUR IN A OYAO maY or EITMEA OONFLIOT, OOOPEAATION OA

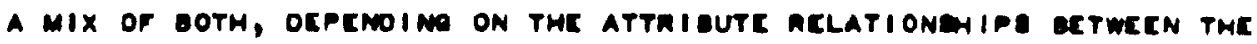
aOton ano tanect. ThK COOEERATION ThEOnEM LOOKS UPON the JOINT RANK Or mitions as contrieutino to oocechative cochaviour. That is,

$$
c 0_{1 \rightarrow j}=-\alpha_{1,} \alpha_{1-j, 1}-\alpha_{12} \alpha_{1-j, 2}
$$

WHERE $C O_{1 \rightarrow j} 18$ OIACOTIOMAL WITH THE MMOUNT OF OOOPCEATION OF 1

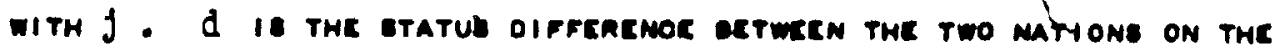
coonomio orvelopment (1) ano pomen (2) as pnevioush bigovesco unoch

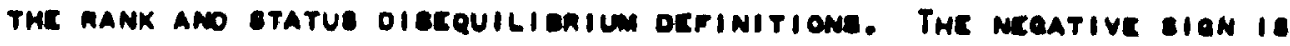

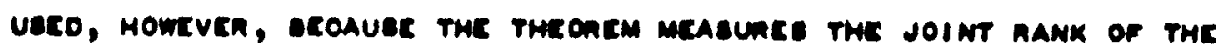
Matione oY theIn oletanor, not tmeIn sum.

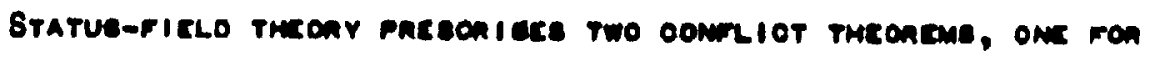

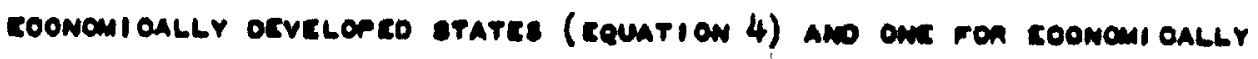
unochocvelopto otatre (zquation 5 ) 51

51. $1010 ., \ldots .36$ 


$$
\theta P_{1+j}=\beta_{11} d_{1-j, 1}-\beta_{12} d_{1-j, 2}
$$

ANO

$$
C P_{1 \rightarrow j}=-\left(\beta_{11} d_{1-j, 1}-\beta_{12} d_{1-j, 2}\right.
$$

Fon the EOONOMIOALLY UEVELOPEO THEOAEM IT IS EXPECTED THAT WHEAC CF - $J$ 1. THE CONFLIOT echaviour or 1 WITH $J$, OEVELOPto 1 'B WILL EXPOAT LOW OONFLICT TO J'B AaOVE THEM AMO HIOH CONFLICT TOJ'B ELLOW, ANO ON THE POWER OIMENEION WILL EXPOAT HIOM CONFLIOT TO J'S ADOVE, ANO LOW

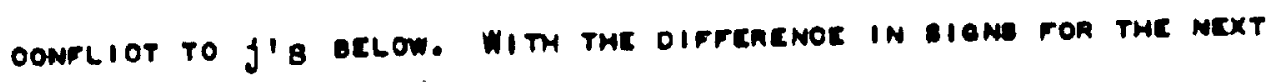

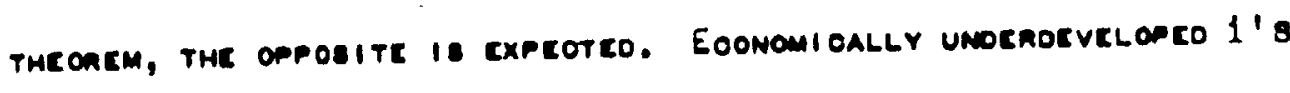
WILL EXPONT HIOH OOMFLIOT TO J'B ABOVE, ANO LOW OOMFLIOT TO J'B OLLOW, ANO ON THE POWER OIMENEION 1 WILL CXPORT LOW OONFLIOT TOIJ' AEOVE IT ANO HIAM OONRLIOT TO J'B OCLOW. 52

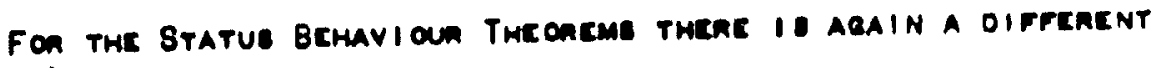
THEOAEM rOA THE COOMOMI OALLY DEVELOPEO AHO UNOEROEVELOPEO MATIONE.

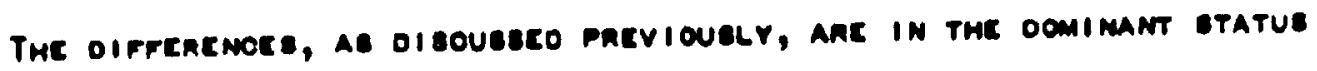

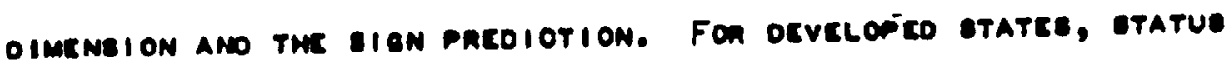

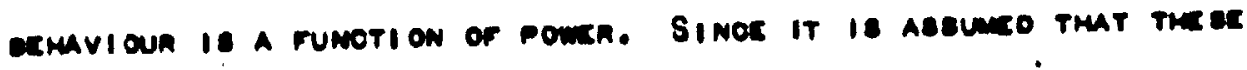

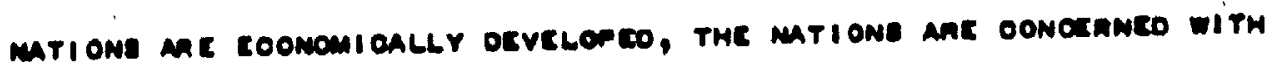

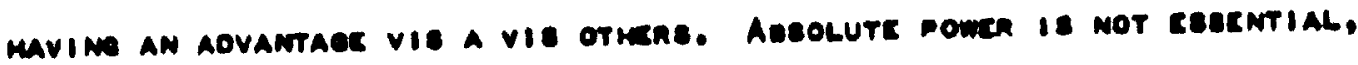

52. J. Vimoent, matrmi eute ano Atrni gute Distamor Theony of

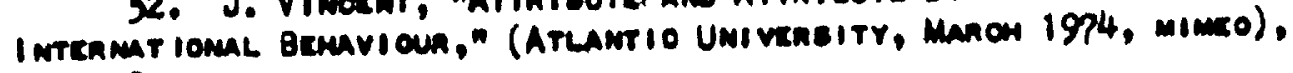
pr. 7-8. 


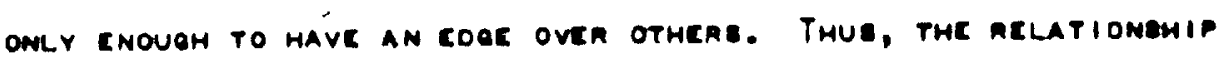
ectween the aoton ano tanect mar oc etateo as

$$
c o_{1+1}+c F_{1+1}=y_{12} d_{1-1,2}
$$

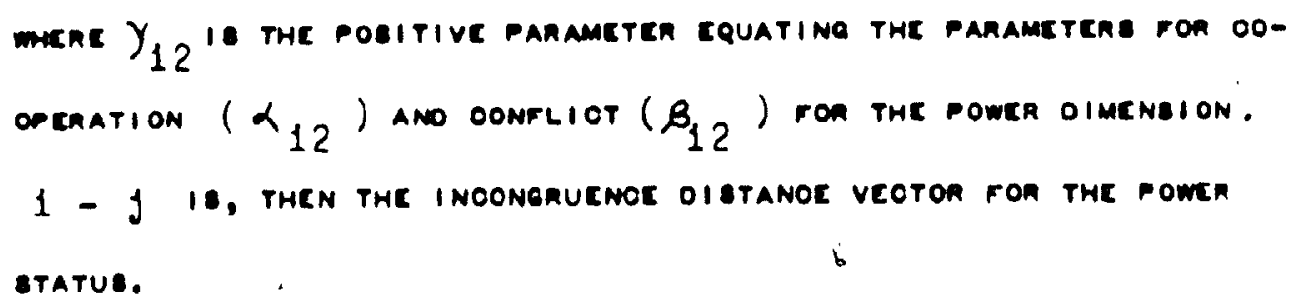

UNOEROEVELOREO MATIONE, HOWEVEA, ETREAS EOONOMIO OEVELOPMENT.

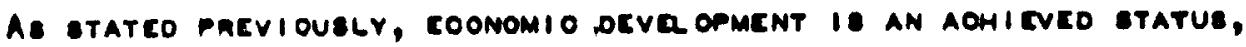

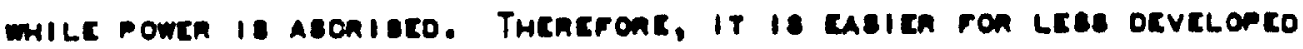

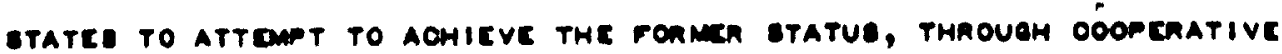
- ano oonflictive eemavioun. Thus a testadele cquation is

$$
C 0_{1+j}+C P_{1+j}=y_{11} d_{1-j, 1}
$$

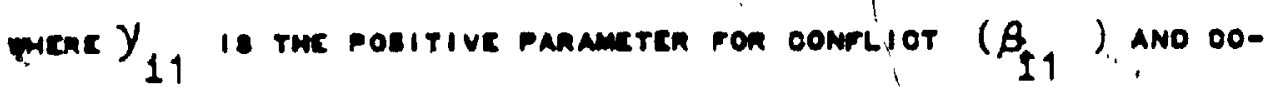

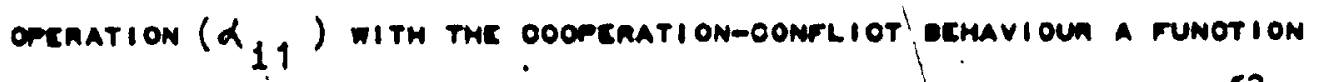

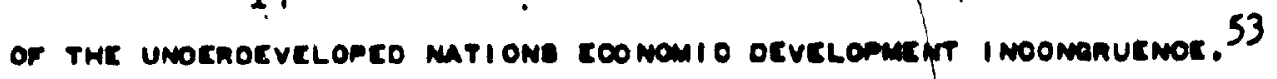

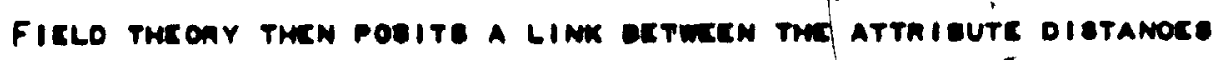
in oYade ano oradio aemayioun. ThIS these mostuqatese that the

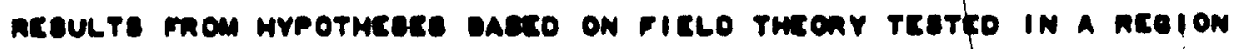
amOULO MEPLIOATE THE FINOIme In the BLOEAL OYOTEM. TMAT IS, ATTMI-

53. HILTOW, A REvisw, No: 37-38, 


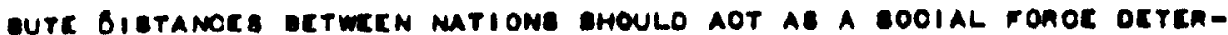

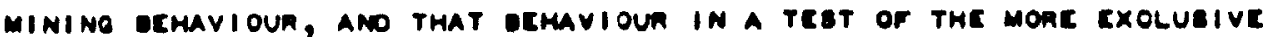

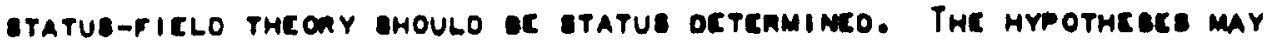

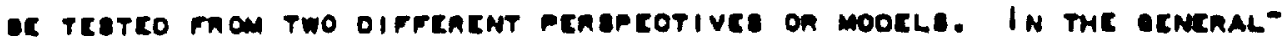

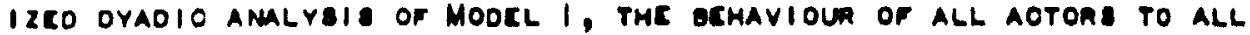

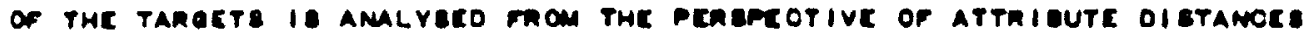

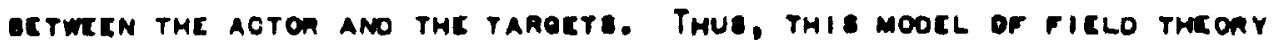

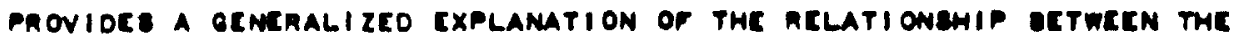

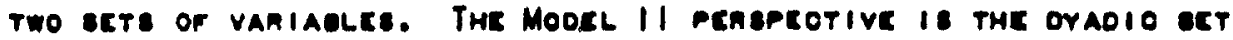

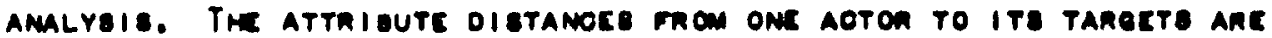

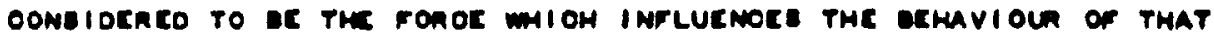

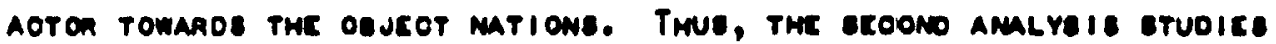

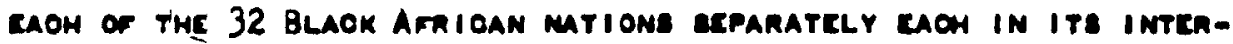
AOTIONE WITH ALL OF ITE TARECTS.

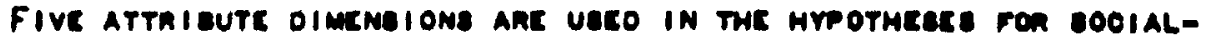
piclo tacony - Power, Uneanization, Deviloment, Relioion ano

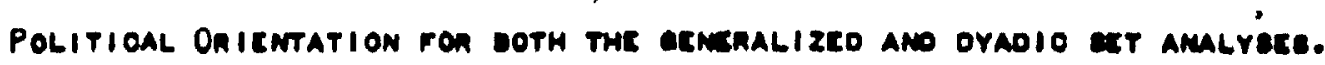
The echavioun olmensiows anc Intenaorive Bchavioun, Comajtreo Conpliot

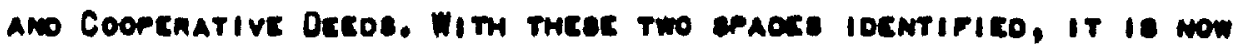

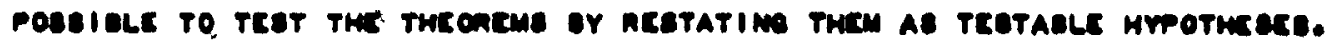

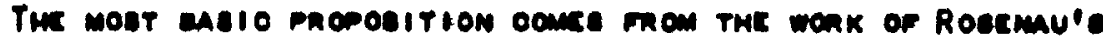

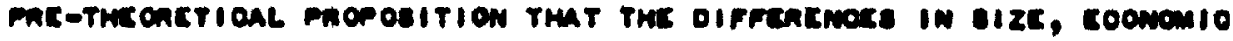

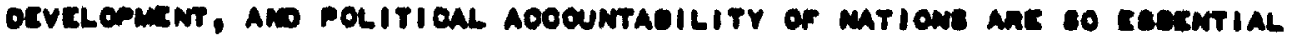

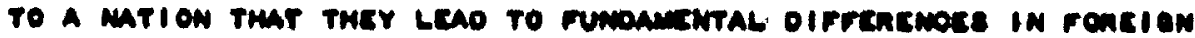




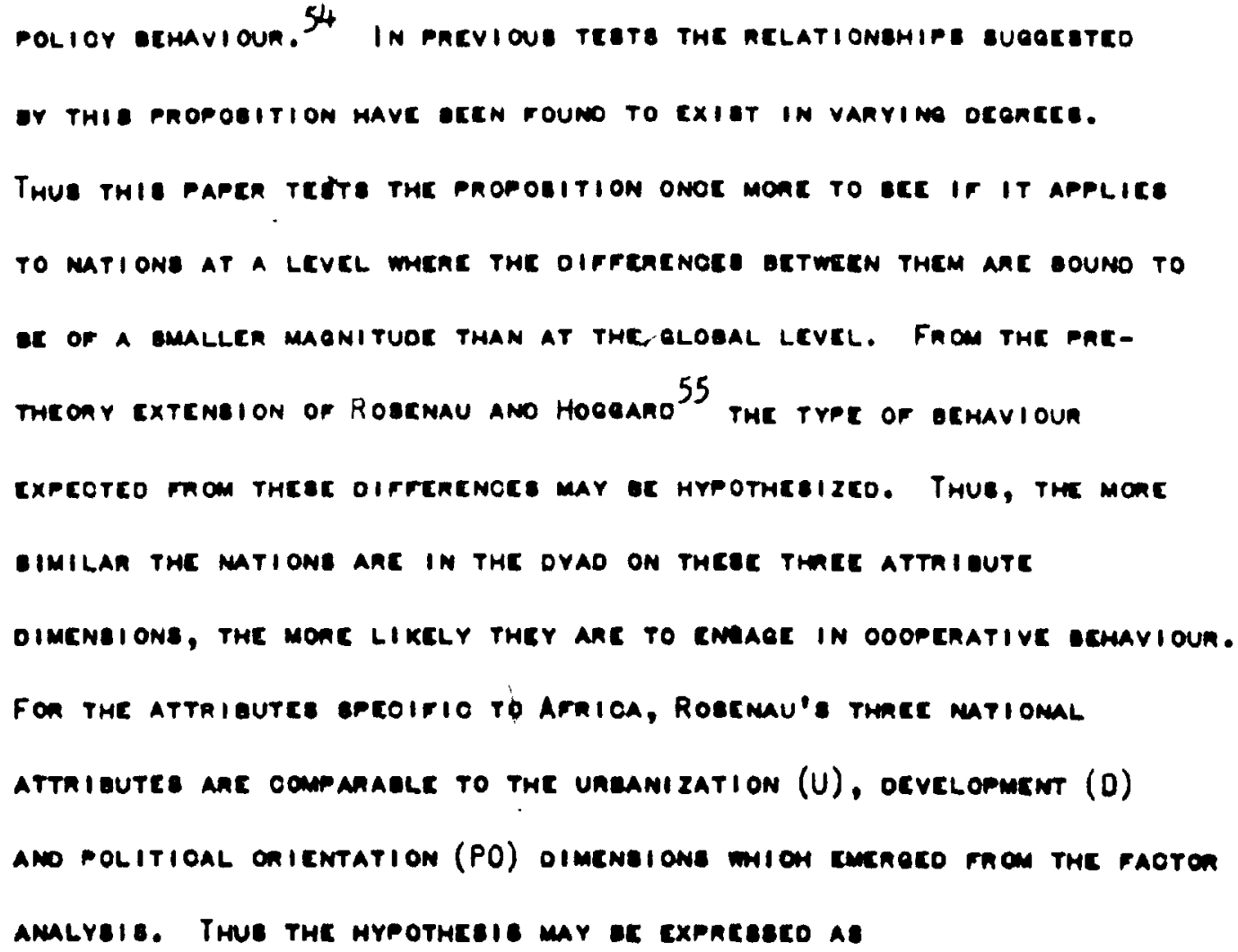

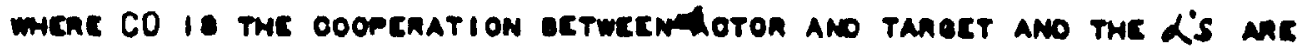

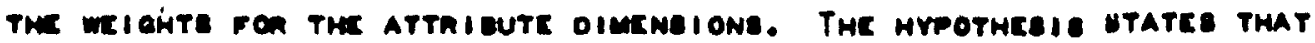

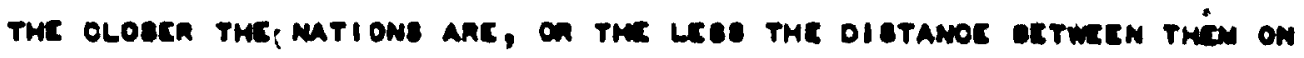
THE ATtRI

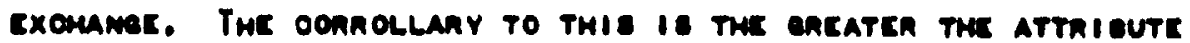

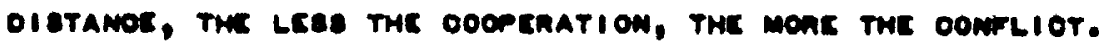

54. J. Roermau, mpre-Theonice ano Thconice in Foncion Polior," in Apranonones to Commanative ano Intennatiomal Poujtics, co. R. FanarLL (Evaneton: Montwwetenn Univeneity Pacse, 1966). $3 x$

55. Roermau and Hooenno, "Fontian," me. 125-7. 
THE sEOONO PAOPOEITION IE THE HOMOEENCITY PAOPOBITION THAT THE DISTAMOE VECTON DETWEEN THE AOTOR-NATION ANO AN OEJEOT-MATION ON KOONOMIO DEVELOPMENT, POWER, UREANIZATION, RELIOION ANO POLITIOAL ONIENTATION DIMENEIONE WILL OONTAI GUTE NCEATIVELY TO THE OOOPERATIVE Demavioun of THE AOtOA TO THE OEJEOT-MATION. THUS, THE MONE IMILAA

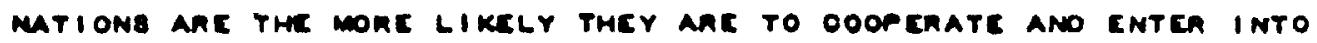
AEREEMENTE WITH CAOH OTHER. THIS HYPOTHESIO BUILOS ON RUMALL' 56

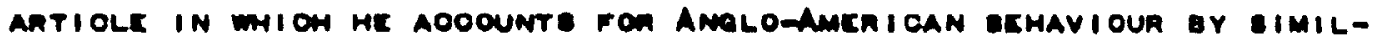
ARITY IN LOOMOMIO DEVRLOMUEN, DIEEIMILARITY IN FOAEION OONFLIOT

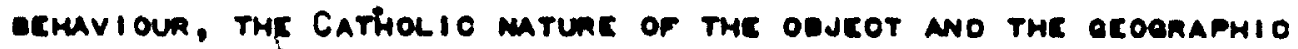

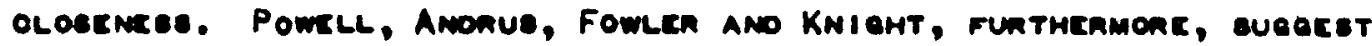

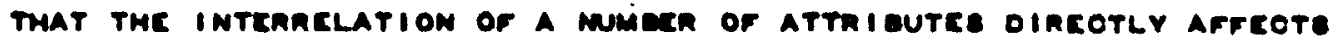

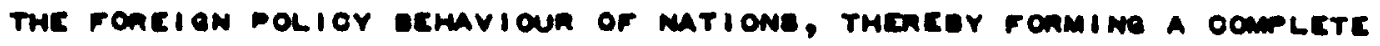

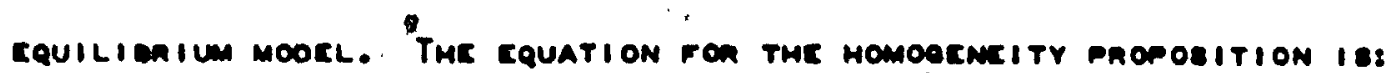

$$
c \sigma_{1+j}=-\alpha P_{1-j}-\alpha U_{1-j}-\alpha D_{1-j}-\alpha R_{1-1}-\alpha P O_{1-1}+8
$$

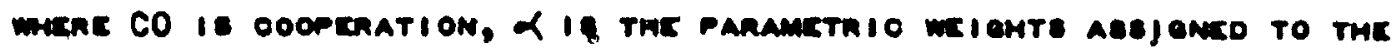

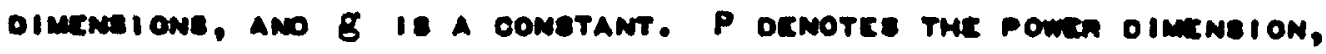

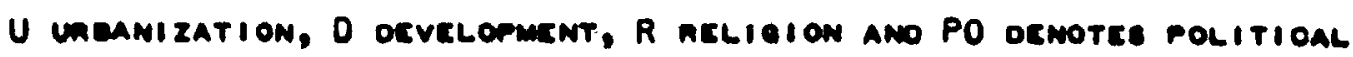
onicarration. THE nrpothesis is the mone eimilan mations ant in

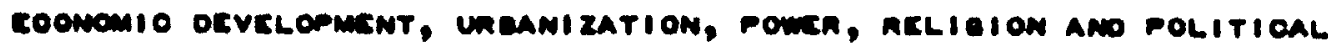

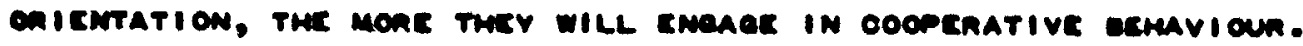

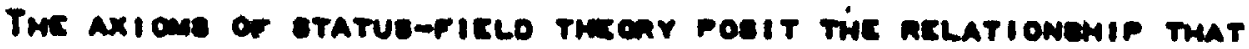
56. Rumant, U.8.," . 105. 
and

THE TWO MAJOR DIMTNEIONE OF COONOMIC OEVELOPMENT ANO POWLA IMFLUCNOC etatue ecmavioun. That is, eome ochavioun is otatus ocpcnocnt; in

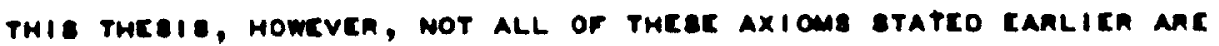
Explonco.

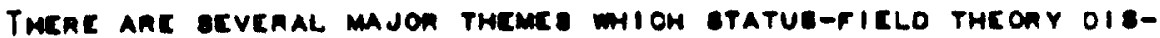

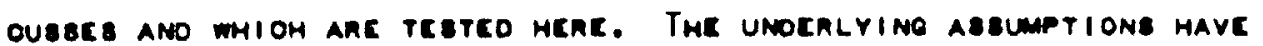

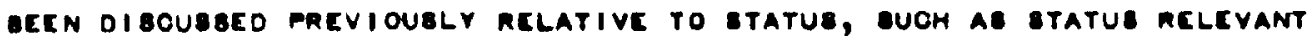
echavioun ocine oincoteo tomanos michen nankine mations, ano the oncater a mation's RANK, THC mone its status ermavioun. From this

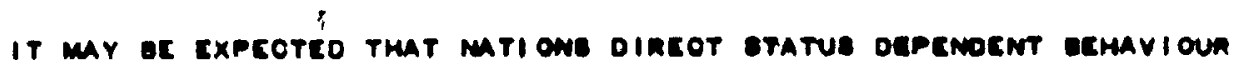

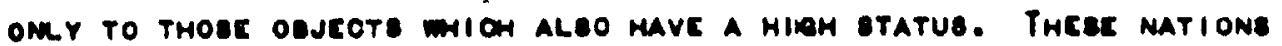

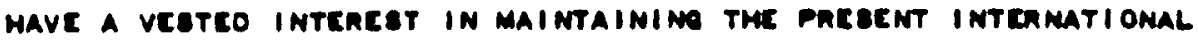

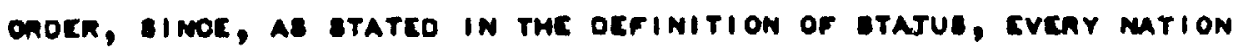

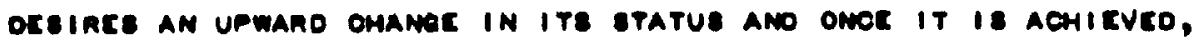
oEsince to maintain the statue. The moet matunal way to maintain

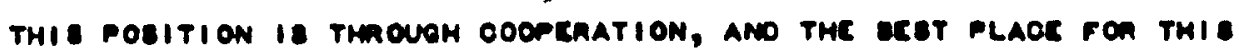
ImTERAOTION IS WITH OTHER MATIONE IN THE game POSITION. THUS, veino the Coopchative Theonem (cquation 3) acetatco

$$
c 0_{1+1}=-\alpha_{1 D} d_{1-1, D}-\alpha_{1 p} d_{1-1, p}
$$

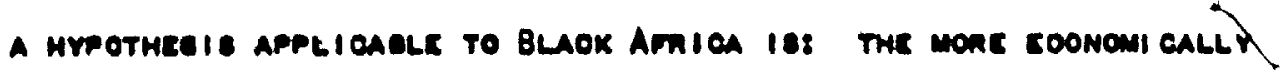

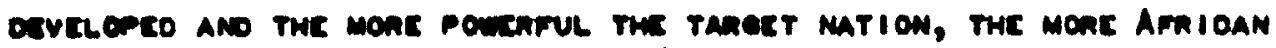

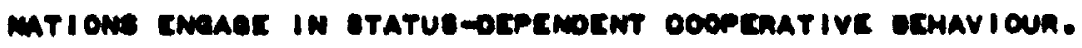

The Aovterives "mone" on "Lege" ant waco to imply tmat the aoton is nelatively adove, on aclow, the tanert in the guantity of the 


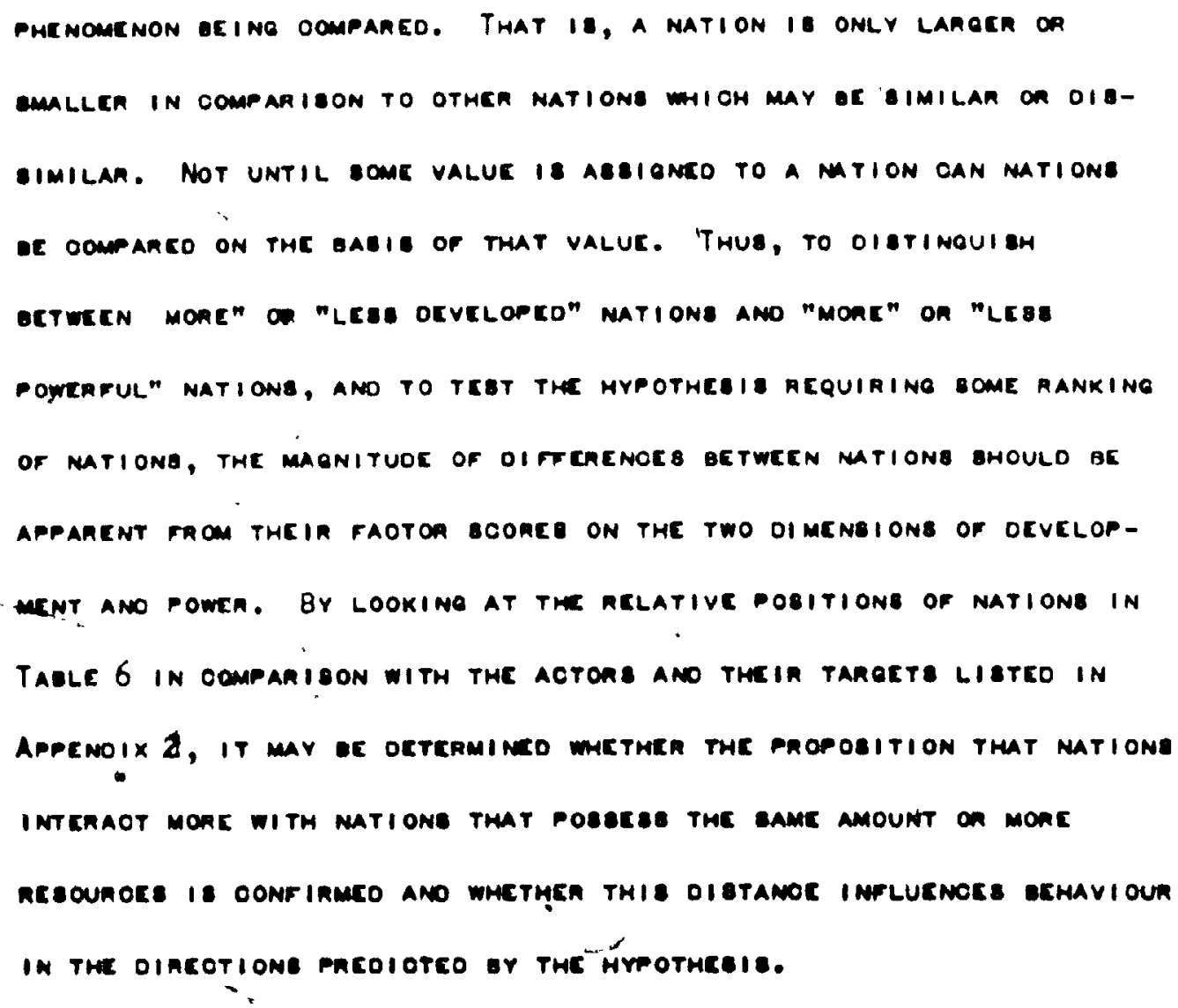




\title{
TAGLE 6
}

\author{
Relative PlaOement of Natione Aooondine ro Faoton SOOnEs on the \\ DeVELORMENT ANo POWER Dimeneiona
}

\section{DrVRLLOMERT}

\section{Pown}

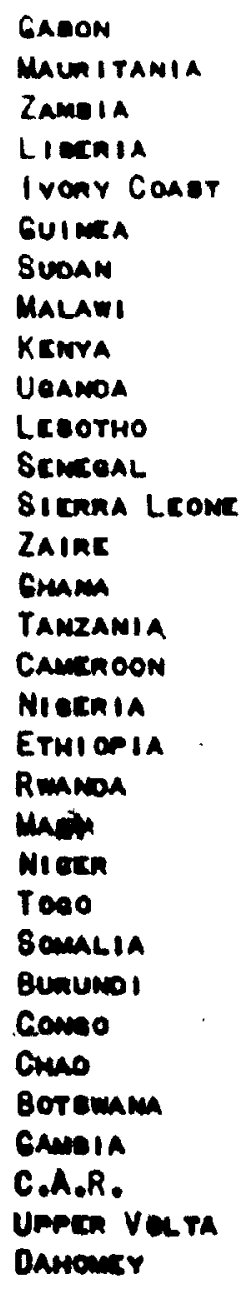

2.94

2.41

1.74

1.72

.78

.42

.38

.37

.23

.23

$-.00$

$-.00$

$-.01$

$-.04$

$-.0 ?$

. .19

$-.31$

$-.34$

$-.38$

$-.39$

$-.41$

$-.44$

$-.49$

$-.52$

$-.59$

$-.65$

$-.75$

$-.84$

$-.96$

$-1.05$

$-1.26$

$-1.52$

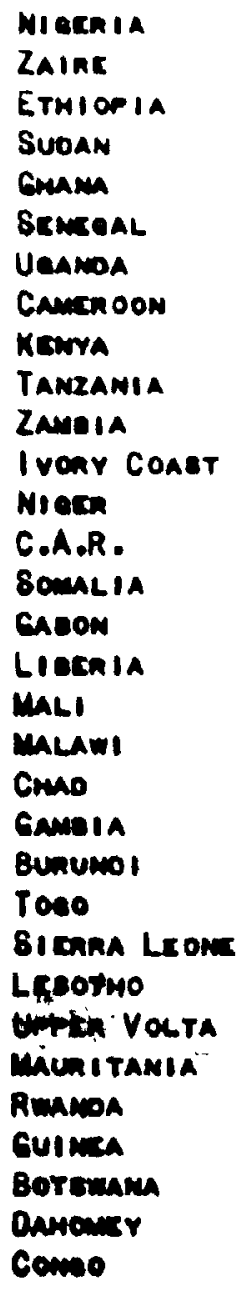

4.35

2.00

1.38

.80

.52

.14

.10

.09

.07

.05

$-.07$

$-.09$

$-.15$

$-.20$

$-.21$

$-.25$

. .30

$-.32$

$-.33$

$-.36$

$-. .44$

$-.48$

$-.49$

$-.49$

$-.50$

. .52

$-.59$

$-.64$

$-.64$

$-.75$

$-.83$

$-.86$ 
114.

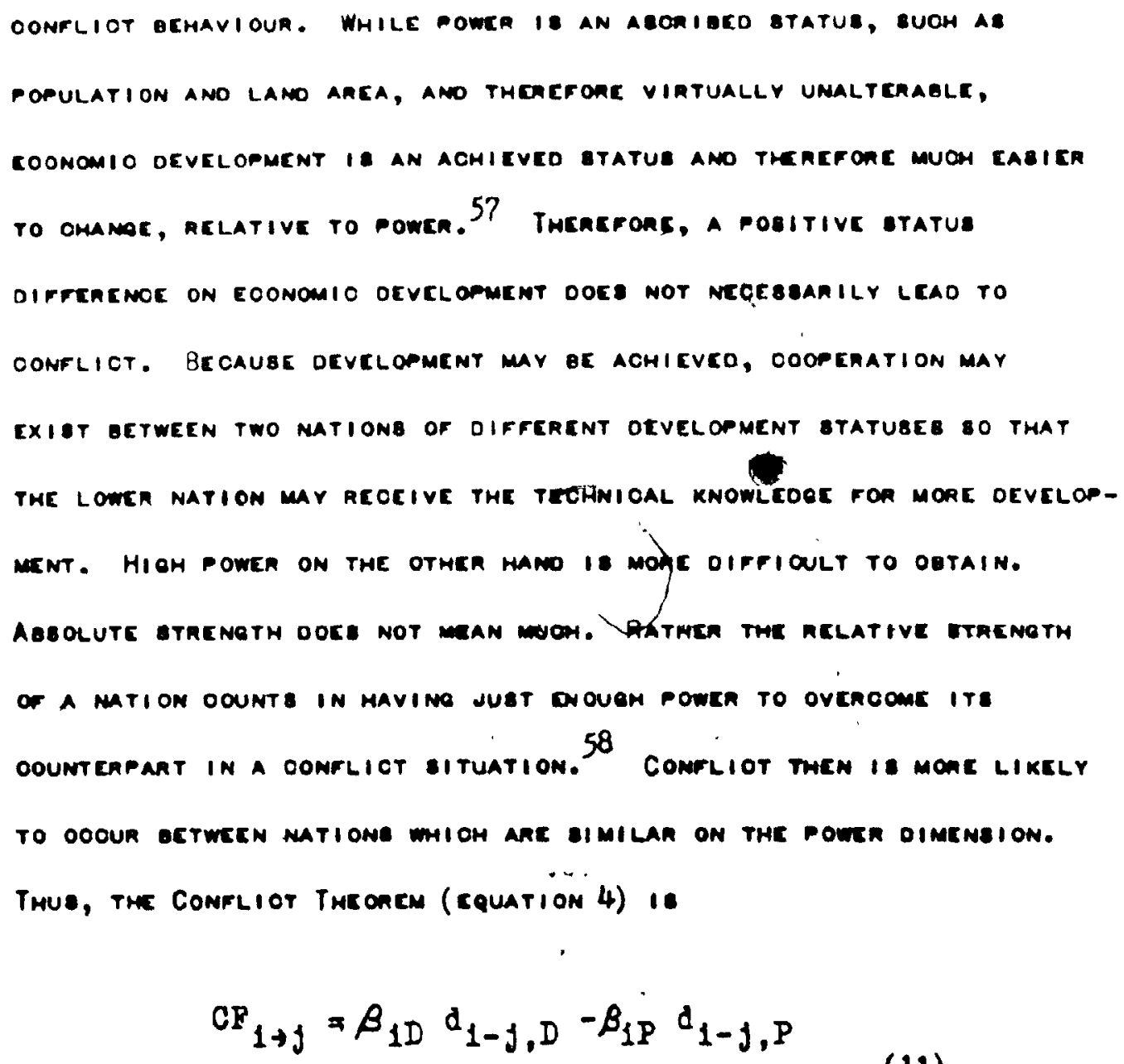$$
C F_{1 \rightarrow J}=\beta_{1 D} d_{1-J, D}-\beta_{1 P} d_{1-J, P}
$$

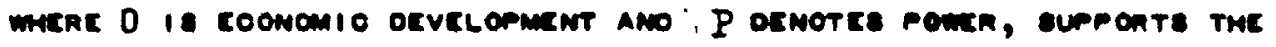

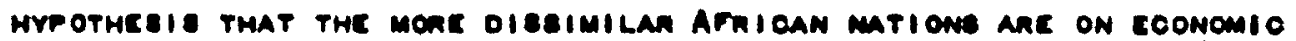

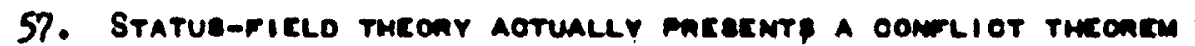

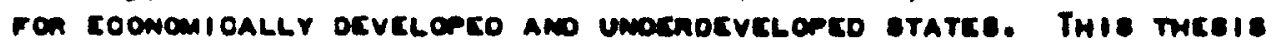

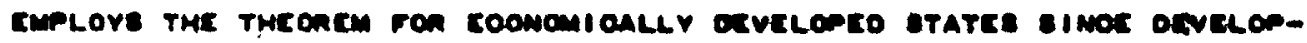
merr is a relatiomal tenm ano true buack Arnicam matiome ane nelatively

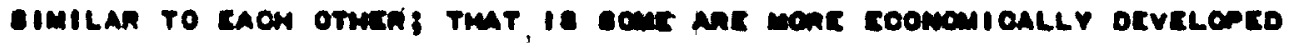

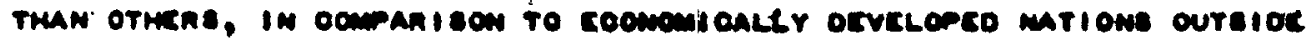
The ncelon.

58. S. Rrex, "Cuime Gooperiation, Commior ano Interaotion

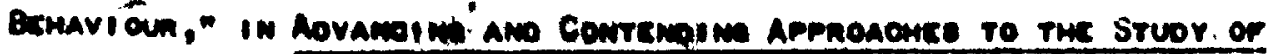

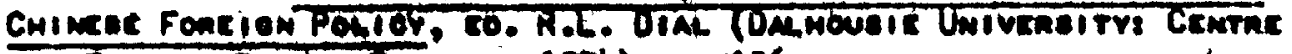
Fon Fonsion Poilor stroice, 1974), F. 13. 


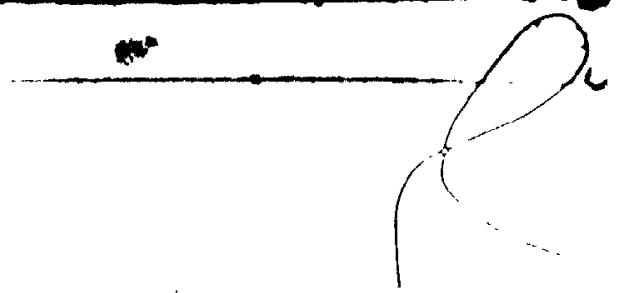

115.

OEVELOPMENT ANO THE MORE IMILAR ON POWER, THE MONE CONFLICT ACTIONE THE AOTON WILL DIREOT TO THE TANOETS.

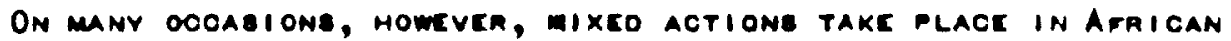
ocmavioun. SOME COOPERATIVE ANO BOME OONRLICT AOTIONE ARE DIRCCTEO

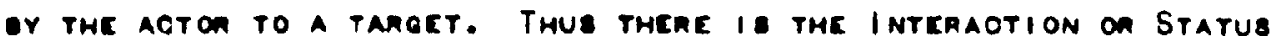
Behavioun TheOREM, a comeimation of the coOPEMATION ano conflict THEORM. THIS EQUATION IB:

$$
\begin{aligned}
& C O=-\alpha_{D} d_{D}-\alpha_{P} a_{P} \\
& +C F=\beta_{D} d_{D}-\beta_{P} d_{P} \\
& C O+C P=\left(\beta_{D}-\alpha_{D}\right) d_{D}-\left(\beta_{P}+\alpha_{P}\right) d_{P} \\
& \text { If }\left(\beta_{D}-\alpha_{D}\right) \text { is oenoted AE } y_{D} \text { Ano }\left(\beta_{P}+\alpha_{P}\right) \text { al } Y \mathrm{P} \text { then the } \\
& \text { cquation mom (6) orcomes } \\
& c O+c F=y_{D} d_{D}-y_{P} d_{P}
\end{aligned}
$$

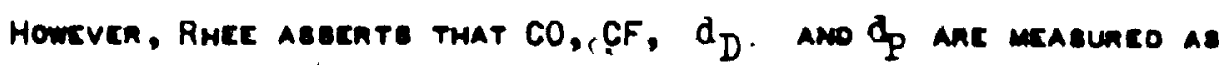

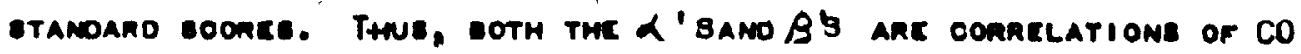
ano CF with the otatus olotanoce. THE manametens then ane positive ano vani octween 0.0 ano 1.0. Thenefone, $\left(\beta_{n}-\alpha D\right)$ eroulo ex

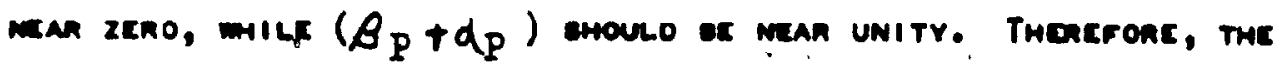
nEvieco EQUATI OM, is

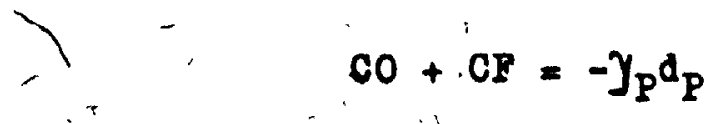

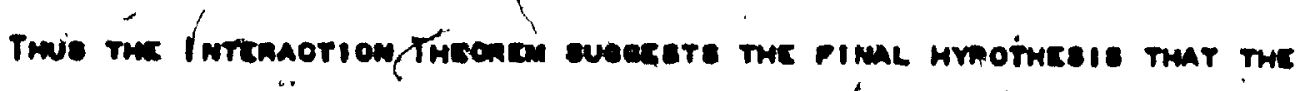

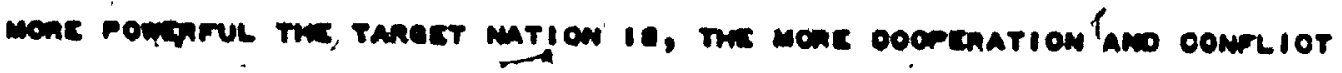
THE AOTON WILL OINEOT TO IT. 
A. HAS EEEN POINTED OUT, THE EEMAVIOUR DIMENSIONE FOR ARAICA OORREBPONO ON COOPERATION, CONFLTOT ANO INTERACTION. THE TWO MAJOA DILFNBLOHB OF COOPERATION ANO CONFLIOT ANE OIMILAR TO THE DICHOTOMY

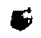
DE TWEEN THE TWO AOTION TYPEB. INTERAOTIVE BEHAVIOUR OORREGPONOB WITH / ThE MIX OF COOPERATION AMO CONFLICT INTO A TYPE OF PARTIOIPATION IN THE AEOIONAL BYBTEM. IT 18 A FORM OF COMMITMENT TO OTHER NATIONB, ANO ALSO AN INTERAOTION GAOTON REPREEENTINO THE MIX OF EVENTB EXOHANOEO

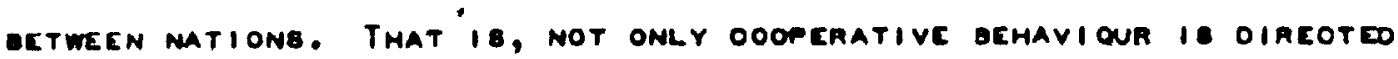
TOWARDA A TAREET, QUT ALBO CONFLICT EEHAVIOUN.

TME ATTRIBUTE DIMENGIONE ARE A FUNTHER REFLCOTION THAT OONOEPTE DEVELOPEO AT THE BYOTEM LEVEL AMALYBI MAY DE APPLIED TO A SUBSYETEM

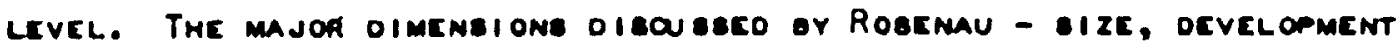
ANO AOOOUNTAEILITY, ANO THE ETATUE OIMENEIONB OF RUMALL - PONER ANO

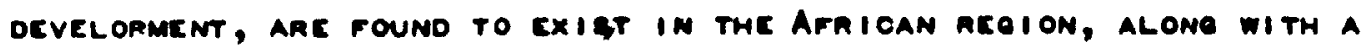

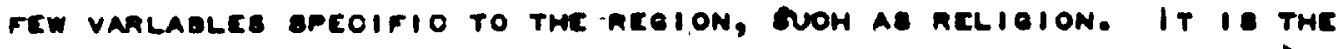

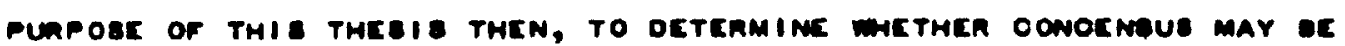

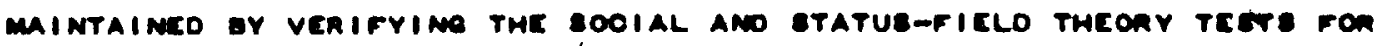
ThE stwor of THE BLAOK Ama IOAN ACEION.

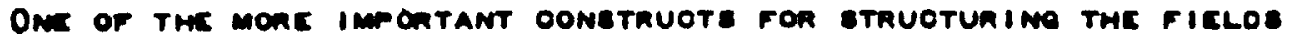
in sooial ano statue-ficlo thicont inolvice vicótons ano in this panti-

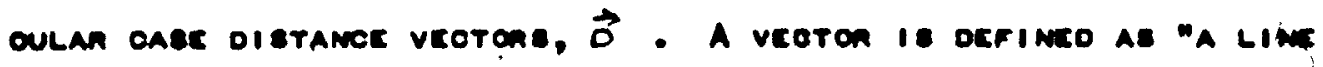

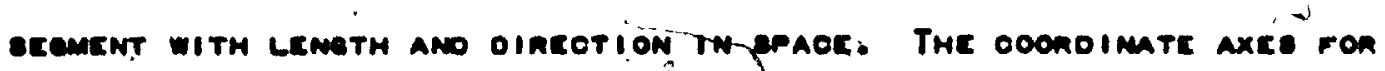

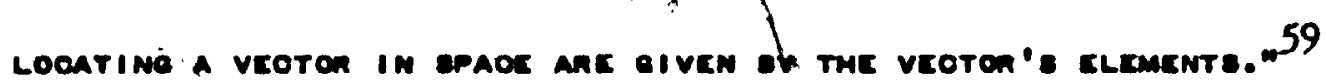

59. Rumme, Faoton Amere 18, P. W6. 
- (Rcrea to flounc 2) Fon caoh attaloute oimenelon, a veoton may ac

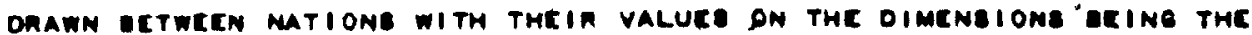

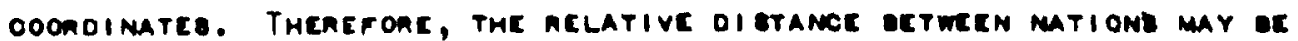

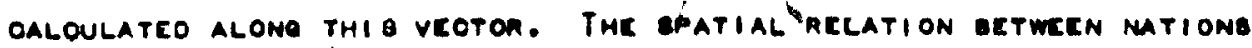

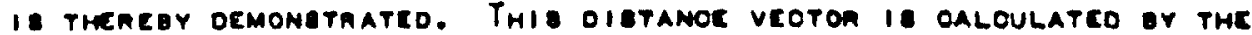
EQUATION

$$
\vec{d}_{1+j, 1}=\alpha_{1,1}-\alpha_{1,1}
$$

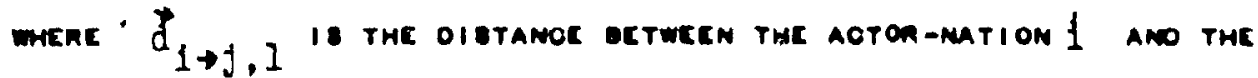

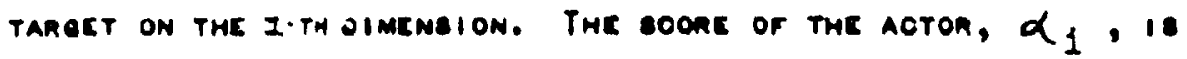

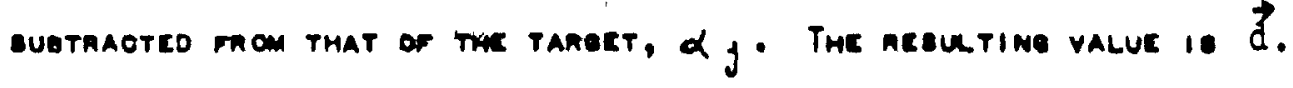

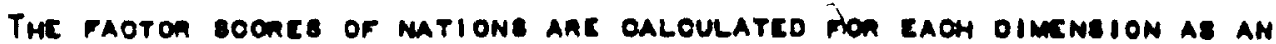
OVERALL IMOIOATON OF THE VANIADEO IMPACT ON TME MATION FER THAT

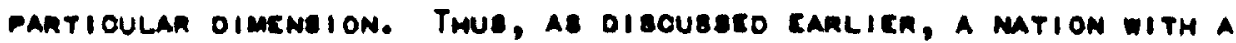

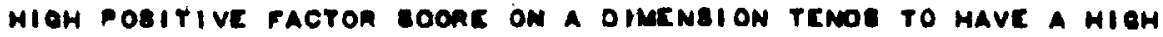
ABSOOIATION WITH THE HIOH LOAOIMO VAMIAGLES ON THAT OIMENBION. THESE

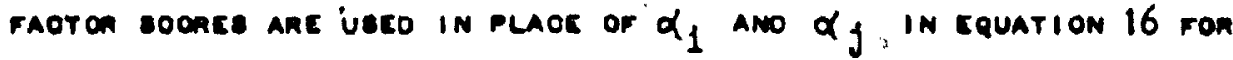
OALOULATINe THE OIETANOL veOtone.

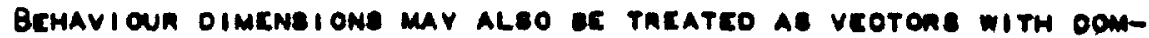

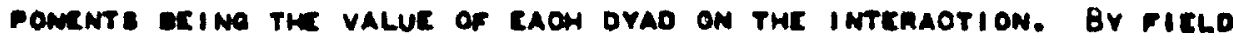

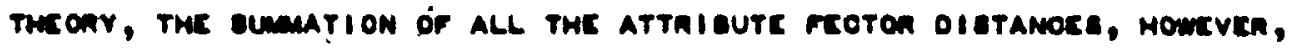

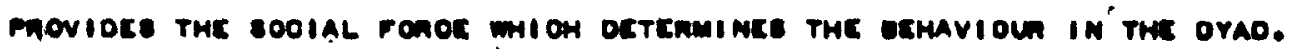
TMAT 10, "The position or a prao veoron in ecmavioun paor is a

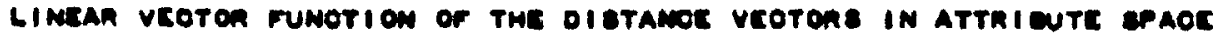




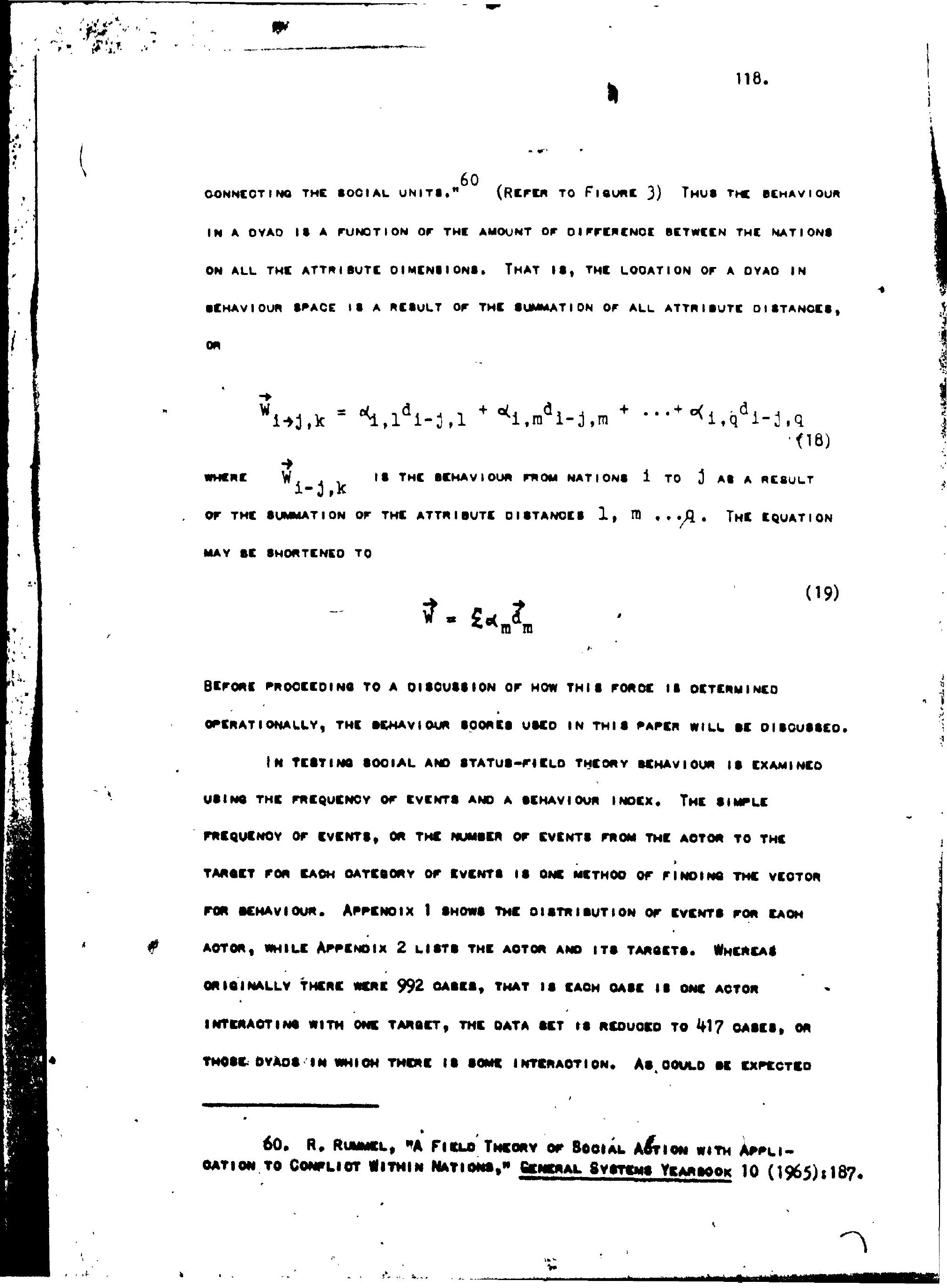




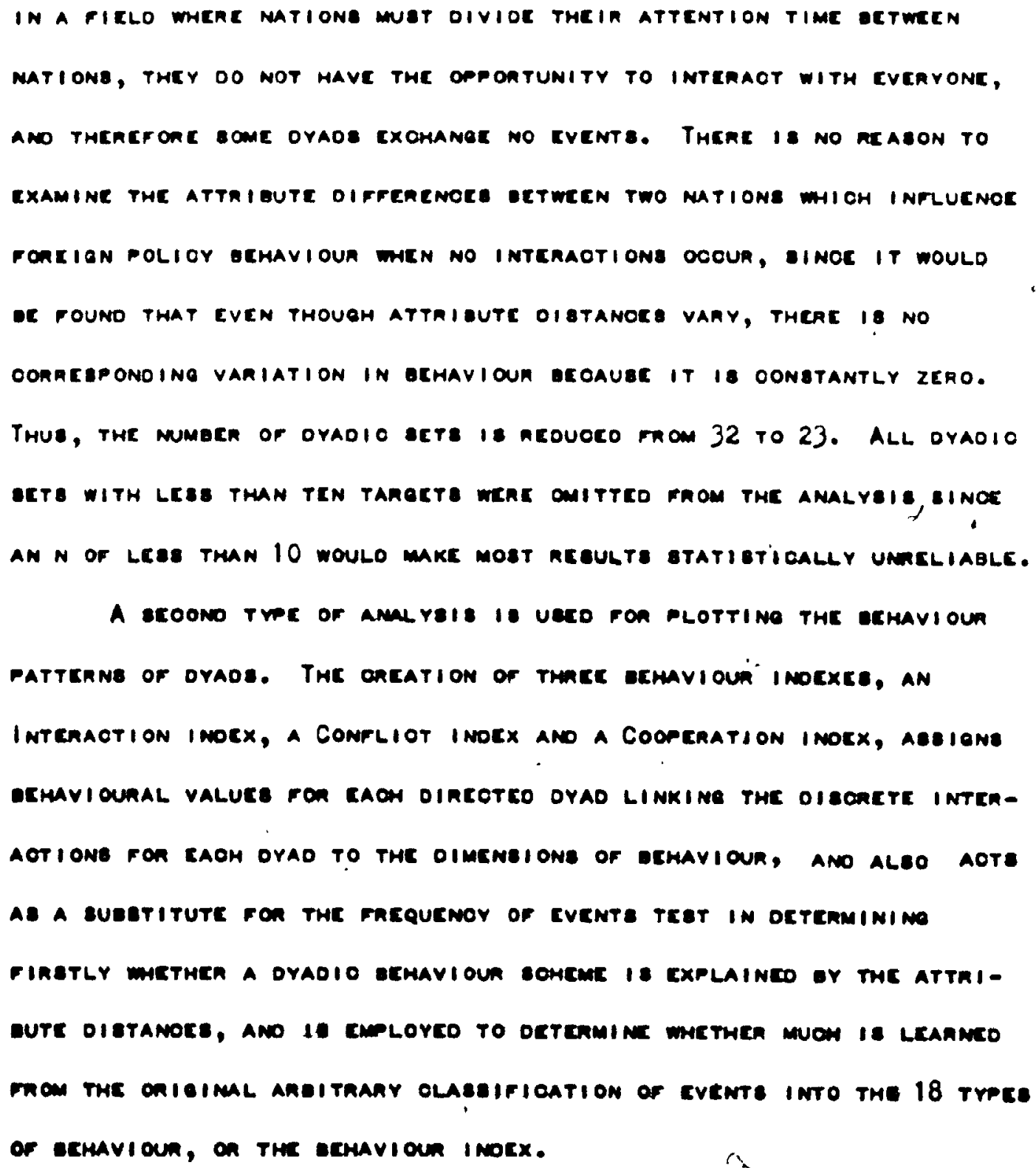

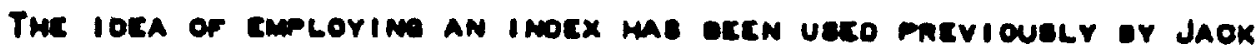

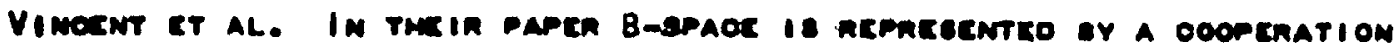

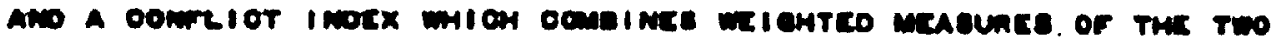

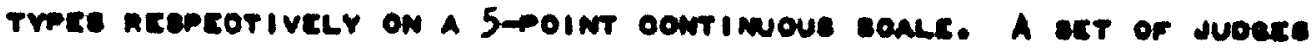

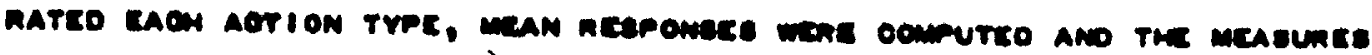

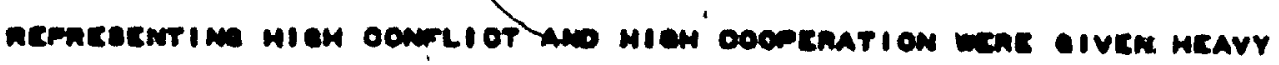


120.

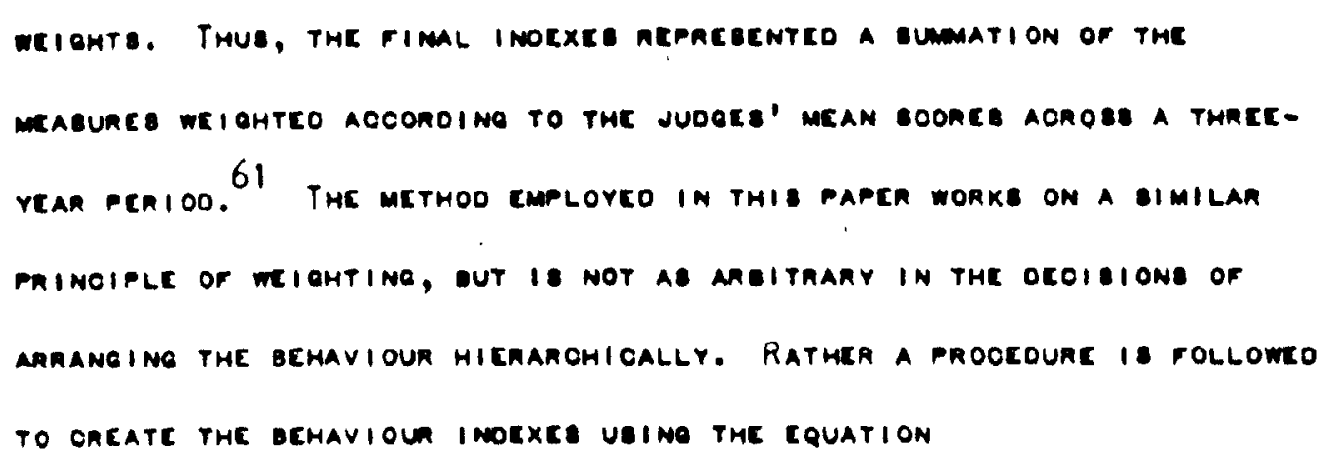

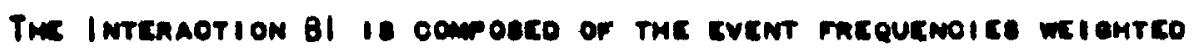

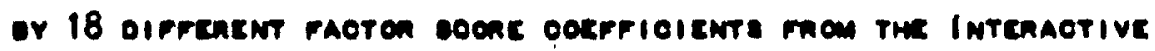

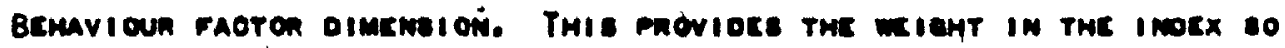

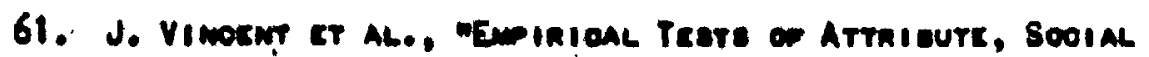
Ficlo and Btatue Ficlo Tmeony on Imrenmatiomal ReLatione Data," 18914 (Drocrmesn 1973): 415417. 


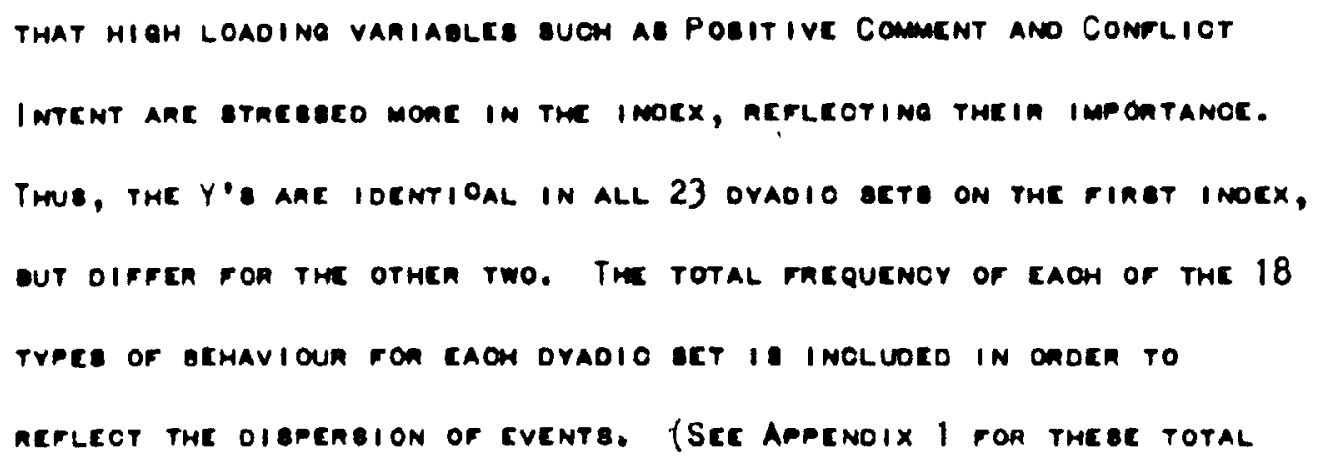

This

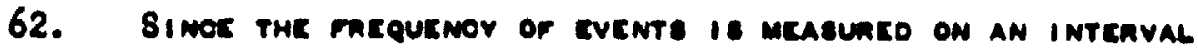

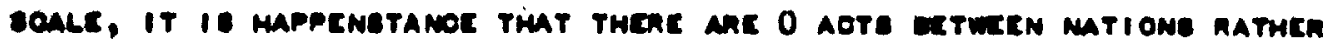

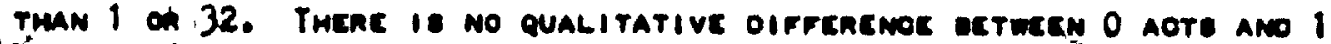

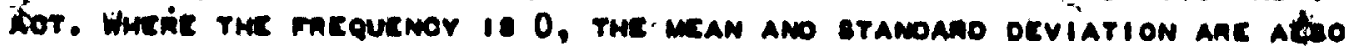

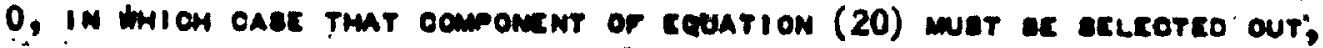

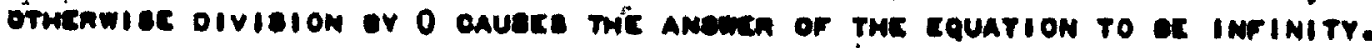

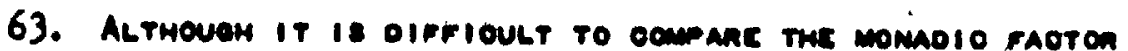

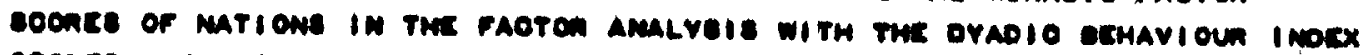

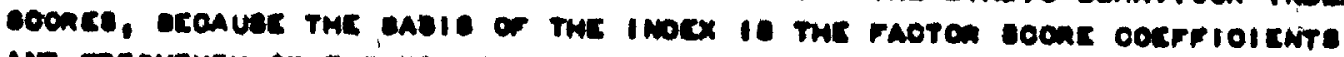

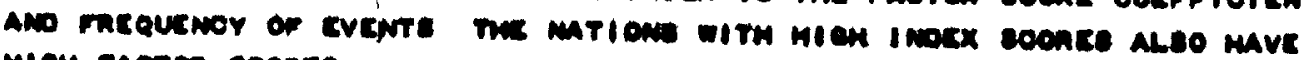
mien racton socncs.

64. Rumme, "8coinl AOTIQH," P. 145. 


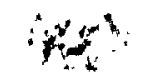

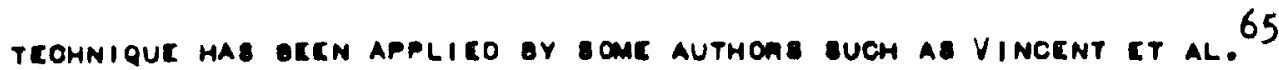

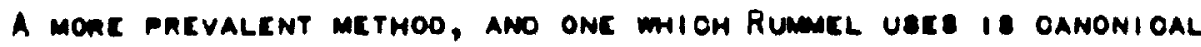
amalreie. Fon extTen companative aEgulte, twe latten is emplored henE.

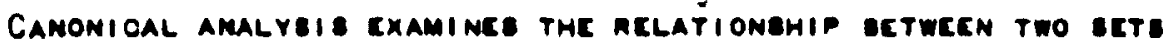

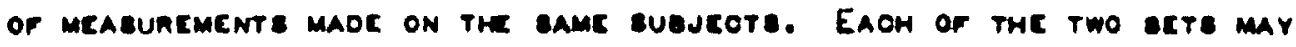

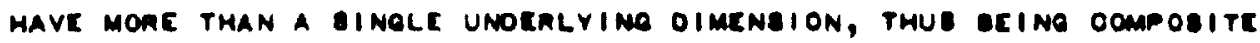
InOEXEB. THE OANONIOAL OOAARLATION MAXIMIZE THE CONAELATION GeTWEEN THE LINEAR FUNCTIONE OF THEEE TWO oxtO, ANO IS INTERPAETEO AS EQUIVALENT TO THE SIMPLE PROOUOT mOMENT, R. 66 THE FIRET OANONIOAL OORREL-

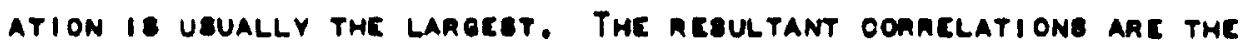
CANONIOAL VARIATEE, WhIOH ARE ONTHOOOMAL TO EAOM OTHER, aNo the mMMER

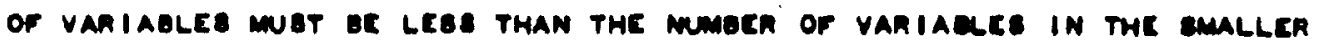

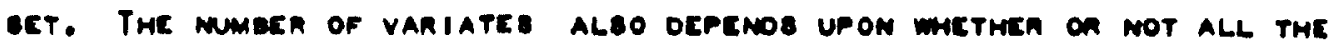
VARIANOE 18 EXPLAIMEO OY THE FIRET oAMONIOAL VARIATE. IF MOT, THE PnDOESE OONTINUES FINOINE MEW LIMEAR DOMBIMATIONE OF THE ECTS UNTIL it aocounte fon this variamor. The clocmualuce ane also eiven. They ACOACEENT THE PROPOATION OF VARIANOE IN OAR VARIATE EXPLAINEO OY THE

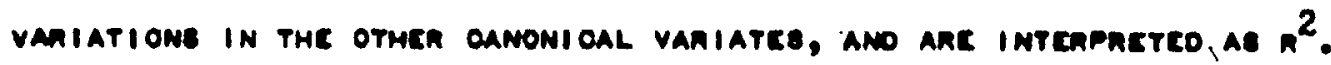

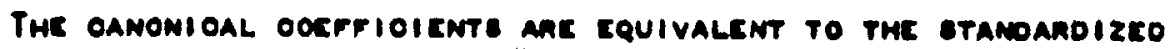

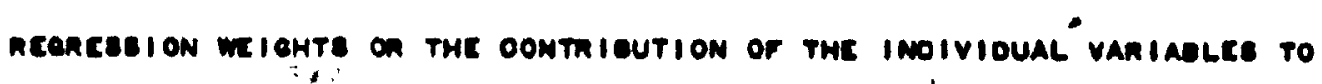

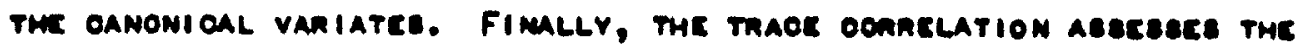

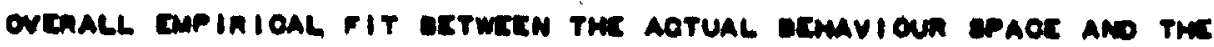

65. VImocer, Empinioal TCeta."

66. The Dirrencmoci egtwern oanowionl ano recencesion amalreis

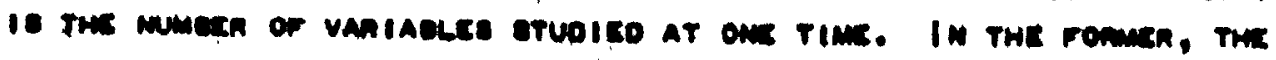

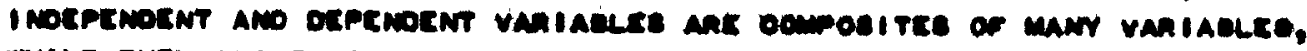
wille ther ane simple vaniagles in the catron. 


\begin{abstract}
ATralButc DIBTANCE. 67

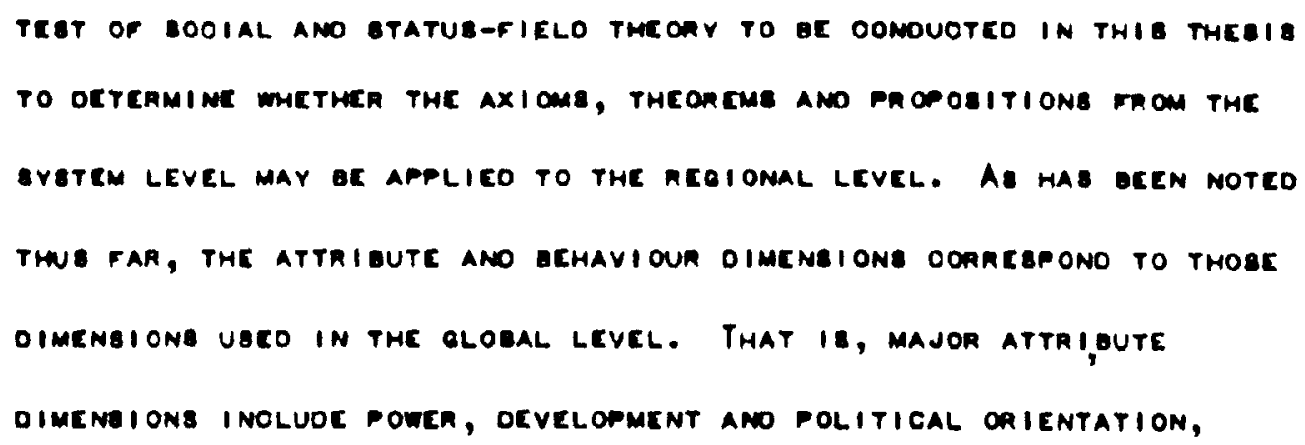

67. THE thaOr comaclation is oalounatco or $\bar{r}=\sqrt{\varepsilon r_{k}^{2} / 9}$

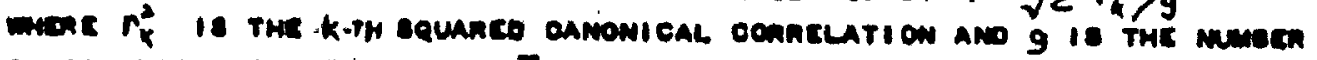
or oAmonioal oomnclatione. F is the rewornt or the vaniation in ochavi oun tmat il ospenocist un on atrmi oute distahoce. 


\section{CHAPTER 5}

DLACK AFRICA ATTRIBUTE DISTANCE ANO EEMAVIOUR RELATIONSHIP

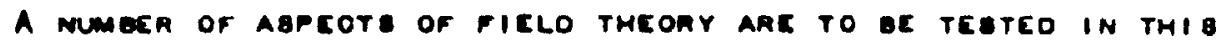
THE I8, REquIRINO A MUMEER OF PARTITIONS OF THE AFRIOAN DATA BET IN onotn TO ABBEB FULLY THE IMPLIOATIONB OF BOTH BOOIAL ANO BTATUB-

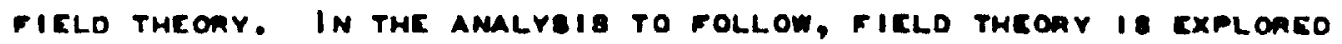

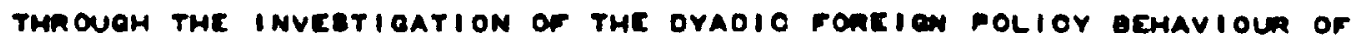

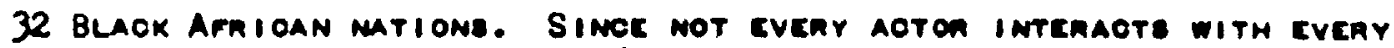

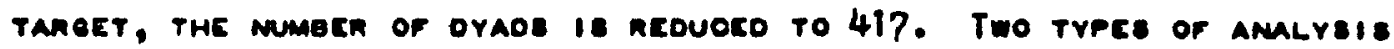
TAKE PLAOE INITIALLY ON ALL OF THEE OYAOB. MODEL I AMLYBIS IB

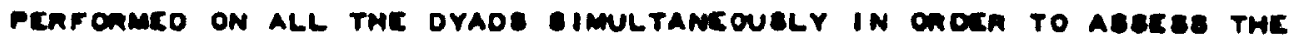

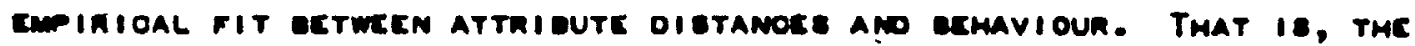

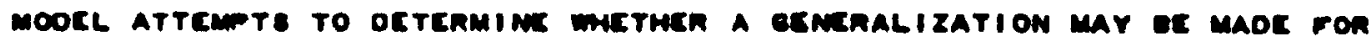

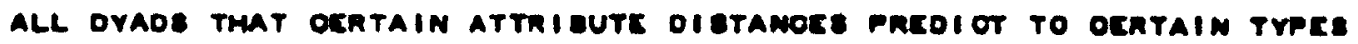

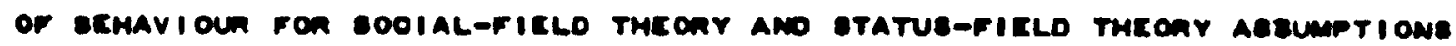

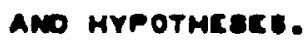

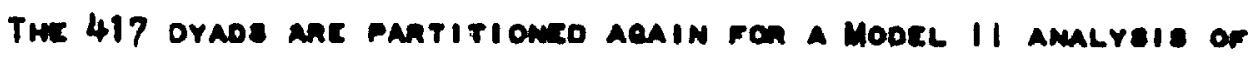

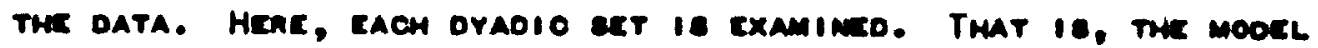

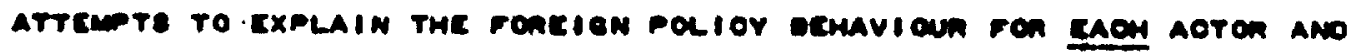

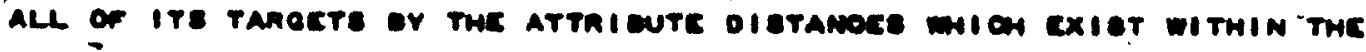

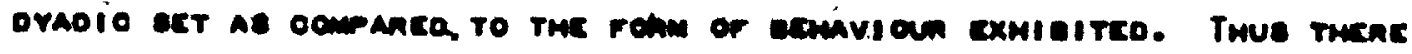

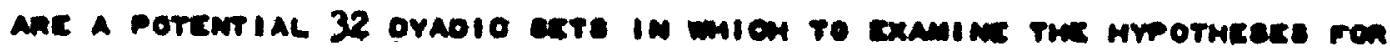


gooial ano etatus-pielo theont. Howeven, fon etatietioal measons

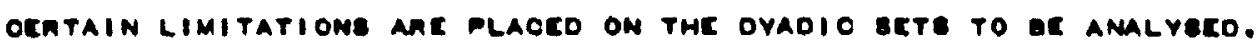

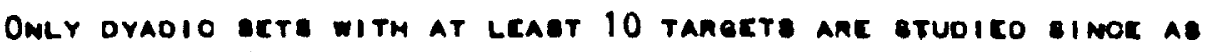

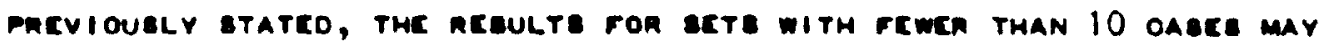

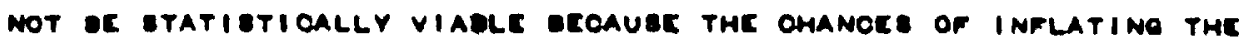
AEEULTE ARE MUOH HIOHER WHENe THER ARE FEWER OAses.

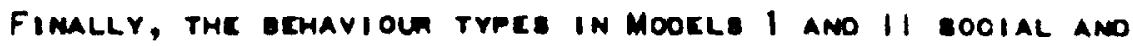

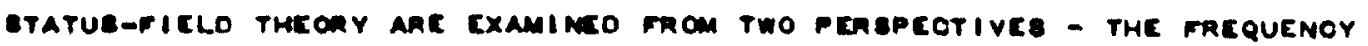

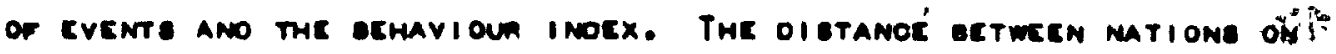

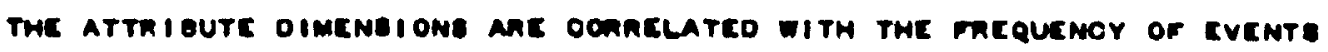

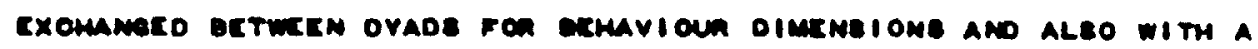

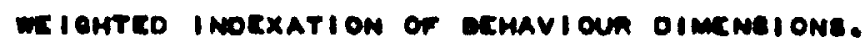

Tmus, Five hropthese ane testeo in this tmesis ano ane ochiveo $\checkmark$ mon the axions ron the rwo models ano two rome or ochlvioun. Or

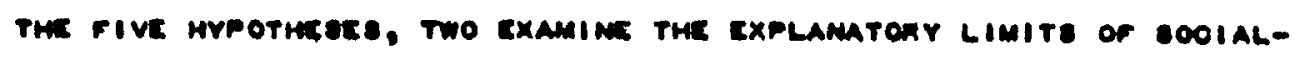

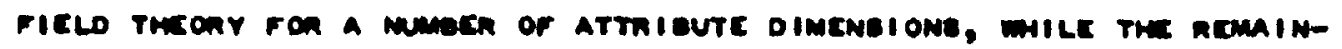

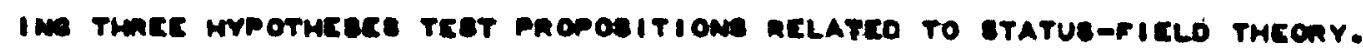

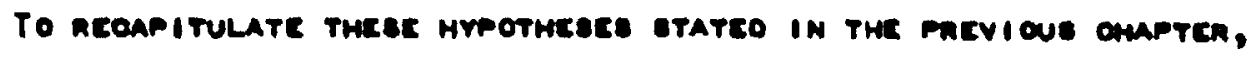
Thace AnE:

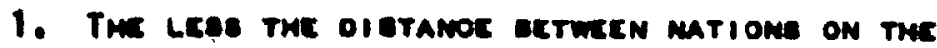

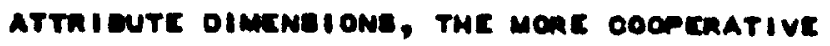
- eranavioun timer wILL cxomanec.

$$
\begin{aligned}
& c 0_{1+1}=-\alpha D_{1-j}-\alpha D_{1-j}-\alpha P O_{1-1}+q \\
& c F_{1+1}=\alpha n_{1-1}+\alpha D_{1-j}+\alpha P O_{1-j}+q(8 b)
\end{aligned}
$$


2. THE mone BIMILAR matione aAe In EOONOWIO ocvelopment, ungamization, Relieion ano POITIOAL ONICNTATION, THE MONE THEY WILL Emoaer in OOORERATIVE ermavioun.

$C O_{1 \rightarrow j}=-\alpha U_{1-j}-\alpha D_{1-j}-\alpha R_{1-j}-\alpha P O_{1-j}+B$

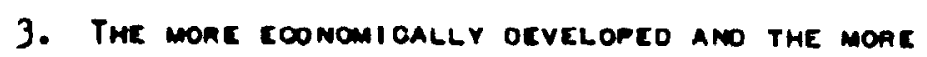
powekrul the takeet mation, the mone is an AFRIOAN MUTION' STATUE-OEFEMOENT COOPERATIVE ecravioun.

$$
C O_{1 \rightarrow 1}=-\alpha_{1 D} d_{1-1, D}-\alpha_{1 P} d_{1-1, p}
$$

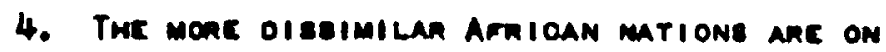
roOmoulo OKVELOMENT ANO THE mone BIMILAR ON powin, twe mone confliot aOtIONe the hoton

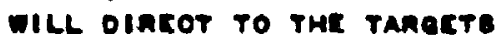

$$
C P_{1 \rightarrow j}=\beta_{1 D} d_{1-j, D}-\beta_{1 P d_{1-j, P}}
$$

5. THe monc roweaful the tanget mation 18, THE

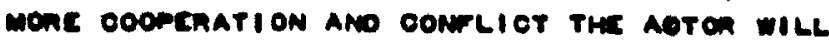
oincot ro it.

$$
c o_{1 \rightarrow J}+c P_{1 \rightarrow j}=-y_{P} d_{P}
$$

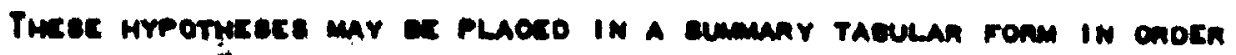
4 :

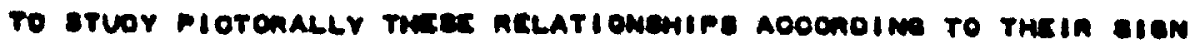

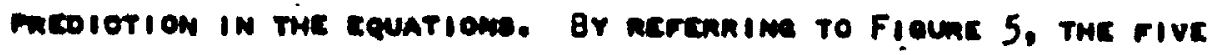

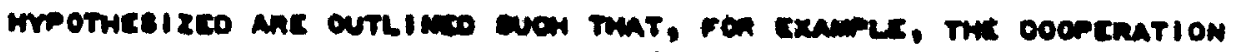

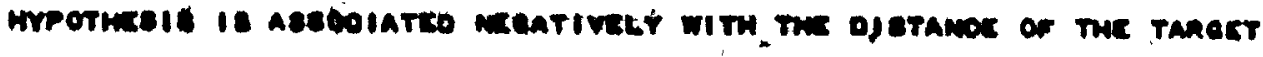

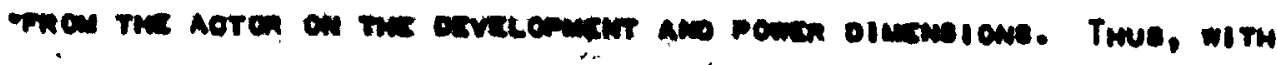




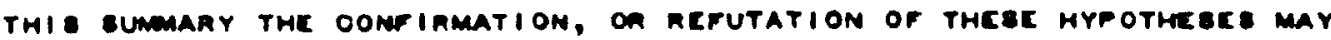
er olsouseco vis a VIs an amalysis of thK oATA fon the two moorle ANO THE TWO THKonics.

\section{Fioune 5}

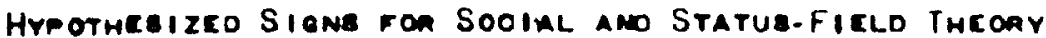
FON BLAOK AFRIOA

AtTaldute SPace Dimensions

HYPOTHCOIS

1. Linkuer

2. Homern.

3. Coop

4. Conar.

5. Gtatue

\section{Bemavioun}

COOP, OONF.

coop

000

oom.

0000 + 00N
Powen Una. DeV. Rel. POL. On.

DIET. DIET. DIsT. OIST. DI8T.

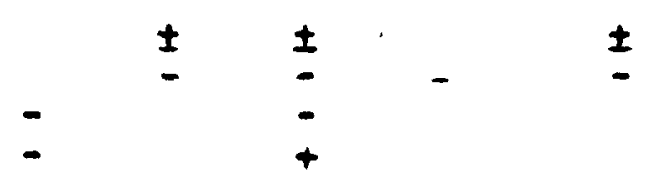

Moocl 1 Amalreis

THE MoOEL I amalysid or BLACK Amican fonelon polior comavioun

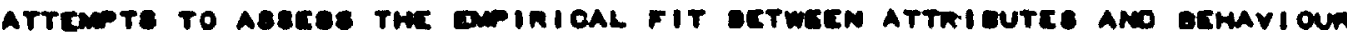

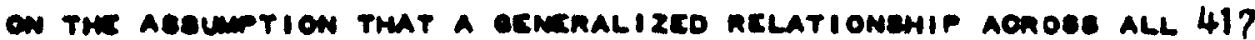

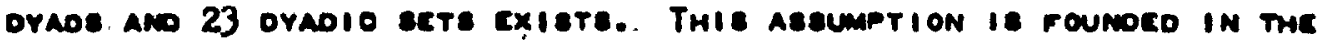
ceuation $\vec{V}_{1 \rightarrow 1,1}=\sum \alpha_{1} d_{1-1,1}$ (1) pisouseco in twe previous

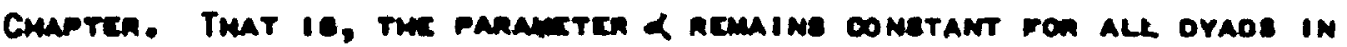

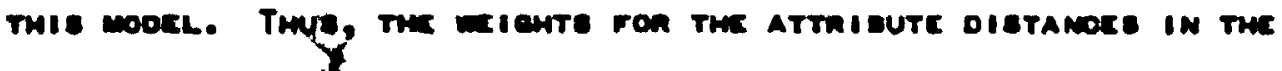

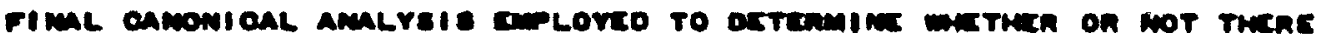

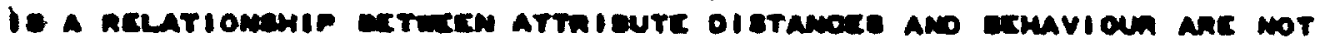

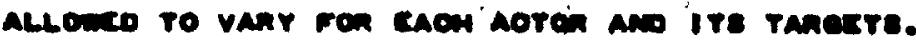


$4 p^{2}+x^{2}$

In Amalysine the acsults fon Model 1, gocial-fixld theony,

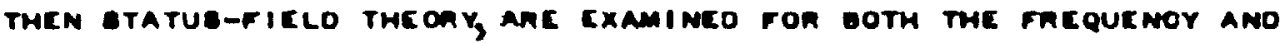

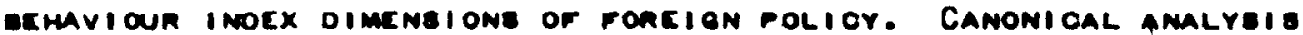

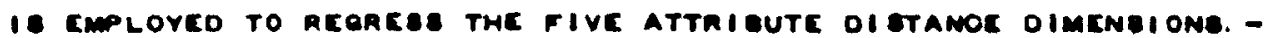
POMER, URBANIzATION, DEVELOMMET, RELIOION ANO POLITIOAL OAIENTATION -

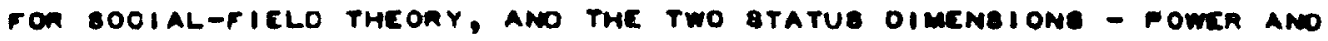
DEVELOPMENT - FOR BTATUO-FIELO TMEORY WITH THE DIMENEIONE OF

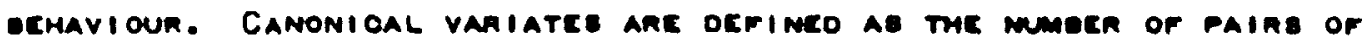

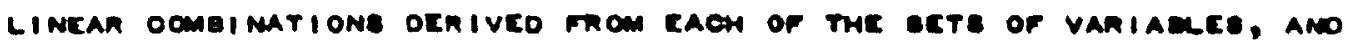

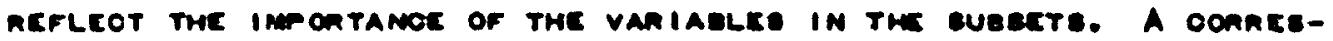

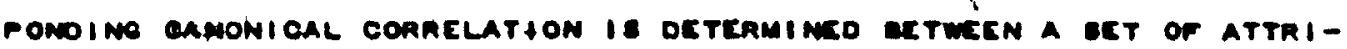

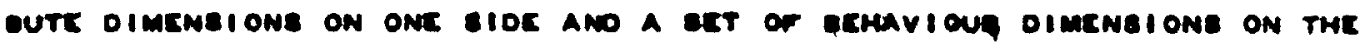

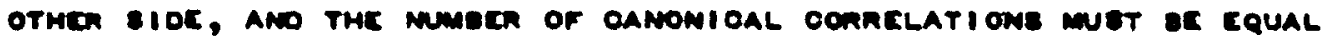

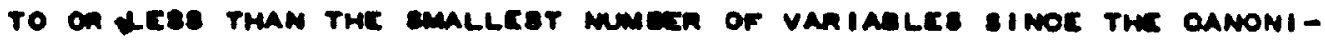

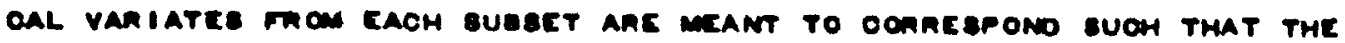

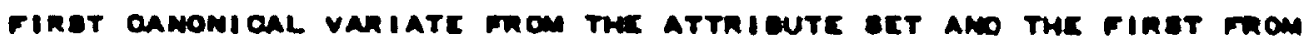

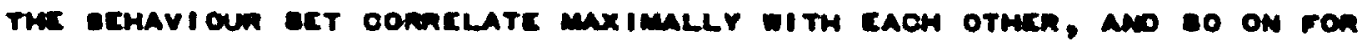
ousecquent variates. In mis tmceis twerc ane roun variatce fon

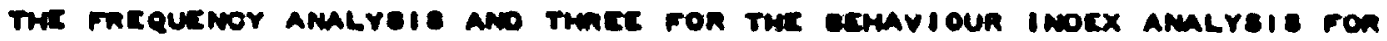

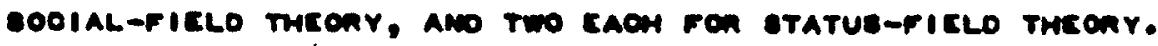

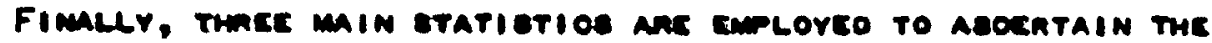
amount or vaniation in roncien polioy cthavioun explatime or the

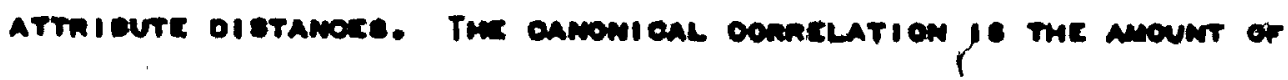

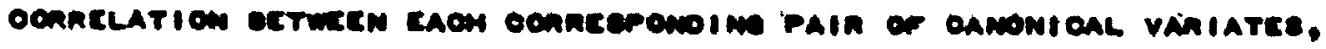

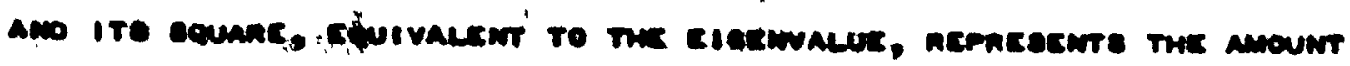


OF VARIAMOE IN ONE OAMONICAL VARIATE THAT IS aOCOUNTED FOA DY THE otmen camonioAL vaniates.' As ol govereo in Chapter 3, the thace

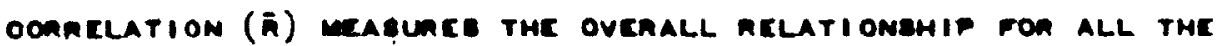
OAMONICAL OONRELATIONE DETWEEN TME ATTRIBUTE DIMENEION SET AND THE

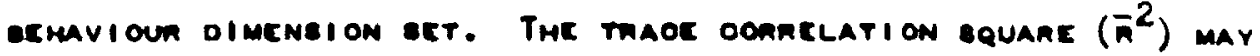
DE INTEmPRETEO AS THE mENOENTAOE OF VARIATION IN THE OIMENBIONS OF AFnioAn ecmavioun ACODUNTEO OY THE ATTRIBUTE DI STANOE IN THE FiElo theORY MOOELS.

TAELE 7 PROVIDCE THE CESENTIAL ETATIBTICE MEOESARY TO QAUEE THE OVERALL LIMEAR RELATIONEMIP ectwEEN ATTMIBUTE DIBTANCE ANO

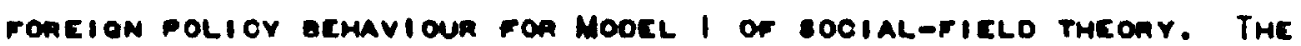

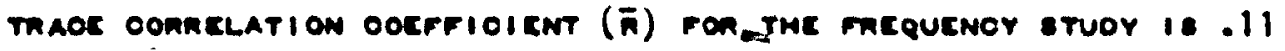

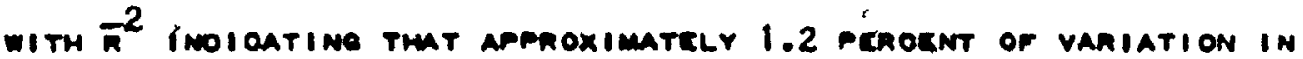

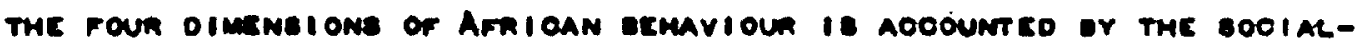

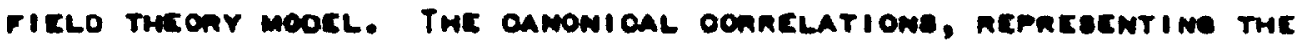

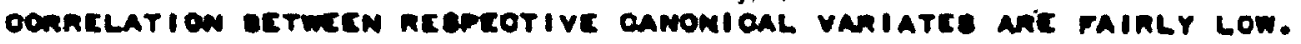
Twe roun n's, .19,.09,.05 ans .03 ocnncepono to the foun vaniate

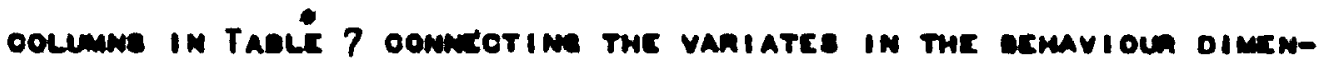
sions on ons bioc or the Equation to THE oonncenonoine waniatce fon

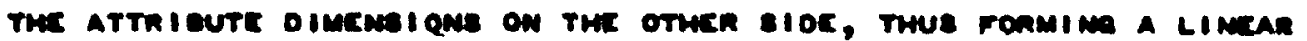
ntcincesion couation. Twus, mat pinet cquation -1.53 orw +.92 CFD $\div .66$ ocv +.56 PoL $(n=.19)$

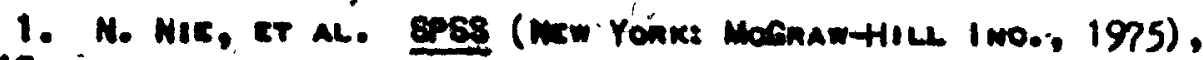
P. 517. 


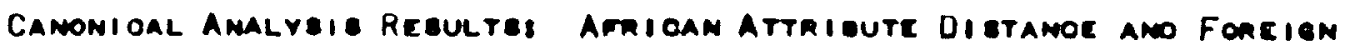
Pollor Bemavioun, Mookl 1 Amalyale - Social ficlo Theomy

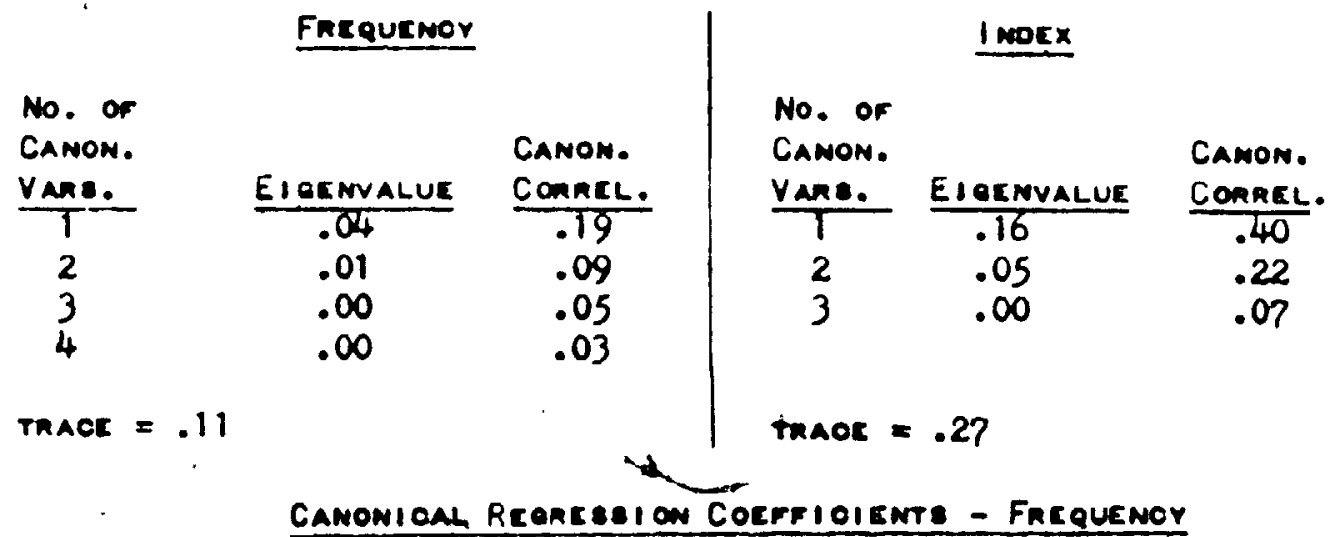

CAMONIOAL REQREBeION COEFFIOIENTE - FncQuENOY

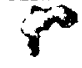

\section{Camonioal Variatzo}

Bxmavioun
COW
CFW
COD
CFO

ATtRIDUTE:

POW

URB

OEV

RE

$P \alpha$
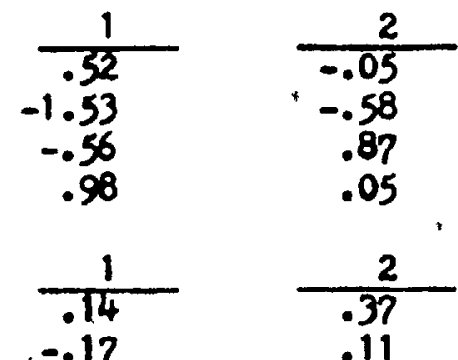

.65

.52

.55

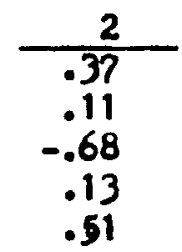

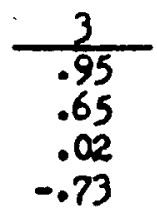

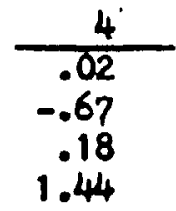

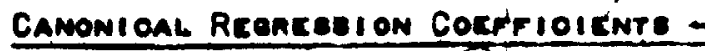

\section{Camoulioal vamiates}

Bemavioun

IBI

CFI

cor

Atraicute:

Pow

Ure

ozV

Ra

- pa
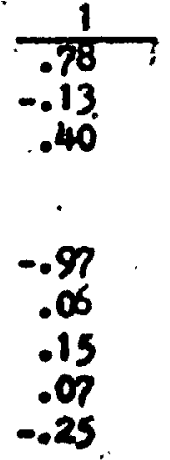

$\frac{2}{.05}$

.94

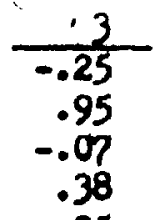

$-.25$

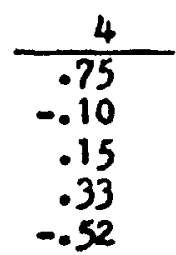




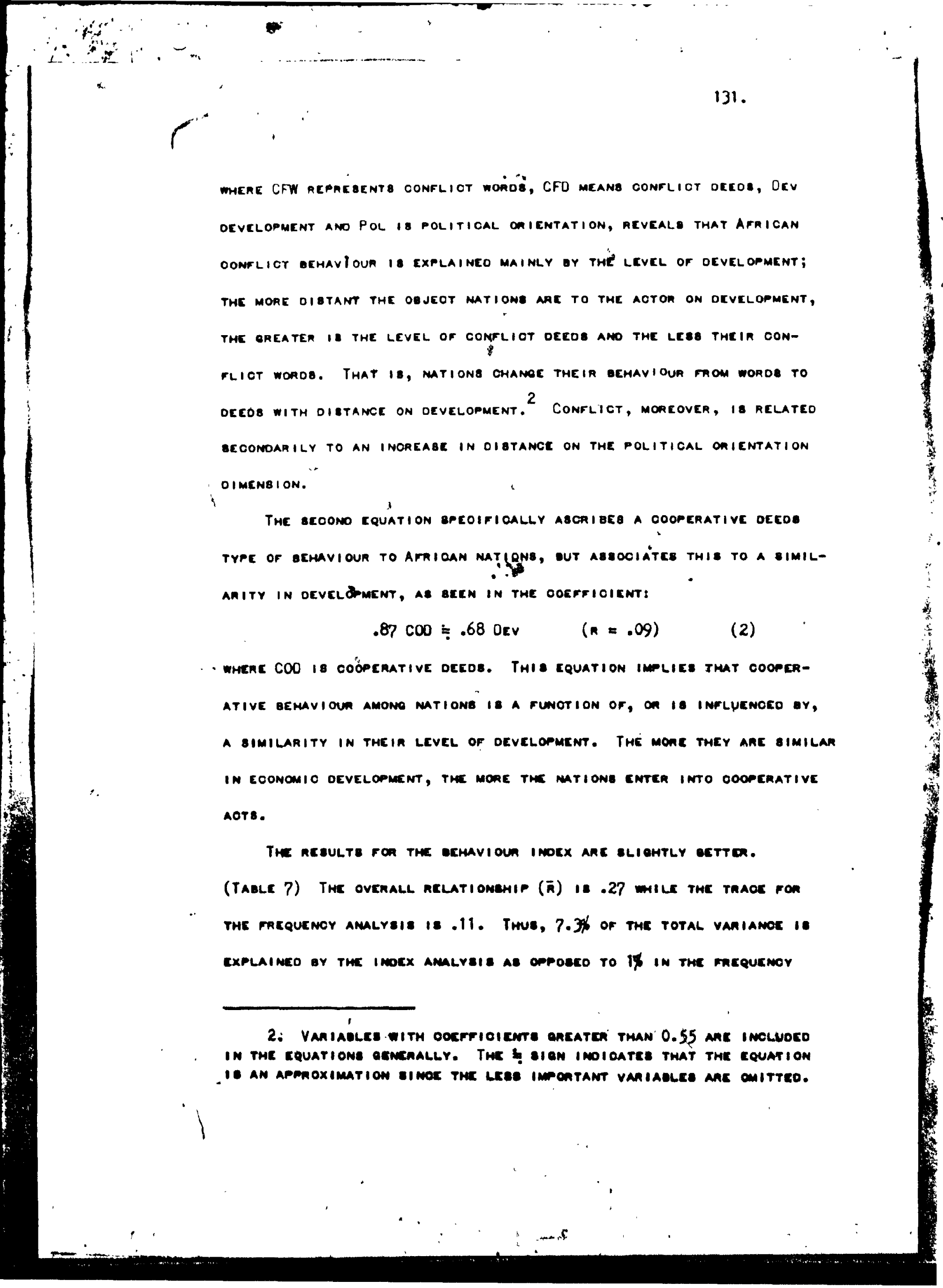




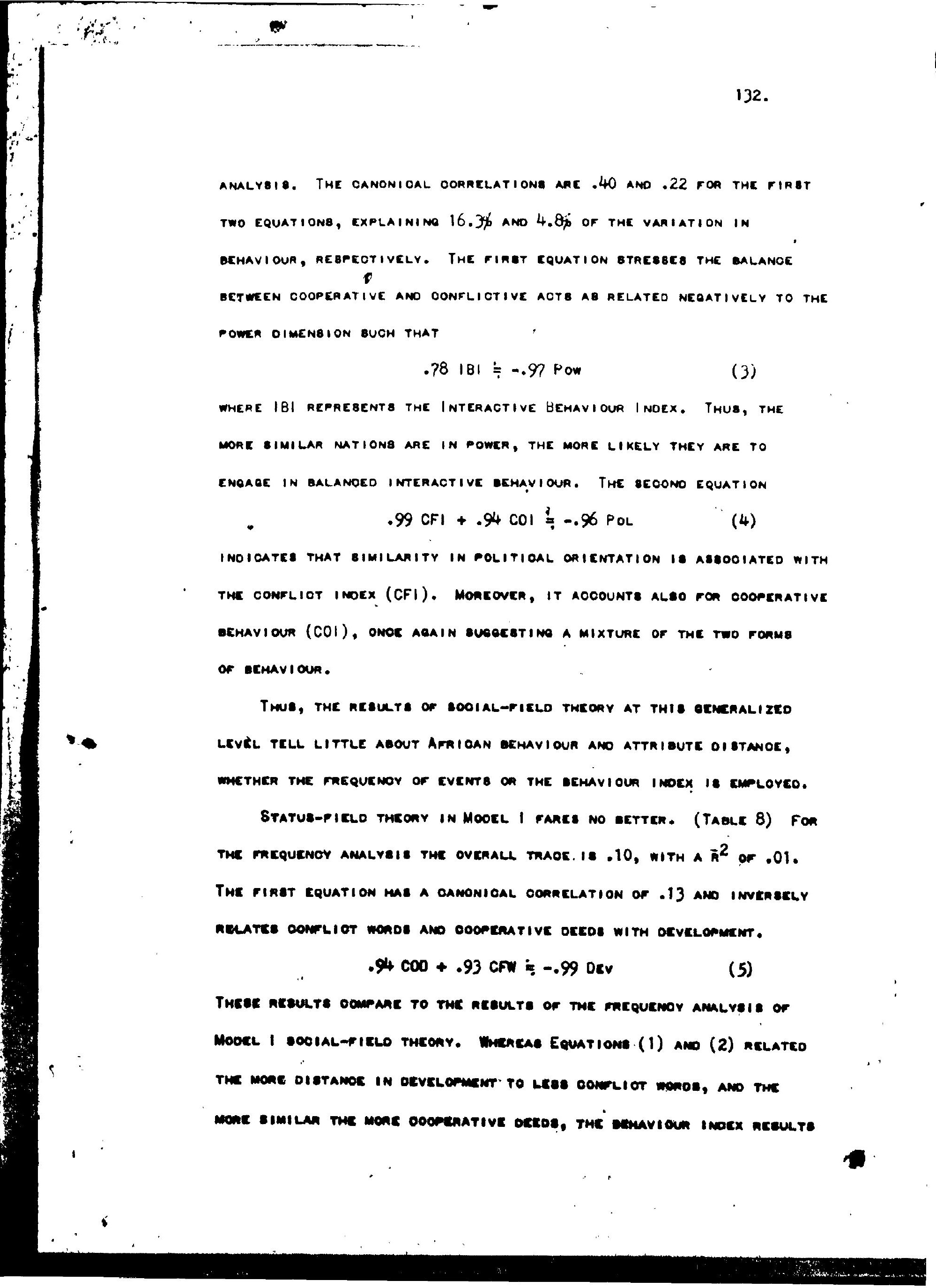


TAele 8

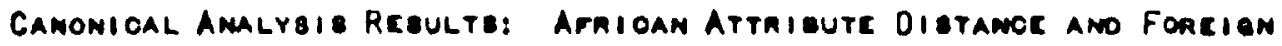

Polior Bemarioun, Moocl I Amalrale - Status ficlo TheoRy

\begin{tabular}{|c|c|c|c|c|c|}
\hline \multirow[b]{2}{*}{$\begin{array}{l}\text { No. or } \\
\text { CANON. } \\
\text { VAME. }\end{array}$} & \multicolumn{2}{|c|}{ FALQUENOY } & \multicolumn{3}{|c|}{ I nose $x$} \\
\hline & EloenNalue & $\begin{array}{l}\text { Camon. } \\
\text { ConnEL. }\end{array}$ & $\begin{array}{l}\text { No. or } \\
\text { CANON. } \\
\text { VAns. }\end{array}$ & Eloeminalue & $\begin{array}{l}\text { CANON. } \\
\text { CONREL }\end{array}$ \\
\hline $\begin{array}{l}1 \\
2\end{array}$ & $\begin{array}{l}.02 \\
.00\end{array}$ & $\begin{array}{l}.13 \\
.04\end{array}$ & $\begin{array}{l}1 \\
2\end{array}$ & $\begin{array}{l}.15 \\
.00\end{array}$ & $\begin{array}{l}.39 \\
.04\end{array}$ \\
\hline TRACR $=$ & & & Thaoc & 28 & \\
\hline
\end{tabular}

CAMONIOAL REeacseion CoEfFiolente - Farquenor

Camomical Variates

Bcmavioun
CON
CFN
COO
CFO

ATtaisutes

POW

DEV
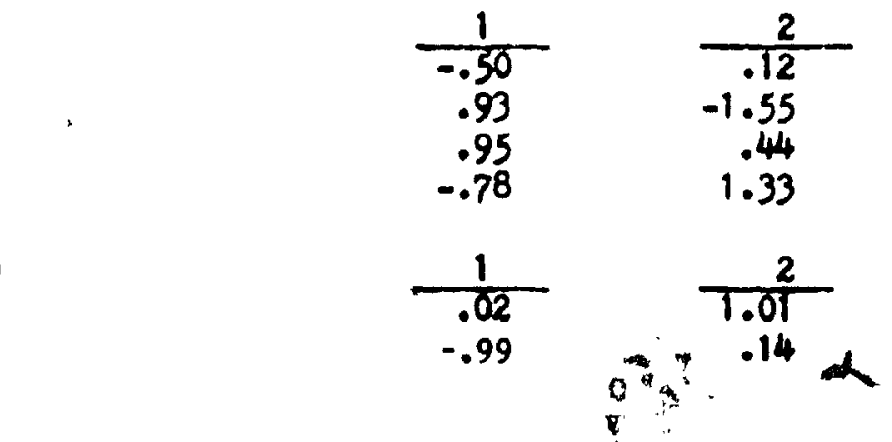

CamonionL Rconcesion Cocrpioucnte - Bcmavioun I morx

Camomical Vaniates

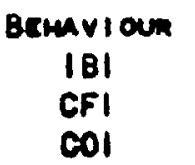

Atraieutes

PON

OEV

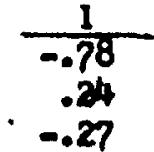

.96

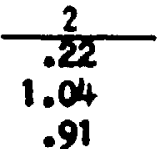

.30

.99 


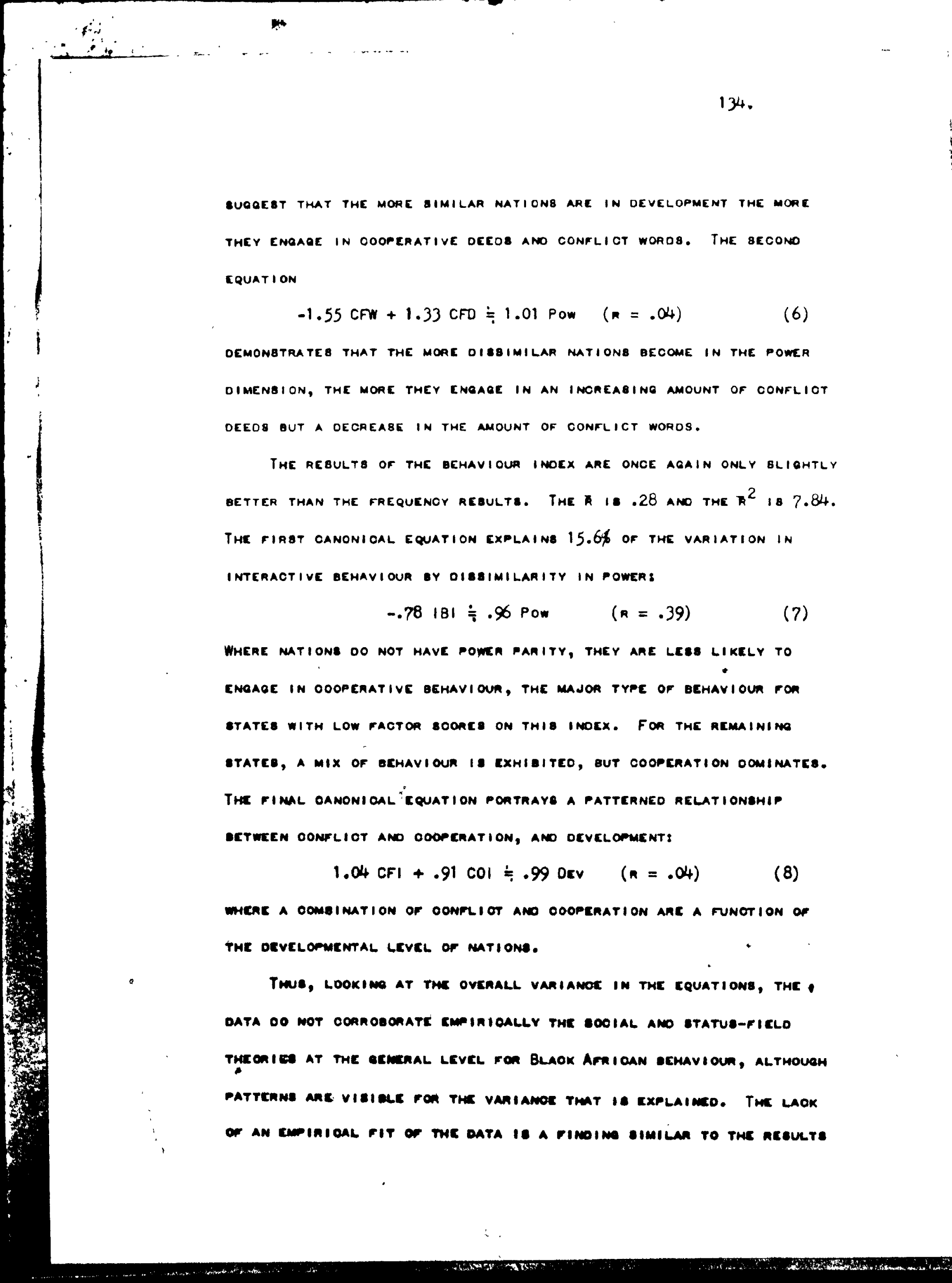




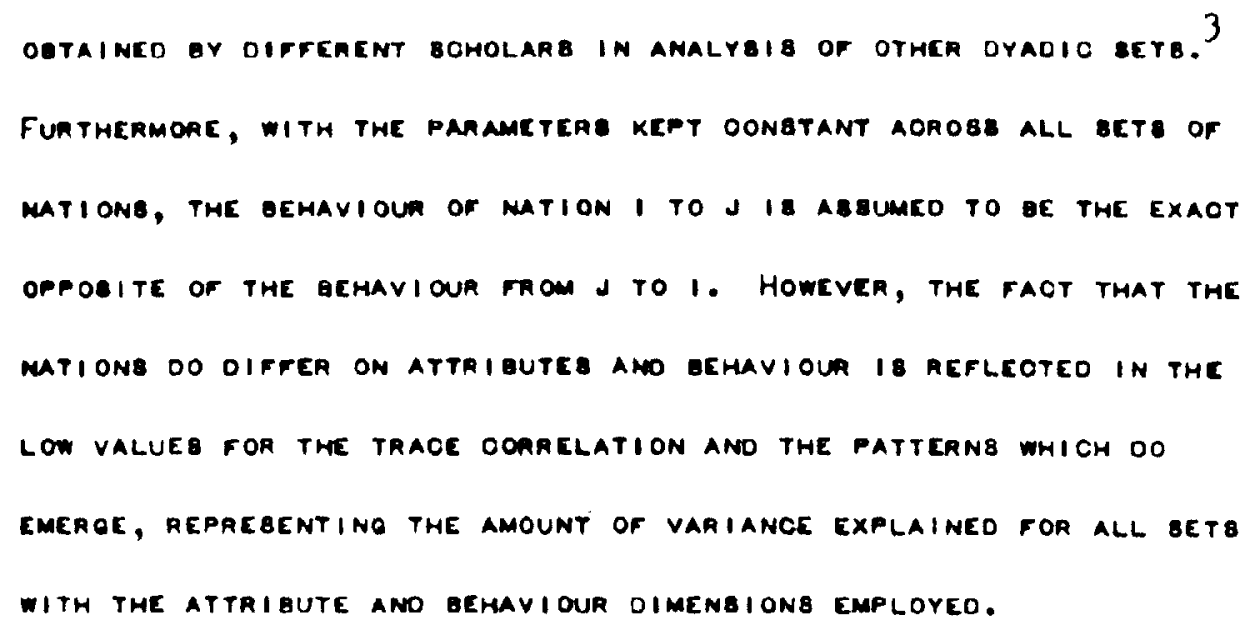

IN OROER TO QAUEE THE OIFFERENOES DETWEEN MATIONB, SCHOLARB EMAAEEO IN THE DON PROJECT MAVE PROPOELO MODEL II. IN THI ARPROAOH COOIAL ANO BTATUB-FIELD THEOAY AAE EXAMINED FROM THE PEREPECTIVE OF

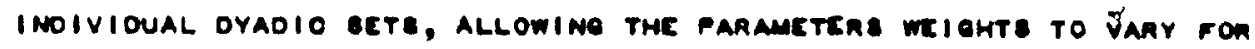
EAOH AOTOR-MATION. THAT IS, THIS MOOR LIMKE THE PAMAMETER TO THE AOTINE MATION IN THE OYAO. IN THIS WAY, THE EEHAVIOUR OF ONE MATION TO ANOTHER IS UNLIKELY TO HAVE THE BVMMETRIC ABPCOTE AS ARE PRE-

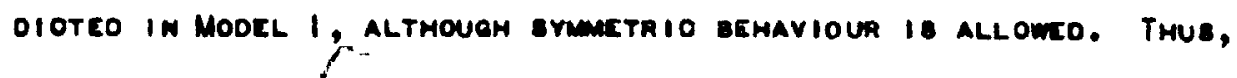
In THE LQUATION

$$
\vec{w}_{1 \rightarrow j, 1}=\sum \alpha_{1,1} a_{1-j, 1}
$$

LIMKAEE ARE ePROIFIO TO THE PAATIOULAR AOTOA-MATION I. WHILE TME

3. Fon example sec R. VAn Atta, "Fielo Theony ano Mutional-

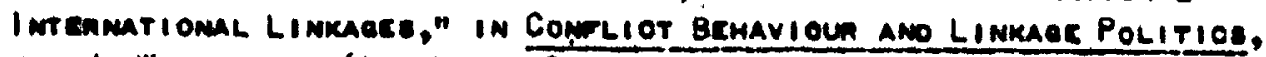
co. J. Wilkenfelo (New Yonx: Davio Mokay Co.; I mo., 1973), ano R. Van Atta ano R. RUmel, "Teetime Ficlo Tmeony on the 1963 Bemavioun Space or Marione," Praoc Reacanon Soolcty Papene 16 (1970). 
136.

DIMENBIONE OF ATTRIBUTE BPACE AAC THE same FON ALL aCtón, THE

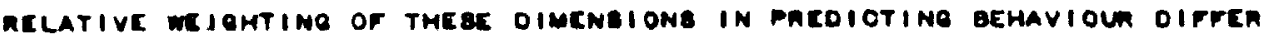

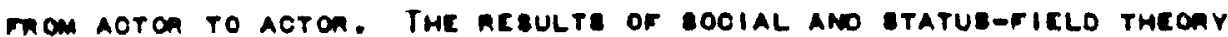

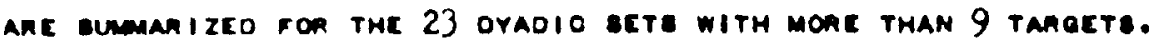
RATHER THAN DIBOU88 CACH DYADIO GET FON THE EEOONO MOOEL, OHLY A EAMLE OF OYADB CHOBEN AB REPREBENTATIVE OF OYAOB WITH BIMILAR TRACE COARELATIONB ARE OI SCUBAED IN THE THEBIS. THEBC REQULTB ARE Displared in Taeles 9 throvah 13, ano the nesults fon the nemainima OYADIO BETB ARE LISTEO IN APPEMOIX 3 AMO 4.4

\section{SOOIAL-FIELO ThEORY AMALYBie}

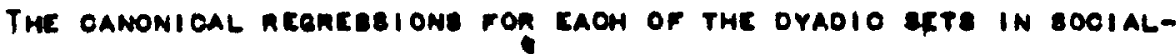

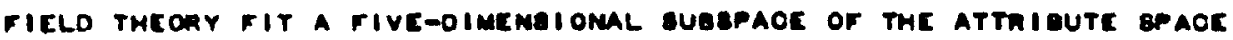

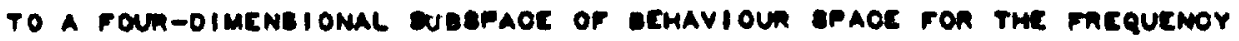

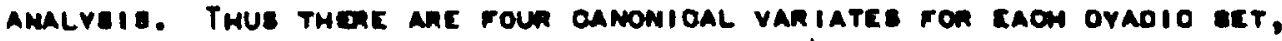

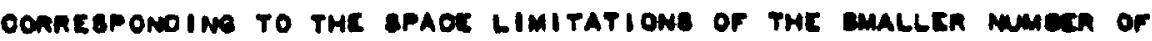

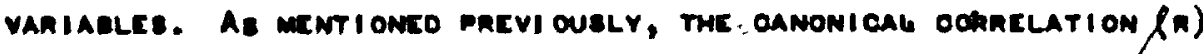

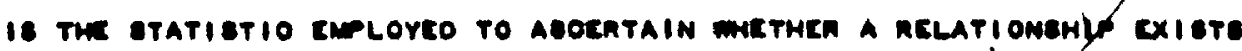

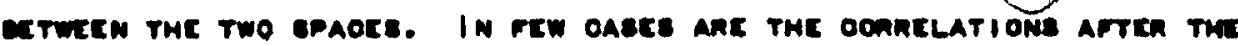

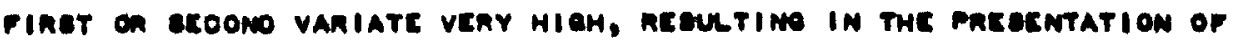

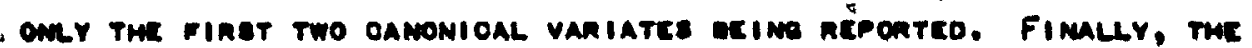

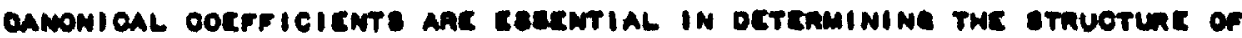

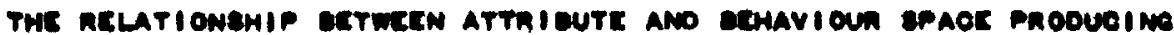

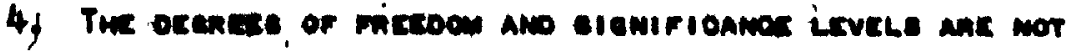

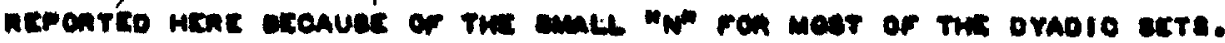

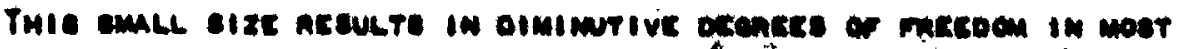

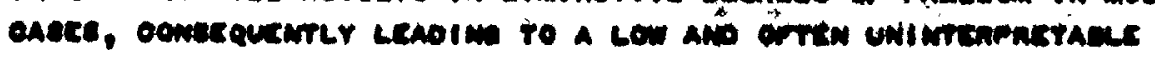

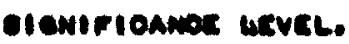




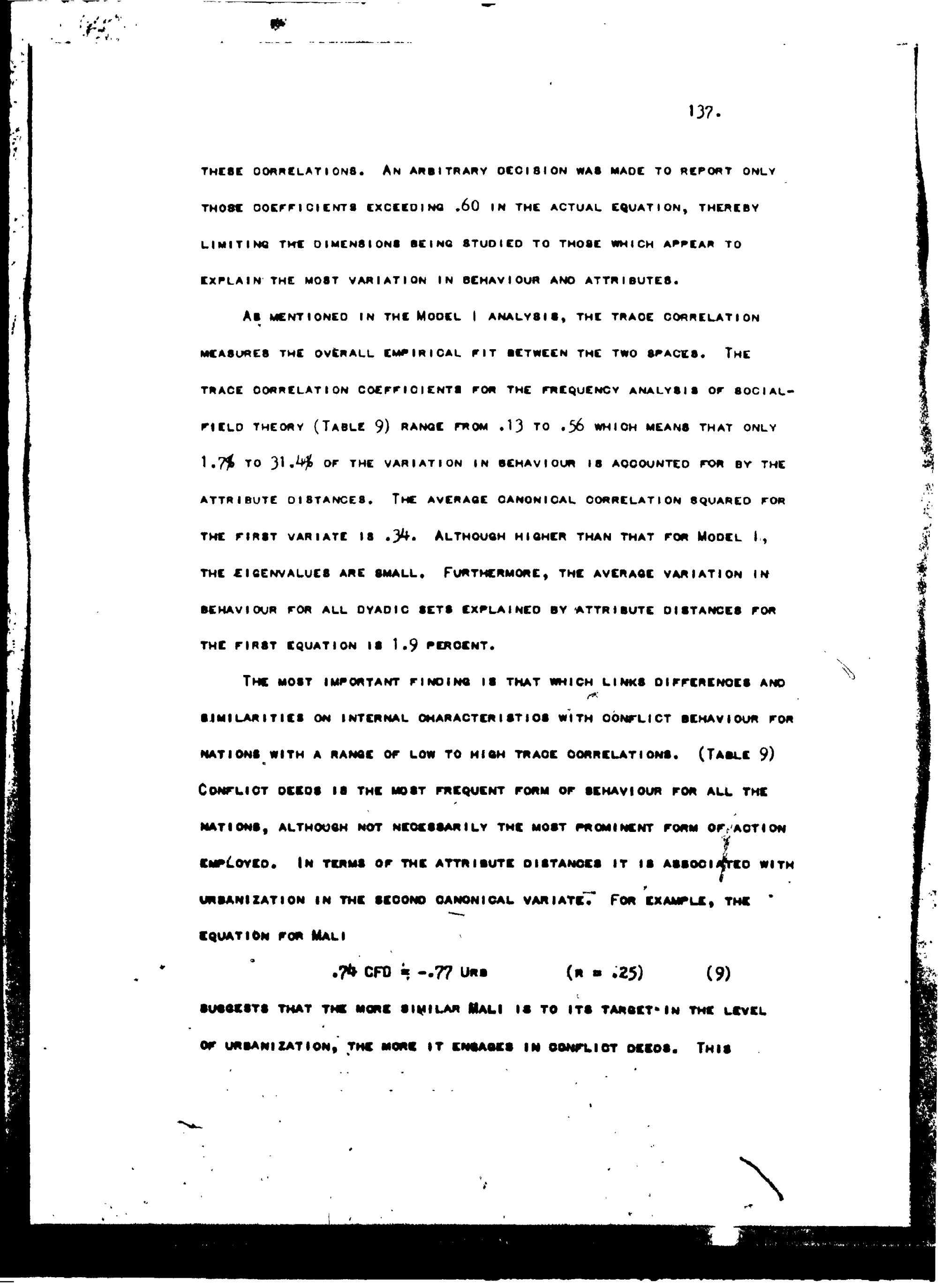


138.

TADece 9

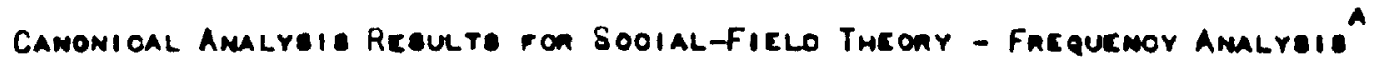

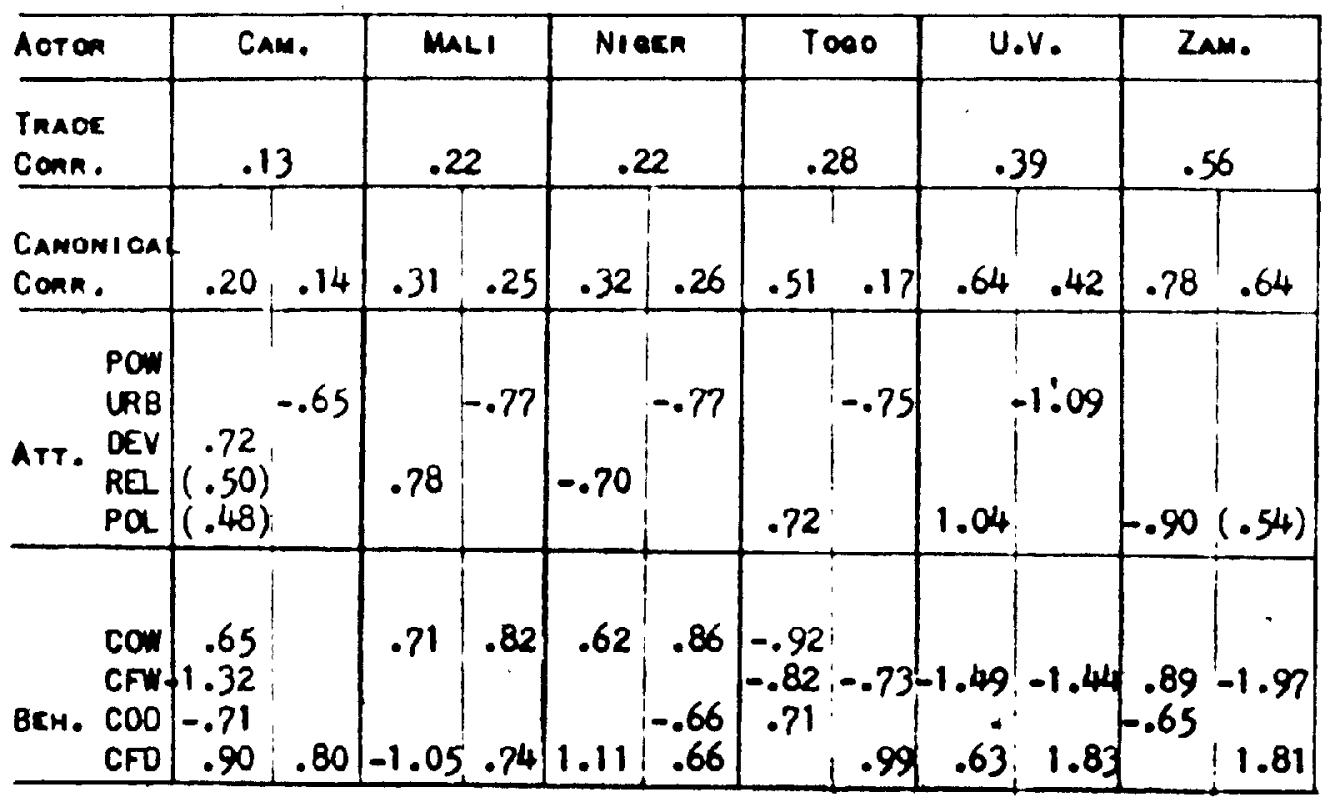

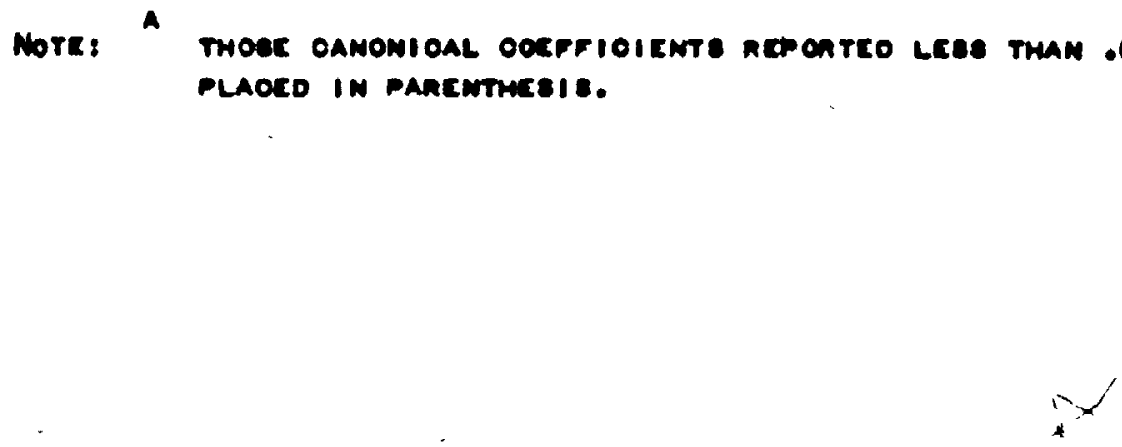


RELATIONBHIP IA OONBTANT FON MOST OYADIC BETS, 5 EXOEPT Fon EXAMLLE

ZAMEIA mEAE OONFLIOT OEEDs ARE RELATEO TO POLITIOAL ORIENTATION, ALTHOUOH THE CANONICAL VAAIATE rOA THE ATTAIBUTE IB GMLLER THAN IN OYAOIO BETB WMERE UABANIZATION IS EMPMABIzEO.

CONFLIOT WORDE APPEAR TO GE AN IMAORTANT TOAM OF BEMAVIOUA FOR

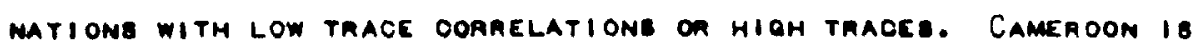
REPREBENTATIVE OF NATIONB WITH E EETWEEN.13 AMO.17. In THIB particular case, the relationghip eetween the two betg of vapiagleb ON THE FIRBT CANONICAL EQUATION EXPLAINB APPROXIMATELY 4.06 OF THE VARIATION IN CONFLIOT BEHAVIOUR BY THE LEVEL OF DEVELOPMENT. THE RELATIONBHIP MAY DE BTATEO AB:

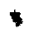

$$
-1.32 \mathrm{CFW} \doteqdot .72 \mathrm{DEv}
$$

THE MOM OISTANT THEBE PARTIOULAR MATIONB ARE TO THEIM TAROETS ON THE DEVELOPMENT OIMENEION, THE LEA TMEY ENOAEE IN OONFLIOT WOADB. THE ATTRIBUTE DIMENBION FON MATIONB WITH MIOH TRACE OORRELATION

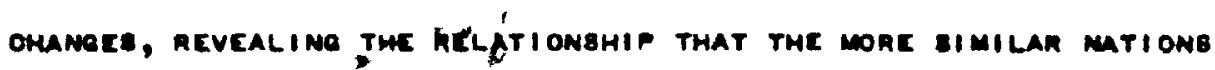

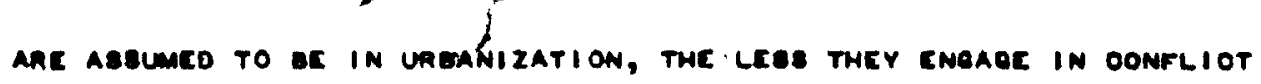

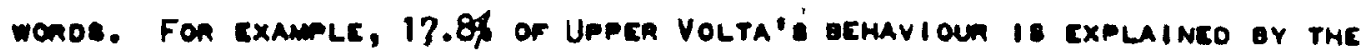
Equation

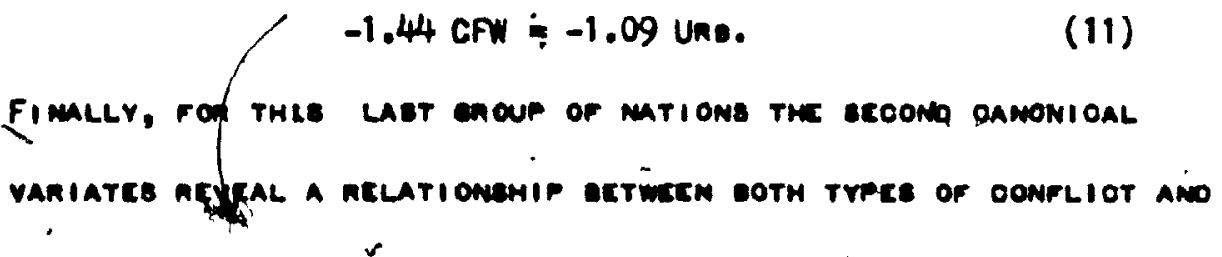
unanization ron a indonity of the misions. As zhown or Tooo's

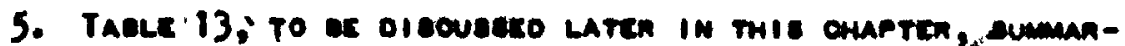

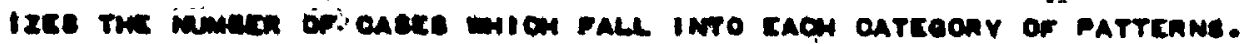

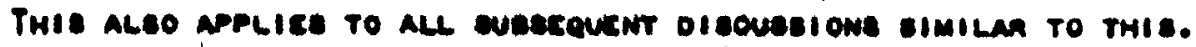




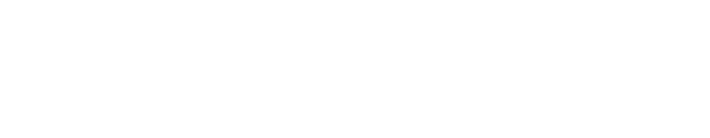

CANONICAL EQUATION

$$
.99 \text { CFO }-.73 \mathrm{CFW}=-.75 \text { Una. } \quad(n=.17)
$$

A8 THE OIBTANOE ON THE LEVEL OF UREANIZATION DECREABEg IN TOQO'B OYAOB, IT ENGAOEB IN MONE CONFLIOT OCEOA BUT LEBB OONFLIOT WORDB.

LABTLY, MATIONB WITH '́'s FALLine OETWEEN APPROXIMATELY. 18 ANO .26, WMEAE $3.2 \%$ TO $6.8 \%$ OF THE VAAIANCE 18 EXPLAINEO BY THE CANON-

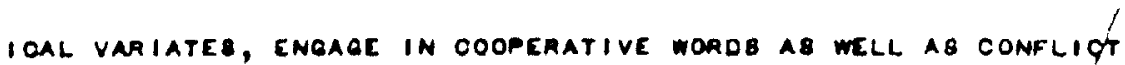

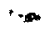
DEEDB, ANO THIB IB AgBOCIATEO WITH THE AELICION DIMENBION IN THE

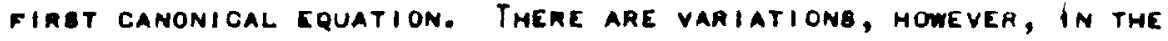
DIREOTION OF CONFLICT WOADS ANO RELIGION. IN MOST OABES, THE EQUATION hEPREEENTATIVE OF MALI

$$
-1.05 \text { CFO }+.71 \text { COW } \fallingdotseq .78 \text { REL. } \quad(N=.31)
$$

WUeEgTa THE ACLATIONBHIP TMAT THE MOME DIBSIMILAR MATIONE AAE IN AELIOION, THE LESE THEY ENBAOE IN DONFLICT DEEOS ANO THE MOAE THEY

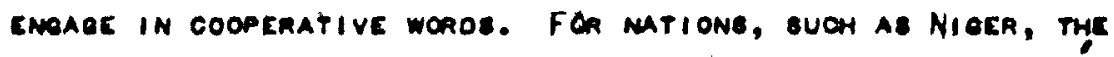

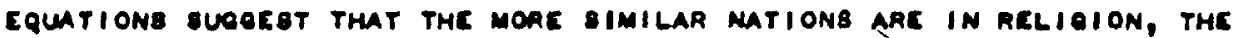
MONC THEY EMAAC IN COOPEAATIVE WOROS ANO CONFLICT DCEDB.

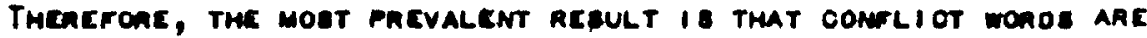
ABEOOIATEO WITH RELIOION ANO UREANIZATION. IN EXAMINING THE RELATIONG

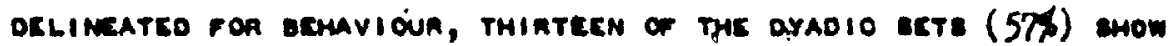

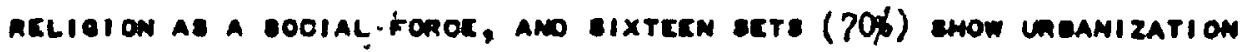

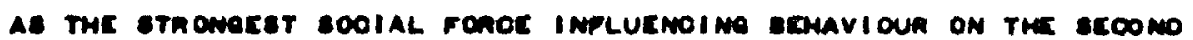

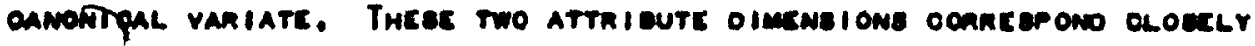

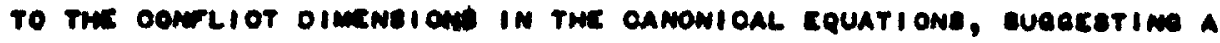

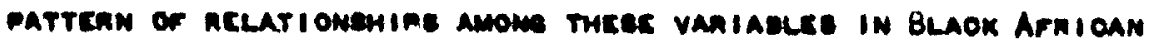
exuA 104 . 
The patterned relations eetween AfRican mations employine the BEMAVIOUA INOEXEB HAVE AN INCAEABE IN THE AMOUNT OF VARIANOE IN

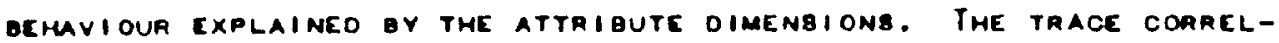
ATIONB RANGe MUCH HIGHER, FROM .26 TO .81, OR $6.8 \%$ To $66 \%$. (TABLE 10) The average cigenvalue for the fiagt camonical variate in thig INOTANCE 1852.1 PEAGENT, IN COMPARIBON TO THE 14 PERCENT EXPLAINED IN THE FREQUENCY ANALYAI8. THE DIFFERENCE IN REBULTB VBINO THE TWO rOAMB OF MEABUREMENT MAY BE DUE TO THE FORMAT FOR THE BEHAVIOUR INDEX. A. DIBCUSBEO IN THE PAEVIOUS CHAPTER, A RATHER COMPLEX PROCEDURE 18 USEO TO CREATE THE INOEX INYOLVING THE FACTOR BOORE COEFFIDIENTS FOR EACH BEHAVIOUR TYPE, THE FRequency ANO MEAN FOR THE EVENTB ANO THE VARIANCE. THE cQUATION (21) WEIOHTB CACH EVENT TYPE OY ITS FACTOR SCORE COEFFICIENT. THE OOEFFIOIENTB ON THE FIRBT FACTOR DIMENBION COAREBPONO TO TWE Y'B IN THE FIRBT INOEX, AMO 80 FORTH. THE PREQUENOY OF EVENT TYPEB BETWEEN OYAOB ARE OONBTANT FOR ALL THE INDEXES SINCE THE FREQUENOY OF INTERACTIONB DO NOT CHANOE. WhERE INTEAAOTIONS DO NOT OCCUN THE EVENT IS OMITTEO, OTHEAWIBE THE AESULT OF AN CQUATION WITH A GTANOARO DEVIATION OF 0 WOULD DE IMFINITY. THUS, THE INOCX STREescs BEAYIOUR BUT IONORES NON-

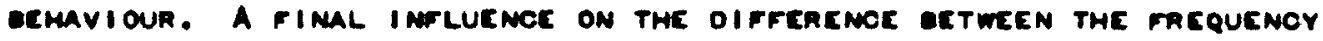

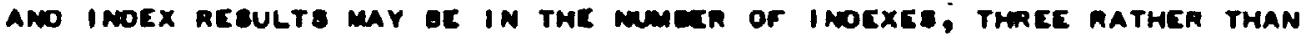

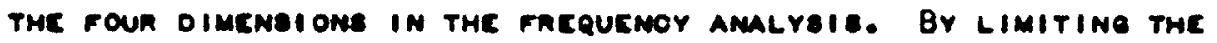

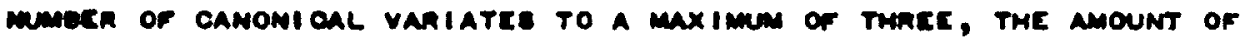

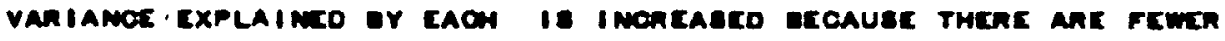

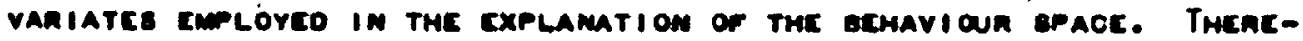

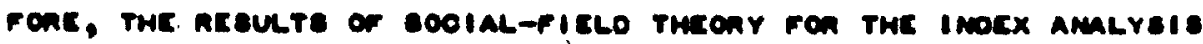


GNOULO DE MOAE BUCOINCT THAN PREVIOUBLY FOUNO.

A sumany of sonc OF THE nEQULTE FOA THE BOCIAL-FIELO THEOAY ermuioup inoex analveib ane reporteo in Table IO. The Intenactive Bemavioun InDEX (IBI) IO THE MOBT COMMON FORM OF EEHAVIOUA EVIOENOEO

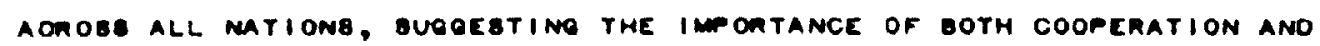
CONFLICT INTERACTION, BUT WITH LEBS OF AN EMPMABIS ON CONFLICT. THE BEHAVIOUR FOA MATIONB IB DEFINEO FURTHEA BY THE PAEBENCE OF A BECONO fogm of eemavioug inoex, cither the Conflict I noex (CFI) OR the COOPERATION I NOEX (COI).

The CoOperative InoEx appeare in matione with low and hiah taAce CORRELATIONB WITH TME VARIAMOE IN EEHAVIOUA EXPLAINEO BY THE RELIGION

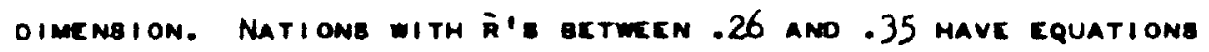
oimilar to Tooo:

$$
.60|B|-.64 \mathrm{CO} \fallingdotseq-.67 \mathrm{RzL} . \quad(n=.55)
$$

HEAE 30.36 OF VARIATION IN TOQ0'B COOPERATIVE BEMAVIOUR IS ACCOUNTEO

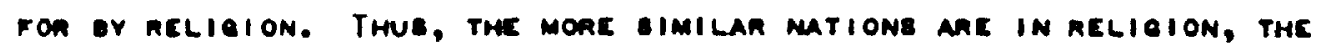
mone THEY EMOAOE IN MIXEO BEMAVIOUR, BUT THEY ENGACE IN LESS OO-

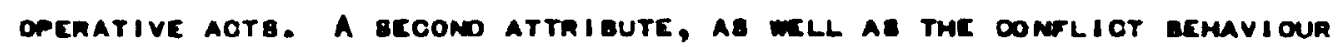
INOEX DIMENBION EMEREE ON THE SCOONO CAMONIOAL VARIATE FOR MOAT OF

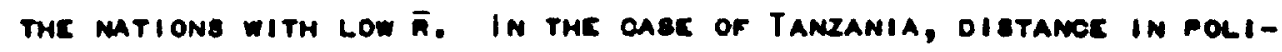
TIOAL OAIENTATION AE WELL AD BIMILARITY IN RELIGION EXPLAIN ITE VAMIATION IN OONFLIOT ELHAVIOUR. THE AMOUNT OF VARIAMOL EXPLAINLO oy The eccono vaniate is eenenally mall. The á ron Takzania ano Toso ane .20 and .15 nearcotively. A eimilan nelationemip odoune with aotons mavim an

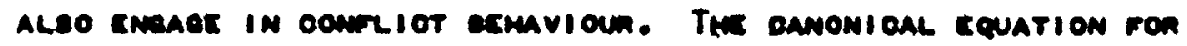


TABLE 10

Canonical Amalysis Reaulto ron Sooial-ficlo Theony - Bemavioun Inokx Amalrais

\begin{tabular}{|c|c|c|c|c|c|c|c|c|c|}
\hline \multirow{2}{*}{\multicolumn{2}{|c|}{ 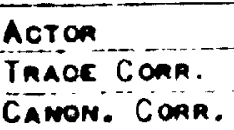 }} & \multicolumn{2}{|c|}{ IAN. } & \multicolumn{2}{|c|}{$T \infty}$. & \multicolumn{2}{|c|}{ NIO. } & \multicolumn{2}{|c|}{ GHA. } \\
\hline & & .53 & .32 & .55 & 33 & $.63^{\circ}$ & $.37^{-}$ & .73 & .42 \\
\hline Art. & $\begin{array}{l}\text { POW } \\
\text { URB } \\
\text { OEV. } \\
\text { REL } \\
\text { PQ }\end{array}$ & -.78 & $\begin{array}{c}(-.56) \\
.81\end{array}$ & -.67 & $\begin{array}{r}-.67 \\
(.57) \\
(-.55)\end{array}$ & -.99 & $\begin{array}{l}.76 \\
(.50) \\
\end{array}$ & -.80 & $\begin{array}{r}.64 \\
.81\end{array}$ \\
\hline BkM. & $\begin{array}{l}|\mathrm{B}| \\
\mathrm{CF} \mid \\
\mathrm{CO} \mid\end{array}$ & $\begin{array}{r}.76 \\
(-.41) \\
\end{array}$ & $\begin{array}{r}-.61 \\
.80\end{array}$ & $\begin{array}{r}.60 \\
-.64 \\
\end{array}$ & $\begin{array}{r}.64 \\
-.91\end{array}$ & $\begin{array}{l}(.55) \\
-.73\end{array}$ & $\begin{array}{l}-.87 \\
-.64\end{array}$ & .73 & .94 \\
\hline
\end{tabular}

\begin{tabular}{|c|c|c|c|c|c|c|c|c|c|c|}
\hline \multirow{3}{*}{$\begin{array}{l}\text { AOTOR } \\
\text { LAACE_CORR, } \\
\text { CANON. CORR. }\end{array}$} & \multirow{2}{*}{\multicolumn{2}{|c|}{$\frac{\text { OAH. }}{50}$}} & \multicolumn{2}{|c|}{ ETH. } & \multicolumn{2}{|c|}{ 601. } & \multicolumn{2}{|c|}{ MAU. } & \multicolumn{2}{|c|}{ WALI } \\
\hline & & & & & & & .7 & & & \\
\hline & .20 & .45 & .66 & .62 & .81 & .64 & .85 & .79 & .92 & .82 \\
\hline $\begin{array}{r}\text { POW } \\
\text { URB } \\
\text { ATT. DEV } \\
\text { REL } \\
\text { PQ }\end{array}$ & $\begin{array}{c}.63^{\circ} \\
(.59) \\
(.58)\end{array}$ & $\begin{array}{r}.75 \\
(-.58 \\
.72\end{array}$ & -.68 & $\begin{array}{l}.79 \\
.61\end{array}$ & $\begin{array}{r}.60 \\
.73 \\
-.79\end{array}$ & $\begin{array}{l}-.94 \\
(.54) \\
(.55)\end{array}$ & .87 & 1.13 & -.79 & $\begin{array}{l}.60 \\
.92\end{array}$ \\
\hline $\begin{array}{r}|B| \\
\text { BEM. } \\
C F \mid \\
C O \mid\end{array}$ & .84 & $\begin{array}{r}-.79 \\
.69\end{array}$ & .65 & .94 & $\begin{array}{r}.61 \\
1.54 \\
\end{array}$ & $\begin{array}{r}-1.14 \\
1.26 \\
1.41 \\
\end{array}$ & $\begin{array}{r}2.57 \\
(.56) \\
-1.31 \\
\end{array}$ & $\begin{array}{l}1.59 \\
2.20\end{array}$ & $\begin{array}{r}.66 \\
-.95 \\
-.62 \\
\end{array}$ & $\begin{array}{l}3.08 \\
5.14 \\
2.58\end{array}$ \\
\hline
\end{tabular}


MAURITANIA

$$
2.57181+.56 \mathrm{CFI}-1.31 \mathrm{COI} \fallingdotseq .87 \mathrm{REL} \text {. }
$$

EUGGEBTB THAT 72. F6 OF THE VARIATION IN ALL OF ITE BEHAVIOUR 18 AOCOUNTEO FOR GY AELIOION. THE MORE MATIONB ARE DIBBIMILAR IN RELIGION, THE MORE THEY ENGAEE IN BeHAVIOUR ABBOCIATED WITH INTER-

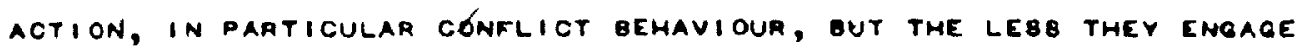
In cooperative bemaviour. Political oRIENTATION and uaganization ARE ALBO ATTRIBUTE OIMENBIONB WHIOH EXPLAIN BOME OF THE VARIATION

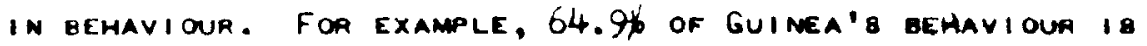
EXPREBBED IN THE EQUATION

$$
1.54 \mathrm{COI}+.61 \mathrm{CFI}=-.79 \mathrm{POL} .+.73 \mathrm{REL} .+.60 \mathrm{URB} .
$$

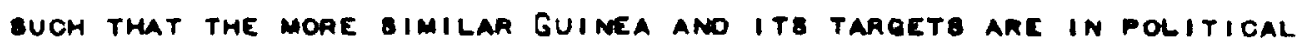
ORIENTATION ANO THE MORE DIBTANT THEY aRE IN RELIGION ANO URBANIZATION, THE MORE THEY ENOAEE IN COOPERATIVE ANO CONFLICTIVE BEMAVIOUR. THE GEOONO CANONICAL VARIATE 8 FOLLOW BMILAR PATTERNB AB THE FIRBT.

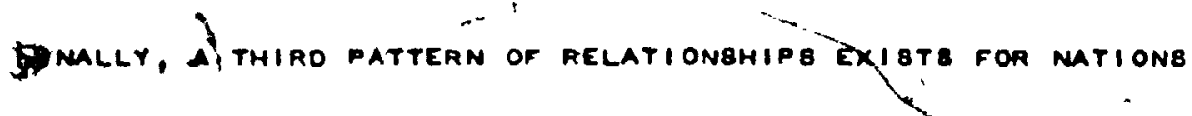
In THE INTERMEdIATE zONEB BeTWEEN THE NATIONB WITH hTOH ANO LOW TRACEB WITH BEHAVIOURAL PATTERMB BOROERINO ON THE OTHER TWO QROUPB.

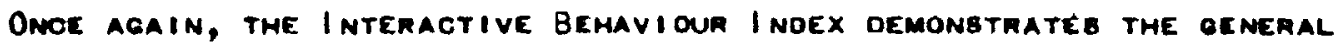
MIX OF DEHAVIOUR; HOWEVER, THE DOMIMANT INTERAOTION BEMAVIOUR IS THE CONFLIOT I moEx, A RELATIOMBHIP FOUNO PAEVIOUBLY ON THE BECONO VARIATE FOA LOW Ā. POWER 18 ALSO TME DOMIMANT ATTRIOUTE DIMENBION, ALthOUAM RELIGION PREVAILE THOOUGH THE BEOONO CANONIOAL VARIATE. Thus, Fon example, tme cquation fon Niogria

$$
-.73 \mathrm{CF}+.55 \mathrm{IB1} \mp-.99 \text { Pow. } \quad(n=.63)
$$

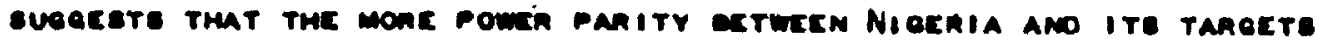




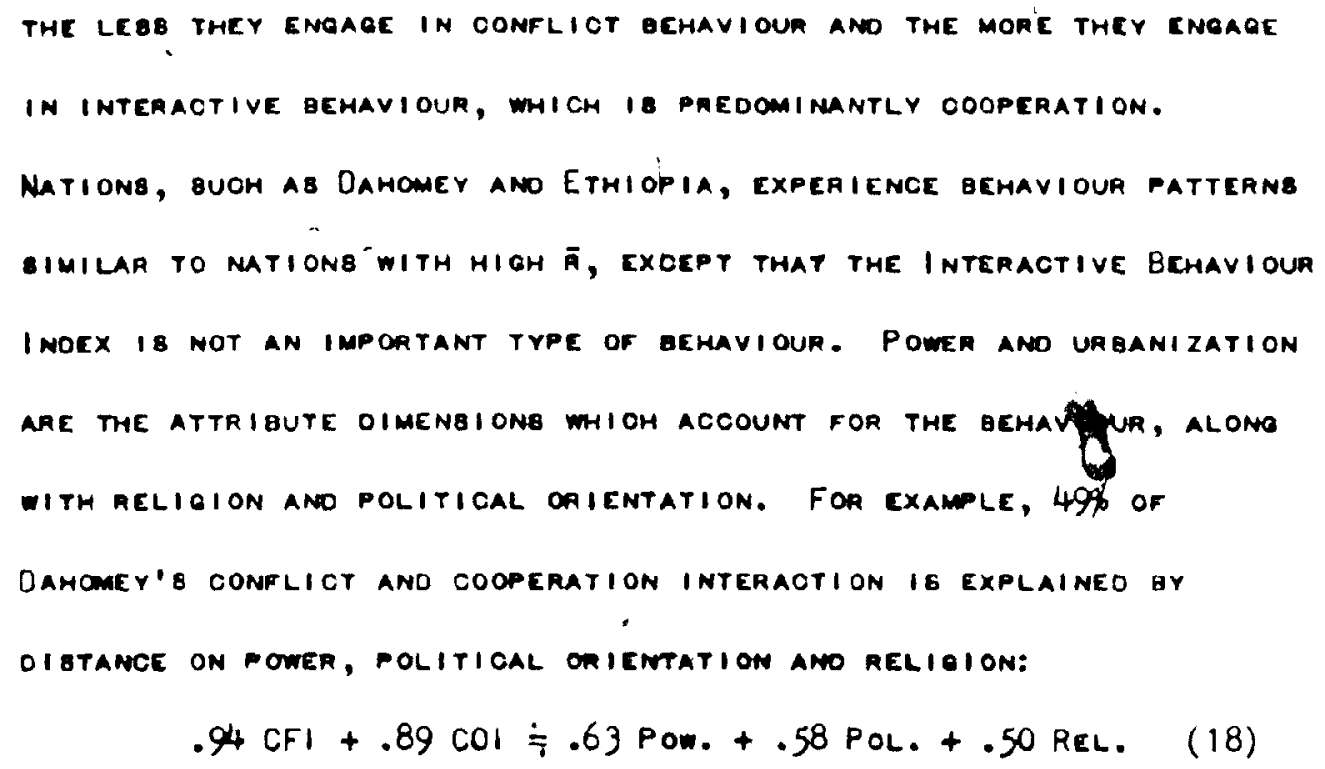

THE MORE DIBTANCE BETWEEN DAMOMEY ANO ITE TAROETB IN POWER, POLITIOAL ONIENTATION ANO RELIGION, THE MOAE IT EMOACES IN COMFLIOT ANO COOPERATIVE BEMAVIOUR. THE DIBTANOE ON THE POMER DIMEMBIQN IN THIB

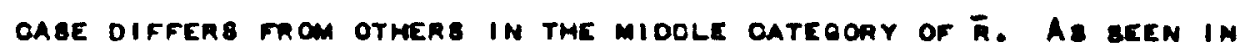

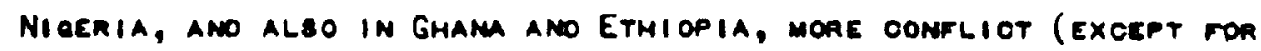
NIGERIA) ANO COOPERATION IS A FUNOTION OF THE BIMILARITY DETWEEN

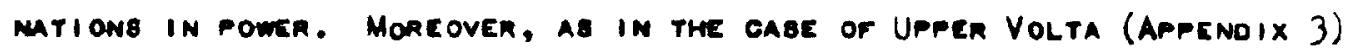
POLITICAL OAIENTATION IMELUENCES OOOPEAATIVE BEMAVIOUR AB BHOWN IN THE CQUATION

$$
.69001=.93 \mathrm{POL} . \quad(\mathrm{R}=.58)
$$

* ON, THE moRe similanitr in political onientation, the moac the

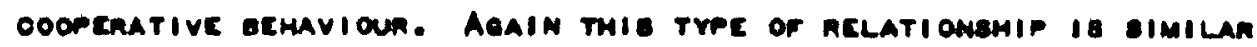
TO MMT FOUNO IN DYADIO ARTE WITH HIOH TRAOE OONRELATIONB. Orenall, Thene is a moeneseion mon nations with LOW Thace

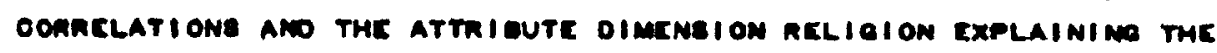

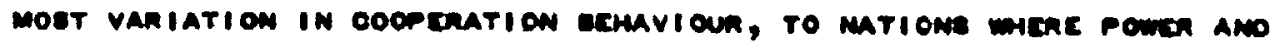


146.

POLITIOAL ORIENTATION ARE THE BOCIAL FORCE EXPLAINING CONFLIOT

Behaviour fiagtly, then coopeaAtive dehavioup, ano fimally to

MATIONE WITH HIOH Á IN MHIOH THE VARIATION IN COOPERATIVE ANO CON-

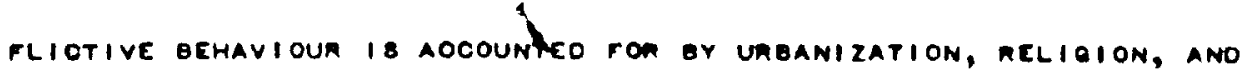
mOLITIOAL ORIENTATION.

IN OOMPARINE BRIEFLY THE REBULTS OF BOOIAL-FIELO THEOAY FrEQUENCY ANO GEHAVIOUA INOEX REBULTB, THE ANALYBIB OF THE INDEX DATA APPEARB'TO CONFIAM THE HYPOTHEBEB FOR BOCIAL-FIELO THEORY BETTER THAN THE FREQUENCY REBULTB, ALTHOUON NEITHER ARE AB BATIBFACTORY AB hOPED. THE LINKAOE hYPOTHEBIB THAT THE MONE BYMETRIC NATIONB ARE IN ATTRIBUTE OIBTANOE THE MOAT OOOPEAATIVE BEHAVIOUR, AMO THE OOAOLLARY THAT THE MORE ABYMGTRIC THE MORE CONFLICT WAS DOMFIRMED PARTIALLY IN A MUMBER OF CABEB. THAT IB, PARTE OF THEBE ?

RELATIONBHIPB OCCURAED, FOR EXAMPLE, IN THE EQUATION

$$
1.54 \mathrm{COI}+.61 \mathrm{CFI} \doteq-.79 \mathrm{PbL} \text {. }+.73 \text { REL. + .60 URE: }
$$

WHOH VEAIFIES PARTIALLY, THE OOOPERATIVE AGPEOT OF THE LINKAER MYPOTHEBIB THAT BIMILARITY IN POLITICAL ORIENTATION INFLUENCES THE EXOHANEE OF MOAE OOOPDATION, ANO PARTIALLY ITE COROLLARY THAT ol otanee on uRBanizatigh, ano also relioion, penpetuate mone confliot

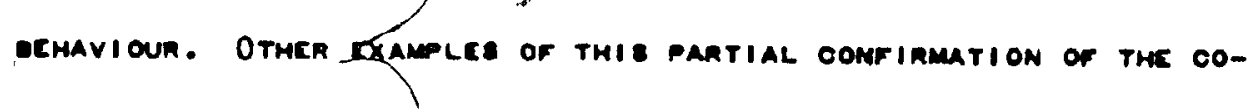

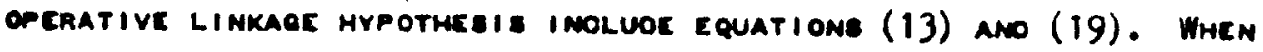
IBI IS mLEARDED. AB a COOPERATIVE INOEX, THE OCOUNRENOES OF CONFIRM-

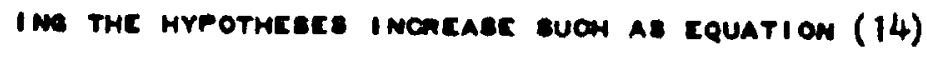

$$
.60|8|=-.67 \text { ReL. }
$$

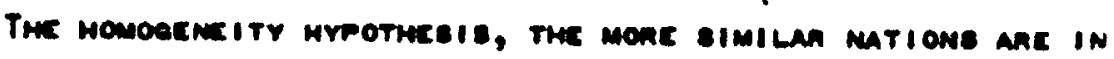

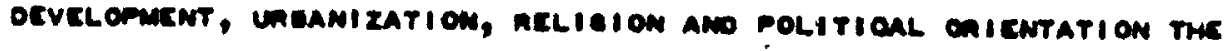


MORE THEY ENQAEE IN COOPEAATIVE GEHAVIOUA IB CONFIRMED BLIOHTLY EETTER THAN THE LINKAGE HYPOTHEBIS IN BOTH THE FREQUENCY AMO

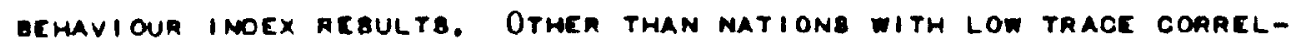
ATIONB IN THE BEHAVIOUR IMOEX AEBULTB, IF ONE CONBIOERB ONLY THE

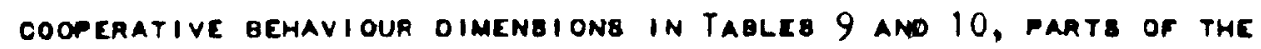
HYPOTHEBIB ARE CONFIAMEO DINCE ONE OF THE ATTAIBUTE OIMENBIONB oenerally has a negative alon, inoIcating BImILARIty on that DIMENBION. FoR EXAMPL, In EQUATIONB (13), (16) ano (19), 8IMILARITY IN RELIOION ANO POLITICAL ORIENTATION AAE, THE BOCIAL FORCEB BEHINO AN INCREABE IN OOOPERATIVE OEMAVIOUR, ANO IN PARTIOULAR COOPERATIVE WOROB IN THE mEQUENOY AMALYBIS. IN THE FREQUENCY REBULTB, UABANIZATION ANO COOPEAATION EMEROE TOQETMER ON THE BCCONO CANONICAL VARIATE as IN THE CABE OF MALI ANo NIOERIA REBPECTIVELy:

$$
\begin{array}{ll}
.82 \operatorname{con} \doteqdot-.77 \text { Une. } & (n=.25) \\
.86 \operatorname{con} \doteqdot-.77 \text { Une. } & (n=.26)
\end{array}
$$

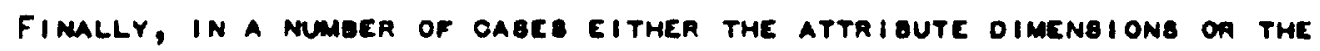
DemaViour oIMENBIONB maVe THE PAEOIOTEO BIONE, OUT NOT BIMULTANEOUSLY. SUCH IS OFTEN THE OABE WITH URBANIZATION FOR GHAMA, DAHOMEY

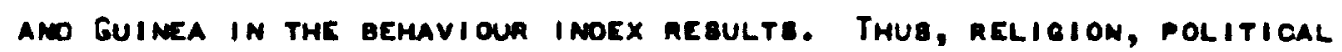
ORIENTATION ANO UREANIZATION, IN THAT ORDER ARE THE VARIABLEB MOET OFTEN ACCOUNTINO FOR OOOPERATIVE GEHAVIOUR IN THE MOMOOENEITY MYPO-

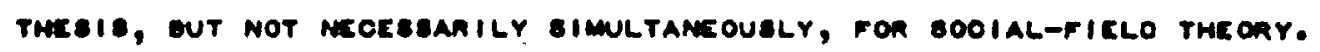
It IS HOPEO THAT OCTTEn OGNFIRMATION OF THE HYPOTHEBEs WILL aE ATtAINEO IN THE AESULTE FOA ETATUS-FICLO THEONY. 
148.

StATUB-FIELO THEOAY AMALYBIS

StATUB-Field theORY PROVIOCB a DIFFERENT PERBPECTIVE ON THE

Relationship oetween attrigute ano bemavioun gPaOc. While the

EEHAVIOUR DIMENBIONB REMAIN THE SMME, THE FOUR FREQUENCY DIMENBIONB

ANO THREE BEHAVIOUR IMOEX DIMENBIONA, THE ATTRIBUTE DIMENBIONG

CONBIBT OF POWER ANO DEVELOPMENT ONLY. THEREFOAE, THE GREATEBT

MUMGER OF CANONICAL VARIATEB ANO CORRELATIONB MAY BE EQUAL TO TWO

ONLY, CORRESPONOING TO THE BMALLEBT EET OF DIMENBIONB, THE ATTRI-

BUTE OIMENBIONB. TO GE CONBIBTENT WITH MATT HAB PREVIOUBLY BEEN

DONE, THE FAEQUENOY AMALYSIS IS DIBCUBBED FIRAT, FOLLOWEO OY THE

gemavioun inOEX AMALYBIS.

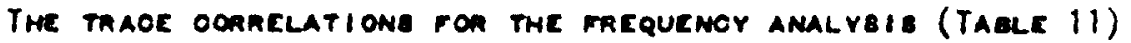

Ahe veRY LOW. WITM THE EXCEPTION OF ZAMBIA $(\bar{A}=.41)$ THE TRACE OO-

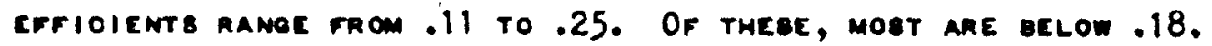

THIS MEANE THAT THE PEROENT OF THE VARIANOE IN GEMAVIOUR acoOUNTEO

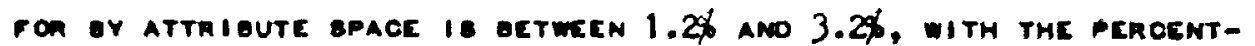

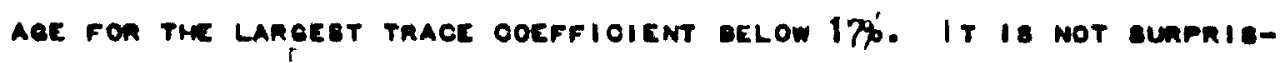

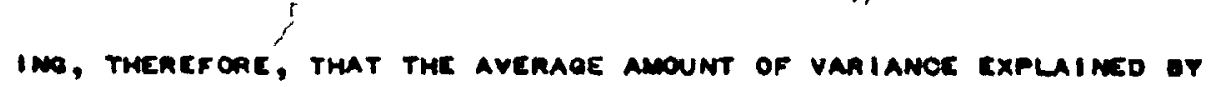
THE FIRST OANONIOAL IS LESE THAN 20\%. HOWEVER, FROM THE VARIANOE

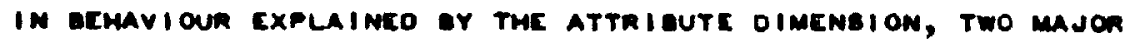
PATtERMS WITH BLIOHT VAMIATIONS IN BOTH EMENOE, ONE FOR CAOH ATtRI-

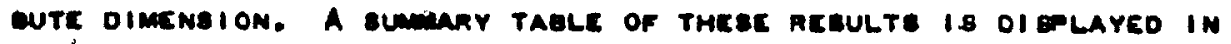

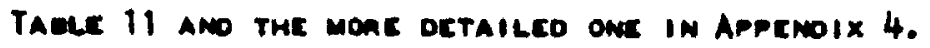

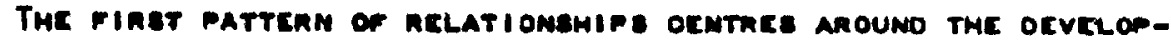

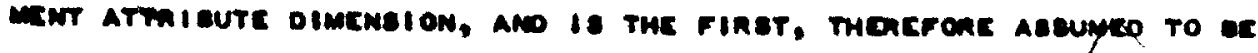



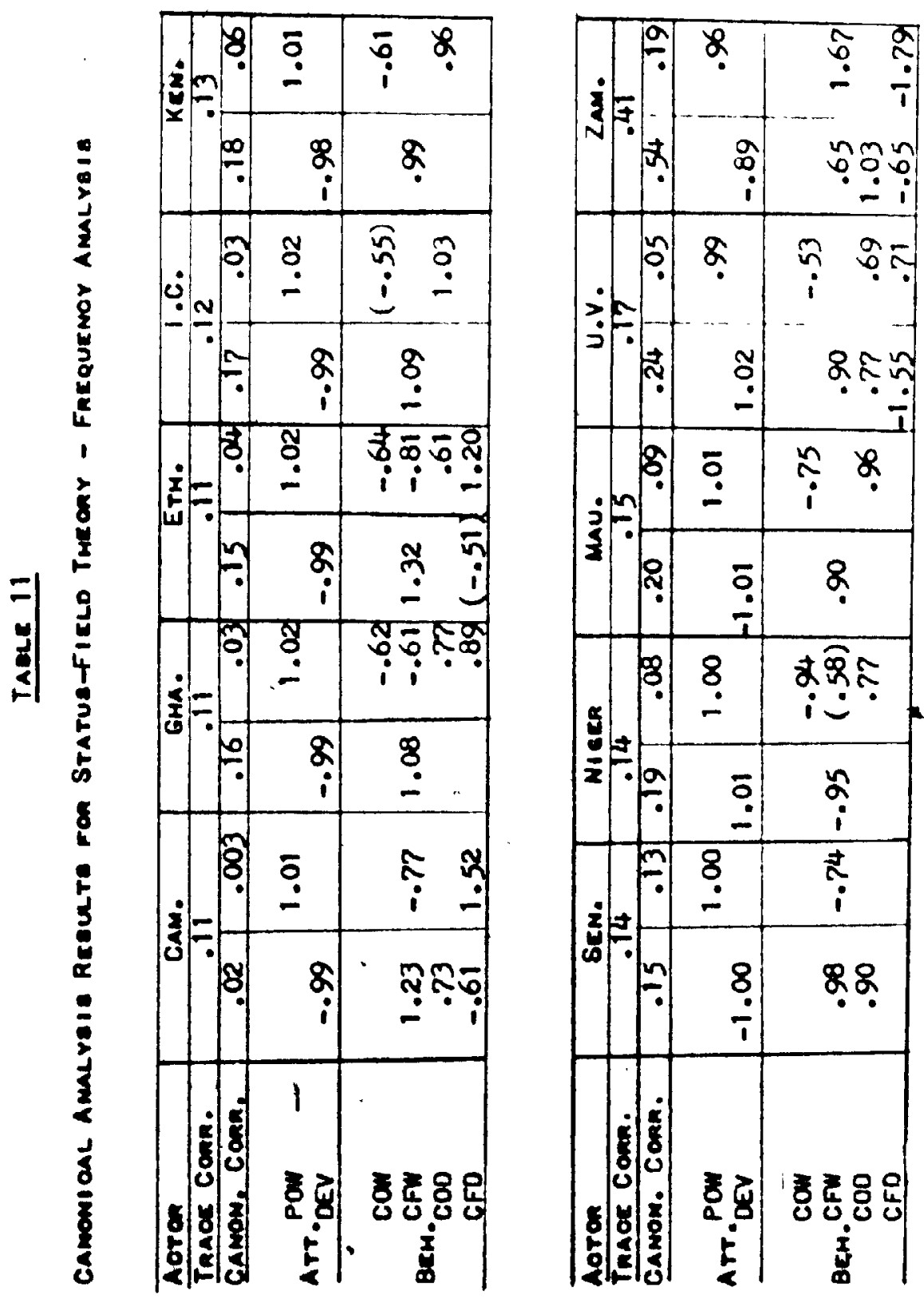
THE MOST IMPORTANT, CANONICAL VARIATE. THE CANONICAL CORRELATIONS

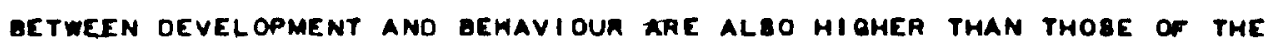

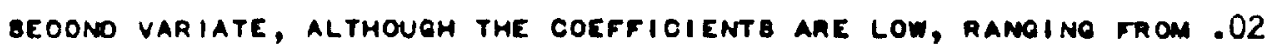

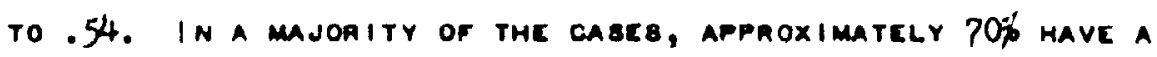
NEOATIVE BIEN PROOEEOING THE CANONIOAL VARIATE COEFFICIENT (THE parameter) for development. THe neoative BION INOICATEB a BimilARITY IN DEVELOPMENTAL LEVELB BETWEEN ACTOR ANO TAREET. THE FIRBT DOMINANT PATTERN TO MEREE IO A RELATIONBHIP GETWEEN OEVELOPMENT ANO CONFLICT WORDB. THE EQUATION FOR I VORY COABT

$$
1.09 \text { CFW }=-.99 \text { DEV. } \quad(n=.17)
$$

WUEEST8 THAT THE MONE IMILAR IVOAY COABT IS TO ITB TAMOLTE IN OEVELOPMENT, THE MORE IT ENOACES IN DONFLIOT MOROS. TMIS RELATIONOHIP EMEROES FOR MORE THAN 8OF OF THE OABES. IN A FEW OABCs, BUOM AB NI EER

$$
-.95 \mathrm{CFW}=1.01 \mathrm{DEv} . \quad(R=.19)
$$

THE 8 IONB ARE REVERSEO SO THAT THE MELATIONEHIP IS THE WONE OIBTANT ON OEVELOPMENT, THE LEAS THE CONFLIOT WONDE. STILL, A MALL MINONITY OF OTHER: DEMONETAATE A DIFFENENT RELATIONEHIP, EUOH AS UPPEA VOLTA.

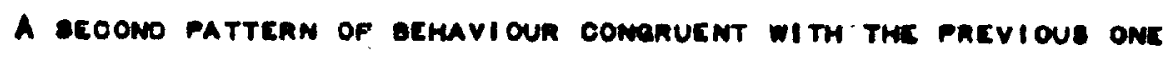

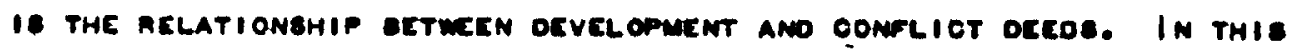
OAEE THE DEVELOPMENT DIMENSION AOCOUNTS FON THE VARIATION IN gOTH

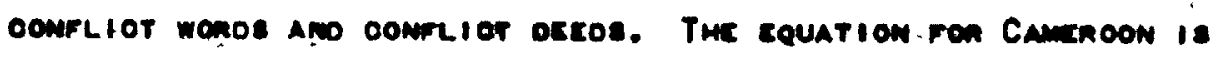
similan to that mouno in matione with LOW (LeEs than . 12) amo migh (encatsh tman :17) màor ognaclation oocffioicmts. It etates

$$
\text { 1.23. CFW - .61 CFD }-.99 \text { ory. } \quad(n=.02)
$$


On, THE CLOBER mations aRE IN OEVELOPMENT TO CAMEROON, THE MORE THEY CMOAQE IN CONFLICT WOADB ANO THE LEBB THEY KNGAQE IN CONFLICT DEEDE. Fon tHE AEMAININO MATIONB, CONFLIOT WOADS IB THE ONLY TYPE OF BEmaviour accounteo fOA OY DEVELOPMENT, WITH THE EXCEPTION OF SENEEAL.

THIS LEAOB TO A FINAL GEMAVI OUP PATTEAN INVOLVING OOOPERATIVE DEEDB. ALTHOUGM THE LEABT OFTEN GEHAVIOUR OIMENBION OCGURAINO WITH a high canonical coefficient of the thaee, it does buRface for a fen

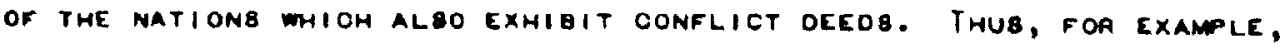
THE EQUATION FOR ZAMBIA

$$
1.03 \mathrm{COO}+.65 \mathrm{CFW}-.65 \mathrm{CFO} \fallingdotseq-.89 \text { OEV }(\mathrm{R}=.54)
$$

IMPLIEB TMAT BIMILARITY IN OEVELOPIENT AOOOUNTS NOT ONLY FOR MORE CONFLIOT WOROB AND LESE CONFLIOT DEEOS, GUT ALBO MORE COOPERATIVE DEEDS BETWEEN ZAMEIA ANO ITS TAREKTE.

THE BLCONO MAJOR PATTERN OF RELATIONBHIPB DETWEEN ATTRIBUTEB ANO DEMAVIOUA REVOLVES AROUNO THE POWER DIMENBION ANO IS CONTAINEO WITHIN

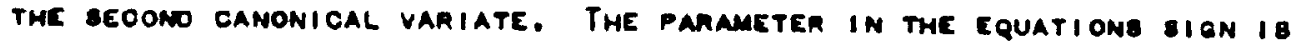

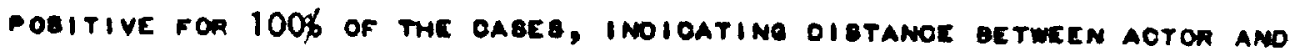

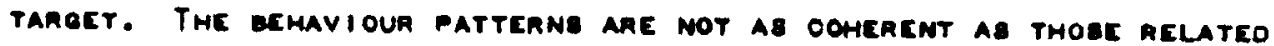
TO oEVELOPMENT, AB REVEALEO BY THE CAMONIOAL OOARELATION OOEFFIOIENTE.

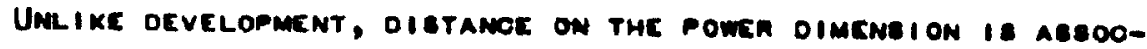
IATEO WITH AN IMOREABE IN OOOPCRATIVE DEEDS. Fon EXAMPL, THE RELATIONBHIP EETWEEN TME TWO OIMCNEIONE IS

$$
.96 \mathrm{c00} \div 1.01 \text { Pow }(n=.09)
$$

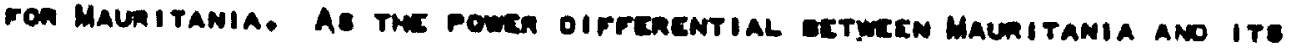

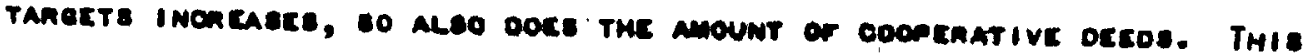




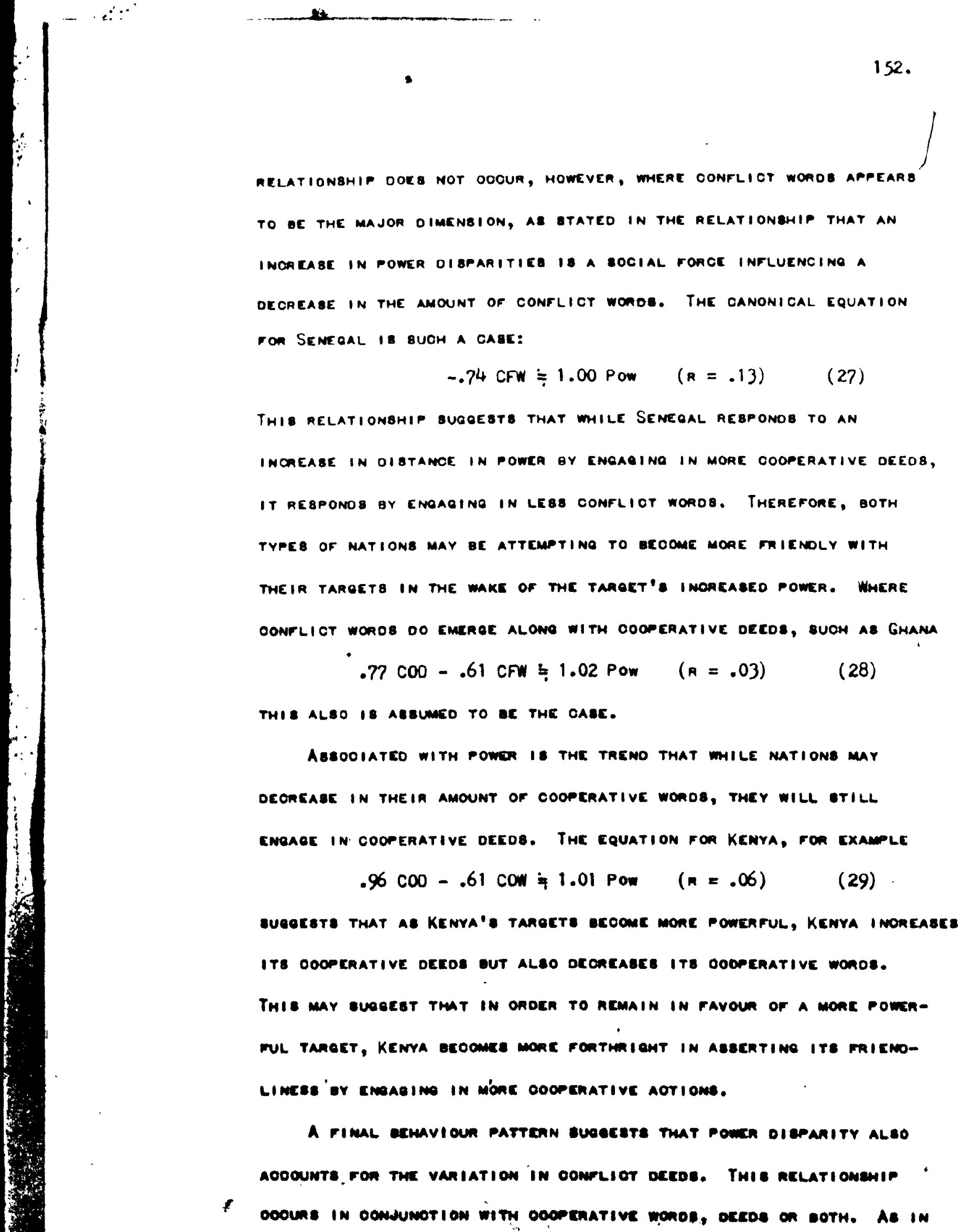


THE CABE OF ETHIOPIA,

$$
1.20 \mathrm{CFO}-.81 \mathrm{CFW}-.64 \mathrm{CON}+.61 \mathrm{COO} \equiv 1.02 \text { POW }(\mathrm{R}=.04)
$$

THE CQUATION BTATE THAT AB THE POWEA DIBPAMITY BETWEEN ETHIOPIA ANO ITS TAROETS INCREABEB, ETHIOPIA ENGAGEB IN LEG CONPLICT ANO COOPEAATIVE WOROB AND MOAE CONFLICT ANO OOOPCAATIVE OEEOB. THIB IMPLIEB THAT ETHIOPIA BECOMEB MOAE FORCEFUL IN ITE COOFEAATIVE ANO CONFLICTIVE ACTIONB AB A TAFOET BEOOMEQ MOAE POWERFUL, AND THEREFORE MORE AB8ERTIVE.

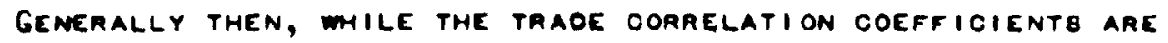
HIOHER FOR THE OEVELOPMENT OIMENBION PATTERNB, ALTHOUGH NOT AB HIOH A8 WOULO BE LIKEO, OEVELOPMENT IE MOBT CLOBELY ABBOCIATEO WITH CONFLICT, ano POWER WITH OOOAERATION FOn THE mequenoY AEBULTB OF BTATUB-FIELD THEORY. ADOED TO THI ARE OTHEN DEMAVIOUR DIMENBIONB WHICH HELP TO EXPLAIN AFRICAN FOREION POLICY GEMAYIOUA. OMY NIOEAIA, TOGO ANO UGAMDA DO NOT FOLLOW THEE PATTERNE. WHERCAS MOET MATIONB HAVE A HIOH BOONE ON ONE ATTAIBUTE DIMENBION PER CANONICAL VARIATE ANO A

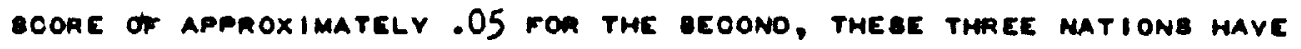
HIOHER DOEFFICIENTE ON THE BLOONO OIMENSION. ALSO, TME IMPORTANCE OF

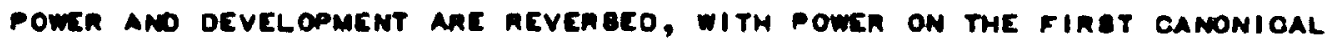
VARIATE. FOA NIOERIA, THE POWER DIOPARITY INFLUENOEB AN INORLABE IN

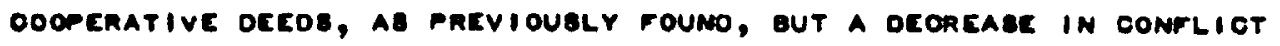

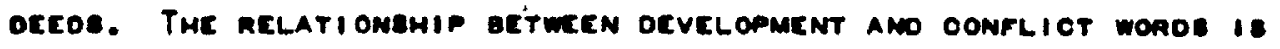

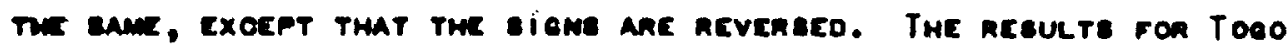

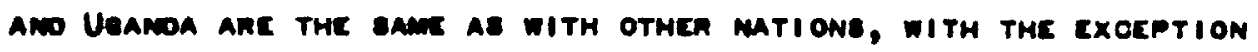

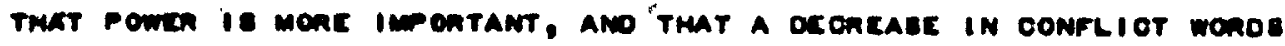

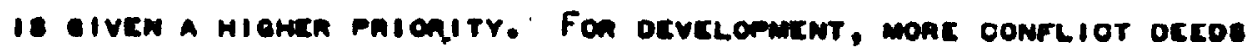

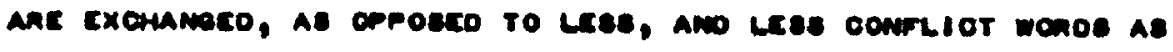


OPPOBEO TO MOAE.

THUA FAR, THE REBULTa FOR THE BTATUA-FIELD THEORY FAEQUENCY AMALBIB HAVE BEEN THE MOST FRUITFUL IN TEAMB OF THE COMERENT PATteans TO EMEROE. THE MAJOR PROBLEM, hOWEVER, LIEB IN The LOW TIAOE COARELATION COEFFICIENTS.

TABLE 12 PROVIDEB THE FINAL DATA ANALYGIB FOR BTATUB-FIELD

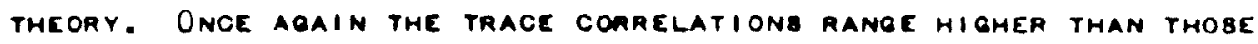
OF THE FREQUENCY ANALYBIB, FaOM. 10 To.64. THE average mount of BEMAYIOUR EXPLAINED BY ATTRIBUTE DIBTAMCEB FOR THE FIRBT CANONICAL VARIATE IB APPROXIMATELY 47\%. THE PATTERN, OF AELATIONBHIPE EETWEEN

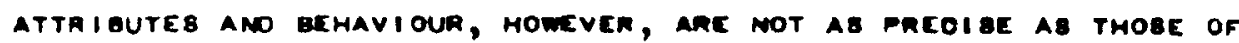
THE FREQUENCY ANALYBI8, AND POWER EMEREE AS THE DOMINANT VARIABLE FOA THE FIRST VARIATE, MHLE DEVELOPMENT LOADE ON THE BECONO. THE PATTERNS WHICH ARE MANIFEOTED, GENERALLY RELATE AN INOREABE IN POWER DI BPAAITY WITH AN INCREABE IN CONFLIOT ANO COOPERATION, MHILE - imilarity in deVEloment ib ab8ociateo with a ocgacage in confliot.

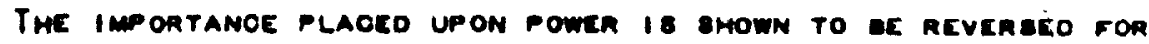
MATIONB WITH TRACE CORRELATION OOEFFIOIENTA OF LESE THAN . 30.

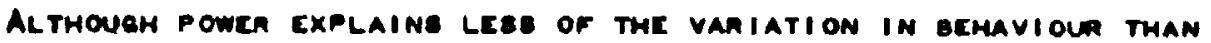
DEVELOPMENT (R'S BETWEEN .05 ANO .20), THE RELATIONBMIP DETMEEN

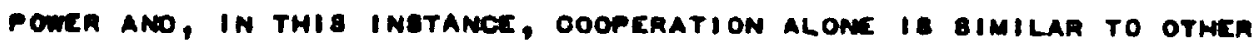

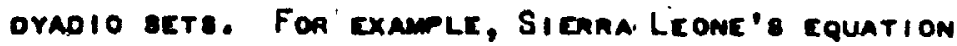

$$
.83 \mathrm{col}=.75 \text { Pow } \quad(n=.06)
$$

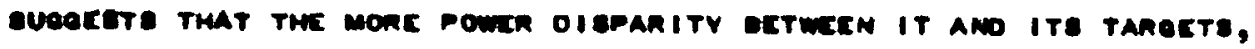

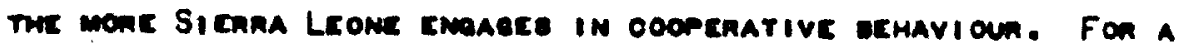

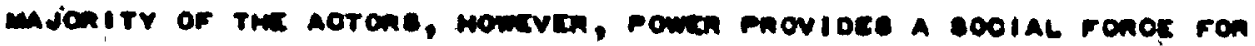




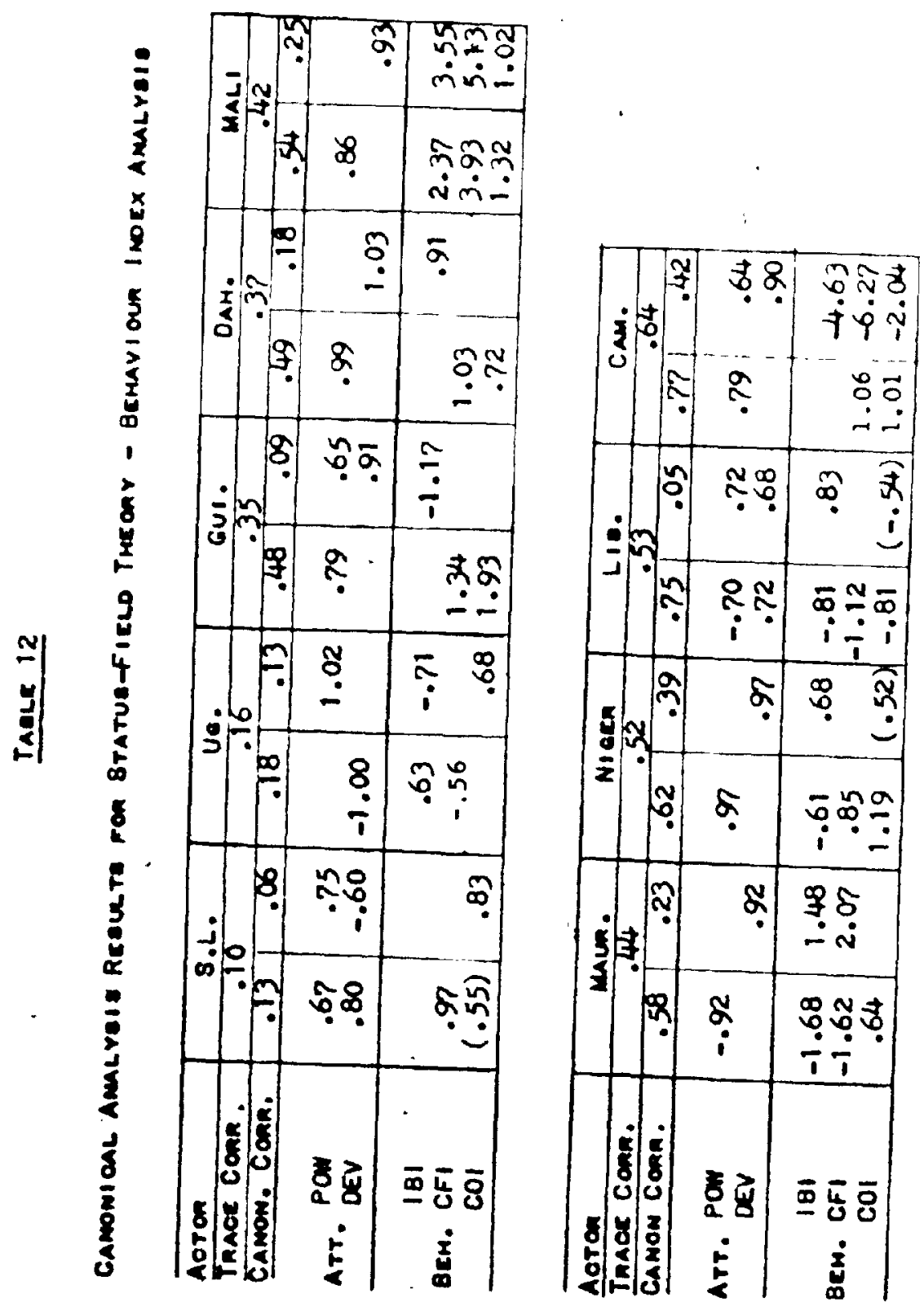




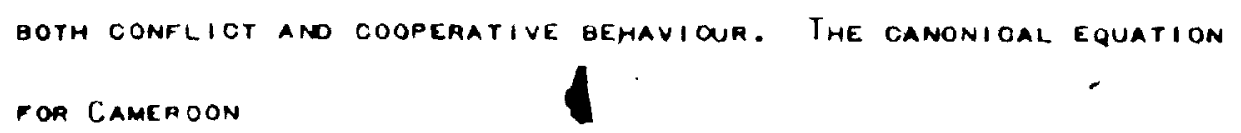

atates that 56.38 OF THE VAMIATION IN OEOAEABING amountB OF CONFLICt AMO COOPERATIVE BEHAVIOUR FOR LIBERIA 18 A8800IATEO WITH A OKCREABE IN THE POWEA DIFFEnEMOCE DETWEEN LIOEAIA ANO I TO TAROETB. AN EXCEPTION 18 MAURITANIA. THERE, a ORCREABE IN POWER DIBPARITY

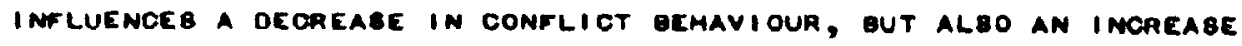
IN OOOPEAATION. FIMALLY, FOR OYAOIO SETE IN WHIOH THE OVERALL VARIANCE ACCOUNTEO FOR BY THE FIRET CANONICAL CORRELATION IA

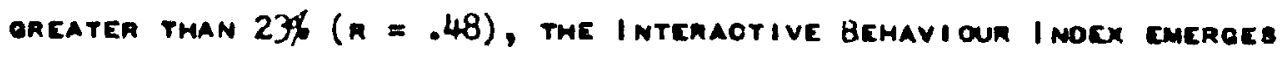
As a Fonm of Bemavioun associateo WITH THE POWER DIMENEION. AS AM EXAMLLE, the CANONICAL gQuation fón MaLI

$$
3.93 \mathrm{CFI}+2.37 \mid \mathrm{Br}+2.32 \mathrm{Col} 5.86 \mathrm{POW}(\mathrm{n}=.54)
$$

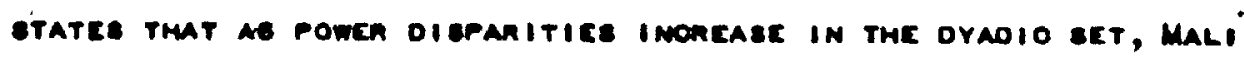
Emeaces IN mOAE INTERACTION (IBI ECINE COOPERATION ANO OONFLIOT) OUT

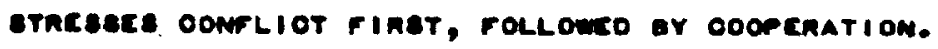

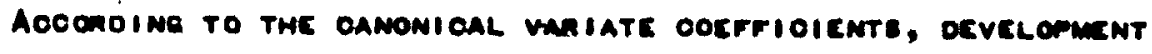
18 assoofatco most etmomely and posfively with oomplot. Tmat is,

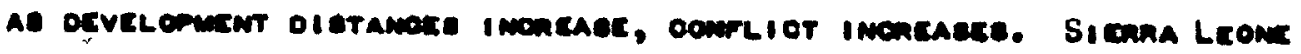




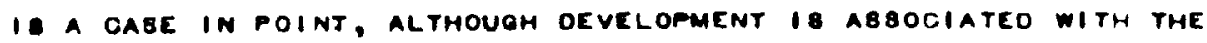
FIRBT OANONICAL VARIATE. ITE EqUATION

$$
.97 \text { CFI } \fallingdotseq .80 \text { Der } \quad\left(R^{\circ}=.13\right)
$$

IMPLIE THAT THE MOAE SIEARA LEONE IS OIBTANT FAOM ITS TARGETB IN

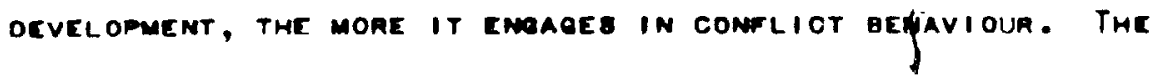
OOAOLLARY OF THIB AELATIONBHIP EXIBTB BETWEEN OTHER BTATE8. FOR EXAMPLE, THE EQUATION FOA UQANOA

$$
-.56 \mathrm{CFI} \fallingdotseq-1.00 \text { DeV } \quad(\mathrm{A}=.18)
$$

ETATEB THAT IN THIB OYADIO BET AB POWER OIBPARITY DEOAEABES BETWEEN THE AOTOR ANO TAMOET, UEANDA EMOAESB IN LEBB CONFLICT. THIB DUQQEBTE THAT IN THIB TYPE OF RELATMONBHIP OF EXOMANGIMO OOOOB, AB MATIONB APPROAOH PARITY IN OEVELOPMEMT, THERE IS LEBS OF A MEED TO interaction IN CONFLIOT TVPES OF OEMAVIDUR. ONOE AOAIN THE INTER-

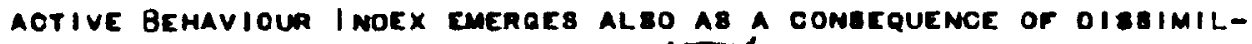
ARITY IN LEVELS OF OEVELOPMENTA AS EEEN IN THE EQUATION FOR MALI,

$$
5.13 \mathrm{CF} 1+3.55181+1.02 \mathrm{CO1} \fallingdotseq .93 \mathrm{Drv}(4=.25)
$$

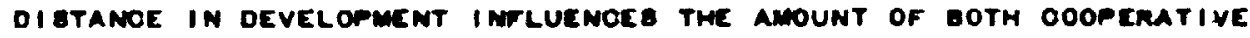

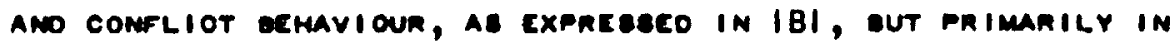

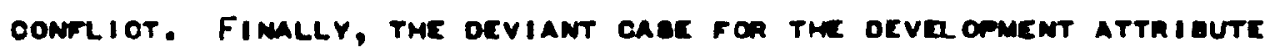

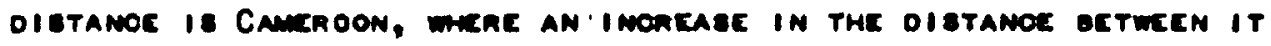
AMO ITE TAREETE IMFLUEMES A OEONEABE IN.THE MMOUNT OF INTEAAOTION

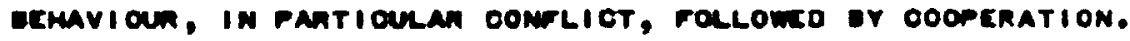

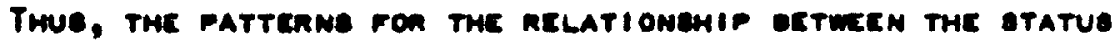

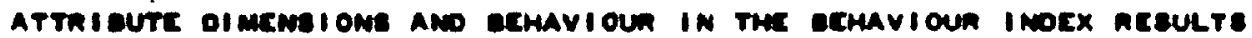

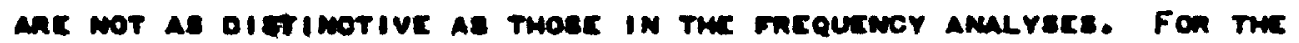

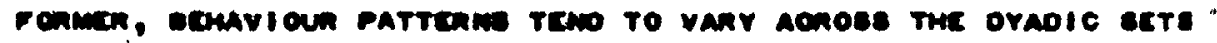




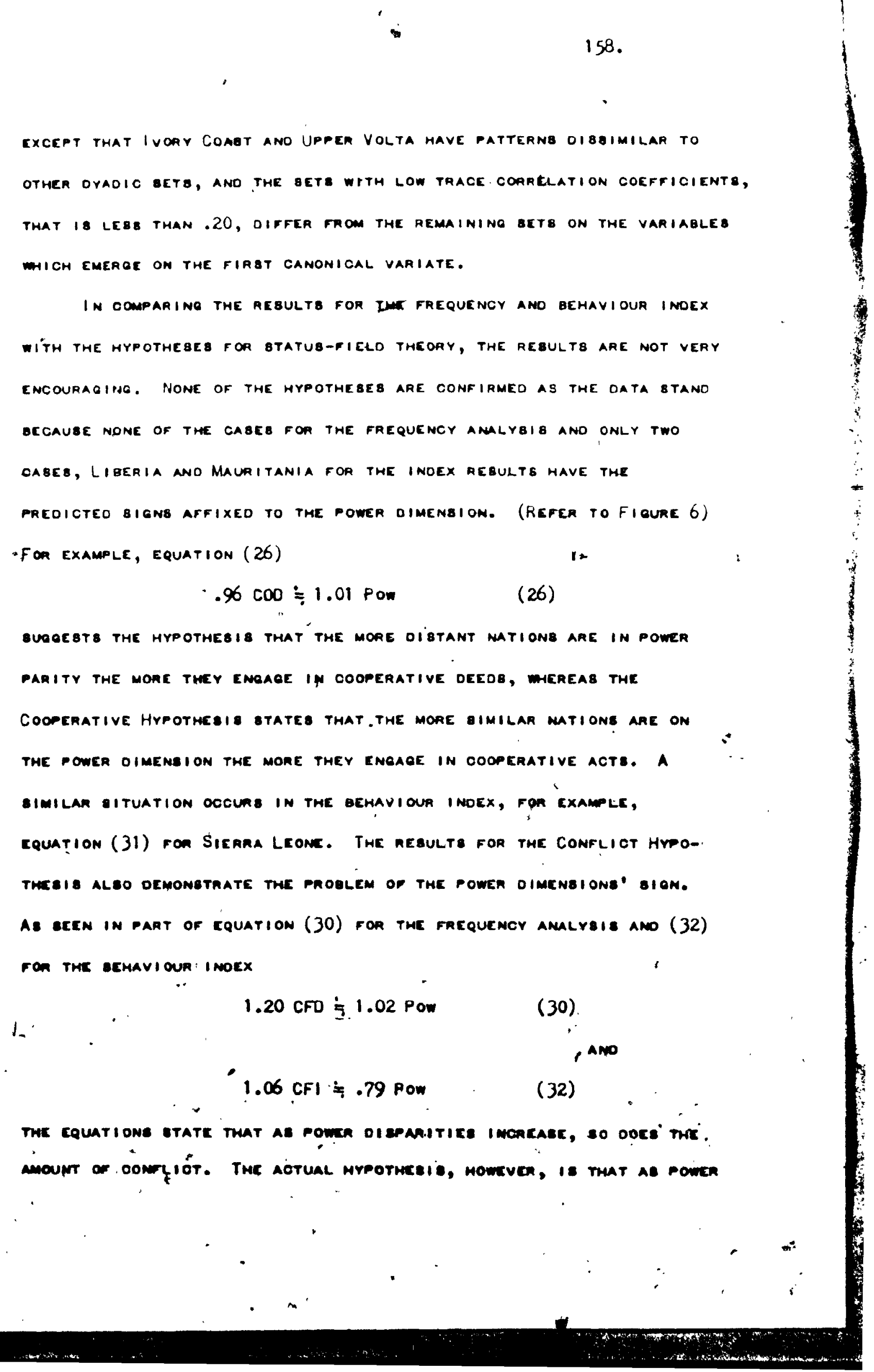


DIBPARITIEB OECAEABE, THE aMOUNT OF OONFLICT INCREABEB. The Status

- Hypothe8is, finally, is not confirmeo. ongy for li geaia ano MauaiTANIA 18 THE OIBTANCE BETWEEN THEBE NATIONB ANO THEIR TARQET OEGAEABINE, DUT BTATUB-DEPENDENT CONFLIOT ANO COOPERATION I8 ALBO DECREABIHE, MATMER THAN INCREABINO AS HYPOTHESIZEO. FOR OTHEA OYADIC BETB SUCH As CAMEROON IN EquATION 32 ,

$$
1.06 \mathrm{CFI}+1.01 \mathrm{CO1} \fallingdotseq .79 \text { Pow. }
$$

THE RELATIONBHIP IS THE MORE DIBBIMILAR IN POWER, THE MORE BTATUB-

18

$$
\begin{aligned}
& 1.03 \mathrm{COO}+.65 \mathrm{CFW}-.65 \mathrm{CFD} \fallingdotseq-.89 \mathrm{OEv} \\
& \text { ANO } \\
& .98000 \div-.86 \mathrm{Drr} \quad(\mathrm{n}=.07)
\end{aligned}
$$

Ano

rOR SUOAN. WHEAEAB THE OOMPLETE HYPOTHEBIS IS THE MOAE SIMILAR MTIONS ARE ON EOONOMIO DEVELOPMENT ANO ON POWER, THE MOAC THEV

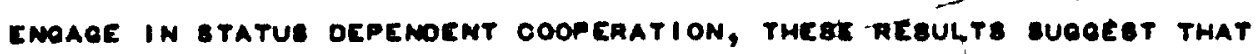
THE MORE SIMILAR MATIONB ARE ON OEVELOPMENT, THE MORL THEY EMPAOE IN

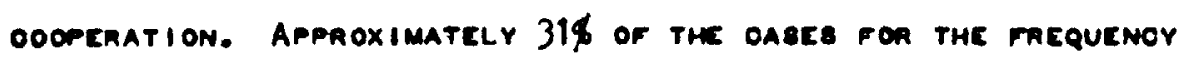

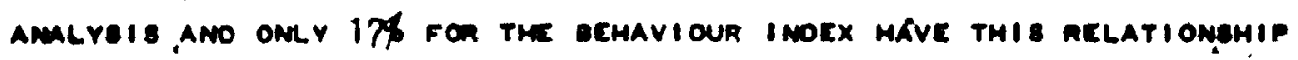
ON TME FIRET CANONIOAL VARIATE.

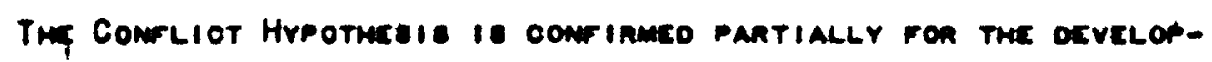
ment asecets in 30\% of the ecmavioun inocx ovadio ects amalyais, out omer rmo, Zainc amo Upré Volta 
$\therefore x^{\circ} \quad \ldots$

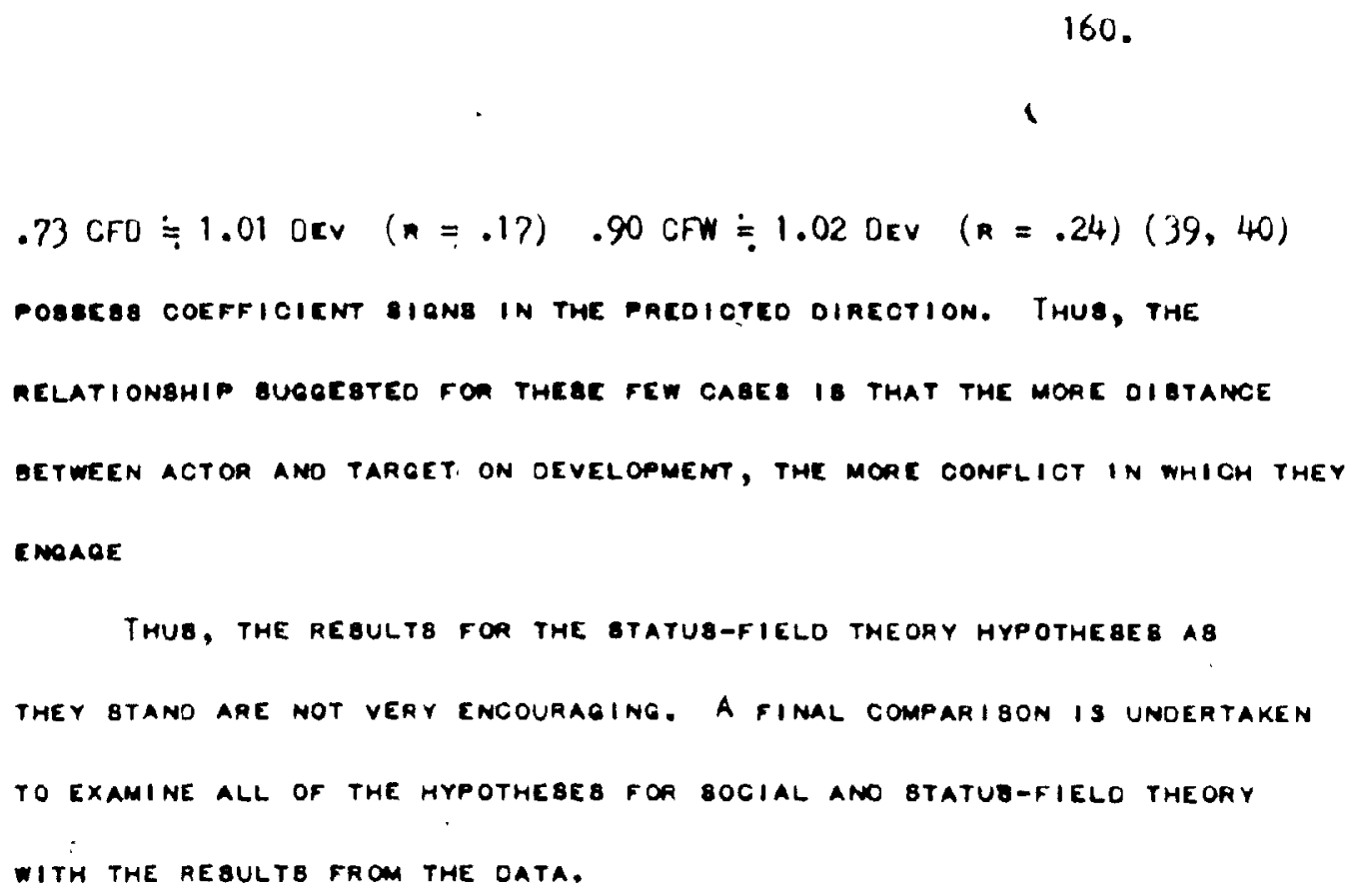

160.

6. TMERE ARE. THEN PO POBIBLE 46 INATANOES IN WHICH THE SIONB

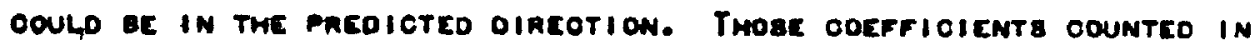
TAELe 13 have a minimum value of.50. ThE VALUCS veEo aRe From Appermolx 3 ano 4. NOTE THAT THE COI, AnO CFI gemavioun fOR THE echavioun inoLx Résults fon the Status HYPothesis inOLUDE THE INTERaOtive Bemavioun fmocx. Also tha CF amo CA inOLUDE Doth OONFLIOT

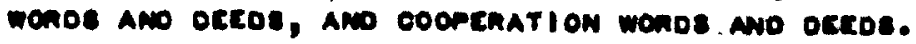


TAOLE 13

aotual Signe fon Social ano Statur-fielo Theory hypothebis

\begin{tabular}{|c|c|c|c|c|c|c|c|c|}
\hline HYPOTHEB I 8 & & SEMAVIOUR & & Pow. & UAB. & DEV. & REL. & POL. OR \\
\hline 1. LInKage & $\begin{array}{l}\text { SION } \\
\text { FREQ. } \\
\theta .1 .\end{array}$ & $\begin{array}{l}\mathrm{CF} / \mathrm{CO} \\
\mathrm{CFI} / \mathrm{COI} \\
\mid \mathrm{BI}\end{array}$ & $\begin{array}{l}+1+ \\
32 / 27 \\
20 / 16 \\
22\end{array}$ & & $\begin{array}{l}+1- \\
1 / 15 \\
5 / 8\end{array}$ & $\begin{array}{l}+1- \\
8 / 3 \\
6 / 5\end{array}$ & & $\begin{array}{r}+/- \\
9 / 6 \\
13 / 10\end{array}$ \\
\hline 2. Homo. & $\begin{array}{l}\text { SIEN } \\
\text { FAEQ. } \\
\text { B.l. }\end{array}$ & $\begin{array}{l}\mathrm{CO} \\
\mathrm{CO} \\
|\mathrm{B}|\end{array}$ & $\begin{array}{l}+ \\
27 \\
16 \\
22\end{array}$ & & $\begin{array}{r}- \\
15 \\
8\end{array}$ & $\begin{array}{l}- \\
3 \\
5\end{array}$ & $\begin{array}{r}- \\
6 \\
14\end{array}$ & $\begin{array}{r}- \\
6 \\
10\end{array}$ \\
\hline 3. Coop. & $\begin{array}{l}\text { SION } \\
\text { FACQ. } \\
\text { B.1. }\end{array}$ & $\begin{array}{l}C O \\
C O \mid \\
|B|\end{array}$ & $\begin{array}{r}+ \\
25 \\
23 \\
12\end{array}$ & $\begin{array}{l}- \\
0 \\
2\end{array}$ & & $\begin{array}{r}18 \\
13\end{array}$ & & \\
\hline 4. CONF. & $\begin{array}{l}\text { SION } \\
\text { FREQ. } \\
\text { B.1. }\end{array}$ & $=\left\{\begin{array}{l}\text { CF } \\
\text { CFI }\end{array}\right.$ & $\begin{array}{r}+ \\
29 \\
18\end{array}$ & $\begin{array}{l}- \\
0 \\
2\end{array}$ & & $\begin{array}{r}+ \\
9 \\
20\end{array}$ & & \\
\hline 5. Status & $\begin{array}{l}\text { SION } \\
\text { FREQ } \\
\text { B.1. }\end{array}$ & $\left\{\begin{array}{l}\mathrm{CO}+\mathrm{CF} \\
\mathrm{COI}+\mathrm{CF} I\end{array}\right.$ & $\begin{array}{l}+4 \\
13 \\
116\end{array}$ & $\begin{array}{l}- \\
0 \\
2\end{array}$ & & & & \\
\hline
\end{tabular}

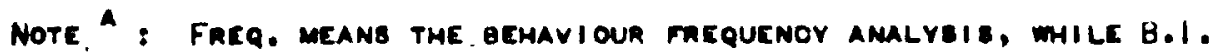
REFERE TO THE BEMAVIOUR I NOEX AMULYBIB, CO COOPERATION, COI COOPERATION INOEX, |B| THE INTERACTIVE INOEX, aMO 80 ON. 
THE FAEQUENCY ANALYBIB ANO ONLY TWICE IN THE INOEX ANALYSI8 FOA Liberia ano Maupitania. ON the othea mano, the preoicteo oigna in DEHAVIOUR OCCUR UPWAFOB TO $70 \%$ OF THE DYADIO BETS IN THE LinKage HYPOTHE8I8. FINALLY, THE FREQUENCY OF TIMEA IN WHIOH ATTRIGUTE8 AND BEHAVIOUR ARE IN THE PROPER DIREOTION DOEB NOT NECEBSARILY CORAEQPONO TO ACTUAL EQUATIONB WHICH BUPPOAT THE HYPOTHESLB IN THEIR ENTIRETY.

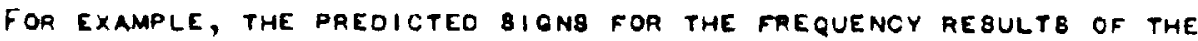
COOPERATION HYPOTHESIS WERE + CO $=$ POW. -OEV. ThE EQUATION FOR SIERPA LEONE

$$
-1.09 \mathrm{CFW}+.55 \mathrm{COW} \equiv .78 \text { Pow }+.70 \text { DEV. }
$$

INDICATEB THAT ALTHOUEH CON IB IN THE PROPER DIRECTION (AND THEREFORE INOLUDEO IN THE FREQUENCY OF 25 fOA the aCtuAl OIRECTION) POW.AND DEV. AAE NOT IN THE PREOIOTED DIREOTION. FOR THE CONFLIOT HYPOTHEBI8, ONLY DEV. 18 PREDIOTEO. AB MA BEEN BTATEO, NONE OF thE BTATUBHYPOTHEBEs AAE CONFIRMED TOTALLY, ANO WITH A CUT-OFF VALUE OF . 50 NONE OF THE BOCIALGFIELD THEORY HYPOTHEBEB ARE CONFIRMED. ?

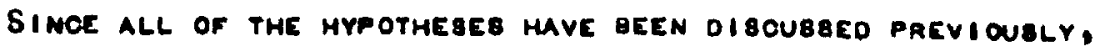
THEY WILL ONLY BE DIBCU88ED BRIEFLY NOW. THE FIRET HYPOTHESIB RELATES OOOPERATION AB A FUNCTION OF THE BIMILARITY IN THE ATTAIBUTES

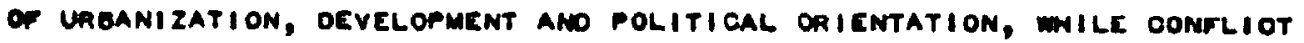

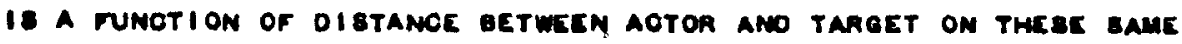

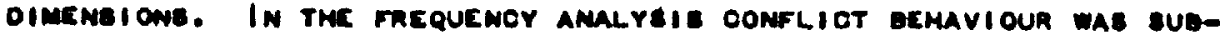
BtantIATEO IN CONNEOTION WITH DEVELOMAENT AND POLITIOAL ONIENTATION.

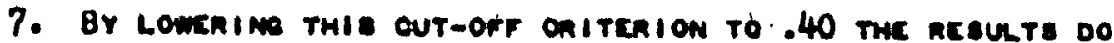

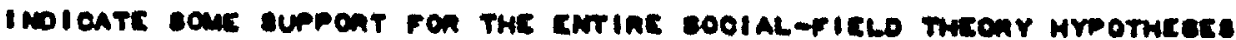

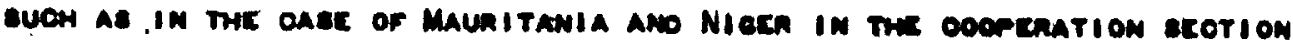
or The Limeac Hrootraseis. 


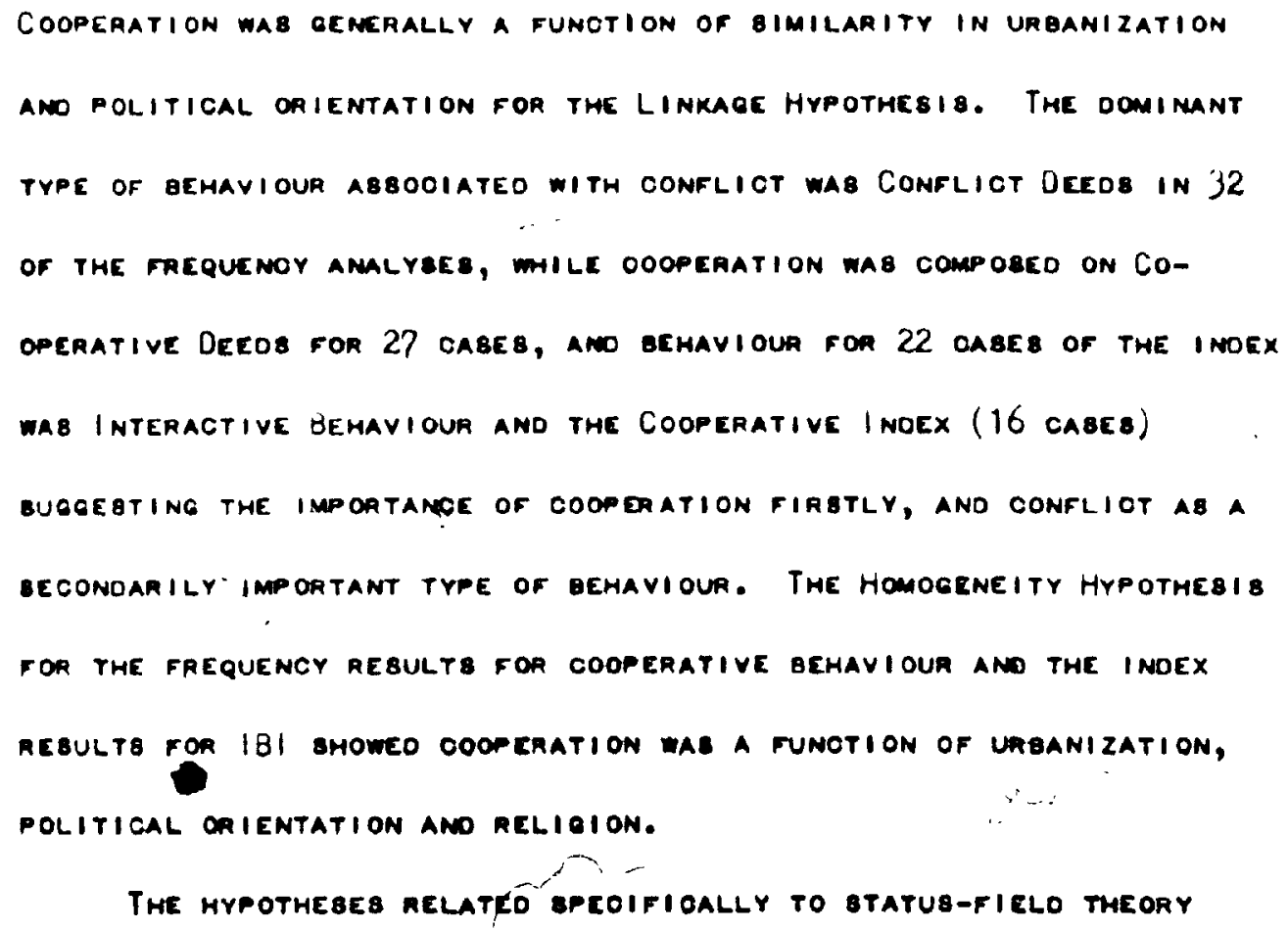


COOPERATION.

THE FOURTH HYPOTHESIS, THE EcCONO ITATUS MYPOTHESIS STATES THE MORE OIBTANCE BETWEEN ACTOA ANO TARERT AN OEVELOPMENT ANO THE MORE imilar in power, the mone these mitions eneace in conflict, mence

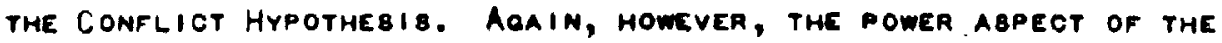
HYPOTHEBIS 18 NOT CONFIRMED, ANO THE RESULTB FOR THE REMAINDER OF THE HYPOTHEBIB ARE CONFIRMED FOR 40\% OF THE CAEE 8 FO THE FRLQUENCY AMALYBIB ANO 27\% FOR THE FREQUENGY ANALY8I8. IN ANOTHER U4D ANO $21 \%$ REBPECTIVELY a CQROLLARY TO THIS MYPOTHESIS APPEARB, BUCH THAT THE MOAE BIMILAR MATIONB AAT IN OEVELGMENT, THL LES8 OONFLICT GEHAVIOUR In WHIOH THEY EMBAOE. In A MAJOAITY OF THE UNEXPLAINEO OAEES, THE CONFLICT DIMEMSION EITHER IS RELATED MEQATIVELY TO ATTRIBUTE DIBtance, or the camonical correlation goefficient IB low.

THE REQULTS FOA THE FIMAL MYPOTHEBIS THAT THE MORE BIMILAR ARE THE ACTOR ANO TAREET IN POWER, THE MORE THEV EMGAEE IN BTATUE-

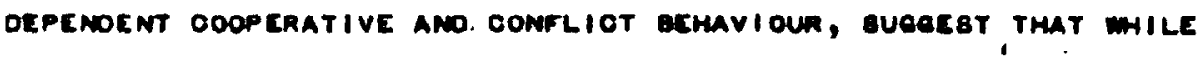
28\% OF THE ETATUS DEMAVIOUR FOR THE FREQUENCY AMALYIS OAgEB ANO $35 \%$ ron the inokx REaUlts WERE In THE PREOICTEO DIREOTION, POWER IMOQNORUEMOE DID NOT INFLUENOE BTATUS-OEPEMDENT OOOPEAATIVE AMD COAFLIOT DEHAVIOUR. THUS, THE nEBULTE COMPLETELY AEJECT THE StATUE Hrootmesis. $\checkmark$

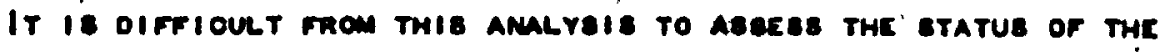

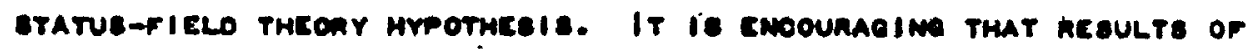

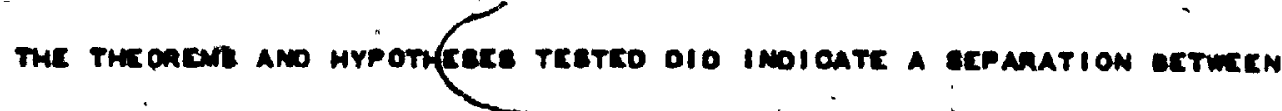

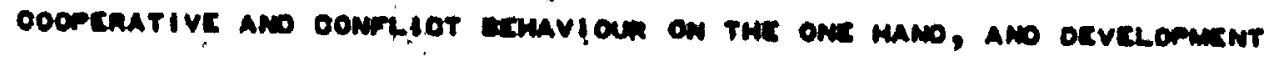


ON THE OTHER. HOWEVEA, THE HYPOTHEBEs WERE NOT CONFIRMEO FOR THE POWEA DIMENBION. IN PAEVIOUB REBEAROH ON THE RELATIONBHIP GETWEEN gehavioua ano ATtaigute dibtance, Rumael concluded that Relative BTATUB ON OEVELOPMENT ANO POWER OIMENBIONB EXPLAIN WE BTERN EUROPEAN plus deteraent behaviour for the Uniteo States dyad8. 8 homever, RHEE'B REBULTS CORREBPONO TO THOBE FOUNO IN THIB THEBI8, THAT I8 "THE joInt Values of ChINM'B cooperation ano conflict behavioua was OCTEAMINED MAINLY OY POWEA DISTANOE ALOME, OIO NOT HOLO UP IN THE

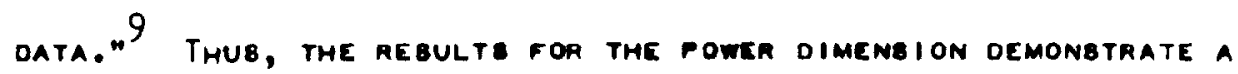
DIBADYANTAEE OF BTATUB-FIELO TMEOAY, THAT THE HYPOTHEBCS DO NOT EXPLAIN VARIATION IN BEHAY IOOUR FOR BLAOK AFRICAN STATES OY THE POWER DIMENEION AB WAB THEOAIZLO.

THE TRACE CORRELATION OOEFFIOTENTE WERE NOT AB HIOH FOR ALL THE BLACK AFRICAN MATIONB AB WEE EXPEOTEO. WHILC THE REQULTS FOR BOOIAL-FIELO THEORY WERE OEMERALLY ACCEPTEO WITHIN THE MATHEMATICAL ANO THEOAETICAL OONFINE OF FIELO TMEOAY, THE TRACE CORAELATIONB WERE

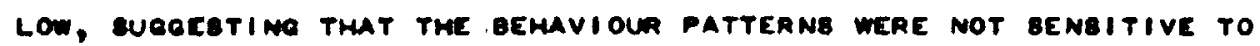
THE SHIT IN ATTRIEUTE DIBTAMOEB OETWEEN ACTOR AND TAREETS AMO THE

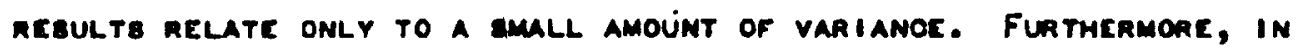
THE RESULTO FON THE STATUB TFIELO THEOAY HYPOTHEBEB, IT WAB OIFFIOULT TO INTERPRET WHIOH OF THE OAMONIOAL VARIATEB WAS THE MOST IMPONTANT.

8. R. RUmarl, mu.S. Foneion Relations," in Peace, Wan ano

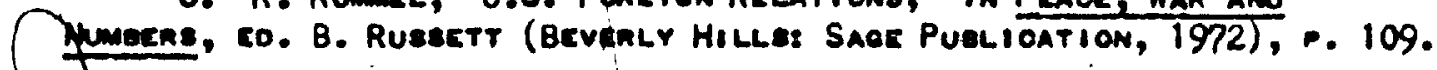

9. 8. Rhec, "Chima's Coopenation, Conmlot ano Intenaction Bemavioun," in advamolmo ano Contemoine Aprmoaghe to the Stuor of Cminese Foncion POLIOY, ED. R.L. Dial (Dalmoueie Univereitr: CENTRE Fon Fonelon PoLior 8Tuoice, 197/4), p. 176.

F 


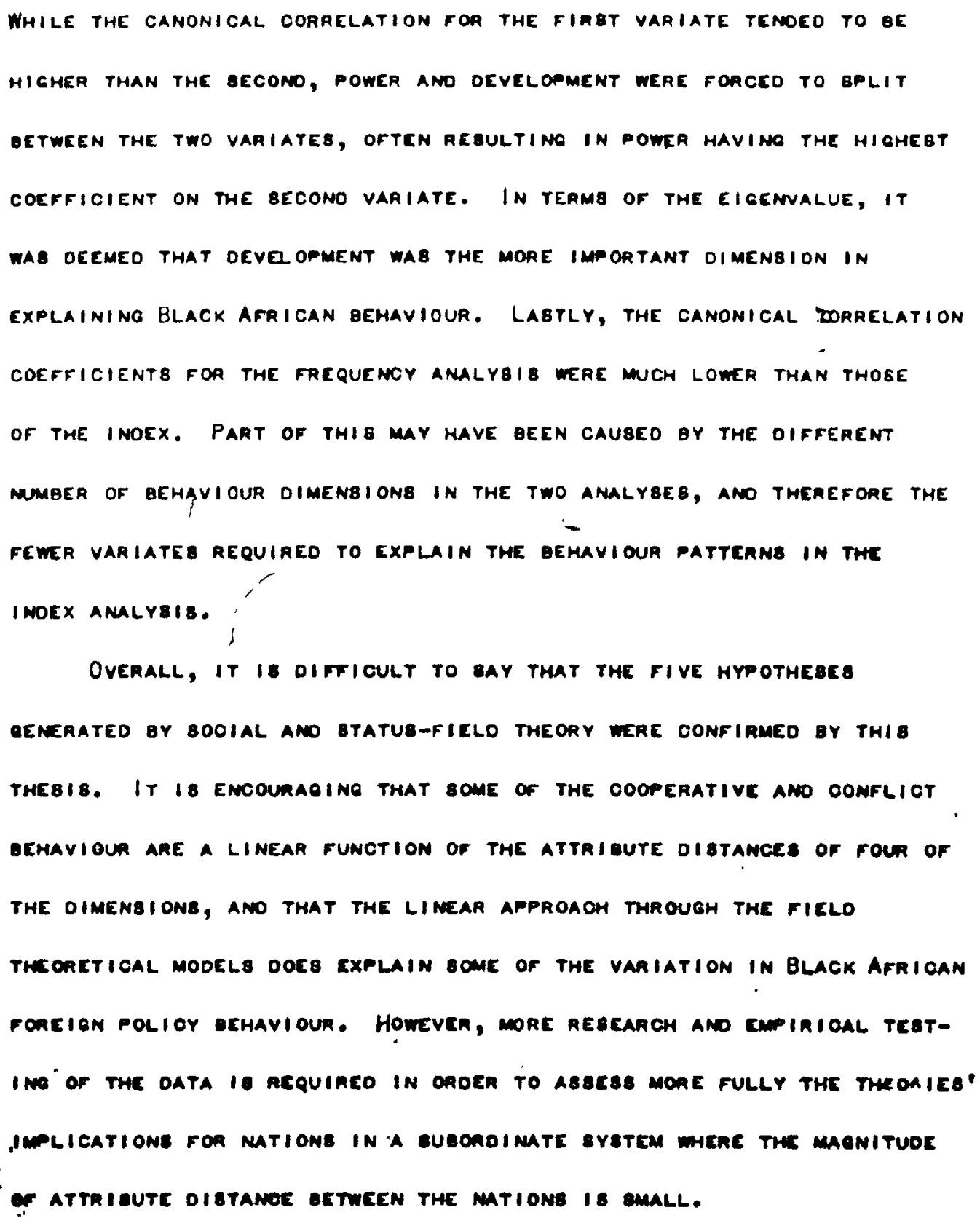




\author{
Chapter 6 \\ SUMMRY AND CONCLUSION: FIELO THEORY \\ AND AFRICAN FOREIGN POLICY BEHAVIOUR
}

THI8 THEBI G MAB PREBENTEO AN EMPIRICAL TEBT OF BOOIAL ANO 8TATUB-FIELO THEOAY. THE PUAPOBE OF ANY THEORY IB TO PREBENT A BET OF ABBUMPTIONB AT GOTH A HIOH LEVEL OF EENEAALITY, PAOVIDING THE "INNEA CORE" OF THE THEORY, AND A LOW fEVEL OF MOAE SPECIFIO HYPDTHEBEB. IN THIS WHESIB, THE EE HYPOTHESES WERE OEDUCED FROM AXIOMB DERIVEO FROA THE LITERATURE ON FIELO THEORY AND UNOERWENT TEBTB OF FALBIFICATION TO OETERMINE mETHER IN FAOT THEY CORAEBPONO TO REALITY. IN THI PARTIOULAR OABE, THE BLACK AFA IOAN MATIONB MEAE UBEO TO TE8T THE APPLICABILITY OF THEEE HYPOTHE8EB. AT THE BAME TIME, A REPLIOATION OF BIMILAR BTUDICE me CAARIEO OUT EMPLOVINO DIFFEREMT DATA TO HYPOTHE8ES TEBTEO PREVIOUSLY.

Fon a tmeony to de viagle, it must of aQLe to change as newER ANO BETTER THEONIEB EITHER ADO TO OA SUBSUm IT. FON BOCIAL ANO

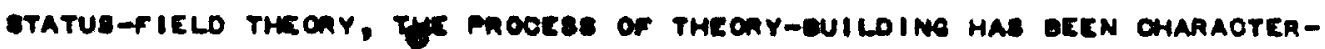

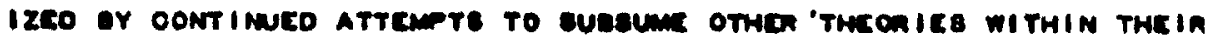
AxIOMTIO BTHUdTUE. SOOLAL-FIELO THEOA GCAN WITH INITIAL WOAK

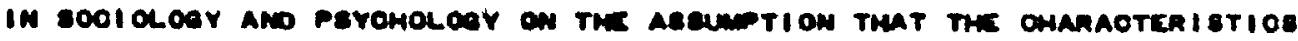

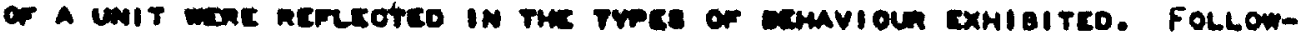

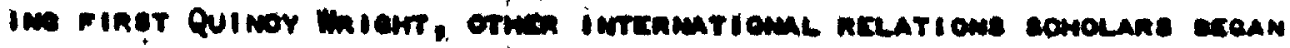


168.

TO EXPAND FIELO THEORY FOOUBING ON THE ATTRIBUTE8 OF MATIONB ANO FOREION POLICY BEHAVIOUR. RUDOLPH RUMALL EMPLOYED THE HEURIBTIO QUALITIEB OF SOOIAL-FIELO THEONY TO OEVELOP A METHODOLOQICAL APPARATUS TO TEST THE THEORY EMPIRICALLY OY ABSUMINE THAT THE DIBTANCE VECTOAS OF ATTRIBUTE BPACE FOA THE ACTOR ANO TAROET WEAE THE BOCIAL FOACE INFLUENCING THE FOAEION POLIOY BEHAVIOUR GeTWEEN MATIONB. THE FIELD IN WHIOH THIB BPAOE WAB LOCATEO WAB DEFINEO AB A EUOLIDEAN BPACE. THE LINEARITY AB8UMPTION OF THE RELATIONBHIP BETWEEN POINTB ANO VECTORB IN THIS SPACE ALLOWED THE INTERRELATIONBHIP AMONG POINTS TO BE REPREBENTED AB AMELEB. THE METHOD OF FAOTOR AMALYBIB PROVIDED THE LIMITB PLACEO ON BNACE IN TRAMB OF VARIABLEB DEBCRIBINO THE ATTRIDUTEg ANO EEHAVIOUR AMO MAY IN FACT hAVE PREOATEO THE MATHEMATIOAL ABsuMPTIONB OF EUCLIDEAN SPACE. 2

THE BEVEM AXIOMS OF BOOIAL-FIELO THEORY PROVIDEO THE LINKAOE BETWEEN THE BABIO THEORETIOAL OTATEMENTS, ANO THE METHOOOLOQY PROVIDLO

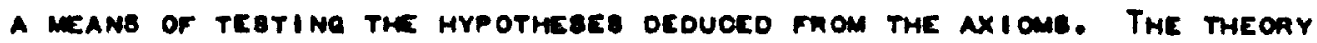

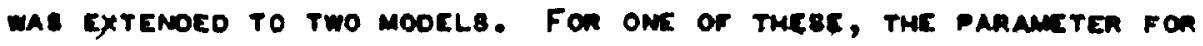
ATTRIBUTE DISTAMOC WAB THE BAME FOR ALL OYADS, MHILE A BCOONO MOOEL WAg AOLE TO EXPLAIN MOAE OF THE VARIANOE IN FONCION POLIOY OEMAVIOUR or THEEE VARYINO PARAMETERB.

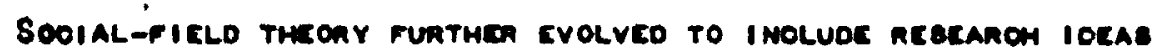

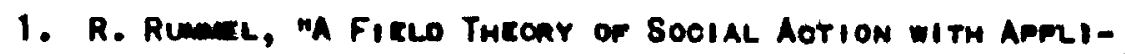
carion to Confliot WirHin Matioing," Gemenal Sveteme Yraneook 10 (19\%5).

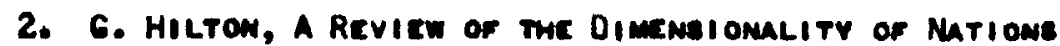
Pnoveot (Beventr Hillse Saer Puelioation, 1973), P. 16. Hilton

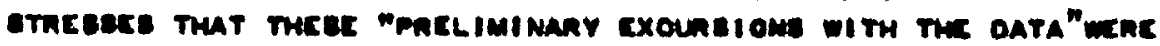

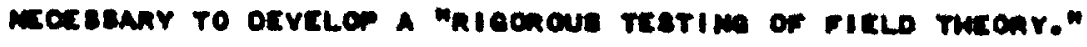


mopobeo or othea scholaho such as Joman galtung ano Maurice East

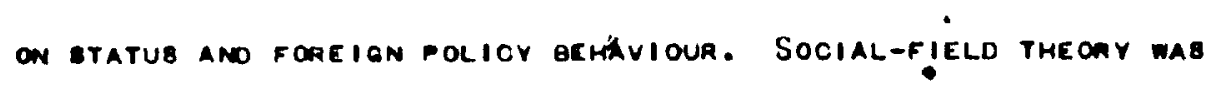

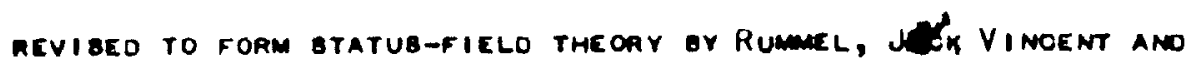
Sano-woo RHEe. The babio axiomatio ano mathematical Btructures were

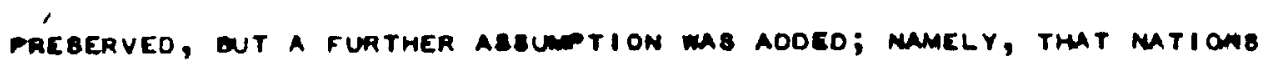
maY BE QROUPED into a sthatified bocial BYBtem, ano, "rupther that TME POWER ANO DEVELOPMENT ATTAIBUTE DIMENSIONB FOA OYADB PROYIOED THE EABIC VEOTOR DIBTAMCEB MHICH INFLUKNCE FOAEION POLIOY BEHAVIOUA. THE THEORY WAB DEBIOMED TO TAP STATUB AB THE AMALYTIC CONGTRUCT UBEO TO MEABURE A MATION'B RELATIVE LOCATION ON THEBE SPECIFIC DIMENBIONB. THE DIFFEREMCE BETWEEN THE LOCATION OF THE ACTOR ANO TAROET MAY LEAO

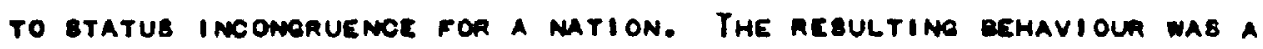
FUNCTION OF THIB INCONORUENCE, ANO A VARIETY OF VARIABLE ON BITUATIONB

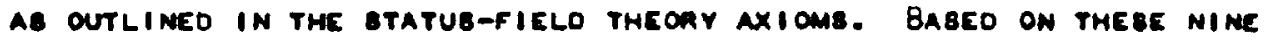
AXIOMB, RUMEL DEDUCEO THIRTEEN THEOREMS, MOST OF WHICH WEAE OISCUSSEO FrEviously, ANo bOME OF mHIOH wene testeo.

THIS THESIS ATtEMPTE TO REPLIOATE THE APPLIOATIONE OF BOCIAL AND ETATUS-FIELD THEONY UBING DIFFERENT DATA THAN HAO PREVI OUBLY CEEN EMPLOVEO, ANO TEETINO THE THEONIEB IN A CONTEXT PAEVIOUSLY

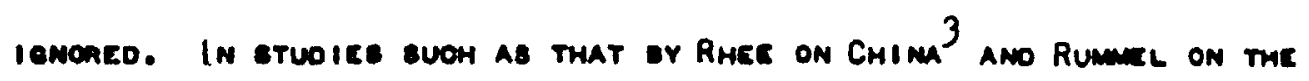

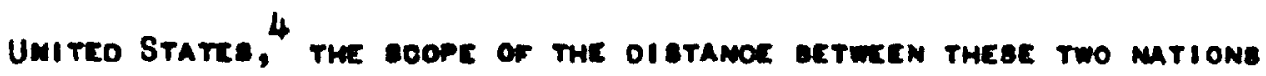

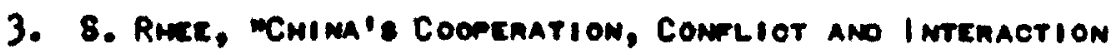

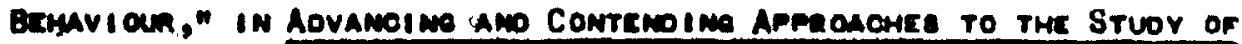

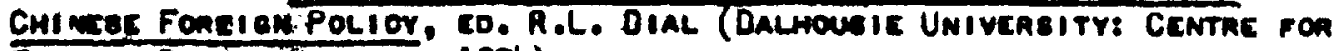
Foneian PoLior Btuoles, 1974).

4. 'R. Rumel, MU.8. Foneion Recationez" in Peaes, Wan amo

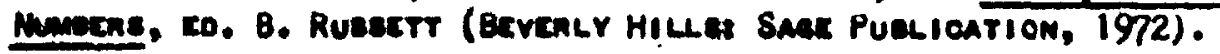




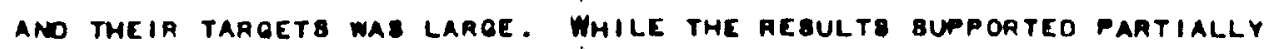
bocial ano bTatus-fielo theopy, one does not knOW IF the theory ACCOUNTEO FOA BEMAVIOUR IN OMRY THOEE OYADS IN WMICH THEAE WERE LAREE ATTRIBUTE DISTANCEB, OR MHETHER THE THEORY CAN AL8O ACCOUNT FOR DEMAVIOUR IN MORE BVMETRIO DYADB: THAT IS, DOEB THE THEORY AOOOUNT

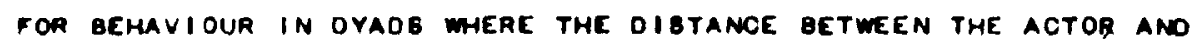
TARGET IS SMALL, OR IS THIS THE COAE AREA IN WHICH UNEXPLAINEO VARIANCE 18 CONCENTRATED? THIS THEBIS MMOE CERTAIN THAT IN FOCUBINO ON BYMAETAIC OYAOB, ACTORB EVIOENCEO INTERACTION IMPORTANCE. THERE WAB LITTLE BENBE IN ATTEMOTINO TO DIBCERN PATTERNB OF RELATIOMEMIPB BETWEEN ATTRIBUTE DIBTANCES ANO BEHAVIOUR MEN MO INTERAOTIONB TOOK MLAOE ON FOR OYAOS IN WHIOH INTEAACTION WAB OF RELATIVELY LOW IMPORTAMOE. THEREFOAE, A REOIOMAL FOOUS WA CMOSEN. FROM mREVIOUB LITERATUAE ON THE SUBSYBTEM, IT WAS ABSUMEO THAT MATIONB IN REGIONB REOAAO THE REGION AB AN IMPOATANT BUEBYETEM OF FOREION POLICY BEHAVIOUA.

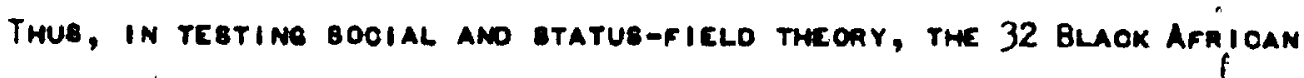

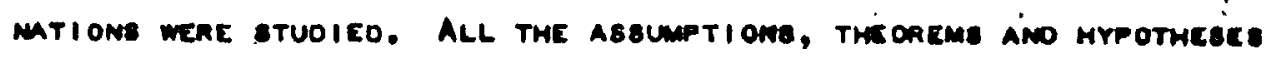
REMINED INTACT, ANO THE METHOOOLOQV EMPLOYED IN OTHER STUOIES WAS WECD TO OOMPARE AEQULTO.

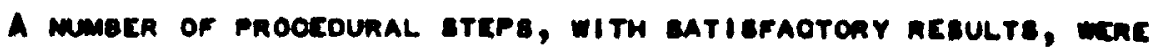

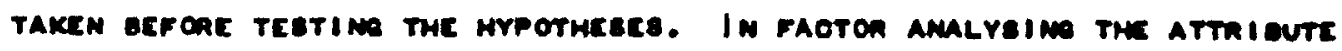

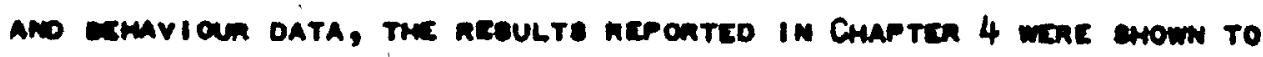

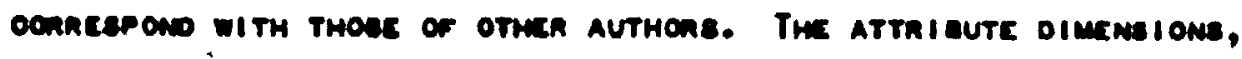

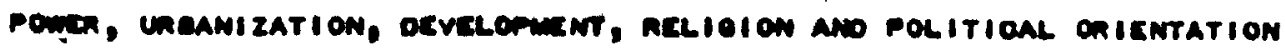

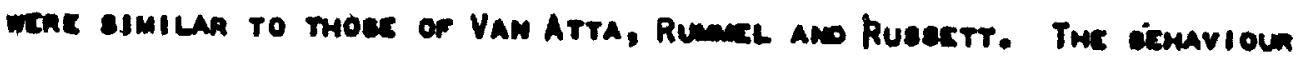


FAOTÓ DIMENGIONB WEAE NOT AB APPARENT AB THE ATTAIBUTE DIMENBIONB, NOA WERE THEY AB APPANENT AB THOBE OBTAIMED BY OTHER AUTHOR SUCH,AB C. Keoler ano R. Van Atta. Howevea, aftea inbecting the acoults of

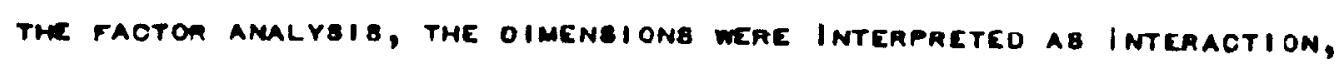

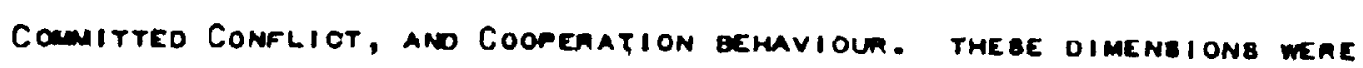
- imilar to Status Conflict ano Cooperation behavioupl oiscusged in BTATUB-FIELO THEOAY THEOREMB, ANO WERE BIMILAR TO THOBE DETAINED BY S-w. RHEE. 5 BABED ON THE

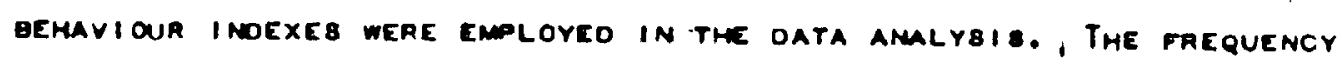
AMALYSIB WAB, COMPARABLE TO PAEVIOUB BTUOIES BUCM AS THAT OY VINCENT ET AL, 6 WHILE THE BEHAVIOUR INOEX AMALYBIS WAB UTILIZEO AS AN INOICATOR OF THE EMPHABIS PLACEO ON CAOH DEHAVIOUR TYPE OY IMOHVIOUAL ACTOR8. THUS, THE BABIC CONBTRUOTS WERE VIABLE TO THE EXTENT THAT THE BEHAVIOUA ANO ATTRIBUTE DIMENBIONB CONGOAM TO REBULTE PAEVIOUBLY Founo.

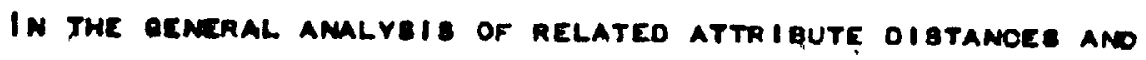
ocmavioun, OERTAIN PATtERMS OF RELATIONBHIP EMERGED FOR DIFFERENT

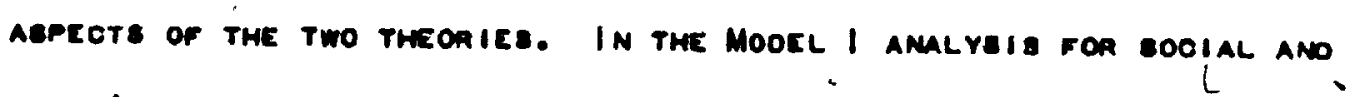

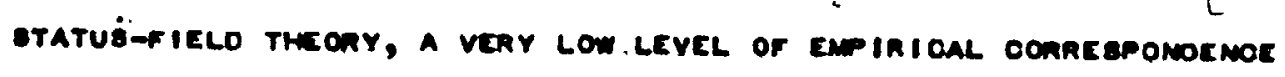

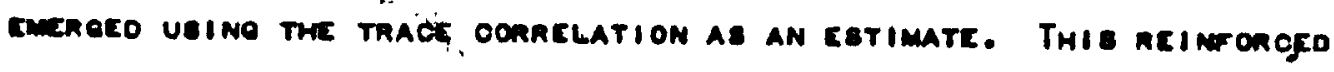
mevious finoInos mion suenceteo THAT THE MOET OEMERAL LEVEL OF

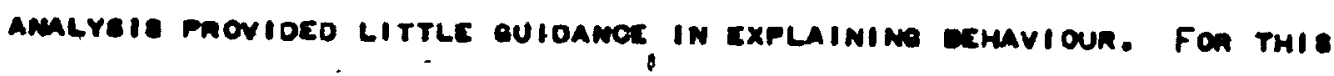

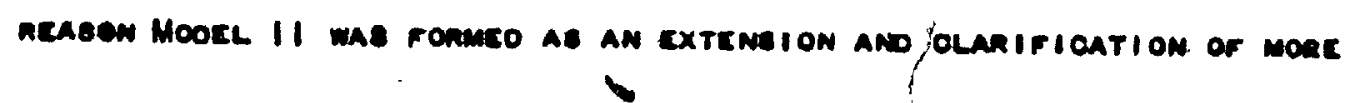

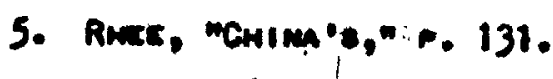

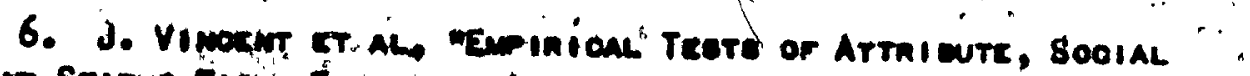

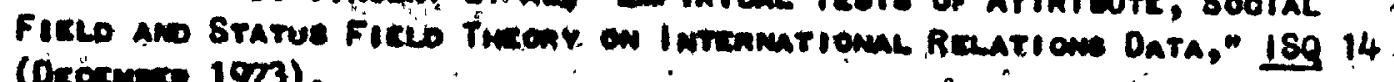
(0)ocmen 1973). 
OI8TINCT RELATIONB BETWEEN ATTRIBUTE DIBTANCE ANO BehaVIOUR. HOWEVER,

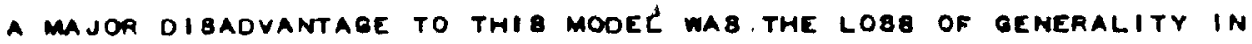
EXPLAINING FOREIGN POLICY BEHAVIOUR BY ATTRIBUTE DIBTANCEB ACROB8 ALL NATIONB IN ONE ANBLYBIB.

THE REBULTB FOR THE FREQUENCY ANO BEMAVIOUA INOEX AMALYBIS FOR BOCIAL-FIELD THE OAY DIFFEREO, WITH THE LATTER MAVING MUCH HIOHER average trace correlations. The imoividual canonical correlations WERE NOT AB BIGNIFICANT AB EXPECTED, WITH THE EXCEPTION THAT THE INOEX RESULTB WERE MOAE BTRONGLY BUPPOATED WITH HIOHER CORRELATION COEFFIOIENTB." THE MAJOR FORM OF BEHAVIOU PAEDICTED FOA THE FREQUENOY AMMLYBIB WAB OONFLICT, MOST OFTEN ABSOCIATEO WITH UREANIZATION ANO POLITHCAL ORIENTATION. FOR THE GEMAVIOUR INDEX ANALYIIB, POLITICAL ORIENTATION plaYeo a major role in contributine to conflict behaYiour. The uRBanIZATION AND DEVELOPMENT DIMENBIONB DIO NOT APPEAR TO BE AE STRONG AS MYPOTHE BIZED OY BOOIAL-FIELD THEORY. RATHER THAN EXPLAIN COOPERATIVE DCHAVIOUA AS PREOICTEO IN THE BECONO HYPOTHEBIB, OONFLICT WAB AB8OCIATED WITH DIBTANCE ON THEBE. ATTRIBUTE DIMEABIONO. ONLY IN THE CABE OF UREANIZATION FOR THE FREQUENOY ANALVBIB ANO POLITIOAL ORIENTATION FOn THE INDEX AMLLYIB DID DOOPERATION APPEAR AB AN IMPORTANT FORM OF ocmuviour.

THE ELOONO MAJOA EROTION OF THI ETwOY WAB TO EXAMIML TME

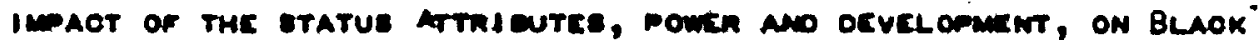

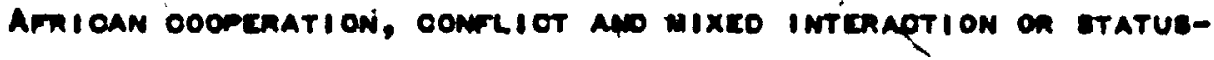

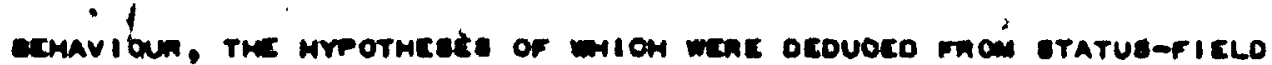

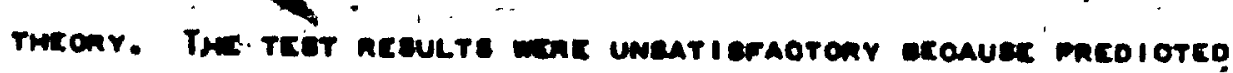




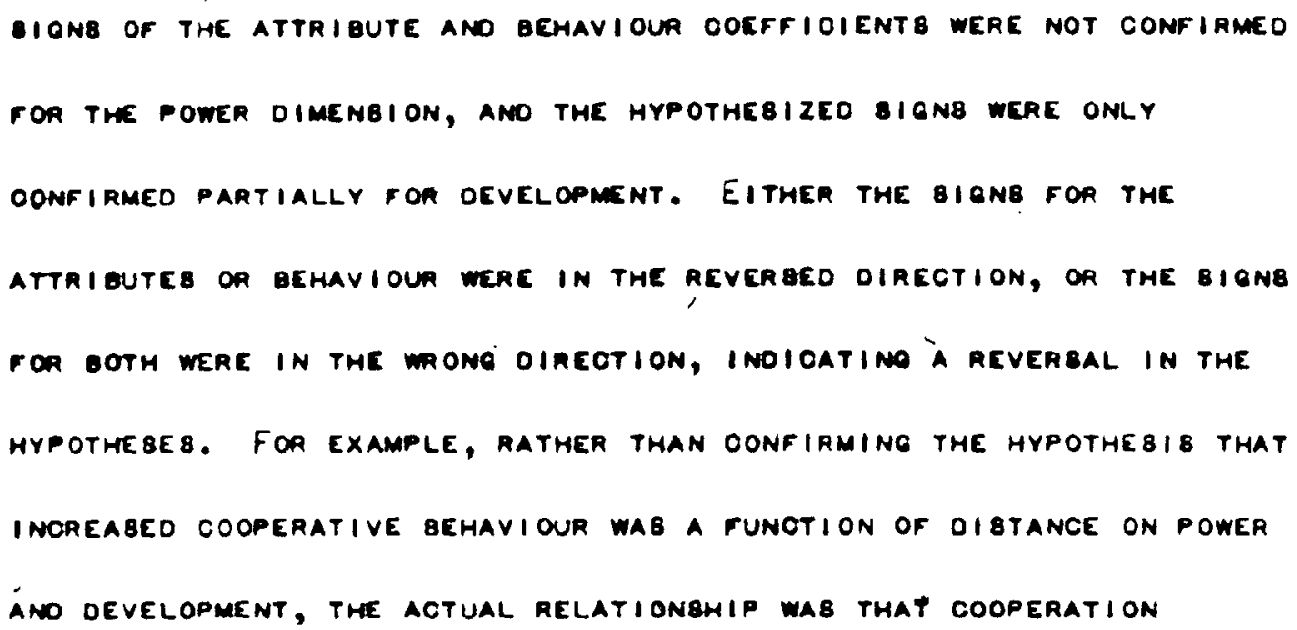

THE FIRBT COOPERATION HYPOTHEBIS ENCOMPABBED EITHEA CONFLICT EEHAVIOUR IN THE OABE OF THE FREQUENCY AMALYsis, On A MIX OF CONFLIOT ANO INTERAOTIVE EEHAVIOUR IN THE INOEX AMALYBIB. ALTHOUEH BIMILARITY

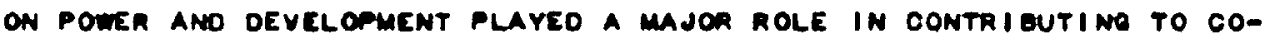
OPERATIVE BEHAVIOUR, OMLY DEVELOPMENT WAS IN THE PREOIOTEO OIREOTION,

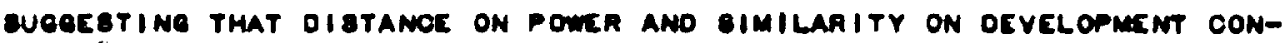
TRIButio positively ro coopchative intenaotion.

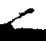

CONFLIOT hYPOTHEOIS TMAT BLAOK AFHIOAN

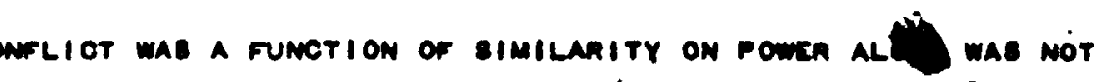

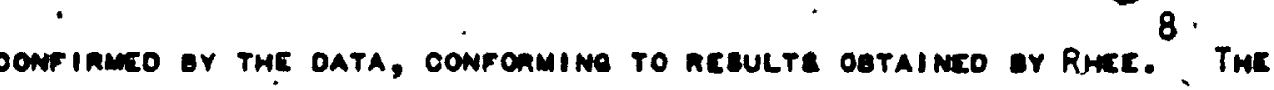

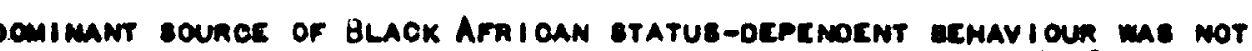
i.

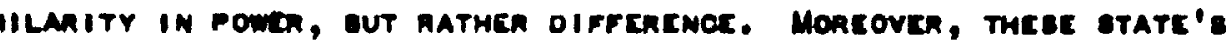

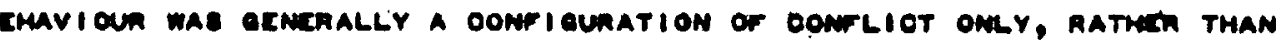

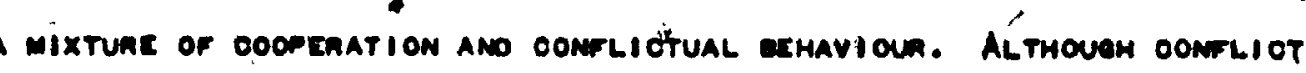

8. Rerer, "CHIMn'e," .. 176 . 


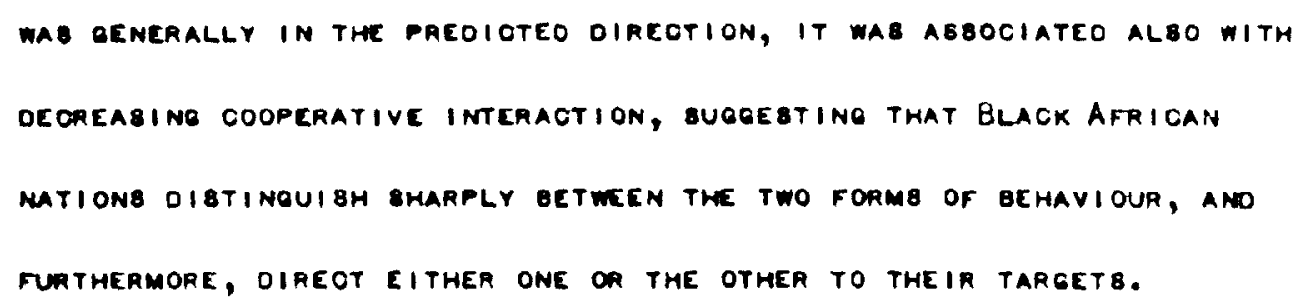


LITEAATURE IT WAB KNOWN THAT THEBE MATIONB CONBIOER OTHEAB IN THE REQION TO GE IMPORTANT FOR INTERACTION. HOWEYER, BOCIAL ANO BTATUBFICLO THEORY DIO NOT APPEAR ENCOMPABBINE ENOUOH TO MONITOR THEBE BMLL ATTRIBUTE OIFFERENCE 8 BETWEEN MATIONB, OR AT LEABT IN THE DIRECTIONB PREOICTEO BY THE THEORIEB. WHAT IB REQUIRED IB MOAE PAECIBE AXIOMS DIFFERENTIATINO BETWEEN MATIONB ANO AXIOMB TO MONITOR - the most minibcule changes in atraloute distance. While the btatusFIELO THEORY WAS ABLE TO DO THIB FOR THE DEVELOPMENT DIMENBION, BEHAVIOUR WAB LEFT UNEXPLAINEO EY THE POWER DIMENBION.

$$
\text { FIMALLY, ALTHOVEH FIELD THEORY REQUIREB THE FACTOR AMALYBIB }
$$

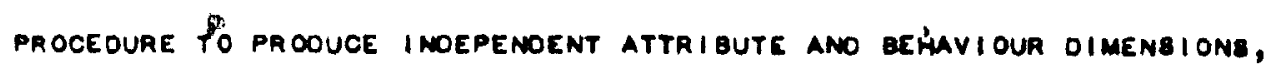
THE OPERATIONAL ADEQUACY OF THE BLAOK AFRIOAN BEMAVIOU, maY OE, ORITICIZEO. HHILE THE ATTRIBUTE DIMENBIONB OQTAINED WERE WELL WITHIN THE REQUIREMENTS PF BOCIAL AND BTATUB-FIELO THEORY, THE BEHAYIOUA OIMENBIONB WERE DIFFICULT tO INTEAPRET." FIELO THEORY BTRICTLY DICHOTOMIBES BEMAVIOUR AS OONFLICT ANO COOPERATION, WITH NO ABQUMPTIONE OR THEOREMB OONCERNING BEMAVIOUR OUT8IDE THE8E CATEBORIES, OR A MIXTURE OF THE TWO INTO ONE DIMENBION. THEREFORE, WHLE THE DIMENBIONB IN THIB THEBIS WEAE LABELLEO, THEY WEAE, NOT DEFINEO AS OLEARLY AS THOSE IN THE THEOAIES. FON EXAMPLE, ComaltTEO Confliot was composeo

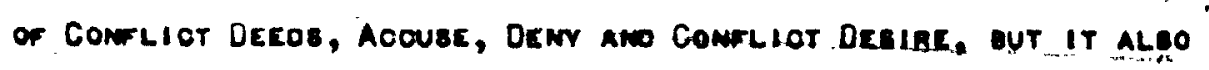

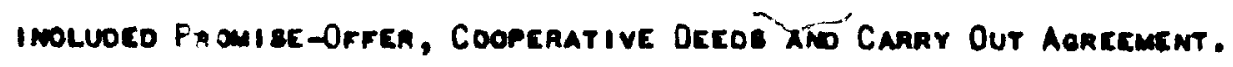

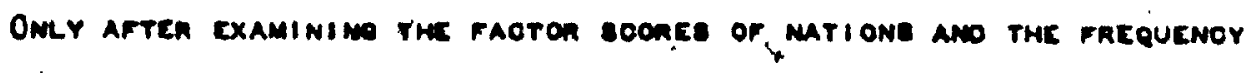

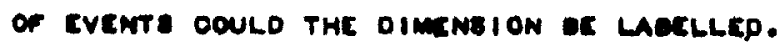

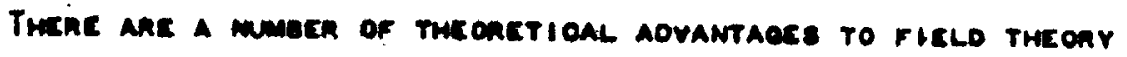

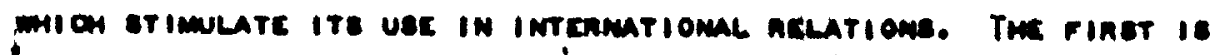
- 
THE CONCEPT OF "FIELO" ITBELF. DEFINED AB a EUCLIOEAN MAOEOITH NATIONB AB POINTB ANO VARIAGLES AB VECTORB, THE FIELO PROVIDEB A CONFIGURATION DEMONBTRATING THE INTERAELATIONBHIP AMONO VARIABLEB ano mations. Seconoly, the field 18 exhaugtive. That 18, hehaviour 1. A FÚNCTION OF THE INTENBITY OF FIELO FORCEB, WHICH 18 THE OOMEINATION OF ALL ENVIAONENTAL CONOITIONB UNOER WHICH LEAOERB MAXE OECIBIONB ABOUT THE MATION'B POLICY. MOREOVER, THROUGH ITB MATHEMATICAL FRAMEWORK, FIELO THEORY LOOKS AT THE AOTUAL DISTANCE BETWEEN THE AOTOR AND TAREET TO EXPLAIN WHY ANO HOW THEBE DIBTANOEB INFLIJENCE gemavioua, ano mhy yarying oI THUB, BEMAVIOUR MAY BE DETERMINEO PREGIBELY BY ACTUAL BIMILARITIES EETWEEN MATIONB, anO maY OE INOLUDĆO WITHIN A LAREER CONTEXT. THIS THEB I8 IS AN EXAMPLE OF REBEARCH TAKING DIFFERENT HYPOTHEBEB ANO IMOORPOAATING THEM INTO FIELO THEOAY. IN OROER TO OBTAIN A ClEARER UNDERBTANOINE OF BTATUB-FIELD THEOAY, AXIOMB ANO PROPOBITIONB FAOM THE THEORY WERE TEBTEO. IN AOOITION, ABBUMPTIONB RELATINO REOIONAL EemaVIOUR TO MATIONB' PERCEPTIONB OF THE REQION AB AN IMPORTANT 8PHERE OF INTERACTION WERE UEEO TO TEBT THE APPLIOABILITY OF OOTH BOOIAL AND etATUS-FIELO THEORY IN THIB CONTEXY. THEAE AAE, MOAEOVER, OtMER TYPEO OF "MIDOLE-RANGE" THEORIES WHIOH MAY AE INCORPORATED INTO THIB

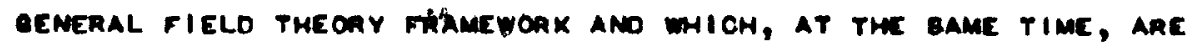
EXTEiva IOND of THE THCONY.

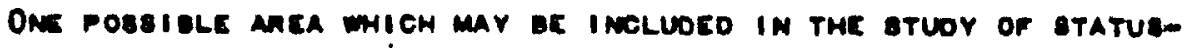

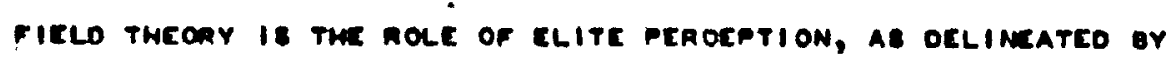
RUMmEL' ELITE docnoLLANY, "A MATION'S ELITE IOENTIFY WITM TMEIA RANK 
$\sin ^{\circ} \quad$

ano Btatus cónflouation." 9 While human gemaviour is conoitional on ENVIROMMENTAL BITUATIONB, THE MUMAN' POSITION PN THE ENVIROMMENT ALTERB HIB PERCEPTION OF IT. IT 18 ONE THTNO TO OAY THAT THE ENVIRONMENTAL FACTOAB INFLUENOE BEHAVIOUR OUT THI LINK 18 MEOIATEO

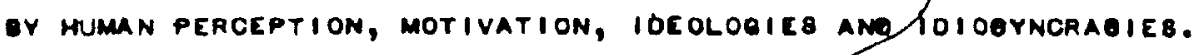
WHILE THE OIBTANCE IN POWER ANO ECONGMIIO OEVELOPMENT EETWEEN MATIONB may be preoloteo to relate to conflict behaviour, the leader of the RCTOA-MATION MAY PEACEIVE THAT THERE ARE BENEFITB TO BE OAINEO FAOM POBITIVE RELATIONB WITH THE TAROETIN ECONOMIC OR BEOUAITY AREAB, FOR EXAMPLE THEREBY FAOILITATINO AN EXOMANGE IN COOFERATIVE ACTB RATHER THAN CONFLIOT.

ANOTHER OONCEPTUALIZATION FOR ELABORATINO THE BTRUGTUAE OF

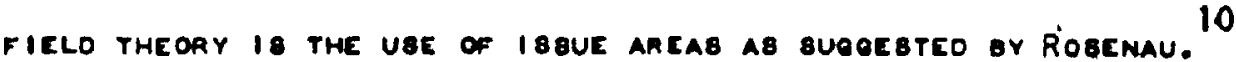
THAT 18, the actions of mations gluster arouno certaIn I DIFPERENCE IN CCONOMIO OEVELOPMENT, BIZE ANO POLITICAL OAIENTATION EFFEOT DEHAVIOUA IN OIFFERENT WAYS DEPENOINO ON THE IESUE. EACH

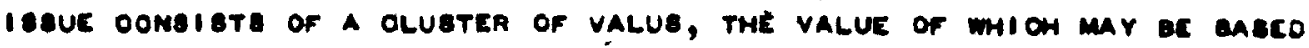
ON THESE ATTRI UUTE OONBIOERATIONB.

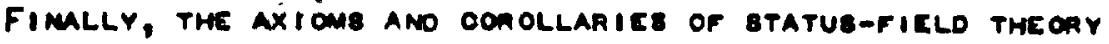

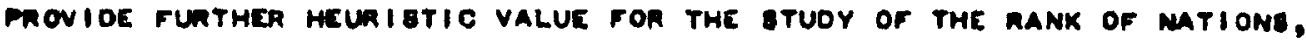

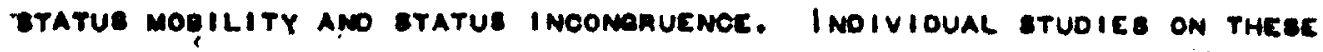
S.

9. 1810.,... 129.

10. J. Rosemau, "Pne-thronice ano Theonies in Foncion Polioy," in Apmoaghes to Combanative ano Intenmatiomal Politios, co. R. Farrell (Evanetom: Nonthmetienn, Univensitr Paces, 1966), P. 53.

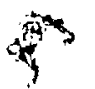


.8

TYPEB MAVE BEEN OARRIED OUT BY VARIOUS AUTHORS, BUCH AB GALTUNe,

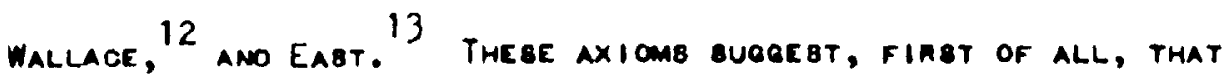
MMTIONB DEBIRE TO OAIN UPMARO MOBILITY ANO, CONBEQUENTLY A HIGHER 8TATUB. IF THEY POBBEB HIGH oTATUB ON ONE DIMENBION, BUT RETAIN A LOW BTATUS ON ANOTHEA, THEN THE MatION I8 IN A BTATE OF GTATUS DI8EQUILIBRIUM. MOREOVER, MHEN TWO NATIONB IN A DYAO maVE DIFFERENT - statub ranks ano they thembelves are statug olBequieibrateo, then btatus incongruence rebults. Once again, presuming that mational DECIBIONMAKERB PERCEIVE THEAE BTATUS OIFFEREMCEB, THE FOREION POLICY BEMUVIOUR OF THE MATION WILL OIFFER FOR OYADS DEPENOINE ON THE MATIONB WHICH ARE BTATUB INCONGRUENT ANO DIBEQUILIBRATEO, ANO WHICH DIMENGION, power on oevelomment, influemceb the behaviour eXomaneeo artween THEBE MATIONS.

JAOK VINCENT HAS PROPOBEO FALLACIOUSLY THAT THE REFINEMENT OF

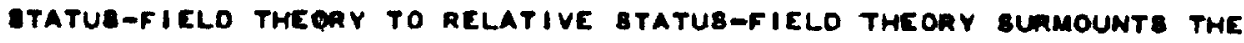

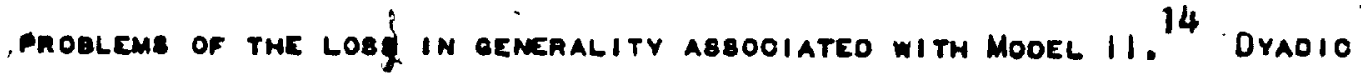
Ect anE PARTITIONED aOCORDING TO THE POBITION OF DYADE ON THE POWEA AMO ECONOMIO DEVELOOMENT OIMENEIONB ANO ARRAYEO INTO OOMFIQURATIOME -imilar to galtume's tT, TU, UT ano uU categorics. patterne of echavioun similar to all oyado in the pantition ghould emerak. While

11. J. Galtune, "A Stmuctumal Theopr of Acencseion, "JPR 2 (1964).

12. M. Mallack, "Status, Formal Onganization, ano arms levels ae Faotons Leaoine to the Ondert or War, 1820-1964," in PEace, WaA ano

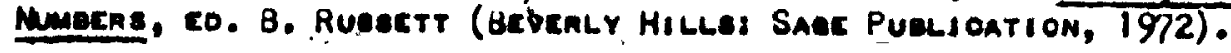

13. M. EAat, "Statue Disonemanor and Violenor in the I wTEA-

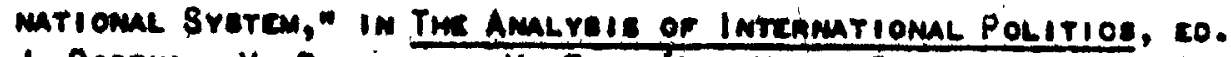

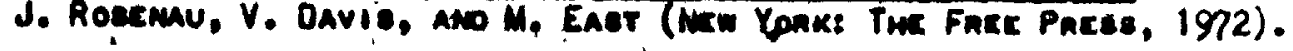

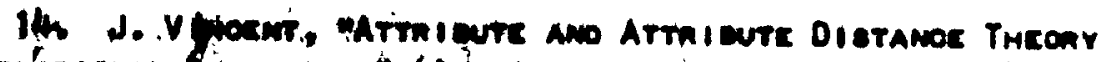

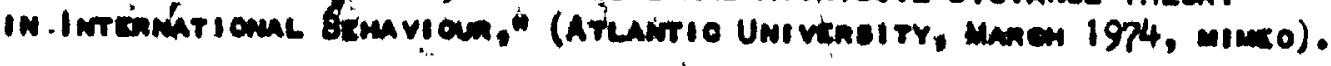


At FIRBT GLANCE THE PROPOBAL MAY BE haILED aB "A BtEP IN THE RIGHT DIRECTION," UPON FURTHER BCRUTIMY IT BECOME 8 APPARENT THAT IN PLACE OF MODEL 1'8 ONE OYADIO 8ET, BUCH A8 CANADA TO ALL OF IT8 TARQETB, VINCENT 18 BUGGEBTING THE PAATITION OF EACH DYAOIC BET BUCH THAT THERE ARE NOW FOUR PARTITIONED BET8. THU8, CAMAOA IB BTUDIED AB a TT TOWARDB ALL TAREETB WHIOH ARE DIBTANT FROM, ANO BELOW IT IN CCONOMIC DEVELOPMENT AND FOR THE TU PARTITION AB A TOPDOO ON ECONOMIC DEVELOPMENT AND AN UNDERDOG ON POWER VIB-A-VIS OTHER TARGETB, ANO SO ON. IN ACTUALITY THEN, THERE 18 AN EVEN GREATER LOBS IN GENEAALITY WITH FOUR TIMES THE OAIOIMAL OYADIO BETS TO ANALYSE.

Relative Statub-fielo Theony, however, remains as an heuristic VALUE IN THE CONCEPTION OF RELATIVE BTATU8. THAT I8, THE EXAMINATION OF OYADIO BETS THROUQH AXIOMS ANO THEOREMB BIMILAR TO STATUB-FIELO, BUT IN TERMB OF THE POBITION OF. "IE ACTOR'RELATIVE TO ITS TAAOETB.

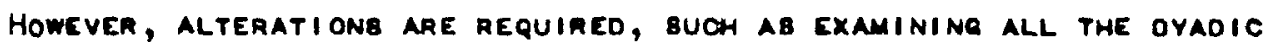

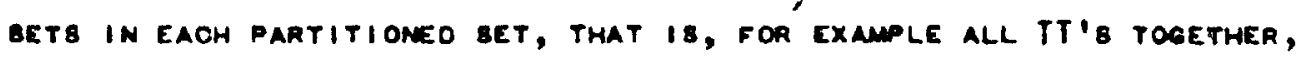
IN ONDER TO IMPROVE THE LEVEL OF OENERALITY WITHOUT A BUBAEQUENT OHANGE IN THE PARBIMONY OF THE THEORY.

THUS, THE THEORETICAL EXPANBION OF FIELO THEORY CEEME To be PROEREBBINO BTEAOILY FROM THE ORIOIMLL ATHEOAETICAL BEOINNINOS OF DOCIAL-FIELO thLOAY TO BTATUB-FIELD THEOAY ANO ON TO AOOITIOMAL.

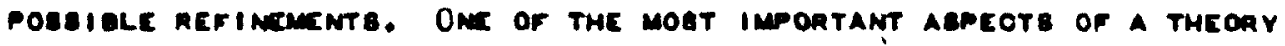

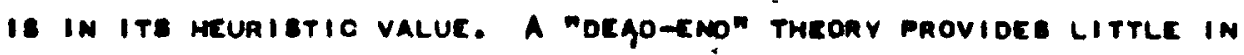

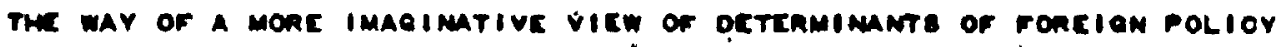

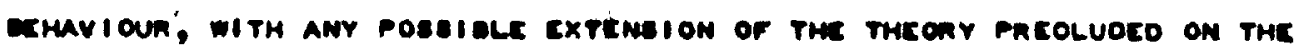


180.

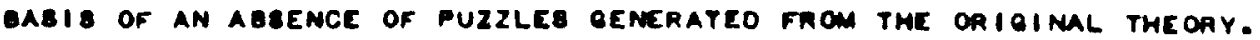
HOWEVEA, WITH A MEURIBTIO THEONY THE ORIOIMAL FORM MAY BC EXPANOEO OA MOOIFIEO TO CONFORM TO NEW FINOINGB AND DIRECTIIONB IN INTERMATIONAL RELATIONB. ALTHOUCH THE HYPOTHEBIZEO REBULTB IN THIS PAPEA WERE CONOLUBIVE ONLY PARTIALLY, IT EXPLOREO A PREYIOUBLY UNEXPLORED AREA OF APPLICATION FOR THIS BOOY OF THEORY. IN THIS WAY, ONE IS ABLE TO IMPROVE UPON THE EXIBTINO THEORIEE BY EXAMINING IN MORE DETAIL THE RELATIONBHIP BETWEEN BTATUS, ATtRIBUTE DIBTANOE ANO FOREION POLICY BEHAYIOUR AT A BUBBYSTEM LEVEL. IN THE REOION ATTRIGUTE DIBTANOEB DO EXI8T IN OYAOB ANO THE RELEVANCE OF THIB ANO BTATUB TO BEMAYIOUN MUT BE EXPLORCD MOAE FULLY TO DETEAMINE THE EXTENT TO WHICH BOCIAL ANO BTATUB-FIELO THEORY mAY BE APPLIEO TO NATIONB ANO BVBTEMB OUTEIDE AN INTERMATIONAL BYBTEM PERBPECTIVE.
\end{abstract}


omfta

onmanonm-ogn-no-n-nNmonghomminnm

-

oOำ

om-o-mngooz=hg- - maNmooto

onnm

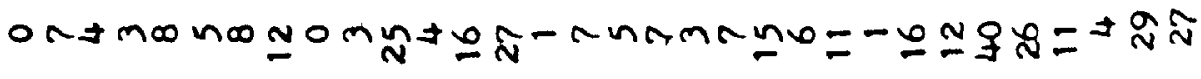

on

N

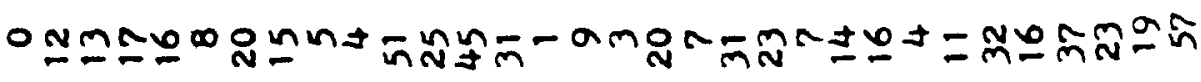

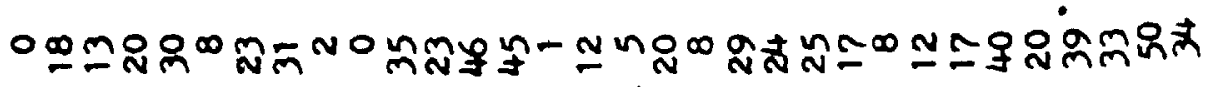


182.

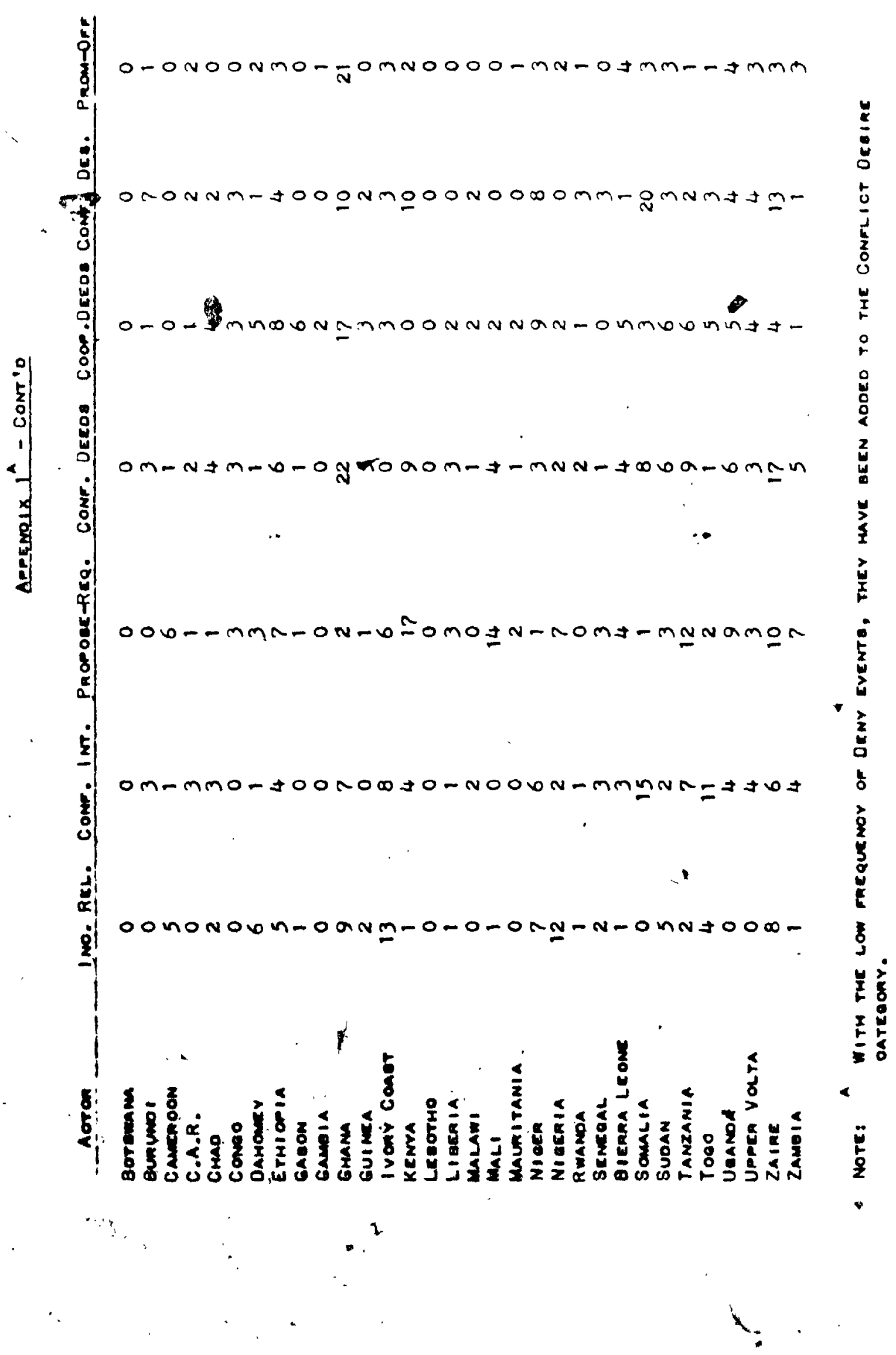




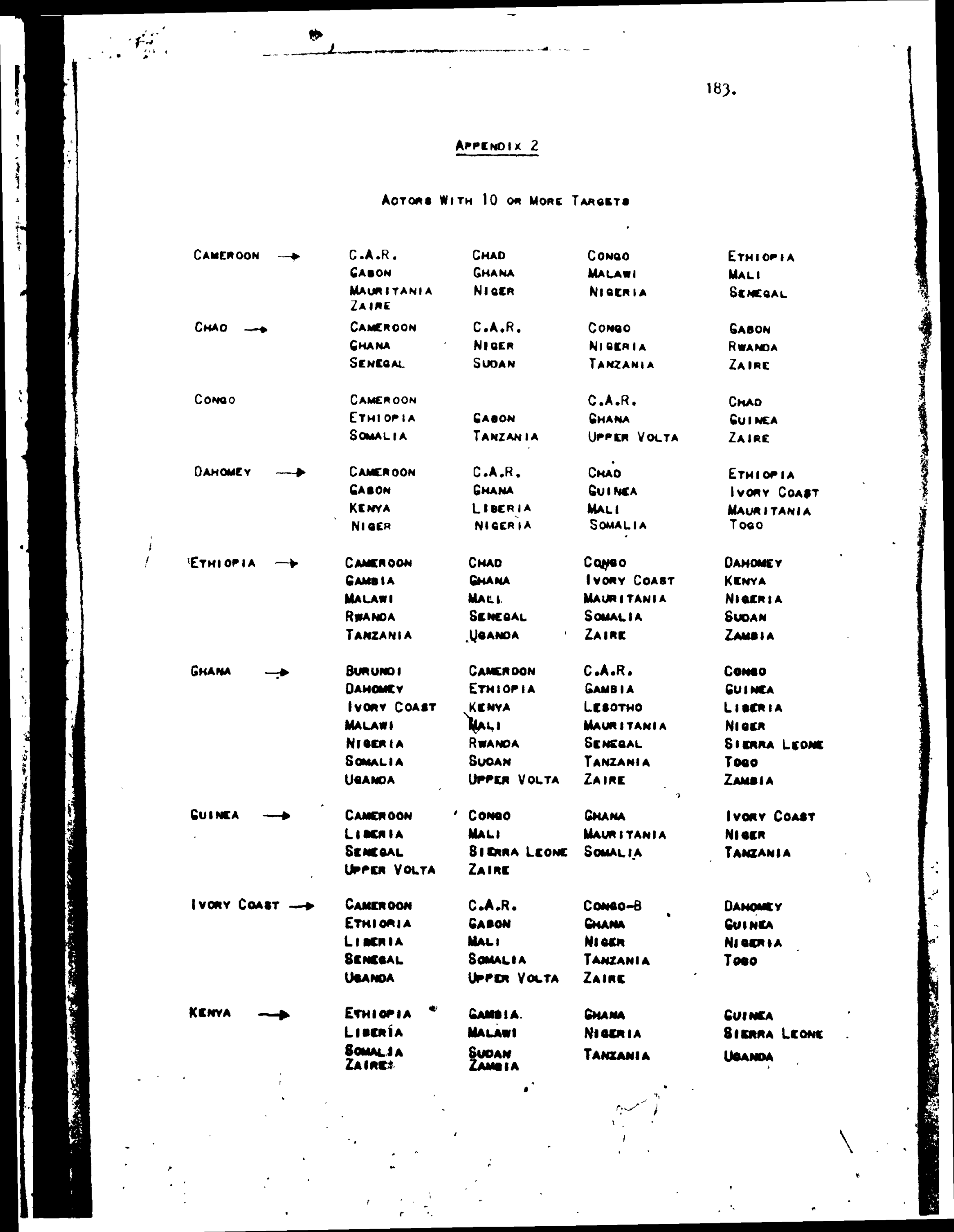




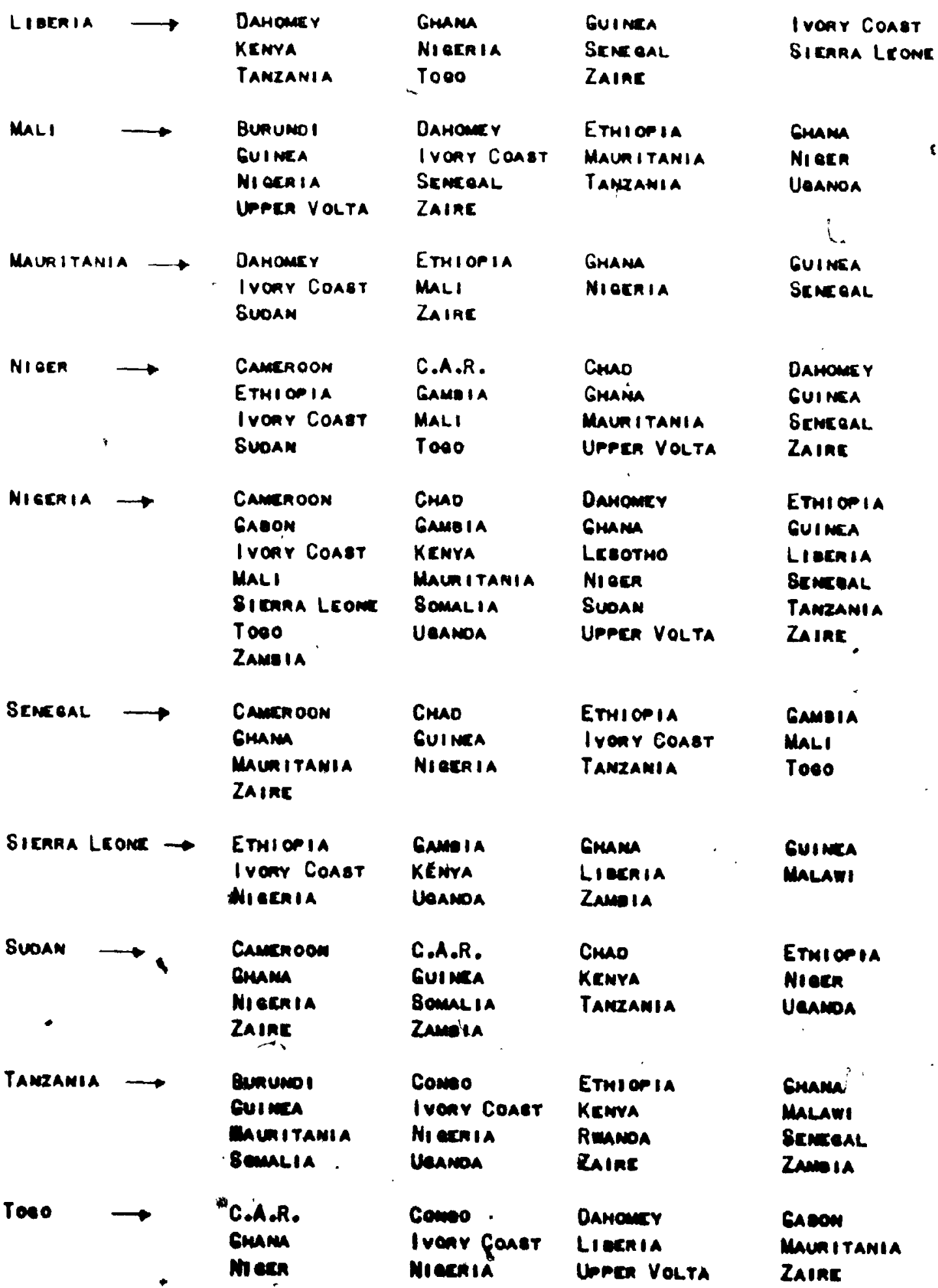




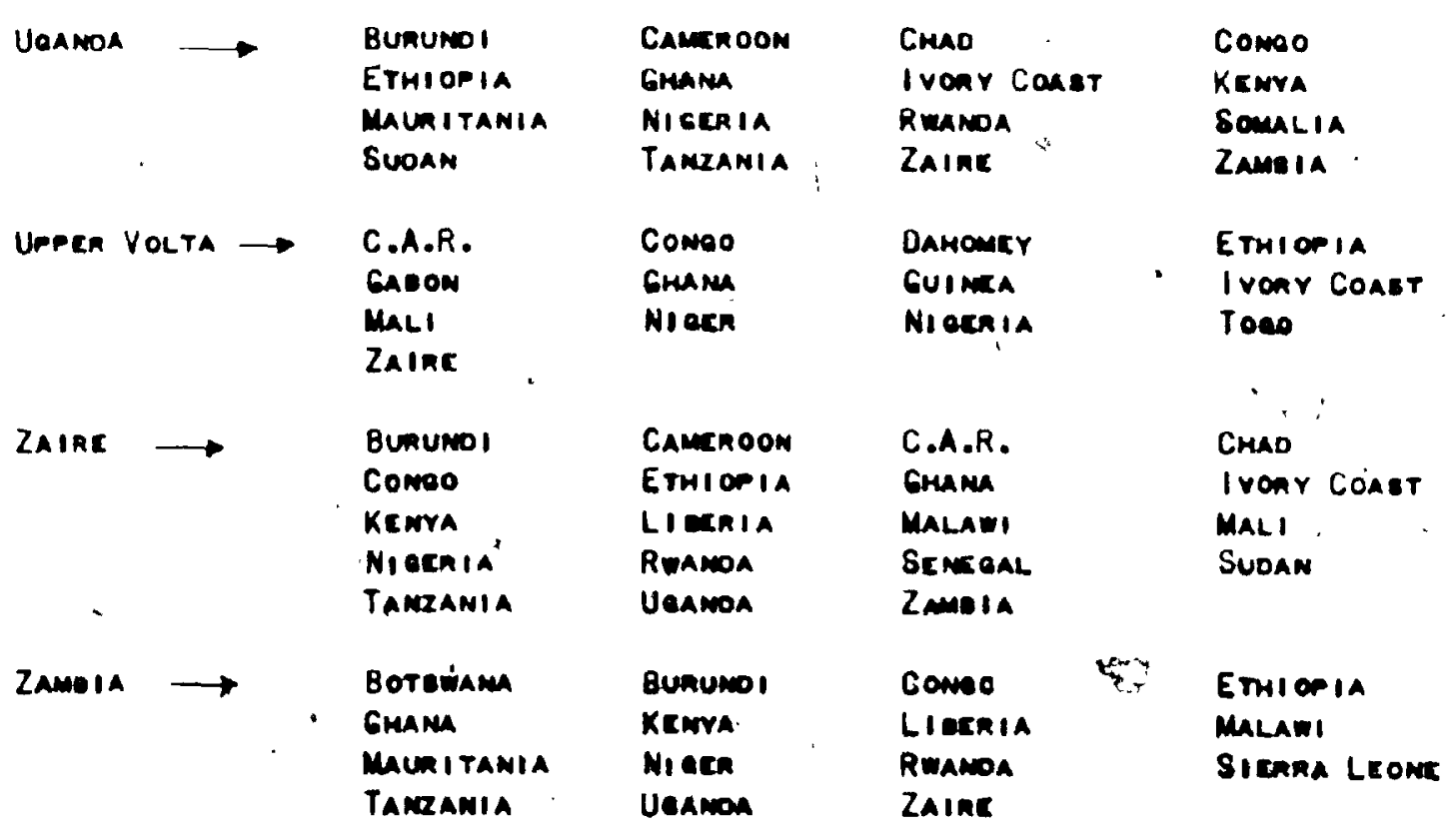

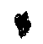
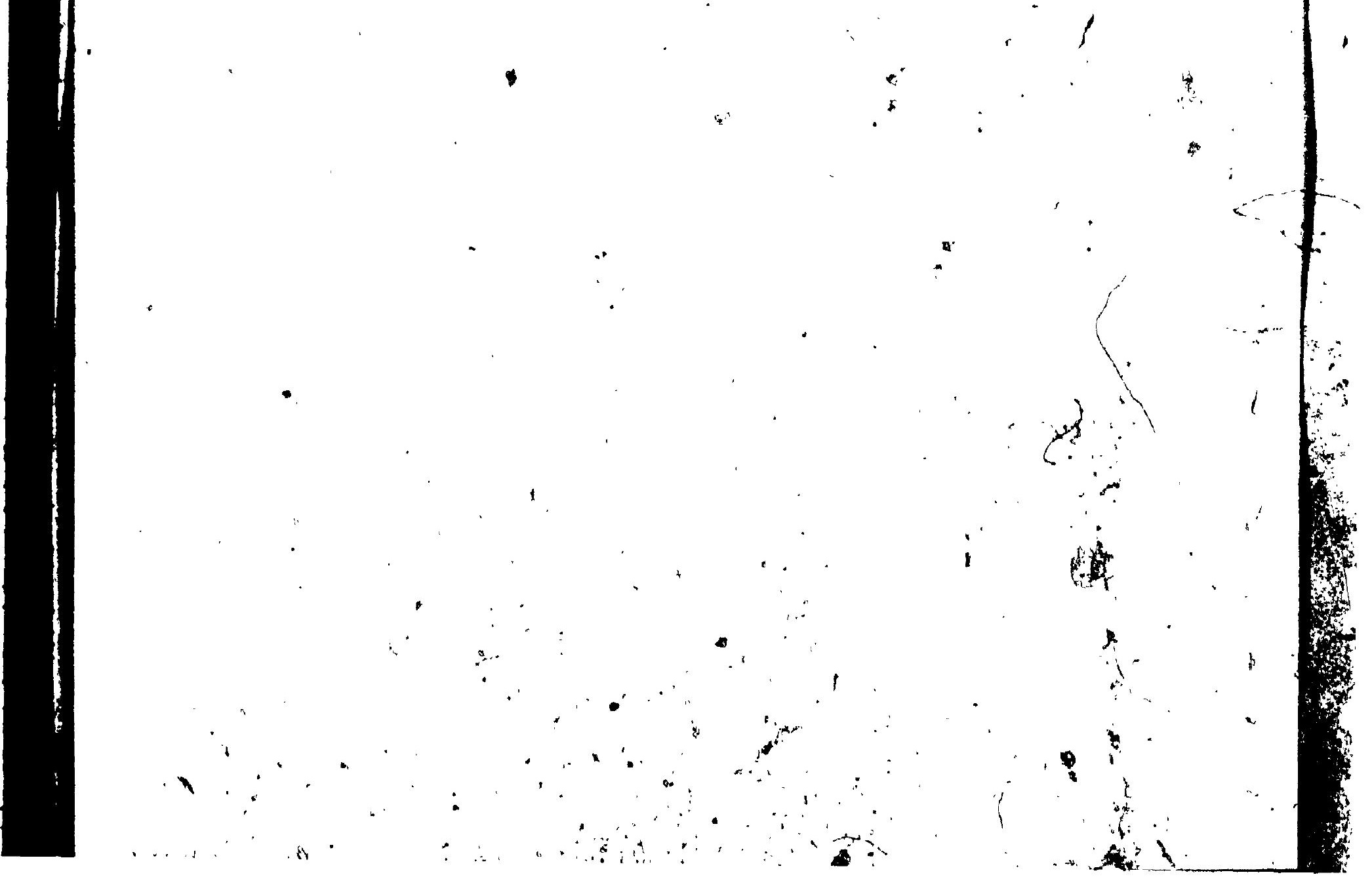

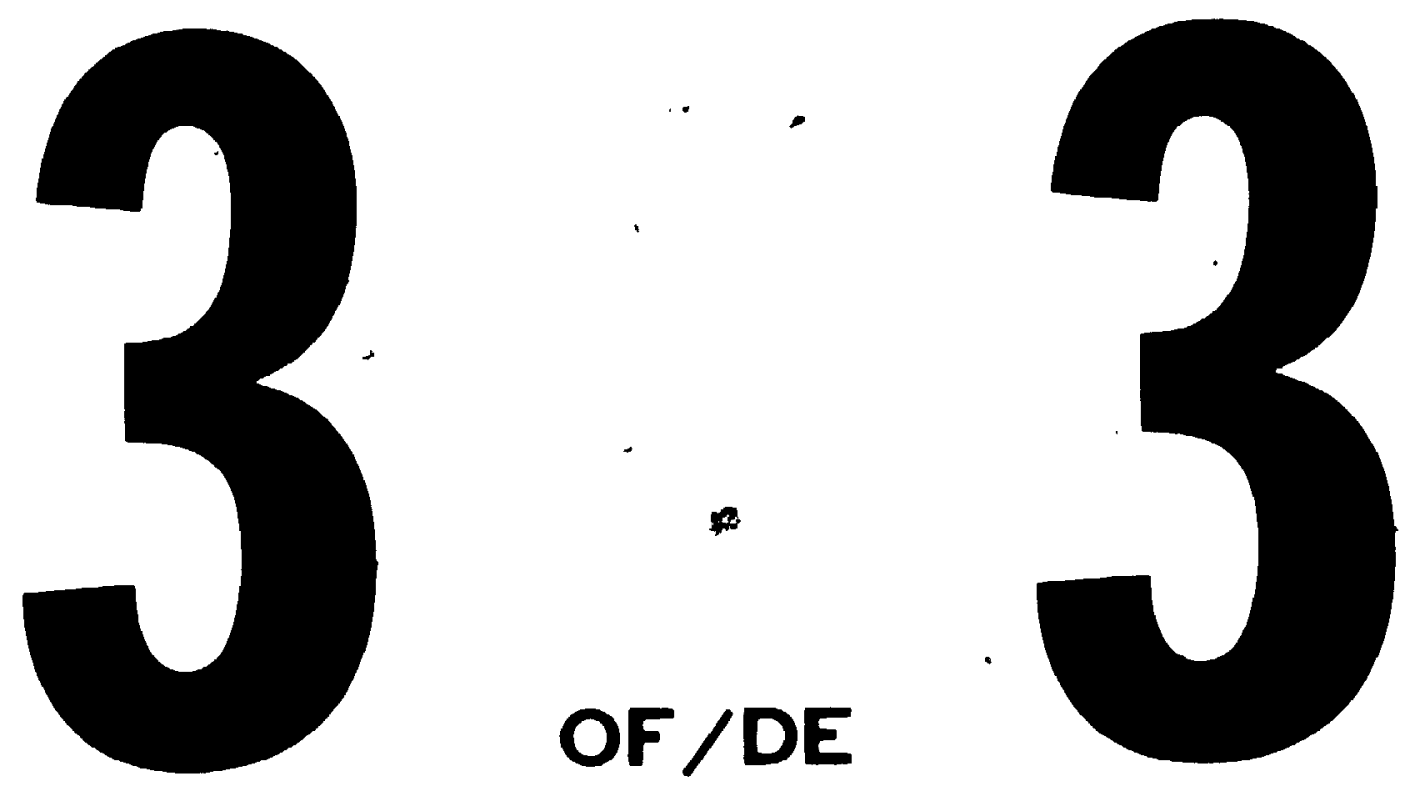

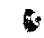

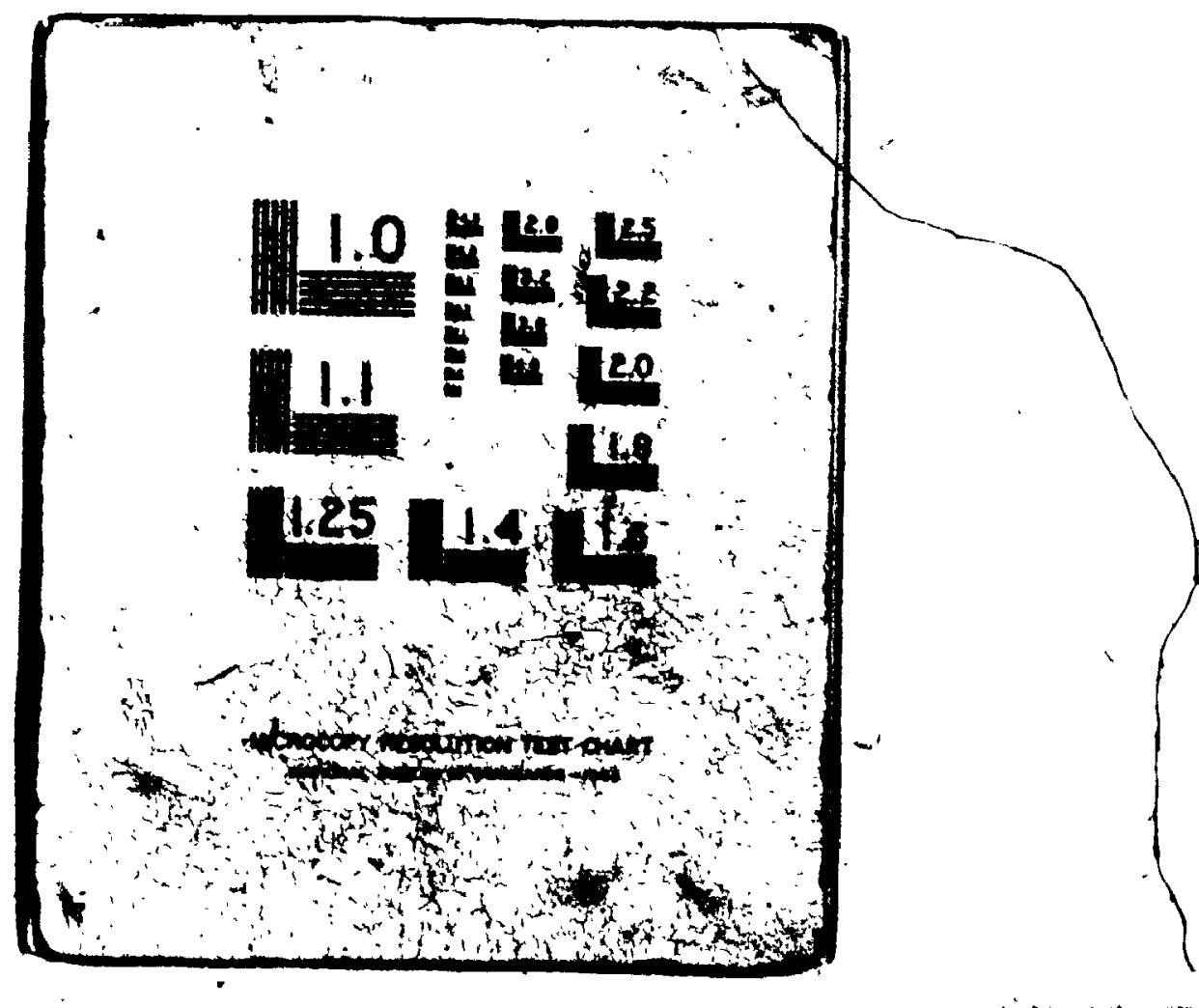

9

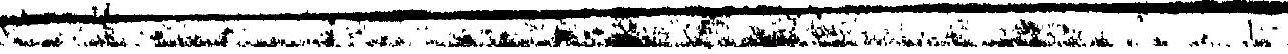




\section{APPENDIX 3}

CANEROON

SOCIAL-FiELo ThEORY RESULTB

\begin{tabular}{|c|c|c|c|c|c|}
\hline No. of & \multicolumn{2}{|c|}{ Finequency } & No. or & Bemaviou & I NOEX \\
\hline $\begin{array}{l}\text { CANON. } \\
\text { VARB. }\end{array}$ & E IOENVALUE & $\begin{array}{l}\text { CANON. } \\
\text { CORELL. }\end{array}$ & $\begin{array}{l}\text { CANON. } \\
\text { VARB. }\end{array}$ & E IoEnVALUe & $\begin{array}{l}\text { CANON } \\
\text { CORAEL. }\end{array}$ \\
\hline $\begin{array}{l}1 \\
2 \\
3 \\
4\end{array}$ & $\begin{array}{l}.0393 \\
.0191 \\
.004 ? \\
.0003\end{array}$ & $\begin{array}{l}.1983 \\
.1383 \\
.0687 \\
.0176\end{array}$ & $\begin{array}{l}T \\
2 \\
3\end{array}$ & $\begin{array}{l}.8826 \\
.4231 \\
.1892\end{array}$ & $\begin{array}{l}.9395 \\
.6505 \\
.4349\end{array}$ \\
\hline aces & 56 & & TMAOE & .7058 & \\
\hline
\end{tabular}

Canonical Regrebgion CoefficientB - Frequenct

CANONI GAL VARIATES

\begin{tabular}{l} 
3EHAVI OUR \\
\hline CON \\
CFN \\
COO \\
CFO
\end{tabular}

\begin{tabular}{l} 
ATTRI BUTEB \\
\hline POV \\
UR3 \\
DEV \\
REL \\
PQ
\end{tabular}
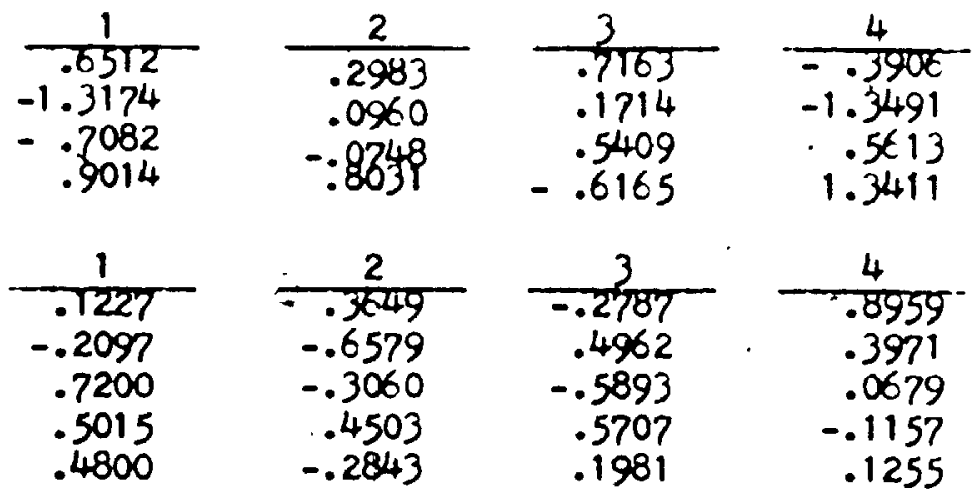

4

.8959

.3971 ,

.0679

$-.1157$

.1255

\section{r}

CANONICAL REQREBBION COEFFICIENTB - JEHAVIOUR I NOEX

Canonical VARiates

Bemaviour

$|B|$

CFI

$\mathrm{COI}$

\section{ATtRIBUTES. \\ PON}

URB

DEV

RE

$P \alpha$
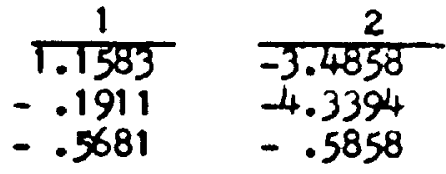

$\frac{3}{2.8807}$
4.6836
2.5948
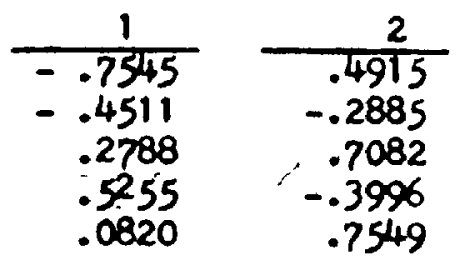


\section{ArPEMIX}

CHAO

SOCIRLFIELO THEDAV REQULIB

\begin{tabular}{|c|c|c|c|c|c|}
\hline No. of & \multicolumn{2}{|c|}{ FREQUENCY } & No. or & \multicolumn{2}{|c|}{ Jewav COJn I voEX } \\
\hline $\begin{array}{l}\text { SANON. } \\
\text { VARS. }\end{array}$ & -I OENUALUE & $\begin{array}{l}\text { CANON. } \\
\text { CORKEL. }\end{array}$ & $\begin{array}{l}\text { CAMON. } \\
\text { VAAB. }\end{array}$ & E I GENUALUE & $\begin{array}{l}\text { CANDM. } \\
\text { CORREL. }\end{array}$ \\
\hline$T$ & .8426 & .2064 & 7 & .7941 & $.8911^{\circ}$ \\
\hline $\begin{array}{l}2 \\
3 \\
4\end{array}$ & $\begin{array}{l}.0230 \\
.0052 \\
.0004\end{array}$ & $\begin{array}{l}.1516 \\
.0724 \\
.0187\end{array}$ & $\begin{array}{l}2 \\
3 .\end{array}$ & $\begin{array}{l}.3579 \\
.0406\end{array}$ & $\begin{array}{l}.5983 \\
.2014\end{array}$ \\
\hline TRACE = & .1334 & & TRACE & .6274 & \\
\hline
\end{tabular}

CAMONHCAL TEORESS ON COEFF CIENT3 - FPEQUENCY

CANON,CAL VAN:ATES

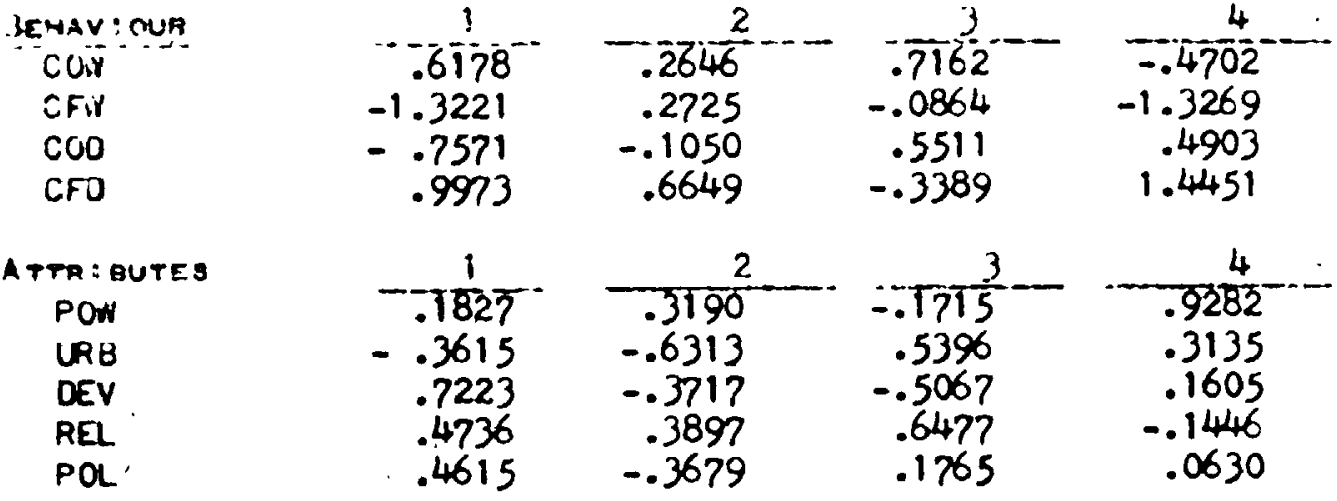

CANONICAL QEGRESBI ON COETF:CIEITS - BEMAV'CUR INOEX

CANONICAL. VARIATCB

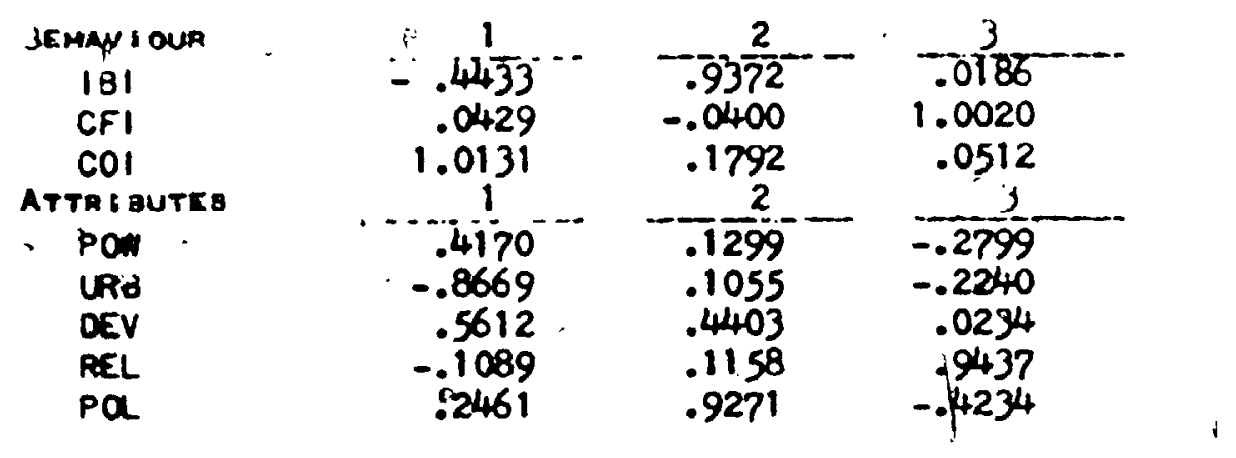


188.

APFENUIX 3

CONGO

SOOIAL-FJCLO THEONY REMULSS

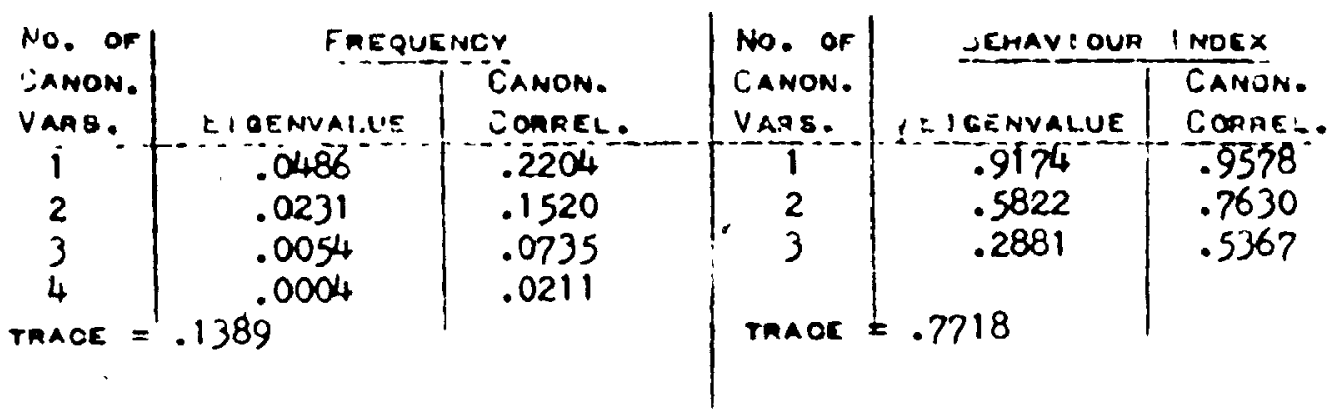

CANONICAL REOAEBSION COEFF, C ENTB - FRE RUENCY

CANONICAL VARIATES

3Emavioun
CUNY
CFN
COD
CFO

ATtRigutes

pón

URB

DEV

REL

PQ

$$
\begin{array}{r}
1 \\
-.5526 \\
-1.3497 \\
-.7631 \\
.9477
\end{array}
$$
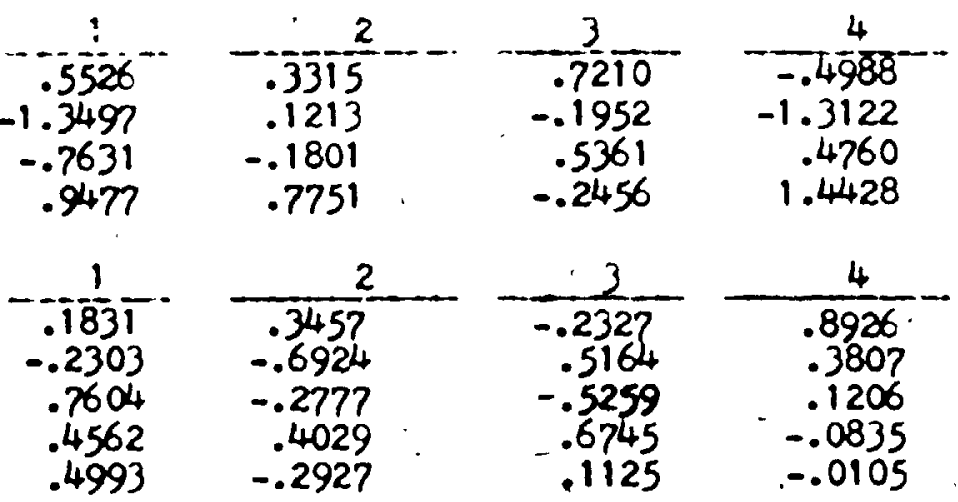

CAMOMIOAL REGRESBION COEFFICLENT3 - BEMAVIOUR INOEX

CANONICAL VARIATEg

Jimavioun

$|B|$

CFI

COI

Atralautes

POW

URB

DEV.

REL

$P \alpha$

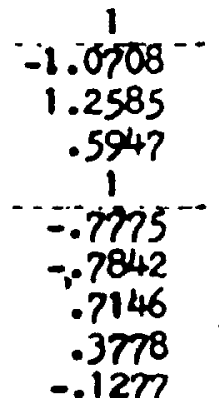

$-.1277$

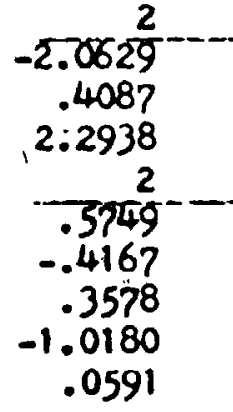

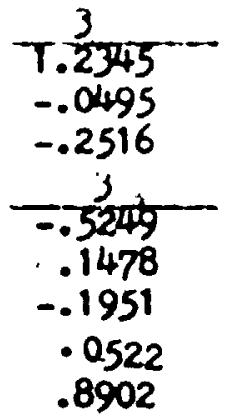


189.

\section{APPENLIX;}

OAHONEY jOOIALFIELO THEOPY REBULTB

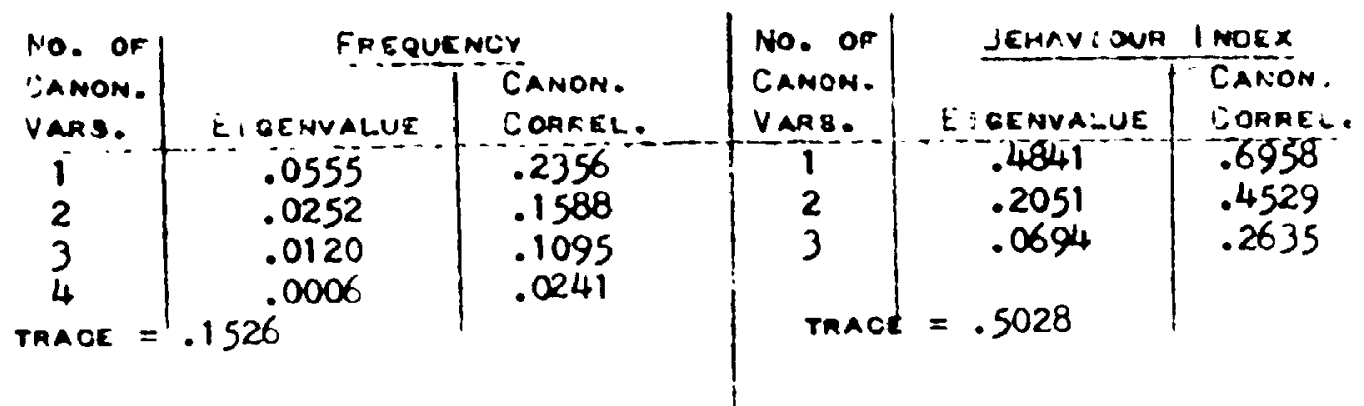

CANONICAL REOTESS: ON COEFE:CIENTB - FREQUENEV

\section{CANONICAL VAR:ATES}

JemaviOUR
CON
CFN
COD
CFO

ATYR : BUTEE

PON

URB

DEV

REI

pa

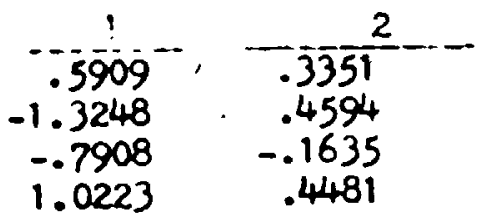
$.3 \frac{3}{.625}$
$-.3254$
.5573
$-.0802$

$\frac{2}{.2511}$
-.5958
-.4205
.4764
-.3633

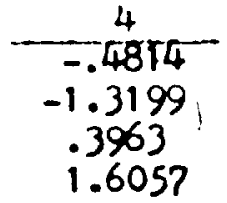

$-\frac{3}{-.3078}$

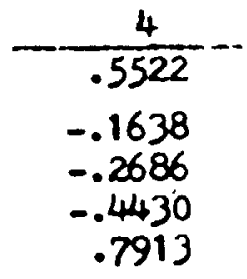

CANONIOAL REGREBSION COEFFICIENTS - BEMAV!OUR INOEX

CANONICAL VARIATES

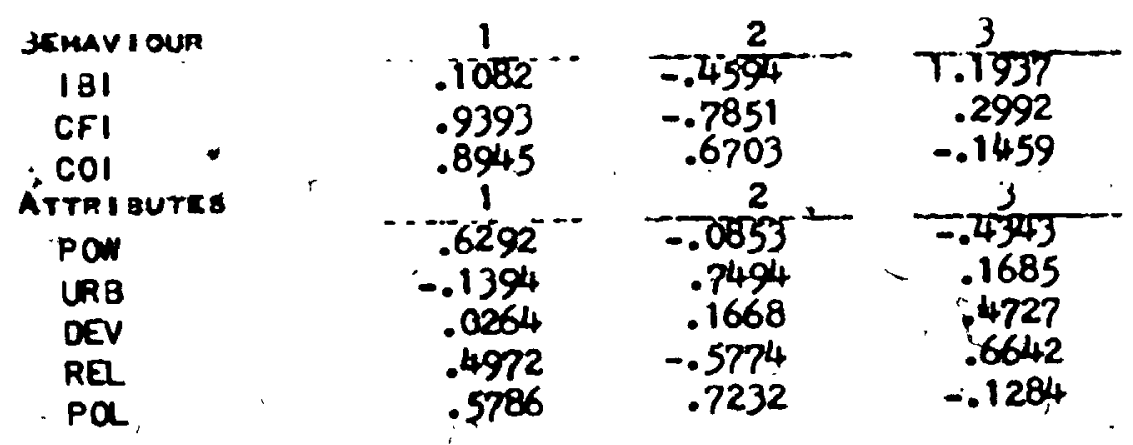




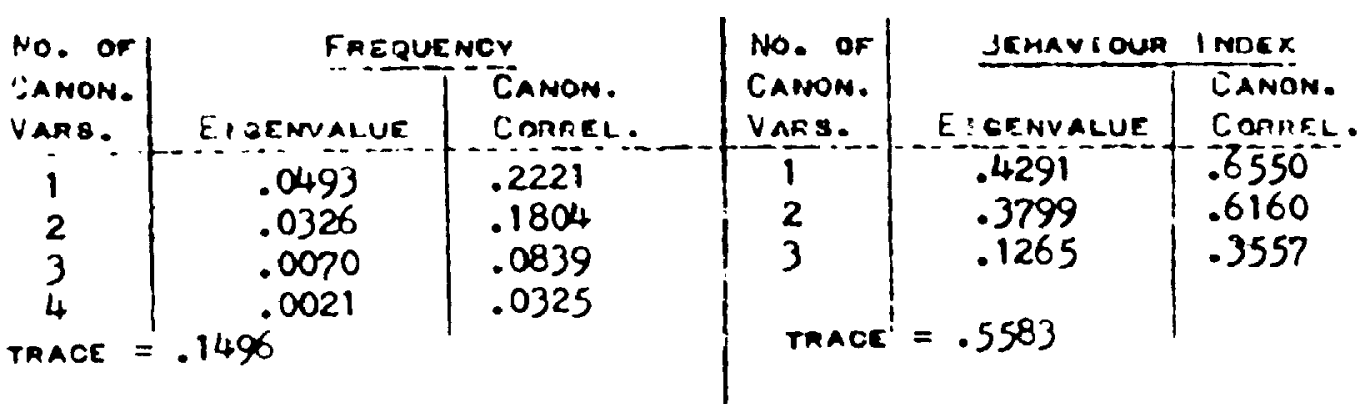

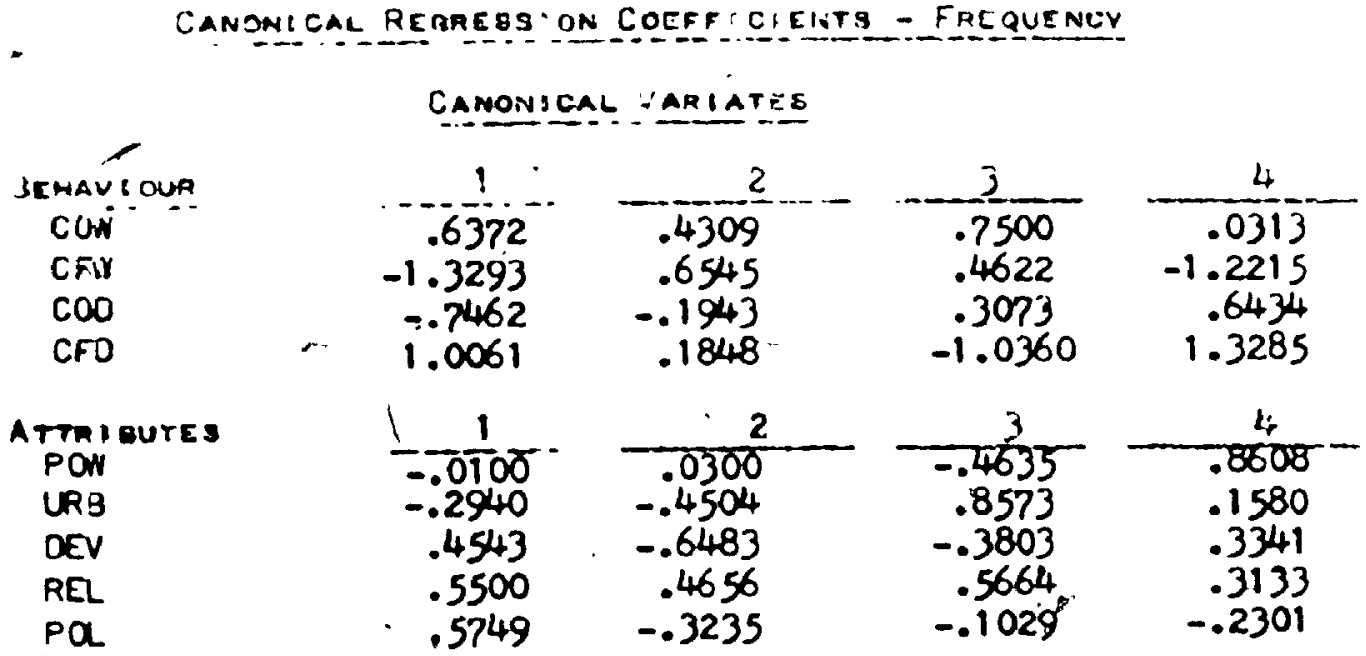

CANONIOAL REQREBGION COEFF:CIFATS - BgHAVTOUA INOEX

Canonical vaniateg

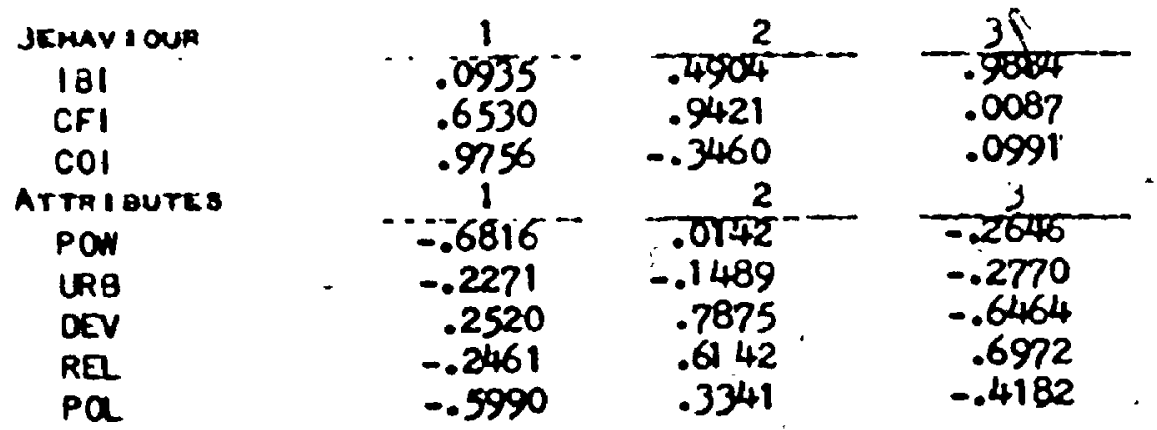


APFENUIX 3

GHANA

SOOIAL-FIELO THEORY REQULTO

\begin{tabular}{|c|c|c|c|c|c|}
\hline No. or & FnEqu & & No. of & jerrav: own & 1 nos $x$ \\
\hline $\begin{array}{l}\text { "AAMON. } \\
\text { VARB. }\end{array}$ & E. OENUALUE & $\begin{array}{l}\text { CANON. } \\
\text { CORREL. }\end{array}$ & $\begin{array}{l}\text { CAMON. } \\
\text { VARS. }\end{array}$ & E: Genvalue & $\begin{array}{l}\text { CANON. } \\
\text { CMRPEL. }\end{array}$ \\
\hline $\begin{array}{l}1 \\
2 \\
3 \\
4\end{array}$ & $\begin{array}{l}.0547 \\
.0356 \\
.0152 \\
.0006\end{array}$ & $\begin{array}{l}.2339 \\
.1887 \\
.1231 \\
.0239\end{array}$ & $\begin{array}{l}1 \\
2 \\
3\end{array}$ & $\begin{array}{l}.5266 \\
.1792 \\
.0299\end{array}$ & $\begin{array}{l}.7257 \\
.4233 \\
.1729\end{array}$ \\
\hline ACE & 627 & & thace & .4952 & \\
\hline
\end{tabular}

CANONICAL REOREBS: ON DOEFFNCIENTS - FREQUEWCY

CanONICAL vaAtates

JEMAVI OUR
CON
CFN
COO
CFO

ATTRI BUTES

POW

URB

DEV

REL

pa

$$
\begin{array}{r}
1 \\
.6512 \\
-1.1906 \\
-.7915 \\
.8469
\end{array}
$$

$$
\begin{gathered}
1 \\
-.0935 \\
-.3907 \\
.3493 \\
.4497 \\
.6927
\end{gathered}
$$
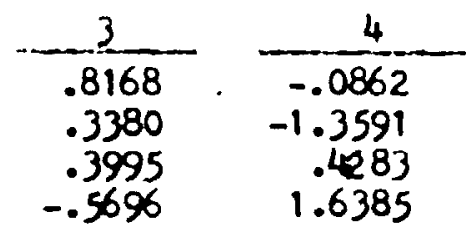

.2909

2
.0917
-.5926
-.7032
.1602
-.1788

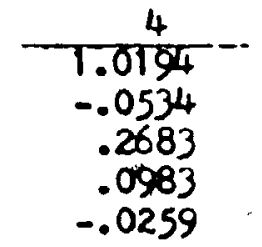

CAMONICAL REGREBEION COEFF:CIENTS - BEMAVI DUA INOEX

Canonical vamiates

JEMAVI oun.
IBI
CFI
COI
ATrRI ButEs
POY
LR3
OEV.
RQ
PÓ
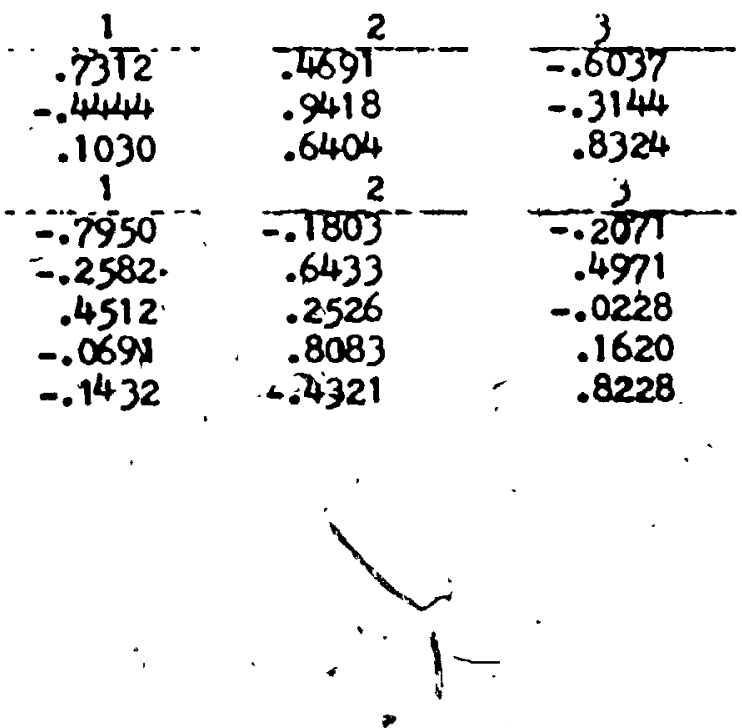


\section{APPENUIX :}

GUINEA

jOOIALFICLO THEOAY FEBULTR

\begin{tabular}{|c|c|c|c|c|c|}
\hline No. or & FREQ & Ner & No. of & jemavious & $1 \operatorname{mog} x$. \\
\hline $\begin{array}{l}\text { 'JANON. } \\
\text { VARS. }\end{array}$ & E! OENVALUE & $\begin{array}{l}\text { CANON. } \\
\text { CORAEL. }\end{array}$ & $\begin{array}{l}\text { CAMON. } \\
\text { VARE. }\end{array}$ & EI GENVALUE & $\begin{array}{l}\text { CANON. } \\
\text { CORAEL }\end{array}$ \\
\hline $\begin{array}{c}1 \\
2 \\
3 \\
4 \\
\text { TaAcs = }\end{array}$ & $\begin{array}{l}.0862 \\
.0486 \\
.0208 \\
.0034 \\
.1989\end{array}$ & $\begin{array}{l}.2936 \\
.2205 \\
.1417 \\
.0585\end{array}$ & $\begin{array}{l}1 \\
2 \\
3 \\
\text { TAACE }\end{array}$ & $\begin{array}{r}.6628 \\
.4070 \\
.1432 \\
=.6356\end{array}$ & $\begin{array}{l}.8141 \\
.6379 \\
.3784\end{array}$ \\
\hline
\end{tabular}

CANONICAL REOREGS. ON COEFE:CIENTS - FREQUENCY

CANONICAL VAR:ATES

$$
\begin{aligned}
& \text { JEMAVIOUA } \\
& \text { CCNY } \\
& \text { CFI' } \\
& \text { COO } \\
& \text { CFO }
\end{aligned}
$$

ATTE I BUTE
POW
URS
OEV
REI
PQ.

ATtRi ButEs

URS

$P \alpha$

$\frac{2}{.4189}$
-.3457
-.7244
.9662

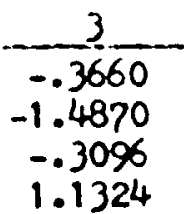
$\frac{2}{.1409^{-}}$
$-.8182$
$-.3333$
.2178
.1810

.7135

.6045

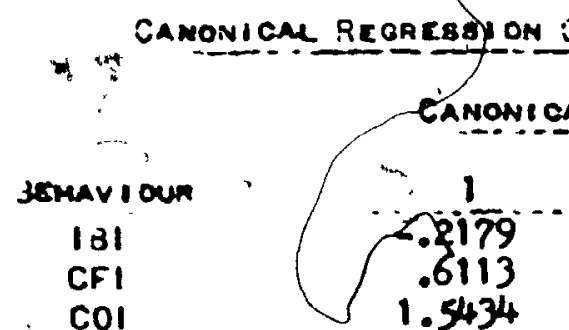

Attriautes

POW

URB

OEV

PEI

PQ

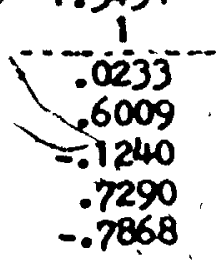

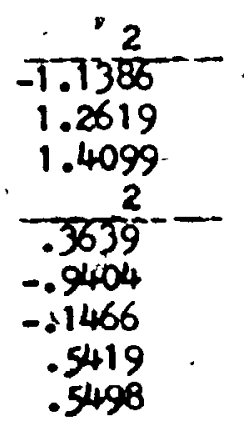

$$
\begin{array}{r}
-\frac{4}{.5155} \\
-1.0980 \\
.4792 \\
.9651
\end{array}
$$

$$
\begin{array}{r}
3 \\
-.0972 \\
-.5161 \\
.7790 \\
-.3771 \\
.2654
\end{array}
$$

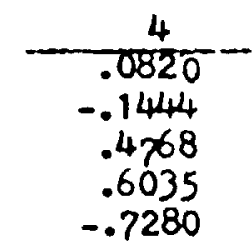

CORFFEC:ENTS

BEMAV: OUR INOEX 


\section{APPENUIX is}

IVORY COAST

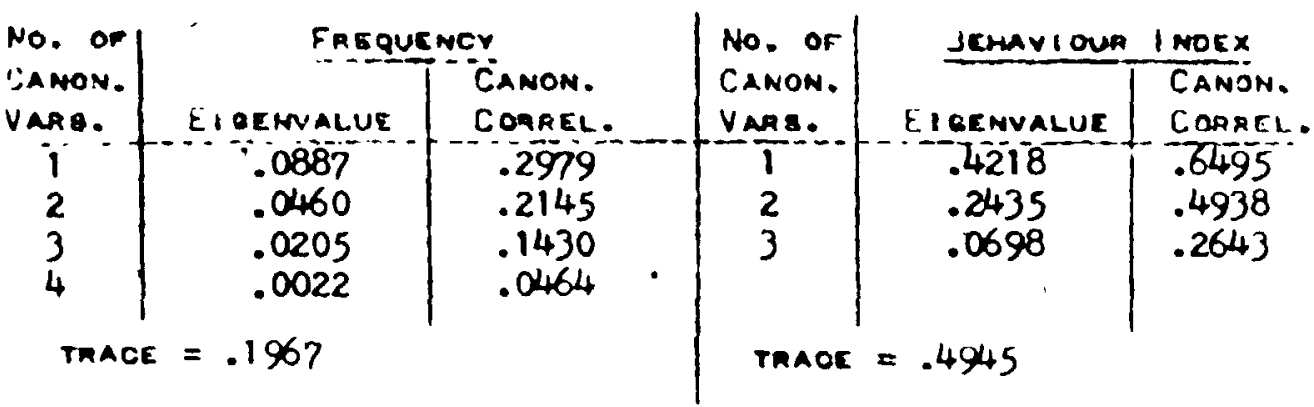

SOOIALFIELD THEOAY REBULTB

CANONICAL. REOREBS" ON COEFF'CIENTB - FREQUENCY CANONEGAL VAR:ATES

JeHAY OUR
COY
CFW
COO
CFO

ATtRI Butes

POA

URZ

DEV

REL

$P Q$

$$
\begin{gathered}
1 \\
. .7641 \\
.1043 \\
-.4068 \\
-.8947
\end{gathered}
$$

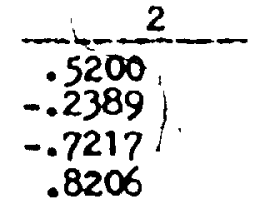

$$
\begin{aligned}
& \frac{.3}{-.0526} \\
& -1.7721 \\
& -.3454 \\
& 1.3208
\end{aligned}
$$

$\begin{array}{cr}\frac{2}{.0907} & -\frac{3}{.0612} \\ -.7624 & -.5563 \\ -.3435 & .8846 \\ .3095 & -.1058 \\ .1346 & .0008\end{array}$
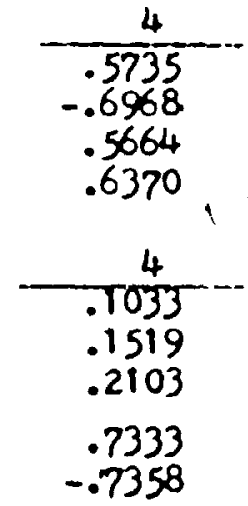

CANONIOAL REORESBION COEFFICIENTS = BEHAVIOUN INOEX

Camon: ól variateg

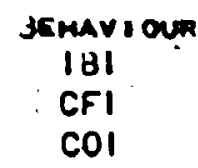

Artaloutes

PON

UR3

DEV

REL

Pa

$$
\begin{gathered}
1 \\
-.9229 \\
.8798 \\
.1789 \\
1 \\
.0230^{-\cdots} \\
-.6509 \\
.3385 \\
-.6950 \\
.0442
\end{gathered}
$$

$\frac{2}{.4746}$
.3040
-.5792
$\frac{2}{.0471}$
-.1249
-.4398
.1082
-9342

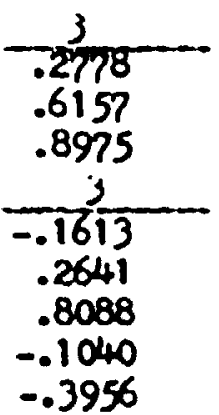




\section{APPENUIX 3}

KENYA

SOOIALFIILLO THEONV REQULTS

\begin{tabular}{|c|c|c|c|c|c|}
\hline No. or 1 & Faxqu & NCr & No. of & Jrmavi OuA & 1 mokx \\
\hline $\begin{array}{l}\text { GANON. } \\
\text { vaABE. }\end{array}$ & E I IENVALUE & $\begin{array}{l}\text { CAMON. } \\
\text { CORAEL. }\end{array}$ & $\begin{array}{l}\text { Camon. } \\
\text { VAR8. }\end{array}$ & E: GENVALUE & $\begin{array}{l}\text { CANON. } \\
\text { COARSL. }\end{array}$ \\
\hline $\begin{array}{l}1 \\
2 \\
3 \\
4\end{array}$ & $\begin{array}{l}.0755 \\
.0393 \\
.0322 \\
.0010 \\
857\end{array}$ & $\begin{array}{l}.2747 \\
.1982 \\
.1489 \\
.0317\end{array}$ & $\begin{array}{l}1 \\
2 \\
3\end{array}$ & $\begin{array}{r}.2404 \\
.0956 \\
.0426\end{array}$ & $\begin{array}{l}.4903 \\
.3092 \\
.2065\end{array}$ \\
\hline
\end{tabular}

CanONical RECAEQjion COKEFIC:ENTB - FREquency

\section{CahONBCal VAMIATEB}

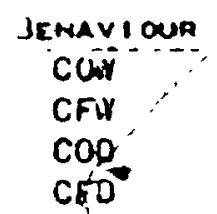

Atreigutes

POW

URB

DEV

REL

Pa

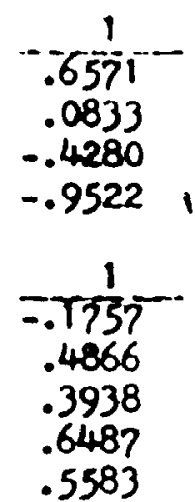

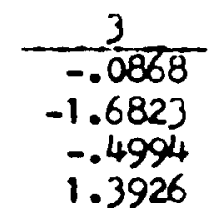

.7025

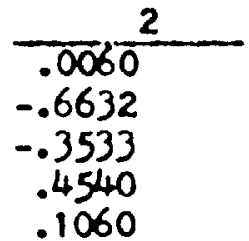

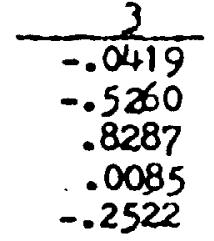

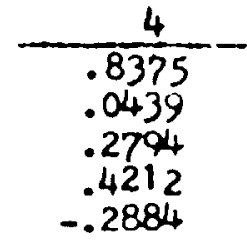

CANONIOAL REGRESOION COEFFIC:ENTS - BeHAVIOUR INOEX

\section{Camonical variateg}

jemavi oun

|B!

CFI

$\mathrm{COI}$

ATtai aUtEs

PON

UR 8

OEV

REL

Pa.

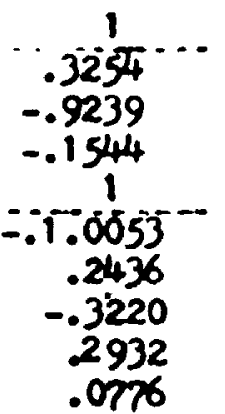

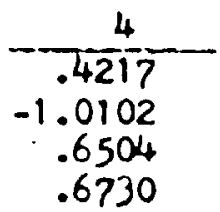

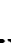

0102

6504

.6730 
195.

LIBERIA SOOIALFIELD THEOAY REBULTS

\begin{tabular}{|c|c|c|c|c|c|}
\hline No. or & FRE & & No. OF & jemaviour & I NOEX \\
\hline $\begin{array}{l}\text { 'AAMON. } \\
\text { VAAB. }\end{array}$ & EI 3ENVALUS & $\begin{array}{l}\text { CANON. } \\
\text { CORREL. }\end{array}$ & $\begin{array}{l}\text { CLANON. } \\
\text { VARS. }\end{array}$ & E' QE NYALUE & $\begin{array}{l}\text { CANON. } \\
\text { CORAEL. }\end{array}$ \\
\hline $\begin{array}{c}1 \\
2 \\
3 \\
4 \\
\text { TAACE }\end{array}$ & $\begin{array}{l}.0960 \\
.0521 \\
.0238 \\
.0020 \\
.2083\end{array}$ & $\begin{array}{l}.3098 \\
.2283 \\
.1544 \\
.0451\end{array}$ & $\begin{array}{l}1 \\
2 \\
3 \\
\text { TAAOE }\end{array}$ & $\begin{array}{r}.8591 \\
.5762 \\
.0926 \\
=.7135\end{array}$ & $\begin{array}{l}.9269 \\
.7591 \\
.3044\end{array}$ \\
\hline
\end{tabular}

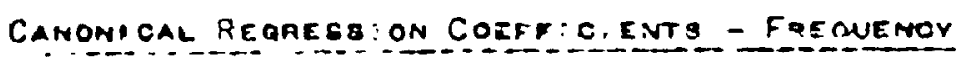

CANONICAL VARBATES

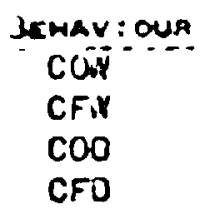

Attmidutes

POW

URB

DEV

REL

$p Q$

$$
\begin{array}{r}
1 \\
.7110 \\
.1213 \\
-.3338 \\
-1.0325
\end{array}
$$
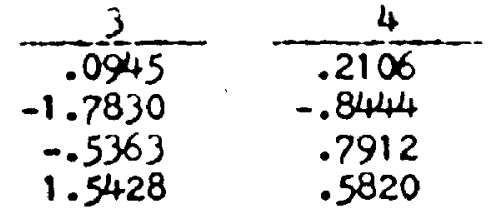

$\frac{2}{.8192}$
.0917
-.3415
.3737

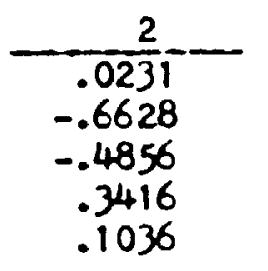

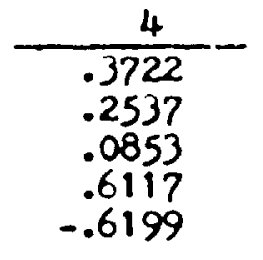

CAMONICAL REORESBION COEFFICIENTS - BEMAVIOUR INOEX

CanONICAL VARIATEO

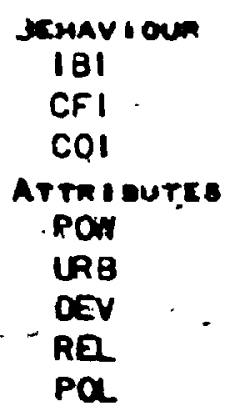
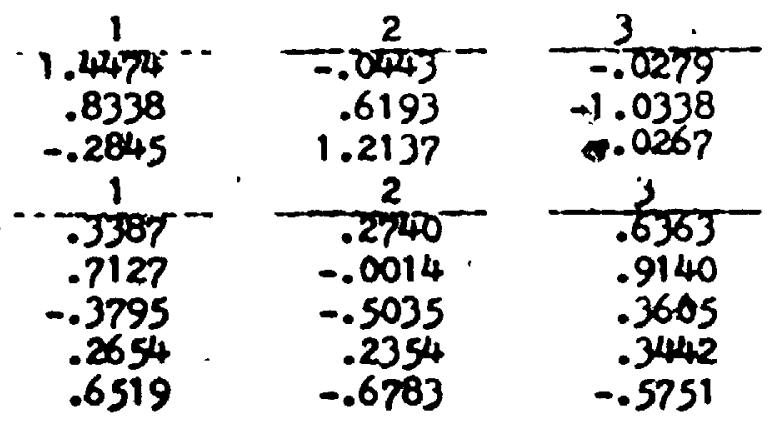
196.

\section{APPENUIX 2}

MAL 1

SOOIALAFEELO THEOAY REBULTB

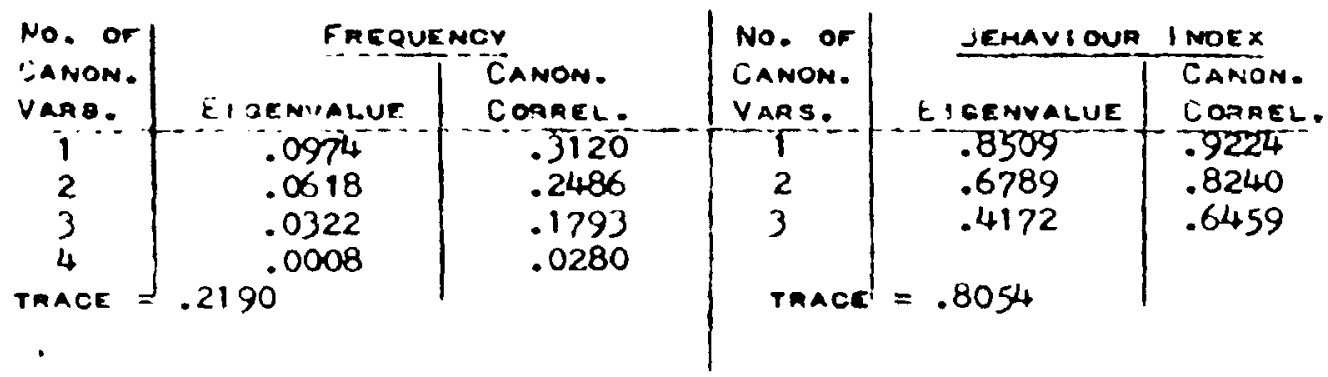

CANONICAL REOREQSION COEFFIC ENTB - FREQUENCV

$\rightarrow$

CANONIOAL VAR:ATES

lemavsoun
COIY
CFW
COD
CFO

ArTm S sute:

PQN

URB

DEV

REL

$P O L$

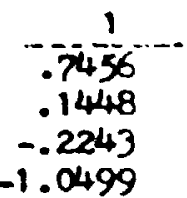
$-\frac{1}{-1489}$
.3754
.4039
.7773
.4915

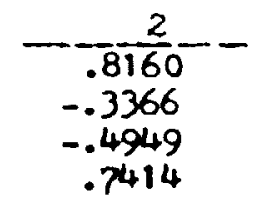
$\frac{3}{-.0885}$
$-1.5297$
$-.6245$
1.1687
$\frac{3}{-.0883}$
$-.0883$
.8892
$-.0152$
$-.3885$

4
.1282
-1.2148
.6904
.9741

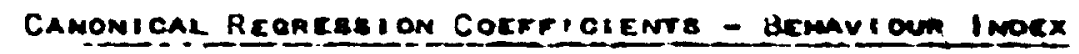

Canon!cal vaniateg

JTHAI OUA
IBI
CFI
COI
ATTI DUTEs
POW
URB
DEV
REL
PQL

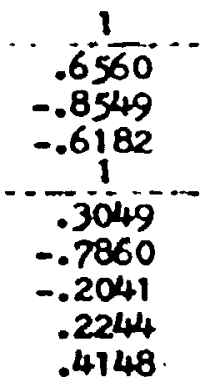

\begin{tabular}{c}
$\frac{2}{3.0756}$ \\
5.1426 \\
2.5837 \\
\hline 2 \\
\hline .2767 \\
.5994 \\
.1976 \\
.9181 \\
-.3081
\end{tabular}

$$
\begin{array}{r}
-3 \\
\hline 4.2437 \\
4.2394 \\
.2155 \\
\hline-.0790 \\
-.4260 \\
-.2698 \\
-.0759 \\
-.8656
\end{array}
$$


197.

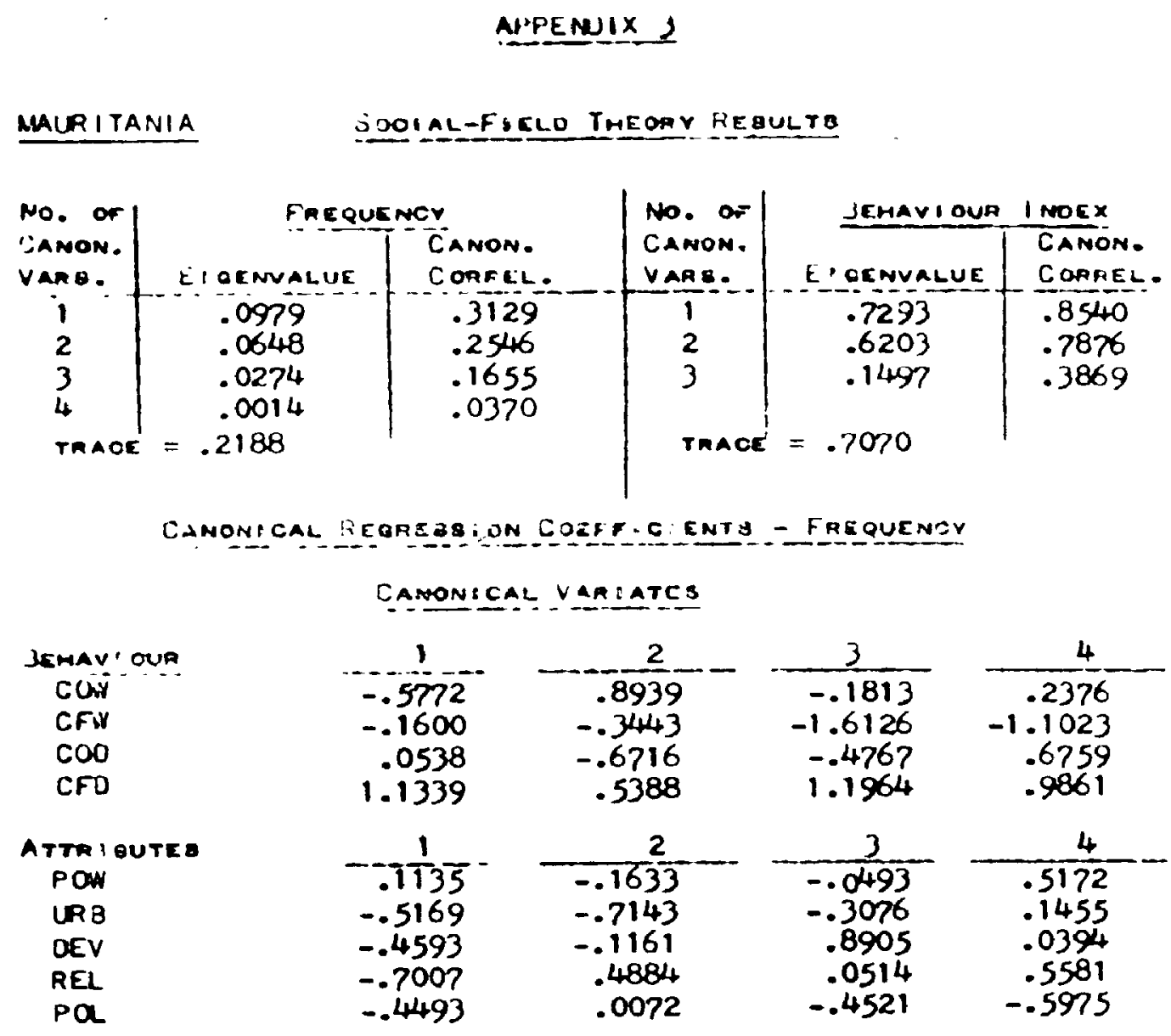

CANONIOAL RECREBBION COEFFICIENTS - BEMAVHOUP INOEX

Canowion variateg

\begin{tabular}{|c|c|c|c|}
\hline scmavioun & 1 & 2 & 3 \\
\hline $\begin{array}{l}|B| \\
\text { CFI } \\
\text { COI } \\
\text { ATtRI sutEs }\end{array}$ & $\begin{array}{r}2.5733 \\
.5573 \\
-1.3118\end{array}$ & $\begin{array}{l}1.5939 \\
2.1961 \\
-.0548 \\
\end{array}$ & $\begin{array}{r}-1.1257 \\
1.8310 \\
3.3041 \\
\end{array}$ \\
\hline $\begin{array}{l}\text { POW } \\
\text { URB } \\
\text { DEV } \\
\text { REL } \\
\text { PQ }\end{array}$ & $\begin{array}{r}.2747 \\
-.1165 \\
-.0007 \\
.8687 \\
.0276\end{array}$ & $\begin{array}{r}.7045 \\
.2309 \\
.1731 \\
-.2776 \\
1.1269\end{array}$ & $\begin{array}{r}.8893 \\
-.1636 \\
-.4971 \\
-.6272 \\
-.1138\end{array}$ \\
\hline
\end{tabular}


3

198.

APPENIX 2

NI GER

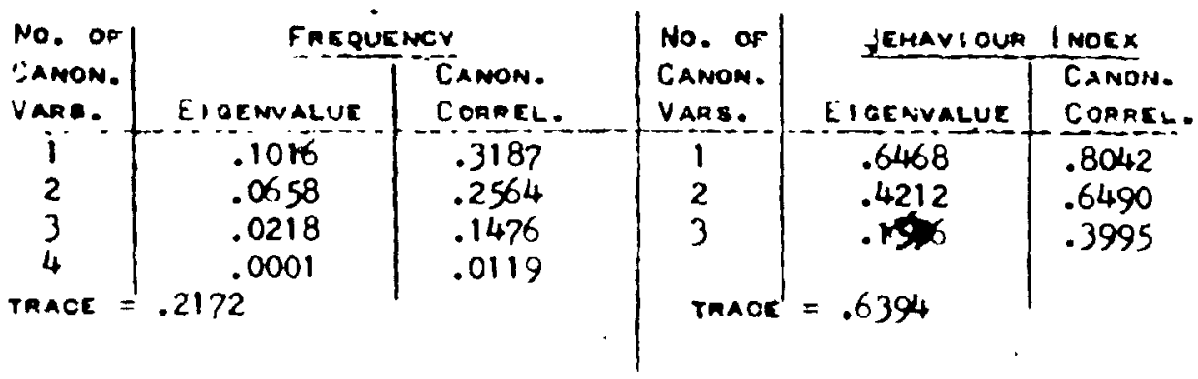

CANONICAL RECRE83 ON COEFA CIENT3 - FRCOUEMCY

CANOHSCAL VARIATEE

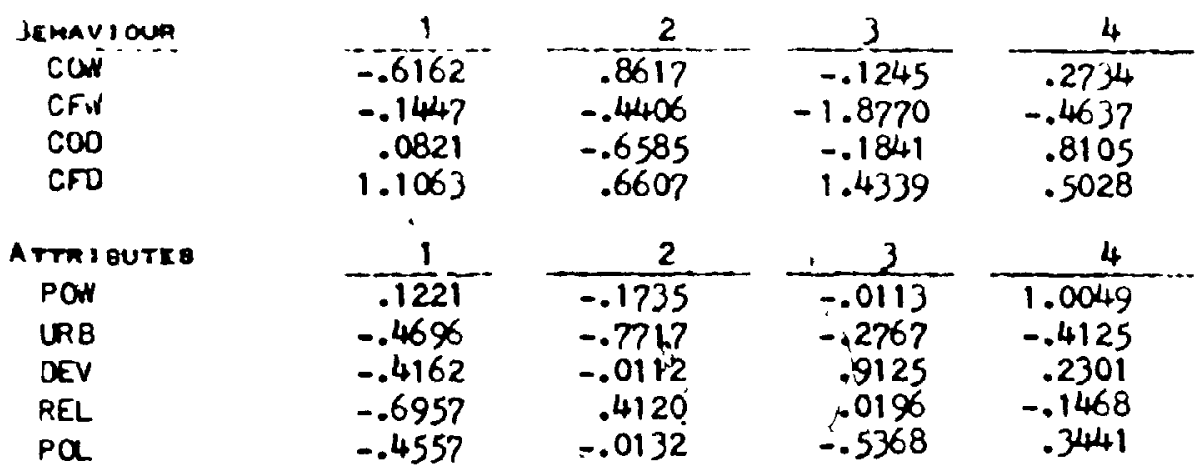

CAMONiCAL RCGREBajon COEFFICIENTS - BEMAY CUR InOEX

Canínigal variateg

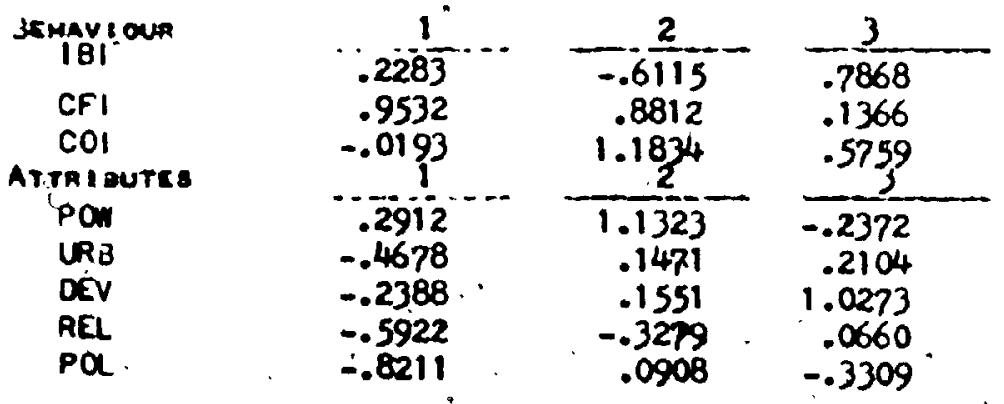


199.

\section{APPENUIX 3}

NIFERIA

jOCIALFjELO THEOAY REgULTB

\begin{tabular}{|c|c|c|c|c|c|}
\hline No. - or & FREQ & Cr & No. of & JEHAvi our & I NOEX $X$ \\
\hline $\begin{array}{l}\text { GANON. } \\
\text { vans.: }\end{array}$ & Erognvalue & $\begin{array}{l}\text { CANON. } \\
\text { MoAREL }\end{array}$ & $\begin{array}{l}\text { CANON. } \\
\text { VANB. }\end{array}$ & EIGENVALYLE & $\begin{array}{l}\text { CANON. } \\
\text { ConpEL. }\end{array}$ \\
\hline $\begin{array}{c}1 \\
2 \\
3 \\
4 \\
\text { TRACE }\end{array}$ & $\begin{array}{r}.0904 \\
.0410 \\
.0137 \\
.0054 \\
.1939\end{array}$ & $\begin{array}{l}.3007 \\
.2025 \\
.1169 \\
.0735\end{array}$ & $\begin{array}{l}1 \\
2 \\
3 \\
\text { Thad }\end{array}$ & $\begin{array}{r}.4016 \\
.1358 \\
.0130 \\
=.4282\end{array}$ & $\begin{array}{l}.6337 \\
.3685 \\
.1141\end{array}$ \\
\hline
\end{tabular}

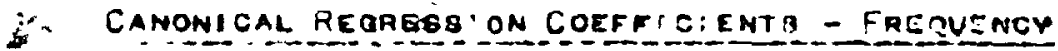
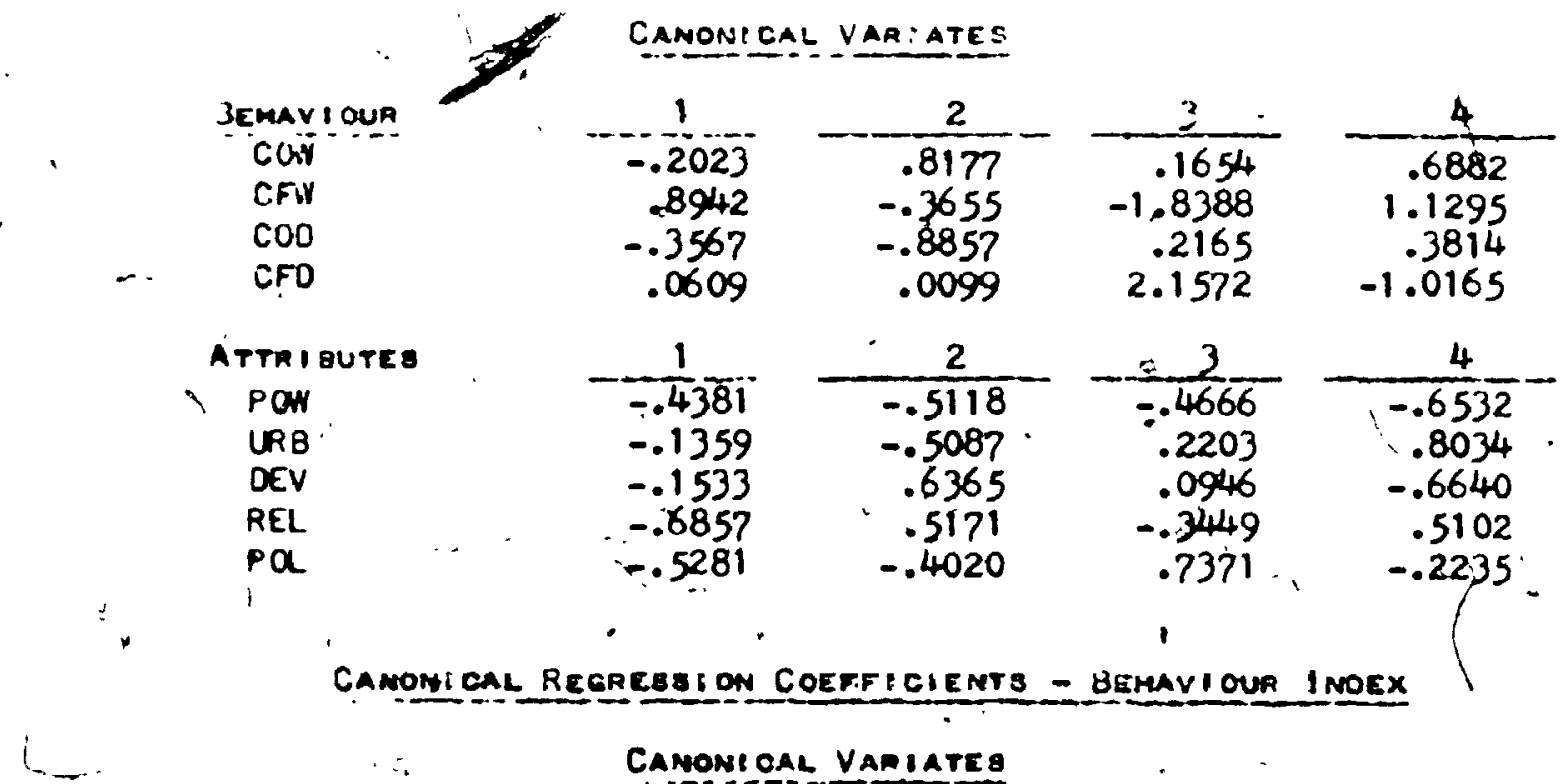

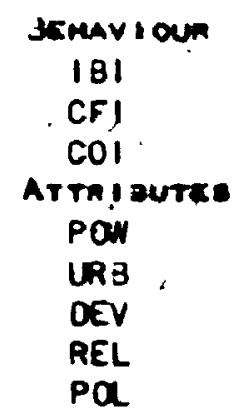

Canonioal variateg
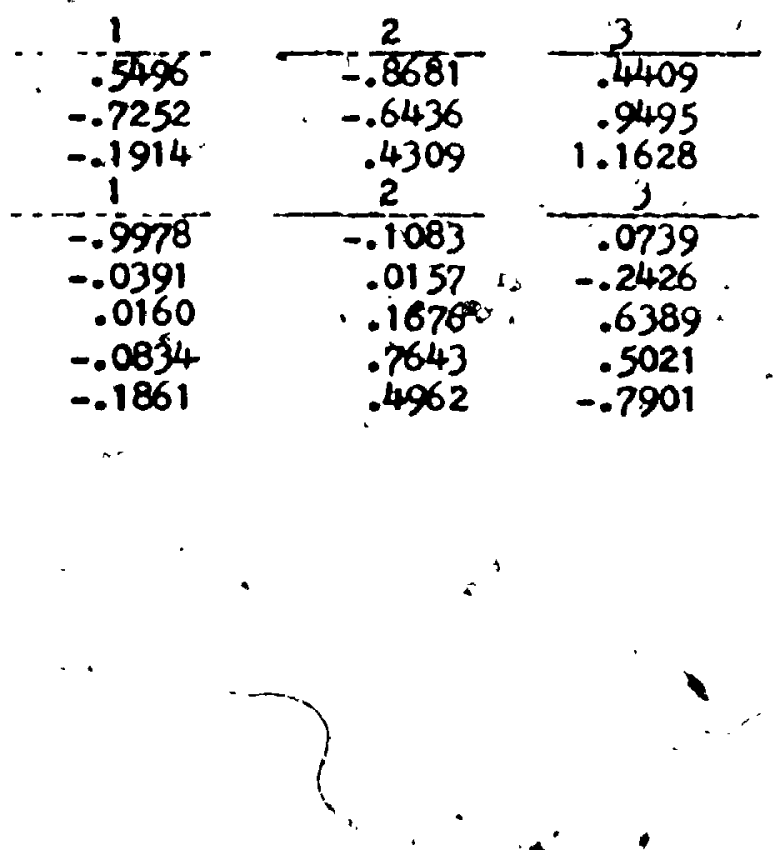
SENEGAL JOO'AL-F SELD THEORV REgULTS

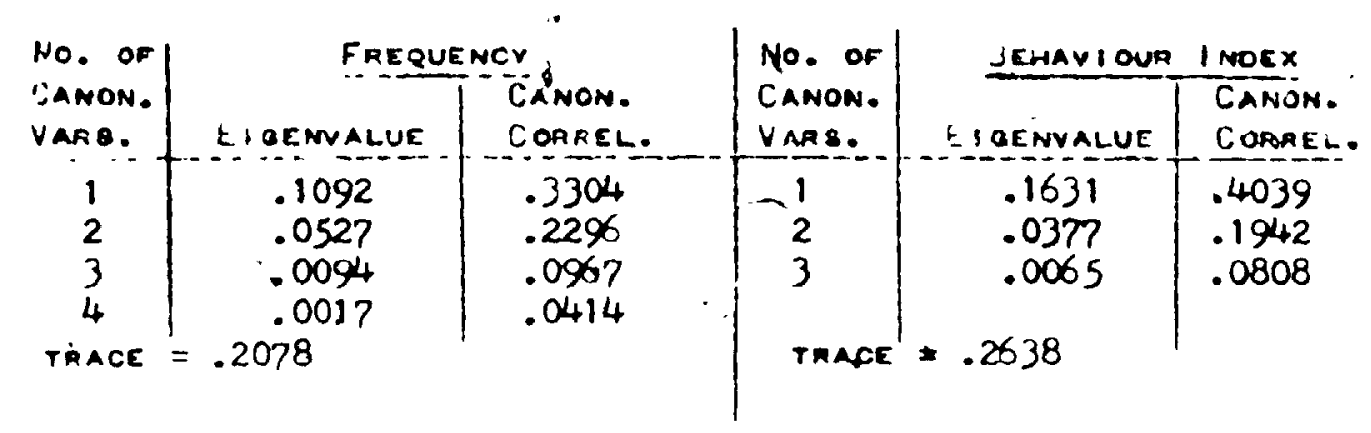

CAROONIGAL FESREBS: ON COEFE CENTB - FPEZUENCY

CABHONICAL VARIATES

JEMAY :OUR
CON
CFIY
COO
CFO

$$
\begin{array}{r}
1 \\
.3976 \\
-1.2122 \\
.3245 \\
.3222
\end{array}
$$
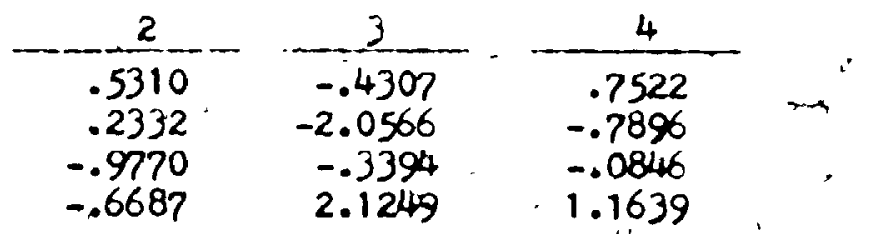

\section{Attaibuteo}

POW
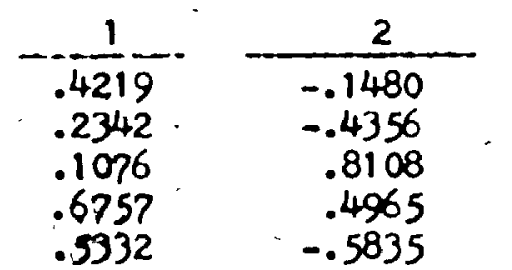
$-\frac{3}{-.0848}$
$-.0948$
.6351
$-.5029$
.5984

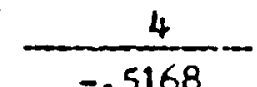

URS

DEV

REL.

.5332

$-.5835$

.9020

$-.0512$

.3565

$-.2191$
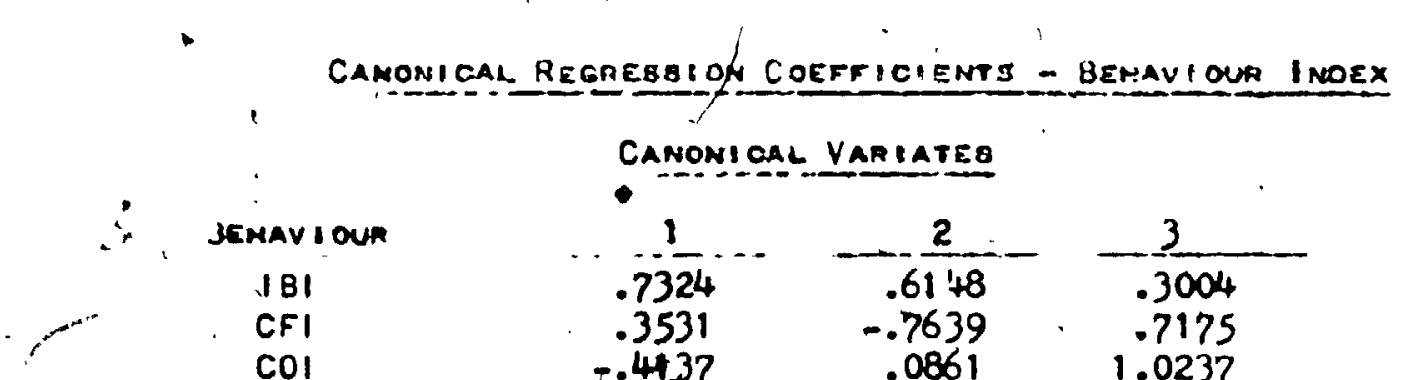

JEMAVIOUR
IBI
CFI
COI
ATTRI OUTEB
POW
URB
OEV
REL
POL
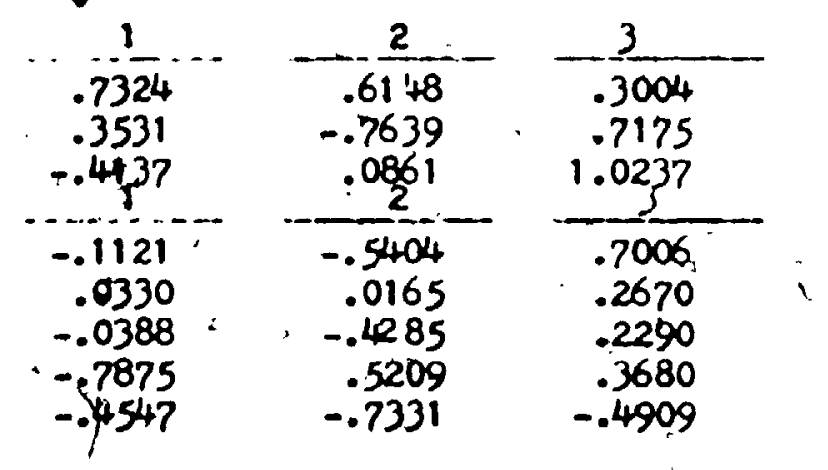
201.

APFENIX I

SIERRA LEONE

jOOIALFFIELO THEOAY REBULTB

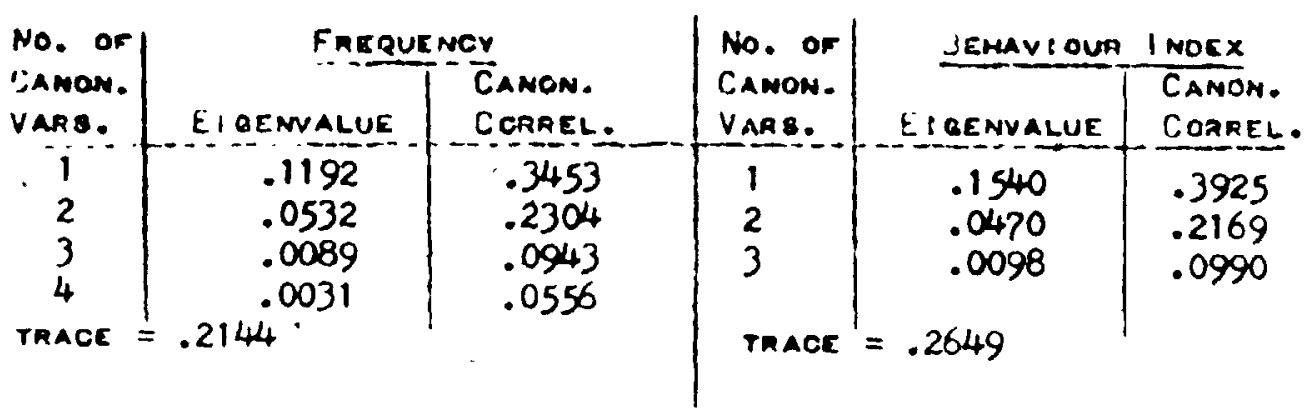

CANONBCAL REGREBSION COEFE CIENTS - EREOUEMCY

CAMONICAL VAABATES

3EHAVIOUA
CON
CFI.
COO
CFO
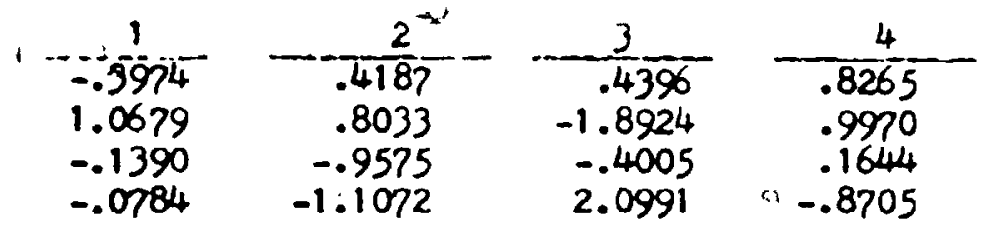

AtraideutKs

POW

URB

DEV

REL

$$
\begin{gathered}
-\frac{1}{-.4254} \\
.0523 \\
-.2819 \\
-.7063 \\
-.4591
\end{gathered}
$$

$P Q$
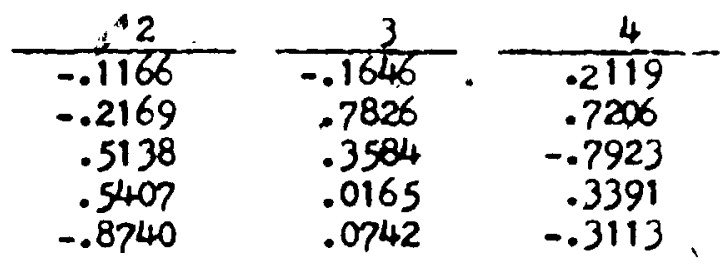

CANONIOAL REEREBAION COKFT: CIENTS

- Bemarsoun inosx

Canonical Vaniateo

JEMAVI OUA
IBI
CFI
COI
ATTEI BuTE:
POW
URB
OEV
REL
PO
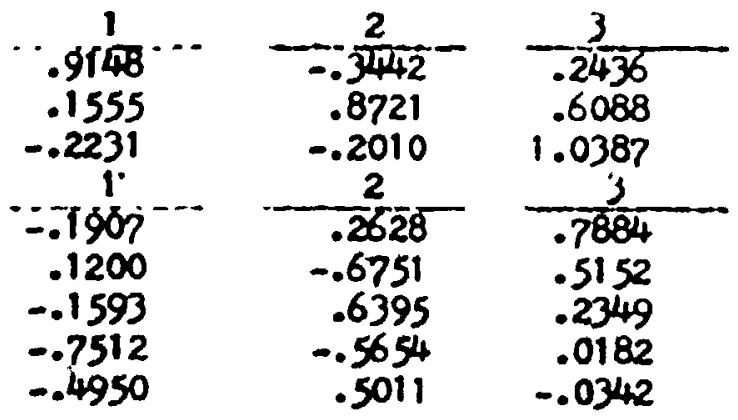


\section{APPENUIX 3}

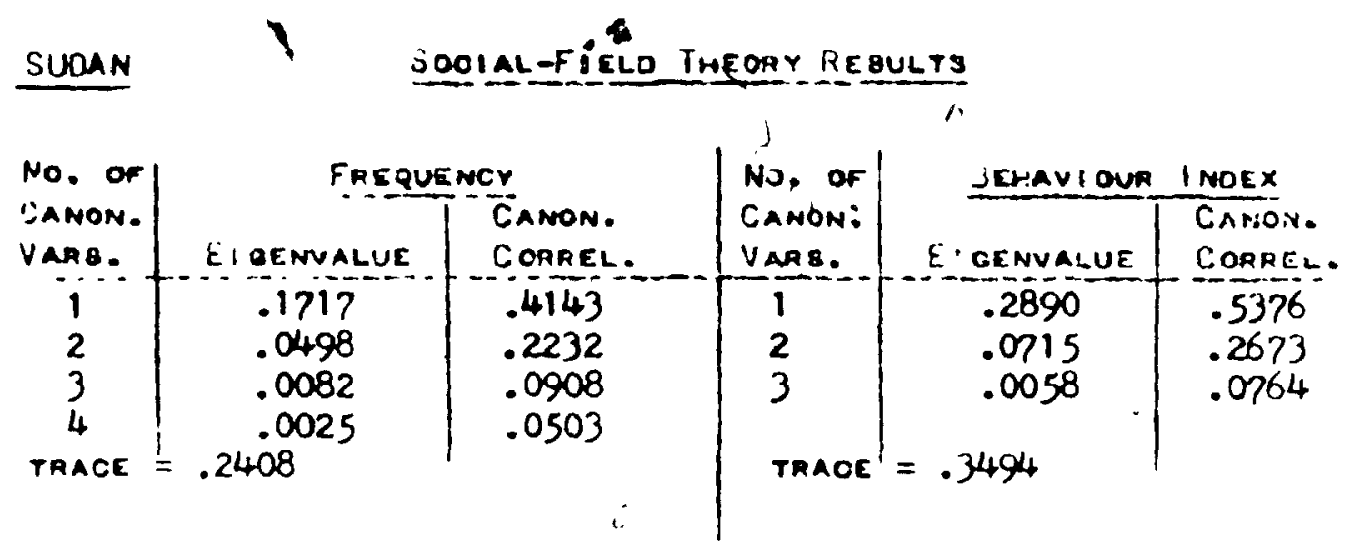

CANONIGAL REGREBB:ON COEFFELENTO - FRECUENCY

GANON:CAL VARBATES

\begin{tabular}{|c|c|c|c|c|}
\hline JEHAVIOUR & 1 & 2 & 3 & 4 \\
\hline $\begin{array}{l}\text { CON } \\
\text { CFW } \\
\text { COD } \\
\text { CFO }\end{array}$ & $\begin{array}{r}. .1999 \\
.9131 \\
-.5390 \\
.0370\end{array}$ & $\begin{array}{r}. .6371 \\
-.0758 \\
.8069 \\
.6638\end{array}$ & $\begin{array}{r}.6589 \\
.8230 \\
.3428 \\
-.8026\end{array}$ & $\begin{array}{r}.6126 \\
-.8416 \\
-.2940 \\
1.1032\end{array}$ \\
\hline ATTRI BUTES & 1 & 2 & 3 & 4 \\
\hline $\begin{array}{l}\text { POW } \\
\text { URB } \\
\text { DEV } \\
\text { REL } \\
\text { POL }\end{array}$ & $\begin{array}{r}-.4582 \\
-.3057 \\
.0488 \\
-.2491 \\
-.8636\end{array}$ & $\begin{array}{r}-.1647 \\
-.4472 \\
-.3015 \\
-.7629 \\
.5442\end{array}$ & $\begin{array}{r}-.4989 \\
.6634 \\
-.9881 \\
.0962 \\
-.0362\end{array}$ & $\begin{array}{r}-.0280 \\
.7251 \\
-.0080 \\
-.6157 \\
.0421\end{array}$ \\
\hline
\end{tabular}

CANONIOAL REQRESGION COEFFiCSEMTS - BEMAV́ OUR YNOEX

CANONIOAL VARIATES

JEmAY IOUT
I 31
CFI
COI
ATTRI BUTEB
PON
URB
OEV
REL
PQ

$\begin{array}{ccc}1 & -2 & 3 \\ -.7229 & -.5981 & -.3621 \\ .5420 & .9304 & -.3778 \\ -.2962 & .4357 & -1.1074 \\ 1 & 2 & .1 \\ --.2486 & -.0879 & -.6232 \\ .2070 & -.3457 & -.4117 \\ -.2996 & .4761 & -.5168 \\ -.9110 & -.4302 & -.0630 \\ -.2779 & .8129 & .1411\end{array}$




\section{APPENUIX i}

TANRANIA

DOCIAL-FIELD THEORY AFSULTE

\begin{tabular}{|c|c|c|c|c|c|}
\hline No. or & FREQ & cr & No. of & JEHAVI OUR & $1 \operatorname{mos} x$ \\
\hline $\begin{array}{l}\text { VANON. } \\
\text { VARE. }\end{array}$ & EIOEMUALUE & $\begin{array}{l}\text { CANON. } \\
\text { CORREL. }\end{array}$ & $\begin{array}{l}\text { CAMON. } \\
\text { VARS. }\end{array}$ & EI GeNVALUE & $\begin{array}{l}\text { CAMON. } \\
\text { CORREL. }\end{array}$ \\
\hline $\begin{array}{c}1 \\
2 \\
3 \\
4 \\
\text { TAACE }\end{array}$ & $\begin{array}{r}.1940 \\
.0282 \\
.0059 \\
.0016 \\
.2395\end{array}$ & $\begin{array}{l}.4404 \\
.1681 \\
.0766 \\
.0402\end{array}$ & $\begin{array}{l}1 \\
2 \\
3 \\
\text { Tnace }\end{array}$ & $\begin{array}{l}.2783 \\
.0400 \\
.0069 \\
=.3290\end{array}$ & $\begin{array}{l}.5175 \\
.1999 \\
.0830\end{array}$ \\
\hline
\end{tabular}

CANONICAL REGREBSION GOEFEDOIENTG - FREQUENCY

\begin{tabular}{|c|c|c|c|c|}
\hline \multicolumn{5}{|c|}{ CAHON:CAL VARIATES } \\
\hline 3Emavioup & 1 & 2 & 3 & 4 \\
\hline $\begin{array}{l}\text { COA } \\
\text { CFIY } \\
\text { COD } \\
\text { CFD }\end{array}$ & $\begin{array}{r}. .1465 \\
.9115 \\
-.5353 \\
.0586\end{array}$ & $\begin{array}{r}-.3243 \\
.4360 \\
.9247 \\
.0099\end{array}$ & $\begin{array}{r}-1.0601 \\
.0098 \\
.1786 \\
.0120\end{array}$ & $\begin{array}{r}-.1853 \\
-1.1517 \\
.0387 \\
1.5482\end{array}$ \\
\hline ATTRI BUTES & $\ldots 1$ & 2 & 3 & 4 \\
\hline $\begin{array}{l}\text { PON } \\
\text { UR3 } \\
\text { DEV } \\
\text { REL } \\
\text { PQL }\end{array}$ & $\begin{array}{r}-.3265 \\
-.4102 \\
.0727 \\
-.5123 \\
-.6672\end{array}$ & $\begin{array}{r}-.6947 \\
.0680 \\
-.7647 \\
-.0930 \\
.2607\end{array}$ & $\begin{array}{r}-.1548 \\
-.8404 \\
.6017 \\
.6004 \\
-.1065\end{array}$ & $\begin{array}{r}.5767 \\
-.6644 \\
-.0188 \\
-.6077 \\
.6146\end{array}$ \\
\hline
\end{tabular}

\section{CAMONICAL Reoression COEFFICIENTS - Bemavioun InDEX \\ Camonical variateg} $\alpha$

Jemav I oup
I8I
CFI
COI

Artai aute.

POA

LRB

DEP

REL

Pa

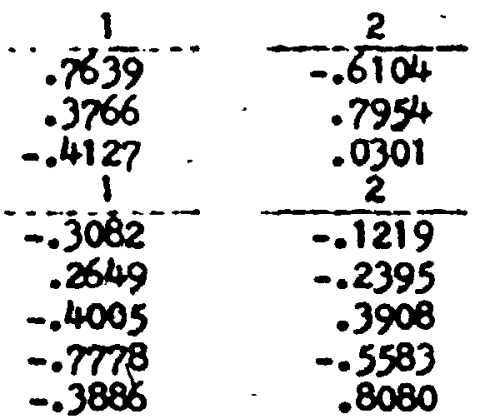

$\frac{3}{.2232}$
. .7822
1.1055
$\frac{3}{-.3301}$
.9572
.0291
. .3394
-.0621


204.

\section{ArPENUIX 1}

TOGO

SOCIAL-FIELO THEORY RESULTO

\begin{tabular}{|c|c|c|c|c|c|}
\hline \multirow{2}{*}{$\begin{array}{l}\text { No. or } \\
\text { SAMOM. } \\
\text { VARE. }\end{array}$} & \multicolumn{2}{|c|}{ FREQUENEV } & \multirow{2}{*}{$\begin{array}{l}\text { Na. of } \\
\text { Canow; } \\
\text { YAAB. }\end{array}$} & \multirow{2}{*}{$\begin{array}{l}\text { Jemavioua } \\
\text { Eleenvalue }\end{array}$} & \multirow{2}{*}{$\begin{array}{l}\text { INOEX } \\
\text { CANON. } \\
\text { CEREEL. }\end{array}$} \\
\hline & E OENUALUE & $\begin{array}{l}\text { CANON. } \\
\text { COAREL }\end{array}$ & & & \\
\hline $\begin{array}{l}1 \\
2 \\
3 \\
4\end{array}$ & $\begin{array}{l}.2628 \\
.0286 \\
.0214 \\
.0008\end{array}$ & $\begin{array}{l}.5127 \\
.1692 \\
.1067 \\
.0276\end{array}$ & $\begin{array}{l}1 \\
2 \\
3\end{array}$ & $\begin{array}{l}.2994 \\
.0231 \\
.0110\end{array}$ & $\begin{array}{l}.5472 \\
.1521 \\
.1050\end{array}$ \\
\hline TAACE & $=.2754$ & & Thac & $=.3333$ & \\
\hline
\end{tabular}

CANONICAL PEORE83iON COEEFCEIENTA-FRERUENCY

\section{CANONICAL vaAiAtes}

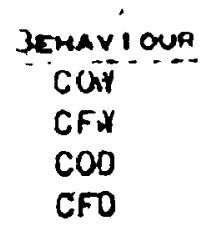

Artal gutes

PON

URB

OEY

REL

pa.
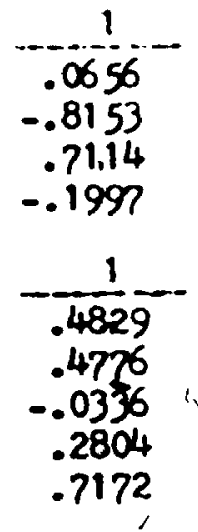
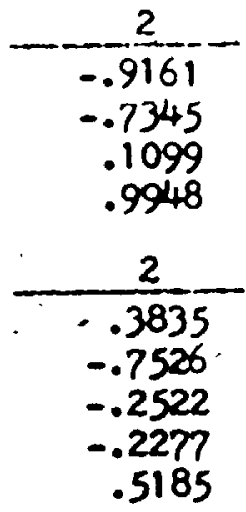
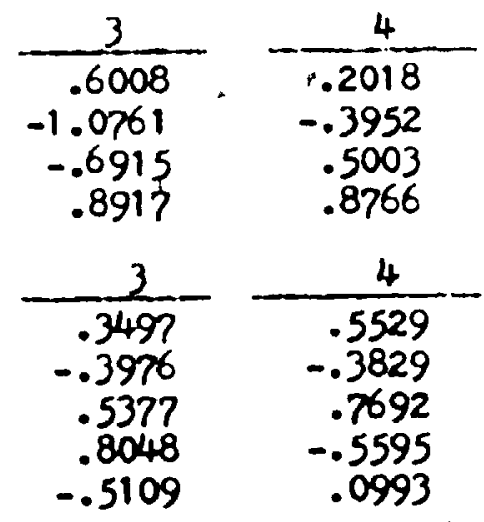

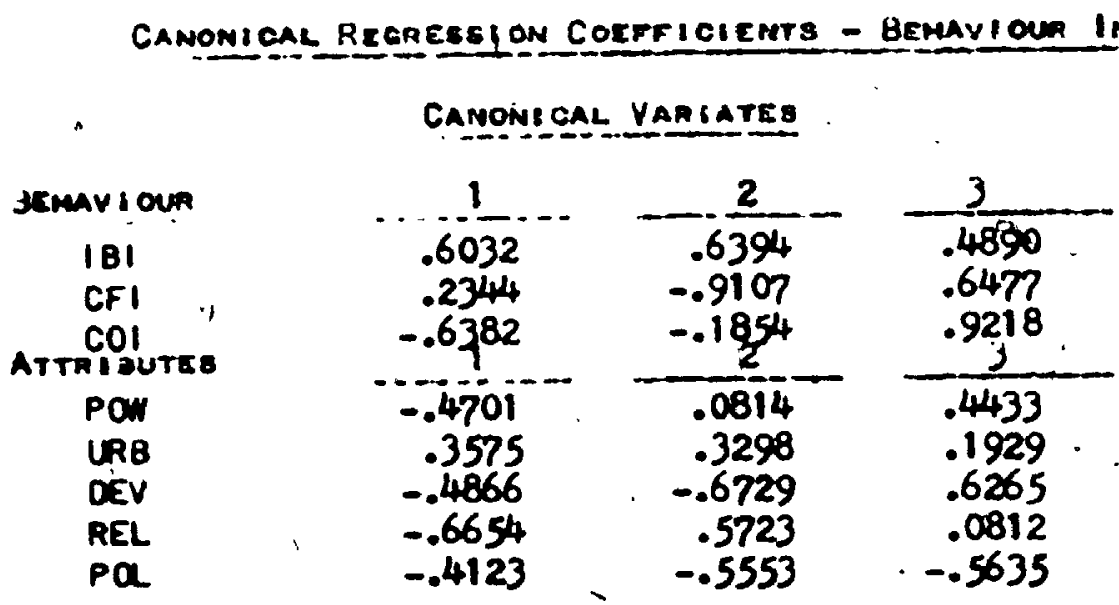




\section{ARPENUIX 3}

UGANOA

SOO:ALAFHELD THEOFV RE:QULTS

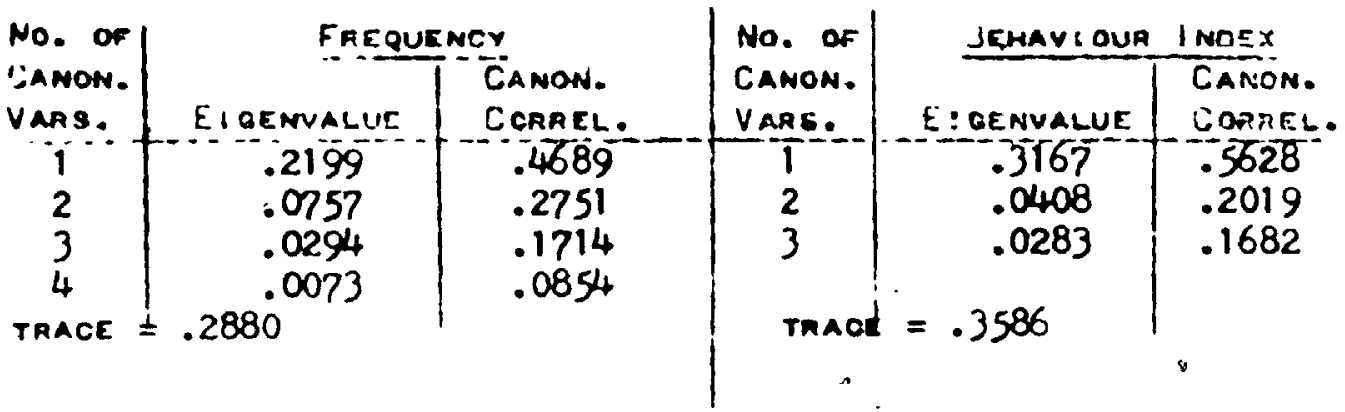

\section{CANONICAL REOAERS:ON COEFFCGIENTB - FREQUENTV}

CANONSCAL VARIATES

$$
\begin{aligned}
& \text { JEMAV IOUA } \\
& \text { COA } \\
& \text { CFW } \\
& \text { COO } \\
& \text { CFO }
\end{aligned}
$$

ATrR : BUTE:

POW

URO

OEV

REL

POL

$$
\begin{array}{r}
1 \\
.-1647 \\
. .2770 \\
.8596 \\
-.6482
\end{array}
$$

$-\frac{1}{.4871}$
.6479
.0914
.0806
.6069
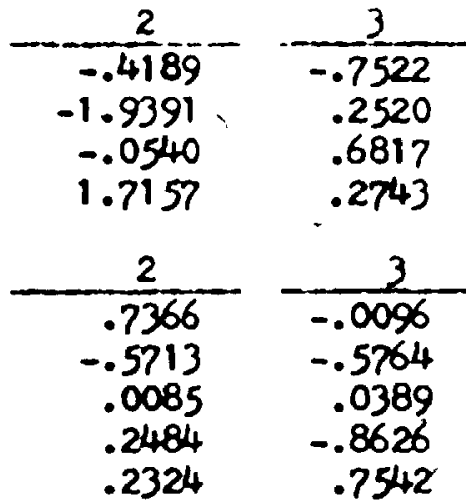

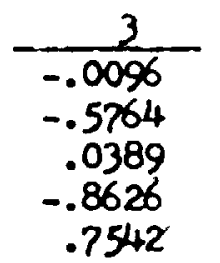

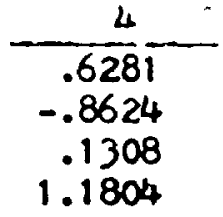

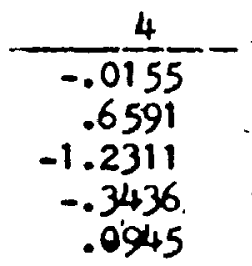

CANONICAL REGREGBI ON COEFFicienrs - BEMAY OUA INOEX

Canonical VARIATCB

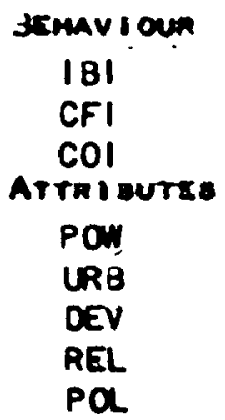
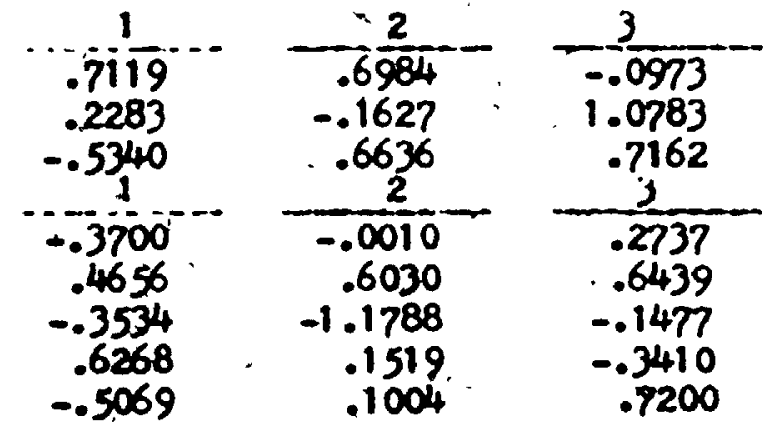


\section{APPENUIX 2}

UPPER VQTA

SOOIAL FIELO TMEORY REOULTS

\begin{tabular}{|c|c|c|c|c|c|}
\hline \multirow{2}{*}{$\begin{array}{l}\text { No. or } \\
\text { YAMON. } \\
\text { VARS. }\end{array}$} & \multicolumn{2}{|c|}{ Frequenor } & \multirow{2}{*}{$\begin{array}{l}\text { No. Of } \\
\text { CANON. } \\
\text { VAR5. }\end{array}$} & \multicolumn{2}{|c|}{ Jemaviour I mocx } \\
\hline & E reENVALUS & $\begin{array}{l}\text { CANON. } \\
\text { COAREL. }\end{array}$ & & EjeENVALUE & $\begin{array}{l}\text { CAMON. } \\
\text { CORREL }\end{array}$ \\
\hline $\begin{array}{l}1 \\
2 \\
3 \\
4\end{array}$ & $\begin{array}{l}.4162 \\
.1789 \\
.0181 \\
.0064\end{array}$ & $\begin{array}{l}.6451 \\
.4229 \\
.1344 \\
.0803\end{array}$ & $\begin{array}{l}1 \\
2 \\
3\end{array}$ & $\begin{array}{l}.3373 \\
.1019 \\
.0658\end{array}$ & $\begin{array}{l}.5807 \\
.3193 \\
.2565\end{array}$ \\
\hline & AOC $=.3935$ & & $\operatorname{Tna}$ & $E=.4102$ & \\
\hline
\end{tabular}

CANONICAI. REOREBS:ON COEFFKCIENTS - FREQUENUY

CANONIGAL YAR:ATES

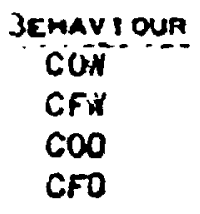

CFO

ATTRISUTEO

PON

URB

DEL

REL

$P \alpha$

$$
\begin{array}{r}
1 \\
-.0812 \\
-1.4880 \\
.5012 \\
.6273
\end{array}
$$
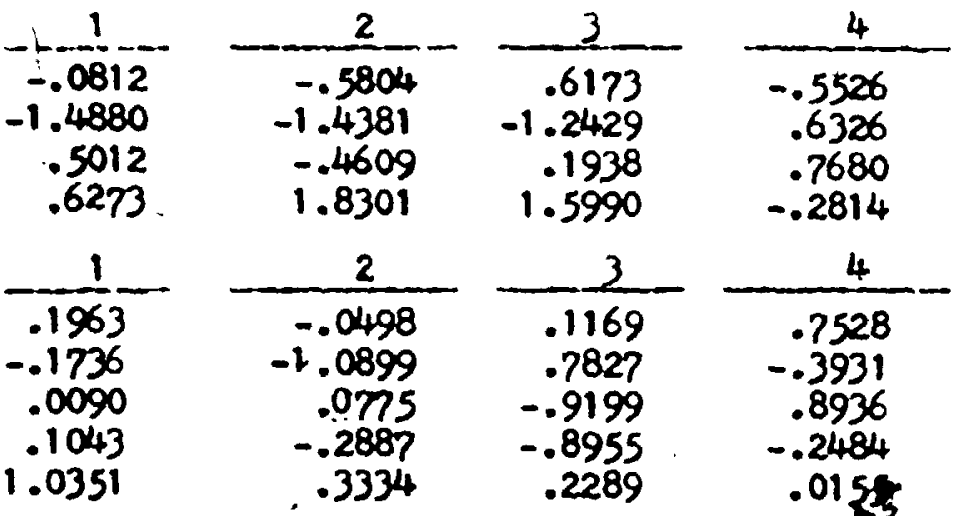

$$
\begin{gathered}
3 \\
\hline .1169 \\
.7827 \\
-.9199 \\
-.8955 \\
.2289
\end{gathered}
$$

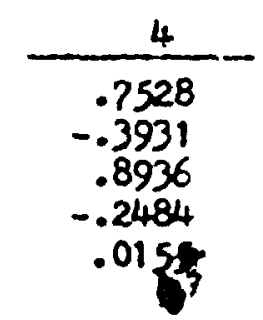

CANONICAL REORESEION COEFF: OIENTO BEHAVIOUP INOEX

Camoingaz Vamiatea

\section{serróv i oun}

$|B|$

CFI

COI

ATthi suts:

POW

URA

DEV

REL

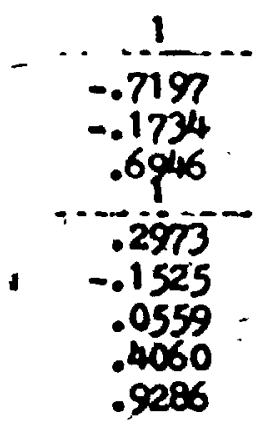

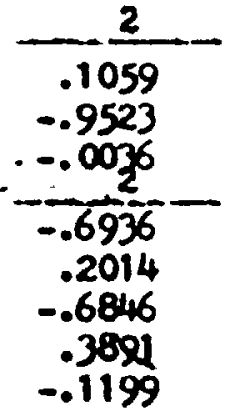

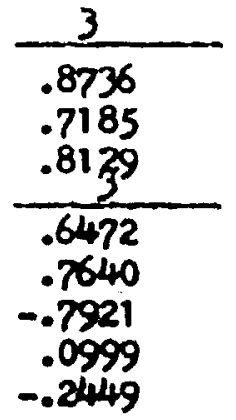


ZAIRE SOOIALFIELO THEORY REUULTB

\begin{tabular}{|c|c|c|c|c|c|}
\hline No. or & EREq & ICr & No. of & Jemavi oup & I MOEX \\
\hline $\begin{array}{l}\text { Jamon. } \\
\text { vane. }\end{array}$ & EIOENNALUE & $\begin{array}{l}\text { CAMON. } \\
\text { COAREL }\end{array}$ & $\begin{array}{l}\text { CANON. } \\
\text { VAAE. }\end{array}$ & & $\begin{array}{l}\text { CAMON. } \\
\text { COAREL }\end{array}$ \\
\hline $\begin{array}{l}1 \\
2 \\
3 \\
4\end{array}$ & $\begin{array}{l}.0505 \\
.0241 \\
.0110 \\
.0007\end{array}$ & $\begin{array}{l}.2248 \\
.1554 \\
.1044 \\
.0248\end{array}$ & $\begin{array}{l}4 \\
2 \\
3\end{array}$ & $\begin{array}{l}.7293 \\
.1738 \\
.0447\end{array}$ & $\begin{array}{l}.8540 \\
.4168 \\
.1213\end{array}$ \\
\hline InACE & .1466 & & ranad & $=.5530$ & \\
\hline
\end{tabular}

CANONICAL REORESSION COEFEICIINTS F FREQUENEY

$$
\text { CANONICAL VARGATES }
$$

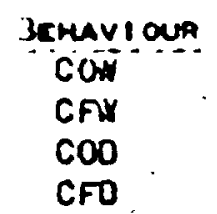

ATTRIOUTES

POW

LR3

DEV

REL

Pa
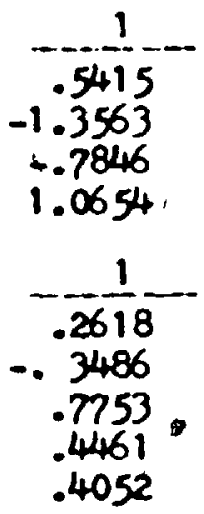
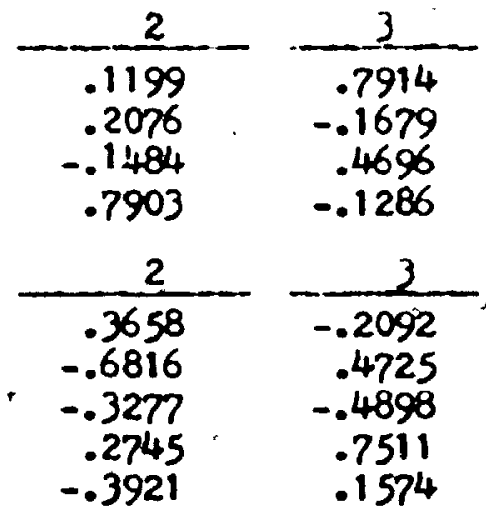

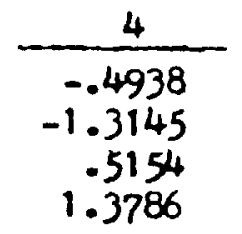

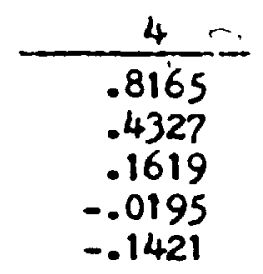

Canomical RegRegsion COETFicients. - BEHAY OUR I MOEX

Canonigal variateg

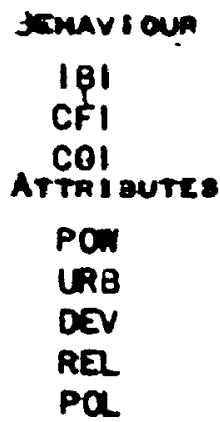
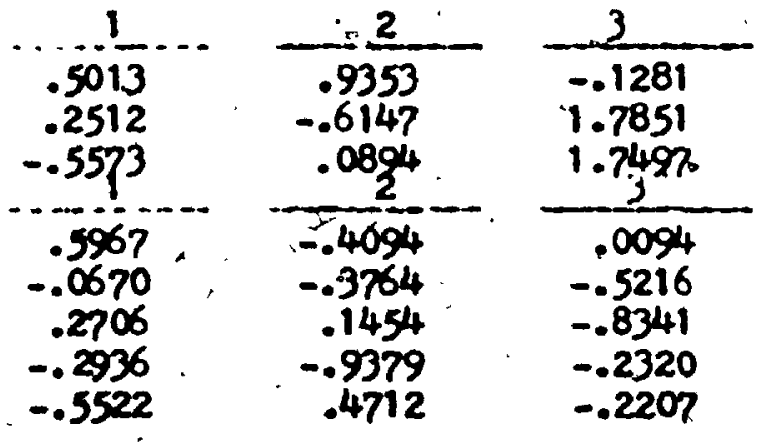


\section{ARPENUIX 2}

ZAMBIA

SOOIALFIRLD THEONY REBULTE

\begin{tabular}{|c|c|c|c|c|c|}
\hline No. or & Fane & & No. of & JEHAV I OUA & I noEX \\
\hline $\begin{array}{l}\text { 'AANON. } \\
\text { VARO. }\end{array}$ & Ei oenualue & $\begin{array}{l}\text { CANON. } \\
\text { CORELL. }\end{array}$ & $\begin{array}{l}\text { CAMON. } \\
\text { VAAB. }\end{array}$ & & $\begin{array}{l}\text { CANCN. } \\
\text { CORACL }\end{array}$ \\
\hline $\begin{array}{c}1 \\
2 \\
3 \\
4 \\
\text { TaAce }\end{array}$ & $\begin{array}{r}.6093 \\
.4090 \\
.1921 \\
.0417 \\
.5594\end{array}$ & $\begin{array}{l}.7806 \\
.6395 \\
.4383 \\
.2043\end{array}$ & $\begin{array}{l}1 \\
2 \\
3 \\
\text { ThAo }\end{array}$ & $\begin{array}{r}.5740 \\
.1815 \\
.0535 \\
=.5192\end{array}$ & $\begin{array}{l}.7577 \\
.4161 \\
.2312\end{array}$ \\
\hline
\end{tabular}

CANONICAL REBAEBSY ON COEFFIC:ENTE - FREQUENCY

CANONIEAL VARIATEQ

\begin{tabular}{|c|c|c|c|c|}
\hline Bemaviour & 1 & 2 & 3 & 4 \\
\hline $\begin{array}{l}\text { COA } \\
\text { CFIY } \\
\text { COO } \\
\text { CFO }\end{array}$ & $\begin{array}{r}.4722 \\
.8940 \\
-.6504 \\
-.5881\end{array}$ & $\begin{array}{r}.1340 \\
-1.9707 \\
-.6334 \\
1.8082\end{array}$ & $\begin{array}{r}.4584 \\
-.1841 \\
.4422 \\
.8209\end{array}$ & $\begin{array}{r}-.7591 \\
.0774 \\
-.2265 \\
.6719\end{array}$ \\
\hline ATtR I QUTE: & 1 & 2 & 3 & 4 \\
\hline $\begin{array}{l}\text { POW } \\
\text { URB } \\
\text { DEV } \\
\text { REL } \\
\text { POL }\end{array}$ & $\begin{array}{r}-.1266 \\
.4115 \\
.4674 \\
.0467 \\
. .9033\end{array}$ & $\begin{array}{r}-.4011 \\
.4568 \\
.3301 \\
-.4130 \\
.5441\end{array}$ & $\begin{array}{r}-.2461 \\
-.0653 \\
-.9712 \\
. .9487 \\
.0145\end{array}$ & $\begin{array}{r}-.0594 \\
-.8316 \\
.1933 \\
-.4982 \\
.2285\end{array}$ \\
\hline
\end{tabular}

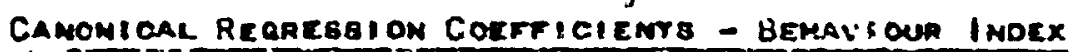

CAMON!CAL VARiATES.

STMavioun
IBI
CFI
COI
ATTMI DUTT:
POW
URB
OEV
REL
POL
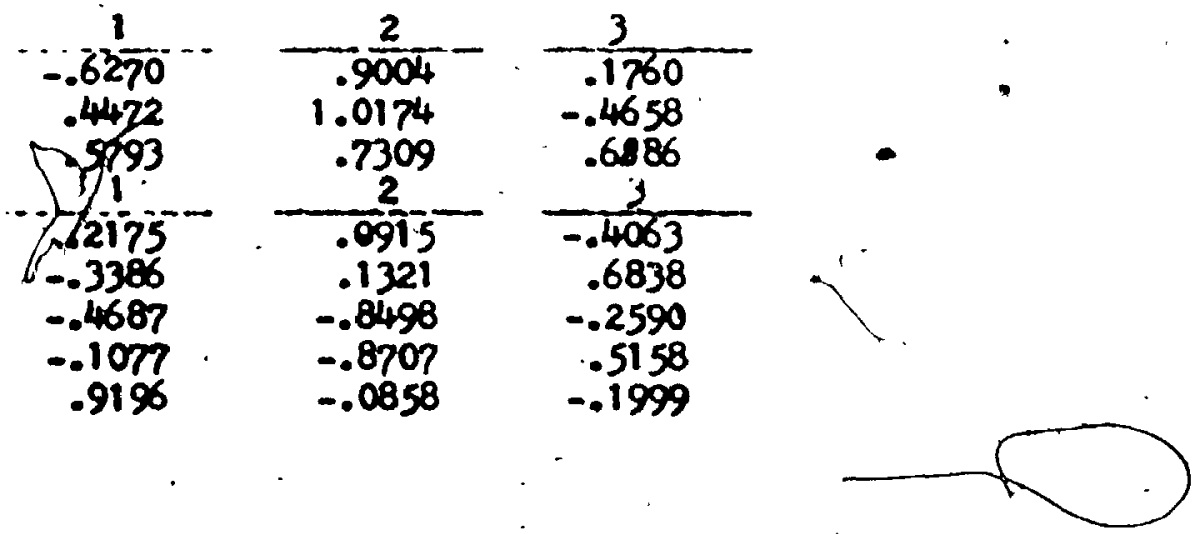


\section{APPENOIX 4}

CAMEROON

STATUS-FIELO THEOAY REEULTS

\begin{tabular}{|c|c|c|c|c|c|}
\hline \multirow{2}{*}{$\begin{array}{l}\text { No. of } \\
\text { CAAMON. } \\
\text { Vans. }\end{array}$} & \multicolumn{2}{|c|}{ Facquenor } & \multirow{2}{*}{$\begin{array}{l}\text { No. of } \\
\text { Canon. } \\
\text { Vane. }\end{array}$} & Begmavioun & I nOEX \\
\hline & EIOEMNALUE & $\begin{array}{l}\text { CANONON. } \\
\text { CORALL. }\end{array}$ & & Eigenvalue & $\begin{array}{l}\text { CANON. } \\
\text { CORAEL. }\end{array}$ \\
\hline $\begin{array}{l}1 \\
2\end{array}$ & $\begin{array}{r}.0201 \\
.0034\end{array}$ & $\begin{array}{l}.0204 \\
.0034\end{array}$ & $\begin{array}{l}1 \\
2\end{array}$ & $\begin{array}{r}.5985 \\
.2328\end{array}$ & $\begin{array}{l}.7736 \\
.4825\end{array}$ \\
\hline TRAOE & 1086 & & TRACE & 47 & \\
\hline
\end{tabular}

Canomical Regre8sion Coefricients - Frequeney

\section{CANONICAL VARIATES}

\begin{tabular}{l} 
BEmav loun \\
\hline CON \\
CFW \\
COO \\
CFO
\end{tabular}

$$
\begin{array}{cc}
\frac{1}{-.2559} & \frac{2}{.1945} \\
1.2283 & -.7686 \\
.7328 & -.2823 \\
-.6145 & 1.5164
\end{array}
$$

$\frac{\text { ATrRi BuTES }}{\text { POW }}$

$\begin{array}{cc}1 & \frac{2}{.0199} \\ -.9973 & .0080 \\ .1482\end{array}$

CAMOONICAL REORESBION. COEFFIOIENTS - BEMAVIOUR I nOEX

CAMONIOAL VARIATEB

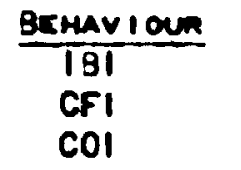

$$
\begin{array}{cc}
\frac{1}{-.5874} & \frac{2}{1.0630} \\
& -6.26309 \\
1.0084 & 2.0386
\end{array}
$$

ATrnisutce

PON

DeV

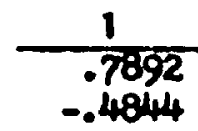

$$
-\frac{2}{.6428}
$$


APPENOLI 4

CHAD

SiTATUB-FicLO ThEOAY REBULTE

\begin{tabular}{|c|c|c|c|c|c|}
\hline \multirow{2}{*}{$\begin{array}{l}\text { PMS. OF } \\
\text { ANON. } \\
\text { VARR. }\end{array}$} & \multicolumn{2}{|c|}{ FREQUENCY } & \multirow{2}{*}{$\begin{array}{l}\text { No. of } \\
\text { CAMor. } \\
\text { VAlg. }\end{array}$} & JEMLV: OUR & I morx \\
\hline & E iogarvalue & $\begin{array}{l}\text { CAMON. } \\
\text { COMREL. }\end{array}$ & & E: GINYALUE & $\begin{array}{l}\text { CAANOH. } \\
\text { COPREL. }\end{array}$ \\
\hline $\begin{array}{l}1 \\
2\end{array}$ & $\begin{array}{l}.0214 \\
.0034\end{array}$ & $\begin{array}{l}.1463 \\
.0587\end{array}$ & $\begin{array}{l}1 \\
2\end{array}$ & $\begin{array}{l}.2285 \\
.0383\end{array}$ & $\begin{array}{l}.4780 \\
.1957\end{array}$ \\
\hline TAAOE & .1153 & & TRAOE & $=.3652$ & \\
\hline
\end{tabular}

CANONICAL KEGREBS: ON COEFFIC-ENTE - FREQHENOV

CANONIGAL VAR:ATES

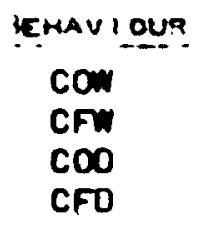

ATTR : DUTES

PON

DEV

$$
\begin{array}{cc}
-\frac{1}{-.2147} & -\frac{2}{.3056} \\
1.2297 & -.7759 \\
.7072 & -.3408 \\
-.5935 & 1.4749
\end{array}
$$

$\frac{1}{.0178} \frac{2}{-.9974} \quad \frac{1.0096}{.1578}$

CAMONLOAL REGHEDEION COEFFIOIENTE - DEMAVIOUA I NOFX

Canonical Variatre

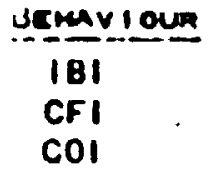

Arraisures

Pow

OEV

$\begin{array}{cc}1 & \frac{2}{-.3183} \\ .0023 & -.9125 \\ 1.0252 & -.3470 \\ & -.0753\end{array}$
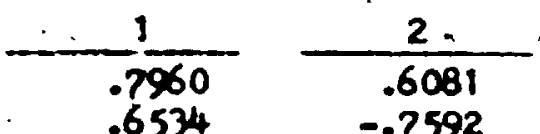


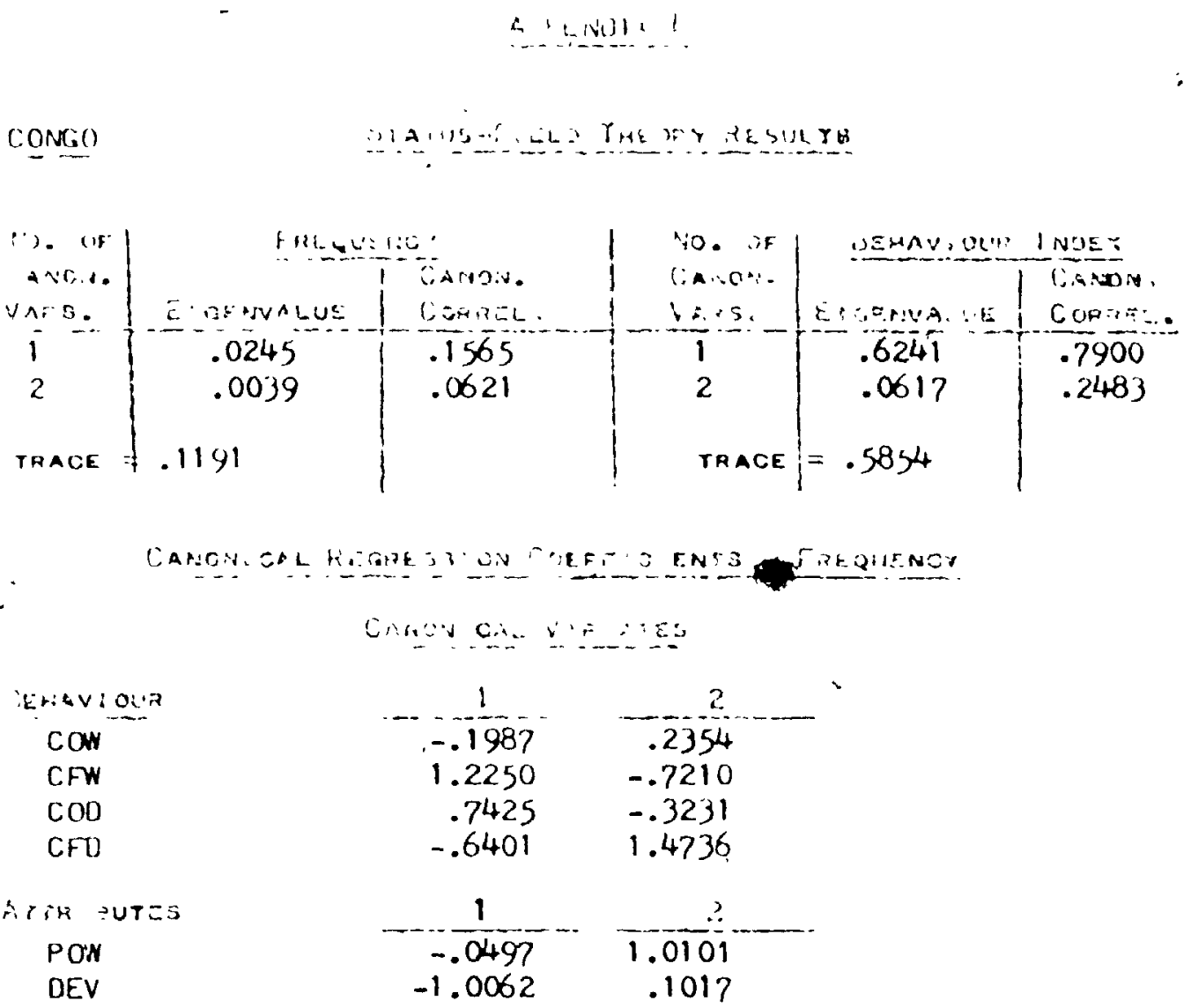

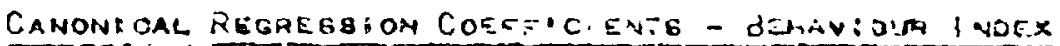

CANONICAL VARIATEB

JEMAVIOUR

$|B|$

$\frac{1}{.2735}$
$-\frac{2}{-.5989}$
$-.0453$
$-.4185$

CFI

$-1.0695$

$\mathrm{COI}$

.1370

ATrR:DUTE 3
PON
OEV
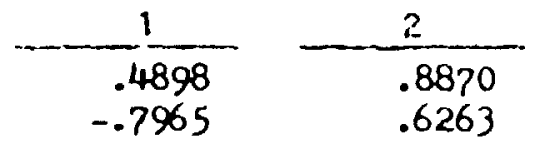


\section{An's?}

IIAHCWM:Y

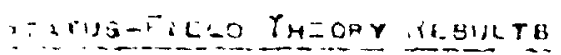

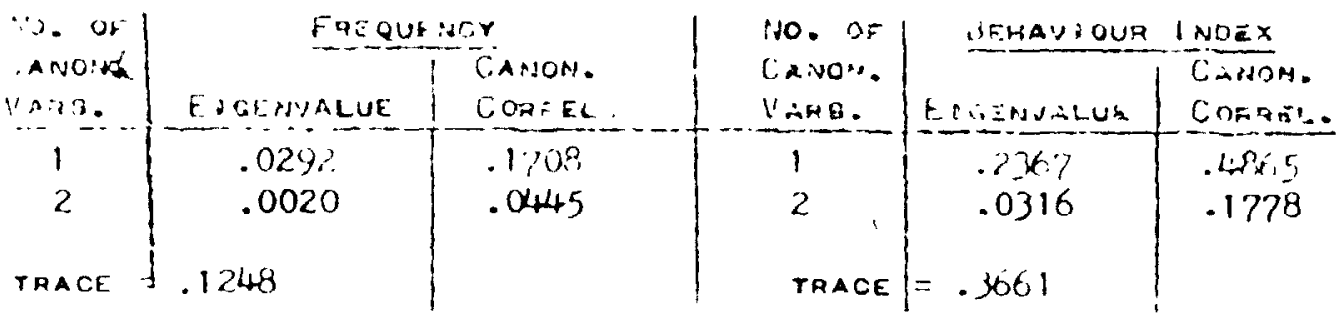

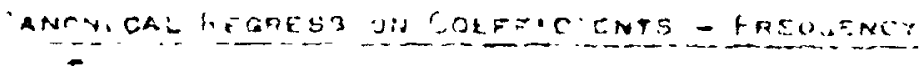

CANOSS:CA: VAR:STE:

\begin{tabular}{|c|c|c|c|}
\hline \multicolumn{2}{|l|}{ IEHA IOUR } & $\ldots 1$ & 2 \\
\hline $\cos$ & & -.1819 & .1199 \\
\hline CFW & ; & 1.1720 & -.2944 \\
\hline $\mathrm{COO}$ & & .7432 & -.5534 \\
\hline GFO & & -.5640 & 1.1397 \\
\hline जर:स guyas & & 1 & $?$ \\
\hline $\begin{array}{l}\text { POW } \\
\text { OEV }\end{array}$ & & $\begin{array}{r}.0260 \\
-1.0039\end{array}$ & $\begin{array}{r}1.0129 \\
.1373\end{array}$ \\
\hline
\end{tabular}

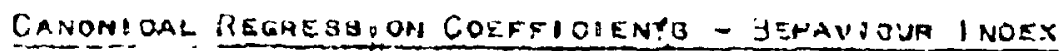

CANOI.GGAL VARIATR.S

UEMAY I OUR

|BI

CFI

$\mathrm{COI}$

ATrRosutes

PON

DEV
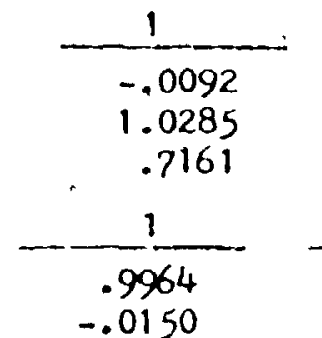

$-.0150$

2
.9104
.2207
.3681

$\frac{2}{.2526}$




\section{$1: \because 31 \times 4$}

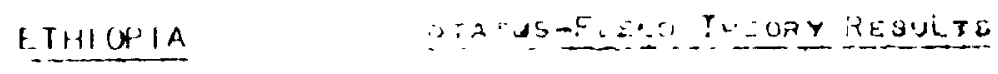

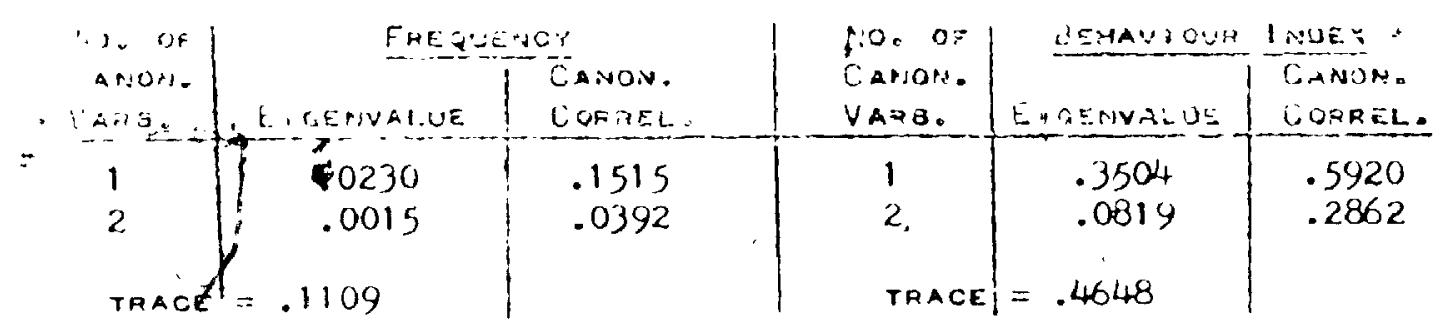

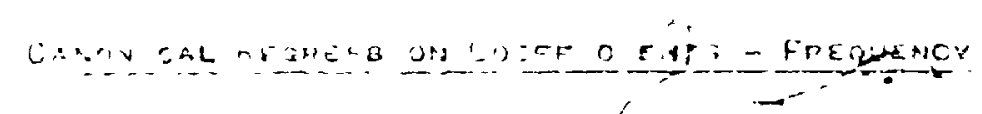

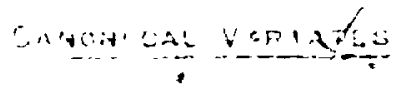
〔ேnAV: OUA.
CON
CFW
$\mathrm{COO}$
CFO

ATRA GUTES

POW

DEV

$$
\begin{gathered}
1 \\
.1156 \\
1.3237 \\
.2357 \\
-.5075
\end{gathered}
$$

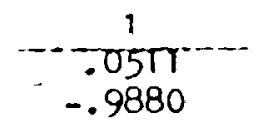

$$
\begin{gathered}
2 \\
-.6407 \\
-.8067 \\
.6081 \\
1.2049
\end{gathered}
$$

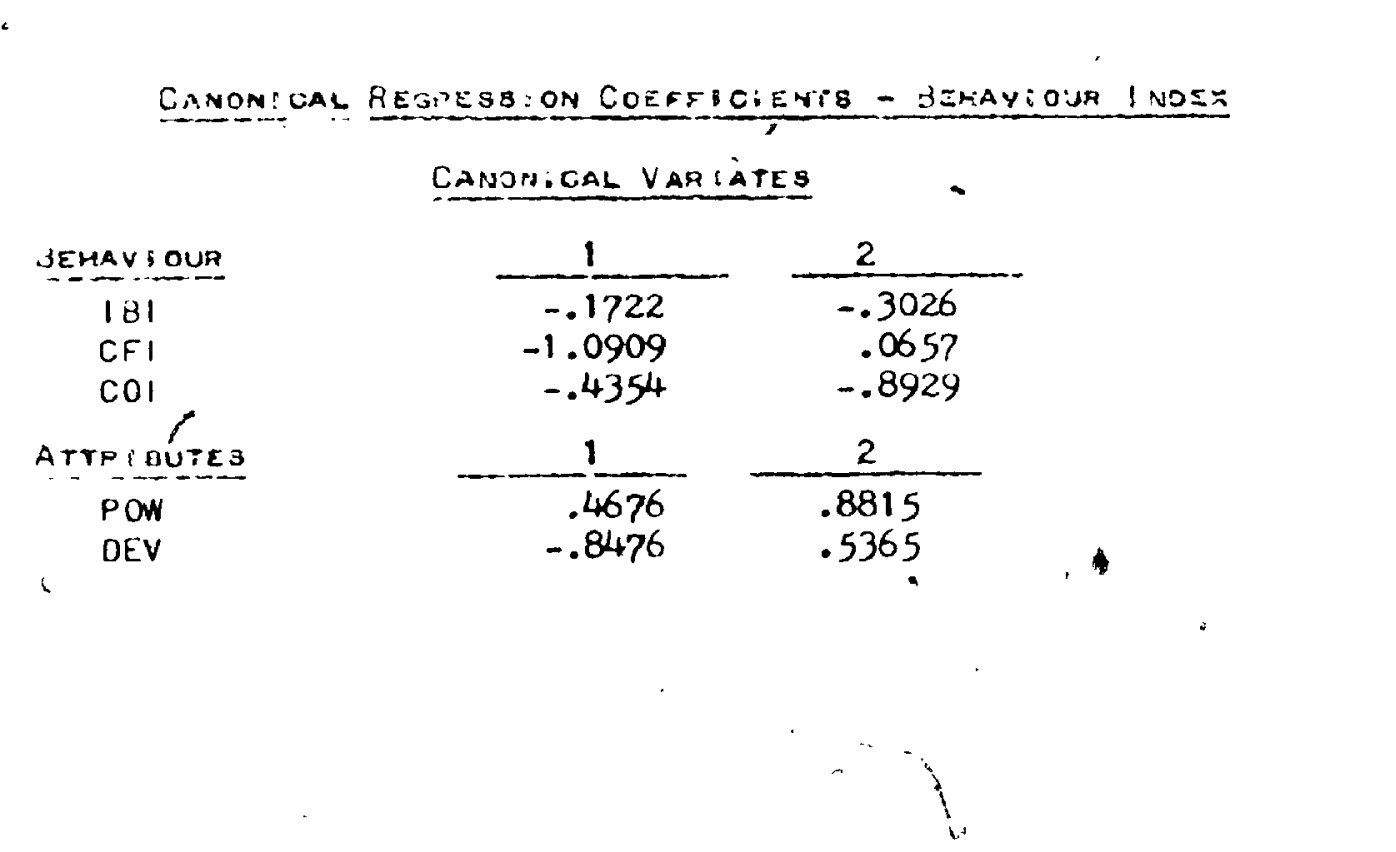

CANORIGAL VARTATES 


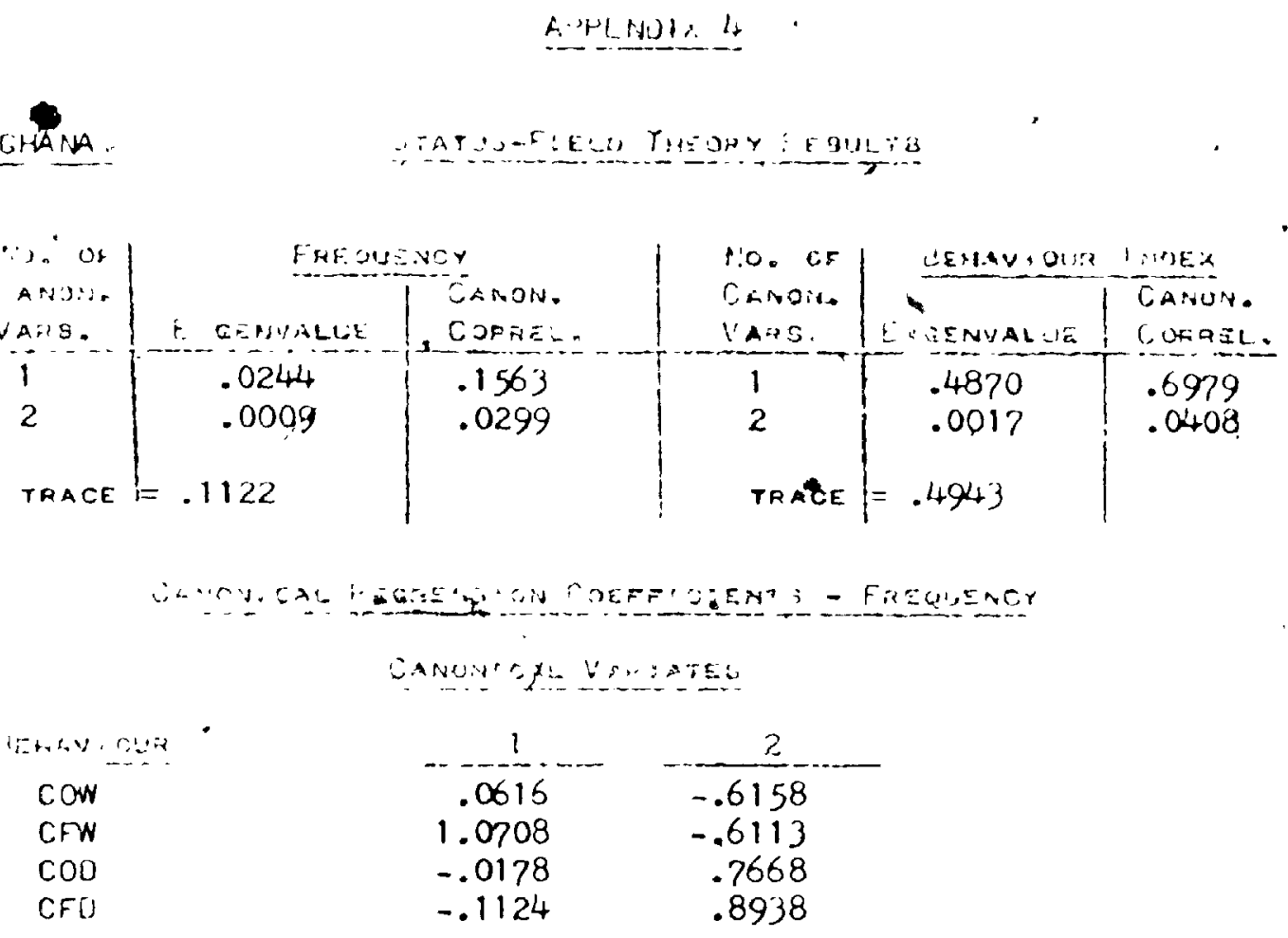

ATR : BUTES

PON

DEV

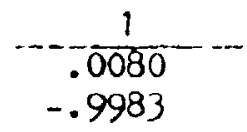

$-\frac{2}{1.022} \overline{0}$
.2189

I

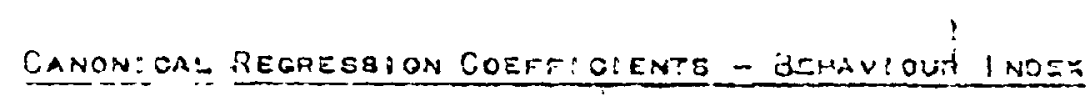

CALION. CAL VAPTATES

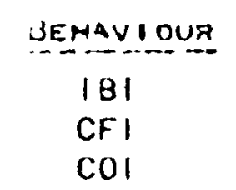

RITPR BUTES

POW

DEV

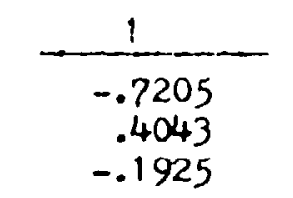
2
.5163
.0288
$-.9585$

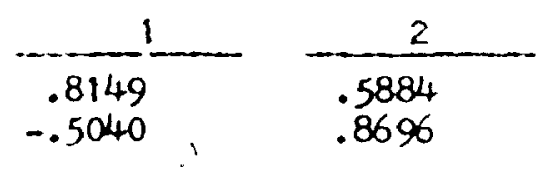




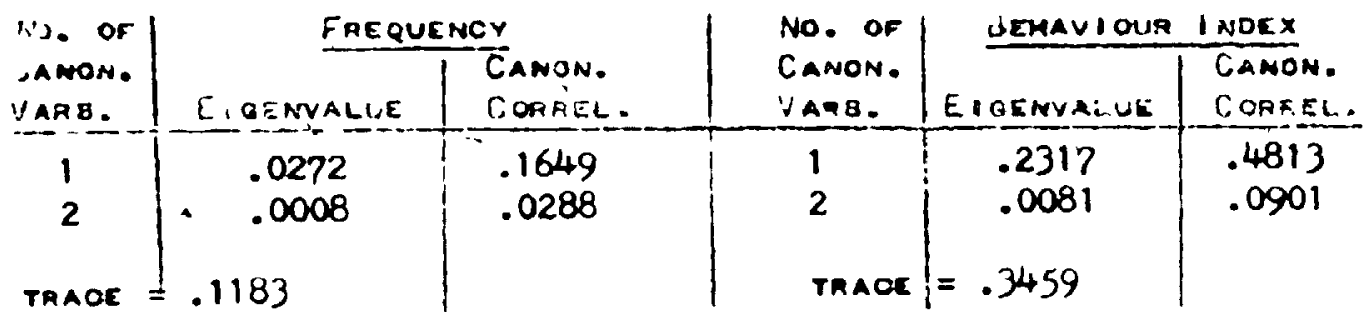

CANCH:CAL HEGREES OH COEFF'OLENTS - FOEQIENGY

\section{CAMONECAL VARBATES}

3EWAV: OUR
COW
CFW
COO
CFO

AtTriautes

PON

DEV

$$
\begin{aligned}
& -\frac{1}{.0964} \\
& 1.0180 \\
& . .0643 \\
& -.0557
\end{aligned}
$$

$-\frac{2}{-.2281}$
.5134
1.0405
-.5200

1
.0062
. .9989

\begin{tabular}{|c|}
\hline $\begin{array}{l}|\mathrm{B}| \\
\mathrm{CFI} \\
\mathrm{COI}\end{array}$ \\
\hline
\end{tabular}

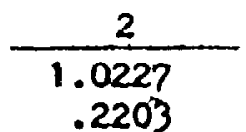

CANONICAL REGREBS YON COEFF:OLENTB D JEMAVIOUA I NOEX

CANONIGAL VARIATEO

ATtR igutes opon DEV

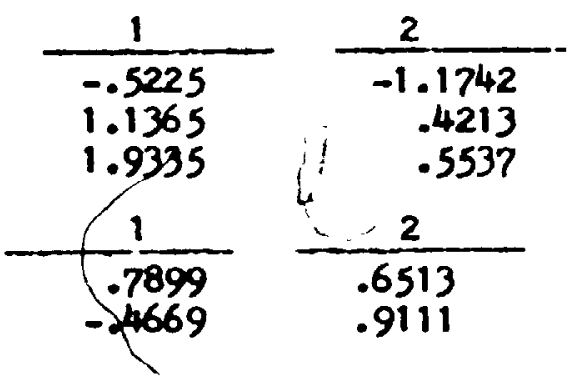




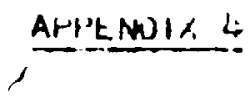

I VORY COAST

STATUB-FLELO THEOAY REBULT

\begin{tabular}{|c|c|c|c|c|c|c|}
\hline \multirow[b]{2}{*}{ 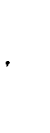 } & \multirow{2}{*}{$\begin{array}{l}\text { A's. OF } \\
\text { ANON. } \\
\text { VARB. }\end{array}$} & \multicolumn{2}{|c|}{ FaEquENCY } & \multirow{2}{*}{$\begin{array}{l}\text { No. of } \\
\text { C.ANON. } \\
\text { VAng. }\end{array}$} & Jemaviour & I NDEX \\
\hline & & E:GEMVALUE & $\begin{array}{l}\text { CAMON. } \\
\text { COARELL. }\end{array}$ & & Eloginualue & $\begin{array}{l}\text { CANON. } \\
\text { COARE: }\end{array}$ \\
\hline$\because$ & $\begin{array}{l}1 \\
2\end{array}$ & $\begin{array}{l}.0293 \\
.0012\end{array}$ & $\begin{array}{l}.173 \\
.0342\end{array}$ & $\begin{array}{l}1 \\
2\end{array}$ & $\begin{array}{l}.0980 \\
.0081\end{array}$ & $\begin{array}{l}.3134 \\
.0898\end{array}$ \\
\hline & TRAOE & .1232 & & TRAOE & $=.2300$ & \\
\hline
\end{tabular}

CARONGCAL HEGRESB: OH COEFFIE.ENTS - FREQUENOT

CANCNICAL VARBATES

SEHAV: OUR
CON
CFW
COD
CFO

Atratoutes

POW

DEV

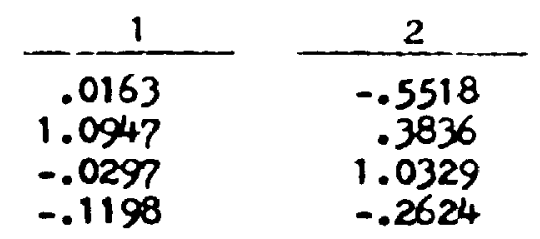

$\frac{1}{.0092}-\frac{2}{-.9981}-\frac{2}{1.0216}$

CANONIOAL REgREBSION COEFFICGEMTB - DENAVIOUA I MOES

CANONIGAL VARIATES

JEMAY OUR
IBI
CFI
COI

Arrnigute:

PON

DEV

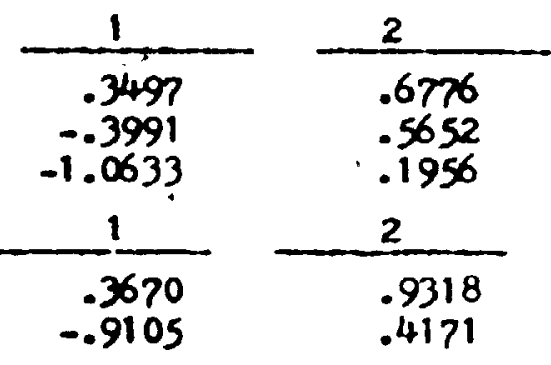


$2 r i$.

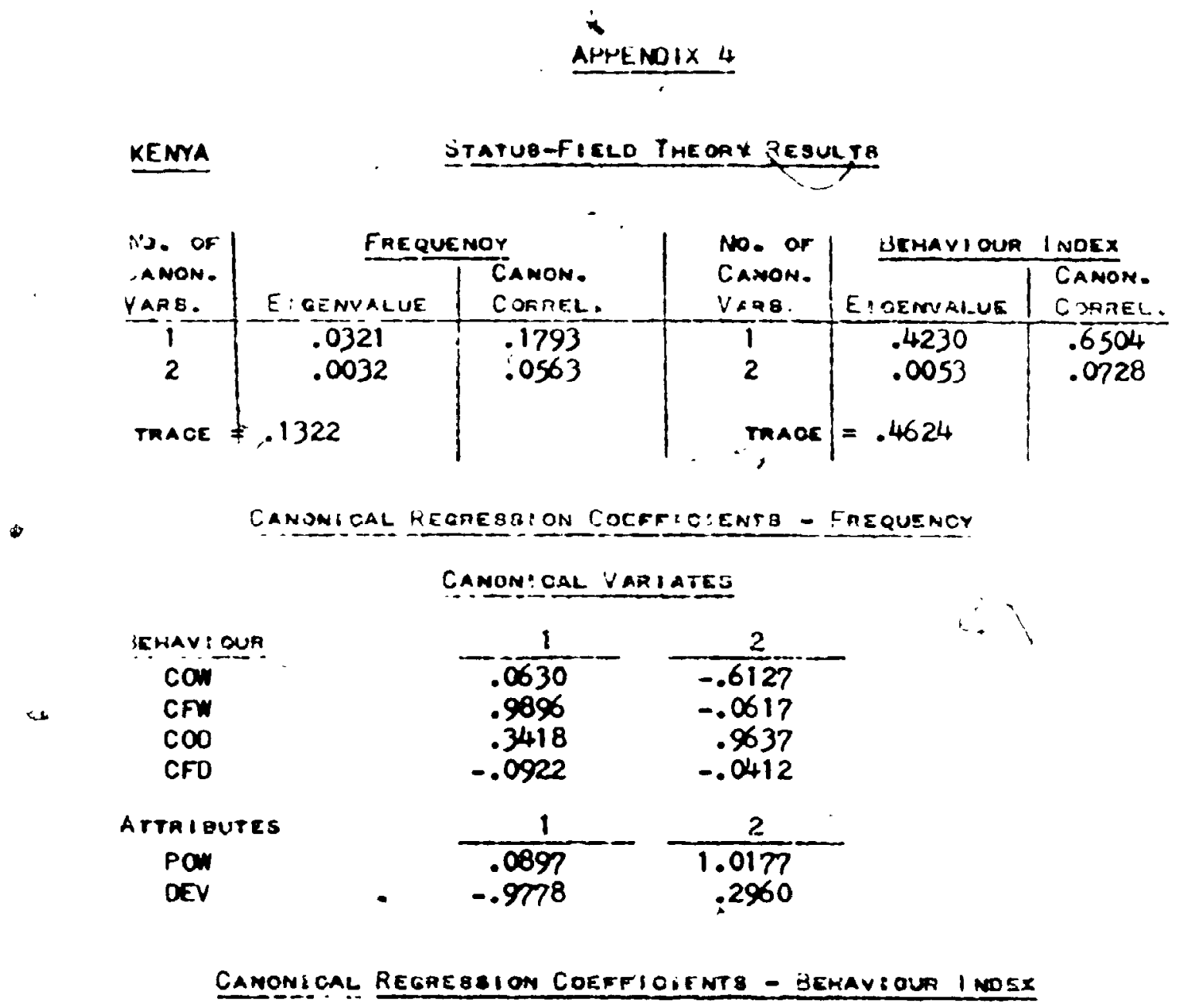

CANONICAL Variates

demav I oun

|81

CFI

$\mathrm{COI}$

$\begin{array}{cc}\frac{1}{2.3402} & \frac{2}{-.3630} \\ -5.3609 & 4.6928 \\ -6.8762 & 4.6677\end{array}$

ATral BuTE:

Pow

DEV

$\frac{1}{.6431} \frac{2}{.9481} \frac{.8104}{-.4148}$




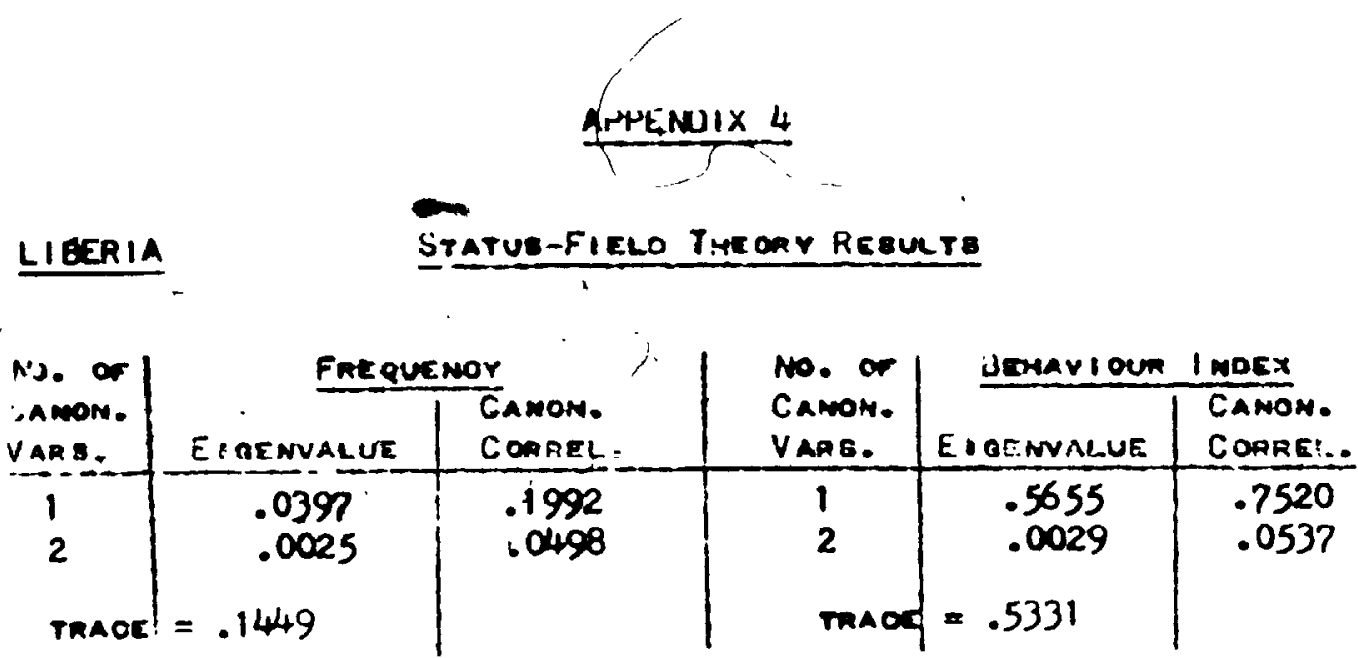

CANONGCAL REGAEB B: ON COEFF:OLENTB - FAEQUEMOY

CAmone QAL VARiATES

Seruvi our

can

CFI

$\mathrm{COO}$

CFO

Arthideutes

PON

D2Y
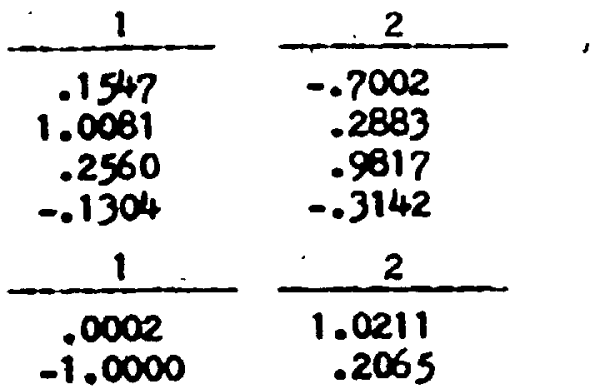

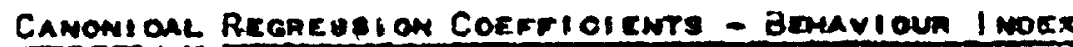

\section{Canomical Variatre}
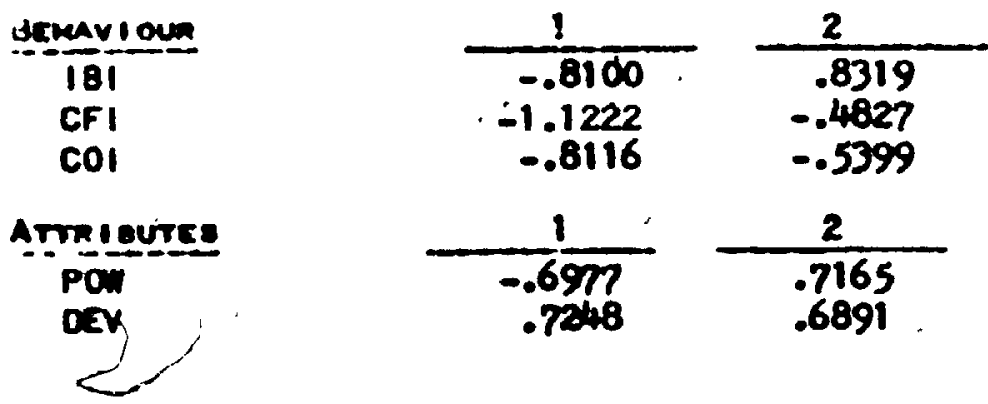


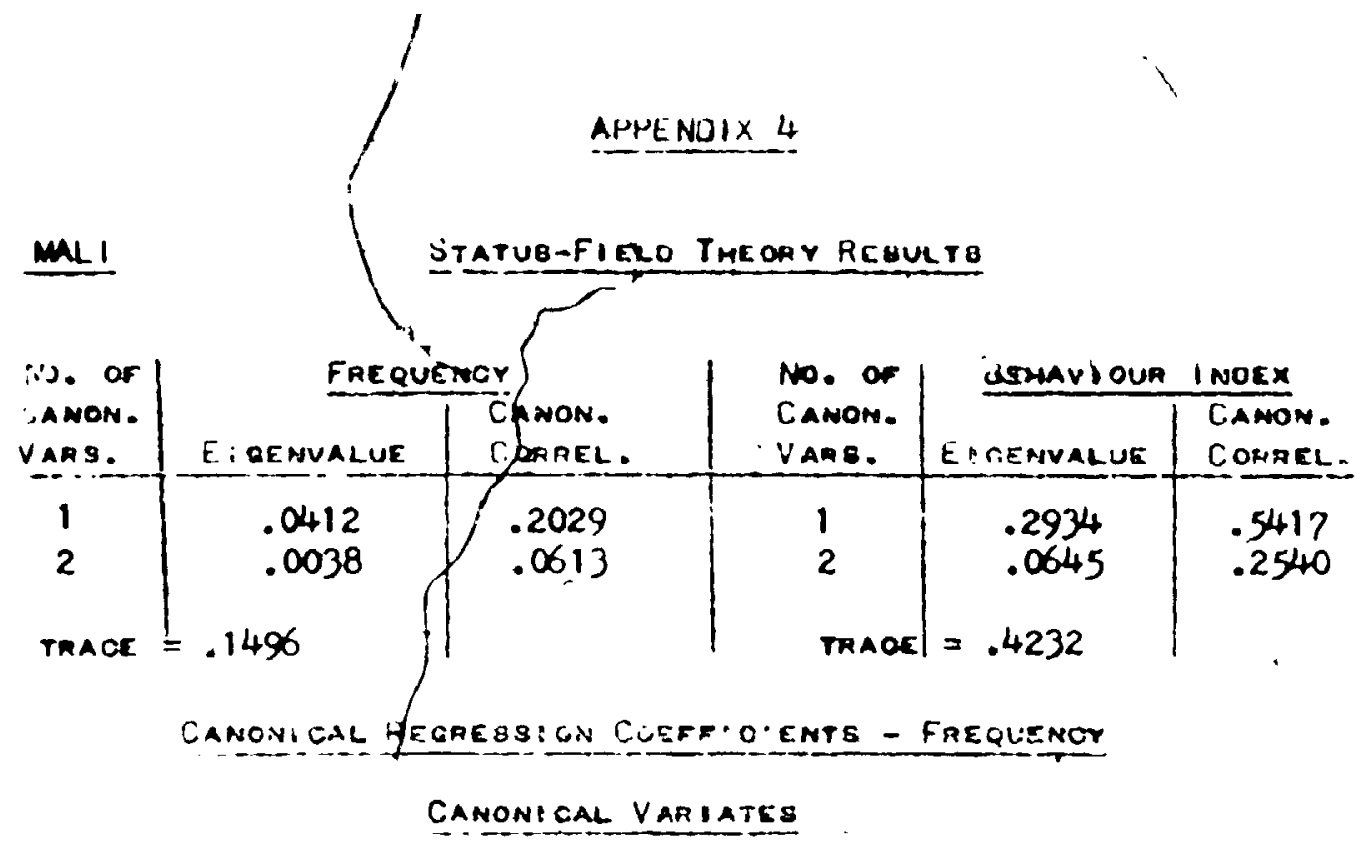

$$
\begin{aligned}
& \text { BEMAY : OUR } \\
& \text { CON } \\
& \text { CFW } \\
& \text { COO } \\
& \text { CFD }
\end{aligned}
$$

Attaloutes

POW

DEV
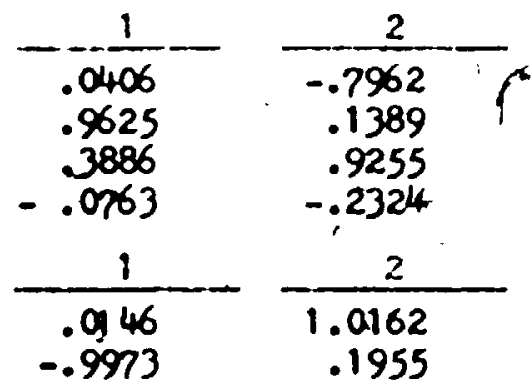

$\frac{2}{1.0162}$

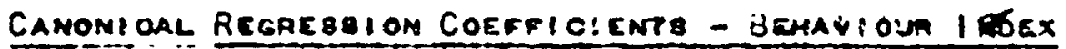

Camonical variates

SEmavioun
CFI
COI

ArThieutes
POW
OEV

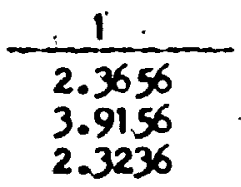

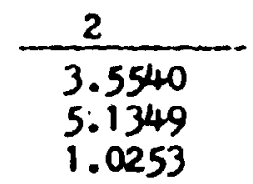

$\frac{1}{.8632} \frac{2}{-.3929} \frac{2}{.5270} .9322$




\section{A sil ivilis is}

MAUR I TANIA

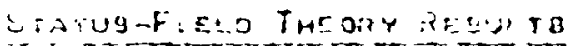

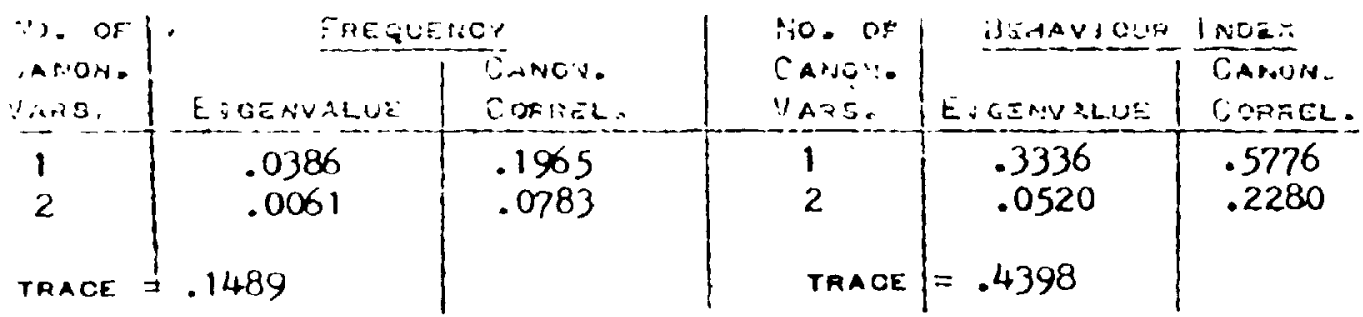

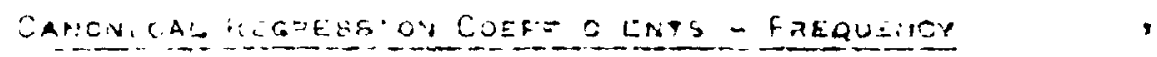

CONSN!CAL Y'PR ATEZ

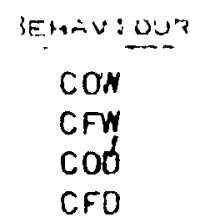

$$
\begin{array}{cc}
1 & -1.2 \\
.0878 & -.7489 \\
.8976 & .3993 \\
.1575 & .9618 \\
.0603 & -.3452
\end{array}
$$

ATthisures

PON

DEV

$$
\frac{1}{-.0961}
$$$$
-\frac{2}{1.0137}
$$

.0955

\section{CANON:CAL REGRS3BION COEFFIOIENTS - UEHAV:OUF IMOEX}

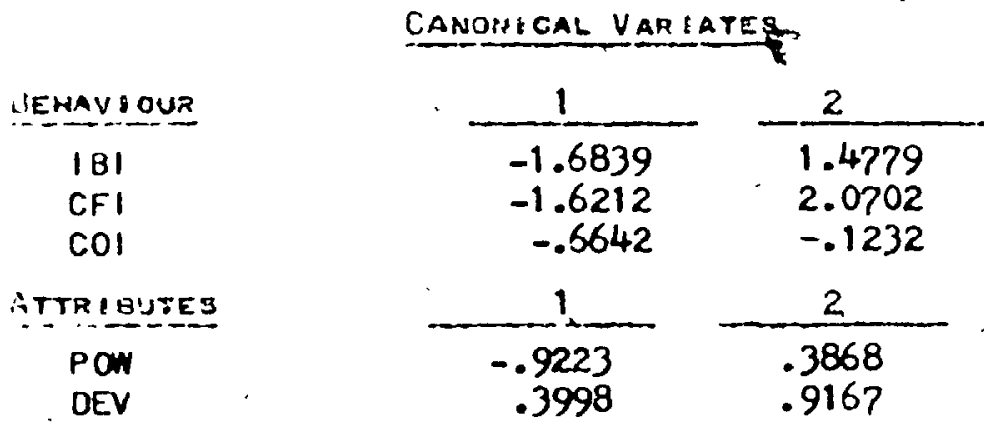




\section{Arithingla L}

NI GER

STARUS-FESLO THEORY TESULIG

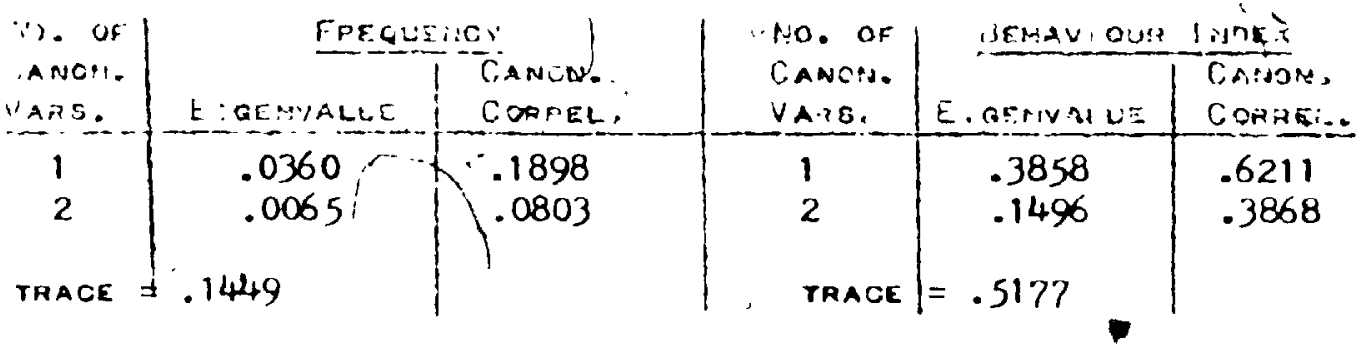

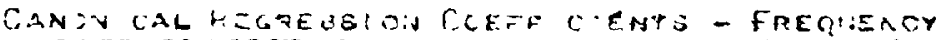

CARONACAL : IA:ATZS

SEHA : OUR
COW
CFW
COO
CFO

ATrP;日UT:5

POW

DEV

$$
\begin{array}{r}
. \\
.0840 \\
-.9519 \\
.0442 \\
-.0764
\end{array}
$$

2
-.9382
.5772
. .7677
-.4293

$$
-\frac{11}{.0959}
$$$$
1.0065
$$

\section{CANONEGAL REGREBBION COEFFEC.ENTS - JERAY:OUR I NOEX}

CANOMIGAL VARTATEB

$$
\begin{gathered}
\text { JEHAV: OUR } \\
\begin{array}{l}
\text { IBI } \\
\text { CFI } \\
\text { COI }
\end{array}
\end{gathered}
$$

ATTRP BUTES

PON

DEV

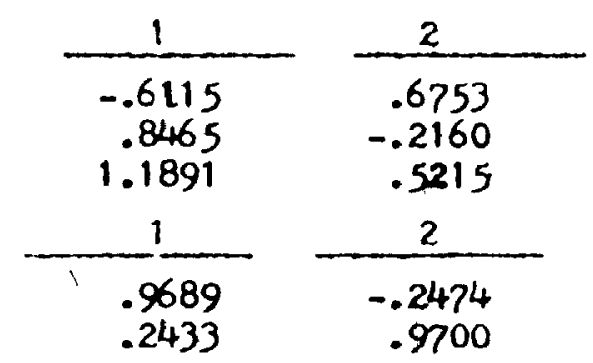





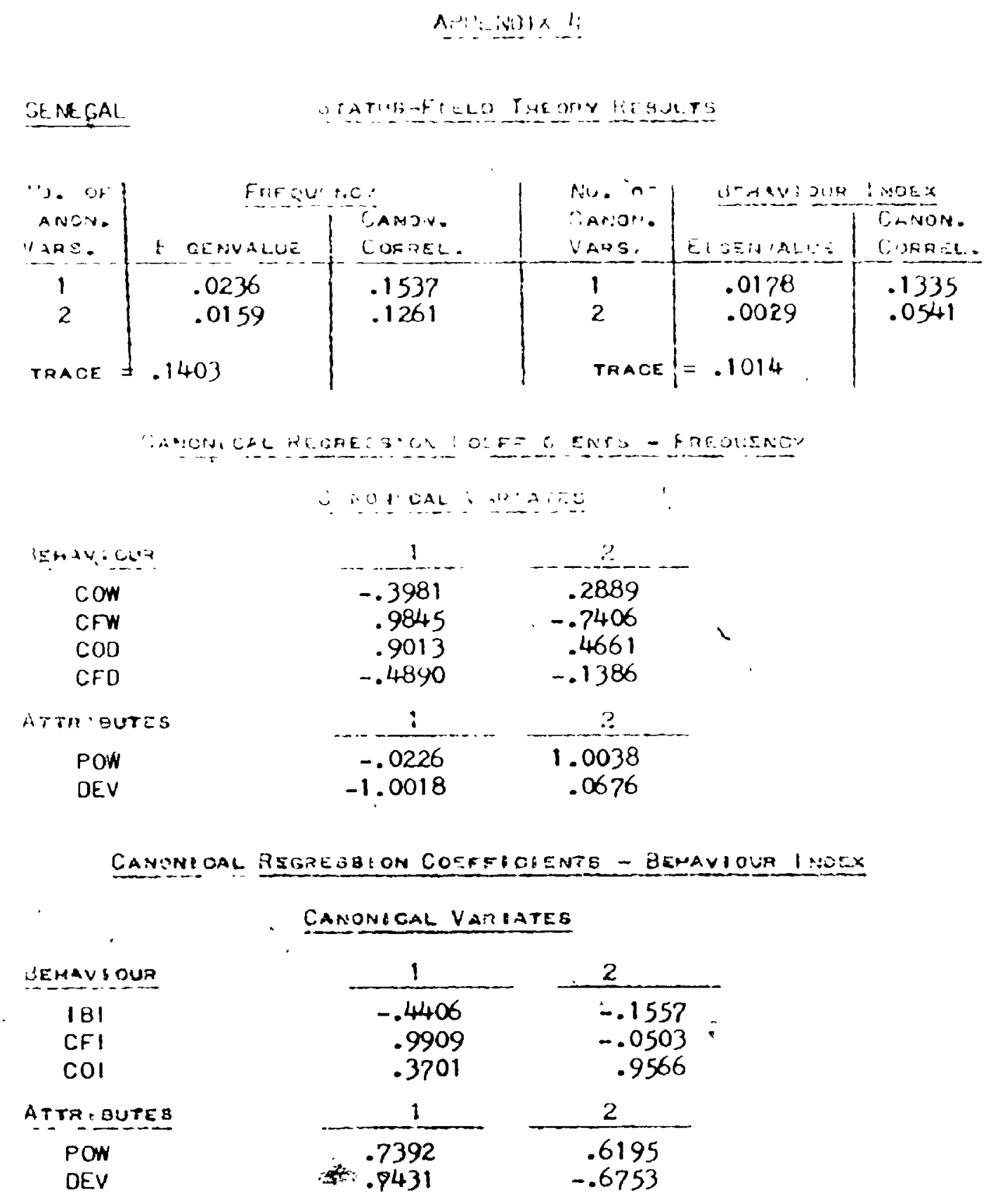


APHENDIX 4

SIERRA LEONE

Statuafizlo Theony Reguts

\begin{tabular}{|c|c|c|c|c|c|}
\hline \multirow{2}{*}{$\begin{array}{l}\text { N'J. of } \\
\text { iAMON. } \\
\text { VAASE. }\end{array}$} & \multicolumn{2}{|c|}{ FaEquencY } & \multirow{2}{*}{$\begin{array}{l}\text { No, or } \\
\text { CAmom. } \\
\text { VAFB. }\end{array}$} & \multicolumn{2}{|c|}{ Joravioua I nOEX } \\
\hline & E: OEMVALUE & $\begin{array}{l}\text { CAMON. } \\
\text { COMREL. }\end{array}$ & & E: GËWNALUT & $\begin{array}{l}\text { CANEON. } \\
\text { CoRAEL. }\end{array}$ \\
\hline $\begin{array}{c}1 \\
2 \\
-\quad \\
\text { TRAOC }\end{array}$ & $\begin{array}{r}.0210 \\
.0093 \\
.1228\end{array}$ & $\begin{array}{l}.1451 \\
.0963\end{array}$ & $\begin{array}{l}1 \\
2 \\
\text { Thaos }\end{array}$ & $\begin{array}{r}.0173 \\
.0038 \\
=.1024\end{array}$ & $\begin{array}{l}.1315 \\
.0620\end{array}$ \\
\hline
\end{tabular}

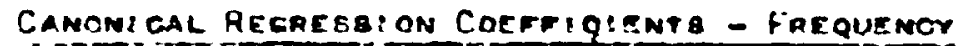

CANONE CAL VARIATEE

$$
\begin{aligned}
& \text { SEHAviour } \\
& \text { COW } \\
& \text { CFW } \\
& \text { COO } \\
& \text { CFO }
\end{aligned}
$$

Armieutes

PON

DEV
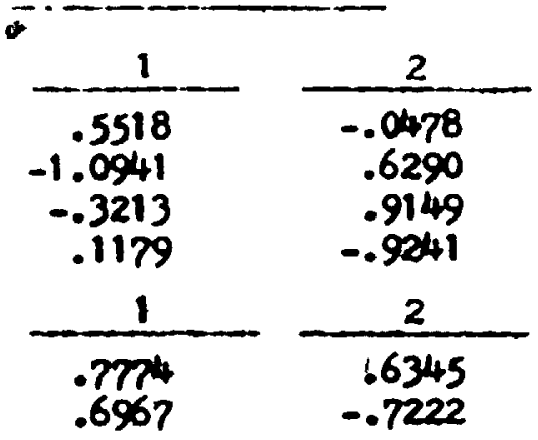

;

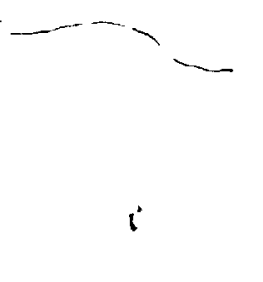

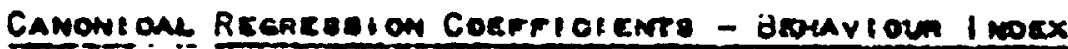

Camomical Vaniates

demavioun

IBI

CFI

COI

Armigures

POW

ocy
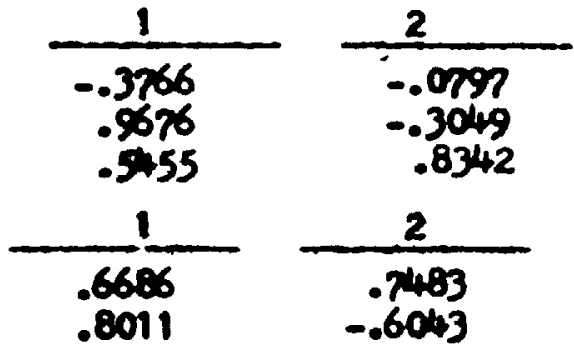


$$
\text { A1:1 Ni:1: 1: }
$$

SUDAN

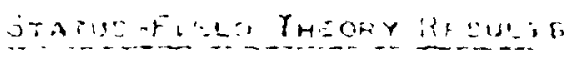

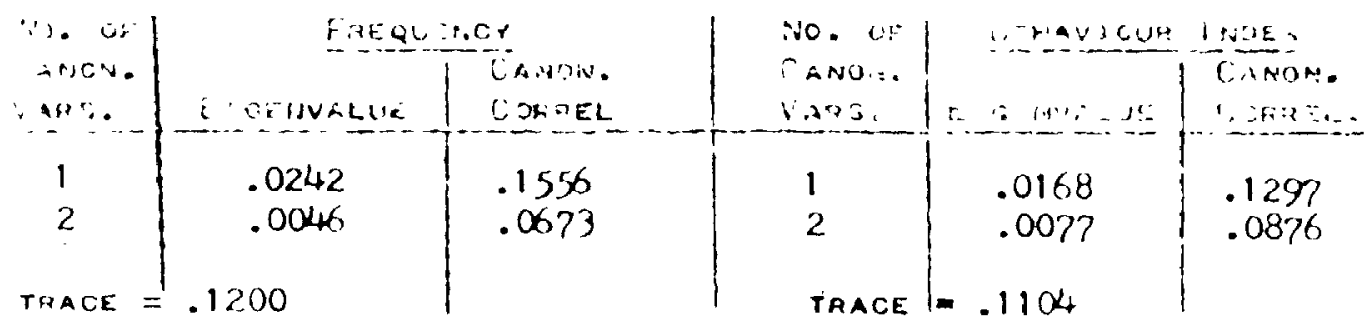

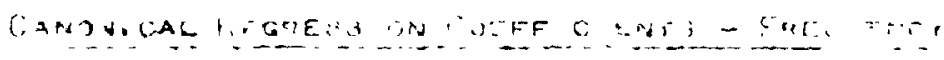
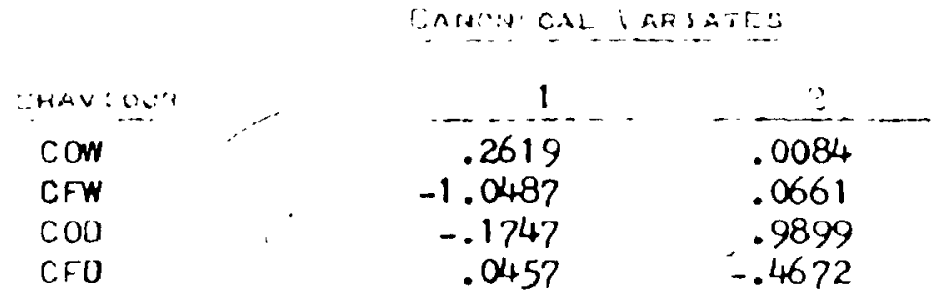

$\begin{array}{lrr}\text { HOA Eutes } & \frac{1}{2} & ? \\ \text { PEV } & .9005 & .4445 \\ .5256 & -.8558\end{array}$

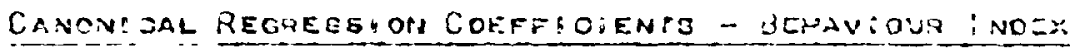

CANOHACAL VAR:ATEB

SEMAV IOLR

I 31

CFI

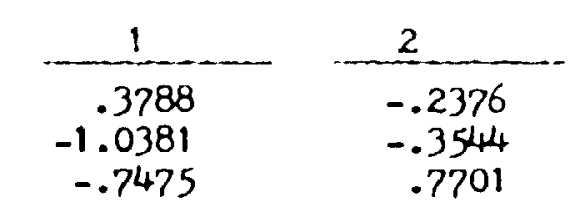

A:?h-nures

PON

DEV

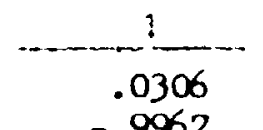

$\frac{2}{1.0038}-$




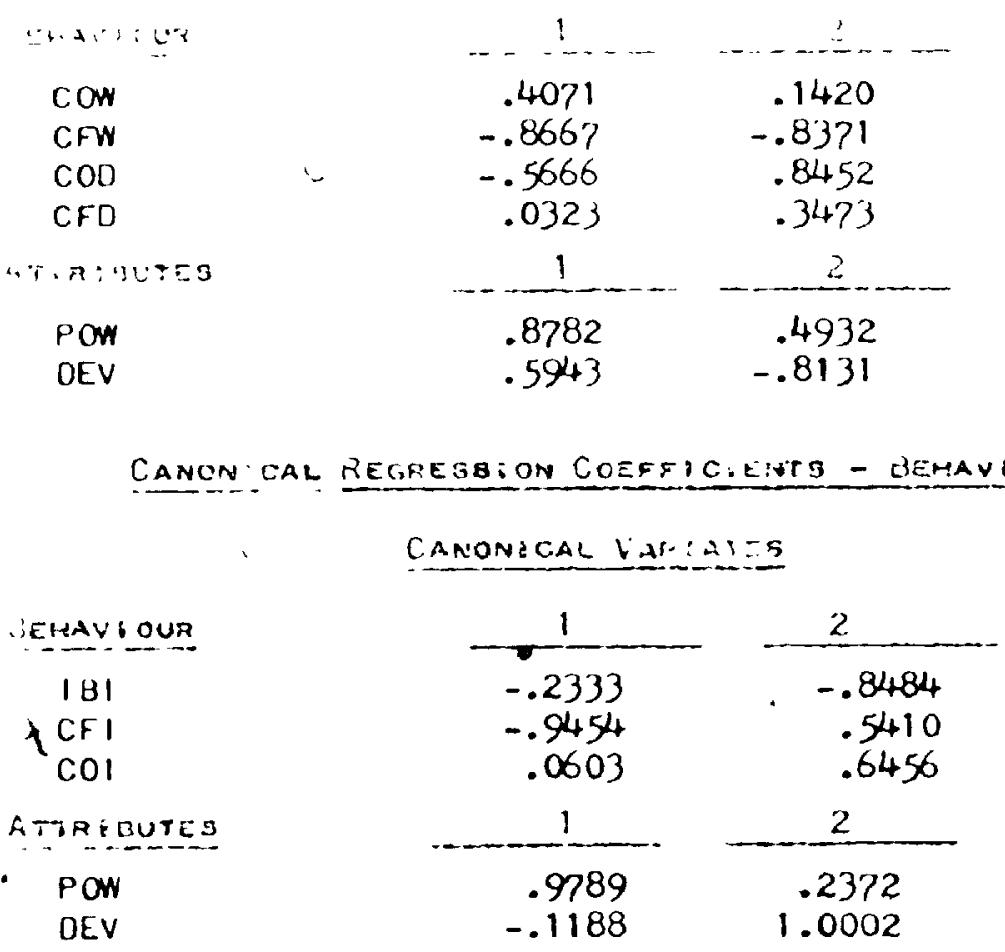




\section{Artrofuls L}

TOGO

ORATUB-THELU THEORY RC JULYS

\begin{tabular}{|c|c|c|c|c|c|}
\hline$\because$. of & Farcis & cy & No. or & ¿E:YAVJOUK & INJEX \\
\hline $\begin{array}{l}\text { AHCOA. } \\
V A R \text { S. }\end{array}$ & ․; GENVALUE & $\begin{array}{l}\text { CAAIUIN. } \\
\text { COPAEL }\end{array}$ & $\begin{array}{l}\text { Carroin. } \\
\text { VARS. }\end{array}$ & ELOERU,ZUE & $\begin{array}{l}\text { CANOA, } \\
\text { CORADII: }\end{array}$ \\
\hline $\begin{array}{l}1 \\
2\end{array}$ & $\begin{array}{l}.0473 \\
.0110\end{array}$ & $\begin{array}{l}.3274 \\
.1047\end{array}$ & $\begin{array}{l}1 \\
2\end{array}$ & $\begin{array}{l}.0533 \\
.0121\end{array}$ & $\begin{array}{l}.2308 \\
.1101\end{array}$ \\
\hline$F$ & .1705 & & TRACE & .1805 & \\
\hline
\end{tabular}

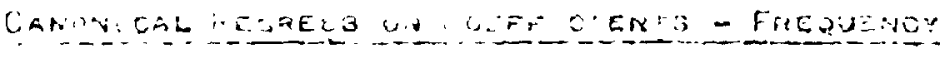

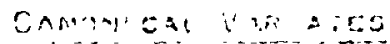

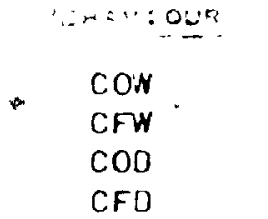

Arrit? sutas

POW

DEV

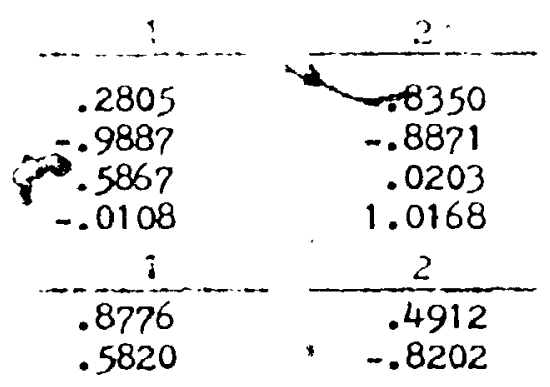

CANONEOAL REgAESSION COSFFICIENTE - DEMAYIOUR INDEX

CARIOMICAL VAR IATEG

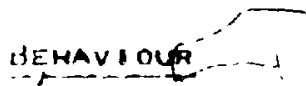

181

CFI

$\mathrm{COI}$

A tra' BÜTEs

POW

DEV

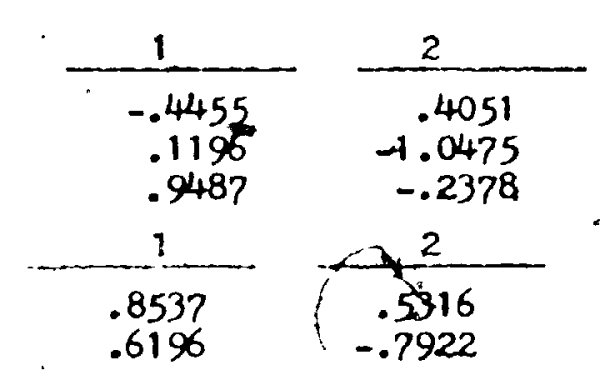

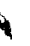




\section{Arrthidi, i:}

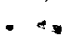

UGANUA

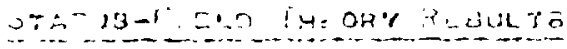
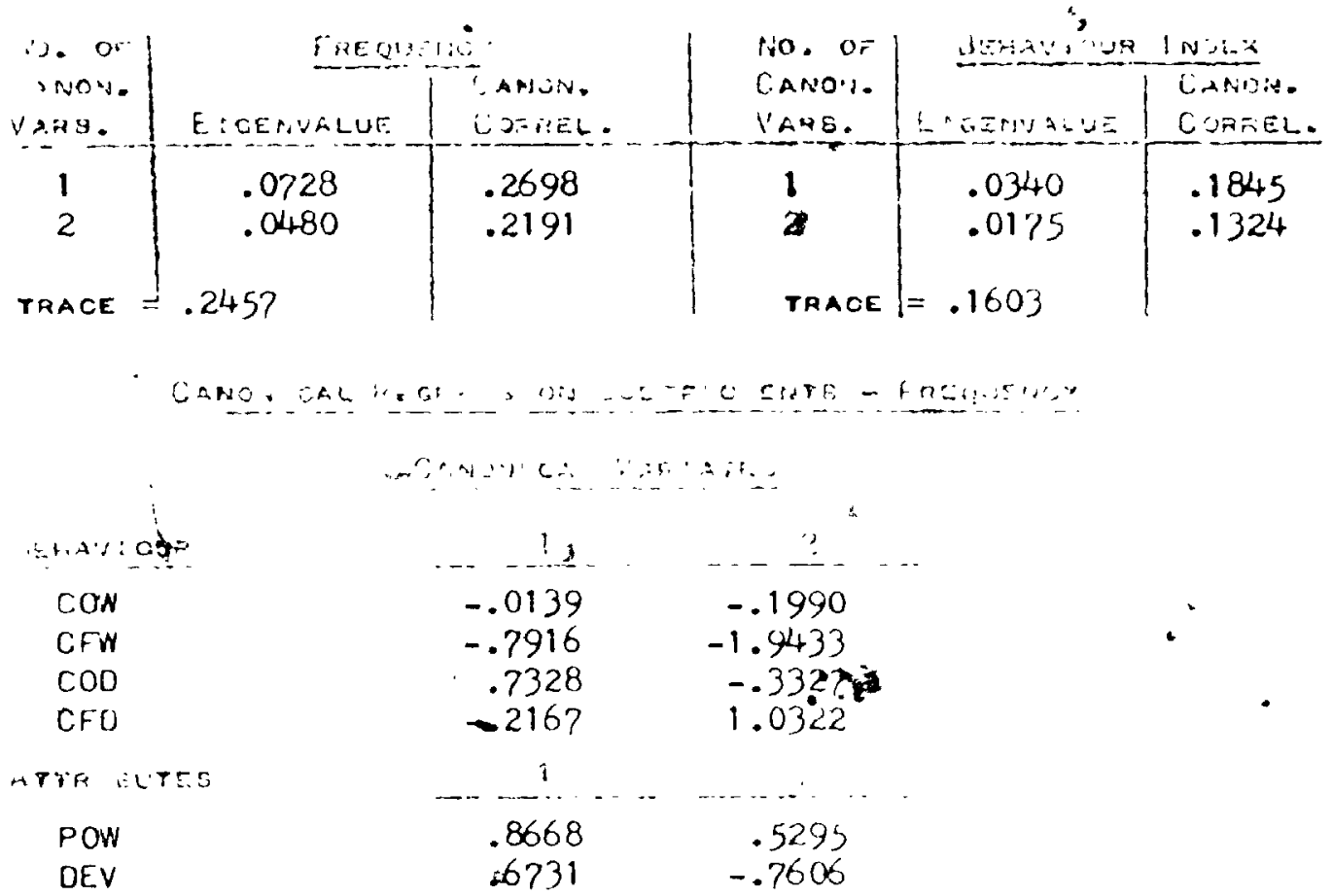

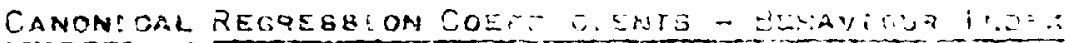

CAHOUICAL UAPT2T:S

SEHAVIOUA
CFI
COI

ATrit BUTEs

POW

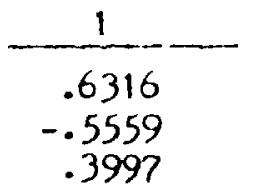

\begin{tabular}{r}
2 \\
-.7120 \\
.0103 \\
.6807 \\
2 \\
\hline 1.0157 \\
.1730
\end{tabular}

DEV

$\begin{array}{rr}-.0050 & \frac{1}{1.0157} \\ -1.0009 & .1730\end{array}$




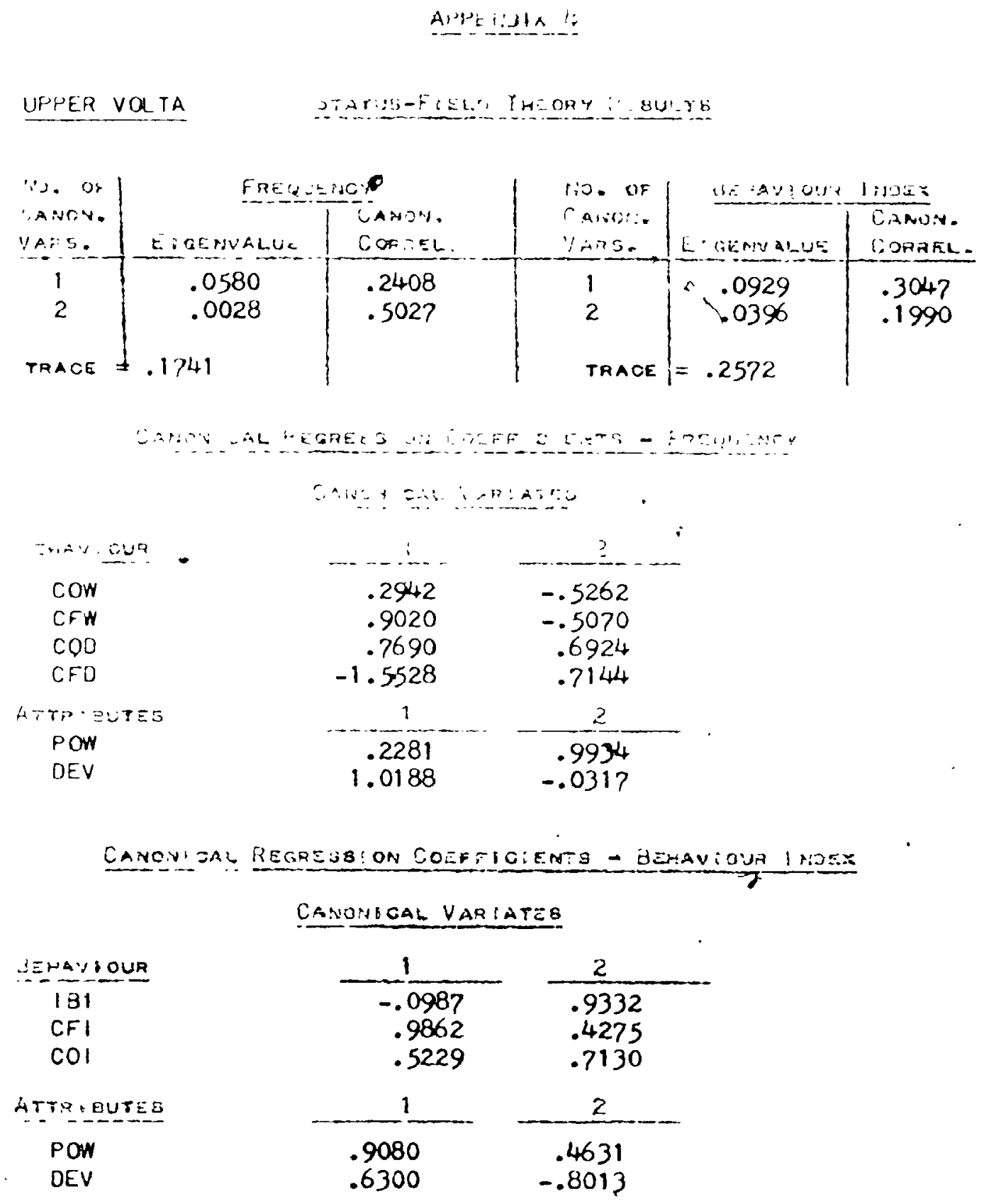




\section{A.P.M MIKL}

$\angle A \mid R E$

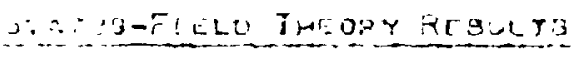

\begin{tabular}{|c|c|c|c|c|c|}
\hline $\begin{array}{l}\text { ire or } \\
\text { MNon. } \\
\text { W. }\end{array}$ & 5. LENUALE & $\begin{array}{l}\text { EY } \\
\text { UAA:ON. } \\
\text { EOFIEL. }\end{array}$ & $\begin{array}{l}110.1= \\
\text { Ca.ton'. } \\
\text { 'ars. }\end{array}$ & AE:13J 2IR & 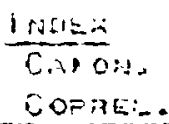 \\
\hline $\begin{array}{l}1 \\
2\end{array}$ & $\begin{array}{l}.0279 \\
.0048\end{array}$ & $\begin{array}{l}.1671 \\
.0693\end{array}$ & $\begin{array}{l}1 \\
2\end{array}$ & $\begin{array}{r}.4086 \\
.0278\end{array}$ & $\begin{array}{r}.5920 \\
.2812\end{array}$ \\
\hline & .1276 & & & $=.4670$ & \\
\hline
\end{tabular}

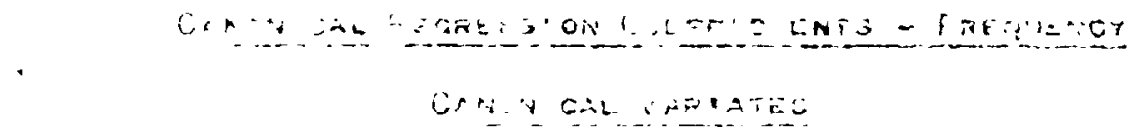

SEHAV : OUH
COW
CFW
COO
CFD

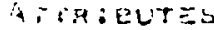

POW

DEV

$$
\begin{gathered}
.1 \\
.1807 \\
-1.2617 \\
-.7583 \\
.7267 \\
-\frac{1}{.1404} \\
1.0126
\end{gathered}
$$

$$
\begin{array}{r}
.1356 \\
-.7056 \\
-.2555 \\
1.5052
\end{array}
$$

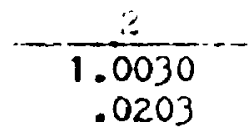

CANON:CAL REGAEGBION COEFFIOEENIB - JGUAY OUR INCEZ

\section{CANONTGAL VARIATEB}

JEMAV: OUR
IBI
CFI
COI
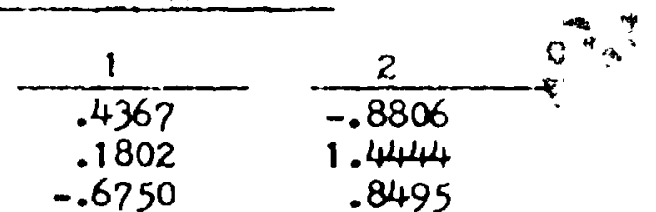
ATTRIGUTEE
POW

DEV

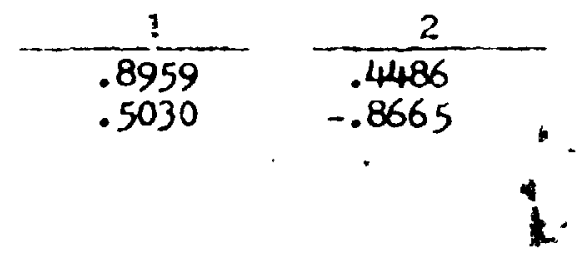


ZAMBIA

\section{STATUB-FIELO THEOAY REBULTB}

\begin{tabular}{|c|c|c|c|c|c|}
\hline $\begin{array}{l}\text { WJ. OF } \\
\text { 'AMON. } \\
\text { YARB. }\end{array}$ & $\begin{array}{r}\text { Frequ } \\
\text { Eigemvalue }\end{array}$ & $\begin{array}{l}\text { GY } \\
\text { CAnON. } \\
\text { ConREL. }\end{array}$ & $\begin{array}{l}\text { NO. O* } \\
\text { CAMON. } \\
\text { YARE. }\end{array}$ & $\begin{array}{l}\text { UEMAVIOUF } \\
\text { E GENVALUE }\end{array}$ & $\begin{array}{l}\text { I NOEX } \\
\text { CAMON. } \\
\text { CORKEL. }\end{array}$ \\
\hline $\begin{array}{l}1 \\
2 \\
\text { TAAOE }\end{array}$ & $\begin{array}{r}.2929 \\
.0366 \\
=.4058\end{array}$ & $\begin{array}{r}.5412 \\
.1913\end{array}$ & $\begin{array}{l}1 \\
2 \\
\text { TRACE }\end{array}$ & $\begin{array}{r}.1905 \\
.0194 \\
=.3238\end{array}$ & $\begin{array}{l}.4364 \\
.1394\end{array}$ \\
\hline
\end{tabular}

CANOWICAL HEGREGRION COEFFIO:ENTS - FPEOUENCY

CANUNEQAL VAR:ATES

SENAviOUR
CON
CFW
COO
CFO

ATrni Butes

PON

DEV

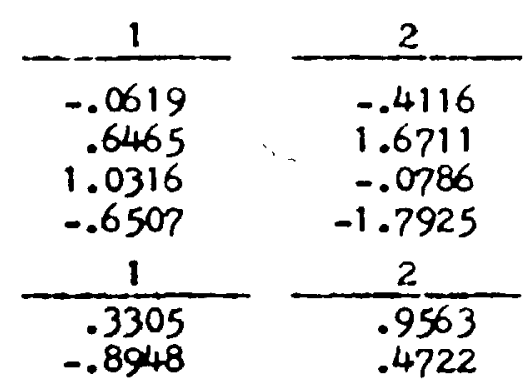

CANONEOAL REgREsGion COEFFICIEMT8 - BEMAVIOUA I MOEX

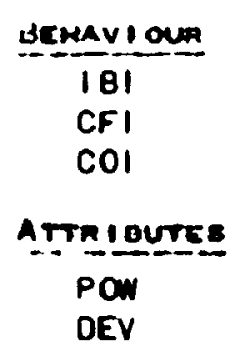

CANOMICAL VARIATES

$\begin{array}{cc}1^{\circ} & \frac{2}{.0018} \\ .8256 & -.2291 \\ .9995 & -.6056 \\ -.5211\end{array}$

$\frac{1}{.3226} \frac{2}{-.8987} \frac{.9590}{.4648}$




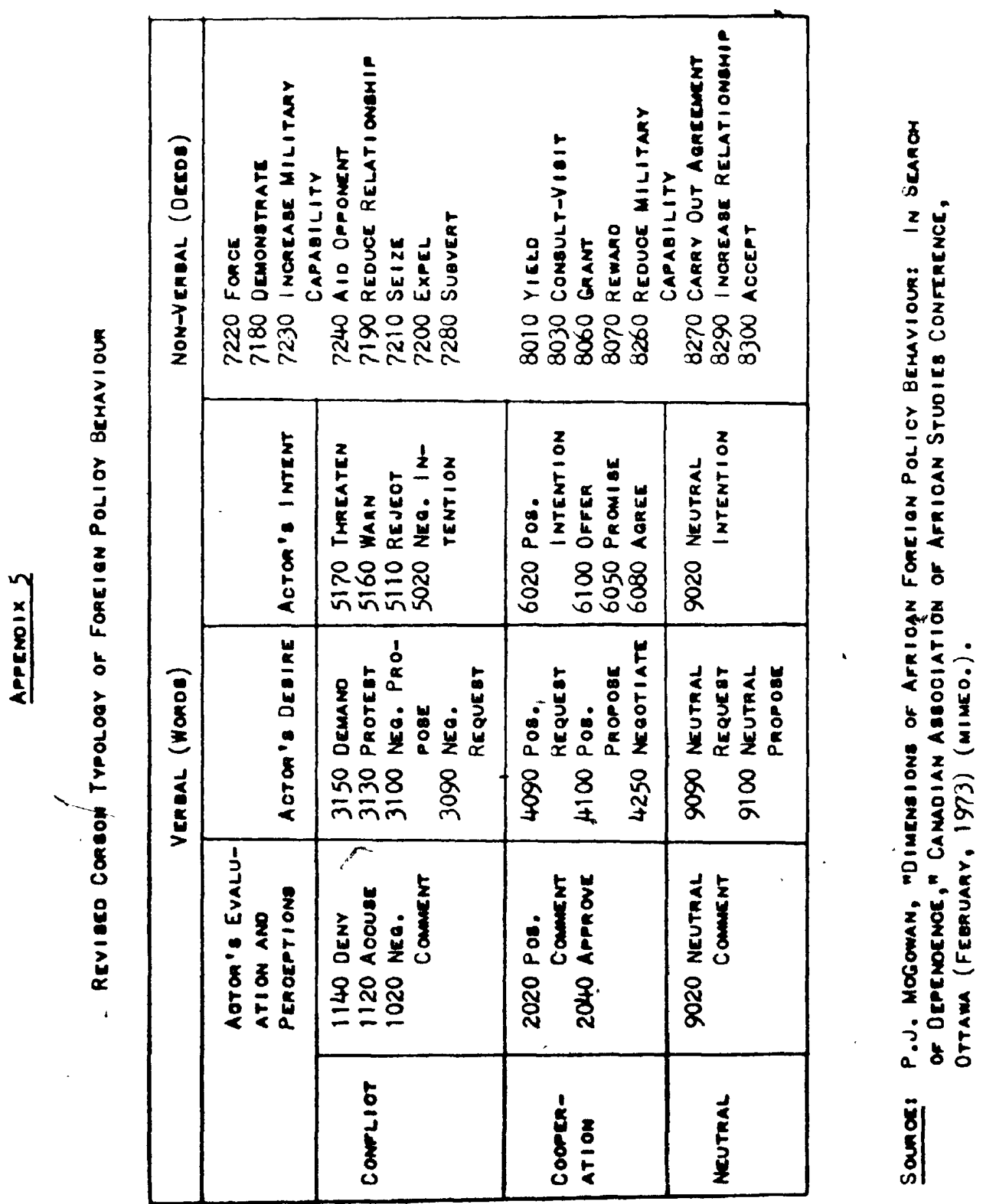




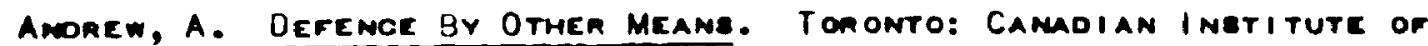
INTERMATI OMLL AFFAIRE, 1970.

Bereen, J.; ZEOITCH, M., JA.; ANO ANOERBON, B., EOB. SOCIOLOQICAL THECRIES IN PROCEsa. VOL. 1. BOstON: HOVOMTON MIFFLIN Co., 1966.

Binoea, L. mthe Midole East as a Subondimate I nteamational System." in Regional politice ano worlo Drokr. Eoited er R. FalK ano S. Menolovitz. SAN FranBic8o: Freeman \& Co., 1973.

BOAL8, K. MTHE CONOEPT OF SUEOROIMATE INTERMATIONAL SVBTEME: A CRITIqUe." In Regiomal POLITICB ano wORLo ORder. Eoiteo er R. FALK ANo S. MENOLOVITZ. SAN FRANCi BCo: FAEEMAN \& Co., 1973.

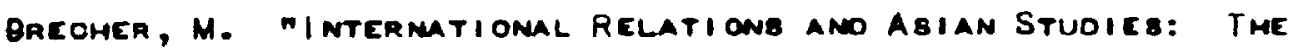
Subonoinate State Sygtem of Southern ABIA." IN REOIOMAL POLITICB ano WOALO OROER. EOIteo or R. FALK ANo S. MEnolovitz. SAN Francisco: Freeman \& Co., 1973.

THE NEw STETEM OF SMALL SHATEB: A POLITICAL AMALYBis. LONOON: OXFORD UNIVERBITY PREsB, 1963.

BAcoY, R.A. "THE Stuor of INTERMATIONAL POLITIOs QUA SCIEMOE: THE EMPhasi: ON METhOOB aNo TEOHNIQUE8." In CONTENoINo AprRonomes to INTEANATIONAL POLITIC8. EOITEO OV K. KMORR ANO J.N. ROBEMAU. NEW JERBEY: PRINCETON University PREse, 1969.

Bunecse, P.M., ANo LAwTON R.W. InOIOATON OF INTERMATHONAL BEMAVIOUR:

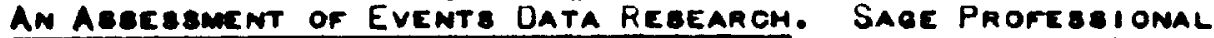
papena in Inteanatiomal Stuoies, Vol. 1, Beaice no. 02-010. Bevenly Hilla: Saee Puelication, 1972.

Camton!, L.J., amo SPicekl, S.L. THE Intenmational Politice of Regions. New Jenery: PaEnTIOEHALL INC., 1970.

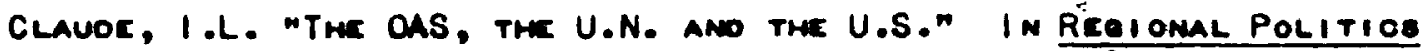
ano Woalo ORoER. EOIteo or R. FALK ano S. MENolovitz. SAN FRAMOIsoo: Frezman \& Co., 1973.

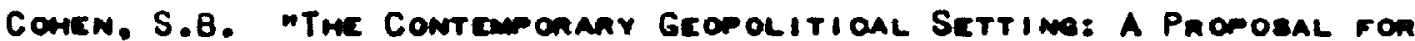
Gloeal Gcopolitical Equilienium." In Egeare in Political Gcosnaphy. 2no co. Eoiteo or C.A. Figmen. Lonoon: Metrmern \& Co., 1968.

Copeon, R. "Foneien Poilor Commlict Amome Amion Statea, 1964-1969." In Sace I mrennational Yeaneook or Foncion Polior Stuoice. Vou. 1. Eoitro er P. MogomaM. Brventy Hille: Saer Puokiontion, 1973. 
Cooler, W.H., ano Lomme, P.R. MULTIVARIATE PRoceduRe foR the Bemavioural SCIENOEB. New YOAK: JOHN WILEY \& SONO INO., $19 \overline{62}$.

East, M.A. "Status Di Bcaepancr ano Violence in the Inteamational SYETEM: AN EMPIRICAL AMALYBI8." IN THE AmALYBIB OF I NTERMATIOMAL POLITICB. EOITEO BY J.N. ROBENAU, V. UAVIB AM M.A. EABT. NEW YOAK: THE FREE PRE Gs, 1972.

EVERBON, D.H., ANO PAIME, J.P. AN INTROOUCTION TO SYBTEMATIC Pol ITICAL SCIENCE. GEORGETOWN, ONTARIO: IRWIN-UORBEV LTO. 1993.

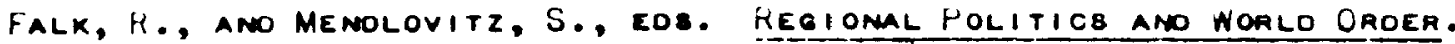
SAN FRANCI BCO: FREEMAN \& $\mathrm{Co}, 1973$.

FarRel, R.B., EO. APPROACHEB to Comparative and I NTERNATI ONAL POLITIC8. EVANBTON: NORTWWE BTERN UNIVERBITY PREBS, 1966.

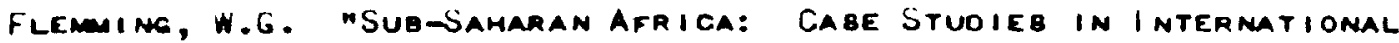
ATtituder ano TRANBACTTONB of Ghana amo voanoa." In LINKAEE POLITICB. EOITEO BY J.N. KOBENAU. NEW YOAK: THE FREE PRE 88, 1969.

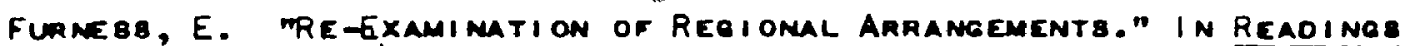
IN INTERMATIONAL POLITIC8. EOITEO OY C. LEACHE AMO M. LERCHE. NEW JERBEY: OXFOAD UNIVEREITY PRE88, 1958.

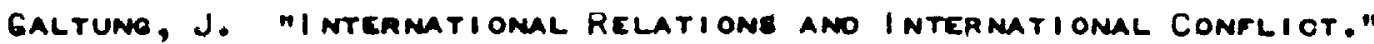
In TRANBACtions of THE SIXTH HORLD CONGREas of SOCIOLOOY, VOL. T. INTERMATIOMAL SOCIOLOSIOAL A FSOCIATION, 1966.

- mrank ano Social integration: a multi-oimensional Amproach." In Social Theory in PRogress. VOL. 1. EOITEO OY J. BEROEAET AL. BOBTON: HOUGMTON MIFFLIN Co., 1966.

- "The Social Scienchs: antesear on Polanization amo

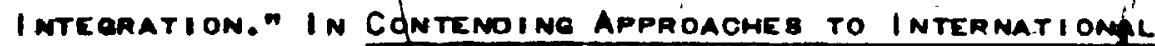
POLITICE. EDITEO By K, KnORA AND J. ROBEMAU. NEW JeReEY: PRI MOETON UNIVERsitr PRE88, 1969.

- Theoni amo methoos of Sootal Research. Oolo: UniveraitEtsFOALAOET, 1967.

Gamez, M. "THE ROLE OF MEXICO As a MIDOLE POWER." In CAMOA'g ROLE A. A MIOOLE POWEA. EOITEO BY K. GOMOON. TORONTO: CAMMDIAN INETITUTE of I MTCRMATIONAL AFFaIRe, 1965.

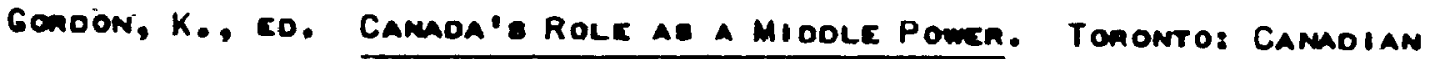
I metiture of Intenmatiomal AFFaiha, 1965. 
GaEog, W. TTHE U.N. REQIONAL EOONOAIO COMMIBBIONB ANO INTEORATION

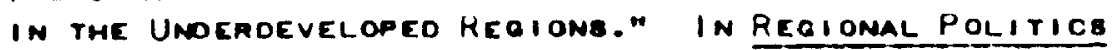
ano WORLd OROER. EDITEO OY R. FALK ANO S. MENOLOVITZ. SAN FRAMOI aco: FAEEMaN \& Co., 1973.

HAAB, E.B. "THE STUOY OF REOIOMAL INTEORATION: REFLECTIONB ON THE JoY ano ANGUISH OF PRETHEORIINO." IN REGIOMLL POLITICB aNo WOALO OADER. EOITEO BY R. FALK ANO S. MENOLOVITZ. SAN FRANCIBOO: FREEMAN \& Co., 1973.

Hanson, E. "The ECONOMIO POLICIEs OF a MIOdLe POWER." In CAMAOA'B ROLE A. a Midole POWER. EOITEo ar K. GORDON. TORONTO: CAMMDian Institute of I nTERnational AFfaIRB, 1965.

HERMAN, C.F. "POLICY Claseification: a Key to the COMPARATIVE STUOY OF FOREION POLICY." IN THE ANALYBIS OF INTERMTIONAL POLITIC8. EOITED OV J.N. ROBEMAU, V. U̧AVIS ANO M.A. EABT. NEW YoRK: THE FREE PREBB, 1972.

HILTON, G. A REVIEW OF THE DIMENBIONALITY OF NATIONB PROJEOT. SAEE

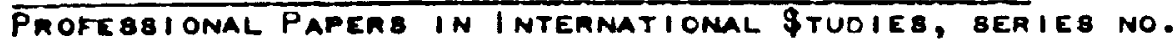
02-015. Beverly hillo: Sage Publications, 1973.

Holme8, J. Better Part of Valoun. Tononto: Carleton library, 1970.

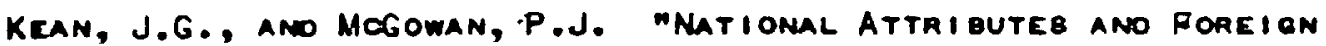

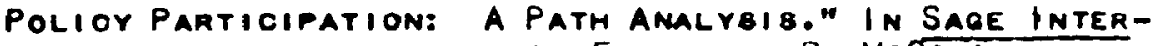
mational YeARBoOK. VOL. 1. EDITED OY P. MCGOWAN, Beverly Hillo: Saee PuBlications, 1973.

Keoley, C.W. A gemeral Empirical TyPology of foreion policy Bemaviour. beverly hilla: Saee Pualicationa, 1973.

3

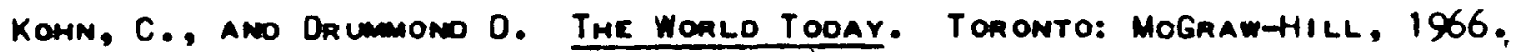

KMONn, K. POWER aNo WEALTH. NEW YONK: BAslo Books, 1973.

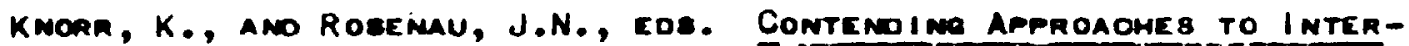
Mational PoLITICs. NEw YoRK: PRINOETON UNIVERsity PREse, 1969.

KMONR, K., ANO VEREA, S. THE INTERMATIOMAL SVETEM. NEW JEREEY: PRINOETON UNIVEREITY PREes, TS6T.

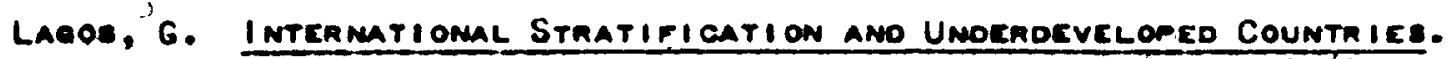
? Cmaptl Hill: Univereity of North Canolima Prese, 1963.

lasawell, H., ano Kaplan, A. Powen ano Sooicty. New Havenz Yale Univeneitr Prese, 1961.

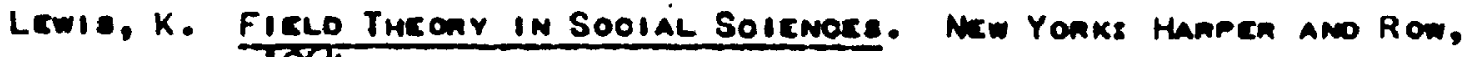
7584. 


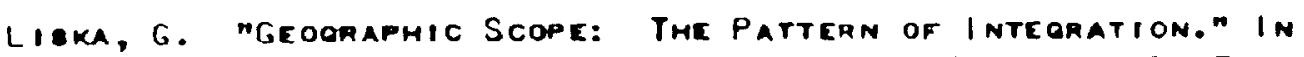

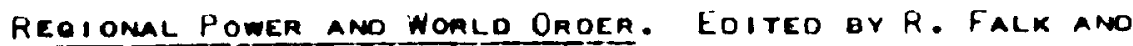
S. MENOL ovitz. SAN FaAncigco: Freman \& Co., 1973.

Moclellano, C.A. "On the founth wave: Past ano future in the Stuoy OF I NTERNATIONAL SYBTEMB." IN THE ANALYBIg OF INTERNATIONAL Politics. EotTed er J.N. Roseñu, V. UAVI8 AMO M.A. EAst. New York: The FREe Pne88, 1972.

moclellano, C.A., ano hogcaro, G. "Confloot Pattern in the interaCtion AMONO Nations." In InTERNATIONAL POLITICB ano EOREION POLICY. 2NO EO. EOITEO OY J. ROBENAU. TORONTO: THE FREE PRE $88,1969$.

mogowan, P.j. "a manual ano coocoook for the loentification. abstraction, and CoDine of foreion Policy acts." Rebearch REPORT NO. I OF THE AFRIOAN FOREIGN RELATIONB AND INTERmatiomal CONFLICT AmALYGIB (AFRICA) PROJECT, SYRACUEE UNIVERBITY, AUGUBT 1972.

MOGOWAN, P.J., EO. SAOE INTERNATIONAL YEARBOOX OF FOREION POLICY Stuoles. Vol. 1 Bevealy Hilla: Sage publicationg, 1973.

megoman, P. ano O'Leary, M. Comparative foreion Policy analysis. Srracuse Universitr: Markham Pyblications, 1971.

MILLER, L.H. mREOIOMAL OROANIZATIONB ANO SUBÓRoIMATE SYBTEMB." IN REOIONAL POLITICB ANo WORLD OROER. ' EOITED BY R. FALK AND S. MENolovitz. SAM Francisco: Freeman \& Co., 1973.

MOORE, D.W. "NATIONAL ATtRIBUTE8 ANO NATIONAL TyPOLOQIEB: A LOOK at the Rosemau Genotrpe8." In Comparine foreion POLICIEs. Eoited or J. Rosemu. TORONTO: JOHN WILEY \& SONS LTO., 1974.

MORRISON, D.C.; MITOhELL, R.C.; PADEN, J.N.; ANo Stevenson, H.M. BLACK AFRICA: A HAMOBOOK FOR COMPAAATIVE ANALYBIB. NEW YOAK: THE FREE PREB8, 1971.

- "Cooceook for amrican national integration PRoject." T NetITUTE FOA BemaVIOURAL REBEARCH, TORONTO: YONK UNIVEREITY, MANOA 1972 .

NiE, N.H.: HULL, C.H.; Jengim, J.G.: Steinenennes, K.; ano Bent, D.H. SPSS. 2mo co. TONONTO: MOGaAw Hill Book Co., 1975.

Paimohavo, P. midolefomermanship as an locolger." In Camada's Role Ae A MIODLE POWEn. EOITEO or K. GORDON. TORONTO: CAMEOIAN INETITUTE of InTERMATIOMAL AFraine, 1965. 


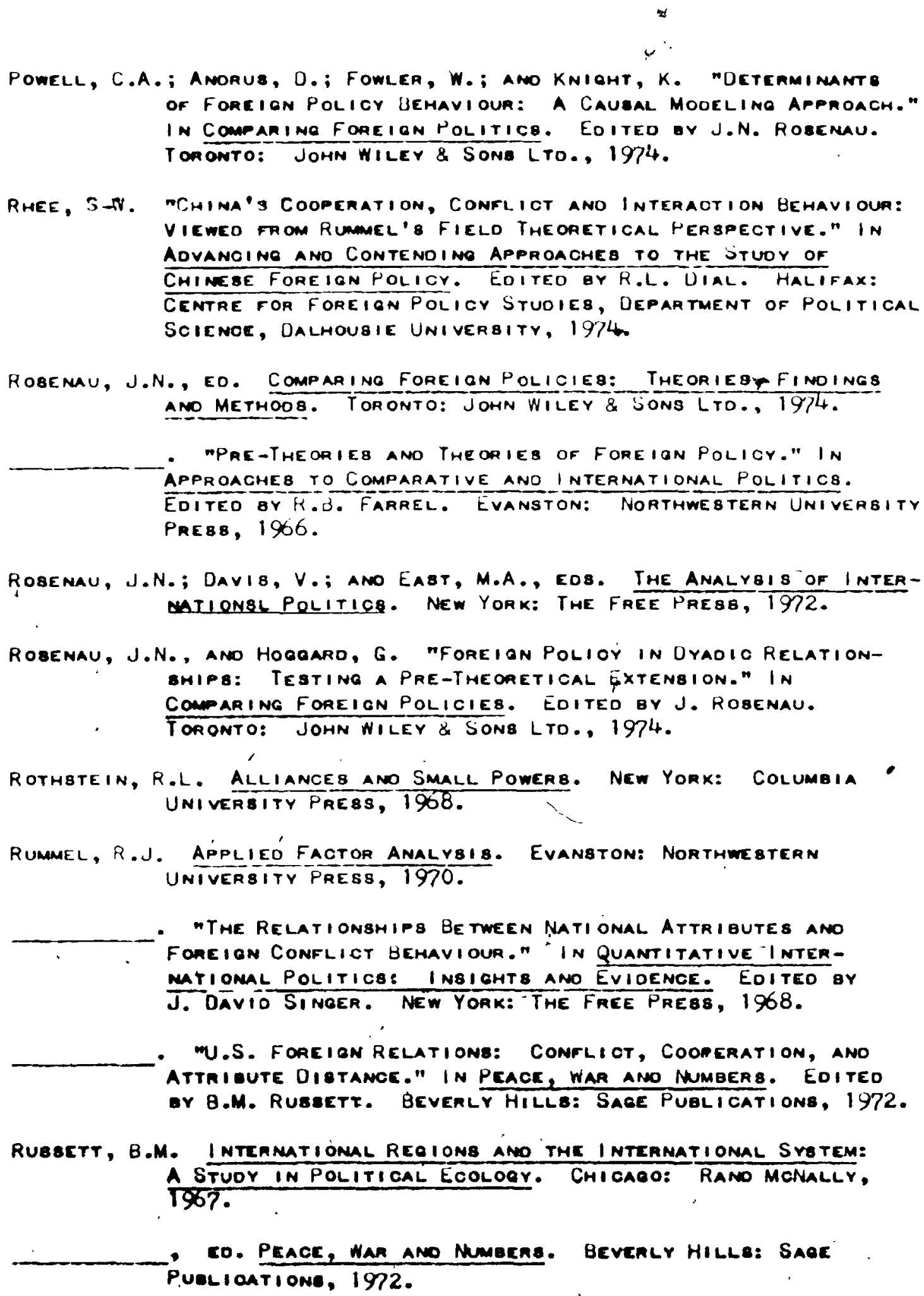

RUBSETT, B.M. INTEANATIONML REOIONS ANO TME INTERNATIONAL SVETEM:

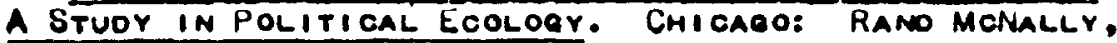
1567.

- co. Peace, war ano Numezna. Bevenlr Hillo: Saez Pueliontione, 1972. 


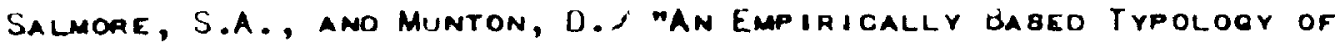
FOAEION HOLICY dEHAVIOUR." In COMPARING FOREION POLICIEB. EOITED OY J. ROBEMUU. TORONTO: JOMN WILEY ZSONB, 1974.

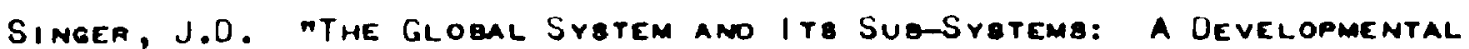
VIEW." IN LINKAGE POLITIC8. EOITEO BY J. ROBENAU. NEW YoAK: THE FREE PRE8, 1569.

- "The level of Amalyeis Paoglem in International RELATIONB." IN THE I NTERMATIONAL SYBTEM. EDITED OY K. KNORA ANO S. VERBA. NEW JERBEY: PRINCETON UNIVERBITY, 1961.

Van atta, R. "Fielo theorr amo natiomal-i ntermational linkageb." in CONFLICT BEHAVIOUR ANO LINKAGE POLITICB. EDITED BY J. Nilkenfelo. New Yonk: OAvio Makar Co., 1973.

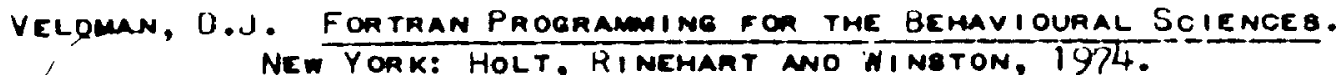

VITAL, D. THE INEQUALITY OF STATES. LONOON: OXFORD UNIVERBITY - The Suavival of Small Stateg. Wasminaton, D.C.: Public AFFAIRB PREg8, 1971 .

wallace, M. mStatus, formal ORganization, and Armb levels as factors LEADINe TO THE ONBET OF WAR, 1820-1964." IN PEACE, WAR ANO NUMEEA8. EOITEO BY B.M. RUBBETT. BEVERLY HILLB: SAOE PUBLIOATION, 1972.

Wilkenfelo, J., Eo. Comflict Bemaviour ano linkage Politics. New York: David MCKay Co., 1973.

WhIOHT, QUINOY. THE STUOY OF I MTEANATIOMAL RELATIONB. NEW YORK: APPLETON-CEMTUNY-CROFT8, INO., 1955.

Yalem, R.J. Regiomaliam ano Wonlo Onder. Wä́minaton, D.C.: Pualic Afratre Prese, 1965.

Youn, O.R. "POLITIOAL DIBOONTIMUITIES IN THE I MTEAMATIONAL SVETEM." in Regional Politics amo Wonlo ORder. Eoiteo er R. Falk amo S. MEMOLONitz. SAN Framoisco: Freeman \& Co., 1973.

\section{Antiolea}

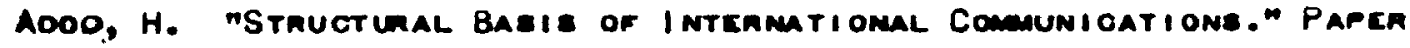

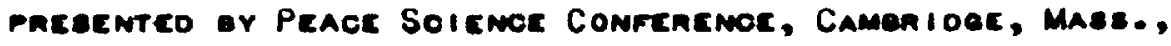
5-7 Novemera 1973. 


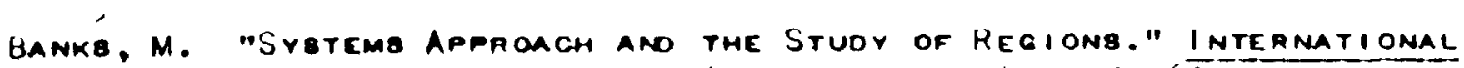
STUDies Quarterly 13 (Uecembea 1909): $335-36 \overline{0}$.

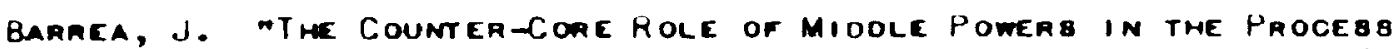
of External POLITICAL I NTEQRATION." NOALD POLITICB 25 (Jamaar 1973): 274-28?.

Berton, P. "I mteamatiomal Sragratems - A Submacro approach to InterMATIONAL STUDIE8." INTEAMATIONAL STUDIEg QUARTERLY 13 (Decemaer 190́9): $32 \overline{9-334 . ~}$

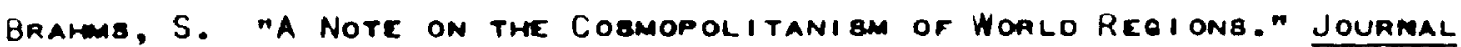
OF PEACE REBEARCH $5(1968): 87-95$.

CABTENEDA, J. "PAN-AMERICANIBM ANO REgIONALI BM." INTERMATIONAL OREAMIzATION $10(1950)$ : 375-389.

DOMINOUEZ, J. "MIOE THAT DO NOT ROAR: SOME ABPECTB OF INTERNATIONAL POLITICB IN THE WORLD'B PERIPHERIEB." INTERNATIONAL QROANIzATION 25 (SPRINO 1971): 175-208.

East, M.A. "Rank Depenoent I ntegaction ano Mboility: Two Aapects of I NTERMATIONAL STRATIFICATION." PEACE REgEaRch Societr PAPEAB $14(1970): 113-128$.

- "Size ano foreion Policy Bemaviour: a Test of Two Modelb." WOALO POLITICs 25 (JULY 1973): 556-576.

EABt, M.A. and GREgQ, P. mFactong Influencine Cooperation amo Conflict IN THE INTERNATIONAL SYBTEM." INTERMATIONAL STUOTEE QuaATERLY 11 (SEPTEMBER 1967).

Galtuno, J. "FOREION POLICY OPINION AB a FUnCtion of SOCIAL POBITION." PeaOc ReBearoh Society, Parers. $2(1965)$ : 206-231.

- "On the future of the Intermational Sretem." Jounnal of Peace Reeranch 4 (1967): 305-333. $\Rightarrow$

- "a Structural Theopr of agoregsion." Jounmal of Peace Rescapon 1 (1964): 95-119.

- "A Structural Theont of Imerialigm." Jourmal of peace Regcanon $8(1971)$ : $81-117$.

- "A Thcorr of Peaceful Cooperation: Coopenation in Eurore." I nTEnmational PEace ReBearch A Boociation 3 (-1970).

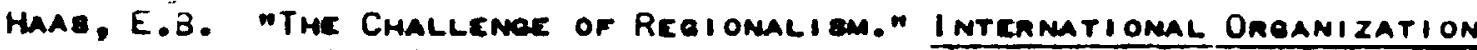
$12(1958): 440458$. 


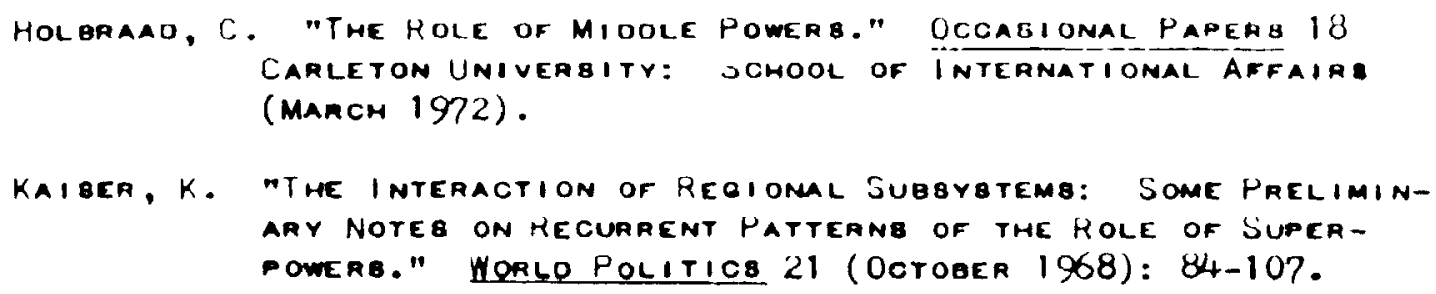

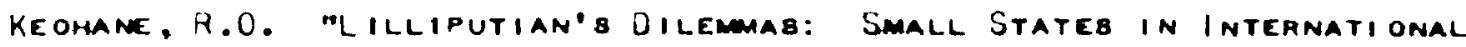
HOLITIC8." INTERNATIONAL URGANIZATION 23 (SPRING 1909): $291-310$.

Lame, W.C., ano RuBbett, B.M. "Politic8 in the EMERging Regions." peace rebearch Societr, papeas 11 (1969).

li jpmart, A. "The Structure of the theopetical kevolution in interMATIOMAL RELATIONB." INTERNATIONAL STUOIE8 QUARTERLY 18 $(1963): 41-74$

moclellano, C.A. "Fielo Theory ano Stotem Theory in inteanatiomal Politics," UNiversity of Southean CALIfoRnia, June 1968. (MIMEOoRAFHED.)

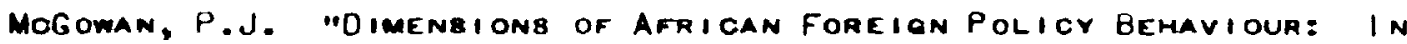

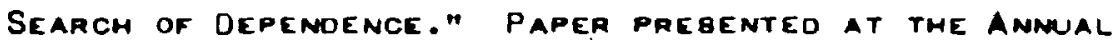

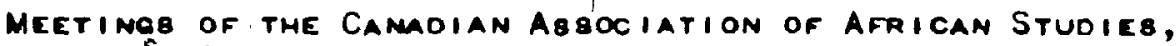
Ottama; 16 - 18 fegrunar 1973.

Megee, M. mproblemg in Regional Measunement." Peace regearch SOCIETY, PAPERS $4(1966): 7-36$.

MORrison, D.G., ano Stevenbon, H.M. mCultural Pluraliga, ModernizATION ANO CONFLICT: AN EMPIRICAL AMALYBIB OF SOURCEB OF Political I nBtagility in AFaican Nations." Camadian Jourmal of Politioal Science 5 (March 1972): 82-103.

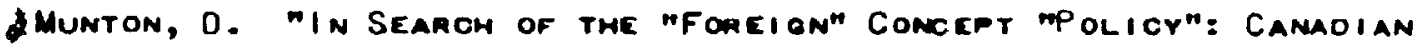
I ntenmational Event gehaviouR in a ReLational MODEL." PAPER PREBENTEO AT THE I MTER-UNI VERBITY SEMINAR ON I nTERMATIOMAL RELATIONB, TORONTO, YORK UNIVERBITY, FEonuanr 1974.

- maitime fon keplen: Evemt data ano Relational model of Camalan foneign Pollor Bemavioun." Papen presenteo at

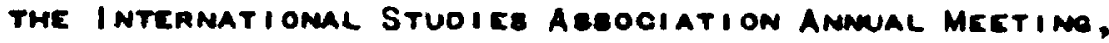
NEw Yonk, Manow 1973.

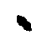

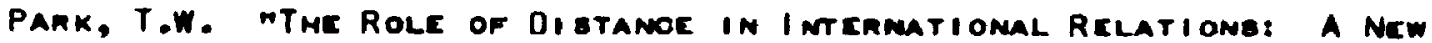
LoOK at THE Social FicLo ThEORY." Bemaviounal SoIEMCE 17 (Amic 1972): 337-348. 
240.

Paul, J., happorteua. "The Contaidution of Regional Stuoieg to an UNOERBTANOING OF WORLo POLITICB." INTERNATIONAL STUOIEB QUARTERLY 12 (MARCH 1968): 109-114.

Phillipg, W.R. "Where have All The Theonies gonel" woalo Politios 26 (JAMUARY 1974): 155-188.

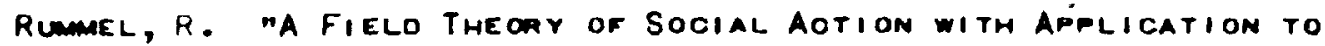
COMFLICT WITHIN NATIONB." GEMERAL SVBTEMg 10 (1965): $183-211 \ldots$

- "I moicator of CRos8-national ano Inteanational patteang." AMERICAN POLITICAL SCIENCE REVIEW 63 (MAROH 1969): 127-147.

- "a social field theory of foreign conflict behaviour." Peace Rebeafch Societr, Paperg 14 (1966): 131-150.

- "Sooial time ano inteamatiomal Relations." geneqal sybtems $17(1972): 145-158$.

- "Some Dimensions in the forelon bemaviour of Nationg." JoURMAL OF PEACE REBEARCM 3 (1966): $201-223$.

- "Teatina some Possible predictors of Conflict behaviour within ano Between nations." Peace Rebearch Societr, PAPERB $1(1964): 79-112$.

Russett, B.M. "Reaiomal TRaoine Patteans 1938-1963." Inteanational. STUDIE QUARTERLY 12 (DEOEMBER 1968): 360-379.

STUDiEs QuARTERLY 12 (Deoemben 1968):

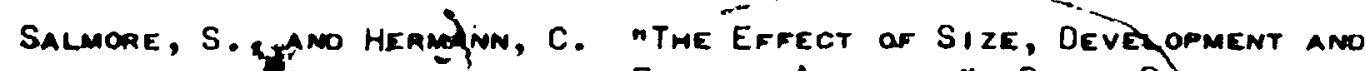

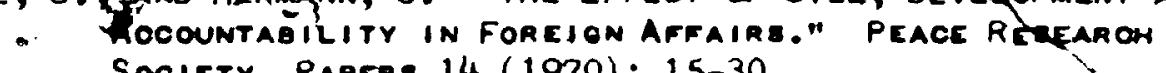
SoOIETY, PAPERB 14 (1970): 15-30.

SAwrer, J. "Dimensions of Nations: Size, Wealth ano Politic8." AMERIOAN JOURMAL OF SOCIOLOQY 17 (SEPTEMEER 1967): 145-172.

SETHi, J. "I noia as a Midole Power." Imoia Quarterly 25

(APRIL-JUNE 1969): 107-125.

Szala,, A. "Conesion Inolocs món Regional Deteamination." PEAOE ReeraRon Societr, Papens $4(1966): 1$ - 6.

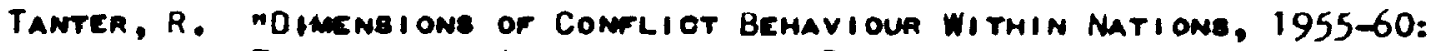
Tunmoil ano Inteamal Mar." Peace Regearom Societr, Papeas 3 :
$(1965)$. $\infty$

- "Status ano linkaes attempta in Intématiomal Politios: Metmodoloqical l sBucs." Papen pResenteo at the Evente OATA

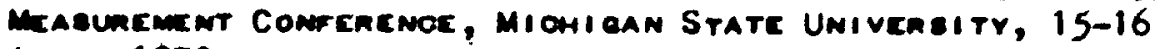
AmIL 1970. 
$24 d$.

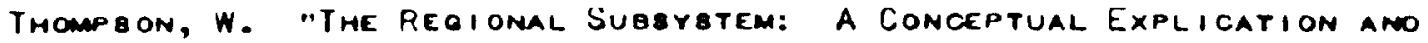
FROPOBITIONAL I NVENTORY." INTERNATIONAL STUOIEB GUARTERLY 17 (ManCH 1973): 89-118.

TOMLIN, B.W. "IN SEARCH ÓF the "FOREIGN" CONCEPt "POLICY": Camadan FOREION POLICY BemaViour in a Kelational MODEL." Paper -REBENTED at THE INTER-UNIVERBITY SEMINAR ON INTERNaTIONAL RELATIONS, TORONTO, YORK UNIVERSITY, FEBRUARY 1974.

Van atta, R., ano Rumel, R. "Testine fielo theopy on the 1963 bemaviour SPace of Nations." Peace Rebearch Societr, PAPERB 16 (1971): 23 - 46 .

VINeEnt, J. "AtTRIBUte ano attribute distanoe theories of InterMational Behaviour: AN UVERVIEN." FLORIOA ATLANTIC UNIVERBITY, MARCH 1974. (MIMEOGRNHEO.)

VINCENT, J.; BAKER, R.; GAONON, S.; HAMM, K.; ANO REILLY, S. "Empirical tests of attribute, Social fielo ano Status Fielo Theoaies on inteanational Relations Data." INTERNATIONAL STUDIES QUARTERLY 14 (DECEMBER 1973): 405 - 44.

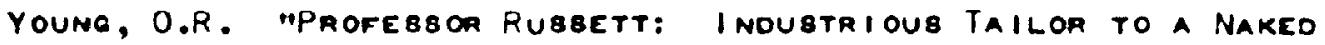
EMPEROR." WORLO POLITICB 21 (APRIL 1969). 


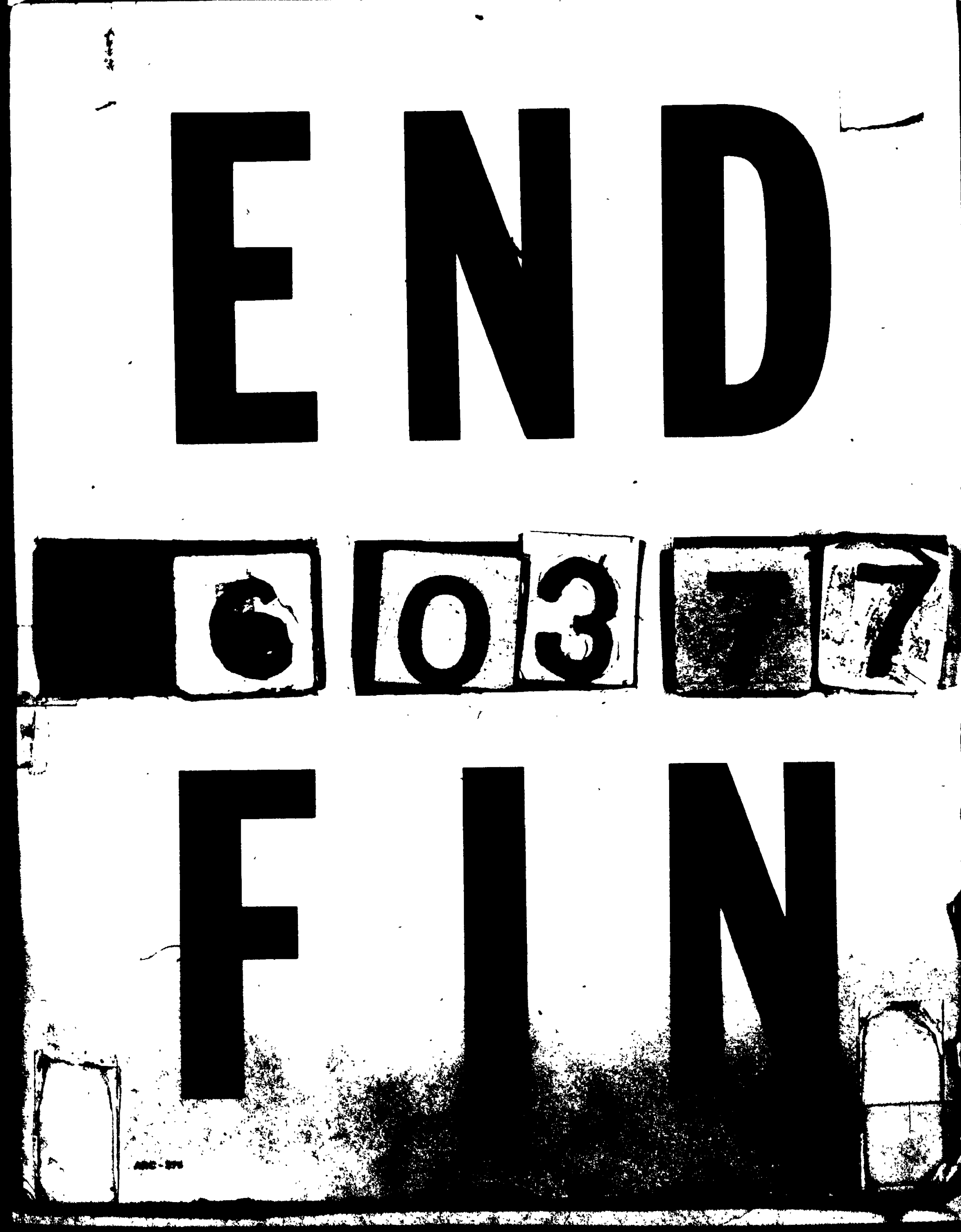

